LATE ANTIQUE AND EARLY MEDIEVAL IBERIA

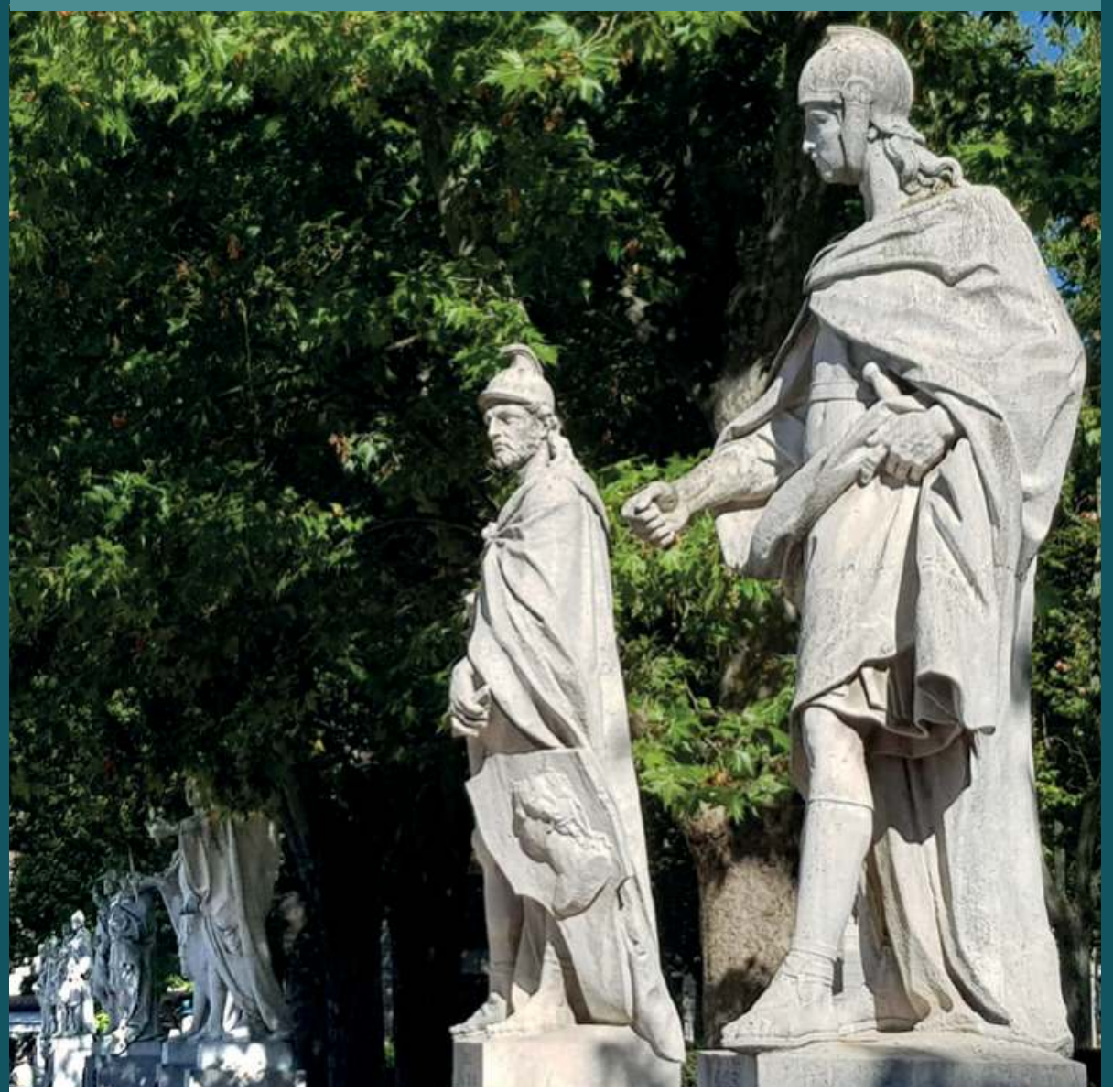

Edited by Sabine Panzram and Paulo Pachá

\title{
The Visigothic Kingdom
}

\section{The Negotiation of Power in Post-Roman lberia}


The Visigothic Kingdom 


\section{Late Antique and Early Medieval Iberia}

Scholarship on the Iberian Peninsula in late antiquity and the early Middle Ages is burgeoning across a variety of disciplines and time periods, yet the publication profile of the field remains disjointed. 'Late Antique and Early Medieval Iberia' (LAEMI) provides a publication hub for high-quality research on Iberian Studies from the fields of history, archaeology, theology and religious studies, numismatics, palaeography, music, and cognate disciplines. Another key aim of the series is to break down barriers between the excellent scholarship that takes place in Iberia and Latin America and the Anglophone world.

Series Editor

Jamie Wood, University of Lincoln, UK

Editorial Board

Andrew Fear, University of Manchester, UK

Nicola Clarke, Newcastle University, UK

Inaki Martín Viso, University of Salamanca, Spain

Glaire Anderson, University of North Carolina, USA

Eleonora Dell'Elicine, University of Buenos Aires, Argentina 


\section{The Visigothic Kingdom}

The Negotiation of Power in Post-Roman Iberia

Edited by

Sabine Panzram

and Paulo Pachá 
Cover illustration: Statues of the Visigothic kings (Athaulf, Euric, Liuvigild) on the south side of Plaza de Oriente, Madrid. Photo by Laurent Callegarin.

Cover design: Coördeisgn, Leiden

Lay-out: Crius Group, Hulshout

$\begin{array}{ll}\text { ISBN } & 9789463720632 \\ \text { e-ISBN } & 9789048551064 \\ \text { DOI } & 10.5117 / 9789463720632 \\ \text { NUR } & 684\end{array}$

(C) The authors / Amsterdam University Press B.V., Amsterdam 2020

All rights reserved. Without limiting the rights under copyright reserved above, no part of this book may be reproduced, stored in or introduced into a retrieval system, or transmitted, in any form or by any means (electronic, mechanical, photocopying, recording or otherwise) without the written permission of both the copyright owner and the authors of the book.

Every effort has been made to obtain permission to use all copyrighted illustrations reproduced in this book. Nonetheless, whosoever believes to have rights to this material is advised to contact the publisher. 


\section{Table of Contents}

$\begin{array}{ll}\text { Abbreviations } & 11\end{array}$

Preface and Acknowledgements

1 The Visigothic Kingdom of Toledo

Current Perspectives on the Negotiation of Power in Post-Roman Iberia

Sabine Panzram

\section{The Day Before - Prologue}

2 Late Roman Spain

Laurent Brassous

\section{Concepts of Central and Local Power}

3 The Visigoths in Hispania

New Perspectives on their Arrival and Settlement Javier Arce

4 The Early Visigothic Presence in Southeastern Hispania

New Finds from a Rural Settlement in the Carthaginiensis, Senda de

Granada (Murcia)

Jaime Vizcaíno Sánchez and Luis Alberto García Blánquez

5 Beyond Central and Local Powers

The General Councils of Toledo and the Politics of Integration Paulo Pachá

6 King Wamba's Campaign against dux Paulus (673) Narration of Military and Royal Power in the Late Visigothic Kingdom

Sebastian Steinbach 


\section{Power, Identity, and Ethnicity}

7 How to Stay Gothic without a Gothic King 139 Herwig Wolfram

8 Who are the Visigoths?

Concepts of Ethnicity in the Kingdom of Toledo: A Case Study of the Vitas Sanctorum Patrum Emeretensium

Manuel Koch

9 The Visigothic Kingdom - A Kingdom without Visigoths? The Debate on the Ethnic Interpretation of the Early Medieval Cemeteries on the Iberian Peninsula Christoph Eger

10 Local Citizenships and the Visigothic Kingdom Javier Martínez Jiménez

\section{Representations of Power}

11 Recopolis

The Representation of Power in a Complex Landscape

Lauro Olmo Enciso

12 Figura et potentia

Coin and Power in the Visigothic Kingdom

Ruth Pliego

13 The Liber Iudiciorum

A Visigothic Literary Guide to Institutional Authority and

Self-Interest

MichaelJ. Kelly

14 Epigraphic Habit and Power in Visigothic Hispania 


\section{Power and Church}

15 Between Throne and Altar 295

Political Power and Episcopal Authority in the Beginning of the

Visigothic Kingdom of Toledo

Rafael Barroso Cabrera

16 Ecclesiastical Landscapes in the Visigothic Capital and

Countryside of Toledo (Spain)

Isabel Sánchez Ramos and Jorge Morín de Pablos

17 Ancient Classics and Catholic Tradition through Time and Space

Martin of Braga and his Cultural Claims

Markus Mülke

18 Conflicts over Episcopal Office in Southern Hispania

Comparative Perspectives from Visigothic and Byzantine Territories Jamie Wood

\section{The Day After - Epilogue}

19 In a Savage Kingdom (regnum efferum)?

Evaluating the Islamic Conquest of Spania from the Archaeological

Record

Julián M. Ortega Ortega

20 Conclusions and Future Perspectives

Paulo Pachá

Index of Places, Names and Subjects 



\section{Illustrations}

Table

Table 5.1 Attendance of bishops from Mérida, Seville, and

Córdoba at the general councils

Figures

Fig. 2.1 The provinces of late Roman Spain.

Fig. 4.1 Plan of the rural complex of Senda de Granada (Murcia, Spain).

Fig. 4.2 View of some silos and detail of silo-dump 4015, where the cloisonné purse mount was found.

Fig. 4.3 Plan of the religious building and the sacred cemetery. Details of the tombs located in the southwestern corner and grave 10, showing the disk brooch and the belt buckle.

Fig. 4.4 Grave goods of tomb 10: disk brooch and belt buckle. $\quad 89$

Fig. 4.5 Cloisonné purse mount found in silo-dump 4015. 91

Fig. 9.1 Cacera de las Ranas, Prov. Toledo, burial 7. 175

Fig. 9.2 The evolution of 'Visigothic' dress accessories in southern France and Spain: diachronic regional sequences. $\quad 183$

Fig. 9.3 San Miguel de Arroyo, Province of Valladolid, burial 10. 186

$\begin{array}{ll}\text { Fig. 11.1 Recopolis. } & 216\end{array}$

$\begin{array}{ll}\text { Fig. 11.2 Aerial view of Recopolis. } & 218\end{array}$

Fig. 11.3 Recopolis: excavated area. $\quad 219$

Fig. 11.4 Recopolis: geomagnetic survey in 2015. 222

Fig. 11.5 Archaeological interpretation of GPR (Ground Penetrating Radar) data from the eastern part of the palatial complex.

Fig. 11.6 Recopolis: reorganization of the territory, new settlement, and road network. $\quad 226$

Fig. 11.7 The reorganized road system around Recopolis. $\quad 226$

Fig. 12.1 Reverse of a Visigothic tremissis of Theodoric II or Euric in the name of Libius Severus (461-465). $\quad 238$

Fig. 12.2 Visigothic tremissis in the name of Anastasius, with pectoral cross. $\quad 238$

Fig. 12.3 Liuvigild of Toledo, $c .580-582 . \quad 241$

Fig. 12.4 Obverse of a tremissis of Liuvigild (Tarracona), post-584. 241 
Fig. 12.5 Obverse of a solidus of Tiberius II Constantine (578-582). 241

Fig. 12.6 Visigothic crowns: obverse of a tremissis of Wamba of Toledo and obverse of a tremissis of Egica of Toledo.

Fig. 12.7 Visigothic crowns: obverse of a tremissis of Egica (Mentesa) and obverse of a tremissis of Egica (Córdoba) with crown topped by cross.

Fig. 12.8 Visigothic crowns: obverse of a tremissis of Roderic (Egitania).

Fig. 12.9 Visigothic crowns: obverse of a tremissis of Erwig (Emerita).

Fig. 12.10 The image of Christ: relief of Christ with a nimb, church of Quintanilla de las Viñas (Burgos).

Fig. 12.11 The image of Christ: Placa de las Tamujas (Malpica, Toledo).

Fig. 12.12 Obverse of a tremissis of Erwig (Córdoba). $\quad 248$

Fig. 12.13 Tremissis of Agila II of Narbona. 249

Fig. 14.1 Epitaph of Fl. Salutius. $\quad 278$

Fig. 14.2 Epitaph of Florentia and Marcella. 279

Fig. 14.3 Epitaph of Ilpericus. $\quad 287$

Fig. 15.1 Map of the municipalities and necropoleis with PonticDanubian materials north of the Sistema Central. $\quad 304$

Fig. 16.1 Plan of Toledo in the seventh century. 318-319

Fig. 16.2 Sculptural decoration in marble found in Toledo. 320

Fig. 16.3 Location of the main Visigothic archaeological sites in the region of Toledo.

Fig. 16.4 Areal view of the pantheon and all the burials documented in the archaeological site of Los Hitos.

Fig. 16.5 Sacred architecture in the territory of Toledo. 326

Fig. 19.1 Cities that signed peace treaties, according the Arabic chronicles and the lead seals.

Fig. 19.2 Location of the archaeological sites of the municipality of Loja (Granada) cited in the text.

Fig. 19.3 Dirhems minted in al-Andalus before year 756 in hoards documented in the central regions of the Umayyad Empire. 


\section{Abbreviations}

Abbreviations specific to individual chapters are defined in the main text or bibliography.

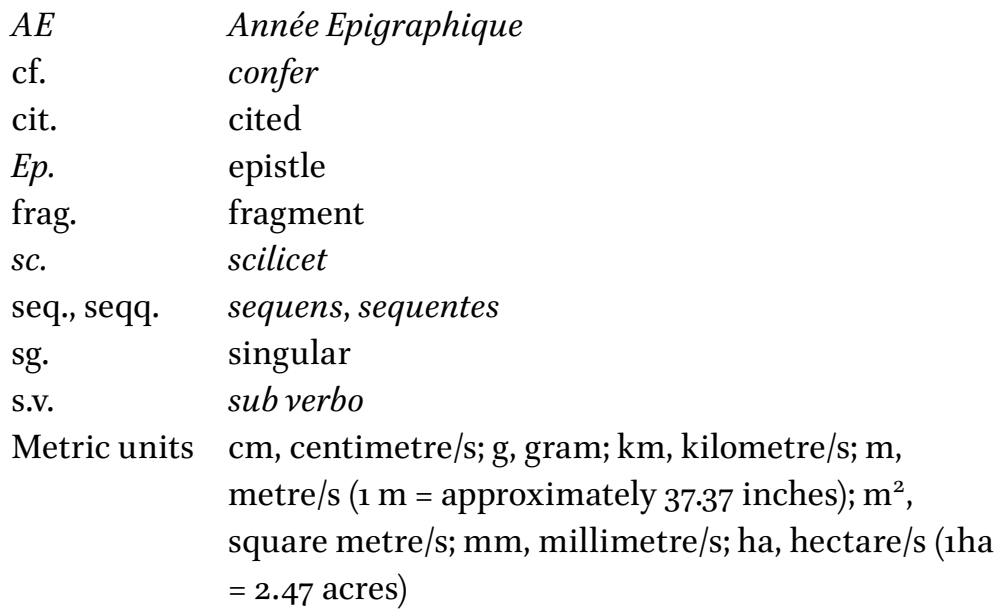





\section{Preface and Acknowledgements}

The fascination of Toledo - the Visigothic kingdom's capital - lies in what little we know of it. The Toletum of late antiquity was superbly defensible due to its size of just 5 ha, its rock formations, and being surrounded by the Tagus river (Tajo). It was well-situated geographically with its roads vital for connecting north to south and northeast to southwest, connecting Barcino (Barcelona), Caesaraugusta (Zaragoza), Hispalis (Seville), and Merida (Mérida), and could thus be easily managed. Economically, Toledo used its position for widespread trade, both for agriculture and the movement of livestock. Toletum is barely known, however, with regard to its urbanism, architectural features, and social structure. What elements are known consist of a few bishops and the churches in which councils are recorded to have taken place: the Basilica of Leocadia outside the walls (today known as Cristo de la Vega) and the church of the Apostles Peter and Paul - also called the ecclesia Praetoriensis - to which the palatium and praetorium were added in the first half of the seventh century. Researchers suspect that the suburbium was developed in this period through residential buildings, while intra muros, in Toletana urbe, an episcopal palace was constructed alongside a basilica dedicated to Mary the Mother of God (now the cathedral). This remodelling and expansion of the town through the type of complexes found in Rome and Constantinople likely shaped the city in the style of an aemulatio imperii.

Indeed, Toledo is all but unknown archaeologically. It may be this invisibility that has furthered both the city's and the kingdom's mythical status. Until three decades ago, little archaeological evidence accompanied the comprehensive documentation, the records from the provincial and general councils, chronicles, legal collections, tracts, biographies and lives of the saints, letters from bishops, monks, and kings, papal decretals, and finally epigraphic monuments such as burial and dedicatory inscriptions. Yet this lack did not prevent the establishment of a narrative for the period from 507 to 711 , the central element of which is the establishment of Toledo's primacy. It has been especially helpful in pinpointing Liuvigild's reign from 569 onwards, as well as Reccared's conversion at the III Council of Toledo in 589 , as preconditions for the glorious period of the reges Visigothorum in the seventh century. However, recent studies, analysing structural developments across epochs and taking into account late antique city foundations (Recopolis, Eio), as well as burial grounds and open-area excavations of rural settlements, raise the question how 'such a fragile construction' could have held together for 200 years. 
Such contradictions plead for knowledge. Toletum, the 'Network for Research about the Iberian Peninsula in Antiquity' (www.toletum-network. com), funded by the Deutsche Forschungsgemeinschaft since 2011, hosts an annual workshop in Hamburg's Warburg-Haus, in which constitutive elements of the Iberian Peninsula's urban world are discussed from the perspective of both ancient and medieval history, classical, provincial Roman, and early Christian archaeology, as well as from the point of view of architectural and Islamic studies. In 2013 the workshop focused on the sculptural embellishment of public and private spaces; in 2014 on the entertainment sites of theatre, amphitheatres, and circuses surrounding places of civic identity; in 2016 on suburbia; and in 2017 on communication paths. While the gatherings had previously concerned the period between the Republic and the year 711, and thus with questions of continuity and change, in recent years transformation processes between the fourth and eighth centuries have come to the fore. It was a logical next step to take Paulo Pachá's suggestion (at that time from the Universidade Federal Fluminense in Rio de Janeiro) and to organize a workshop on 'The Visigothic Kingdom of Toledo: Concepts and Forms of Power', which took place in Hamburg's Warburg-Haus as an international conference from 25 to 27 October 2018. Researchers from Brazil, Germany, France, Great Britain, Italy, Austria, Spain, and the USA discussed negotiations of power in this post-Roman regnum. Themes included the many ways in which power relations were created, transformed, and exerted. Among these themes, some contributors discussed both ideas about central and local power as well as the development of their reciprocal relations in those 200 years. Other papers focused on the crucial links between power and identity - thinking about and beyond of ethnicity -, as well as the diverse ways employed in the Visigothic kingdom of Toledo to represent ideas of and about power. Also discussed was the church's role as a powerful historical agent - albeit a very complex one and constituted by inner divisions and conflicts.

The present volume gathers most of the contributions to this Hamburg conference, supplemented by articles by Jaime Vizcaíno Sánchez, Luis A. García Blánquez, Sebastian Steinbach, Rafael Barroso Cabrera, and Julián M. Ortega Ortega. The editors have reworked the papers presented to reflect the diversity of questions and the form in which they were addressed only in a purely editorial sense; the responsibility for the content and images rests with the respective authors. Finally, the editors want to fulfil the pleasant duty of offering thanks to all those who participated in Toletum IX for their lively and provocative discussions, to Florian Klein (Hamburg) for his help preparing the manuscript for print and for preparing the index, to Timothy 
Wardell (Hopewell, New Jersey) for assistance with copyediting, and to Jamie Wood (Lincoln) for suggesting the 'Late Antique and Early Medieval Iberia' series of the Amsterdam University Press as a home for this volume. The editors also want to thank the anonymous reviewers for their constructive criticism, which helped to improve both individual contributions and the volume as a whole.

As we planned the conference and this collected volume, it seemed natural to us that we would continue our collaboration. However, at the present moment a personal exchange among colleagues at an international conference seems far from possible. The Corona pandemic is not just restricting citizens' fundamental freedoms and leading to the closure of borders, but also to the closing of schools and universities. History shows that humans have found answers to structurally similar challenges, be it the plague under Justinian or the Middle Age's 'Black Death'. Perhaps those solutions can inform us, yet preserving a system for its own sake cannot be a viable one - as the Visigothic kingdom of Toledo exemplifies in an excellent way.

Sabine Panzram and Paulo Pachá

Hamburg - Rio de Janeiro, spring of 2020 



\title{
1 The Visigothic Kingdom of Toledo
}

\author{
Current Perspectives on the Negotiation of Power in \\ Post-Roman Iberia
}

Sabine Panzram

\section{The legacy of history}

Visigothic kings remain present in Madrid to this day. Athaulf, Euric, Liuvigild, Swinthila, and Wamba face each other on the Plaza de Oriente; Gundemar and Chintila can be spotted in the Retiro Park by the 'Paseo de las Estatuas'; Alaric, Reccared II, Erwig, and Theodoric meanwhile grace the balustrade of the royal palace's eastern facade. These carefully crafted, life-size statues of white rock (Piedra de Colmenar), obviously part of some programme, are haphazardly spread across the city, which leads us to the mid-eighteenth century. After Real Alcázar burned to its foundations on New Year's Eve, 1734, ${ }^{1}$ Philipp V charged the Benedictine Martín Sarmiento with developing a new palace design. He saw the destruction of the Arabic residence, previously redesigned by the Trastámara and renovated by the Habsburgs, as an opportunity to fulfil his desire for a new and imposing form of self-display. The Bourbon faced the challenge of combining his French dynasty with the older Spanish one in order to demonstrate legitimacy. By suggesting his so-called Sistema de adornos del Palacio Real (1743), Sarmiento offered a form of display in which sculptures, frescoes, and carpets would complement each other in order to display the Catholic and secular virtues of the Spanish monarchy since antiquity - virtues such as security, strength, continuity, and piety. ${ }^{2}$ The sculptures were to represent the kings - in chronological order - and serve to crown the palace. ${ }^{3}$ They were to be a symbol, visible to all, of sovereignty's continuity, and to

1 Chueca Goitia 1998; Sancho Gaspar 2013.

2 Álvarez Barrientos and Herrero Carretero 2002.

3 Ibid., pp. 244-271.

Panzram, S. and P. Pachá (eds.). The Visigothic Kingdom: The Negotiation of Power in Post-Roman Iberia. Amsterdam: Amsterdam University Press 2020 DOI: 10.5117/9789463720632_CHO1 
transform the palace into a place of remembrance from which Spain could be envisioned (pensar España). ${ }^{4}$ The Benedictine described in detail what the statues were to resemble, their clothing as well as such things as their types of crowns and weaponry. The faces were not be idealized, but true to nature. This enthusiasm for documentation and didactism can be seen in the figures of martyrs, saints, and city patrons, such as San Lorenzo, San Juan de la Cruz, San Isidro, Santa Leocadia, and Santa Teresa, as well as poets such as Martial, Quintilian, and Lucan, and philosophers such as Averroes and Maimonides or 'military types' such as Viriathus, the Cid, and Cortés. ${ }^{5}$ Sarmiento had stones fetched from every quarry in Spain for the construction, so that the representation of the Iberian Peninsula's thirty-two provinces could be realized through a presence from across the kingdom. The elaborate iconographic programme reflects Sarmiento's understanding of his nation's continuity, which was contingent on its territory, geography, and ultimately its history. The didactic impetus is obvious: the Benedictine was convinced of architecture's ability to unleash positive effects in the beholder and educate him through the need for guidance and moral emulation. ${ }^{6}$ When Charles III reached Madrid, in December 1759, he found himself facing a huge construction site. He gave priority to completing the residence, which had been delayed for years, and was able to move in at the end of 1764 . Iconographically, Charles III distanced himself significantly from his predecessors' guidelines. First, he had the statues of all the Spanish kings who had been erected on the facades as part of Sarmiento's programme removed, an order he gave on February 1760, even before his ceremonial entrance to Madrid. They were then distributed across the city's gardens - Plaza de Oriente, Sabatini, Retiro, Glorieta de las Pirámides - with some sent to various cities: Toledo received a few, Burgos, Ronda, Vitoria, Logroño, and San Fernando de Henares others, while Aranjuez, El Ferrol, and Pamplona received a few. Charles was not attempting to make the nation an ideological centre of his sovereignty by didactically instrumentalizing the royal palace. Rather, his rule sought to raise a universal claim by means of eulogies and self-dramatization to harken back to antiquity. The discovery of Herculaneum and Pompeii in the 1740 s was propitious, as it served to validate his buon regno. ${ }^{8}$ The prologue of the luxurious volume Antichità di

6 Santos Puerto 2002; see also Panzram, in press.

7 Morterero 1972, p. 68.

8 Panzram 2012; Pisani 2013. 
Ercolana - which published the paintings, statues, and bronzes - was gifted to members of the European aristocracy, ${ }^{9}$ and celebrated him as Hercules. Charles also secured the services of the notable Anton Raphael Mengs to decorate the royal palace with ceiling frescoes and historic images. ${ }^{10}$ This Dresden court painter's iconography was rooted in an inventory of images related to Trajan. Meanwhile, Charles's generous renovation and beautification, even re-design, of entire neighbourhoods in the capital, ${ }^{11}$ induced Ramón Pignatelli y Moncayo to compare his achievements with those of the first Roman empire - perhaps surpassing Augustus! ${ }^{12}$ Finally, Charles was inspired by the Roman street network when developing his Spanish example. In 1787 he organized the colonization of Sierra Morena, in celebration of which a medal was minted showing him as Romulus, the city founder. ${ }^{13}$ In contrast to Sarmiento, Charles was not concerned with presenting the past as an entirety, as a closed system in order to display a national identity. By referring to antiquity, he modeled an entire epoch as the starting point of socio-political transformations at a time of political conflict and social change, presenting the past as an open frame of reference. ${ }^{14}$

The nineteenth-century nation state was long in search of itself. After the Napoleonic wars, those with political responsibilities in European states strove to accomplish political unity by means of cultural identity. ${ }^{15}$ Questions arose as to whether a nation defined itself more as a state or a culture, whether laws and institutions were the crucial elements by which citizens could govern themselves, or whether a community's members needed to possess the same ethnic culture and history. In any case, the origins of nationalism flourished in parallel with the rise of liberal forces. The founding edict of the Real Academia de la Historia, which Philipp V had founded as early as 1738 in response to universities' untenable conditions, ${ }^{16}$ charged it with 'purging' the nation's fábulas by publishing a Diccionario Histórico-crítico-universal de España, and preparing a 'verdadera Historia

9 Cf. Bayardi, Prodromo delle Antichità d'Ercolano, pts. I-V, 1752, pp. v-xlviii, as well as the praefatio of the introductory volume on the publication of the papyri found in Herculaneum by Carlo Maria Rosini, Dissertationis isagogicae ad Herculanensium Voluminum explanationem, pt. I, 1797 .

10 Roettgen 1999 and 2003; Ehrmann 2010.

11 Moleón Gavilanes 2017.

12 Blech 2009, pp. 355-356.

13 Almagro-Gorbea 2012.

14 Späth 2015.

15 Esdaile 2000; Álvarez Junco 2001; Álvarez Junco and Fuente Monge 2013.

16 Almagro-Gorbea and Maier Allende 2003; Anes y Álvarez de Castrillón 2010. 
Nacional'. ${ }^{17}$ Yet the necessary profession that would establish the search for 'objective truth', with the instrument of positivism, only developed in the course of the nineteenth century. Modesto Lafuente y Zamalloa's Historia General de España desde los tiempos más remotos hasta nuestros días, published in Madrid in thirty books between $185^{\circ}$ and 1866 , became paradigmatic for the developing genre of historical writing. The politically active journalist-historian claimed that he had been motivated by the lack of a national history. Until deep into the twentieth century, his work was accounted 'la historia nacional por antomasia'; ${ }^{8}$ his periodization of Spain's history into edades - 'Antigua, Media, Moderna y Contempóranea' - remains valid to this day. The localization of Spain's transition from antiquity to the Middle Ages in the early eighth century, rather than in the fifth as in the rest of Europe, is due to his work; he considered the Arabic invasion of the Iberian Peninsula of more impact than the fall of the West Roman Empire. He places the beginnings of modernity in the year 1492 and not, as was customary, in 1453 with the fall of Constantinople, and judged the Catholic kings' conquest of Granada, the expulsion of the Jewish inhabitants, and Columbus's discovery of America to be of more significance. And lastly, he did not initiate 'contemporary history' with the French Revolution of 1789 , as was common practice, but rather with the Spanish rebellion against Napoleon's troops in 1808. Even the Spanish nation's founding date, which he cites as the III Council of Toledo in 589 , in the fourth book of his opus magnum, ${ }^{19}$ is still occasionally considered valid. ${ }^{20}$ As such it was the Visigoths who founded Spain as a nation. Lafuente y Zamallao believed that 'Spaniards' had existed before the arrival of Rome, and that it was this culture that 'hispanicized' the Romans and Visigoths and converted the latter to the Catholic faith. It was, however, the Visigoths who created a monarquía española by introducing the relevant institutions. Liberals consider not just political, religious, and territorial unity fundamental, but also the juridical unity gained through the Fuero Juzgo. Councils functioned like a parliament; it was the Hispano-Gothic kingdom in which Spain established its constitutional foundations as those of a 'state'.

17 Sempere y Guarinos, Ensayo de una biblioteca española de los mejores escritores del Reynado de Carlos III, vol. 1, 1787, pp. 63-71. - Almagro-Gorbea 2010.

18 Álvarez Junco and Fuente Monge 2013, esp. 264-283, here p. 265.

19 Lafuente y Zamalloa, Historia General de España desde los tiempos más remotos hasta nuestros días, 1887 .

20 Cañizares Llovera 2008 is an illustrative example. 
The possibility of faithfully reproducing an event - whether contemporary or historical - such as Reccared's conversion found in historical paintings or those awarded at the national fine arts exhibits, which took place from 1856, promoted the development of an artistic style, of which the state became the most important patron. ${ }^{21}$ José Martí y Monsó's Concilio III de Toledo (1892) shows Reccared in a church's apse, evidently at the moment when his conversion was announced to members of the council with Leander's presence. ${ }^{22}$ By royal decree, the picture was hung in the senate on 11 November 1878. In contrast, Antonio Muñoz Degrain's La Conversión de Recaredo (1888) captures the moment in which the Visigothic king swore off Arianism in the presence of his wife, Queen Badda, and Bishop Leander, in St. Leocadia of Toledo's basilica on 8 May 589 . The artist was concerned about the realization of the topic: he believed that 'todo asunto histórico exige [...] un estudio detenido, no sólo de la historia política y social, sino también de los costumbres, la indumentaria, la manera de ser y los detalles más nimios', although he considered his knowledge of the Visigoths limited. ${ }^{23}$ And yet he still executed the piece, as it was a commission that was to grace the senate's Salón de los Pasos Perdidos alongside at least three other pieces: Francisco Pradilla y Ortiz' La rendición de Granada (1882), José Moreno Carbonero's La entrada de Roger de Flor en Constantinopla (1888), and Juan Luna y Novico's El combate naval de Lepanto (1887). The conspectus of these events - Reccared's conversion at the Council of Toledo, Granada's fall, Roger de Flor's march into Constantinople, and the naval battle of Lepanto - as well as the associations they evoked, such as the first political-religious unity, the crown of Aragón's victory in the Mediterranean, the end of the reconquista, unity under the Catholic kings, and the height of imperial power in Europe, created a reference to a 'panegírico del nacionalismo español'. ${ }^{24}$ Not just the senate but also the house of representatives was decorated with historical paintings. The genres of historiography and historical painting reveal the search for, and ultimate spread of, a specific conception of the nation developed through concepts such as autonomy and centralism. An independent Spain was propagated as one that faced its 'invaders' - in Sagunt, Numantia, or Covadonga, in Zaragoza, or on the 2 and 3 May in Madrid; a centralized Spain had its roots in Reccared's conversion, fought for in the

21 Reyero Hermosilla 1989; Díez 1992; Pantorba 1980.

22 López Henares 1980, p. 129; Reyero Hermosilla 1999a.

23 López Henares 1980, pp. 130-131; Díez 1992, pp. 436-437, see also pp. 378-387; Reyero Hermosilla 1999b, p. 29o; cf. Rodríguez García 1966; García Alcaraz 1996.

24 On this, see Reyero Hermosilla 1999c, p. 229; López Henares 1980, pp. 125, 130-131, 132-133, 136-137; Peréz Vejo 2015, esp. pp. 71-77. 
battle of Las Navas de Tolosa, or one won from the Catholic kings, and the 'triumphant' Spain whose discovery of America became a favourite among painters. At the end of the long nineteenth century, the view of the past again embodied a closed system, in which illustrious historical moments served to construct a national identity.

It is not surprising that the declaration of the Spanish nation's founding date should fall in Visigothic times. The history of goticismo began virtually at the moment when the Visigothic kingdom of Toledo was ended by the Umayyad's conquista, i.e. the beginning of the eighth century. ${ }^{25}$ The Christian Asturorum regnum claimed its immediate succession, the Castilian crown viewed itself as part of its tradition, nobles sought to trace their genealogies back to the Visigoths, and artists attempted to visualize Visigothic daily life. Muñoz Degrain's reflections, however, point to the problem that almost no material evidence from the period existed. The interior of St. Leocadia's basilica in La Conversión de Recaredo resembles that of Sant'Apollinare in Classe and the Visigothic royal couple's garments echo those of Justinian and Theodora in San Vitale in Ravenna; ${ }^{26}$ Recceswinth's crown was the only element the painter could base on an original. In 1858 , the so-called treasure trove of Guarrazar surfaced not far from Toledo: votive crowns, crosses, gems made of gold, studded with semi-precious stones and pearls appear as artistic craftsmanship in the Byzantine tradition but were made at Toledo's court. ${ }^{27}$ A number of the twelve crowns and eight crosses went to Paris, but the majority became part of the royal collection. Archaeologist and art historian José Amador de los Ríos, who headed the Real Academia de Historia in Madrid and was responsible for the transfer, described them as representative examples of early medieval, Spanish Catholic art, as the essence of seventh-century Spanish culture. ${ }^{28}$ The treasure trove unleashed a lasting enthusiasm for Visigothic archaeology: Scarcely fifteen archaeological digs were conducted until the 1940 . The research of the 1930s, led especially by the prehistorian Julio Martínez Santa Olalla, following his return to Germany and his appointment as head of the Comisaría General de Excavaciones Arqueológicas, focused on the 'época de las migraciones germánicas'; this was clearly a sign of political alliance with national-socialist Germany. ${ }^{29}$ This association became marginalized after his removal from office in the

Cortés Arrese 2012, esp. pp. 32-43.

7 Perea 2001; Eger 2010; Moreno Martín 2017.

28 Amador de los Ríos 1861, esp. pp. 151-161.

29 Olmo Enciso 1991; Gracia Alonso 2009; Tejerizo García 2017, esp. pp. 123-136. 
50s, with scholars subsequently stressing Christianity's importance for the Visigothic kingdom's development. ${ }^{30}$

The legend of Spain's origins and its unique status was strengthened in following decades. Concepts of unity between church and state were paradigmatically expounded by the universal scholar and intellectual Marcelino Menéndez Pelayo in his Historia de los Heterodoxos españoles in 1877 (concepts that later allowed Franco to build on). Menéndez Pelayo's unity of patria and Catholicism stem from the proselytizing of the apostles, the uniqueness of the Middle Ages in its succession of conquista and reconquista, the strong manifestation of the Counter-Reformation, and the hegemony of a modern, extremely conservative form of Catholicism. ${ }^{31}$ Franco propagated dux Reccared's conversion to Catholicism, which had brought about not just the dominion's territorial unity but also, subsequently, its denominational unity as the origins of the history of a Spain that understood itself as 'one, great, free and Catholic', led by a caudillo. This was accompanied by the privileging of the region of Castile, in which hispanidad had developed in the reconquista period. The scholarly tradition supporting this imaginary was not laid to rest until Franco's death in 1975. Yet even someone in exile such as the historian Claudio Sánchez-Albornoz viewed the Middle Ages as the key epoch. In his significant volume España, un enigma histórico, he located the roots of Spanish identity in ninth-century Asturia, which had regarded itself as the bastion of the last Visigoth kingdom. ${ }^{32}$ An 'historiographical revolution' in the study of Spanish history, and thus of antiquity, was unleashed by the dictator's death. ${ }^{33}$ A democratic Spain, after all, could never utilize what the dictatorship had propagated as an historical benchmark of national identity - the Visigothic period and Castile. Instead, the reference was to Rome - as a Roman province now able to imagine a future as a region within the European community. ${ }^{34}$ The first systematic archaeological digs, begun in the 1980 s in Tarragona, Córdoba, and Mérida, carved their way not just into remnants of the provincial capitals of Roman Hispania, but to Europe as well.

The scientific interest in the Visigothic period was therefore free - without any clear aim such as creating identity, legitimizing socio-political organizational forms, or institutional pressure regarding methodological 
guidelines. ${ }^{35}$ Urban archaeology's activities were linked with a conceptional debate that called into question ancient history's periodization on the Iberian Peninsula and demanded a paradigm change. In 1982, the ancient historian and archaeologist Javier Arce, in his El último siglo de la España romana (284-409), presented sketches of the political, bureaucratic, military, economic, and religious history of a century that had not even counted as worthy of history. $3^{6} \mathrm{He}$ wrote provocatively and critically, demanding an interpretation of the archaeological evidence freed from historiographical transmission. This former interpretation had referred to the latter and had confirmed the dominating interpretational pattern of the so-successfully Romanized Hispanic province's decay and decadence as early as the late third century, instead of its functioning as a correcting force. He postulated continuity, not change - up to and even past 409 AD. He argued that the Hispanic provinces should be inserted into the context of the empire, rather than classifying them as an imperial annexation with no relevance for Rome. The archaeological findings and epigraphic evidence underline the necessity for a shift in perspective, since continuity can be verified for the supposedly 'crisis-laden' third century, while a 'slow change' seems to have dominated the fourth, finally followed by the transformation of urban topographies in the fifth. ${ }^{37}$ The dimensions of the finds made interdisciplinary work the condition sine qua non $3^{38}$ the traditionally separate research of the centuries through different disciplines - i.e. the romanistas jurisdiction over Roman Spain and the mundo germánico specialists for the following centuries - proved obsolete. If archaeologists and construction researchers, epigraphists, and historians (whether of pre-, early, ancient, or medieval history) fail to work together, neither the constructional nor socio-historical developments can be studied à la longue. The centuries after the invasions of the Suebi, Vandals, and Alans in 409, and after the III Council of Toledo in 589 , which scholars had previously viewed as the pre-history of the glorious period of the seventh-century reges Visigothorum, ${ }^{39}$ now became part of the '(post-)history' of the Roman Empire. Only once the years 284, 409, and 589 had lost their status as all-decisive turning points was any analysis of transformation processes from an ancient-history perspective up to the year 711 (and beyond) possible.

37 See also the case studies in Beltrán Fortes and Rodríguez Gutiérrez 2012.

38 For extensive information on this development, see Panzram 2017 and 2019.

39 For example, Orlandis Rovira 1987; García Moreno 1989; Thompson 1969; Collins 2004. 


\section{A paradigm shift, new approaches}

This volume locates itself in this tradition of 'breaking away' and wants to provide a contribution to Visigothic research on the Iberian Peninsula in two respects, thematically and methodologically. Its perspective is that of a young, dynamic research field open to developments at the intersection between late antiquity and the early Middle Ages that has been developing internationally since the 199os and consistently works in an interdisciplinary manner. Thematically, the 'negotiations of power' point to the revision of a central category - 'power' - which has traditionally been used to postulate the establishment of Toledo's hegemony, yet has failed to explain why the central power's expansion went hand in hand with a weakening of its hegemonic structures, which made possible the Umayyad's conquista. On the basis of an understanding of 'power' in the sense of Max Weber, these contributions seek to understand afresh the relationship between the centre and the periphery, between the monarch and the aristocracy, by positing agency for everyone involved in this process and inquiring into its realization. Methodologically, this volume is breaking new ground by taking seriously the Mediterranean world's unity from Marcus Aurelius to Muhammad, already postulated by Peter Brown in the early 1970s, and implementing it on the foundation of new approaches to periodization. If one sets the 'long late antiquity' as one's period of study, ${ }^{40}$ then it is only consistent to examine the causes of the 'power question' in the Visigothic period from Roman late antiquity to the time of the Umayyads, in order to critically question the current debate about the end, change, continuity, or transformation of Roman antiquity. ${ }^{41}$

The contributions that accept this challenge of revising the traditional narrative come from four different research fields - 'Concepts of Central and Local Power', 'Power, Identity, and Ethnicity', 'Representations of Power', 'Power and Church'. They are introduced with a prologue by Laurent Brassous and concluded with an epilogue by Julián M. Ortega Ortega, with Paulo Pachá finishing with an analysis of this thematic and methodological shift in perspective. The picture the classical archaeologist Laurent Brassous paints of the Iberian Peninsula 'the day before', that is, before the arrival

40 Brown 1971; cf. the more recent Brown, Bowersock, Cameron et al. 1997; Cameron 2002; Marcone 2008.

41 A convincing narrative of the Iberian Peninsula in the 'long late antiquity' can be found in Arce's trilogy of Arce 2007, 2011; see also, now, the archaeological perspective of Martínez Jiménez, Sastre de Diego, and Tejerizo García 2018. 
of Germanic ethnicities in the early fifth century, in many ways points to the Hispania of the imperial period, but in others to post-Roman Iberia. The constituents of Rome's power - those approximately 400 cities - continued to function as references; they retained their traditional acceptance of agency and at most gradually adapted to the unique aspects of their region. Their respective hinterlands continued to determine the territory's division; their elites dominated political discourse and occupied key positions in the socio-economic constellation. The cities neither decadently crumbled in the 'crisis of the third century', nor did they suffer from the 'barbarian' invasions and be eleminated by the Vandals, Visigoths, and other ethnicities. Their strength and importance as carriers of sovereignty remained unbroken in these centuries. Their urbanism was characterized, not by destruction, but transformation; their social elites' functions, not by change, but continuity. Confronted by this new picture, which the archaeological evidence especially suggests, the ancient history scholar Javier Arce takes a detailed look at the arrival and settlement of the Visigoths, in the first article from the 'Concepts of Central and Local Power' research field. He utilizes literary findings to ask not just when and how many came, but for what reasons, where and how they settled, as well as who they actually were. He believes they were a poly-ethnic grouping - thanks to the length of their migration and their stay in Aquitania (more than a hundred years) - and argues that it is hardly possible to speak of Goths in Hispania. They fully took on the 'Roman way of life' in the sixth and seventh centuries, while only the elite retained any awareness of a Gothic identity. The archaeologists Jaime Vizcaíno Sánchez and Luis A. García Blánquez also question the established consensus, in this case in relation to the Visigoths' territorial spread. New findings from graves in Senda de Granada (Murcia), in the vicinity of the Roman provincial capital Carthago Nova, suggest that Visigoths settled in southeastern Hispania as early as the late fifth century. Researchers have so far assumed that they only arrived in the context of the Byzantine expansion in the mid-sixth century. Paulo Pachá and Sebastian Steinbach both examine questions of challenges of central and local power, Pácha with a focus on the bishops and Steinbach through the example of the military. The ancient historian Paulo Pachá argues that the councils called in by the Visigothic church from 400 AD onward in Toledo served one primary function - to politically integrate the local powers, which at that time were mostly the episcopal sovereignties that had politically established themselves in the cities. Using the example of Mérida, Seville, and Córdoba he utilizes an analysis of the council records to show that the bishops relinquished their political independence in the course of the seventh century. Yet this attitude was not the result of any 
imposition by Toledo, but the product of a negotiation process between the powers that had been going on for centuries. The medieval historian's case study of the magnate Paulus's rebellion against King Wamba in 673 shows that strong separatist efforts nevertheless existed in the empire: Paulus knew that Septimania and Tarraconensis were behind him. However, Julian of Toledo's description of the events leaves no doubt of the rightful king's victory, who also practised clementia and refrained from executing the rebels.

The contributions from the second research field -'Power, Identity, and Ethnicity' - take up the current debate about identity and ethnicity, focusing on power relations in the Visigothic kingdom. Herwig Wolfram, medievalist, questions how one could stay Gothic without a Gothic king and answers 'by looking for a new one' - a Gothic magnate, a foreign king, or else the Roman emperor. A series of factors had proven decisive for the formation of identity, factors such as the lex Gothica, which guarantied juridical and socio-economic status, language, faith, and more, but not only a monarchical institution. Manuel Koch, an ancient historian, answers the question of who the Visigoths in the kingdom of Toledo were on the basis of a case study of the Vitas Sanctorum Patrum Emeretensium, written around 635. Although researchers have traditionally assumed that the ethnic grouping of Visigoths ruled as elites over Hispano-Romans nominating such characteristics as names, religion, and laws, recent scholarship has shown that this supposed ethnic boundary dissolved quickly, if it ever existed at all. The term 'Gothus' manifested an awareness of a Visigothic identity, but one that rested not on genealogy but through membership in the kingdom's social and political elite. That is, one was not part of the elite because one was Gothic, but one could become Gothic if a member of the elite. Lastly, Christoph Eger postulates the existence of a Visigothic kingdom without Visigoths. The pre-historian postulates this on the basis of a revision of archaeological findings: the grave fields of Meseta. Although the burials there cannot be wholly identified with a Visigothic ethnic identity, elements of the garb and burial practices should be taken as evidence of the presence of emigrated barbarians, at least in the occupancy's early phase. This, he argues, questions not just what relationship existed between them and the Visigoths, but what we actually know about clothing and its significance in Visigothic Hispania: who wore or could wear certain garb of foreign provenance. These questions turned the examination of the so-called Visigothic grave fields of Meseta into a challenge, one that must be faced if one is to adequately grasp its historic significance. Javier Martínez Jiménez moves this array of questions to urban contexts. The classical archaeologist postulates the existence of a civic identity as a form of self-representation beyond any ethnic duality, one 
more attractive because it was open and integrating rather than closed and exclusive, and thus open to change. Urban communities, he argues, were ultimately more significant social groupings than ethnically rooted ones. For a fundamental understanding of how the Visigothic state functioned, he suggests replacing Gothic-Roman duality with that of monarchy-citizen.

While the first two section's contributions ask how power was negotiated and how the Visigoths manifested these structures in their relationships with various social groupings, the third section is concerned with the reproduction of power in representative forms: the organization of a landscape, the minting of coins, the development of a literary form, and the development of an 'epigraphic habit'. The archaeologist Lauro Olmo Enciso shows that the new founding of Recopolis in $578 \mathrm{AD}$ signified a political act, a demonstration of power in a moment of political consolidation and the development of a tax system. However, the city's founding also re-structured the territory through the installation of a new road network, rural settlements, and the reorganization of the agrarian system. Recopolis was to become the region's dynamic urban centre for almost two and a half centuries, uniting political, administrative, and fiscal functions, and 'disciplining' the landscape as a social space. Liuvigild doubly manifested his power. As a numismatician, Ruth Pliego lays out the various possibilities for depicting power offered through the minting of coins. The Visigoths' minting hewed closely to that of Rome; they imitated and transformed Roman iconography with innovative characteristics that reflect the regnum's development in the years from the first settlement to the Ummayad conquista from around 418 to about 71. The tremissis first consisted of romanitas (Victory motif), but then adopted Christian motifs (such 'Cross-on-steps' motif) revealing a desire to express 'sanctified' power. The emergence of a specific type of literature proves as significant as that of city founding and coin minting: Michael J. Kelly analyses the Liber Iudiciorum (also known as the Lex Visigothorum) that Recceswinth enacted in 653 as a 'legal-literary text'. The medieval historian postulates that this body of laws represents a literary character, part of a historical narrative inherent to law. He compares two versions of this narrative - those of Recceswinth and Ervig - and how strongly these depended on concrete historic circumstances, as the Liber Iudiciorum is significant not just as a juridical text but also as a historical narrative. In addition to the power of individual books stood that of inscriptions both in public and in restricted spaces. The epigraphist Javier de Santiago Fernandéz shows how the Visigothic kingdom's elites - both ecclesiastical and civil - used epigraphic monuments for the purposes of self-representation. Both sought to display their privileged social position in the medium of grave, construction, 
or dedicatory inscriptions, thus building on Roman tradition. Workshops made use of traditional techniques, using iconographical elements but also occasionally composing the texts in verse to draw reader's attention. Different forms of representing power have their own codes and specific impacts. A city founding or an epigraphic monument is always both a representative form of power and a given power relationship.

These forms of power are equally true for the institution of the church, whose relationship the fourth research field - 'Power and Church' - addresses. The prehistorian Rafael Barroso Cabrera examines the relationships between political power and episcopal authority in the early Visigothic kingdom of Toledo, positing the significance of Theudis for its genesis instead of what researchers have usually attributed to Liuvigild's military successes and Reccared's political talent. Although Theudis did not succeed in establishing a kingdom within the diocesis Hispaniarum's borders, his cooperation with the bishops first made Toledo into the Carthaginensis's metropolitan seat and then gave it primacy over Hispania. Isabel Sánchez Ramos and Jorge Mórin de Pablos examine the capital from an archaeological perspective and trace both the city's administrative and its ecclesiastical topography (officium palatinum, praetorium/episcopal see of St. Mary, the ecclesia praetorensis of the Holy Apostles Peter and Paul, and the martyrial basilica of St. Leocadia). They also make reference to the surrounding land's villae (Los Hitos, Melque, and Guarrazar), to monasteries known only from literary transmissions, but also to so-called private churches. They argue Byzantium's influence on architecture and sculptures to a greater extent than has been usual. The classical philologist Markus Mülke's article on Martin of Braga refers to the Visigothic kingdom as a member of diverse networks. The bishop of Dumio and Bracara, who guided the Arians to the Catholic faith, was held up as a model for Suebi and Visigoths alike for his fides catholica, due to classic tradition and, spatially, to his relationship to Gaul, Rome, and Constantinople. His 'internationality', rooted in his literary production (Capitula Martini, Apophthegmata Patrum, De trina mersione, De ira, and the three extant pieces of verse), differed significantly from that of his contemporaries. Finally, the ancient historian Jamie Wood examines bishops as key figures in the transition from Roman to post-Roman Hispania. He compares bishops in Byzantine with those in Visigothic Spain. Both, he argues, fought for authority and secured external help. This, however, was less about defending themselves from external oppression and more about pressure coming from various parties within their own cities. He writes that episcopal elections are particularly well suited to revealing the potential fragility of local power structures. His analysis of the Vitas Sanctorum 
Patrum Emeritensium, as well as of several letters exchanged between Pope Gregory I and John, Byzantium's representative in Spania, make clear that bishops were forced to permanently negotiate their positions - between church and state, between central and local powers.

For 'the day after' the Ummayads conquered the Iberian Peninsula, the Islamic scholar Julián M. Ortega Ortega paints a picture of the affected regions that has next to nothing to do with the 'savage kingdom' (regnum efferum) spoken of in an anonymous chronicle from 754. Instead, events such as the distribution of booty, the closure of agreements, the distribution of land to veterans, and the establishment of a tax system indicate the complexity of a system of distribution that was the result of an elaborate process of negotiation. The locus lay in negotiating power not just between conquerors and the conquered, but also between various groupings (Arabs and Berbers, the army and the emirates, the emirates and the caliphs).

\section{Bibliography}

\section{Primary sources}

Bayardi, Ottavio Antonio, Prodromo delle Antichità d'Ercolano (Naples: Regale Stamperia Palatina, 1752).

Lafuente y Zamalloa, Modesto, Historia General de España desde los tiempos más remotos hasta nuestros días, vol. 2 (Barcelona: Montaner y Simón, 1887).

Rosini, Carlo Maria, Dissertationis isagogicae ad Herculanensium Voluminum explanationem (Naples: Regia typographica, 1797).

Sempere y Guarinos, Juan, Ensayo de una biblioteca española de los mejores escritores del Reynado de Carlos III, vol. 1 (Madrid: Imprenta Real, 1787; repr. Madrid: Gredos, 1969).

\section{Secondary sources}

Almagro-Gorbea, Martín, 'La arqueología en la política cultural de la corona de España en el siglo XVIII', in Corona y arqueología en el Siglo de las Luces, ed. by Martín Almagro-Gorbea and Jorge Maier Allende (Madrid: Patrimonio Nacional, 2010), pp. 34-46.

_ , 'La arqueología en la política cultural de la corona de España en el siglo XVIII', in De Pompeya al Nuevo Mundo: la corona española y la arqueología en el siglo XVIII, ed. by Martín Almagro-Gorbea and Jorge Maier Allende (Madrid: 
Real Academia de Historia, Publicaciones del Gabinete de la Real Academia de la Historia, Antiquaria Hispánica 23, 2012), pp. 17-31.

Almagro-Gorbea, Martín, and Jorge Maier Allende, 'La Real Academia de la Historia y la Arqueología española en el siglo XVIII', in Illuminismo e ilustración: le antichità e i loro protagonisti in Spagna e in Italia nel XVIII secolo, ed. by José Beltrán Fortes, Beatrice Cacciotti, Xavier Dupré i Raventós, and Beatrice Palma Venetucci (Rome: L'Erma di Bretschneider, Bibliotheca Italica, Monografías de la Escuela Española de Historia y Arqueología en Roma 27, 2003), pp. 1-27.

Álvarez Barrientos, Joaquín, 'Monarquía y "Nación Española” en el Sistema de adornos del Palacio Real de Madrid, de Martín Sarmiento', in Fénix de España: modernidad y cultura propia en la España del siglo XVIII (1737-1766); homenaje a Antonio Mestre Sanchis, ed. by Pablo Fernández Albadalejo (Madrid: Marcial Pons, 2006), pp. 191-213.

Álvarez Barrientos, Joaquín, and Concha Herrero Carretero, eds., Martín Sarmiento: Sistema de adornos del Palacio Real de Madrid (Madrid: Sociedad Estatal de Conmemoraciones Culturales, 2002).

Álvarez Junco, José, Mater dolorosa: la idea de España en el siglo XIX (Madrid: Taurus, 2001).

Álvarez Junco, José, and Gregorio de la Fuente Monge, 'La evolución del relato histórico', in Las historias de España: visiones del pasado y construcción de identidad, ed. by José Álvarez Junco (Barcelona: Editorial Crítica, Historia de España 12, 2013), pp. 5-437.

Amador de los Ríos, José, El arte latino-bizantino en España y las coronas visigodas de Guarrazar - ensayo histórico crítico (Madrid: Imprenta Nacional, 1861).

Anes y Álvarez de Castrillón, Gonzalo, 'La Real Academia de la Historia: sus orígenes y actividades en el Siglo de las Luces', in Corona y arqueología en el Siglo de las Luces, ed. by Martín Almagro-Gorbea and Jorge Maier Allende (Madrid: Patrimonio Nacional, 2010), pp. 125-133.

Arce, Javier, El último siglo de la España romana: bárbaros y romanos en Hispania, 40o-507 A.D. (Madrid: Alianza, 2007).

—_ El último siglo de la España romana (284-409), 2nd rev. ed. (Madrid: Alianza Ensayo, 2009 [1982]).

—_ Esperando a los árabes: los visigodos en Hispania (507-711) (Madrid: Marcial Pons, 2011).

Beltrán Fortes, José, and Oliva Rodríguez Gutiérrez, eds., Hispaniae urbes: investigaciones arqueológicas en ciudades históricas (Seville: Editorial Universidad de Sevilla, Historia y Geografía 203, 2012).

Blech, Michael, 'Madrid und die Antike: von den Anfängen bis ins 20. Jahrhunderte; ein Versuch', in Spolien im Umkreis der Macht/Spolia en el entorno del poder: 
internationale Tagung, Toledo 2006, ed. by Thomas G. Schattner and Fernando Valdés Fernández (Mainz: Philipp von Zabern, Iberia Archaeologica 12, 2009), pp. 337-397.

Bowes, Kim D., and Michael Kulikowski, 'Introduction', in Hispania in Late Antiquity: Current Perspectives, ed. by Kim D. Bowes and Michael Kulikowski (Boston: Brill, Medieval and Early Modern Iberian World 24, 2005), pp. 1-26.

Brown, Peter, The World of Late Antiquity from Marcus Aurelius to Muhammad (London: Thames \& Hudson, Library of European Civilization, 1971). , Glen W. Bowersock, Averil Cameron, Elizabeth A. Clark, Albrecht Dihle, Garth Fowden, Peter Heather, Philip Rousseau, Aline Rousselle, Hjalmar Torp, and Ian Wood, 'The World of Late Antiquity Revisited', Symbolae Osloenses 72 (1997), pp. 5-9o.

Cameron, Averil, 'The “Long” Late Antiquity: A Late Twentieth Century Model', in Classics in Progress: Essays on Ancient Greece and Rome, ed. by Timothy P. Wiseman (Oxford: British Academy, 2002), pp. 165-191.

Cañizares Llovera, Antonio, El esplendor visigótico, momento clave en la edificación de España y para su futuro: discurso leído el día 24 de febrero de 2008 en el acto de su recepción pública y contestación por el Excm. Sr. D. Luís Suárez Fernández (Madrid: Real Academia de Historia, Discursos, 2008).

Chueca Goitia, Fernando, El Palacio Real de Madrid (Barcelona: Lunwerg/Patrimonio Nacional, 1998).

Collins, Roger, Visigothic Spain: 409-711 (Malden, MA: Blackwell, 2004).

Cortés Arrese, Miguel, Los visigodos de los románticos (Madrid: Los Libros de la Catarata, 2012).

Díaz-Andreu García, Margarita, 'Theory and Ideology in Archaeology: Spanish Archaeology under the Franco Régime', Antiquity 67 (1993), 74-82.

- 'Archaeology and Nationalism in Spain', in Nationalism, Politics and the Practice of Archaeology, ed. by Philip L. Kohl and Clare Fawcett (Cambridge: Cambridge University Press, 1995), pp. 39-56.

Díaz-Andreu García, Margarita, and Manuel Ramírez Sánchez, 'Archaeological Resource Management under Franco's Spain: The Comisaría General de Excavaciones Arqueológicas', in Archaeology under Dictatorship, ed. by Michael L. Galaty and Charles Watkinson (New York: Springer, 2004), pp. 109-130.

Díez, José Luis, La pintura de historia del siglo XIX en España (Madrid: Museo del Prado, 1992).

Eger, Christoph, 'Guarrazar', in El tiempo de los 'bárbaros': pervivencia y transformación en Galia e Hispania (siglos V-VI d.C.), ed. by Jorge Morín de Pablos, Jorge López Quiroga, and Artemio Martínez Tejera (Alcalá de Henares: Museo Arqueológico Regional, Zona Arqueológica 11, 2010), pp. 563-565. 
Ehrmann, Eva, Giovanni Battista Tiepolo und Anton Raphael Mengs: Deckenmalerei am königlichen Hof in Madrid zwischen Barock und Klassizismus (Saarbrücken: VDM Dr. Müller, 2010).

Esdaile, Charles J., Spain in the Liberal Age: From Constitution to Civil War, 1808-1939 (London: John Wiley \& Sons, 2000).

García Alcaraz, Ramon, Antonio Muñoz Degrain (Valencia, 184o-1924, Málaga) (Madrid: Caja de Madrid, 1996).

García Moreno, Luis Agustín, Historia de España visigoda (Madrid: Ediciones Cátedra, 1989).

Gracia Alonso, Francisco, La arqueología durante el primer franquismo (1939-1956) (Barcelona: Ediciones Bellaterra, 2009).

Kamen, Henry, Del imperio a la decadencia: los mitos que forjaron la España moderna (Madrid: Ediciones Temas de Hoy, 2006), pp. 121-152.

Linehan, Peter, Historia e historiadores de la España medieval (Salamanca: Ediciones de la Universidad de Salamanca, Acta Salmanticensia, Estudios Históricos y Geográficos 150, 2012).

López Henares, Jose Luis, ed., El Palacio del Senado (Madrid: Senado, 1980).

Marcone, Arnaldo, 'A Long Late Antiquity? Considerations on a Controversial Periodization', Journal of Late Antiquity 1.1 (2008), pp. 4-19.

Martínez Jiménez, Javier, Isaac Sastre de Diego, and Carlos Tejerizo García, The Iberian Peninsula between 300 and 850: An Archaeological Perspective (Amsterdam: Amsterdam University Press, Late Antique and Early Medieval Iberia, 2018).

Menéndez Pelayo, Marcelino, Historia de los Heterodoxos españoles, 8 vols., vol. 6: Heterodoxia en el siglo XIX, ed. by Enrique Sánchez Reyes (Madrid: 1880-1882); repr. Edición Nacional de las obras completas de Marcelino Menéndez Pelayo, vol. 40, ed. by Ángel González Palencia (Santander: Aldus, 1948).

Moleón Gavilanes, Pedro, 'La nueva imagen de Madrid: urbanismo y arquitectura en tiempos de Carlos III', in Carlos III y el Madrid de las Luces, ed. by Carlos Martínez Shaw and Marina Alfonso Mola (Madrid: Ayuntamiento de Madrid, 2017), pp. 51-75.

Moreno Martín, Francisco José, 'Visigoths, Crowns, Crosses, and the Construction of Spain', Memoirs of the American Academy in Rome 62 (2017), pp. 41-64.

Morterero, Conrado, 'Documentos del Padre Sarmiento para el adorno exterior del Palacio Real de Madrid', Reales Sitios 9 (1972), pp. 57-68.

Olmo Enciso, Lauro, 'Ideología y arqueología: los estudios sobre el periodo visigodo en la primera mitad del siglo XX', in Historiografía de la arqueología y de la historia antigua en España (siglos XVIII-XX): congreso internacional, Madrid 1988, ed. by Javier Arce and Ricardo Olmos Romera (Madrid: Instituto de Conversación y Restauración de Bienes Culturales, 1991), pp. 157-160.

Orlandis Rovira, José, Época visigoda (409-711) (Madrid: Gredos, Historia de España $4,1987)$. 
Pantorba, Bernardino de, Historia y crítica de las exposiciones nacionales de bellas artes celebradas en España (Madrid: J. Ramón García-Rama, 1980).

Panzram, Sabine, 'The Rediscovery of Herculaneum and Pompeii, Carlos III and Winckelmann - A "Rey Arqueólogo" and a Polemical Intellectual, Fighting Just Because of ...?', in Vek Prosveščenija/Le siècle des lumières, vol. 4: L'Héritage de l'antiquité dans la culture européenne du XVIII' siècle, ed. by Sergej Karp (Moscow: Naouka, 2012), pp. 116-139. , ed., OPPIDUM-CIVITAS-URBS. Städteforschung aufder Iberischen Halbinsel zwischen Rom und al-Andalus (Berlin: LIT, Geschichte und Kultur der Iberischen Welt 13, 2017).

— ed., The Power of Cities: The Iberian Peninsula from Late Antiquity to the Early Modern Period (Leiden: Brill, The Medieval and the Early Modern Iberian World 70, 2019).

— - 'De l'utilité de l'antiquité pour l'auto-représentation du souverain: le Palacio Nuevo à Madrid et l'ancienne Rome entre Philippe V et Charles III', in Roma aeterna moderna: les Romes nouvelles de l'époque moderne; coloque international, Grenoble 2017, ed. by Gilles Montègre and Martin Wrede (Rennes: in press).

Perea, Alicia, ed., El tesoro visigodo de Guarrazar (Madrid: Universidad Castilla La Mancha, 2001).

Peréz Vejo, Tomás, España imaginada: historia de la invención de una nación (Barcelona: Galaxia, 2015).

Pisani, Salvatore, 'Die Entdeckung von Herkulaneum und Pompeji und ihre politische Bedeutung für das Königreich Beider Sizilien', in Jenseits von Pompeji: Faszination und Rezeption; internationales Symposium, Saarbrücken 2007, ed. by Carola Reinsberg and Felicia Meynersen (Mainz: Philipp von Zabern, 2013), pp. 22-32. Porcel, Baltasar, 'Roma a Catalunya: una realitat d'ahir i una lectura d'avui', in Roma a Catalunya, ed. by Marc Mayer Olivé (Barcelona: Institut Català de la Mediterrània, 1992), pp. 7-9.

Reyero Hermosilla, Carlos, La pintura de historia en España: esplendor de un género en el siglo XIX (Madrid: Cátedra, 1989).

—_, 'José Martí y Monsó (1839-1912), Concilio III de Toledo (1862)', in El Arte en el Senado, ed. by Pilar de Miguel Egea, Trinidad de Antonio, and Carlos Reyero Hermosilla (Madrid: Servicio de Senado, 1999a), pp. 278-279.

— - 'Antonio Muñoz Degrain (1840-1924), “La conversión de Recaredo” (1888)', in El Arte en el Senado, ed. by Pilar de Miguel Egea, Trinidad de Antonio, and Carlos Reyero Hermosilla (Madrid: Servicio de Senado, 1999b), pp. 290-292.

— - 'La pintura de Historia', in El Arte en el Senado, ed. by Pilar de Miguel Egea, Trinidad de Antonio, and Carlos Reyero Hermosilla (Madrid: Servicio de Senado, 1999c), pp. 219-235. 
Rodríguez García, Santiago, Antonio Muñoz Degrain, pintor valenciano y español (Valencia: Institución Alfonso el Magnánimo, Cuadernos de Arte 17, 1966).

Roettgen, Steff, Anton Raphael Mengs 1728-1779, 2 vols., vol. 1: Das malerische und zeichnerische Werk (Munich: Hirmer, 1999).

, Anton Raphael Mengs 1728-1779, 2 vols., vol. 2: Leben und Wirken (Munich: Hirmer, 2003).

Sánchez-Albornoz, Claudio, España, un enigma histórico (Buenos Aires: Editorial Sudamericana, 1956).

Sancho Gaspar, José Luis, 'Los Sitios Reales españoles bajo Felipe V como espacios de representación y sociabilidad cortesana (1744-1746)', in La corte de los Borbones: crisis del modelo cortesano, 3 vols., vol. 3, ed. by José Martínez Millán, Concepción Camarero Bullón, and Marcelo Luzzi Traficante (Madrid: Polifemo, 2013), pp. 1865-1913.

Santos Puerto, José, Martín Sarmiento: ilustración, educación y utopía en la España del siglo XVIII, 2 vols. (La Coruña: Fundación Pedro Barrié de la Maza, 2002).

Späth, Thomas, 'Provincializing Antiquity? Uses of the Past Compared', in Uses and Perceptions of the Past in South Asia, Mesoamerica, and Europe, ed. by Ute Schüren, Daniel Marc Segesser, and Thomas Späth (Berlin: Reimer, 2015), pp. 319-337.

Tejerizo García, Carlos, 'Arqueología y nacionalismo en (el) movimiento: apuntes sobre la arqueología de época visigoda durante el segundo franquismo', ArqueoWeb 17 (2016), pp. 144-162.

— - 'Nazis, visigodos y Franco: la arqueología visigoda durante el primer franquismo', in El franquismo y la apropiación del pasado: el uso de la historia, de la arqueología y de la historia del arte para la legitimación de la dictadura, ed. by Francisco José Moreno Martín (Madrid: Editorial Pablo Iglesias, 2017), pp. 107-136.

Thompson, Edward A., The Goths in Spain (Oxford: Oxford Clarendon Press, 1969). Wulff Alonso, Fernando, and Manuel Álvarez Martí-Aguilar, eds., Antigüedady franquismo (1936-1975) (Málaga: CEDMA, 2003).

\section{About the author}

Sabine Panzram is Professor of Ancient History at Hamburg University (Germany). She focuses on social history of power in the Western Mediterranean, and in particular on urban history in the Iberian Peninsula. Currently she is preparing a study on Christendom without the Church: The Genesis of an Institution in the Dioecesis Hispaniarum (4th to 7 th centuries). 



\section{The Day Before - Prologue}





\title{
$2 \quad$ Late Roman Spain
}

\author{
Laurent Brassous
}

\begin{abstract}
This chapter offers a summarized overview of late Roman Spain, especially during the fourth century AD. The break between Roman Spain and the world of the barbarian kingdoms was not as sudden and brutal as scholars have traditionally imagined. Roman Hispania dissolved gradually, in a process that seems to have been spread over several decades. The new barbarian kingdom adopted numerous features of the Roman provincial organization and civilization. In order to give this summarized and updated picture, this chapter will discuss various elements, paying particular attention to the historiographical background and current scholarship debates and issues of each. The chapter will finally attempt to give a general point of view on the current interpretation of the economics and society of late Roman Spain.
\end{abstract}

Keywords: Roman Spain; late antiquity; invasion; barbarian kingdom; society; economy

The history of Hispania after the installation of the Germanic peoples was built on the substratum of the last Roman world. This contribution proposes a synthetic picture of late Roman Spain before the great changes provoked by the affirmation of Visigothic power and the foundation of the kingdom of Toledo, in order provide an understanding of the origin and forms of this new state. The title of this section is simply a synecdoche. Its aim was not to draw a picture of the precise day before the disappearance of Roman Spain. The exercise would have been pleasing, but the reality of the facts does not allow it. Indeed, would it have been necessary to consider the day before the founding of the kingdom of Liuvigild in 569 , the day before the victory of Theodoric over the Suevi in 456, the day before the entrance of Athaulf and his troops in 411, or, more traditionally, the day before the ingress of

Panzram, S. and P. Pachá (eds.). The Visigothic Kingdom: The Negotiation of Power in Post-Roman Iberia. Amsterdam: Amsterdam University Press 2020 DOI: $10.5117 / 9789463720632 \_$CHO2 
Alans, Suevi, and Vandals into Hispania in 409? Is it nevertheless relevant to produce a picture of such a precise date? This process would inevitably lead to setting a historical periodization whose defects are well known. It has been demonstrated for some years that the break between Roman Spain and the world of barbarian kingdoms was not as sudden and brutal as such a precise date might suggest. Roman Spain indeed gradually dissolved, a process that seems to extend over several decades. It is possible to discuss the duration of this process according to the markers used to gauge this transition period. According to Arce, the fifth century is a long century of transition, marked in many areas by important processes of continuity in the administrative, economic, or cultural domains. ${ }^{1}$ He lends to the barbarians a role in the conservation of the Roman way of life. Others consider a rapid transition with more changes: for Le Roux, the apparent conservation of structures, such as the provincial frameworks, can't disguise the evolution of power relations or regional balances. ${ }^{2}$ These different points of view partly reflect a more general debate about the end of the Roman Empire, on the brutality of its disappearance, or its long decomposition. ${ }^{3}$ Rather than enter into this debate, we will propose, more modestly, a synthetic picture of Roman Spain in the fourth century before its dissolution into the barbarian kingdoms. Arce's book El último siglo de la España romana, written almost four decades ago, provided an enduring new vision of late Roman Spain. Since its publication, many studies have been done on this period. It would be difficult to give an inventory here, but let us consider two useful syntheses, one of Teja and the other of Bowes and Kulikowski. ${ }^{4}$

The difficulty in making a history of late Roman Spain is not due to the scarcity of sources, but to their changing nature. Archaeological data, more numerous each day, are diverse and more precise, ${ }^{5}$ but remain raw material open to interpretation. On the other hand, in the historian's workshop, codes of law or Christian texts surpass epigraphic documentation, but reflect a different state. While the epigraphic documentation celebrates local and civic successes, the codes of law testify globally to a world dominated by the state, which appears more constraining and repressive. So, the set of data does not provide an exhaustive or always coherent picture. The interpretation of these sources differs according to the authors, their own

1 Arce 2005.

2 Le Roux 2010.

3 Ward-Perkins 2006 vs. Brown 1971.

4 Teja 2002; Bowes and Kulikowski 2005.

5 Rodríguez Gutiérrez 2011. 
history, and academic traditions. Given these limitations, what picture is it possible to draw of late Roman Spain?

At the end of the fourth century, praising the Spanish emperor Theodosius, the rhetorician Pacatus celebrates the wealth of Hispania, terra omnibus terra felicior ('a land more fortunate than all the others'). ${ }^{6}$ The depiction, however, seems too laudatory to be faithful. More measured, although marked by topoi, is the image left at the beginning of the second half of the fourth century by the Expositio totius mundi et gentium, which recalls the base of Hispanic economic exportation: oil, fish sauce, clothing, lard, and horses. ${ }^{7}$ Extensive archaeological data studied by P. Reynolds confirm the importance in the fourth century of agricultural and artisanal production on the peninsula, and the trade to which it gave rise. ${ }^{8}$ In the fourth century, economic activity undoubtedly benefited by the absence of major conflict. Nevertheless, the relative contribution of Hispania to the economy of the late empire remains difficult if not impossible to quantify. The land and its exploitation remained the base of economic activity with a large portion of the production destined for local consumption, if not regional. Any surpluses available were used to pay taxes collected by the state and communities and then exported. Occasionally, some regions or cities participated in a wider trade, beyond the peninsula, not only with Rome but with other major cities and provinces of the empire. The exportation of oil seems to have decreased. On the contrary, fish sauce and salted fish were better distributed. Areas less oriented towards the Mediterranean, such as the northwest of the peninsula, were more protected from African competition, and developed and exported their own production of fine ware. ${ }^{9}$ Agriculture, however, remained the base of the economy and the villa remained the frame of production. Well-known examples reflect the diversity of changes affecting the rural environment. ${ }^{10}$ The most luxurious residential villas coexisted with small rural and productive establishments. It seems difficult though to link in a systematic way their development to each other, or to an alleged escape of the curiales, or a crisis. ${ }^{11}$ This variety reflects the local diversity of the land's mode of exploitation. The villa's owners, whether absentees or not, were able to derive as much profit from the direct exploitation of their lands, with slaves or free workers, as from leasing to conductores

6 Pacatus Drepianus, Panegyricus, 12.4.2.

7 Expositio totius mundi et gentium, 59.

8 Reynolds 2010.

9 Ibid., pp. 74-84.

10 Chavarría Arnau 2005, pp. 522-527.

11 Ariño Gil and Díaz Martínez 2002; Chavarría Arnau 2005. 
or simply coloni. The establishments were transformed according to the opportunities seized. In the palatial villa of São Cucufate, and testifying to the wealth and power of its owners, the main body of buildings overshadows that of the pars rustica dispersed in the outskirts. ${ }^{12}$ Here, the model corresponds to that of its owners, a people of a fundamentally urban culture, who preferred renting their lands than operating them directly. In the villa of Torre Llauder in Tarraconensis, baths and mosaics were replaced with productive installations. ${ }^{13}$ This example indicates the new importance of the pars rustica in some villas. It has long been interpreted as a sign of crisis but could simply reflect a change in the mode of exploitation without a decrease in agricultural production. The difficulty for the analysis lies in a lack of information about the status of the occupants (owners or tenants) of the structures discovered by archaeologists.

Land remained the source of wealth. Due to its unequal distribution, the society remained fundamentally hierarchical. The documentation leaves it difficult to grasp the nuances of the Hispanic social order in the fourth century. ${ }^{14}$ The summit of the social pyramid was dominated by the honestiores, generally the great landowners, some of whose names appear in sources, among them no doubt the elite formed by the great servants of the state. The base of the social order was formed by a predominantly anonymous group of humiliores, i.e. the urban plebs, merchants and artisans, small landowners, the mass of coloni, and the servile population. Social inequality probably increased in the fourth century. ${ }^{15}$ The Theodosian Code indicates changes in the norms and legal framework, giving the impression of more regulated conditions, but it is illusory to think that it translated into daily reality. ${ }^{16}$ Beyond the law, the arbitrary abuse of power and the corruption of the state's agents remained common. ${ }^{17}$

Provinces and their governors still formed the imperial administrative framework of control in Hispania. Diocletian's reform of the provincial framework - probably linked to fiscal concerns and a desire to bring the imperial administration closer to citizens - modified the old Augustean division. ${ }^{18}$ Late Roman Spain was divided into five provinces (Fig. 2.1 - Baetica, Lusitania, Tarraconensis, Gallaecia, and Carthaginiensis - with which

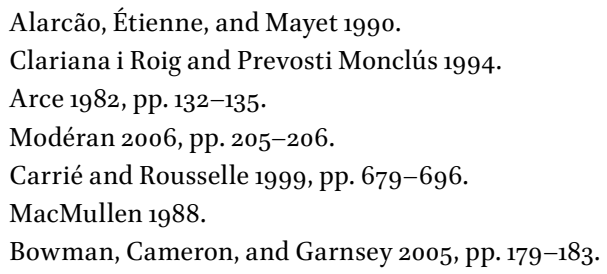




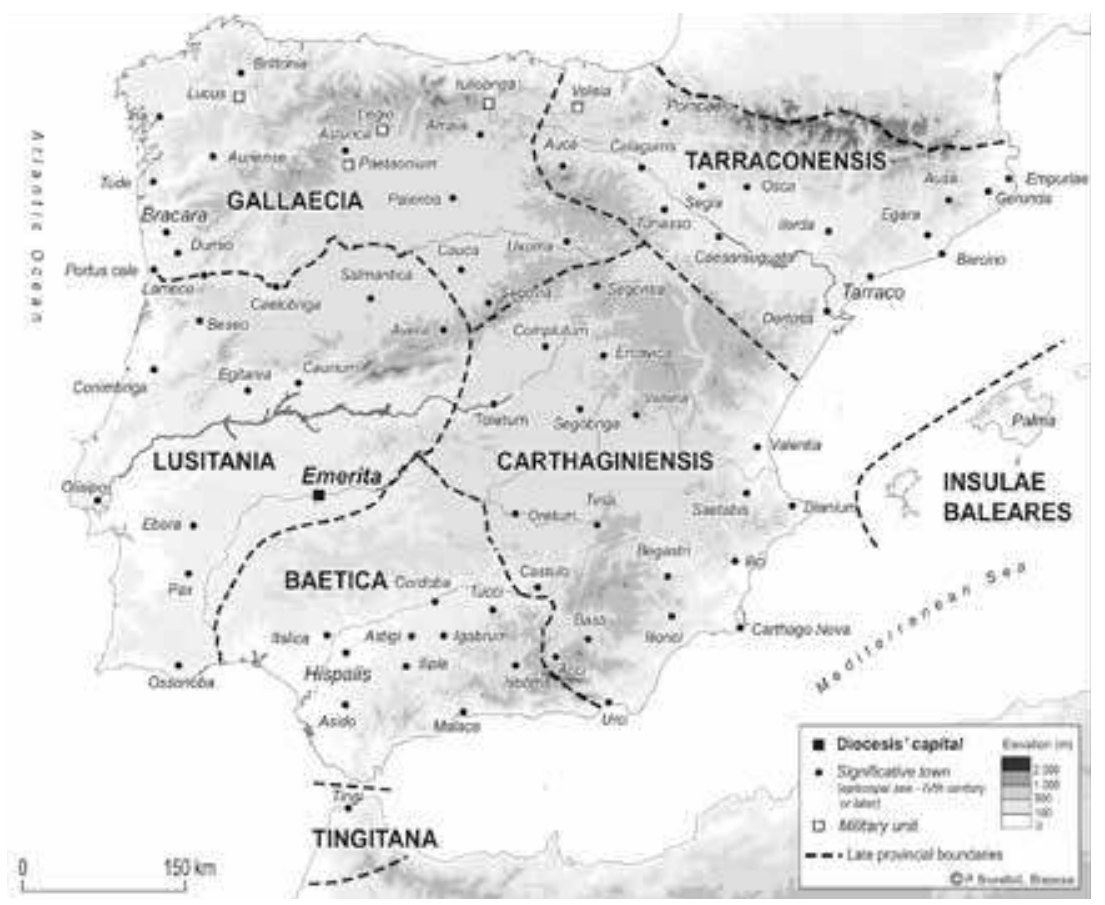

Fig. 2.1 The provinces of late Roman Spain. @ Pascal Brunello and Laurent Brassous.

the province of Tingitana was associated to form the diocesis hispaniarum, itself dependent on the praetorian prefecture of Gaul since the reign of Constantine. ${ }^{19}$ While sources do not specify the exact date of the reform, they nevertheless indicate an evolution of the administrative framework. The general notion of the state is first mentioned around 314 in the Verona list. ${ }^{20}$ The Breviarum of Festus written around $369-370$ indicates that there was a hierarchy among these provinces, indicated by the governors' titles. ${ }^{21}$ Governors of Baetica and Lusitania were consulares, while others were praesidiales. The Laterculus of Polemius Silvius indicates the formation, at the end of the fourth century, of the province of Insulae Baleares removed from the province of Tarraconensis. ${ }^{22}$ The Notitia dignitatum reveals the hierarchical promotion of Gallaecia during the last decades of the fourth century, which became consular. ${ }^{23}$ The provincial reorganization highlights

Laterculus Veronensis, 11.1-7. 
a shift of Hispania's political centre of gravity towards the interior and the west. $^{24}$

In these provinces sat the governor or iudex. He had to ensure the exercise of justice but also tax collection. He was also responsible for the proper functioning of the cursus publicus, the good conduct of the curies and maintenance of the cities. ${ }^{25} \mathrm{He}$ worked under the authority of the vicar sitting in the capital of the diocese of Emerita, himself dependent on the praetorian prefect of Gaul. Each governor or vicar had a small team for the exercise of his office, relative to the extent of his duties and the size of his jurisdiction. While the vicar had about 300 people, each governor could count on a hundred employees. Two agents of the comes sacrarum largitionum and comes rerum privatarum also took part in the diocese. ${ }^{26}$ Apart from these provincial officials, the state had central service agents, such as notaries or agentes in rebus who occasionally came to Hispanic provinces.

This administrative framework was completed by a military organization also marked by the reforms undertaken by Diocletian and Constantine. ${ }^{27}$ It should be remembered that these reforms transformed the military command, which was gradually withdrawn from the ranks of civil administrators, governors, and praetorian prefects. The latter only taking care of supplying troops. The command was then entrusted to comites and duces dependent on the magistrimilitum and equitum. The reforms also increased the number of units distributed since the time of Constantine between comitatenses and ripenses, which became limitanei units. Recruitment difficulties, far from provoking a so-called barbarization of the army, led to a taxation by the creation of protostasia encouraging the maintenance by landowners of men in arms.

The organization of the late Roman army in Spain resulting from these reforms is mainly known by the Notitia dignitatum, whose manuscript record doesn't permit to date more precisely than the beginning of the fifth century. The problem appears clearly in the case of the comitatenses troops in Hispania mentioned by the document. ${ }^{28}$ About 11 auxilia palatina and 5 legiones were mentioned, but they could have been sent to the peninsula as a result of the civil war provoked by the usurpation of Constantine III in 407. This document mentions that the legio VII and the ancient cohorts were maintained in the northwest (Fig. 2.1), mainly in Gallaecia where they

Notitia dignitatum in partibus Occidentis, 11.17 and 12.12.

Carrié and Rousselle 1999, pp. 615-649; Bowman, Cameron and Garnsey 2005, pp. 120-130. Notitia dignitatum in partibus Occidentis, 7.118-134. 
formed units of limitanei. ${ }^{29}$ However, one no longer thinks that it was a border army. $3^{30}$ Moreover, since the integration of Tingitana into the diocese of Spain the military defence system of the diocese also included units of this province. ${ }^{31}$ These were limitanei troops who seemed to defend the frontier of the empire against the incursions of Moors, as well as comitatenses troops, whose mobility would have occasionally been used to intervene in the Iberian Peninsula. The number of soldiers in Hispania is estimated at between 13,000 and 15,000 men in the fourth century. ${ }^{32}$

No source explicitly mentions the engagement of these troops in conflicts with external enemies. They probably took part in the civil wars that punctuated the history of the Roman West during the last centuries of the empire. We know that several usurpations concerned Hispania more or less directly - that of Magnentius (350), then that of Maximus (383) - which rallied temporarily and perhaps timidly the Hispanic provinces. ${ }^{33}$ The intervention of the military units of the peninsula seems more assured during the usurpation of Constantine III (407), probably supported by troops of limitanei, provoking the intervention of private armies raised by Didimus and Verinianus, parents of the emperor Honorius, and opponents of the usurper. This conflict opens a new page in the history of Hispania, provoking the penetration of barbarian armies, which would have been summoned by the belligerents. ${ }^{34}$

Civilian or military, the state's supervision of the population remained modest in the fourth century. Most of juridical, fiscal, and administrative functions were in the hands of civitates. In late Roman Spain, cities remained the environment of provincials, but the civic organization and network, gradually built over centuries, undoubtedly changed. The problem in understanding this change is, firstly, the rarefaction of the epigraphic habit that celebrated great moments of a city's life. The few late civic inscriptions known involve provincial authorities such as a governor or vicar, with specific meaning. ${ }^{35}$ Despite a lack of epigraphic data, it cannot be said that there was a decline in civic institutions in late Hispania. ${ }^{6}$ Indeed, several

Ibid., 42.24-30.

Arce 1982, pp. 67-72.

Notitia dignitatum in partibus Occidentis, 7.135-139.

Le Roux 2010, p. 255.

Ibid., pp. 26o-268.

4 Arce 2005, pp. 41-47.

35 In Olisipo in 336 (CIL II, 191); in Tarraco, at the end of the third century (RIT, 91) and during the fourth century $(R I T, 155)$; in Emerita ( $A E$ 1935, 4 and $A E$ 1927, 165).

36 Kulikowski 2004; Curchin 2014. 
documents confirm the survival of civic institutions. Various provisions of the Theodosian Code seeking to combat the flight of curiales, affecting in particular the Iberian Peninsula, show that curies still existed in the fourth century. ${ }^{37}$ The modius of Ponte Puñide or the inscription of Oretum suggest that cities still participated in the collection of tax at that time..$^{38}$ Finally, the canons of the Council of Iliberris testify to the difficulties that some Christians met in reconciling their faith with the exercise of civic functions. 39 Cities could not disappear because they were necessary for the good running of the empire and in particular taxation. Curiales decided the distribution of the tax and designated among them the exactores and the susceptores who were in charge to collect it. However, the continuity of the institution does not mean that there was no change. First, the Theodosian Code uniformly speaks of civitates and makes no mention of the differences that existed between coloniae and municipia, indicating a probable uniformization of the statutes. ${ }^{40}$ Besides, the place of the curator rei publicae then the defensor civitatis, or their role in the curia, probably surpassed that of the old duovirii. They were designated by the curiales, whose choices were validated by the state administration. The cities also lost some of their financial autonomy, since the free disposal of their income was withdrawn during the reign of Constantine, before recovering only one-third of this income. ${ }^{41}$

In the field of municipal history, problems arise from archaeological sources that testify to an abandonment or degradation of civic spaces in various towns from the third century and even from the end of the second century, such as Carthago Nova, Baelo, Emporiae. ${ }^{42}$ In these towns, the degradation of civic spaces concerned both civil and religious buildings of the forum and other sanctuaries, buildings for entertainment, or intraurban networks of roads or water supply that were sometimes reoccupied for habitats or craft workshops. ${ }^{43}$ Whatever the cause of these changes, ${ }^{44}$

Codex Theodosianus, 12.1.4 and 12.1.77.

Arce 2015.

La Colección Canónica Hispana, pp. 1-15.

40 Lepelley 2001.

41 Codex Theodosianus, 4.13 .7 and 15.1.18.

42 Various examples in Brassous and Quevedo 2015; Andreu Pintado 2017.

43 Diarte Blasco 2012.

44 The answers given by historians and archaeologists, who debate the notion of crisis, are sometimes general and structural, sometimes local and conjunctural (depletion of resources, natural disaster, imperial intervention). Two contributions give important focal points of reflection: Cepas Palanca 1997, pp. 13-27, and Witschel 2009. The only point of consensus today is that it is no longer possible to incriminate the so-called Moorish invasions or barbarians at the end of the second or the third century. 
municipal authorities do not seem to have reacted, or did so insufficiently, to what appears to be a deterioration of the places necessary for the functioning, memory, and the very existence of the community. They do not seem to have had the means or will to preserve or repair these community's spaces. Admittedly, archaeological reports do not testify here to the civic institution proper, but to its meeting places or its achievements, according to a model of the high empire. Nevertheless, such a degradation of places of the expression of civic community puts into question the survival of the civitas in the towns where it was observed.

The archaeological documentation, however, is contrasted. In a number of cities, the degradation of civic spaces came late, only after the fifth century when Roman administration in Hispania ended. This is particularly the case in the provincial capitals, Tarraco, Corduba, and Emerita, ${ }^{45}$ but also in smaller towns such as Olisipo, Complutum, and even Valentia. ${ }^{46}$ We must also mention many towns where walls were built or rebuilt from the end of the third century and throughout the fourth: walls were civic monuments since they protected the community, which most likely financed them (Barcino, Lucus, Asturica, Gijón, etc.). ${ }^{47}$ It has been thought that these constructions did not belong to the communities but to the state, but even if the state had intervened to finance these walls it was in the form of an indulgentia that allowed cities to use sums that they usually returned to the central state. It would finally have been the revenue of these cities that would have allowed the construction of their walls. In these cases, archaeology confirms the survival of civitates.

However, if the civic institution survived in the Iberian Peninsula in the late period, how do we explain the paradox raised by archaeological documentation? The sources are too scattered to provide a complete picture; nothing is said about the network of cities in late Roman Spain. Kulikowski

45 The colonial forum of Tarraco was undoubtedly partially restored at the end of the third century, as suggested by the inscription RIT, 91, evoking the restoration of a portico. It seems abandoned in the second half of the fourth century (Aquilué Abadías 2004). The latest discoveries made in Mérida do not show abandonment of the forum during the third century. The monumental buildings housing the probable curia and a hypothetical aerarium do not appear abandoned, stolen, or reoccupied before the fifth century (Ayerbe Vélez, Barrientos Vera, and Palma García 2009, pp. 828-831). In Corduba, imperial dedications offered by the city at the beginning of the fourth century in the area known as the colonial forum suggest that the civic heart of the city was still active and frequented during this period (CIL II ${ }^{2} / 7,261$ and 264$)$.

46 For Conimbriga, see Alarcão and Etienne 1977, pp. 145-146; for Complutum, see Rascon Marques and Sánchez Montes 2015, pp. 199-220; for Valentia, Morín de Pablos and Ribera i Lacomba 2015.

47 Brassous 2011a. 
suggested that this network remained substantially stable since its formation until the sixth century. ${ }^{48}$ Nevertheless, archaeological documentation would testify to a specification in the network of cities, by which some cities lost their privilege of liberty and became contributa to their neighbours, or in other words secondary towns.

The difficulty is evaluating the global transformation of the cities' network. To measure this transformation, it would be necessary to compare similar sources between high empire and late antiquity. But the difference in sources between these two periods is an obstacle. Thanks to Book 3 of the Natural History of Pliny the Elder, who presumably draws his information from a formula provinciarum of the Flavian period, as well to the numerous municipal inscriptions of the high empire, we have a relatively detailed picture of the network of cities for the high empire. The data from Pliny make it possible to estimate that there were more than 513 cities in the three provinces of Hispania. ${ }^{49} \mathrm{On}$ the other hand, for the late period sources are too incomplete to estimate the global number of cities to determine the durability of a network. There are less than ten epigraphic monuments and episodic mentions in the literature. Unlike in Gaul, there is no inventory such as the Notitia Galliarum. The only sources providing rather exhaustive accounts are the Nomina Hispanarum sedium, lists of episcopal sees in the Middle Ages. If it is postulated that the organization of the church is modelled on the civil administration, according to the recommendations set forth in the Council of Nicaea, ${ }^{50}$ the late bishoprics would generally correspond to cities. This 'principle of accommodation' is widely used by historians in other provinces, such as in Gaul. ${ }^{11}$

The Nomina Hispanarum sedium are heirs of a document of the seventh/ eighth century roughly known as 'the donation of Wamba', which could be a twelfth-century fake..$^{2}$ These lists mention 71 bishoprics for all Hispania (Fig. 2.1), a number well below the 513 cited by Pliny. If the principle of accommodation was followed by the church, making each city an episcopal see, the reduction of the number of civitates would have been considerable. It should be remembered that many former cities' capitals became secondary agglomerations. The main problem with these lists, however, is their chronology, which may reflect transformations between the period of interest and

48 Bowes and Kulikowski 2005, p. 48.

49 Pliny, Naturalis Historia, 3.3.7; 3.3.18; 4.21-22.

$5^{0}$ Mayeur, Pietri, and Pietri 1998, pp. 507-509.

51 Beaujard and Prévot 2004, p. 25; for a discussion of the limits of this principle of accommodation, read Mazel 2016, pp. 16o-163.

52 Vázquez de Parga Iglesias 1943; Mansilla Reoyo 1994. 
the eighth century. Nevertheless, the comparison of these lists with an earlier one collected in the canons of the Council of Iliberris held in the fourth century ${ }^{53}$ underlines the relative stability of the network of bishoprics in this province, in which there only appeared the bishoprics of Assido, Ilipa, and Astigi. This relative similarity between the lists reinforces the validity of the Nomina Hispanarum sedium, despite the temporal distance between the date of writing and the end of Roman Hispania. By extension, we can assume that the Nomina Hispanarum sedium delivers for other Hispanic provinces a state of affairs relatively close to that of antiquity. If the principle of accommodation, which is the beginning postulate of this analysis, is valid, the network of bishoprics mentioned in the Nomina Hispanarum sedium may reflect partially that of the civitates of late Roman Spain and witness a transformative deepening of the network of cities between the high empire and late antiquity, which seems to corroborate in part the archaeological data pointing to the degradation of a number of civic centres between the second and fourth centuries. Nevertheless, if civic communities have not disappeared with the degradation of their civic places evidenced by archaeology, then we must consider that there was in the fourth century a significant change in civic practices and that civic communion no longer used the same places, did not bring together the same people and probably did not meet the same expectations.

For all that, the place of the bishop in the city seems to have become important only from the fifth century when the imperial authority and the curies were failing, and when the bishop imposed himself as the defensor civitatis. ${ }^{54}$ The fourth century remains a period of development of Christianity and the structuring of ecclesiastical organization that transformed the peninsula. As elsewhere, persecutions and martyrs of the third and early fourth century may have also increased the visibility of these communities among the population of the provinces, but the influence of these martyrs, whose cult developed mostly from the sixth century, and whose importance was strengthened in the Middle Ages, 55 should not be overestimated in the fourth century. As in other parts of the empire, Christianity could have become a majority religion only in the last decades of Roman Hispania or later. The edicts of tolerance in 311 and

53 Traditionally placed at the beginning of the fourth century, the date of celebration of the council but also its nature are always subject to caution. The council could be later, and date from the second half of the fourth century (Sotomayor Muro 2005).

54 Liebeschuetz 2001, pp. 137-167.

55 Castillo Maldonado 2005. 
313, the conversion of Constantine, certainly marked an important stage in the history of the development of Christianity, but did not immediately change religious practices. ${ }^{6}$ In the fourth century, Christianity still largely coexisted with paganism, but the new religion was dynamic, as evidenced by controversies that occupied the political scene, including Priscillianism, which may have extended into the Arian controversy. ${ }^{57}$ However, there is no reason to believe that Hispanic Christianity presented a specific regional model. The holding of the Council of Iliberris or the Spanish origin of the Nicosian emperor Theodosius, should not be allowed to mislead us about the importance of Christianity in the peninsula and the Christian community, which remains unfortunably difficult, if not impossible, to quantify. From an archaeological point of view, it was not until the end of the fourth century, but especially the fifth, that the first Christian basilicas flourished in urban areas, ${ }^{8}$ with rural Christian communities appearing more dynamic.

\section{Conclusion}

The history of late Roman Spain is difficult to reconstruct due to an unequal distribution of documentation. It is tempting to do so from the evidence of the general evolution of the empire, for example concerning social aspects. It would be illusory to propose a late Hispanic singularity. Despite its peculiarities, late Roman Spain reveals what one could call an integrated periphery. Its peripheral situation allowed it to be relatively untouched by the difficulties of the time, and specifically kept it away from important military conflicts. It seems to have intervened only marginally in the political game, when the ambitions of some individuals became manifest. Hispania participated in a secondary way in the economy of the empire. But its previous integration into the empire explains the relatively high conservation of the classical culture marked by civic organization. It is marked as well by the development of Christianity and its controversies, without however constituting a major polarity. Hispania was concerned with military, fiscal, and administrative reforms intended to stabilize the weakened bases of the empire. What has been provided presents a general point of view. In detail, local developments are emerging and must be 
better considered. In general, scholars rely on either the negative balance or the positive balance sheet to give a reading of the trajectory followed by Hispania in the fourth century: crisis or continuity, decline or restoration, etc. However, the diversity of situations underlines how the balance sheet should also consider changes in territoriality. Indeed, changes affecting the provincial framework, the distribution of economic activities, and the network of cities indicate that late Roman Spain presents various local historical evolutions. In order to understand the substrate on which Visigothic Spain is based, it is necessary to consider the general evolution of Hispania in regard to an analysis of the diversity of provincial changes the day before the arrival of the Germanic peoples.

\section{Bibliography}

\section{Primary sources}

CIL II = Corpus Inscriptionum Latinarum: Inscriptiones Hispaniae Latinae, ed. by Emil Hübner (Berlin: De Gruyter, 1956 [1869]).

Codex Theodosianus = Le code théodosien, ed. and trans. by Sylvie Crogiez-Pétrequin, introd. by Pierre Jaillette (Turnhout: Brepols, 2009).

Expositio totius mundi et gentium, ed., introd., and trans. by Jean Rougé (Paris: Éditions du Cerf, Sources chrétiennes, 1966).

Festus, Breviarium = The Breviarium of Festus: A Critical Edition with Historical Commentary, ed. by John W. Eadie (London: Athlone Press, University of London Classical Studies 55, 1967).

La Colección Canónica Hispana, 6 vols., ed. by Gonzalo Martínez Díez and Félix Rodríguez (Madrid: Consejo Superior de Investigaciones Científicas, 1966-2002). Laterculus Veronensis, in Notitia dignitatum: accedunt Notitia urbis Constantinopolitanae et laterculi provinciarum, ed. by Otto Seeck (Berlin: Weidmann, 1876), pp. 247-251.

Nomina Hispanarum sedium = Provinciale Visigothicum seu Nomina Hispanarum sedium (Brepols, Library of Latin Texts, 2010).

Notitia dignitatum in partibus Occidentis, in Notitia dignitatum: accedunt Notitia urbis Constantinopolitanae et laterculi provinciarum, ed. by Otto Seeck (Berlin: Weidmann, 1876), pp. 103-226.

Pacatus Drepianus, Panegyricus Theodosio Augusto dictus, in C. Plinii Caecilii Secundi Epistolae et Panegyricus, vol. 2 (Zweibrücken, 1789), pp. 383-416.

Pliny, Naturalis Historia = Natural History, trans. by H. Rackham, 10 vols. (Cambridge, MA: Harvard University Press, 1938-1962). 
Polemius Silvius, Laterculus, in Chronica minora, 3 vols., vol. 1, ed. by Theodor Mommsen (Berlin: Monumenta Germaniae Historica, Auctores Antiquissimi 9, 1892), pp. 511-551.

RIT = Die Römischen Inschriften von Tarraco, ed. by Géza Alföldy, 2 vols. (Berlin:

Madrider Forschungen 10, 1975).

\section{Secondary sources}

Alarcão, Jorge de, and Robert Etienne, Fouilles de Conimbriga, 7 vols., vol. 1: L'Architecture (Paris: Musée Monographique de Conimbriga, 1977).

Alarcão, Jorge de, Robert Étienne, and Françoise Mayet, eds., Les villas romaines de Sâo Cucufate (Portugal) (Paris: Musée Monographique de Conimbriga, 199o). Andreu Pintado, Javier, Oppida labentia: transformaciones, cambios y alteración en las ciudades hispanas entre el siglo IIy la tardoantigüedad (Uncastillo: Serie Monografías 'Los Bañales' 2, 2017).

Aquilué Abadías, Xavier, 'Arquitectura oficial', in Las capitales provinciales de Hispania, 3 vols., vol. 3: Tarragona: Colonia Iulia Urbs Triumphalis Tarraco, ed. by Xavier Dupré i Raventós (Rome: L'Erma die Bretschneider, 2004), pp. 41-53. Arce, Javier, El último siglo de la España romana (284-409) (Madrid: Alianza, 1982). — , 'Los governadores de la dioecesis Hispaniarum (siglos IV-V d.C.) y la continuidad de las estructuras administrativas romanas en la Península Iberica', Antiquité Tardive 7 (1999), pp. 73-83.

—, Bárbaros y romanos en Hispania, 400-507 A.D. (Madrid: Marcial Pons, 2005). , 'La inscripción de Orcistus y las preocupaciones del emperador', in $U r$ banisme civique en temps de crise: les espaces publics d'Hispanie et de l'Occicent romain entre les $I I^{e}$ et $I V^{e}$ s., ed. by Laurent Brassous and Alejandro Quevedo (Madrid: Collection de la Casa de Velázquez 149, 2015), pp. 311-323.

Ariño Gil, Enrique, and Pablo C. Díaz Martínez, 'El campo: propiedad y explotación de la tierra', in La Hispania del siglo IV: administración, economía, sociedad, cristianización, ed. by Ramón Teja (Bari: Edipuglia, Munera 19, 2002), pp. 59-96. Ayerbe Vélez, Rocío, Teresa Barrientos Vera, and Félix Palma García, eds., El foro de Augusta Emerita: génesis y evolución de sus recintos monumentales (Madrid: Consejo Superior de Investigaciones Científicas, Anejos de Archivo Español de Arqueología 53, 2009).

Beaujard, Brigitte, and Françoise Prévot, 'Introduction à l'étude des capitales “éphémères" de la Gaule ( $\mathrm{I}^{\mathrm{er}} \mathrm{s}$.-début VII ${ }^{\mathrm{e}} \mathrm{s}$.)', in Capitales éphémères: des capitales de cités perdent leur statut dans l'Antiquité tardive; actes du colloque organisé par le Laboratoire Archéologie et Territoires, Tours, 2003, ed. by Alain Ferdière (Tours: Fédération pour l'Édition de la Revue Archéologique du Centre de la France, Revue Archéologique du Centre de la France, Suppl. 25, 2004). 
Bowes, Kim D., and Michael Kulikowski, eds., Hispania in Late Antiquity: Current Perspectives (Leiden: Brill, Medieval and Early Modern Iberian World 24, 2005). Bowman, Alan K., Averil Cameron, and Peter Garnsey, The Crisis of Empire, A.D. 193-337 (Cambridge: Cambridge University Press, Cambridge Ancient History 12, 2005).

Brassous, Laurent, 'Les enceintes urbaines tardives de la péninsule Ibérique', in L'Empire romain en mutation: répercussions sur les villes romaines dans la deuxième moitié du $3^{e}$ siècle; colloque international, Bern/Augst, 20o9, ed. by Regula Schatzmann and Stefanie Martin-Kilcher (Montagnac: Editions Mergoil, 2011a), pp. 275-300.

__ 'L'Identification des capitales administratives du diocèse des Espagnes', in Roma generadora de identidades: la experiencia hispana, ed. by Antonio Caballos Rufino and Sabine Lefebvre (Madrid: Collection de la Casa de Velázquez 123, 2011b), pp. 337-357.

Brassous, Laurent, and Alejandro Quevedo, eds., Urbanisme civique en temps de crise: les espaces publics d'Hispanie et de l'Occident romain entre les $I I^{e}$ et IV siècle (Madrid: Collection de la Casa de Velázquez 149, 2015).

Brown, Peter, The World of Late Antiquity: From Marcus Aurelius to Muhammad (London: Library of European Civilization, 1971).

Carrié, Jean-Michel, and Aline Rousselle, L'Empire romain en mutation: des Sévères à Constantin 192-337 (Paris: Seuil, Nouvelle Histoire de l'Antiquité 10, 1999).

Castillo Maldonado, Pedro, 'The Cult of the Saints in Late Antique Spain', in Hispania in Late Antiquity: Current Perspectives, ed. by Kim Bowes and Michael Kulikowski (Leiden: Brill, Medieval and Early Modern Iberian World 24, 2005), pp. 151-188.

Cepas Palanca, Adela, Crisis y continuidad en la hispania del siglo III (Madrid: Consejo Superior de Investigaciones Científicas, Anejos de Archivo Español de Arqueología 17, 1997).

Chavarría Arnau, Alexandra, 'Villas in Hispania during the Fourth and Fifth Centuries', in Hispania in Late Antiquity: Current Perspectives, ed. by Kim Bowes and Michael Kulikowski (Leiden: Brill, Medieval and Early Modern Iberian World 24, 2005), pp. 519-555.

, A la sombra de un imperio: iglesias, obispos y reyes en la Hispania tardoantigua (siglos V-VII) (Bari: Edipuglia, Munera 43, 2018).

Clariana i Roig, Joan Francesc, and Marta Prevosti Monclús, 'Un exemple de ruralització a l'antiguitat tardana: la vil.la de Torre Llauder', in III Reunió d'arqueologia cristiana hispànica, ed. by Pedro de Palol i Salellas (Maó: Institut d'Estudis Catalans, Monografies de la Secció Històrico-Arqueològia 2, 1994), pp. 117-126. Curchin, Leonard A., 'The Role of Civic Leaders in Late Antique Hispania', Studia Historica: Historia Antigua 32 (2014), pp. 281-304. 
Diarte Blasco, Pilar, La configuración urbana de la Hispania tardoantigua: transformaciones y pervivencias de los espacios públicos romanos (siglos III-VI d.C.) (Oxford: BAR International 2429, 2012).

Escribano, Victoria, 'Heresy and Orthodoxy in the Fourth-Century Hispania: Arianism and Priscillianism', in Hispania in Late Antiquity: Current Perspectives, ed. by Kim Bowes and Michael Kulikowski (Leiden: Brill, Medieval and Early Modern Iberian World 24, 2005), pp. 121-149.

Kulikowski, Michael, Late Roman Spain and its Cities (Baltimore, MD: Johns Hopkins University Press, 2004).

Le Roux, Patrick, La péninsule Ibérique aux époques romaines: fin du III s. av. n.è-début du VI s. de n.è. (Paris: Armand Colin, Collection U Histoire, 2010).

Lepelley, Claude, 'Le nivellement juridique du monde romain à partir du III ${ }^{\mathrm{e}}$ siècle et la marginalisation des droits locaux', Mélanges de l'École Française de Rome 113.2 (2001), pp. 839-856.

Liebeschuetz, John H.W.G., The Decline and Fall of the Roman City (Oxford/New York: Oxford University Press, 2001).

MacMullen, Ramsay, Corruption and the Decline of Rome (New Haven: Yale University Press, 1988).

Mansilla Reoyo, Demetrio, Geografia eclesiastica de España: estudio historícogeográfico de las diocesis, 2 vols. (Rome: Iglesia Nacional Española, Publicaciones del Instituto Español de Historia Eclesiástica, Monografías 35, 1994).

Mayeur, Jean-Marie, Charles Pietri, and Luce Pietri, eds., Histoire du christianisme des origines à nos jours, vol. 3: Les Églises d'Orient et d'Occident (Paris: Desclée, 1998).

Mazel, Florian, L'Évêque et le territoire: l'invention médiévale de l'espace (Paris: Seuil, 2016).

Modéran, Yves, L'Empire romain tardif, 235-395 ap. J.-C. (Paris: Ellipses, 2006).

Morín de Pablos, Jorge, and Albert Ribera i Lacomba, 'Los foros de "Valentia y Ercavica”: dos modelos de crisis urbana a finales del Alto Imperio', in Urbanisme civique en temps de crise: les espaces publics d'Hispanie et de l'Occicent romain entre les $I I^{e}$ et $I V^{e}$ s., ed. by Laurent Brassous and Alejandro Quevedo (Madrid: Collection de la Casa de Velázquez 149, 2015), pp. 105-126.

Rascon Marques, Sebastián, and Ana Lucía Sánchez Montes, 'Complutum: modelo urbanístico para una ciudad romana privilegiada en los siglos III-V', in Urbanisme civique en temps de crise: les espaces publics d'Hispanie et de l'Occicent romain entre les $I I^{e}$ et $I V^{e}$ s., ed. by Laurent Brassous and Alejandro Quevedo (Madrid: Collection de la Casa de Velázquez 149, 2015), pp. 199-220.

Reynolds, Paul, Hispania and the Roman Mediterranean, AD 100-700: Ceramics and Trade (London: Duckworth, 2010). 
Rodríguez Gutiérrez, Oliva, Hispania arqueológica:panorama de la cultura material de las provincias hispanorromanas (Seville: Editorial Universidad de Sevilla, Historia y Geografía 187, 2011).

Slootjes, Danielle, The Governor and his Subjects in the Later Roman Empire (Leiden: Brill, Mnemosyne, Suppl. 275, 2006).

Sotomayor Muro, Manuel, 'Sobre la fecha del concilio', in El Concilio de Elvira y su tiempo, ed. by Manuel Sotomayor Muro and José Fernández Ubiña (Granada: Universidad de Granada, 2005), pp. 137-168.

Teja, Ramón, ed., La Hispania del siglo IV: administración, economía, sociedad, cristianización (Bari: Edipuglia, Munera 19, 2002).

Vázquez de Parga Iglesias, Luis, La división de Wamba: contribución al estudio de la historia y geografía eclesiásticas de la edad media española (Madrid: Sucesores de Rivadeneyra, 1943).

Ward-Perkins, Bryan, The Fall of Rome and the End of Civilization (Oxford: Oxford University Press, 2006).

Witschel, Christian, 'Hispania en el siglo III', in Hispaniae: las provincias hispanas en el mundo romano, ed. by Javier Andreu Pintado, Javier Cabrero Piquero, and Isabel Rodà de Llanza (Tarragona: Institut Català de Arqueologia Clàssica, Sèrie Documenta 11, 2009), pp. 473-503.

\section{About the author}

Laurent Brassous is Maître des Conférences in Ancient History at the University of La Rochelle (France). He works on the urban history of late antiquity, especially in the Iberian Peninsula, and serves as the director of an archaeological research project on late occupation in the ancient town of Baelo Claudia in southern Spain. 



\section{Concepts of Central and Local Power}





\title{
3 The Visigoths in Hispania
}

\author{
New Perspectives on their Arrival and Settlement \\ Javier Arce
}

\begin{abstract}
This chapter tries to answer a series of questions about the first arrival of the Goths in Spain: the date and means of their arrival, their numbers, the exact identity of those entering the peninsula, where they settled, and how. Concerning the problem of who the people entering the peninsula were, the question is whether we can truly call them 'Goths'. After considering the history of the Gothic people before their arrival in Aquitania and after they remained for more than a hundred years, I conclude that they were a mixture of peoples that represented a poly-ethnic group, a group clearly not made up exclusively of Goths, and perhaps including only very few.
\end{abstract}

Keywords: Iberia; Aquitania; Visigoths; settlement; identity; ethnicity

In this paper I will try to answer - if possible - a series of questions concerning the earliest presence of Goths in the Iberian Peninsula: first, when they arrived; second, why they arrived; third, how many; fourth, who the people that entered the peninsula were; and fifth, where they settled and how.

These are fairly obvious questions, although many of them are difficult to answer, and in some cases impossible to answer with any reasonable degree of certainty. Some are easier in view of the nature of the evidence. I pose them because of a lack of consensus in the replies in the abundant literature on the subject. In many cases, as scholars disagree, I put forward interpretations in order to stimulate debate, without being certain they are correct.

Panzram, S. and P. Pachá (eds.). The Visigothic Kingdom: The Negotiation of Power in Post-Roman Iberia. Amsterdam: Amsterdam University Press 2020 DOI: $10.5117 / 9789463720632$ CHO3 


\section{When?}

Many modern scholars consider that the arrival of the Goths in Hispania took place over the course of the fifth century, particularly as a consequence of the expansionist policies of King Euric (466-484). ${ }^{59}$ I make a distinction in defining when the general emigration of people that settled in Aquitania after 418 occurred. In contrast, the arrival of Goths in Hispania as a part of armies that entered the peninsula in order to undertake military interventions is another matter. During this period, and beforehand, sources tell us of the frequent arrival in the peninsula of contingents of Gothic forces, under the leadership of military commanders, but does not imply that the population as a whole arrived..$^{60}$

In particular, two entries in the Consularia Caesaraugustana and an inscription on the bridge at Emerita, as well as a reference in Iordanes's work, have been used to claim that the Gothic people had settled in the peninsula.

The texts of the Consularia refer to the years 494 and 497 (i.e. after Euric's death). The first (494) states Goti in Hispanias ingressi sunt ('the Goths advanced into the Hispaniae') ${ }^{61}$ and the second (497), only a few years later, Goti intra Hispanias sedes acceperunt ('the Goths settled in the Hispaniae'). ${ }^{62}$ In 1986, Dominguez Monedero questioned whether these two texts referred to the supposed 'mass penetration of the Goths into the Peninsula'. ${ }^{63}$ More recently, Koch has insisted on the fact that in both texts, Goti refers to the army and not the Gothic people (likewise of the word ingressi), considering that sedes does not refer to settlements but rather to the cities (sedes) that supported Burdunelus's rebellion in 494, which were occupied by Gothic troops. ${ }^{64}$ Leaving aside any debate as regards the meaning of sedes acceperunt, the text referring to the year 497 could refer to a settlement, probably only of some troops, in cities, and not in the

59 See, for example, González Salinero 2017, pp. 33-36; Chavarría Arnau 2018, pp. 18-19; Orlandis Rovira 1977, p. 61; García Moreno 1989, p. 72; Collins 2004, pp. 31-33; Wolfram 1985, pp. 315-316 (with reservations); Arce 2017, pp. 32-38 (which specifies the exceptional and military nature of this expansionism).

6o On the movements of these soldiers, see Arce 2017, pp. 31-32. Cyrilla, dux in 458: Hydatius, Continuatio Chronicorum Hieronymianorum, 183; Sunericus, Nepotianus, Vincentius: Arce 2005, pp. 137-145. On Sunericus and Nepotianus, cf. Hydatius, Continuatio Chronicorum Hieronymianorum, 196; Sunericus in Scallabis: 201; Gautericus in Pompaelo and in Caesaraugusta: Chronica Gallica of 511,651 .

61 Consularia Constantinopolitana, ad annum 494.

62 Consularia Constantinopolitana, ad annum 497.

63 Cf. Domínguez Monedero 1986a, and Pérez Rodriguez-Aragón 2002.

64 Koch 2006. See also Domínguez Monedero 1986b. 
territory as a whole; on no account can we propose that it is indicative of large-scale immigration. ${ }^{6}$

Similarly problematic is the text of the inscription from the bridge at Emerita, which is only preserved in an eighth-century manuscript (Codex Toletanus). It records that in the time of King Euric, the dux Salla, with the assistance of the bishop, Zeno, rebuilt the city's walls and bridge, which I have considered elsewhere ${ }^{66}$ I do not plan to debate whether the inscription that has come down to us is accurate. ${ }^{67}$ What needs to be emphasized is whether the reference to the dux Salla at Emerita, an individual referred to by Hydatius as an ambassador from Theodoric as early as $466,{ }^{68}$ can be interpreted as indicating that the city was controlled or dominated, or constituted at Mérida as ducatus of Euric's at that time. ${ }^{69}$ Far less can it be concluded, as Thompson did, that 'it is beyond question, then, that the Goths were occupying Mérida in the last year of Euric's reign and that a Goth was commanding there'.$^{70}$ Garcia Moreno uses the inscription to speak of 'a defensive system established by Euric in Mérida, the centre of Visigothic domination in the whole south-western quadrant [...] in addition to carrying out a major Gothic military settlement of client-aristocratic nature. ${ }^{71}$ Neither can it be accepted as Chavarría Arnau has recently claimed on the basis of the inscription, that 'Euric focused his interest on consolidating a limes against the Suevi, transforming Emerita into the keystone of this defensive system'.$^{72}$ Such statements cannot be supported by the text. The dux Salla might have been merely passing through Emerita and, for practical reasons, could have placed his troops at the disposal of those repairing the bridge and defences. His presence could have been of the same transitory nature as that of other Visigothic comites or duces that passed through the peninsula in the fifth century with frequency.

Finally, we are left with a text in Iordanes. On one occasion, the historian states that Euricus totas Hispanias Galliasque sibi iam iure propio tenens ('Euric already held all of the Hispaniae and Gaul by his own right'), words

65 Discussion in Arce 2005, p. 170 seq., and 2017, pp. 35-37.

66 Arce 2008a with the discussion in the same volume by Velázquez Soriano 2008; and Koch 2008, with my reply in Arce 2008b.

67 On this point, see Velázquez Soriano 2008, pp. 131-134.

68 Hydatius, Continuatio Chronicorum Hieronymianorum, 233.

69 König 1980.

70 Thompson 1982, p. 190.

71 García Moreno 1989, p. 73.

72 Chavarría Arnau 2018, p. 19. 
that need not be understood literally. ${ }^{73}$ They may indicate that he possessed a certain legal control, but not that the Gothic people had already settled in the peninsula.

There is, however, a text by Procopius that has not been sufficiently taken into account, a text that shows that, in fact, this arrival took place much later. I am referring to De bello Gothico V.13.12-13, which recounts the defeat of King Amalaric in Narbonne by the Franks, who as a result obtained the part of the Visigothic territory in Gaul that corresponds to Aquitania Prima. Afterwards, as Procopius states, 'the survivors of the vanquished emigrated from Gaul with their wives and children and went to Hispania, where Theudis ruled'. This event can be dated to 531; it is the first time that we read in an ancient source a reference to a Visigothic migration to Hispania, not just of soldiers, but also of people with families and children. The arrival of the Goths from Aquitania in Hispania took place in the 530s. ${ }^{74}$

This date represents a problem with regards to the chronology attributed by archaeologists to cemeteries on the Meseta, which they place between the mid-fifth century and the late sixth century, and which they consider to imply that the arrival (and settlement) took place long before the sixth century. ${ }^{75}$ These finds have been used by many historians to attempt to define the settlement area that was a consequence of the distribution of lands among the Visigoths. Hence, a commonly held opinion is that the Visigothic rural space was located between sites such as Herrera del Pisuerga (Palencia), Carpio (Toledo), Duraton (Segovia), and Castiltierra (Segovia). ${ }^{7}$ None of these cemeteries were excavated stratigraphically in such a way that might provide a satisfactory chronological sequence. Two further problems these cemeteries give rise to are, firstly, that of their identification as 'Gothic' or 'Visigothic' and, secondly, the fact that in no case are they associated with a settlement such as a vicus, villa, or civitas. In addition, it should be emphasized that it is not certain that these cemeteries can be identified with a specific ethnic group, and neither is the chronology proven, as the dating is based on a priori assumptions and stylistic arguments. The scholar who has analysed these excavations in greatest detail has recently recognized that 'the possibility that the so-called Visigothic cemeteries of the Castilian Meseta are actually not Visigothic might be contemplated'. ${ }^{77}$ Some have 
identified them as burials of Ostrogoths, while others have considered them to be 'Gothicized' Romans who followed Gothic fashions.

\section{Why?}

The Battle of Vouillé did not represent a total defeat for the Goths at the hands of the Franks, as Theodoric immediately took possession of a part of the kingdom that the enemies had occupied and restored it to the Goths' jurisdiction: Theodoricus Italiae rex [...] francos proterit partem regni, quam manus hostium occupaverat, recepit Gothorumque iuri restituit $7^{8}$ ("Theoderic, king of Italy [...] crushed the Francs, recovered the part of the kingdom which the forces of the enemy had occupied, and restored it to the authority of the Goths'). Theodoric recovered partem regni, Narbonensis, where a part of the population that had settled there after the foedus of 418 continued to live. Therefore, there was not a massive population movement to Hispania immediately after Vouillé. Gesalic, son of Alaric II, was proclaimed king in Narbo in 508: Narbonna princeps efficitur - per Isidore. After the Battle of Vouillé, the part of the population settled in Aquitania continued to live under Frankish rule in other areas of the region, at least those who had survived the battle.

The conflict between Amalaric and his wife Clotilde led to the intervention of the king of the Franks, Childebert, who defeated the Goths in Narbo and conquered the region; it is at this moment that Procopius points out that the Goths that remained were forced to emigrate to the Iberian Peninsula: men, women, children, and the elderly. It was a question of an enforced emigration rather than a conquest, which took place in 531.

Theodoric had already been proclaimed king of the Goths in 511 and began to intervene in peninsular affairs (as reflected in Cassiodorus's letters). In this same year, 531, Theudis was elected king in Hispania. Part of his armed retinue, or personal guard, was formed neither by Ostrogoths nor Goths, but rather by clients from the estates of his wife, who was of Hispanic origin.79 It has been said that Theudis established the capital of the kingdom in Toletum. This statement lies in the fact that a law issued by him (the only one known) on the expenses of justice, dated 546, was signed by the king in Toledo. This argument, however, is not valid. Many laws included in the Codex Theodosianus, for example, mention emperors signing laws in unlikely 
places - Sirmium, Serdica, Mediolanum - without indicating that these were places in which they resided, or which were their capital, rather than places through which they had passed. This is the value I believe should be given to Theudis signing this law in Toledo (Data sub die VIII Kalendas decembrias, anno XV, regni domini nostrigloriosissimi Theudiregis Toleto. Recognovimus ['issued at the 8th day before the December Kalends, year fifteen, under the rule of our very glorious king Theudis in Toledo. We have reviewed']). ${ }^{80}$ Toledo was only to be transformed into the central place of the kingdom from the time of Athanagild, or, more probably, of Liuvigild (569-586).

\section{How many came?}

The question how many came is impossible to answer. However, it is of fundamental importance in order to gain an idea of the nature of the population that emigrated to the Iberian Peninsula, and the extent of the area they might have settled. Yet we know nothing about such aspects with any degree of certainty.

An entry by Olympiodorus of Thebes tells us, the Goths who settled in Barcino in 416/7 finally received, when they handed Galla Placidia to Honorius (or perhaps even beforehand), a quantity of 600,000 modii of wheat, which they had been demanding for some time, and which had been promised by Rome. ${ }^{81}$ The Goths urgently needed grain supplies. Shortly beforehand, they had had to buy it at an exorbitant price from the Vandals in Baetica. ${ }^{82}$ Jones calculated that this amount would be sufficient to feed some 15,000 men for a year. ${ }^{83}$ Does this mean that the individuals that had settled in Barcino numbered 15,00o? Was only the army being referred to? Was this an exceptional payment on one occasion or was this expected to last several years? Jones' calculations have been discussed by several scholars, and some consider them to be 'too long' (Nixon). Be that as it may, the Goths or the people who were in Barcino with Athaulf did not plan to settle there, and it is by no means certain that all those that had accompanied him from Italy after Alaric's death in Cosenza were actually there. There is no archaeological trace of their presence in Barcino. Whatever the numbers involved, this group moved from Barcino to Gallia, where they settled in

8o Velázquez Soriano and Ripoll López 200o, pp. 526-529.

81 Olympiodorus of Thebes, frag. 30, commentary in Arce 2005, pp. 275-276.

82 Olympiodorus of Thebes, frag. 3 .

83 Jones 1964, vol. 3, p. 39, n. 65, with the criticism of Nixon 1994, pp. 64 seq. 
accordance with the foedus of 418 . However, what would be interesting to know is how many moved to the peninsula in 531. More than a century had elapsed since they settled in Aquitania.

Historians have calculated the approximate numbers of those who moved to the peninsula. These calculations are very generic, and are not based on secure evidence. Abadal i Vinyals considered that the Visigothic kingdom was in the hands of some 1,500 families and thus the total population must have numbered 7,000 or 10,000; Reinhardt believed that they would have been about 80,000 or 100,000, while Orlandis and Sánchez-Albornoz put forward a figure of 200,00o. There is no evidence whatsoever to support such population figures. Perhaps the one closest to reality is that proposed by Abadal i Vinyals, whose total is quite close to the figure calculated by Jones. ${ }^{84}$

\section{Who were the people who entered the Peninsula?}

The essence of the problem is whether it can be stated that the people who entered the peninsula were 'Goths'. It should be remembered that, from 395 onwards, the Goths accompanying Alaric followed him along a route that took them from Thrace to Constantinople, and from there to Thessaly, Boeotia, Achaea, Corinth, and the Peloponnese, and subsequently to Epirus; they later moved to regions of Illyricum; afterwards to Italy (Mediolanum, Pollenza, Verona, Rimini, Ravenna, and Rome), before heading southwards to the Strait of Messina and, after part of the fleet in which they were trying to reach Africa sunk, returning to Cosenza. ${ }^{85}$ From there, now under Athaulf's leadership, they headed to the north of Italy and entered Gallia, were expelled from Narbonense towards Barcino, and returned to Narbonense. It was there that an agreement was reached. A hundred years later, in 531, they entered Hispania. The loss of people in the course of this long journey must have been considerable (from Pollenz and Verona, encounters with different military bodies, the loss of a large part of the fleet in the Strait, to which should be added the periods of shortages, illnesses, desertions, etc.). In addition to these factors, we must bear in mind the different groupings of people who joined them in the course of these travels (slaves, Vandals, Celts, Romans, etc.). This mixture of peoples represented a multi-ethnic group, a group clearly not made up exclusively of Goths, or perhaps including very few Goths. Liebeschuetz justifiably stated that 'the army that was settled in

84 Abadal i Vinyals 1958; Reinhardt 1945; Sánchez-Albornoz 1959; Orlandis Rovira 1975.

85 See now Arce 2018, pp.141-155. 
418 [in Aquitania] could have included a small proportion of men that had left their territory in $395 .{ }^{86}$ For this reason, he continues: 'they had become a new people'. Heather is more hesitant: 'the Visigoths [...] who founded successor states to the western Roman Empire were not purely Gothic;; $; 7$ and although over the course of time 20,000 or 30,000 individuals joined the original group, this did not alter the Gothic nucleus. The newly incorporated members were 'Gothicized' with the passage of time. If it is borne in mind that in 531 a part of 'the Goths' remained in Narbonense, and the remaining members of the families, the elderly, the children, and women, entered Hispania, the question that should be raised is whether the people who entered the peninsula in the early sixth century were 'Goths'. The generic references to them in the sources reflect a historiographic convention.

González Salinero has recently summarized the problem, in my opinion, extremely prudently: 'The basic population of the Visigothic kingdom in Hispania was made up by a great majority of Gallo-Romans and subsequently Hispano-Romans, as well as a powerful minority of strictly speaking Gothic ascendancy'. 88

This statement takes us back to Abadal i Vinyals's theory and to that of Liebeschuetz. Only a minority made up the Gothic core of what was subsequently to appear in the sources as the regnum Gothorum. The continuity in power of this nucleus was guaranteed because, as the IV Council of Toledo (AD 633) lays down, nobody could be elected king unless he was of Gothic lineage. The other peoples who lived alongside them in Aquitania did not so much become Gothicized, but rather Romanized. But above all, the regnum cannot be understood without the church. It was the church that permeated its actions in all spheres of activity. And the church was not interested in whether its faithful were Goths or Romans or Silingian Vandals. It was exclusively interested in their being followers of the church's faith and doctrine. This was clearly a process that fundamentally took place from the reign of Reccared and the III Council of Toledo.

\section{Where and how did they settle?}

The last question and the final point in this contribution is to endeavour to establish how they settled and where. No text speaks about either point. All

Liebeschuetz 1992, p. 76

Heather 1991, p. 330.

González Salinero 2017, p. 237. 
we can do is speculate. Some historians defend the view that 'the Visigoths in Spain were settled on individual lots. The rules of the settlement - hospitalitas - were the same as those [that] had been applied for the settlement of the Visigoths in Gaul. The Goth received two third[s] of an estate while the Roman kept one third. ${ }^{89}$ This statement is based on two texts in the Lex Visigothorum that, under the heading of antiqua reproduces extracts from Liuvigild's Codex Revisus, which in turn date back to Euric..$^{90}$ The problem is to clarify whether we can consider these references, which reflect events that took place in early fifth-century Gaul, to be applicable to the situation in sixth-century Hispania.

Since there was no longer a Roman authority in the peninsula, it should be considered that the settlement took place by means of agreements with individuals or local authorities but agreements that remain unknown because of a lack of written evidence. There is no reference in the records to conflict between newcomers and the Hispano-Romans. Was the system established by Euric used in this new distribution of lands? We do not know.

If a group of immigrants moved from Narbonense to Hispania, the logical route for them to have followed would have been via the pass of Le Perthus. For this reason, the first area in which they settled might be expected to have been Tarraconense, which corresponds to present-day Catalonia. Afterwards, they spread throughout the peninsula, with the exception of the furthermost regions occupied by the Suevi. Archaeology has confirmed these settlements in a broad sweep of Spanish territory. These new peoples occupied villae as well as cities. It is very difficult to detect their presence in the latter; and in villae it is extremely unlikely that it can be demonstrated that they were 'Goths'.

After posing this series of questions it is appropriate to develop further a number of comments related to them. The presence of the Goths in Hispania can be divided into two clearly differentiated phases: an initial one of a military nature (in the late fifth century) and a second one of a peaceful nature, the consequence of immigration (the first few decades of the sixth century).

The arrival of the Goths in the Iberian Peninsula initially led to a degree of unrest among certain local groups, who offered resistance, precisely because of the military nature of their interventions. Bearing in mind the state of abandonment in existence in the peninsula, the obvious solution was to take

89 Liebeschuetz 2007.

90 Ibid. and González Salinero 2017, p. 241-242. 
control over it by proclaiming oneself emperor. This was what happened initially, during the period in which King Euric (466-484) undertook an aggressive policy of conquering different cities and regions of the peninsula. However, the revolts, or the events described below, did not start in this king's reign, but in that of Alaric II.

The Goths had first come into contact with the Iberian Peninsula as a consequence of their alliance with Rome (foedus) when they acted as troops against the Suevi, Vandals, and Alans who had crossed into Hispania in 409. Theodoric I's expedition, which had been sent cum voluntate et ordinatione Avitii imperatoris ('at the request and order of the emperor Avitus'), ${ }^{91}$ led to the former's interest in the peninsula. ${ }^{92}$ As long ago as 1923, Bury stated: 'But, though he [Theodoric] went in the name of Avitus and the Roman Republic, we cannot doubt that he was deliberately preparing for the eventual fulfilment of the ambition of the Goths to possess Spain themselves, by weakening the Suevic power'.93 But the death of Avitus in Gaul in 457 forced Theodoric to leave the Iberian Peninsula and return to Gaul. ${ }^{94}$ Although he continued to show interest in Hispania, he never undertook his project to expand the Goths' presence throughout the area. His successor, King Euric, was to fulfil this policy of expansion, starting with Tarraconense, thus trying to wrest from Rome a province that had hitherto traditionally always been under Roman control. It was therefore in Euric's reign that the gradual occupation of Hispania by the Gothic people, who until that moment had occupied the area of Aquitania in Gaul, truly began. However, this activity was restricted exclusively to the cities; this stage still did not represent a period of settlement. Euric had acceded to the throne by assassinating his brother Theodoric. ${ }^{95}$ In the Chronica Gallica of 511, it is mentioned that, after the death of the Roman emperor Anthemius, in 472, Euric sent Count Gautericus to take Pamplona, Caesaraugusta, and several nearby cities: Gauterit comes gothorum Hispaniam per Pampelonam et Caesaraugustam et vicinas urbes obtinuit.${ }^{96}$ Subsequently, Heldefred and Vincentius, who were similarly sent by Euric, besieged Tarraco and a number of other cities on the Mediterranean coast (in the year 474).

94 Isidore of Seville, Historia de Regibus Gothorum, Wandalorum et Sueborum, 32; Hydatius, Continuatio Chronicorum Hieronymianorum, 176.

95 Hydatius, Continuatio Chronicorum Hieronymianorum, 238; Isidore of Seville, Historia de Regibus Gothorum, Wandalorum et Sueborum, 34.

96 Chronica Gallica of $511,651$. 
These early, localized military conquests did not enjoy the support and acquiescence of the local aristocracy of Tarraconense. Both Isidore and the Consularia Caesaraugustana mention this reaction in their accounts. In fact, Isidore states in general terms that, by means of the invasion with his army, Euric eliminated the nobility of Tarraconense who had fought against him: Tarraconensis etiam provinciae nobilitatem, quae ei pugnaverint, exercitus irruptione evertit. ${ }^{97}$ The impact of the aggressive interventions of Euric's Gothic forces made itself felt or led to a reaction during the reign of his successor, Alaric II (484-507). A certain part of society in Tarraconense did not accept the presence of the Goths in the province or at least not in the violent way that it was exercised by Euric's armies. Tarraconense preferred to remain faithful to the empire, both in Constantinople and in Rome. One indication of this local reaction was probably expressed in an inscription dedicated to the emperors Anthemius (467-472) and Leo I (457-474), who ruled the Western and Eastern empires respectively, which was displayed in the forum of Tarraco. ${ }^{8}$ The inscription is in a marble plaque probably affixed to a statute pedestal. ${ }^{99}$ The inhabitants of Tarraco - and especially its aristocracy - still continued a well-established Roman tradition, that is the display of statutes in the most prestigious points of the city, and by means of this inscription they expressed their adherence - perhaps as an act of desperation - to the ruling emperor's legitimacy. They felt themselves to be Romans and proclaimed this fact at moments of doubt and danger. Nevertheless, by this stage nobody was able to offer assistance. They had to resist by themselves. And it is in this context that the usurpations of Burdunelus and Petrus should be placed. The Consularia Caesaraugustana provide two almost consecutive entries reflecting events in the years 496 and 506. In the first entry, it is stated that a certain Burdunelus in Hispania tyrannidem assumit ('Burdunelus became a tyrant in Hispania'), and for the following year the Consularia refer to the occupation of cities on the part of the gothi (that is to say the Gothic army). It is perfectly reasonable to think that Burdunelus's usurpation (tyrannidem assumit) was related to the Goths' attempt to gain control of the cities of Tarraconense. In the first instance, Burdunelus did not act alone and could count on the support of others, but once he was betrayed by the latter, he was handed over to the Goths, who transferred him to Tolosa (Toulouse), at the time the capital of the kingdom of Aquitania, where he was condemned to an exceptional and particularly 
gruesome death: he was placed inside a bronze bull, which was placed over the fire until it melted (Burdunelus a suis traditus et Tolosam directus in tauro aeneo impositus igne crematus est). Burdunelus's revolt was a failure. Where this proclamation, this usurpation took place is unknown. We do not know whether it was in a city, but it seems fairly logical to think that it must have been in one in Tarraconense: Caesaraugusta? Tarraco? Barcino? The usurpation lasted scarcely a year. He received an exemplary punishment; he was condemned to the fate endured by usurpers, capital punishment, but on this occasion by means of particularly atrocious and savage suffering, although it should be pointed out that this was not unknown among Roman punishments. ${ }^{100}$ News of the event spread swiftly, reaching Caesaraugusta, where it was gathered by the author of the Consularia.

Who was this Burdunelus? The name seems to point to non-Roman origins, but it is clear that, even if he were a Goth by birth, he acted in the name of Rome against the Goths. ${ }^{101}$ Was he a noble? Did he belong to the administration? We have no information whatsoever regarding these points.

Thereafter, the Consularia record that in 504 that a circus show was held in (Caesaraugusta circus spectatus est), an entry that requires further explanation. After Burdunelus's failure, there was another attempt at usurping power, on this occasion led by a certain Petrus, who in the year 506 also proclaimed himself tyrannus ('emperor/usurper'): Petrus tyrannus interfectus est. He was defeated in the same year as his revolt and, after being taken prisoner in Dertosa (Tortosa), he was executed and beheaded; his head was sent, placed on a spearhead, precisely to Caesaraugusta:Dertossa a Gothis ingressa. Petrus tyrannus interfectus est et caput eius Caesaraugustam deportatum est. Once again, a member of the established society of Tarraconense rebelled against the Goths, this revolt rapidly being crushed. The punishment meted out to him was similarly of the type reserved for usurpers in the Roman world: beheading. I have elsewhere proposed that Petrus proclaimed himself emperor in Caesaraugusta, on the occasion of the circus shows, and, for this reason his head was subsequently displayed there to reflect the exemplary punishment that he was given, which had to be shown to his followers who had supported this proclamation in the former Augustan colonia. ${ }^{102}$

The presence of the Goths in Hispania was not well received, at least not in Tarraconense. In the other provinces of the diocese the Suevi were

100 On the subject, see Callu 1984.

101 Abadal i Vinyals 1958, p. 545, and Thompson 1982, p. 303, n. 31, considered that he was a Roman and not a Goth.

102 See Arce 2005, pp. 171-172. 
already living alongside the Hispano-Romans, and neither does it seem that the Goths were readily accepted in subsequent years from what is known of the later resistance to Liuvigild in Baetica.

A number of years later - almost thirty years afterwards - a part of the Gothic people settled in Aquitania were forced to emigrate to Hispania as a consequence of the Frankish victories and pressure; however, this population movement was of a very different nature from the initial Gothic incursions.

Was this Gothic migration, which on this occasion was peaceful in nature, well received? In contemporary sources at least, or in those that subsequently narrated the event, there is no reference to confrontation or violent clashes. The problem is to establish, as was pointed out above, how the process of accommodation took place. There must necessarily have been agreements and negotiations, but on this occasion the Goths were not in a position to impose anything. The Hispano-Romans are likely to have allowed them to settle in exchange for their working the land and taking responsibility for other necessary 'industrial' tasks. However, none of the extant sources explains how lands were assigned or what system was used for settling the Goths.

It should not be forgotten that prior to this population movement (c. 531), Hispania was ruled from Italy by King Theodoric from the year 511 onwards. ${ }^{103}$ This does not mean that the Goths had already occupied the lands of the Iberian Peninsula, but rather that the Ostrogothic king controlled the provinces of Hispania, as is demonstrated by some of Cassiodorus's letters. Theodoric was interested in guaranteeing the supply of grain from the Iberian Peninsula to Italy, but some individuals had diverted cargos from Italy to Africa. There were abuses in the tax-collection process and in coin weights, as well as in the running of the cursus publicus. In response to complaints by residents of the province, the king sent two high-ranking officials -Ampelius and Liuvirit - to put the administration in order. ${ }^{104}$ In Letter V.39 there is a reference to an individual named Lietus, one of Theodoric's administrators in the Iberian Peninsula, whom some scholars identify as a governor. In addition, on another occasion garrisons of Gothic soldiers quartered in cities are mentioned. These details reveal that an organized administration continued to exist in the peninsula. Chavarría Arnau considers that, since among the tasks of these officials sent by Theodoric

103 Consularia Caesaraugustana, 511.2, and Isidore of Seville, Historia de Regibus Gothorum, Wandalorum et Sueborum, 39.

104 Cassiodorus, Variae epistulae, V.35 and V.39; the letters are dated 523 and 526 , respectively; on this question, see García Iglesias 1975 . 
was that of taking care of the imperial patrimonium, now in the hands of the Ostrogothic king, the lands linked to the ruling Ostrogothic power could have been used for the settlement of both Ostrogoths and Goths; she considers that 'these properties were located in Tarraconense, and more precisely in the upper Duero valley, characterized by the existence of large tracts of cereal-producing lands'. ${ }^{105}$ However, this is simply a hypothesis.

It is clear that the Goths who entered Spain encountered the administration of Theudis, king from 531 onwards, that is to say at almost the same time that the Goths arrived. Theudis had a good relationship with the local aristocracy, as shown by his marriage to an extremely wealthy Hispano-Roman noblewoman who owned extensive rural estates in the Iberian Peninsula. ${ }^{106}$ Theudis could have contributed to the settlement of the newcomers and used his good offices to establish agreements.

The areas where the Goths settled may have been varied and widespread or specific and limited in size. The cities are likely to have accommodated many of them, especially the elites (the cases of Emerita, Tarraco, Barcino, Toletum, Corduba, Hispalis). However, they may also have taken up residence in the countryside, where examples of Roman villae being reoccupied can be identified. ${ }^{107}$ Moreover, it is not absolutely impossible that, as Gisela Ripoll López has suggested, they could also have occupied the agri deserti, areas that were unoccupied in the late Roman period. The Gothic people had been settled in Aquitania since 418 (or 419), not only in rural areas, but also in cities. Likewise, in Hispania beforehand this must have been the case of the Suevi. Thompson pointed out that the only places that were not subjected to sacking in the many raids carried out by the Suevi within their own lands were Bracara, Lucus, and Asturica; this may indicate that Suevi lived in the cities. In fact, Thompson was of the opinion that the bulk of them lived in Bracara. ${ }^{108}$ Nevertheless, in 460 Hydatius expressly states that the Suevi living in Lucus (Luco habitantes) murdered some Roman nobles in their own city.

However widespread, the idea that the Goths did not take advantage of urban life and that they took over almost all the villae or that they built settlements consisting of wooden huts roofed with leaves and branches is absurd. A large proportion of the Goths settled in the built-up areas of Roman cities and were housed in the domus or alternatively settled in open public

105 Chavarría Arnau 2018, p. 22.

106 Procopius, De bello Gothico, V.12.50.

107 For this subject, see Chavarría Arnau 2007, pp. 73-77.

108 Thompson 1982 , p. $15^{8}$. 
spaces in the cities or the suburbium. It is true that they used villae, which they exploited either directly or through the Hispano-Romans themselves. For the Goths, the city represented continuity and identification with the Roman past, an attitude that they appropriated and reused in accordance with their ways of life, which, in the majority of cases, imitated that of the Romans. Needless to say, these new inhabitants had no intention of laying waste to the villae or cities. They needed them for themselves.

The problem is that their presence is not easily recognizable in the archaeological record. The same situation can be found in southern Gaul where, after having lived there for almost a hundred years, the presence of the Visigoths, on the basis of archaeological evidence alone, could be said never to have taken place. ${ }^{109}$ Recently, Esmonde Cleary has come to the same conclusion. ${ }^{110}$ Nevertheless, and as he points out, they continued to preserve their Gothic identity, which was expressed by the existence of a regnum and obedience to the king, as well as adherence to the Arian faith. Maintenance of this 'identity' was restricted to the circle of the elites and powerful in a general way for the purposes of propaganda and merely as required for the cohesion of power. Historians such as Isidore and others contributed to the creation of this identity and the idea of the regnum.

In addition to the Hispano-Romans, the Goths, above all those who settled in the cities, encountered a mixed population that included Orientals (from Syria, Egypt, and the Orient in general). Evidence for individuals of oriental origin can be found in Greek inscriptions from cities in southern Baetica, on the Mediterranean coast (Tarraco, Dertosa, Cartago Nova, Malaca) and in Lusitania, etc. Through the use of such evidence many historians have created a sort of historiographical myth, referring to the existence of 'colonies of oriental traders' in the Iberian Peninsula in this period. ${ }^{111}$ I consider this designation to be inappropriate. The presence of a Greek inscription does not mean that there was a trading colony in a particular place. Neither does the presence of a sarcophagus of 'oriental' style and manufacture. Furthermore, the fact that reference is made to the arrival of a group of oriental traders in the city in the Vitas Sanctorum Patrum Emeretensium does not mean that there was a 'trading colony' in Mérida. There were definitely contacts between Hispania and the pars Orientis in this period,

109 'Without the historical sources no archaeologist could have suspected the occupation of Aquitaine by the Visigoths from 418 to 507'; James 1991, p. 149.

110 Esmonde Cleary 2018.

111 See, for example, García Moreno 1972; Chavarría Arnau 2018, pp. 26-27; González Salinero 2017, pp. 243-245; and many others. This phenomenon is much better testified in Gaul. 
and we are aware of the trade in goods of eastern Mediterranean provenance (in no circumstances, however, substantial). In the vast majority of cases these were travellers belonging to differing professions who travelled to the Iberian Peninsula. ${ }^{112}$

In brief, the majority of the population of Hispania in the sixth and seventh centuries were not Goths and those who were had totally adapted to Roman ways of life. Only the ruling elite really warrant the description of 'Goths'. ${ }^{113}$

\section{Bibliography}

\section{Primary sources}

Cassiodorus, Epistulae Theodoricianae variae, in Cassiodori Senatoris variae, ed. by Theodor Mommsen (Berlin: Monumenta Germaniae Historica, Auctores Antiquissimi 12, 1981 [1894]), pp. 387-392.

—, Variae epistulae, 5 vols., vol. 2: Libri III-V, ed. by Andrea Giardina (Roma: L'Erma di Bretschneider, 2014).

Chronica Gallica of 511, in Chronica minora, 3 vols., vol. 1, ed. by Theodor Mommsen (Berlin: Monumenta Germaniae Historica, Auctores Antiquissimi 9, 1892), pp. $647-666$.

Consularia Caesaraugustana = Victoris Tunnunensis Chronicon cum Reliquiis ex Consularibus Caesaraugustanis et Iohannes Biclarensis Chronicon, ed. by Carmen Cardelle de Hartmann (Turnhout: Brepols, Corpus Christianorum, Series Latina 173A, 2001).

Consularia Constantinopolitana, in The Chronicle of Hydatius and the Consularia Constantinopolitana, ed. and trans. by Richard Burgess (Oxford: Clarendon Press, 1993), pp. 215-246.

Hydatius, Continuatio Chronicorum Hieronymianorum, in The Chronicle of Hydatius and the Consularia Constantinopolitana, ed. and trans. by Richard Burgess (Oxford: Clarendon Press, 1993), pp. 69-124.

Inscriptiones Latinae selectae, 3 vols., vol. 2.2, ed. by Hermann Dessau (Berlin: Weidmann, 1906).

Inscriptions of Roman Tripolitania, ed. by J.M. Reynolds and J.B. Ward-Perkins (Rome: British School at Rome, 1952).

112 Handley 2011, pp. 82-85.

113 I must express my warmest thanks to Philip Banks for the translation of my Spanish text and for his always useful remarks. 
Iordanes, Getica, in Iordanis Romana et Getica, ed. by Theodor Mommsen (Berlin: Monumenta Germaniae Historica, Auctores Antiquissimi 5.1, 1982 [1882]), pp. 53-200.

Isidore of Seville, Historia de Regibus Gothorum, Wandalorum et Sueborum, in Chronica minora, 3 vols., vol. 2, ed. by Theodor Mommsen (Berlin: Monumenta Germaniae Historica, Auctores Antiquissimi 11, 1894), pp. 241-303.

Olympiodorus of Thebes, Fragmenta, in The Fragmentary Classicising Historians of the Later Roman Empire: Eunapius, Olympiodorus, Priscus and Malchus, 2 vols., vol. 1, ed. by Roger Charles Blockley (Liverpool: Cairns, 1981), pp. 27-47.

Procopius, De bello Gothico, ed. and trans. by Hugo Grotius (Mainz: Franzius, 1854).

\section{Secondary sources}

Abadal i Vinyals, Ramon d', 'A propos du legs wisigotique en Espagne', in Caratteri del secolo VII in Occidente (Spoleto: Centro Italiano di Studi sull'Alto Medioevo, Settimane di Studio del Centro Italiano di Studi sull'Alto Medioevo 5, 1958), pp. 541-584.

Arce, Javier, Bárbaros y romanos en Hispania (400-507) (Madrid: Marcial Pons, 2005). — , 'La inscripción del puente de Mérida de época del rey Eurico (483 A.D.)', Pyrenae 39.2 (2008a), pp. 121-126.

— - 'Aportaciones a la discusión sobre la traducción e interpretación de la inscripción del puente Mérida de época del rey Eurico (483 A.D.)', Pyrenae 39.2 (2008b), pp. 143-145.

—_Esperando a los árabes: los visigodos en Hispania (507-711), 2nd ed. (Madrid: Marcial Pons, 2017).

—, Alarico (365/70-410): la integración frustrada (Madrid: Marcial Pons, 2018).

Bury, John Bagnell, History of the Later Roman Empire, 2 vols. (London: Dover Publications, 1923).

Callu, Jean-Pierre, 'Le Jardin des supplices au Bas-Empire', in Du châtiment dans la cite: supplices corporels et peine de mort dans le monde antique (Rome: Publications de l'École Française de Rome 79, 1984), pp. 313-359.

Chavarría Arnau, Alexandra, El final de las villae en Hispania (siglos IV-VIII) (Brepols: Bibliothèque de l'Antiquité Tardive 7, 2007).

—, A la sombra de un imperio: iglesias, obispos y reyes en la Hispania tardoantigua (siglos V-VII) (Bari: Edipuglia, Munera 43, 2018).

Collins, Roger, Visigothic Spain (409-711) (Malden, MA: Blackwell, 2004).

Domínguez Monedero, Adolfo, 'La Chronica Caesaraugustana y la presunta penetración popular visigoda en Hispania', in Los Visigodos, historia y civilización (Murcia: Serie Antigüedad y Cristianismo 3, 1986a), pp. 61-68. 
, 'Las necrópolis visigodas y el carácter del asentamiento visigótico en la Península Ibérica', in Actas del Primer Congreso de Arqueología Medieval Española, 5 vols., vol. 2: Visigodo (Zaragoza: Diputación General de Aragón, Departamento de Educación y Cultura, 1986b), pp. 165-186.

Esmonde Cleary, Simon, 'Villas, Visigoths and Evangelisation: Rural Archaeology in Late Antique Novempopulana', in Interpreting Transformations of People and Landscapes in Late Antiquity and Early Middle Ages, ed. by Pilar Diarte Blasco and Neil Christie (Oxford: Oxbow, 2018), pp. 53-66.

García Iglesias, Luis, 'El intermedio ostrogodo en Hispania (507-549 d.C.)', Hispania Antiqua 5 (1975), pp. 89-120.

García Moreno, Luis Agustín, 'Colonias de comerciantes orientales en la Península Ibérica, ss. V-VII', Habis 3 (1972), pp. 127-154.

—, Historia de España visigoda (Madrid: Catédra, Historia, Serie Mayor, 1989). González Salinero, Raúl, Introducción a la Hispania visigoda (Madrid: UNED, 2017). Handley, Mark, Dying on Foreign Shores: Travel and Mobility in the Late-Antique West (Portsmouth, RI: Journal of Roman Archaeology, Suppl. 86, 2011).

Heather, Peter, Goths and Romans 332-489 (Oxford: Oxford University Press, Oxford Historical Monographs, 1991).

James, Edward, 'Les problèmes archaéologiques du Sud-Ouest wisigotique et franc', in Gallo Romains, Wisigoths et Francs en Aquitaine, Septimanie et Espagne: actes des VII' Journées internationales d'archéologie mérovingienne, Toulouse, 1985, ed. by Patrick Périn (Rouen: Association Française d'Archéologie Mérovingienne/ Musée des Antiquités des la Seine-Maritime, 1991), pp. 149-153.

Jones, Arnold H.M., The Later Roman Empire, 284-6o2: A Social Economic and Administrative Survey, 3 vols. (Oxford: Blackwell, 1964).

Keay, Simon, 'Tarraco in Late Antiquity', in Towns in Transition: Urban Evolution in Late Antiquity and the Early Middle Ages, ed. by Neil Christie and Simon T. Loseby (Aldershot: Scolar Press, 1996), pp. 18-44.

Koch, Michael, 'Gothi intra Hispanias sedes acceperunt: consideraciones sobre la supuesta inmigración visigoda a la Península Ibérica', Pyrenae 37.2 (2006), pp. 83-104.

—, 'Nunc tempore potenti getarum Eurici regis: el impacto visigodo en Hispania a través de la inscripción del puente de Mérida (483 d.C.)', Pyrenae 39.2 (2008), pp. 137-142.

König, Gerd G., 'Archäologische Zeugnisse westgotischer Präsenz im 5. Jahrhundert', Madrider Mitteilungen 21 (1980), pp. 220-247.

Kulikowski, Michael, Late Roman Spain and its Cities (Baltimore, MD: Johns Hopkins University Press, 2004).

Liebeschuetz, John H.W.G., Barbarians and Bishops (Oxford: Oxford University Press, 1992). 
, 'Latest Barbarians and Taxes', in Archeologia e Società tra tardo antico e alto medioevo, ed. by Gian Pietro Brogiolo and Alexandra Chavarría Arnau (Mantua: Società Archeologica Padana, Documenti di Archeologia 44, 2007), p. 73.

Nixon, Charles E.V., 'Relations between Visigoths and Romans in Fifth Century Gaul', in Fifth Century Gaul: A Crisis of Identity? ed. by John F. Drinkwater and Hugh Elton (Cambridge/New York: Cambridge University Press, 1992), pp. 64-74.

Orlandis Rovira, José, Historia económica y social de Hispania visigoda (Madrid: Confederación Española de Cajas de Ahorros, 1975).

— L La España visigótica (Madrid: Gredos, 1977).

Pérez Rodriguez-Aragón, Fernando, 'Las “necrópolis visigodas” y el establecimiento de los ostrogodos de Vidimero', in Arqueología militar romana en Hispania, ed. by Angel Morillo Cerdán (Madrid: Consejo Superior de Investigaciones Científicas, Anejos de Gladius 2, 2002), pp. 637-650.

Reinhardt, Wilhelm, 'Sobre el asentamiento de los visigodos en la península', Anejos de Archivo Español de Arquelogía 18 (1945), pp. 134-139.

Ripoll López, Gisela, 'The Arrival of the Visigoths in Hispania: Population Problems and the Process of Acculturation', in Strategies of Distinction: The Construction of Ethnic Communities, 30o-8oo, ed. by Walter Pohl and Helmut Reimitz (Leiden: Brill, Transformation of the Roman World 2, 1998), pp. 153-187.

—, 'Las necrópolis visigodas; reflexiones en torno al problema de la identificación del asentamiento visigodo en Occidente según los materiales arqueológicos', in Hispania gothorum: San Ildefonso y el reino visigodo de Toledo, ed. by Rafael García Serrano (Toledo: Museo de Santa Cruz, 2007), pp. 59-74.

Sánchez-Albornoz, Claudio, 'Tradición y derecho visigodos en León y Castilla', Cuadernos de Historia de España 29-30 (1959), pp. 244-265.

Thompson, Edward A., The Goths in Spain (Oxford: Oxford Clarendon Press, 1969). - Romans and Barbarians: The Decline of Western Europe (Madison, WI: University of Wisconsin Press, 1982).

Velázquez Soriano, Isabel, 'El puente de Mérida: algo más que un problema de traducción', Pyrenae 39.2 (2008), pp. 127-135.

Velázquez Soriano, Isabel, and Gisela Ripoll López, 'Toletum, la construcción de una urbs regia', in Sedes Regiae (40o-80o), ed. by Gisela Ripoll López and José María Gurt Esparraguera (Barcelona: Real Acadèmia de Bones Lletras, Series Maior 6, Memorias de la Real Academia de Buenas Letras de Barcelona 25, 2000), pp. 521-578.

Wolfram, Herwig, Storia dei Goti, trans. by Maria Cesa (Rome: Salerno, 1985). 
About the author

Javier Arce is Professor Emeritus of Roman Archaeology at the University of Lille (France). He has written widely on late antique Spain, as well as on late antique history and archaeology. He is currently preparing a book on Constantinople in the fourth century. 


\title{
4 The Early Visigothic Presence in Southeastern Hispania
}

\author{
New Finds from a Rural Settlement in the Carthaginiensis, \\ Senda de Granada (Murcia) \\ Jaime Vizcaíno Sánchez and Luis Alberto García Blánquez
}

\begin{abstract}
This chapter analyses some aspects of the late antique occupation of 'Senda de Granada', a rural settlement in Murcia. In the late fifth century, after they arrived in Hispania, the Visigoths attempted to assimilate Roman culture. Archaeological research has revealed the possibility of a religious building, with a well-defined funerary enclosure. Grave goods, mainly dress accessories, from the burial and a nearby dump, are decorated with the cloisonné technique. The presence of such items was previously unknown in southeastern Carthaginiensis. These finds and, more widely, the resulting settlement pattern, are evaluated and will be used as a blueprint for the examination of early Visigothic presence in the region.
\end{abstract}

Keywords: Hispania; Carthaginiensis; Visigoths; rural settlement; grave goods; cloisonné

\section{Archaeological characterization of the site}

The rural complex of Senda de Granada is located in the hinterland of Carthago Spartaria, $50 \mathrm{~km}$ to the south. The setting of the site is the vicinity of the Roman route that linked the capital of the Carthaginiensis and Ilunum and Complutum. This important road connected the Mediterranean coast with the central areas of Hispania. The plain in this central sector of the Segura valley is a strategic crossroad that provides communication between the Levantine coast and Baetica. Beside being of geostrategic importance, the

Panzram, S. and P. Pachá (eds.). The Visigothic Kingdom: The Negotiation of Power in Post-Roman Iberia. Amsterdam: Amsterdam University Press 2020 DOI: 10.5117/9789463720632_CHO4 
valley is a fertile agricultural landscape watered by the Segura river, where several late Roman villae, such as La Alberca or Algezares, have been attested. ${ }^{1}$

The site was identified during the construction of housing in the developing residential belt around Murcia. ${ }^{2}$ There were no previous records of its existence, which triggered an archaeological rescue plan within the construction area. The site lies on a gentle southward slope located in Espinardo, $2.6 \mathrm{~km}$ from Murcia, the old Mursiya founded in 825 . The area north of Murcia has changed substantially since Roman times; during the Roman period, the area was watered by only two seasonal watercourses, which limited its agricultural potential. Since the Islamic period, after the building of an irrigation system connected to the Segura river, the region has undergone a thorough transformation. Before this metamorphosis, the settlement pattern was dependent on the impact of seasonal floods. Between the fourth and seventh centuries (phases 1-3), the main structures were built on the top of small hills, while work areas and humble dwellings were located on low inundation areas.

Despite the fact that a large area has been excavated (Fig. 4.1), not all of the original complex could be documented due to the area affected by the construction project. Moreover, the record of the site has been affected by construction during the later Middle Ages and a substantial area has been repeatedly subjected to soil removal for agricultural purposes. As a result, buildings and other features were in a precarious state of preservation. Some of them were preserved only by their foundations, built with poor materials.

Analysis of the stratigraphic, structural, and material contexts allowed us to establish six occupational periods. Scattered archaeological remains dating to the early Roman Empire were found in late antique silos. These materials must have come from a nearby area, as yet unidentified. The site began its development from the fourth century (first phase), when oil presses, pottery kilns, and probable forges signal production for the purposes of self-supply and, possibly, local redistribution. We think these structures belong to the pars fructuaria of a partially unknown villa. At the end of fifth century (second phase), this function changed, when the original villa became a new rural settlement. Similar development has been attested for other nearby villae, such as La Alberca and Algezares, the residential buildings of which underwent a thorough transformation in the late fifth century. ${ }^{3}$ The archaeological record suggests this to be a

1 Ramallo Asensio, García Blánquez, and Vizcaíno Sánchez 2012.

2 About the complete excavation, García Blánquez 2010.

3 Ramallo Asensio, García Blánquez, and Vizcaíno Sánchez 2012, pp. 332-340. 


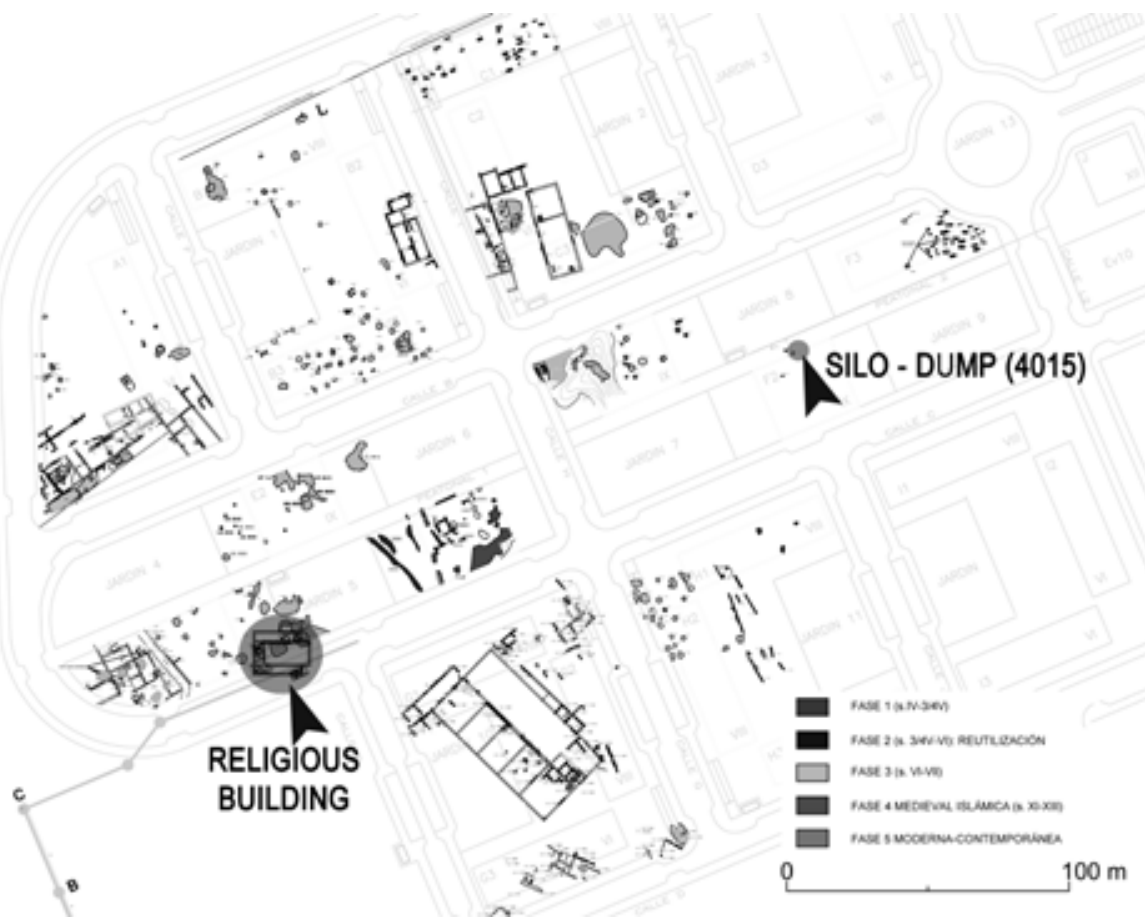

Fig. 4.1 Plan of the rural complex of Senda de Granada (Murcia, Spain). @ Jaime Vizcaíno Sánchez and Luis Alberto García Blánquez.

widespread phenomenon, not only in the southeastern territory, but in most regions of Hispania. ${ }^{4}$

This second phase yielded more information. During this period, the settlement was occupied by a different community, dedicated to agriculture and stock-breeding. Some former production structures were reused as humble dwellings. Domestic activities resulted in large rubbish dumps deposited in the old workshops. Different funerary areas were also identified, including three burial phases: the western necropolis (fourth-fifth centuries), the northern necropolis (fifth-seventh), and the eastern necropolis (sixth-seventh), mainly related to the second phase, in addition to privileged funerary area and other scattered burials. Finally, at the beginning of the seventh century (third phase) the rural complex was abandoned, perhaps in the context of changing settlement patterns in southeastern Spain. No evidence for violent destruction has been found; the archaeological evidence shows a gradual process of abandonment until the arrival of Arabs in the late ninth century (fourth phase), when the settlement was reoccupied. 


\section{An early medieval rural settlement}

Senda de Granada shows the late reoccupation of a rural complex, possibly the pars fructuaria of a Roman villa, whose pars urbana is still to be identified. The transformation of rural occupation patterns during late antiquity is an increasingly well-known process. The changes undergone by this site are reminiscent of similar processes attested at the villae of El Val and Aguilafuente. It stands as another piece of archaeological evidence for a widespread phenomenon, detected throughout Europe: the replacement of villas by another sort of rural settlements, inhabited by a different social class and, therefore, a different material culture. ${ }^{5}$ Senda de Granada is one of the few known examples from southern Spain.

The villa became an agricultural settlement from the fifth century. Our fieldwork has revealed humble dwellings, whose reuse has divided older buildings into smaller units. The later structures are built in rammed earth and timber walls, set on a masonry plinth. The detection of post holes suggests a wooden roof. Old tegulae are rarely attested and appear only as plundered material in walls, ovens, or small cisterns. These new residential and industrial structures, built in reused and perishable materials, have simple hearths, although a few small kilns have been recorded.

In this occupational context, we found a number of ditches or pits, mainly in the depressions caused by small gullies. Most of them are silos, a type of storage structure in this region generally found pre- or post-dating the Roman imperial period, i.e. associated with Iberian or late antique rural settlements (Fig. 4.2). They were common between the fifth and seventh centuries, as illustrated by Senda de Granada or the nearby site of Los Villares. ${ }^{6}$ Significantly, these storages are not found in the vicinity of Carthago Spartaria, but only in its territorium.

Unlike traditional cemeteries found in the Castilian plateau, in this occasion it was possible to excavate both the cemeteries and related settlement. As such, Senda de Granada is an opportunity to analyse multiple features of the settlement, including two cemeteries (the northern and eastern necropolis), a small, private necropolis inside a hypothetical 'church', and small groups of scattered tombs. The scattered graves mainly appear in lower and inundation areas, which are regarded as marginal burial spaces. One of those is a tomb in which a corpse was found alongside a potential purse clasp. 

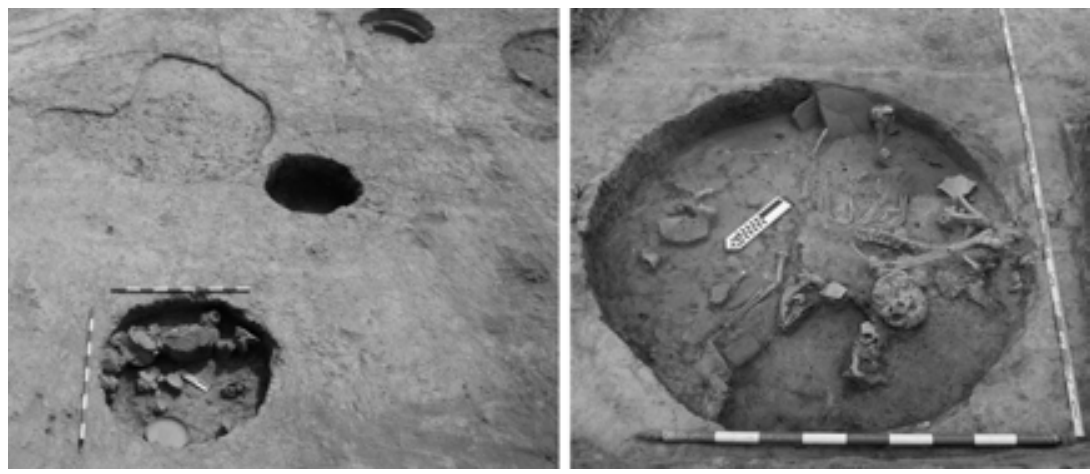

Fig. 4.2 View of some silos and detail of silo-dump 4015, where the cloisonné purse mount was found. (๑) Jaime Vizcaíno Sánchez and Luis Alberto García Blánquez.

Overall, these features are reminiscent of those recorded in an increasing number of sites around Madrid. Their similarity to northern European sites has led some scholars to link them to Visigothic practices. ${ }^{7}$ This type of site is unusual for the southeastern Carthaginiensis. Recent excavations have revealed only a handful of such sites, near Los Villares (Murcia) and Rinconada de Olivares (Jumilla), both of which feature sunken-floor huts, postholes, kilns, and an associated cemetery. In Senda de Granada, apparent from this changed settlement pattern, an interesting set of items of personal adornment were found, allowing us to ask about their individual or social significance, but also about manufacturing techniques and ornamental styles, which traditionally have been considered to be 'Germanic' or even 'Gothic' signs of identity. ${ }^{8}$ Indeed, the southeastern Carthaginiensis was instilled with strong Roman traditions, where a significant Visigothic presence has not been considered to predate the mid-sixth century, when Liuvigild sent his troops against the Byzantine province which had taken over the coast between the Fretum Gaditanum and Dianium..$^{9}$ Recent finds suggest that this should be qualified, and that groups were much more mixed than previously believed.

Although little quantitative data are available, their qualitative significance cannot be denied. We want especially to highlight three pieces characteristic of a long Germanic tradition, although some scholars have indicated that they are not necessarily exclusive to these peoples. Their typology, manufacturing techniques, and decoration belong to Ripoll López's

9 García Moreno 1998, pp. 118-121; Arce 2011; Vallejo Girvés 2012. 
second (480/9o-c.525) and third $\left(c .5^{2} 5^{-560 / 80}\right)$ styles. ${ }^{10}$ They are mainly characterized by the use of the cloisonné technique. A disk fibula and a belt buckle, alongside another incomplete item depicting an eagle, are the most important pieces in the assemblage. These pieces are generally found in the central area of the Castilian plateau, in cemeteries that have been linked to the initial stages of Visigothic settlement. ${ }^{11}$ In fact, some scholars have pointed out that these items reflect a fashion that was largely restricted to the area between the Douro and the Tagus rivers. They are at the core of a heated debate concerning whether they were imported or produced in Iberian workshops. ${ }^{12}$

However, no similar items have previously been found in southeastern Carthaginiensis, where they were thought to appear only in the middle sixth and seventh century, by which time they were under the influence of other Mediterranean styles. As such, given the scarcity of related objects, we think that these foreign-appearing materials, dated to the early sixth century, can become a relevant piece of evidence concerning the production and circulation of this sort of object. Furthermore, these new finds blur traditional boundaries, altering the distribution map of early Visigothic settlement. Clearly, we should start asking questions about the nature of these items and their value in terms of fashion, tradition, and even identity. ${ }^{13}$ Especially, we think that Senda de Granada could help us understand the convergence of different traditions in the early Visigothic West. ${ }^{14}$

\section{The religious building and the sacred cemetery}

A hypothetical religious building and its related cemetery were built a short distance from the settlement. Unfortunately, the building could not be entirely revealed due to limitations posed by the rescue nature of the project. The eastern side of the structure, probably an apse, was beyond the excavation limits and remains unexcavated (Fig. 4.3). Also, the state of preservation of the structure was precarious. The floor of the building had completely disappeared, and only the foundation of the walls, without superstructure, could be identified. The inadequate remains strongly

Ripoll López 1998.

11 Ebel-Zepezauer 2000; Eger 2005.

12 A synthesis of the problems and proposals, now updated in these same pages, in Heather 1999 and Ripoll López 2010.

13 Ripoll López 2010.

14 Pinar Gil 2013. 


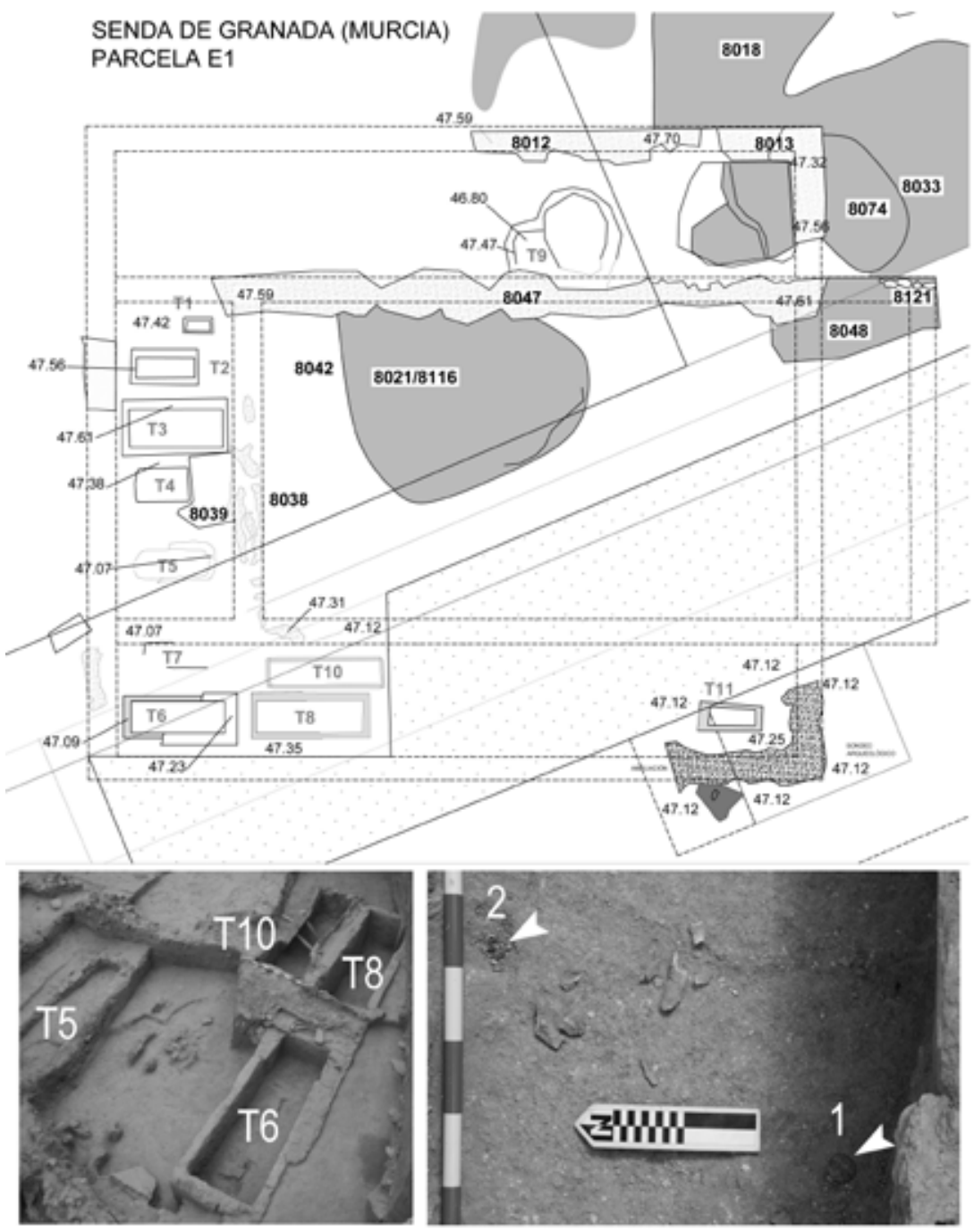

Fig. 4.3 Plan of the religious building and the sacred cemetery. Details of the tombs located in the southwestern corner and grave 10, showing the disk brooch and the belt buckle. $\odot$ Jaime Vizcaíno Sánchez and Luis Alberto García Blánquez.

recommends caution. However, if our hypothesis is correct, this complex would join the long list of churches built on the remains of abandoned villae, reused for the construction of humbler rural dwellings. ${ }^{15}$

Although, as noted, we cannot determine the precise shape of this hypothetical 'church', six parallels walls suggest the division of space into 
three uneven rectangular rooms conforming to a three-nave basilica, oriented to the east, as was typical for these buildings. A funerary area comprising several tombs, which are perfectly aligned with the structure, was excavated on the western side of the building. The central nave was $7.5 \mathrm{~m}$ wide, but its length remains unknown, although it was probably longer that the southern aisle, which is $17.48 \mathrm{~m}$. Two aisles flank the central nave, to the north $(14.68$ excavated length $\times 3.58)$ and the south $(17.48 \times$ 3.24). The walls were built directly over the late Roman occupation level. There were several dumps $(8018,8042,8048)$ beneath the building, which suggest a construction date for the 'church' in the final years of the fifth century. Dump 8018, in addition to faunal remains and different bronze and lead objects, yielded a small pottery assemblage, the most recent datable typologies of which include African Red Slip Ware (ARSW) Hayes 59 A $(c .320-380 / 400)$ and Hayes $61 \mathrm{~A}(c .325-400 / 420)$. Dump 8048 yielded another significant ARSW assemblage, including types Hayes $61 \mathrm{~A}(c .325-400 / 420)$, but also Hayes 73 A (c.420-475), Hayes $76(c .425-475)$ and Hayes 91 (midlate fifth century). Next to wall 8047, identified as the northern wall of the central nave, dump 8042 provided, among different fine and coarse wares, ARSW Hayes $58 \mathrm{~A}(c .290 / 300-375)$, Hayes $59 \mathrm{~B}(c .320-420)$, and Hayes $61 \mathrm{~A}(c .325-400 / 420)$. The northern (8012) and eastern (8013) foundations walls of the northern aisle were built in mud and masonry. However, the southern (8047) and eastern (8038) foundation walls used a different building technique. Pebbles, mainly local metamorphic rocks, were mixed with mud and lime, which included aggregates such as crushed pottery. Two fragments of ARSW embedded in this mortar could be identified as Hayes 91 and Hayes 61 A types. This evidence confirms a date for the 'church' in the late fifth century.

The feebleness of the foundations leads us to think that the walls were made on rammed earth. In fact, the new walls do not reuse spolia. The design of this modest-sized 'church' (three simple, long and wide spaces), built, probably on rammed earth on feeble foundations, in addition to the lack of further reinforcing structures, indicates that the building was timber-roofed, but not vaulted. On the other hand, there is no indication of liturgical furnishings or baptismal facilities. We have found eleven tombs, mostly located in the western and southern sides. The number of tombs is, in our opinion, a significant variable for the interpretation of the building. The funerary use of space is unsystematic, as nine tombs occupy only in a small area. Other known rural funerary spaces, such as mausolea and private chapels, developed in a very different manner. Also, the cemetery is located inside the building, and is clearly oriented east-west, which confirms that 
this was not an open cemetery located over the remains of an abandoned villa, as in the nearby site of Los Villaricos (Mula), which also includes a larger number of tombs. ${ }^{16}$

The tombs were intentionally dismantled and the covers damaged. Only a few bones could be found. Grave 6 preserved part of its cover; it was made of brick and tegulae, and probably had been covered with sandstone slabs. A few bones were found in anatomical position, laid on their backs with head to the west and feet to the east, in perfect alignment with the structures. Due to later alterations, it is unclear whether some of the graves were reused. Five of the tombs formed a cluster inside a rectangular feature in the western side of the central nave, the 'narthex'. These tombs (1-5) are made of masonry mixed with lime mortar. On the southern aisle, the tombs $(6,8,10)$ were also oriented east-west, and made with sandstone slabs of different width, mixed with lime mortar and small pebbles. The external measurements (length and width) of the tombs were: graves $6(2.7 \times 1.24 \mathrm{~m})$; $8(2.3 \times 1.20 \mathrm{~m})$, and $10(2.55 \times 1.0 \mathrm{~m})$. Tomb 11 , in the east end of the southern aisle, was used for a child burial (8300), and contains the only monolithic sarcophagus of the necropolis $(1.07 \times 0.47 \mathrm{~m})$, carved in calcarenite sandstone. It is trapezoidal in shape, wider at the western end. Some of the corpses were placed inside coffins. The wood remains preserved by the corrosion of the iron nails have been analysed. ${ }^{17}$ The results indicate that the wood used was conifer (Coniferae), although three of the tombs afforded no precision; in the other two, the coffins were made of Mediterranean-type pine. This wood could have been sourced locally, so not necessarily trade material. As such, we think that the wood used was not a status symbol for a 'privileged' social group buried in this cemetery.

The existence of a nearby necropolis dated to the same period seems to show that those buried in this 'church' were probably individuals of high social standing in this community of peasants. The differences attested between these cemeteries could be interpreted in several ways, as a sign of ostentation by higher-status individuals, or a sign of spatial distribution based on social and/or family groups. Coeval cemeteries used plundered material, even reused amphorae or bricks, which are completely lacking in this small cemetery. Only tomb 10 provides a defined funerary deposit with personal adornments: a disk fibula with cloisonné and a belt buckle. Apart from the costume accessories in the Germanic tradition, no 'allochthonous' funerary customs were attested. 


\section{A privileged tomb? The grave goods of tomb 10}

Unfortunately, the grave had lost its cover. The body had been partially removed, and the excavation only yielded a group of disjointed bones. Therefore, nothing may be said about the position of the body or its relation to other objects. It is the only body that preserves remains of any burial garment.

\section{Cloisonné disk brooch}

The fibula shows an earlier form of the cloisonné style: 'clasped cloisonné', also referred to as 'jointed cloisonné. ${ }^{18}$ This technique includes narrow cells set closely together directly upon the back plate (Fig. 4.4). The design is simple, reflecting the beginning of mass production of cloisonné jewellery during the sixth century. The reverse of the plate is flat and slightly convex, and its central axis presents traces of joints, which themselves are lost. Its diameter is $38.8 / 37.8 \mathrm{~mm}$. The thickest areas of the base plate are covered by a gilded copper alloy grid, the lower frame of which is also visible through the empty cells. The overlain grid is pierced with three parallel rows of small circular cells. Only the cell located in the middle of the disk is quadrangular in shape. This cell is also the only one to preserve the inlay: a green glass, a common material in the cloisonné style during this period. This pattern is combined with a net of rectangular or trapezoidal cells decorated with red inlays. Due to this arrangement, these cells have a convex or concave extension on opposing sides. The usual chromatic trends of the earlier cloisonné style suggest that the now empty circular cells probably contained green glass, as did the central piece.

From a technological and craftsmanship point of view, the brooch is of middling quality. The different inlays have been roughly cut in various shapes and sizes. As a result, the edges are clearly visible. The cloisonné disk brooch is a characteristic type of Visigothic metalwork. Numerous parallels

of this type come from cemeteries located in the centre of Hispania, which were in use at the beginning of Visigothic occupation. This type belongs to Level III, between $c .525$ and $c .560 / 80 .^{19}$ Although it is difficult to attribute an accessory dress to a particular gender, the cloisonné disk brooches are 


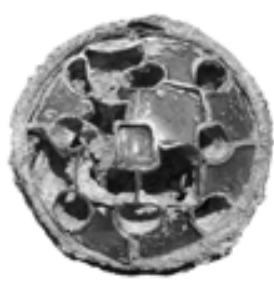

$1 \mathrm{a}$

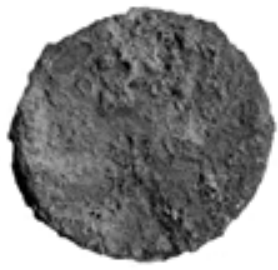

$1 \mathrm{~b}$

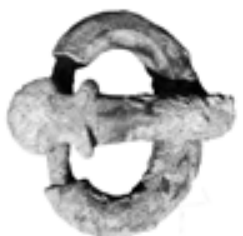

2
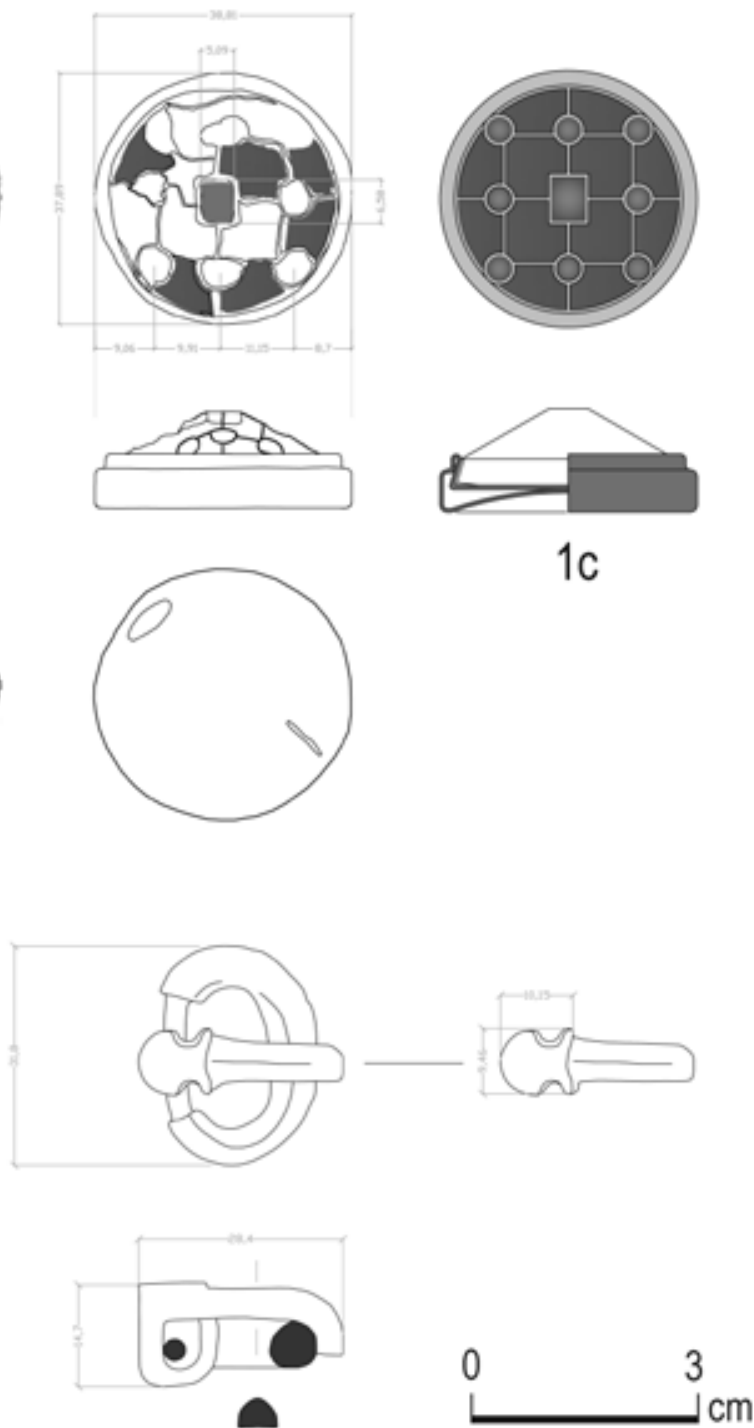

Fig. 4.4 Grave goods of tomb 10: disk brooch and belt buckle. @ Jaime Vizcaíno Sánchez and Luis Alberto García Blánquez.

usually found in female graves. A pair of small garnet brooches usually adorned the upper part of the Frankish costume, either to fasten a peplos-like garment at the shoulders or to close it at the waist. ${ }^{20}$ 


\section{Belt buckle}

The belt buckle consists of a heavy oval loop and a tongue with a basal shield. The buckle loop is oval in shape, $2.9 \mathrm{~cm}$ in length and $2 \mathrm{~cm}$ in width; the cross section is also oval and narrows towards the pin. The elongated tongue is wound around the loop with an attachment spring and rests on a small depression in the buckle loop. In his study of dress accessories from El Carpio de Tajo, Sasse classes these loops with type 10002, and tongues with basal shield with type A1010o. The buckle falls within Sasse's style 3 $(c .530-570){ }^{21}$ Other scholars, such as Schulze-Dörrlamm, refer to this type as 'ovale schilddornschnalle'/A13, dated to the first half of the sixth century. ${ }^{22}$ This type of buckle is not frequent in this area where we know of just one piece from Carthago Spartaria. ${ }^{23}$

\section{The silo-dump}

In addition to the cemeteries, some scattered burials were also attested. Some are secondary tombs, originally conceived as silos, later used to bury bones brought from their primary locations. Two pits used as secondary tombs were found in sector $\mathrm{F}_{2}$, to the north of the main production building. These 'deviant burials' seem to differ from other 'burials in non-funerary context' relatively common in Visigothic Spain. ${ }^{24}$ For instance, our silos contained only a few human bones, not complete skeletons. The bones were thrown in the pits without any funerary treatment. As a rule, after the deposition of the bones, the 'deviant burial' was covered by domestic rubbish.

One of these silos (4015) was a circular pit in which a purse mount was found (Fig. 4.5). It was dug at the beginning of the second phase, during the fifth century. Afterwards, the silo was used to deposit miscellaneous rubbish. The object decorated in cloisonné style was found in one of the latest fill layers, beside the wall of the silo-dump and near an incomplete human skull. The pit also contained several disjointed human bones, including the skull, a lower jaw, a complete femur and other broken bones, such as a pelvis and a clavicle. The purse mount may have been part of the dress accessories 

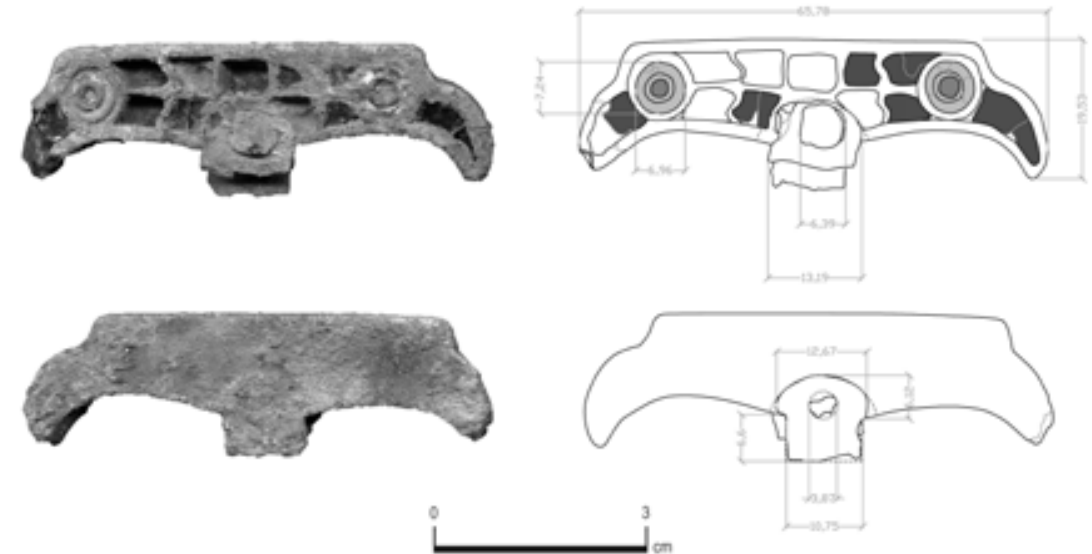

Fig. 4.5 Cloisonné purse mount found in silo-dump 4015. @ Jaime Vizcaíno Sánchez and Luis Alberto García Blánquez.

worn by this incomplete corpse. Concerning its state of preservation, it is unclear whether it had been broken during the transference from its primary position, or whether it was already broken. On the other hand, the human bones were found over the complete skeleton of a goat, which was intentionally deposited. The goat's head was turned to the left, beside the front legs, which were extended and crossed, while the rear legs were folded against the abdomen. Otherwise, the dump mainly contained pottery, but also animal bones and agricultural implements, such as an incomplete grinding stone and an iron sickle. With regard to pottery, we should highlight a rim of ARSW, type Hayes 99 B (c.525-c.60o). As such, the obliteration of the silo between the late sixth and the early seventh century is a perfect limit ante quem for dating our artefact.

\section{A cloisonné purse mount}

The purse mount consists of a bronze plate with two terminals in the shape of a predatory bird (length: $6.5 \mathrm{~cm}$; width: $1.9 \mathrm{~cm}$; thickness: $0.5 \mathrm{~cm}$ ). One of the beaks is missing. The reverse of the mount is flat. Like our disk fibula, this bronze piece belongs to one of the earliest forms of the cloisonné style, the 'jointed cloisonné. ${ }^{25}$ As such, the back plate is also the background of the inlays, as revealed by examination of the empty cells. The red inlays resemble garnets, but the breaks reveal that they are, in fact, glass. 
The technical details of the construction can be easily appreciated. A schematic cell-grid is set upon a back plate; the small inlays are cut irregularly, and do not exceed $3 \mathrm{~mm}$ in width; the cells are arranged so as to form geometric patterns. The inner cells are mainly rectangular, although those located at the corners, beside the bird's heads, have concave sides. Although only a few of the inserts have survived, it seems that all were cut red inlays, and that, therefore, there was no combination of colours, unlike the disk brooch. This is relevant, because polychrome cloisonné is characteristic of a later period. ${ }^{26}$ Only the eagle's eyes break this pattern, being made of mother-of-pearl. In our purse mount, these eyes are highlighted by a silver edge around the inside of the cell walls. It is possible that the inner pupils were a different colour, giving the piece some degree of polychromy.

One of the most notable features in the piece is the shape of the corners, with the heads of predatory birds, an uncommon motif (contrary to, for instance, horse heads). Here, the shape, especially the beak, facilitates its identification as an eagle. These birds appear in a wide range of migrationperiod metalwork, such as sword scabbards, belt buckles, and fibulae, among others. ${ }^{27}$ However, the interpretation of this piece as a purse mount seems clear. These clasps share not only certain typological and technical features but also size and style of decoration. Nevertheless, our plate was only about $7 \mathrm{~cm}$ long, a more common size being in the region of $10-11 \mathrm{~cm}$, perhaps indicating a child purse mount.

If the interpretation is correct, the piece would present a buckle on the middle area for attaching a strap. While the required central buckle has not survived, two flat sheets attached with rivets are visible where this clasp would normally be. The clasp would belong to a leather bag, not preserved, used to contain other artefacts. Unfortunately, the transfer of the grave to a secondary location has led to the loss of most of the skeleton, making the sex of the buried individual uncertain. We have no information about the mount's original deposition which, judging by other parallels, may have been at the waist or the knees of the corpse.

No examples of this type of purse mount have been found in the classic Visigothic cemeteries of Hispania. Indeed, purse mounts are not a frequent Visigothic dress accesory, and the few examples that exist, for instance in Madrona (Segovia), are poorer than our mount, lacking in cloisoneé decoration. ${ }^{28}$ 
However, this type of purse mount with garnet cloisonné is a typical item in upper-class Frankish graves, where richer versions have been found. These come in different varieties: they can be manufactured in gold, iron, or bronze and the cloisonné style can present widely varying styles, as following examples will illustrate. A purse mount currently at the Metropolitan Museum, with terminals shaped with the typical horse head, is especially interesting. ${ }^{29}$ Unlike our piece, this iron plate, with cell walls made of low-grade silver, is multicoloured, featuring garnets and green glass, which form a more complex pattern than our purse. Also, some of the pieces are mounted over an underlying layer of gold foil. The eyes have independent, cross-shaped cells, topped by a central cabochon. Based on parallels, the purse should be dated to the last decades of the fifth century. One of the closest parallels may be a purse mount found in a rich warrior grave from Planig (Rhine-Hessen, Germany). The piece is dated c.530 and was manufactured in the same jointed cloisonné technique. $3^{0}$ Other examples are found at Saint-Dizier (Haute-Marne, Champagne-Ardenne, France) and include lapis lazuli. They are grave goods of rich graves dating $525-550$, which are linked with sixth-century 'Frankish chieftain' graves. ${ }^{31}$

Most examples are better than the one from Senda de Granada in terms of technology and craftsmanship. The European examples were made in different metals, especially gold, and are associated with richly furnished burials, such as those at Lavoye, Saint-Dizier, or Planig. These differences are obviously not only technological but also social. Our bronze purse betrays a technique less sophisticated than its parallels, suggesting a different social group. Objects of similar quality to our example found in Merovingian Gallia include one found in the necropolis of Han-sur-Lesse, dated to $480-525$. This purse was made in iron with golden brass plating, and presents only three garnets, the rest of the surface being decorated by an incised grid..$^{2}$ Our piece is also similar to an earlier, and famous, group of eagle brooches. These artefacts present cloisonné decoration, and are classed in the second style (480/90-c.525). It has been pointed out that they are one of few elements that can be considered a specific sign of identity. ${ }^{33}$ However, some scholars have rejected the idea that this is symbolic of Germanic origin. In this perspective, the eagle would have resulted from cultural contact among

Truc 2012. 
different groups. The use of this animal would be a sign of status, in the new habitus barbarus. ${ }^{34}$ Nevertheless, distribution maps show that these objects concentrate in areas where the Germanic presence is strong. Another product of Visigothic metalwork featuring this iconography is a type of bow brooch, the plate of which sports schematic bird heads projecting from the edges. Although this type, which is dated to the mid-sixth century (Level III), is not particularly common.

Apart from the total lack of parallels in Hispania, the morphological and decorative features of our cloisonné artefact, a hypothetical purse mount, unknown in Hispania to date, leads us to suggest that this object may be of foreign origin. Unfortunately, the lack of cement or gypsum below the inlays does not allow us to make the archaeometric analysis required to pinpoint the exact workshop in which it was produced. We think that it is safe to assume that the piece was made in a Germanic workshop, as suggested by its strong affinity with fifth- and sixth-century central European clasps. Other questions need to be answered: Is this object a Germanic high-status grave good? How can long-range relations between early medieval Germanic elites be explained? In central Europe, graves that feature this type of purse mount are often located near forts or other strategically or economical significant locales, usually alongside important roads. Does that indicate that Senda de Granada may meet these criteria?

\section{Conclusion}

Unfortunately, the partial nature of the excavation means that our interpretations must remain provisional and should be taken as hypotheses for future research rather than firm conclusions. To establish the specific workshop in which these pieces were manufactured would require advanced techniques. However, the site can be viewed from another perspective, that of the chronology of the dress accessories and the typological and technological features of its structures but also stratigraphic and material criteria.

If we evaluate the data from Senda de Granada as a whole, including changing settlement patterns and the nature of items of personal adornment, the site's uniqueness in the context of the southeast of Carthaginiensis between the fifth and seventh centuries becomes apparent. Concerning the origin of these pieces, we think it likely that they were produced in a central European workshop, reaching southeastern Hispania in the context 
of an early Visigothic settlement that is still unknown. The purse mount, which is practically identical to early sixth-century Merovingian examples, is especially worthy of note. In fact, two of the items found in this site, the cloisonné disk brooch and the purse mount, are a characteristic set found in Merovingian necropolises. Owing to the lack of parallels for this sort of purse in Spanish Visigothic necropolises, this new find may be seen as indicative of ethnic diversity within the Visigothic population, which amalgamated Gothic and Germanic elements as well as non-Germanic groups. Although a single artefact is hardly evidence, these items are much more than simple artefacts. They contribute new evidence to the ongoing debate about the Visigothic nature of Spanish finds, that they may actually partially represent other Gothic groupings and their eastern Germanic federates.

Traditional historiography divides the Visigothic period into two phases: the arrival and settlement of new ethnic groups in central Hispania and, after having imposed their domination, the progressive merging with the Hispanic-Roman population. This historiographical model, however, has important flaws. According to mainstream historiographical thought, the southern Carthaginiensis was all but exclusively Roman territory. It is argued that new Gothic groups did not arrive in the region until they began attacking the Byzantines in the third quarter of sixth century. Unfortunately, the written sources yield little information. Was there Visigothic presence before the reign of Liuvigild? Was the south coast of Spain irrelevant for the new Germanic elites? Does this area lack strategic importance for the former Gothic kingdom before the Byzantine conquest?

It should be taken into account that the presence of these Germanic groups in Spain goes back to 416. Despite this, the Chronica Caesaraugustana mentions two periods of entry, in 494 and 497.35 At first these Germanic groups, comprising soldiers and their families, were not numerous, as the bulk of their population had settled in Gaul. In this regard, there are epigraphic testimonies of an early Gothic settlement in Baetica. However, the fact that southern Carthaginiensis was spared the Gothic presence or influence for more than several decades is difficult to comprehend, especially after their defeat at Vouillé.

In recent years, the academic community has indulged in a striking paradox: while contradicting old theories about the 'homogeneous' Visigothic presence in Spain, marked by an outdated ethnic (and in some cases even racial) approach, it has also rejected the idea that territories considered fully Roman could be anything other than homogenous, ruling out any 
form of 'Gothic contamination'. Modern historiography seems to admit the idea of a cultural merge only for some areas. Archaeology is only capable of indicating traces of this process, but the Visigothic archaeological record goes much beyond a small number of tombs furnished with weapons. ${ }^{36}$ If we think about material culture in southern Carthaginiensis, marked by a classical-looking and 'homogeneous' Roman style, the newly found artefacts do not fit easily. They seem like 'foreign' objects, and they can, therefore, be regarded as imports. They are an isolated expression of the cloisonné style in the region. The 'ethnic' implication of this type of materials is much debated, but we need to explain why it is so scarce in southern Carthaginiensis, in contrast to other areas.

\section{Bibliography}

\section{Secondary sources}

Ager, Barry, 'Byzantine Influences on Visigothic Jewellery', in Intelligible Beauty: Recent Research on Byzantine Jewellery, ed. by Chris Entwistle and Noel Adams (London: British Museum Research Publication 178, 2010), pp. 72-82.

Arce, Javier, Esperando a los Árabes: Los visigodos en Hispania (507-711) (Madrid: Marcial Pons, 2011).

Arrhenius, Birgit, 'Garnet Jewelry of the Fifth and Sixth Centuries', in From Attila to Charlemagne: Arts of the Early Medieval Period in the Metropolitan Museum of Art, ed. by Katherine Reynolds, Dafydd Kidd, and Charles T. Little (New York: Metropolitan Museum of Art, 2000), pp. 214-225.

Cattelain, Pierre, Nathalie Bozet, and Giuseppe V. di Stazio, eds., La parure de Cro-Magnon à Clovis: 'Il n'y a pas d'Âge(s) pour se faire beau' (Treignes: Éditions du Cedrac, 2012).

Chavarría Arnau, Alexandra, El final de las villae en Hispania (siglos IV-VII d. C.) (Turnhout: Brepols, 2007).

—_ 'Churches and Villas in the ${ }^{\text {th }}$ Century: Reflections on Italian Archaeological Data', in Le trasformazioni del V secolo: l'Italia, ibarbarie l'occidente romano, ed. by Paolo Delogu and Stefano Gasparri (Turnhout: Brepols, 2010), pp. 639-662. Ebel-Zepezauer, Wolfgang, Studien zur Archäologie der Westgoten vom 5.-7.Jh. $n$. Chr. (Mainz: Philipp von Zabern, Iberia Archaeologica 2, 2000).

Eger, Christoph, 'Westgotische Gräberfelder auf der Iberischen Halbinsel als historische Quelle: Probleme der ethnischen Deutung', in Cum grano salis. Beiträge 
zur europäischen Vor- und Frühgeschichte: Festschrift für Volker Bierbrauer zum 65. Geburtstag, ed. by Bernd Päffgen, Ernst Pohl, and Michael Schmauder (Friedberg: Likias, 2005), pp. 165-181.

García Blánquez, Luis Alberto, 'Senda de Granada: un asentamiento rural tardoantiguo en el entorno de Murcia', in Poblamiento rural romano en el Sureste de Hispania: 15 años después, ed. by José Miguel Noguera Celdrán (Murcia: Editum, 2010), pp. 467-513.

García Martínez, María Soledad, and Luis Alberto García Blánquez, 'Identificación taxonómica de fragmentos de madera de los féretros de la necrópolis tardorromana de Senda de Granada (Murcia)', Lucentum 31 (2012), pp. 195-206.

García Moreno, Luis Agustín, Historia de España visigoda (Madrid: Cátedra, 1998).

— ' 'Gothic Immigrants in Spain: Researching the History of a Nobility', in Foreigners in Early Medieval Europe: Thirteen International Studies on Early Medieval Mobility, ed. by Dieter Quast (Mainz: Römisch-Germanisches Zentralmuseum, Monographien des Römisch-Germanischen Zentralmuseums Mainz 78, 2009), pp. 169-180.

Giostra, Caterina, 'Goths and Lombards in Italy: The Potential of Archaeology with Respect to Ethnocultural Identification', Post-Classical Archaeologies 1 (2011), pp. 7-36.

González Fernández, Rafael, and Francisco Fernández Matallana, 'La villa de "Los Villaricos" (Mula, Murcia): un ejemplo de asentamiento rural romano', in Poblamiento rural romano en el Sureste de Hispania: 15 años después, ed. by José Miguel Noguera Celdrán (Murcia: Editum, 2010), pp. 347-375.

Heather, Peter, 'The Creation of the Visigoths', in The Visigoths of the Migration Period to the Seventh Century: An Ethnographic Perspective, ed. by Peter Heather (Woodbridge: Boydell Press, 1999), pp. 43-73.

Hilgner, Alexandra, 'A Short History of Garnet: The Development and Chronology of the Cloisonné Style', in Tempo e preziosi: tecniche di datazione per l'oreficeria tardoantica e medievale, ed. by Isabella Baldini and Anna Lina Morelli (Bologna: Ante Quem, 2017), pp. 77-97.

Koch, Manuel, 'Gotthi intra Hispanias sedes acceperunt: consideraciones sobre la supuesta inmigración visigoda en la Península Ibérica', Pyrenae 37.2 (2006), pp. 83-104.

Madrid Balanza, María J., and Jaime Vizcaíno Sánchez, 'La necrópolis de Carthago Spartaria: dinámica de un espacio funerario entre el Bajo Imperio y la época bizantina', in Contextos funeraris a la Mediterrània nord-occidental (segles V-VIII), ed. by Joan Pinar Gil and Toni Juárez Villena (Sant Cugat del Vallès: Gausac 34-35, 2009), pp. 185-203. 
Molinero Pérez, Antonio, 'Guarniciones de carteras en sepulturas visigodas segovianas', in X Congreso Nacional de Arqueología (Zaragoza: Congresos Arqueológicos Nacionales, Secretaría General, 1969), pp. 463-475.

Pinar Gil, Joan, 'A Crossroads of Cultures in a Mosaic of Regions? The Early Visigothic Regnum from the Perspective of Small Finds', Archaeologia Baltica 18 (2013), pp. 103-117.

Pinar Gil, Joan, Jan Jílek, and Milan Vokác, 'A Head of a Predatory Bird from the Migration Period Found at Drnholec (South Moravia, Czech Republic)', Archäologisches Korrespondenzblatt 36 (2006), pp. 429-444.

Quirós Castillo, Juan A., 'Early Medieval Villages in Spain in the Light of European Experience: New Approaches in Peasant Archaeology', in The Archaeology of Early Medieval Villages in Europe, ed. by Juan A. Quirós Castillo (Bilbao: Euskal Herriko Unibertsitatea, 2009), pp. 13-28.

Ramallo Asensio, Sebastián F., Luis A. García Blánquez, and Jaime Vizcaíno Sánchez, 'Poblamiento rural de época tardía en el entorno de Murcia', in Visigodos y omeyas: el territorio, ed. by Luis Caballero Zoreda, Pedro Mateos Cruz, and Tomás Cordero Ruiz (Mérida: Instituto de Arqueología de Mérida, 2012), pp. 329-374. Ripoll López, Gisela, Toréutica de la Bética (Siglos VIy VII d.C.) (Barcelona: Reial Acadèmia de Bones Lletres, 1998).

— , 'Symbolic Life and Signs of Identity in Visigothic Times', in The Visigoths of the Migration Period to the Seventh Century: An Ethnographic Perspective, ed. by Peter Heather (Woodbridge: Boydell Press, 1999), pp. 403-431.

, 'The Archaeological Characterisation of the Visigothic Kingdom of Toledo: The Question of the Visigothic Cemeteries', in Völker, Reiche und Namen im frühen Mittelalter, ed. by Matthias Becher and Stefanie Dick (München: Wilhelm Fink, 2010), pp. 161-179.

Ripoll López, Gisela, and Javier Arce, 'The Transformation and End of Roman Villae in the West (Fourth-Seventh Centuries): Problems and Perspectives', in Towns and their Territories between Late Antiquity and the Early Middle Ages, ed. by Gian Pietro Brogiolo, Nancy Gauthier, and Neil Christie (Leiden: Brill, 2003), pp. 63-114.

Sasse, Barbara, 'Westgotische' Gräberfelder aufder Iberischen Halbinsel am Beispiel der Funde aus El Carpio de Tajo (Torrijos, Toledo) (Mainz: Philipp von Zabern, Madrider Beiträge 26, 200o).

Schulze-Dörrlamm, Mechthild, Byzantinische Gürtelschnallen und Gürtelbeschläge im Römisch-Germanischen Zentralmuseum, 2 vols., vol. 1 (Mainz: Verlag des Römisch-Germanischen Zentralmuseums, 2002).

Truc, Marie-Cécile, 'Probable Frankish burials of the sixth century AD at Saint-Dizier (Haute-Marne, Champagne-Ardenne, France)', in ACE Conference Brussels: The 
Very Beginning of Europe? Early Medieval Migration and Colonisation, ed. by Rica Annaert (Brussels: Flanders Heritage Agency, 2012), pp. 51-66.

Vallejo Girvés, Margarita, Hispania y Bizancio: una relación desconocida (Madrid: Akal, 2012).

Vigil-Escalera, Alfonso, 'Cabañas de época visigoda: evidencias arqueológicas del sur de Madrid: tipología, elementos de datación y discusión', Archivo Español de Arqueología 73 (2000), pp. 223-252.

, 'Comunidad política aldeana y exclusión: una revisión de las formas de inhumación altomedievales (siglos V-VIII d.C.)', Reti Medievali Rivista 14.1 (2013), pp. 1-42.

Von Rummel, Philipp, 'L'Aquila gotica: sull'interpretazione di un símbolo', in $L a$ trasformazione del mondo romano e le grandi migrazioni: nuovi popoli dall'Europa settentrionale e centro-orientale alle coste del Mediterraneo (Cimitile: Tavolario Edizioni, 2012), pp. 51-66.

\section{About the authors}

Jaime Vizcaíno Sánchez (Universidad de Murcia) is Postdoctoral Research Associate at the University of Murcia (Spain), working on the archaeological contexts of late antique Spain, especially in metalwork between the fourth and seventh centuries. His PhD thesis in archaeology was on the Byzantine presence in Spain.

Luis Alberto García Blánquez is an independent researcher in archaeology who collaborates closely with the University of Murcia (Spain). He is the director of the archaeology company Arqueotec, which has conducted productive fieldwork in Murcia. His main research interest is in the archaeology of rural communities between the Roman and Islamic ages. 



\title{
$5 \quad$ Beyond Central and Local Powers
}

\author{
The General Councils of Toledo and the Politics of \\ Integration \\ Paulo Pachá
}

\begin{abstract}
The problem of political integration is one of the most pressing questions of the history of the Visigothic kingdom of Toledo. Historians have traditionally framed it as a structural opposition between the monarchy and the nobility; in the last decade, however, some authors have begun to conceptualize it as an array of more complex dynamics between central and local powers. In this contribution, I will argue that we must go beyond the concepts of central and local powers and focus on their power relations - their integration. To achieve this objective, I will analyse how these relationships developed in the context of the general councils of the Visigothic church, an institution that had a central and determinant place in the process of political integration.
\end{abstract}

Keywords: Visigothic kingdom; Toledo; general councils; monarchy; nobility; integration

\section{Historical models of political dynamics in the Visigothic kingdom of Toledo}

The traditional approach to the formation of the Visigothic kingdom of Toledo frames it as a process with clear chronological limits. Historians usually ascribed its starting point to the beginning of Liuvigild's reign (569) and his military conquests. ${ }^{1}$ The process's conclusion appears more

1 According to García Moreno: 'The period between 569 and 714 , approximately, constitutes the essential of what we know as Visigothic Spain.' García Moreno 1989, p. 111.

Panzram, S. and P. Pachá (eds.). The Visigothic Kingdom: The Negotiation of Power in Post-Roman Iberia. Amsterdam: Amsterdam University Press 2020 DOI: $10.5117 / 9789463720632 \_$CHO5 
debatable: 589 , the Kingdom as a result of the III Council of Toledo and the religious unity; ${ }^{2} 601$, the end of Reccared's reign as the high point of his father's work; ${ }^{3}$ or even 624 , the expulsion of the Byzantines from the peninsula. ${ }^{4}$ Nevertheless, in all of these possibilities both centralization and unity appear as the essential elements of the formation process. ${ }^{5}$ Therefore, the Visigothic kingdom's formation process appears to be a process of state-building, but with the state being understood as an incomplete projection of the modern state. ${ }^{6}$ The concept of state is then characterized by a certain degree of territorial control, social homogeneity, and institutional centralization.

In this approach, both centralization and unity appear as the monarchy's (here equated with the state's) exclusive attributes, and in opposition to the nobility's objectives of independence or fragmentation. In this way, the kingdom's formation process appears directed by the monarchy, but in opposition to the nobility. According to García Moreno, this structural opposition would be the 'origin of the central power structural fragility'? This opposition, the traditional narrative goes, would have had developed into open conflict during the seventh century, being the recurrent political dynamic of the Visigothic kingdom of Toledo until its end in $711 .{ }^{8}$ This political dynamic, the backbone of the traditional narrative, I call the MoNo model - Monarchy vs. Nobility, hence MoNo. ${ }^{9}$

Once this 'structural opposition' between monarchy and nobility is set in motion in the traditional narrative, the history of the Visigothic kingdom of Toledo appears only to reproduce it. Therefore, in the traditional narrative there is no place for an integration process - the relation between central and local powers is determined by the model's dynamics as only another form of the opposition between monarchy and nobility. An effective relationship between central and local powers was possible only in the moment of territorial expansion and conquest. Once asserted the formal Visigothic dominance

2 García Moreno 1989.

3 Concilio III de Toledo.

4 Arce 2009, p. 40. Isidore of Seville, Historia de Regibus Gothorum, Wandalorum et Sueborum, ed. by Rodríguez Alonso, pp. 274-277.

5 Liuvigild's reign would be a mark in 'Spanish history' because from then on the 'peninsular history can be followed in a fundamentally unitary way'. García Moreno 1989, p. 113.

6 It is possible to characterize premodern societies as state-based, but this has as its precondition the adaptation of the concept. Wickham 2005; Pohl and Wieser 2009.

7 García Moreno 1989, p. 132.

8 Díaz Martínez 2013, p. 201.

9 Pachá 2015. A slightly alternative approach was developed by Collins, but it maintains the basic elements of the MoNo model: Collins 1980, p. 217. 
over a given territory, its elites would be immediately integrated into the Visigothic system - which explains its instability. In this way, as soon as the traditional historiography characterizes the kingdom's formation process as complete, its attention shifts to the kingdom's disintegration process and the Arab conquest. In this way, several historians have analysed Visigothic history during the seventh century in search of the preconditions and determinants of the future crisis and conquest. ${ }^{10}$ Conflict - more specifically, intra-aristocratic conflict - serves as the central category of the traditional historiography. ${ }^{11}$

In 1980, Collins published an influential article entitled 'Mérida and Toledo: $55^{0}-585^{\prime} \cdot{ }^{12}$ In place of the traditional narrative presented above, Collins proposed a model of Visigothic political dynamics where the main relationships were located between Toledo - as the centre of the Visigothic monarchy - and some semi-independent cities, mostly in the peninsula's south, Mérida being his primary example. Even if Collins did not explicitly present his model as an alternative to the traditional narrative, in the last twenty years the types of relationships drafted in his article have moved to the centre of contemporary research on the Visigothic kingdom of Toledo. In line with a historiography concerned with the problem of the transformation of the Roman world - its impacts on the forms of reproduction of local powers, fiscal systems, and the economic integration of the Mediterranean world - Collins's ideas were recovered and reinvigorated. ${ }^{13}$ During the past decade, historians have increasingly seen the political dynamic of the Visigothic kingdom as a complex relationship between central and local powers (the CLP approach).

According to this approach, the key to understanding the 'articulation' of central and local powers is through the prominent elements of their dialogue. That is to say, according to Castellanos García and Martín Viso, 'the mechanisms that made possible the local implantation of central power [...] two-way channels of communication, of mutual collaboration, of consensus or of its breakdown'. ${ }^{14}$ Through these elements, the central power would have had the necessary mechanism for its process of local implantation as 
a function of the 'two main networks of central political power': the church and the local aristocracy. ${ }^{15}$

Therefore, the authors working within the CLP approach point to an analysis of the relationships between the central and local powers that is not restricted to their structural opposition and conflict but also highlights their cooperation. According to Koon and Wood, 'when viewed in toto, there are far more instances of cooperation between church and king in the Visigothic kingdom than opposition and conflict'. ${ }^{16}$ Castellanos García and Martín Viso fully developed this position. According to the authors: 'The fundamental basis of the structure of post-Roman political power in Hispania, we believe, was not the antagonism between central power and the aristocracies, but the construction of avenues of collaboration.' ${ }^{17}$ The contrast between the CLP approach and the traditional narrative is clear: the structural dynamics of the Visigothic kingdom of Toledo were not those of intra-aristocratic conflict, but intra-aristocratic collaboration.

The CLP approach clearly is more complex than the MoNo model and more adequate to the investigation of the Visigothic kingdom. Nevertheless, it also has its own shortcomings and limits. The new approach's main theoretical problem is the rigid separation between central and local (powers). Castellanos García and Martín Viso built their model on the image of communication channels and avenues, that is to say, two spatially distinguished places that are united by channels or avenues during their communication. In this way, central and local are still seen as clearly separate 'places' that may (or may not) be temporarily linked. Therefore, even when this idea highlights collaboration between central and local powers, it also reproduces the idea of two separate entities that is at the core of the MoNo model. By not engaging directly and on a theoretical level with the traditional narrative, the CLP approach reproduces some of the same presuppositions. It transforms a 'conceptual' static opposition between aristocratic factions - monarchy and nobility - into a spatial one - central and local powers.

Here I want to argue that the temporary overcoming of this separation between central and local was a fundamental feature of the integration process itself, driven by both the monarchy and the aristocracy. In this way, we can only talk of communication channels, avenues, or dialogues between central and local powers when these are framed in a wider process of integration in its most basic sense. On one hand, the central power was 
always dependent on specific local insertions - properties, dependent labour, and royal officials; on the other hand, the local power was also dependent on a specific insertion into the central power - to participate in the councils, in the making of and application of the law, and to be the recipient of royal donations. In Visigothic society, the reproduction of a local power was dependent on its simultaneous insertion into the central power; in the same way, the reproduction of the central power was dependent on local power activity.

In this context we do not find purely local aristocrats sometimes acting as delegates of the central power; nor do we find central power agents deployed in the localities who afterwards became the local powers. The agents of power appear as representatives of both central and local powers. When analysing the relationships between central and local, we should think about the agents of these relationships as in changing states and only circumstantially defined as central or local. Framed in this way, it is not usually possible to talk of a specific aristocrat as an agent of the local or the central power. Instead, most aristocrats are bearers of both central and local power.

\section{Beyond local and central powers: the general councils}

In this section, I want to argue that the integration process of the Visigothic kingdom of Toledo - that is to say, the process through which the central and local powers were successfully integrated - was the main element of its formation process. To be able to track the development of this integration process, we need to take into account the ways through which the complex relationships between the Visigothic central power and the local ones changed and developed over time. In this way, the social dynamic in the seventh century appears as an ongoing process of coordination between the Visigothic aristocracies, both in its central as well as in its local aspects.

To investigate this process, it is necessary to draw on a set of sources that express both the central power's inner workings as well the local powers' agency. We find both aspects in the proceedings of the general councils of Toledo. The councils' proceedings have usually been characterized as sources produced by the central power, but here I will frame them as the products of a relationship between central and local powers. That is to say, the council's proceedings were expressions of central power objectives and had clearly defined goals - an ideal vision of how the kingdom should have functioned. However, they also registered, in any chronologically precise 
moment, the shortcomings of this ideal and the changing relationship between central and local powers. Moreover, the councils' proceedings explicitly reveal their essentially collective nature, both in their production and in their dissemination. In this way, these sources, normative as they were, also registered the many ways in which the central power was unable to turn its desires and plans into reality and their necessary transformation in the process of cooperating with local powers.

The Visigothic councils have been analysed usually both as the expression as well as the means through which the conflicts between monarchy and nobility occurred in the Visigothic kingdom of Toledo. ${ }^{18}$ In this way, when historians find evidence of intra-aristocratic conflict in the councils, they immediately frame these within the MoNo model. However, when viewed as a whole, the image that the proceedings of the general councils presents is very different: they are not mere expressions of conflict, but the central tenet of the integration process itself. Being a complex process, the integration of powers in the Visigothic kingdom was carried out both through conflict and cooperation. No set of sources demonstrate this more clearly than the general councils' proceedings. In this way, the general councils were notable for their intent to produce geographical unity (albeit temporarily), as they ideally gathered all the bishops in the kingdom. Nevertheless, the absence of individual bishops or even of several bishops from the same province was an important indicator of the integration process. Therefore, conflict was very much present in the general councils, but also cooperation. To exist, the general council itself relied upon the active participation and coordination of both central and local powers.

Framed in this way, the general councils were the main space and a fundamental mode of coordination between the central and local powers. Kings (as the central power's representatives) could assert their presence and power in the localities through the councils' decisions. This form of mediated local power was critical for the monarchy's reproduction of itself as the central power. Through the same mechanism, the aristocracy was able to assert its presence and power within the centre - the monarchy. In a similar manner, the assertion of local powers at the centre was critical for their reproduction as separate local powers. It is undeniable that both modes of reproduction and power - be it the central power in the localities or the local powers in the centre - represented fertile ground for conflict. However, what I am arguing for here is that this conflict could only have happened within a framework of coordination and cooperation. That is to say, 
intra-aristocratic conflict, even if it was recurrent and, sometimes, expressed itself as civil war, was unable to endanger the fundamental aristocratic coordination. When we look to the general councils, conflict is clearly present in the actas, but so is their resolution in most cases. Councils were modes and spaces of aristocratic coordination - and this coordination was the fundamental aspect in the political dynamic of the Visigothic kingdom of Toledo.

The integration process was necessarily an ever-changing process, and the councils' proceedings are adequate for its analysis because they are a register of these transformations through time. As a relatively long chronological series, the councils' proceedings reveal some aspects of the integration process through the variations in the attendance it records. The ever-changing relationship between central and local powers expressed itself in the variable aristocratic participation in the councils as spaces of aristocratic coordination. The systematic analysis of the general councils' proceedings opens up the possibility of framing the relationship between central and local powers as a continuous process of transformation, cooperation and conflict. In doing that, we will be able to detect some patterns and to have a less partial perception of the dynamics of intra-aristocratic conflict and cooperation in the Visigothic kingdom of Toledo - one that calls into question even the characterization of both central and local powers.

\section{Case studies: Mérida, Córdoba, and Seville at the general councils}

I want to look back at Collins's article mentioned above, still a prime example of an analysis of the relations between central and local powers. As with most historiography on the Visigoths, Collins was primarily interested in explaining how the Arab conquest of 711 was possible. ${ }^{19}$ To do it, his theoretical strategy was to go back to the foundations of the Visigothic kingdom of Toledo - 'the crucial period 550-585, really the formative years of the Romano-Visigothic state' and examine the types of political relationships established there. ${ }^{20}$ In this way, Collins argues for the importance of the relationships between the centre of the monarchical power, Toledo, and its periphery - the other cities - mainly the big southern ones, Mérida being his primary example. 
According to Collins's hypothesis, the southern cities had the power and the necessary requirements 'to live in practice independent of royal authority' when and if the external domination (or exactions) of the kings were seen as excessive. This would be 'the essential weakness of the Visigothic kingdom in the sixth century'. ${ }^{21}$ When Liuvigild crossed this limit and tried to impose his monarchical authority (now directly related to Toledo's authority) over these cities, Collins argued that the result was Hermenegild's rebellion backed by the same cities. This state of affairs would have changed with the conversion of Reccared during the seventh century, but Collins is not clear on how and why this change occurred. On the contrary, he finishes his article stating, 'it is this constant tension between the centre and the periphery that may be termed the main dynamic of the history of Visigothic Spain. Although I have been looking only at the period 550-85, I believe the principle stands for the whole time-span of the kingdom. ${ }^{22}$ Therefore, according to Collins, the independence of these cities in relation to Toledo's authority continued, even if at times in a 'latent' state. Thus, he concludes, 'it may not be wrong to suggest in conclusion that Toledo's disaster may not have been Mérida's.. ${ }^{23}$

Collins's hypothesis is well grounded in his analysis, specifically for the sixth century. However, he rests his whole argument on the presumption that the urban aristocracies from these southern cities saw no advantage to their participation in the central government. That is, we can only say that the local aristocracies chose their independent and limited rule if we could also explain why the prospects of supra-local rule were unattractive. In this game of binary opposition, a closer relationship with the Visigothic central power (the monarchy, in Collins's analysis) would force the southern cities into a submissive position. Nevertheless, it was also necessary to the local urban aristocracies' interest in the expansion of their own power. Thus, Collins argues that the unstable monarchy of the sixth century did not have enough attraction for the local urban aristocracies. ${ }^{24}$ What I want to consider here is whether these processes could ever have developed in reciprocal independence. That is to say, the monarchy's power over the local aristocracies was dependent upon (at least some of) the local aristocracies already being onboard with respect to its political project. 
It is not easy to reconstruct this process - in the end, it is a process of statebuilding - but I want to consider here how the relationship between Toledo and some of the southern cities (Mérida, Córdoba, and Seville) developed during the seventh century. I will do so through an initial analysis of the general councils of the Iberian church. My argument, then, is a simple one and is based on three main points: 1) in most cases the bishops were the main aristocratic representatives of a city; 2 ) the general councils of the Iberian church were a privileged moment of the integration process; 3 ) the pattern of attendance of a city's bishop throughout the seventh-century councils is a way to reveal more about the relationship between Toledo - here seen as the central power - and the major cities as privileged loci of local power. ${ }^{25}$ Lastly, I also want to argue that this type of characterization - central power and local powers - is important as a primary step, but it is also a partial perspective that we should surpass through the development of other models and concepts.

The Iberian church and the Visigothic monarchy held the general councils in Toledo during the entire seventh century, gathering aristocrats from all the regions of the kingdom - churchmen and laics alike. In the sedes regiae they discussed many issues, from the most abstract theological debates to the most concrete questions of the kingdom's daily life. Local powers from everywhere in the kingdom were gathered in Toledo - the central space of power - and summoned by the king to rule over the kingdom's most pressing issues. During the general councils the central and local powers were as one - integration was a visible phenomenon.

Between 589 and 711, twenty-eight councils of the Catholic church were held in the Iberian Peninsula. From these, eighteen happened in Toledo, thirteen of them as general councils of the kingdom. ${ }^{26}$ They had no predefined periodicity - at least none that was effective - and happened when needed and possible. On the one hand, the holding of a general council was a clear response to a given specific context; on the other hand, the series of councils over more than a hundred years points to a structural process that cannot be reduced to an immediate context. That is to say, the general councils were both an expression and one of the main mechanisms of the integration process.

25 Given the limits of this chapter, I will not develop the first point here, which I think it is almost consensual. For a more general view: Brown 2013. For a specific discussion of Iberian bishops: Barbero de Aguilera 1992; Valverde Castro 1992; Panzram 2010.

26 The IX and the XI Councils of Toledo were provincial councils. The XIV had a special character. The XVII did not preserve the signatures. La Colección Canónica Hispana, I.306-325; Concilios visigóticos e hispano-romanos; Orlandis Rovira 1986, p. 167; Stocking 200o, pp. $15^{-17 .}$ 
The general council's debates and decisions were registered and collected in the councils' proceedings - actas. ${ }^{27}$ The proceedings of each council also registered the signature of those who were present and deemed honourable enough to sign it: the bishops and their representatives were the largest group, seconded by the aristocrats in the king's service and the abbots. Taken together, these elements offer us a precious glimpse of the integration process in its development. Historians have analysed this rich data mostly in a contingent way - usually restricted to the comparison of two or three councils - and usually not in any systematic way. ${ }^{28}$ Thus, their most important aspects, that is to say, their historical development, their variation, and transformation over time have been left unacknowledged.

Here I want to demonstrate briefly how these data can be useful in grounding a new analysis of the relationship between central and local powers. In this specific case, my hypothesis is that, during the seventh century, the quasi-independent status of the southern cities proposed by Roger Collins is not verifiable in the patterns of attendance of the church's general councils. That is to say, bishops from all the major southern cities represented their sees in most of the church councils held in Toledo during this period. In support of characterizing the general councils as one of the primary institutions of the process of integration, these patterns of attendance give us important data on the participation of each region in this process over a long period.

In this chapter I will analyse only the data from three important southern cities - Mérida, Córdoba, and Seville - but my working hypothesis is that the pattern of attendance of those cities can be generalized for other cities in the same region. The data regarding those cities and the eleven general councils is presented in Table 5.1 .

We start with Mérida: out of eleven councils, Mérida's bishops were present in eight (Toledo III, IV, VII, VIII, XII, XIII, XV, and XVI), sent a representative to one (Toledo VI), and were absent from two (Toledo V and $\mathrm{X}$ ). Then we

27 With the exception of the last council - XVIII Toledo (702) - all the proceedings were preserved. The actas were preserved in several manuscripts throughout the seventh century. It is impossible to know if the preserved manuscripts contained the actas of all the councils that happened in the Iberian Peninsula during this time, but the specialists in the proceedings' manuscripts argue for a carefull register and preservation of all the available actas. Stocking 2000, pp. 15-17; La Colección Canónica Hispana, I.306-325; Concilios visigóticos e hispano-romanos; Orlandis Rovira 1986, p. 167.

28 The few works that have placed the councils in the centre of their analyses have a clear descriptive nature: Orlandis Rovira 1986; Ziegler 1930. One exception is Stocking's book from 2000, but it is centred in the IV Council of Toledo (633). 
Table 5.1 Attendance of bishops from Mérida, Seville, and Córdoba at the general councils

\begin{tabular}{llll}
\hline & Mérida & Seville & Córdoba \\
\hline III (589) & Masona & Leander & Agapius \\
IV (633) & Stephanus & Isidore & Leodefredus \\
V (636) & ABSENT & ABSENT & ABSENT \\
VI (638) & Gutisclus & Honoratus & Leudefredus \\
& (for Horontius) & & \\
VII (646) & Horontius & Antonius & Valentinianus \\
& & & (for Leudefredus) \\
VIII (653) & Horontius & Antonius & Fosforus \\
X (656) & ABSENT & Fugitivus & ABSENT \\
XII (681) & Stephanus & lulianus & ABSENT \\
XIII (683) & Stephanus & Floresindus & Mummulus \\
XV (688) & Maximus & Floresindus & Mummulus \\
XVI (693) & Maximus & Faustinus & Zaccheus \\
\hline
\end{tabular}

Source: Concilios visigóticos e hispano-romanos.

have Seville, with an even more stable pattern than Mérida: out of the same eleven councils, Seville's bishops were present in ten and absent from another (Toledo V). Finally, there is Córdoba, with a less stable pattern: the city's bishops were present in seven of the eleven councils, sent representatives to one (Toledo VII), and were absent from three (Toledo V, X, and XII).

Let us look more closely at the absences. First, Toledo V, where the bishops from all three cities were absent. This council happened in 636 and King Chintila summoned it. Not only the bishops from Mérida, Seville, and Córdoba were absent, but also several others. In fact, only twenty-two bishops and two representatives were present. ${ }^{29}$ Orlandis Rovira explains this small gathering by how quickly the king summoned and held it. Therefore, most of the bishops present were from the Carthaginiensis..$^{30}$ Then we have Toledo $\mathrm{X}$ (656), summoned by King Recceswinth, a small gathering: seventeen bishops and five representatives. Nevertheless, among them was Seville's bishop - Fugitivus. ${ }^{31}$ Orlandis Rovira argues that the small audience was the result of 'tiredness and lack of interest' on the part of the bishops. ${ }^{32}$

29 Concilios visigóticos e hispano-romanos, pp. 230-231.

30 Orlandis Rovira 1986, pp. 301-302. Baetica and Narbonensis were not represented; Gallaecia and Lusitania were represented by one bishop each. Concilios visigóticos e hispano-romanos, pp. 230-231.

31 Concilios visigóticos e hispano-romanos, p. 319.

32 Orlandis Rovira 1986, p. 361. 
In a similar vein, Díaz Martínez proposed that the several absences in the case of this council were a 'symptom of the bishops' lack of interest after their failed attempt to mediate [a conflict between the king and the nobility] three years before [at Toledo VIII]', ${ }^{33}$ Finally, there is the absence of Córdoba's bishop from Toledo XII (681). According to García Moreno, this absence was the result of a vacant see, given the probable death of the former bishop, Fosforus, and the gathering of the council before the naming of the new one. ${ }^{34}$

What can we conclude from these data? I want to highlight two complementary points: consistency and exceptions. The attendance patterns of the bishops of Mérida, Seville, and Córdoba at the general councils were consistent, not episodic. That is to say, during more than a hundred years the southern bishops diligently left their cities and went to Toledo to be present at the general councils. That in itself seems to be very important. Why did they go there? Why did they keep going? In a context of important transformations, the general councils continued to be an important place of aristocratic integration and coordination. This represents consistency, but we also have exceptions: first, there are the few absences in our three cases; second, as I have shown, we can analyse the context of each absence and find more or less direct explanations for each.

From a more general point of view, the bishoprics functioned as the basis for the integration process. As the fundamental elements of the provincial network, the bishops were nodal points between the central and local powers. ${ }^{35}$ In this way, the development of the integration process was based in the control or cooperation of the bishoprics and their main agents - the bishops. Therefore, the general councils were the essential moments of aristocratic articulation and cooperation in the integration process. That, I would argue, is an important basis for a critique of the separation of central and local powers.

\section{Conclusion}

Given the brief analysis above, it is certainly better to talk about a 'central articulation of local powers' than about a 'structural opposition between 
monarchy and nobility'. Nevertheless, we would still need to answer some further questions: were the bishops acting as local or central powers, for example, when they went to Toledo and gathered in the councils? I think that these dichotomies are not enough and, on the contrary, may hinder our comprehension of the Visigoth political dynamic. Therefore, I want to propose that one of the results of the integration process itself was to surpass this separation between central and local - a result that both the monarchy and the aristocracy struggled to achieve. In Visigothic society, the reproduction of a local power was contingent on its simultaneous presence within the central power; in the same way, the reproduction of the central power was contingent on the local powers' actions.

The series of Iberian councils' proceedings offer us precious information about how the Visigothic kingdom's aristocracy developed a specific mechanism of articulation and negotiation of power over the course of more than a hundred years. Moreover, and most importantly, this mechanism went beyond a simple duality between central and local powers. If we look past the appearance of repetition, we can investigate the councils as evidence of transformation in those relationships. In the brief analysis developed above, I have tried to show how even the most 'plain' data from the councils - their attendance list - can reveal patterns and shed light on the politics of integration. Indeed, when looking at these three important southern cities, we do find a stable pattern of attendance at the general councils. My intention is not to argue that this pattern of attendance is evidence for total cooperation between these local powers and the central power. Nevertheless, this pattern is meaningful in other ways: most importantly, as evidence of how these local aristocracies were invested in the general councils as a locus for negotiation, conflict, and cooperation. The analysis of these patterns of attendance in relation to those of other local powers is the necessary next step to enrich our understanding of its significance and possible variations. The specific contexts and political struggles of the Visigothic kingdom of Toledo were diverse, but the general councils maintained their centrality as a place of aristocratic coordination and negotiation of power. ${ }^{6}$

36 The research for this paper was financed by a postdoctoral grant (2016-2017) from the Fritz Thyssen Foundation awarded to the project 'The process of political integration in the Visigothic Kingdom of Toledo: Cooperation and conflict in the General Councils of the Church', developed at the University of Hamburg under the supervision of Sabine Panzram. 


\section{Bibliography}

\section{Primary sources}

Concilios visigóticos e hispano-romanos, ed. by José Vives (Barcelona: Instituto Enrique Flórez, Consejo Superior de Investigaciones Científicas, España Cristiana, Textos 1, 1963).

Isidore of Seville, Historia de Regibus Gothorum, Wandalorum et Sueborum = Las historias de los godos, vándalos y suevos de Isidoro de Sevilla, ed. by Cristóbal Rodríguez Alonso (León: Centro de Estudios e Investigacion 'San Isidoro', Fuentes y Estudios de Historia Leonesa 13, 1975).

La Colección Canónica Hispana, 6 vols., ed. by Gonzalo Martínez Díez and Félix Rodríguez (Madrid: Consejo Superior de Investigaciones Científicas, 1966-2002).

\section{Secondary sources}

Arce, Javier, 'The Visigoths in Spain: Old and New Historical Problems', in Der Frühmittelalterliche Staat - Europäische Perspektiven, ed. by Walter Pohl and Veronika Wieser (Vienna: Österreichische Akademie der Wissenschaften, Forschungen zur Geschichte des Mittelalters 16, 2009), pp. 31-42.

Barbero de Aguilera, Abilio, 'Las divisiones eclesiásticas y las relaciones entre la iglesia y el estado en la España de los siglos VI y VII', in La sociedad visigoday su entorno histórico (Madrid: Siglo XXI de España, 1992), pp. 168-198.

Brown, Peter, 'Virtutes Sanctorum ... Strages Gentium: "Deeds of Saints ... Slaughter of Nations"', in The Rise of Western Christendom: Triumph and Diversity, A.D. 200-100o (Oxford: Blackwell, 2013), pp. 93-122.

Castellanos García, Santiago, Poder social, aristocracias y hombre santo en la Hispania visigoda: la Vita Aemiliani de Braulio de Zaragoza (Logroño: Universidad de La Rioja, Biblioteca de Investigación 20, 1998).

Castellanos García, Santiago, and Iñaki Martín Viso, 'The Local Articulation of Central Power in the North of the Iberian Peninsula (500-1000)', Early Medieval Europe 13.1 (2005), pp. 1-42, doi:10.1111/j.1468-0254.2005.00147.x (accessed 4 July 2020).

Collins, Roger, 'Mérida and Toledo: 550-585', in Visigothic Spain: New Approaches, ed. by Edward James (Oxford: Clarendon Press, 1980), pp. 189-219.

Concilio III de Toledo: XIV centenario 589-1989 (Toledo: Arzobispado de Toledo, 1991). Díaz Martínez, Pablo C., 'Visigothic Political Instituitions', in The Visigoths: from the Migration Period to the Seventh Century; an Ethnographic Perspective, ed. by Peter Heather (San Marino: Boydell Press, Studies in Historical Archaeoethnology 4, 1999), pp. 321-372. 
'La Dinámica del Poder y la Defensa del Territorio: para una comprensión del fin del reino visgodo de Toledo', in De Mahoma a Carlomagno: Los primeros tiempos, siglos VII-IX (Pamplona: Gobierno de Navarra, Departamento de Cultura, Turismo y Relaciones Institucionales, 2013), pp. 167-206.

, 'Concilios y obispos en la Península Ibérica (siglos VI-VIII)', in Chiese locali e chiese regionali nell'alto medioevo, Spoleto, 4-9 aprile 2013 (Spoleto: Centro Italiano di Studi sull'Alto Medioevo, Settimane di Studio della Centro Italiano di Studi sull'Alto Medioevo 61, 2014), pp. 1095-1154.

García Moreno, Luis Agustín, Prosopografía del reino visigodo de Toledo (Salamanca: Ediciones de la Universidad de Salamanca, Acta Salmanticensia, Estudios Históricos y Geográficos 77, 1974).

__ El fin del reino visigodo de Toledo: decadencia y catástrofe - una contribución a su crítica (Madrid: Universidad Autónoma, 1975).

— Historia de España visigoda (Madrid: Cátedra, 1989).

García Sanjuán, Alejandro, La conquista islámica de la Península Ibérica y la tergiversación del pasado: del catastrofismo al negacionismo (Madrid: Marcial Pons, 2013).

Koon, Sam, and Jamie Wood, 'Unity from Disunity: Law, Rhetoric and Power in the Visigothic Kingdom', European Review of History/Revue Europeenne d'Histoire 16.6 (2009), pp. 793-808, doi:10.1080/13507480903368061 (accessed 4 July 2020). Martín Viso, Iñaki, 'Tributación y escenarios locales en el centro de la Península Ibérica: algunas hipótesis a partir del análisis de las pizarras "visigodas"', Antiquité Tardive 14.1 (2006), pp. 263-290, doi:10.1484/J.AT.2.302434 (accessed 4 July 2020). Orlandis Rovira, José, Historia de los Concilios de la España romana y visigoda (Pamplona: Universidad de Navarra, 1986).

Pachá, Paulo, 'Estado e relações de dependência pessoal no reino visigodo de Toledo (séculos VI-VII)', unpublished PhD thesis, Universidade Federal Fluminense, 2015 .

—, 'To name and control: Space and Power in the Integration Process of the Visigothic Kingdom of Toledo', Mélanges de la Casa de Velázquez 49.2 (2019), pp. 109-131, doi:10.4000/mcv.11081 (accessed 4 July 2020).

Panzram, Sabine, 'Mérida contra Toledo, Eulalia contra Leocadia: listados "falsificados" de obispos como medio de autorepresentación municipal', in Espacios urbanos en el occidente mediterráneo (siglos VI-VIII), ed. by Alfonso García (Toledo: Toletum Visigodo, 2010), pp. 123-130.

Pohl, Walter, 'The Transformation of the Roman World Revisited', in Motions of Late Antiquity: Essays on Religion, Politics, and Society in Honour of Peter Brown, ed. by Jamie Kreiner and Helmut Reimitz (Turnhout: Brepols, 2016), pp. 45-61. 
Pohl, Walter, and Veronika Wieser, Der frühmittelalterliche Staat: europäische Perspektiven (Vienna:Verlag der Österreichischen Akademie der Wissenschaften, 2009).

Stocking, Rachel L., Bishops, Councils and Consensus in the Visigothic Kingdom: 589-633 (Ann Arbor, MI: University of Michigan Press, History, Languages and Cultures of the Spanish and Portuguese Worlds, 2000).

Valverde Castro, María del Rosario, 'La iglesia Hispano-visigoda: “Fortalecedora o limitadora de la soberanía real”, Hispania Antiqua 16 (1992), pp. 381-392.

—, Ideología, simbolismo y ejercicio del poder real en la monarquía visigoda: un proceso de cambio (Salamanca: Ediciones de la Universidad de Salamanca, Acta Salmanticensia, Estudios Históricos y Geográficos 110, 2000).

Wickham, Chris, Framing the Early Middle Ages: Europe and the Mediterranean 40o-80o (Oxford/New York: Oxford University Press, 2005).

Ziegler, Aloysius K., Church and State in Visigothic Spain (Washington, DC: Catholic University of America Press, 1930).

\section{About the author}

Paulo Pachá is Assistant Professor of Medieval History at the Universidade Federal do Rio de Janeiro (Brazil). He works on the history of the Visigothic kingdom and the development of its political structure and power relationships. 


\title{
$6 \quad$ King Wamba's Campaign against dux Paulus (673)
}

\author{
Narration of Military and Royal Power in the Late Visigothic \\ Kingdom
}

\author{
Sebastian Steinbach
}

\begin{abstract}
Following the death of Isidore of Seville (636), Julian of Toledo's Historia Wambae regis is the only contemporary narrative source for the history of the late Visigothic kingdom. It mainly focuses on the rebellion of the dux Paulus within the province of the Narbonensis. Apart from that, it is the only detailed description of the election and unction of a Visigothic king, as well as that of an extensive military campaign during the seventh century. This chapter analyses the narration of military power and the implementation of warlike undertakings in this barbaric reign. It reveals the interconnection between the divine legitimation of royal power and military success in Julian's Historia, and examines the archaeological evidence of the equipment and arming of Visigothic warriors, as well as reference to a Visigothic fleet.
\end{abstract}

Keywords: Iberia; Visigoths; Wamba; Paulus; Julian of Toledo

Leaving the small train station of Toledo today and walking for about twenty minutes to the centre of the former urbs regia of the Visigothic Empire, at first glance hardly anything reminds one that this was once the centre of one of the most long-lived barbaric successor states of the Roman Empire. At best, the geostrategically favourable location might catch the eye of the observer: Toletum was comparatively small in size ( 5 ha) and could easily be defended due to its location in a loop of the Tagus river at the intersection of

Panzram, S. and P. Pachá (eds.). The Visigothic Kingdom: The Negotiation of Power in Post-Roman Iberia. Amsterdam: Amsterdam University Press 2020 DOI: $10.5117 / 9789463720632$ CHO6 
important roads on a steep rock formation. ${ }^{1}$ On the Calle San Román, the Museo de los Concilios y la Cultura Visigoda presents various architectural objects, as well as reproductions of the votive crowns of the Guarrazar treasure find. The historical townscape today is dominated by buildings of the thirteenth through the sixteenth century; something 'Visigothic' can hardly to be found here. In a curious context, however, can be found the Cafetería Wamba on the Calle Comercio.

The fact that this king is still remembered here may not be a coincidence. King Wamba (672-680) marks the beginning of the last chapter of Visigothic rule, ${ }^{2}$ which is often interpreted as a 'time of crisis', and which ended with the fall of the kingdom at the famous Battle of the River Guadalete (711). We are comparatively well informed about his reign by the Historia Wambae regis of the bishop Julian of Toledo $\left(c .65^{2-690) .} .^{3}\right.$ After the death of Isidore of Seville in 636 and a gap of one generation (thirty-six years), a first-hand source informs us of events. This 'story of King Wamba' is, however, less a biography of the Visigothic ruler, but rather a glorification of the Christian king and events surrounding the so-called rebellion of the dux Paulus. This rebellion and the military actions taking place around it are the focus of this essay, which concentrates on the narration of military power and the related sacralization of the Visigothic royalty. ${ }^{4}$ Julian's discussion of the election and coronation of Wamba, however, are central to an understanding of his portrayal of the king.

\section{Wamba's election and coronation}

On 1 September 672, King Recceswinth $\left(653^{-672}\right)$ died in Gérticos. ${ }^{5}$ His wife Recciberga had died before 657 and he had not remarried, leaving no male heir or co-regent for immediate succession. ${ }^{6}$ Due to a vacancy of the throne described in the IV Toletanum (633), and in accordance with the rules for the

\footnotetext{
$1 \quad$ Panzram 2014, p. 471.

2 About the reign of Wamba, cf. Claude 1970, pp. 80-81; Claude 1971, pp. 154-166; Collins 2004, pp. 92-102; Kampers 2008, pp. 208-220; García Moreno 2008, pp. 170-176; Orlandis Rovira 1987, pp. 235-249; Thompson 2011, pp. 259-273.

3 Julian of Toledo, Historia Wambae regis, ed. by Krusch and Levinson and by Pizarro.

4 For an introduction to warfare in the Middle Ages, cf. Clauss 2009; Kortüm 2010; Ohler 1997; especially the Visigothic army, Pérez Sánchez 1989.

5 Located in the province of Valladolid, it is now called Wamba because of the election of the king and is the only settlement in Spain with the letter ' $W$ ' in its name.

6 Kampers 2008, p. 210.
} 
election of the king modified in the VIII Toletanum (653), the acclamation of the new ruler was initiated at the time of his death. Many knew, it was said, that Wamba would become king due to certain revelations (multorum revelationibus). ${ }^{7}$ The description of the circumstances of Wamba's election and coronation show parallels to contemporary hagiography ${ }^{8}$ elevating the ruler into a sphere of the sacred. Referring to his age, Wamba rejected the crown. This refusal, an express that he acted without ambition, belonged to the repertoire of hagiographic topography. Although a strange event was to follow: an army commander drew his sword and gave Wamba the choice of accepting the crown or dying on the spot.

Despite this incident, King Wamba's choice corresponded to the rules of Visigothic uprisings. ${ }^{9}$ Successions were always a balancing act between an electoral monarchy by the ruling elite and the attempt by some kings to form a dynasty with hereditary monarchy. ${ }^{10}$ The short life of many Visigothic kings was already recognized as morbus Gothorum in the chronicle of Fredegar. ${ }^{11}$ That the effort complied with the correct procedure is shown by the fact that even those voters not present were given the opportunity to approve, which postponed the anointing to 19 September in the urbs regia Toledo. In this way, the royal elevation corresponded in two respects to the provisions of the VIII Toletanum, according to which it had to take place either at the place of death of the predecessor or in the capital. ${ }^{12}$

With his detailed description of the king's anointment, Julian brings together three sacral elements that were essential for the legitimization of the king: the divine predestination of the candidate, the election and approval by the noblemen of the empire, and the unction of the ruler. ${ }^{13}$ With the issue of unction, documented here for the first time for a Visigothic

7 On the circumstances of Wamba's election and coronation as well as their sacralization in the Old Testament sense, cf. above all Kampers 2007.

8 Kampers 2008, p. 210.

9 Orlandis Rovira 1987 , p. 236.

10 E.g. Liuvigild - Reccared or Chindaswinth - Recceswinth. About the designation of Visigothic successors, cf. Giese 2000, pp. 68-88.

11 Cf. Fredegar, Chronicarum quae dicuntur Fredegarii Scholastici, IV.82: 'cognetus morbum Gothorum, quem de regebus degradandum habebant'.

12 For the route from Gérticos to Toledo Julian gives 120 miles (Julian of Toledo, Historia Wambae regis, 3: centum viginti milibus), which would be clearly too short if the Roman mile of about $1.5 \mathrm{~km}$ was taken as a basis, because the actual distance between Gérticos and Toledo is about $250 \mathrm{~km}$. According to this, the 'Visigoth mile' should have been about $2 \mathrm{~km}$. Dietrich Claude rightly pointed out, however, that even now not all noblemen could have agreed to the election, since the geographical extension of the empire made a notification in such a short time impossible. Claude 1971, p. 155.

13 Claude 1971, p. 157; Kampers 2008, pp. 210-211; and Orlandis Rovira 1987, p. 236. 
ruler, Wamba is elevated into the proximity of Old Testament priestly kings, which is of importance for following military events and the legitimation of royal power. ${ }^{14}$ During the coronation ceremony, a miracle occurred when smoke rose from the anointed head and a bee was visible - elements that refer both to God-given salvation and to future victories in King Wamba's campaign. Julian refers the frequently used term fides to both fidelity to the legitimate ruler and fidelity to God. ${ }^{15}$ The following insurrection described thus represented a double breach of fidelity both to the king and to God. ${ }^{16}$

\section{The rebellion of dux Paulus}

In the spring of 673, King Wamba left Toledo for one of the annual campaigns against the Basques. Since Julian reports a return of the king in October 673 , six months after the beginning of the campaign ${ }^{17}$ it must have begun in April. In barbarian reigns, warriors were usually called up annually to the 'war field' (campus Martis) ${ }^{18}$ Since the times of King Liuvigild (568-586), the Visigoths repeatedly led campaigns northwards without ever being able to fully integrate the region into their kingdom. ${ }^{19}$ It remains unclear whether the campaign was one of regular expeditions against the Basques, or whether an uprising against the newly crowned king was behind it: Already in 653, when King Chindaswinth died (642-653) and his son Recceswinth

14 The naturalness with which Julia describes the unction nevertheless indicates that Visigothic kings had already been unctioned before. The detailed description at this point probably served to legitimize the rule of Wamba. Claude 1971, pp. $155^{-15}$. The ceremony was carried out by the metropolitan of Cartaginensis, Quiricus (Bishop of Barcelona c.640-666, Archbishop of Toledo $667-680)$, in the church of St. Peter and St. Paul in Toledo.

15 Kampers 2008, p. 210.

16 Claude 1971, p. 159.

17 Julian of Toledo, Historia Wambae regis, 29.

18 Whether this gathering of men capable of military service actually took place in March (Märzfeld; Ohler 1997, p. 39; Hartmann 2012, p. 19), or whether it merely refers conceptually to the field near Rome dedicated to the Roman god of war Mars (Goetz 2003, p. 157) is controversial in research. In any case, the military campaigns normally took place during the months of summer, when the weather enabled better movement and saved nutrition for the troops and the animals taken along. The dating of the campaign in the Historia Wambae regis thus gives an indication that the Visigothic army probably also gathered at the end of March/beginning of April.

19 The fact that the Basque language (Euskara) belongs to a linguistic family (syntax and verbal system) that is independent of the other European languages and has almost no Romance influences gives an indication of the long-lasting independence of the northeastern part of the Iberian Peninsula. Herbers 2006, p. 24. 
(653-672) took over the government, a usurper named Froia, ${ }^{20}$ who had allied himself with the Basques, insurrected in northern Spain. Whether the Basques used the $672 / 673$ change again for a struggle with the Visigoth kingdom $^{21}$ cannot be clarified.

We can assume that the army gathered in Toledo was bid farewell with a solemn liturgical ceremony during which prayers and chants, held in the church in front of the palace, were intended to secure God's support for the king and his warriors on the forthcoming campaign. Here he was presented with a military sign - a golden cross reliquary - which illustrated the sacral character of the king, as well as the sacralization of war itself. ${ }^{22}$ Even if the ceremony is not described in Julian's book, the sign is mentioned later when the king prepares his council for the march against the insurgents: Exurgite iam ad victoriae signum, nomen disperdite perfidorum ('Rally now to the standard of victory, destroy the very name of the traitors'). ${ }^{23}$ The royal field sign is explicitly distinguished from the banners of individual troops (signa bandorum), which were used for orientation during the battle, as Julian reports that the king hid the banners in order to leave the enemy unclear about the actual strength of his army. ${ }^{24}$

On his way to the Basque territory, Wamba received news of an uprising in the province of Narbonensis. This was led by the comes Ilderich of Nîmes, ${ }^{25}$ the bishop Gumild of Maguelonne, and the abbot Ranimir, whom the rebels elevated to bishop of Nîmes. The legitimate owner of this seat, Bishop Aregio, had not joined the traitors and had therefore been handed over in chains to the Franks. The description of Julian gives the impression of a local rebellion: Ilderich is at no time called rex by Julian and seems therefore not to have intended a usurpation of the throne. Also, the handing over

20 Collins 2004, pp. 84-85; Kampers 2008, p. 203; García Moreno 20o8, pp. 165-166; Orlandis Rovira 1987 , pp. $15^{8-159 .}$

21 Collins 2004, p. 93.

22 On the Visigothic ceremony before the beginning of a campaign and its interpretation, $\mathrm{cf}$. Kampers 2008, pp. 213-214, and 2007. On Visigothic ornamental crosses, cf. Eger 2004, pp. 461-467. 23 Julian of Toledo, Historia Wambae regis, 9.

24 Ibid., 16. The designation of the field signs as bandus refers both to the Germanic (Gothic) word banduo ('sign') as well as to the Greek $\beta \alpha$ á $\delta \circ \varsigma$ as a term for field signs in the Byzantine armies of the sixth and seventh century. Like these, the Visigothic battle banners were obviously also kept in a building next to or directly in the church in order to hand them over to the marching troops. Even without the explicit mention of a 'flag blessing ceremony', the storage and handing over of the signs within a sacred district refers to the sacralization of war even in the barbaric regna of the early Middle Ages. Kampers 2007, pp. 75-76.

25 Probably the comes civitatis of Nîmes, since the city had a special importance for the administrative structure of the Visigoth Empire. Claude 1970, p. 44. 
of the bishop to the Franks could indicate that the rebels rather looked for a stronger connection to their neighbouring kingdom. ${ }^{26}$ The Narbonensis was the only province beyond the Pyrenees that could still be held by the Visigoths after the fall of the Regnum Tolosanum in the Battle of Vouillé (507). It may be that in the north certain strivings for autonomy had spread, which were now unleashed with this rebellion. An exact reason for the uprising is not given by Julian. But these developments were certainly favoured by the geographical distance of the provincial capital Narbonne to the royal court in Toledo. ${ }^{27}$

Another factor is that in Septimania, the roots of Visigothic rule that stretched back more than 250 years to the integration of the Gothic elite into Gallo-Roman society may have been more advanced than in the Iberian part of the kingdom. Accordingly, the loyalties of local elites may have been oriented towards regional circumstances rather than to a Visigothic king. The extensive participation of the clergy of the Narbonensis in the uprising is astonishing: in addition to Bishop Gumild of Maguelonne and Abbot Ranimir, Bishop Wilesindus of Agde, bishops Jacintus and Gultricianus, the primicerius of Narbonne, were also involved.

King Wamba reacted immediately to the threat and sent an army under the command of $d u x$ Paulus to quell the uprising. That he might not have considered the situation dangerous at that time may be inferred from the fact that he sent only part of his army. The function of this dux remains unclear. It could merely have been a dux exercitus or the dux provinciae of the Narbonensis himself, who had arrived with his army for expedition against the Basques when the uprising broke out. ${ }^{28}$ There is one remarkable fact: in the papers of the VIII (653) and IX (655) Toletanum a certain Paulus comes notarii appears, which could be the same person. ${ }^{29}$ If so, Paulus belonged to the inner circle of rulership and could certainly be considered for the function of a dux provinciae but also for the role of a dux exercitus, because

26 Collins 2004, p. 93.

27 More than $800 \mathrm{~km}$ separate the two places, which would correspond to a journey of twentynine days on foot, considering a daily travel distance of about $30 \mathrm{~km}$. Ohler 1997, p. 51, counts a daily travel distance of about $20-40 \mathrm{~km}$ for persons on foot.

28 Three things could speak in favor of this second theory: Wamba sent him to fight against the rebellion because he was possibly familiar with the regional circumstances. The name Paulus could speak perhaps for a (Gallo- or Hispano-)Roman, although with all caution before the ethnic allocation of names in the early Middle Ages. For both the Gallic and the Hispanic Visigoths, members of the Roman aristocratic upper class can be found frequently in high civil and military offices (Claude 1970, p. 45). Third, no other person in the Historia Wambae regis is explicitly referred to as the $d u x$ of the Narbonensis.

29 Concilios visigóticos e hispano-romanos, pp. 289 and 307; Collins 2004, p. 94. 
the maiores palatii accompanied and advised the ruler on campaign..$^{0}$ The name Wamba does not appear in the councils, which might suggest that, despite his advanced age and noble origin, ${ }^{31}$ he did not belong to the inner circle of power under the former kings. But since he took part in the funeral rites in Gérticos, he must have already held an important court office at that time.

Further developments are also conspicuous. Instead of fighting the rebels, Paulus took the leadership in the uprising, which the $d u x$ of the province of Tarraconensis, Ranosind, also joined. It is possible that the insurgents of the Narbonensis had convinced 'their' dux of the proclamation of a counter-kingdom and that Paulus negotiated with Ranosind. However, the Historia Wambae regis leaves the circumstances unclear. If Paulus had already held an important position, he might have felt himself withheld from the events in Gérticos. However, he does not seem to have aspired to the crown of the whole kingdom. In his letter to King Wamba, he calls himself the 'Anointed King of the East' ${ }^{2}$ and Wamba the 'King of the South'. Perhaps he wanted the separation of the Narbonensis and thus a division of the empire, as it had existed in 569 between Liuva I (568-572) and Liuvigild (568-586).33 In any case, Wamba rejected the idea of a division of the kingdom and it became clear that things would result in a military showdown between the two. After the rebel forces had united with Paulus's, the whole province of Narbonensis was in open revolt and more warriors were recruited. More than this, Paulus gathered the rebels and declared that he would no longer recognize Wamba as king and that the insurgents should elect a new ruler from their ranks. Ranosindus ${ }^{34}$

30 Kampers 2008, p. 267.

31 According to Julian, Wamba himself referred to his advanced age at his election, which off course could be a topos: modo senio confectum sese pronuntians. Julian of Toledo, Historia Wambae regis, 2.

32 Flavius Paulus unctus rex orientalis and Wambani regi austro: The title used, 'Flavius Paulus, Anointed King of the East', once again underlines the importance of the unction of the elected king. The title 'Flavius' is possibly to be seen in connection with other honorary titles (epitheta) of Visigoth kings in the council acts and on the coins (e.g. iustus, felix, or pius). For the titles on coins, cf. Steinbach 2017, pp. 107-109.

33 Claude 1971, p. 165. On the other hand, the events surrounding the accession of King Sisenand $\left(63^{1}-636\right)$ to the throne must have been well known to Paulus: with the support of Frankish troops from King Dagobert I (629-639), this king led an uprising from the Narbonensis during which the reigning king Swinthila (621-631) was abandoned by his followers at Zaragoza and had to abdicate.

34 Whether the Ranosindus mentioned was the dux of the Tarraconensis or the brother of the same name of the rebel bishop Wilesindus of Agde, as José Orlandis Rovira suspected, without 
then proposed Paulus to take the crown. ${ }^{35}$ The coronation probably took place with a consecration crown, ${ }^{36}$ which Paulus had seized when he took Girona. ${ }^{37}$ The crown was once donated by King Reccared I (586-601) or Reccared II (621) to the church of St. Felix. Such Visigothic votive crowns were found in 1858 by farmers from Guadamur in the field Guarrazar and belong to the famous treasure find of the same name. Among the crowns in Byzantine tradition were two with the names of the kings Swinthila (621-631) and Recceswinth (649/653-672).

Paulus's uprising was certainly prepared long before. He immediately began to acquire a royal treasure to reward his retinue and to recruit warriors. ${ }^{3}$ Julian speaks of the fact that even Franks, Saxons, and Basques are said to have been among them - probably in order to represent Paulus's rebellion in a worse light by having permanent enemies as supporters. The story that the usurper used the Jews to finance his rebellion belongs in this context. 39

\section{The campaign against Paulus}

Wamba once again reacted quickly. He rejected the recommendation of his aristocratic counsellors to return to Visigothic territory in order to assemble a larger army and instead fought against the Basques..$^{40}$ In only seven days he destroyed numerous of their defences, so that the Basques asked for peace, which was granted under the provision of hostages and tribute payments. ${ }^{41}$ After his rapid victory, Wamba moved directly through Calahorra and Huesca to the east. ${ }^{42}$ On his way, he divided the army into

further explanation (Orlandis Rovira 1987, p. 240), is unclear. However, the former seems more probable, due to the circumstances described.

35 Julian of Toledo, Historia Wambae regis, 8.

36 Coronam illam auream. On the use of crowns in the Visigothic kingdom, cf. Bronisch 1999; Eger 2004 .

37 Julian of Toledo, Historia Wambae regis, 26. Kampers 2008, p. 213, states that crowns in the Visigothic realm were not insignias exclusively for kings but symbols for power and sovereignity and therefore worn also by the nobility.

38 On the function and content of early medieval royal treasures, cf. Hardt 2004.

39 Julian of Toledo, Historia Wambae regis, 5; Claude 1971, p. 160.

40 Orlandis Rovira 1987, p. 240, even spoke about a Visigothic 'Blitzkrieg' (ofensiva relámpago) in this context.

41 Julian of Toledo, Historia Wambae regis, 10.

42 From Miranda de Ebro via Calahorra to Huesca it is about $265 \mathrm{~km}$, which with a large army could possibly be covered in one week (30-40 km/day); $528 \mathrm{~km}$ lie between Miranda de Ebro and Vich, which should receive a strategic importance. In total we can expect between ten and 
three parts, putting each under the command of a dux and had them march against Llivia, Vich, and along the coastal road of the Roman via Augusta. This division into three parts is not unknown; it is similar to descriptions in the Old Testament, such as those in Judges 9:43 or 1 Samuel 11:11. Perhaps Julian wanted to position his ruler in the sphere of the priestly warrior kings of the Old Testament. ${ }^{43}$ The king himself followed the three divisions with a large part of the army. That the fighting only began in the far east of the Tarraconensis speaks for the fact that only this region was involved in the uprising and not the whole province. ${ }^{44}$ Since the regions were economically linked by trade between the foothills of the Pyrenees and the Mediterranean coast, a political union is no surprise.

Nevertheless, ties to the insurgents were comparatively loose, as both Barcelona and Girona were quickly captured by Wamba's troops. ${ }^{45}$ The rebels obviously retreated to fortified areas in the Pyrenees in order to halt the king, since he had divided his army again into three divisions and advanced against Collioure, Ultrère, and Llivia. The strategic aim was most likely a crossing at the Pyrenees passes of Colliure, Perthus, and Puigcerdá. ${ }^{4}$ The greatest resistance seems to have been at Les Cluses, because at this point Julian reports that Wamba sent two duces extra to conquer the city. ${ }^{47}$ Ranosindus as well as a gardingio Hildigisus were captured there, which speaks to a concentration of insurgent troops under experienced military leaders.

The rebel army may have been outnumbered by Wamba's troops, as nobody dared to oppose the king in an open battle..$^{48}$ In the sources field battles rarely appear. Normally fortified sites were selected as administrative centres. Liuvigild had conquered the Iberian Peninsula 'city by city'. The victors captured large amounts of gold and silver, which Wamba distributed among his warriors. ${ }^{49}$ The speed with which he forced the crossing

fourteen days before Wamba's warriors reached the rebellious regions in the Tarraconensis. Should there have been a greater army with ox carts, this might have slowed down the speed even more. However, at least a small part of the way could also be covered on the Ebro downstream, although not explicitly said by Julian.

43 Teillet 1984, p. 601, and 1986, p. 419.

44 García Moreno 2008, p. 171.

45 Julian of Toledo, Historia Wambae regis, 11.

46 Kampers 2008, p. 214.

47 Julian of Toledo, Historia Wambae regis, 11: 'missis ante se exercitibus, per duces duos inrupto facta est'.

48 Orlandis Rovira 1987, p. 214.

49 The function of war in the early medieval regna as a means of creating obedience and thus ultimately securing power is clearly expressed here. The king had to be militarily successful in 
of the Pyrenees not only surprises today but seems to have impressed his contemporary opponents as well: Julian tells us of a rebel named Witimirus, who, in view of Wamba's rapid advance, fled to Narbonne, where Paulus had entrenched himself. Generally, the rapid conquest of the rebellious cities is remarkable, since we know that some of the ancient civitates in the third century were surrounded by strong walls..$^{\circ}$ After this second phase of the campaign, Wamba gathered his three armies and let the warriors recover for two days before turning against the provincial capital, Narbonne. He sent four duces to conquer Narbonne, combining the land attack with an additional naval manoeuvre..$^{51}$ Since a fleet is not mentioned in the expedition against the Basques, Wamba must have requested it on his way to Barcelona and Girona. The ships could at the same time have carried supplies for the Visigoth army. The fleet had been expanded under Sisebut (612-621), who used it against the Byzantine exclave in the south of the Iberian Peninsula. ${ }^{2}$ It is possible that the Visigoths had conquered the Byzantine territory and shipyards there, as well as craftsmen and maritime specialists. It has been likewise assumed for the Frankish king Clovis I (482-511) that his military success was based on the fact that he was able to take over the late antique Roman armouries (fabricae) in Soisson, which ensured a constant supply of valuable war equipment. ${ }^{3}$

Whether Visigothic warships were galleys on the ancient Roman model with rowing benches occupied by slaves, ${ }^{54}$ who were numerous in the Visigoth Empire, cannot be determined. This is because the remains of late antique or early medieval ships are not clearly attributable to either Byzantine or Barbarian fleets, owing to the same building type. Moreover, little is known about late antique fleets in the western part of the empire. The Notitia dignitatum mentions maritime units for both river and sea shipping, but the remaining naval forces seem to have been used primarily

order to be able to supply his clientele with loot in regularly sufficient quantities. With the end of the expansion phase of some barbarian gentes such as the Visigoths, adequate compensation had then to be found for the now absent booty to keep the warriors loyal to the king.

50 García Moreno 2008, pp. 256-257.

51 Julian of Toledo, Historia Wambae regis, 12: 'sed statim per quatuor duces lectum numerum bellatorum ad expugnationem Narbonae ante faciem suam mittit, alium exercitum destinans, qui navali proelio bellaturus accederet'.

$5^{2}$ Kampers 2008, pp. 189-190 and 215. If the Visigoths didn't have any fleet before Sisebut, how Thompson 2011, pp. 161-162, states, is hard to say. However, the argumentum ex silentio should not lead us to a hasty statement here.

53 Becher 2011, p. 150.

54 Kampers 2008, p. 292. 
for patrol, troop transport, or smaller landing manoeuvres and not for extended naval warfare. .55

The usurper Paulus had already fled to Narbonne in the face of the advancing army and left the defence to Witimirus. After reporting threats from the secure protection of the city walls - which belongs to the standard repertoire of almost every battle description of the Middle Age $5^{5}$ - Julian goes on to describe the assault of the Visigothic army leaders on the city. This must have been accompanied by the use of siege machines because according to the text, stones are hurled into the city and the city gates were set on fire. After a three-hour fight, the walls were finally overcome and the city captured. Witimirus fled to a church, where he drew his sword without respect for the holy altar and was beaten down by a warrior. The scene enables Julian to differentiate Wamba's warriors from the unholy act of Witimirus. 57

From Narbonne on the way to Nîmes, the Visigothic army immediately moved on to Béziers and Agde as well as Maguelonne, ${ }^{58}$ which were also captured in combined land-sea operations. ${ }^{59}$ Bishop Gumild left in view of the superiority of the army of King Wamba and fled to Nîmes. For the attack on the heavily fortified city of Nîmes, Wamba divided the army into four parts and remained with a larger part of his warriors about 30 miles ahead of the city. The plan of the Gallo-Roman and Franconian defenders to confront the Visigoth king in a field battle was quickly abandoned and a new siege accepted, perhaps in the hope of a Franconian relief army.

The fight for Nîmes seems to have been extraordinarily violent and occupies a large part of Julian's account ${ }^{60}$ as this was the 'final fight', which needed to be narrated more extensively. Within two days the attackers succeeded in overcoming the city walls. This, too, is possibly a rhetorical conceit, as the conquest of the city follows exactly on the anniversary of Wamba's coronation. ${ }^{6}$ The $d u x$ Paulus and his remaining followers retreat to the ancient amphitheatre of Nîmes and entrench themselves there. ${ }^{62}$ This

55 MacGeorge 2002, pp. 306-307; Lewis and Runyan 1985, pp. 4-8.

56 Prietzel 2006, pp. 4-8.

57 Julian of Toledo, Historia Wambae regis, ed. by Pizarro, p. 199, comment 76.

$5^{8}$ Maguelonne, Béziers, and Agde, as well as Elne, Narbonne, Lodève, and Nîmes, were among the 'seven cities' from which the Septimania region takes its name. In Visigothic times, the cities had fortified squares and bishoprics.

59 Julian of Toledo, Historia Wambae regis, 13.

60 Ibid., 13-22.

61 Ibid., 20.

62 Ibid., 18: 'At ubi feroces nostrorum animos sustinere non possunt, intra arenas, quae validiori muro, antiquioribus aedificiis cingebantur, se muniendos includunt.' 
is an excellent example of the functional transformation of public buildings between late antiquity and the early Middle Ages, as massive stone buildings, amphitheatres, or market halls often served as quarries for other buildings or were used as fortified squares or churches. ${ }^{6}$ Surrounded by the troops of Wamba, Paulus's followers abandoned courage and began to fight against each other, so that the insurgents finally offered surrender on 2 September.

\section{Judgment on the insurgents and triumphal procession}

Through the mediation of Bishop Argabadus of Narbonne, the life of $d u x$ Paulus and of the rebels was spared. Wamba raised his hands to heaven in tears and exclaimed words referring to Psalm 88:11, ${ }^{64}$ which again draws a parallel to the Old Testament. The idea of a victory achieved with the help of God of the Catholic son Hermenegild against his father, the Arian Visigoth King Liuvigild (568-586), was already found on coins minted during the uprising (579-584): CVM DEO OPTINVIT SPALI (Seville) or CVM DEO ITALICA (Santiponce) can be read on some of them. What is striking about these coins is that the victory message CVM DEO refers exclusively to victories over the rebellious son and is never used in connection with victories over the Suebi or Basques. ${ }^{6}{ }^{5}$ Possibly this expressed the idea of a war against a usurper rising above the divine will, which we find almost a hundred years later in Julian's Historia Wambae regis.

The trial of the fifty-three rebels named in the Iudicium in Tyrannorum Perfidia Promulgatum took place on 5 September: ${ }^{66}$ according to the provisions of the IV Toletanum (633) and the Liber Iudiciorum (II.1.8) they were sentenced to death, deprived of their property, and excommunicated. ${ }^{67}$ The death penalty was changed by King Wamba; Julian describes only the decalvatio (scalping) of the insurgents, ${ }^{68}$ so probably the piercing of the eyes was omitted. King Erwig (680-687) later rehabilitated the rebels and

63 Collins 2004, pp. 94-95.

64 Julian of Toledo, Historia Wambae regis, 25: 'Te Deus, conlaudo, regem omnium regum, qui humiliasti sicut vulneratum superbum et in virtute brachii tui conteruisti adversarios meos.'

65 Steinbach 2017, pp. 91-95.

66 Julian of Toledo, Iudicium in tyrannorum perfidiam promulgatum, 3-4. Although caution should be exercised about the ethnic interpretation of early medieval names, it should nevertheless be mentioned here that most of the surviving insurgents used Gothic names from a linguistic perspective.

67 Julian of Toledo, Iudicium in tyrannorum perfidiam promulgatum, 7 .

68 Julian of Toledo, Historia Wambae regis, 3 . 
their families with the XII Toletanum (681). The Franconian and Saxon supporters of the uprising were sent home, probably because as 'foreigners' they could not be accused of perfidia or infidelitas. ${ }^{69}$ Julian reports that Wamba also expelled the Franconian army of $d u x$ Lupus, who had besieged Béziers before he could return to Toledo. ${ }^{7^{\circ}}$ Whether he came to strengthen the insurgents besieged in Nîmes or to take advantage of the uncertain situation in the Narbonensis, we are not certain, although a connection with the events around the $d u x$ Paulus seems evident. After this renewed military action, Wamba returned to the capital, where he was honoured with a triumphal procession in October of 673 , the only detailed description of a Visigothic triumphal procession in the urbs regia of Toledo: the insurgents were barefoot and wrapped in rags with shorn hair and beards, transported on a camel-drawn wagon from the fourth milestone in front of the city. ${ }^{71}$ They were preceded by Paulus with a special 'crown'. ${ }^{2}$ We learn nothing more about the whereabouts of the $d u x$ Paulus or the other insurgents.

\section{The Visigothic army and the Historia Wambae regis}

If the campaign against the insurgent $d u x$ Paulus took place as Julian describes it in his Historia Wambae regis, it was an extraordinary tactical and logistical achievement: a large army covered a distance of about $900 \mathrm{~km}$ and conquered several well-fortified sites. ${ }^{73}$ Complicated troop and fleet movements were coordinated. Even though we know nothing about the exact origin of King Wamba, we can assume that he had extensive military experience or good advisors among his leaders. An interesting question concerns the size of the army that Wamba led against Paulus. Julian's entire account contains only one number: to conquer the city of Nîmes, Wamba subordinated 10,000 men under the command of the dux Wademirus to support those already fighting. ${ }^{74}$ If this number is correct, the Visigoth

69 Julian of Toledo, Historia Wambae regis, ed. by Pizarro, p. 214, comment 114.

70 Julian of Toledo, Historia Wambae regis, 27.

71 Ibid., 30.

72 Kampers 2008, p. 215 speaks of a 'crown of herringbones', which he probably took over from Orlandis Rovira 1987, p. 243 ('con una raspa de pescado a modo de diadema'). But the latter may have read the words piscea [...] laurea instead of picae [...] laurea. Cf. Julian of Toledo, Historia Wambae regis, ed. by Pizarro, p. 220, comment 133.

73 Kampers 2008, p. 215.

74 Julian of Toledo, Historia Wambae regis, 15: 'Mira ergo in ordinando celeritate per Wandemirum ducem electos de exercitu fere decem milia viros ad auxiliam pugnantibus destinavit.' 
army must have comprised tens of thousands of men..$^{75}$ There are two things to consider in this case. From his expedition army to the Basque territory Wamba had already sent a smaller part under Paulus to suppress the uprising ${ }^{76}$ and when the news of change of sides reached him, the king let further reinforcement come. ${ }^{77}$

The numbers of troops of medieval armies are rarely reliable ${ }^{78}$ but instead metaphorical, either to increase one's victory or to excuse one's defeat. Although written sources know leaders of a thousand men (millenarius), whose units in turn are said to have been divided into quingentenae (500), centenae (100), and decaniae (10), it is difficult to decide whether these strengths were actually reached..$^{79}$ The fact that Wamba could divide his army into three parts and that he himself remained behind with another part, speaks for an army great in size. The subdivisions of army units show the continuation of Roman military structures in the barbaric successor empires. ${ }^{80}$ Probably this was based on the system of late antique auxiliary units, with whom the Goths had come into contact as foederati of the empire. To what extent this military organization also reflects the Roman-Visigothic social structure is difficult to say. The basic unit of an army was probably the noble Visigothic or Roman warrior and landowner with his armed entourage of free men and slaves. ${ }^{81} \mathrm{~A} d u x$ seems to have united several thousand men under his command. The so-called millenarius never gather in the sources as independent army leaders. ${ }^{82}$ The Latin term millenarius was replaced towards the end of the Visigoth Empire by the Gothic term thiufades in written sources and seems to have been used synonymously.

Wamba's campaign reveals serious deficiencies in the organization of the army. It is possible that the war council, in which the campaign against Paulus was to have been delayed and the king advised to avoid fighting against the Franks, gives an indication that the nobles of the empire no longer wanted to fulfil their obligations as soldiers. ${ }^{83}$ The new law obliged both secular and clergymen, who lived less than 100 miles from the invasion of an enemy of the kingdom, to make their warriors available to the royal army.

76 Julian of Toledo, Historia Wambae regis, 7 .

77 Ibid., 9 .

78 Clauss 2009, p. 95.

79 Kampers 2008, p. 267.

80 García Moreno 2008, p. 314.

81 Ibid., p. 315.

82 Claude 1970, p. 42.

83 Claude 1971, p. 164. 
Clerics who failed in their duty were banished, and laymen lost their liberty. The legislation, however, shows that towards the end of the seventh century the Visigothic army consisted mainly of armed followers of landowners, thus creating war districts that were identical to the land holdings of the ruling elite. The late antique sources distinguish conceptually between bucellarii, equipped with land for their military service, and saiones, living in the household of their masters and supplied with weapons by him. This distinction shows that not all Goths may have been provided with land when they took over the Iberian Peninsula. ${ }^{84}$

That Visigoth kings also actively intervened in the battle themselves is shown by the fact that some of them lost their lives in the struggle. ${ }^{85}$ In the case of Wamba, nothing is reported concerning this. In Julian's Historia Wambae regis, the king appears in the form of an ancient commander as a guiding and leading force, who arranges matters from the background, and keeps a strategic overview. In this context, there is a difference with the high medieval battle narratives, in which a warrior as a heroic protagonist is placed at the centre of the narrative and his deeds emphasize him as someone above the mass of other battle participants. ${ }^{86}$ The Historia Wambae regis does not make the king a 'hero in the danger zone ${ }^{87}$ but shifts the "killing competence ${ }^{88}$ to his military leaders. Almost as difficult is the question of what a Visigoth army might have looked like in the time of King Wamba. The literature on the Spanish Visigoth kingdom usually mentions foot fighters as well as equestrian warriors on whom, according to Isidor of Seville, the Goths placed their special trust. ${ }^{89}$ The former may have been recruited from simple freemen and slaves, whereas the latter probably came from the ranks of the Roman-Visigothic aristocracy. In the Historia Wambae regis, a distinction is made between 'simple warriors' 90 and 'mounted leaders'.$^{91}$ It has been assumed that the importance of the cavalry was based on two things: that during their migration they came into contact with cavalry warriors such as the Sarmatians, Alans, and Huns, and that the army of Alaric I consisted of numerous ethnically heterogeneous groups, which integrated different

84 Claude 1970, pp. 40-41.

85 Roderic (710-711) in the Battle of Guadalete, Theodoric I (418-451) in the Battle of the Katalaun Fields, or Alaric II (484-507) in the Battle of Vouillé.

86 Grieb 2015, p. 54.

87 Ibid., p. 54 .

88 Ibid., p. 61.

89 Kampers 2008, p. 268.

90 Julian of Toledo, Historia Wambae regis, 18: Plerique tamen et nostrorum e vulgo.

91 Ibid., 24: Ducibus nostris equis incidentes. 
fighting styles into the Gothic warrior unit. This 'equestration' of the war had finally led to the consolidation of the barbarian warrior caste and prepared the ground for medieval feudalism and its basic economic conditions. ${ }^{92}$ The sign of this was the adaptation of armour to be used to fight on horseback: a long sword, a round shield, and a throwing spear instead of the short sword, the rectangular shield, and the thrust lance.

The Historia Wambae regis mentions swords (gladii), arrows (sagittae), and lances (spicula). However, these terms are not capable of saying anything about the actual arming of Visigothic warriors in the seventh century, since they are too unspecific to reveal anything about the nature of the equipment actually used. ${ }^{93}$ Since only few pictorial testimonies are preserved and these illustrations strongly bound to ancient traditions, archaeology, and in particular the evaluation of grave goods are a help here. ${ }^{94}$ However, the use of weapons as grave goods was not widespread from the fifth to the eighth century and is limited to certain regions of the Iberian Peninsula. 95 Already at the cemeteries of the Černjachow culture in the Danube region a development of burial habits can be observed with few or no grave goods at all. The only exception are graves of the ruling elite..$^{6}$

Also, the archaeological interpretation of a 'weapon' in the concrete burial context is not always easy. A lance, for example, was a common weapon in late antique armies, but could also have been used simply for hunting. Accordingly, there is the danger of too rapid a conclusion: the buried person must be a warrior because he had an object in his grave that could be used as a weapon. It becomes even more dangerous to ethnically classify the object as that of a 'Gothic warrior' based on its material composition. Modern research has been able to show that the simple equation of barbarians with warriors did not always work out in late antiquity. ${ }^{97}$ Thus 'ethnic' markers such as francisca equals Franconian warrior or sax equals Saxon warrior also do not work, especially since we can assume that the personal equipment of the barbarian warrior was in use over a long period and was likely inherited as booty. Helmets or armour are among objects that clearly indicate a

92 García Moreno 2008, pp. 27, 31, and 35.

93 In a noteworthy essay, Peter Dinzelbacher commented on the problems of research into high-medieval armament in relation to the sources of material and images handed down: Dinzelbacher 1989. The statements made by him can partly also be applied to the early medieval sources for which a similar investigation is still pending.

94 Catalán Ramos 2015.

95 Ibid., p. 292, fig. 16.1 .

96 Kampers 2008, p. 125.

97 García Moreno 2008, p. 316. 
military connection. However, so far almost no finds of defensive weapons have been made in burial contexts relating to the period investigated. The only exceptions are parts of a lorica squamata from Villaviciosa de Odón, which can be dated to the fifth century.$^{98}$ Perhaps such equipment was uncommon and therefore too valuable to be buried with the dead. Swords in graves are far more widespread, whereby a distinction is to be made between single-edged (sax) and double-edged (gladius or spatha) specimens of different lengths. ${ }^{99}$ Especially with shorter specimens the transition to knives is often fluent, which could have served as status symbols without a military context. The shorter variants were worn horizontally on the belt ${ }^{100}$ and are even mentioned in Gregory of Tour's narrative of the murder of Sigibert I $\left(5^{61-575)}\right)^{101}$ In general, it can be said that single-edged sabres are much more common than double-edged swords, which allows conclusions to be drawn about fighting techniques. Of double-edged swords only eight specimens from the seventh/eighth century have been found as burial objects. The find contexts suggest that such weapons were only accessible to a small portion of the population and their forms and decorations show clear links to other European weapons finds, especially in the Gallo-Franconian area, which is why it cannot be assumed that the equipment was 'typical Visigothic'.

Finally, it can be said that war and army organization of the barbaric successor empires of the Roman Empire have not yet been sufficiently researched. This is mainly due to poor written and material sources, which interfere in a precise analysis of the army's organization, tactical deployment, and personal equipment. The Historia Wambae regis is an exception, since it gives particularly large depiction of military events - strategic planning as well as concrete combat situations. It also contains in its narrative indications that even in the seventh-century siege machines were still used to conquer fortified sites and that fleets were used to support military operations on land. Both could indicate a continuation of ancient military traditions even at this late date. In the future only a comprehensive, interdisciplinary-comparative research project could remedy this situation by focusing on war and its narration between late antiquity and the early Middle Ages.

98 Catalán Ramos 2015, p. 297.

99 Ibid., pp. 297-301.

100 Ibid., p. 303.

101 Gregory of Tours, Libri historiarum X, IV.51: 'Tunc duo pueri cum cultris validis, quos vulgo scramasaxos vocant'. 


\section{Bibliography}

\section{Primary sources}

Concilios visigóticos e hispano-romanos, ed. by José Vives (Barcelona: Instituto Enrique Flórez, Consejo Superior de Investigaciones Científicas, España Cristiana, Textos 1, 1963).

Fredegar, Chronicarum quae dicuntur Fredegarii Scholastici libri IV: cum Continuationibus, in Quellen zur Geschichte des 7. und 8. Jahrhunderts: die vier Bücher der Chroniken des sogenannten Fredegar, ed. by Herwig Wolfram, Andreas Kusternig, and Herbert Haupt (Darmstadt: Wissenschaftliche Buchgesellschaft, Freiherr vom Stein-Gedächtnisausgabe IVa, 1982), pp. 1-325.

Gregory of Tours, Libri Historiarum X, ed. by Bruno Krusch and Wilhelm Levinson (Hanover: Monumenta Germaniae Historica, Series Rerum Merovingicarum 1.1, 1951).

Julian of Toledo, Historia Wambae regis, in Passiones vitaeque sanctorum aevi Merovingi, 5 vols., vol. 3, ed. by Bruno Krusch and Wilhelm Levinson (Hanover: Monumenta Germaniae Historica, Scriptores Rerum Merovingicarum 5, 1910), pp. 501-526.

—, Historia Wambae regis = The Story of Wamba: Julian of Toledo's Historia Wambae Regis ed. by Joaquín Martínez Pizarro (Washington, DC: The Catholic University of America Press, 2012).

- Iudicium in tyrannorum perfidiam promulgatum, in Passiones vitaeque sanctorum aevi Merovingi, 5 vols., vol. 3 , ed. by Bruno Krusch and Wilhelm Levinson (Hanover: Monumenta Germaniae Historica, Scriptores Rerum Merovingicarum 5, 1910), pp. 529-535.

\section{Secondary sources}

Bachrach, Bernard S., and David S. Bachrach, Warfare in Medieval Europe c.40oc.1453 (Oxford: Routledge, 2017).

Becher, Matthias, Chlodwig I: der Aufstieg der Merowinger und das Ende der antiken Welt (Munich: C.H. Beck, 2011).

Bronisch, Alexander Pierre, 'Krönungsritus und Kronenbrauch im Westgotenreich von Toledo', Zeitschrift der Savigny-Stiftung für Rechtsgeschichte, Germanistische Abteilung 116 (1999), pp. 37-86.

Castritius Helmut, Die Vandalen: Etappen einer Spurensuche (Stuttgart: Kohlhammer, 2007).

Catalán Ramos, Raúl, 'Elementos de armamento y mundo funerario en Hispania (siglos V-VIII)', in Identidad y etnicidad en Hispania: propuestas teóricas y 
cultura material en los siglos V-VIII, ed. by Juan Antonio Quirós Castillo and Santiago Castellanos García (Bilbao: Universidad del País Vasco, Documentos de Arqueología Medieval 8, 2015), pp. 291-312.

Claude, Dietrich, Geschichte der Westgoten (Stuttgart: Kohlhammer, 1970).

, Adel, Kirche und Königtum im Westgotenreich (Sigmaringen:Jan Thorbecke, 1971).

Clauss, Martin, Ritter und Raufbolde:vom Krieg im Mittelalter (Darmstadt: Primus, 2009).

Cohen, Rodrigo Laham, The Jews in Late Antiquity (Leeds: Arc Humanities Press, 2018).

Collins, Roger, Visigothic Spain 409-711 (Malden, MA: Blackwell, 2004).

Dinzelbacher, Peter, 'Quellenprobleme bei der Erforschung hochmittelalterlicher Bewaffnung', Mediävistik 2 (1989), pp. 43-79.

Eger, Christoph, 'Krone und Kreuz König Svinthilas: westgotische Hofkunst und “plate-inlaying” im 6. und 7. Jahrhundert', Madrider Mitteilungen 45 (2004), pp. 449-506.

García Moreno, Luis Agustín, Historia de España visigoda (Madrid: Catedra, 2008). Giese, Wolfgang, 'Designative Nachfolgeregelungen in germanischen Reichen der Völkerwanderungszeit', Zeitschrift der Savigny-Stiftung für Rechtsgeschichte, Germanistische Abteilung 117 (2000), pp. 39-121.

Goetz, Hans-Werner, Europa im frühen Mittelalter 500-1050 (Stuttgart: UTB, Handbuch der Geschichte Europas 2, 2003).

Grieb, Christine, Schlachtenschilderungen in Historiographie und Literatur (1150-1230) (Paderborn: Schöningh, Krieg in der Geschichte 87, 2015).

Hardt, Matthias, Gold und Herrschaft: die Schätze europäischer Könige und Fürsten im ersten Jahrtausend (Berlin: Oldenbourg Akademieverlag, 2004).

Hartmann, Martina, Die Merowinger (Munich: C.H. Beck, 2012).

Herbers, Klaus, Geschichte Spaniens im Mittelalter: vom Westgotenreich bis zum Ende des 15. Jahrhunderts (Stuttgart: Kohlhammer, 2006).

Kampers, Gerd, 'Anzeichen für eine Sakralisierung des Krieges im spanischen Wisigotenreich', in Emotion, Gewalt und Widerstand: Spannungsfelder zwischen geistlichem und weltlichem Leben in Mittelalter und Früher Neuzeit, ed. by Ansgar Köb and Peter Riedel (München: Wilhelm Fink, MittelalterStudien 9, 2007), pp. 62-79.

— Geschichte der Westgoten (Paderborn: Ferdinand Schöningh, 2008).

Kortüm, Hans-Henning, Kriege und Krieger 500-1500 (Stuttgart: Kohlhammer, 2010). Lewis, Archibald Ross, and Timothy J. Runyan, European Naval and Maritime History 300-1500 (Bloomington: Indiana University Press, 1985).

MacGeorge, Penny, Late Roman Warlords (Oxford: Oxford University Press, 2002). Ohler, Norbert, Krieg und Frieden im Mittelalter (Munich: C.H. Beck, 1997). 
Orlandis Rovira, José, Época visigoda (409-711) (Madrid: Editorial Gredos, Historia de España 4, 1987).

Panzram, Sabine, 'Die iberische Halbinsel um 500 - Herrschaft "am Ende der Welt”; eine Geschichte in neun Städten', in Chlodwigs Welt: Organisation von Herrschaft um 5oo, ed. by Mischa Meier and Steffen Patzold (Stuttgart: Franz Steiner, 2014), pp. 449-486.

Pérez Sánchez, Dionisio, El ejercito en la sociedad visigoda (Salamanca: Ediciones de la Universidad de Salamanca, 1989).

Prietzel, Malte, Kriegführung im Mittelalter: Handlungen, Erinnerungen, Bedeutungen (Paderborn: Ferdinand Schöningh, 2006).

Steinbach, Sebastian, Imitation, Innovation und Imperialisierung: Geldwesen und Münzprägung als wirtschaftshistorische Quellen zur ethnischen Identität und Herrschaftsorganisation des spanischen Westgotenreiches (ca.572-714) (Berlin: LIT, Geschichte und Kultur der Iberischen Welt 11, 2017).

Stocking, Rachel L., 'Early Medieval Christian Identity and Anti-Judaism: The Case of the Visigothic Kingdom', Religion Compass 2.4 (2008), pp. 642-658.

Teillet, Suzanne, Des goths à la nation gothique: les origins de l'idée de nation en occident du V $V^{e}$ au VII siècle (Paris: Les Belles Lettres, 1984).

—_, 'L'Historia Wambae est-elle une ouvre de circonstance?', in Los visigodos: historia y civilización (Murcia: Universidad de Murcia, Antigüedad y Cristianismo $3,1986)$, pp. 415-424.

Thompson, Edward A., Los godos en España (Madrid: Historia Alianza Editorial, 2011).

Wolfram, Herwig, Die Goten: von den Anfängen bis zur Mitte des sechsten Jahrhunderts; Entwurfeiner historischen Ethnographie (Munich: C.H. Beck, 2001).

\section{About the author}

Sebastian Steinbach is a private lecturer in medieval history at the University of Osnabrück (Germany). He works on the economic and social history of the early and high Middle Ages. He has published widely on the history of money and currencies. 


\section{Power, Identity, and Ethnicity}





\title{
7 How to Stay Gothic without a Gothic King
}

\author{
Herwig Wolfram
}

\begin{abstract}
Although kingship was vital for a barbarian society to survive on Roman soil, it wasn't a uniform or even monarchic institution. Different types of kingly figures fulfilled functions, mainly military. The third-century author Dexippos remarked that the leading strata of barbarian societies did not lag behind kings in respect to dignity and fortune (týche). However, popular literature argues that commonness was what guaranteed the existence of Gothic identity, although without their own kings the Goths and their traditions would have disappeared long ago.
\end{abstract}

Keywords: Ostrogoths; Visigoths; barbarian society; kingship; identity; morbus Gothicus

Charles de Montesquieu placed the Goths in his De l'Esprit des loix: Les Goths conquérant l'empire romain fondèrent partout la monarchie et la liberté ('In conquering the Roman Empire the Goths laid the foundation for monarchy and freedom everywhere'). In his eyes the Goths stood for progress and enlightenment as opposed to the decadent Roman world ruled by tyrants. The kingship of the Goths remained rooted in the consent of the people who elected them. ${ }^{1}$ At the Council of Basel (1431-1449) a quarrel erupted between the Austrians and Swedes when each side claimed to be the true descendants of the Goths and thus to outrank the other in questions of protocol and precedence. ${ }^{2}$ Wolfgang Lazius, court historian of Emperor Ferdinand I and professor at the University of Vienna (1531-1564), coined the

1 Cf. Cassiodorus, Epistulae Theodoricianae variae, X.31.1-5, esp. 3; pp. 318 seq.

2 Wolfram 1988, p. 2.

Panzram, S. and P. Pachá (eds.). The Visigothic Kingdom: The Negotiation of Power in Post-Roman Iberia. Amsterdam: Amsterdam University Press 2020 DOI: 10.5117/9789463720632_CHO7 
concept 'migration of nations'. He sought to prove that the Gothic migration across Europe had unified the region from the Black Sea to Cádiz so that 'these countries are now with full right once more united under Habsburg rule'. ${ }^{3}$ But these concepts could only be guaranteed by Gothic kingship. ${ }^{4}$ These views reached back to the court of Ostrogothic Ravenna, where Cassiodorus construed a continous line of Gothic kings. The non-royal warlord Ostrogotha who lived in the lower Danube around 250 was made by Cassiodorus the first Amal king of the Visigoths and Ostrogoths (disregarding that the Amal family had not yet existed), connecting him with the shaping of the Ostrogothic identity as their heros eponymos. ${ }^{5}$

\section{Ostrogotha and the Gothic invasions of $c .250$}

In the year 533, the original version of the Getica appeared when Cassiodorus wrote two related letters to the Roman senate. These texts, although highly anachronistic, were telling pieces of political theory. In the Getica, the Goths who had settled on the shores of the Black Sea had become civilized and intelligent, which according to Hippocrates meant that they were ready to accept royal rulership. The Goths were divided by clans. The western Goths served the family of the Balti, the eastern Goths, whom Ostrogotha commanded, the glorious Amals. ${ }^{6}$ The nobility of the Balti of Toulouse were ranked post Amalos, ${ }^{7}$ but were still considered a clan of kings and heroes. ${ }^{8}$ The Getica continued by citing current Ostrogothic narratives.

Italian Goths in fabulis suis claimed that the seventeenth generation pedigree of the Amals consisted of Ansis, heroes, semi-gods, and non puri homines, by whose fortune, quasifortuna, the Goths won over their enemies. The Getica, however, still spoke of proceres, not of kings. But in his Variae, Cassiodorus had the young King Athalaric claim to have been the seventeenth Amal king. This is in line with the second letter to the Roman senate, in which Cassiodorus tried to legitimize Amalasuintha's role as queen of the army. The author named nine of her ancestors as kings, tot reges habuit quot parentes. ${ }^{9}$

Ibid.

Wenskus 1977, p. 468.

Iordanes, Getica, 79, 82 and 98 .

Ibid., 42.

Ibid., 146.

Wolfram 1988, p. 203, nn. 255 seq.

Iordanes, Getica, 78-80; Cassiodorus, Epistulae Theodoricianae variae, IX.25.4, pp. 291 seq. 
Ostrogotha becomes the pièce de résistance for the composer of the Getica. He tells us that Ostrogotha ruled the eastern Goths, but that he is not sure whether Ostrogotha was the name of the heros eponymos of the Ostrogoths or was named after the (in reality not yet existing) people. ${ }^{10}$ Then he makes Ostrogotha the grandson of Amal, the founder of the dynasty, number sixth in the seventeen-generation Amal pedigree. As the Getica continues, around 250 Ostrogotha levied a huge army to attack Roman territory. ${ }^{11}$ Finally, the Getica cites the Ostrogotha kings of both the Ostrogoths and Visigoths, in contradiction to its own narrative, ${ }^{12}$ however, allowing the Getica-Ostrogotha to defend western Gothic territory against a Gepid attack. ${ }^{13}$ According to other evidence, this occurred forty years later, and twenty years after the destruction of the western Gothic kingship by Emperor Aurelian. ${ }^{14}$

In the spring of 250, columns of barbarians crossed the lower Danube into Roman territory. ${ }^{15}$ The main unit of the Gothic army was led by King Cniva, who was able to muster a number of other tribes in addition to his own people. The Emperor Decius and his son attempted to defeat the Goths, but to no avail. Cniva managed to take Philippopolis/Plovdiv in 250. Laden with booty, the Goths moved northeast. Decius followed them, but in the devastating battle of Abrittus/Hisarlâk near Razgrad, in modern Bulgaria, he and his son were killed in action, and the Roman army was nearly destroyed. In the Getica, which also refers to Ostrogotha, who was seemingly prepared to fight the Romans with a gigantic army, ended achieving almost nothing. ${ }^{16}$ On scarce but dubious evidence it was long believed that this Ostrogotha did not actually exist or was simply Cniva's nom de guerre. ${ }^{17}$

We now know better. A Viennese thirteenth-century Greek manuscript (Vind. Hist. gr. 73, fols. 192-195, esp. fol. 194 ${ }^{\mathrm{r}}$ ) of liturgical texts contains eight palimpsest pages that deal with at least two different barbarian invasions: that of the Goths under Cniva in 250/251 and of the Heruli in 267/268. The fragments, without doubt, stem from the Skythika of Dexippos, who was

16 Iordanes, Getica, 91 and 94,

17 Wolfram 2006, p. 35 . 
a contemporary and eye-witness of the Gothic and Herulian invasions of the third century and was cited in the Getica. ${ }^{18}$ Under the auspices of the Austrian Academy of Sciences in Vienna, Jana Grusková and Gunther Martin have been working on this material. Due to their philological and paleographical skills, ${ }^{19}$ supported by new technology in Berlin and Hamburg, spectacular finds have come to light, that Ostrogotha has become a historical figure as árchōn tōn Skythōn. To translate the Greek word árchōn, the Gothic Bible used the word reiks. ${ }^{20}$ As Vandals, Herulians, and Huns, the Gothic peoples had entered the Roman world under the name 'Scythians', since they came from the rim of the world, that's to say present Eastern Europe. Ostrogotha was not Cniva's immediate predecessor (as per the Getica) but rather an unsuccessful competitor of this very successful war-king (basileus). Goths praised Cniva in heroic songs. This fits the Getica's statement that ante quos (sc. Amalos) there were heroes whom the Goths praised in heroic songs. On the other hand, the palimpsest-Ostrogotha was accused of weakness (malakía) and mishap (distychía) by his people, a life-threatening verdict for a war-lord. ${ }^{21}$

This newly found Ostrogotha was not a king, certainly no Amal, and never would have been a hero. As the Gepid princess Austrigusa (in Gothic Ostrogotho) of the sixth century, ${ }^{22}$ Ostrogotha simply meant 'Splendid Goth'. The earliest datable mention of Ostrogoths appears in September $392 .{ }^{23}$ The author of the Getica learned from Dexippos the name of Ostrogotha and made him not only into an Amal king but into the first Amal king. He purified his name in Gothic history from the reproaches that he was a luckless coward and put him among the Ansis quorum quasifortuna vincebant (sc. Gothi; 'by whose good fortune they seemed to have conquered'). He avoided mention of internal strife and civil war by turning rivals and competitors into predecessors and successors in constructing a Gothic past. By doing so he suppressed the image of Ostrogotha, in the palimpsest, making him the leader of up to 300,000 warriors instead of the equally incredible 50,000 mentioned by Dexippos. If this was enough to establish a Getica-exegesis it is wrong to assume that Ostrogotha presupposes the existence of an Ostrogothic people. ${ }^{24}$ 


\section{The creation of monarchic kingship}

Alaviv and Fritigern led the majority of Visigoths vice regum to a precarious safety on Roman soil. It took time and bloodshed until the core of these peoples and an unknown number of newcomers elected Alaric I their king in 395 (or rather 391). This kingship decisively differed from the pre-migration institution, since Alaric tried hard to turn it into a Roman institution. Hitherto, barbarian kings had not had great careers in the Roman army. If only for a short period of time, Alaric was the first Germanic king who combined his kingship first with a regional, then with a general magisterium militum. These top ranks in the late Roman army implied imperial recognition and combined superior military command with power over the civil bureaucracy, which were vital for a legal settlement on Roman soil. ${ }^{25}$ The Goths became federates and a part of the Roman army they replaced regionally. And so the foundations of territorial kingdoms were laid, even if Alaric I did not live long enough to experience the outcome. It was his successors in Gaul, Theodoric the Great in Italy, Gaiseric in Africa, the kuning Clovis in Gallia and parts of Germania who succeeded in founding these sorts of kingdoms. ${ }^{26}$ Geary's much cited and well-founded proclamation came true: 'The Germanic world was perhaps the greatest and most enduring creation of Roman political and military genius. ${ }^{27}$

\section{The kings and the magnates}

As Dexippos remarked, the leading strata of barbarian societies consisted of kings and their clans, as well as high-ranking nobles and their kinships who did not lag behind the kings in regard to dignity and fortune $(t y$ che $) .{ }^{28}$ From Alaric I to Roderic there existed a balance of power between the kings and the aristocracy, which can be described as a combination of opposition with cooperation. ${ }^{29} \mathrm{~A}$ weak king could not prevent the magnates from increasing their power and independence, which would further the fragmentation of the regnum, whereas a strong and successful king curbed aristocratic opposition and united the kingdom. In a critical situation, Alaric I ordered 
the magnates of his people to assemble for a war council. Alaric listened impatiently to the warning of an old warrior, who was a foster-father to the king, and then rebuked him bluntly. Thereafter, Alaric's orders were carried out without further discussion, let alone contradiction..$^{30}$ There was, however, a life-and-death struggle between Alaric and his royal clan and the Sarus-Segeric people, which ended in the latter's extinction. Around the middle of September 415, Valia had been chosen king over several other candidates. This was likely the reason why members of the losing parties split from the Valia-Goths and followed the Vandal king Gaiseric to Africa. There is no mention of an aristocratic opposition let alone rebellion after the Visigoths had settled in Aquitaine in 418. We have no hint of a movement comparable to the revolt of the Vandal nobility in $442.3^{31}$ Only on the eve of the destruction of the regnum Tolosanum, did magnates oppose their seemingly weak king's strategy and force Alaric II to offer resistance in the pitched battle of Vouillé in 507.32 His death caused chaos and further fragmentation, which even Theodoric the Great could not end as king of the Visigoths between $5^{11}$ and $5^{26}$. Visigoths elected kings, but the morbus Gothicus was raging; they were eliminating their kings as in a fit of madness. Only after Liuvigild came to power in 568 or 569 did the Visigothic kingdom rise like a phoenix from the ashes. ${ }^{33}$ 'Liuvigild restored the land of the Goths, which had been reduced by many small rebellions, to its old boundaries.' That was the verdict of a contemporary, but we wonder how the king accomplished this in so short a time. Apparently he was able to make the regnum attractive once again. He won large numbers of active magnates and their clans to his side, thereby not only turning regional and local potentates into tyrants, unlawful rulers, but also substantially reducing their numbers. ${ }^{34}$ To be sure, Liuvigild failed when he attempted to unite all his subjects, Goths and Romans alike, under the umbrella of a seemingly moderate Arianism. But three years after his death, his son Reccared I changed the ship if not its course and achieved the religious unity of the Spaniards. During the III Council of Toledo in 589 , the Visigoths converted to Catholicism. Thus 'the most holy prince', as a contemporary called him, won the support of the Catholic church which was instrumental in introducing the anointment of the king sometimes after the end of Liuvigild`s family in 
603. This Old Testament sacramental act had no legally constitutive force, which only election possessed. But anointing legitimized a kingship that lacked dynastic charisma. Consequently, the nobility held on to the election and kings, more and more, preferred anointment. ${ }^{35}$

\section{Flavius rex: Gothic political theory and its heritage}

Neither the kings of the Italian nor those of the Gallo-Hispanish Goths were reges Gothorum. Instead they bore the title Flavius rex, as was first used by the royal chancery at Ravenna around 500 . With King Theudis the Visigoths followed suit, the Longobard kings took it over in their diplomas. Charlemagne knew of its importance ${ }^{36}$ and had Theodoric's statue carried from Ravenna and placed in front of his palace at Aachen. His successor, Louis the Pious, could not bear what he considered a scandal and had the statue of this Gothic heretic removed. ${ }^{37}$ But as late as 974, Ramiros III (965-984) used the title Ranimirus Flavius princeps magnus basileus unctus, thus combining all possible Gothic traditions when the kingdom of León went through a period of a relative increase in power. ${ }^{8}$ In this situation the Gothic political heritage was instrumentalized as a movens for the beginning of the reconquista. But the king who did so was not a Gothic king properly speaking, questioning elements of Gothic identity without a Gothic king.

\section{Non-royal elements of Gothic identity}

There is no doubt that monarchic kingship (accordingly 'strong' to Montesquieu) was vital to provide and guarantee Gothic identity on Roman soil. But a Gothic kingship that created, and ruled over, territorial kingdoms that had been Roman provinces never comprised all Goths and existed only during a fraction of Gothic history. There must have been other elements of Gothic identity: there were non-monarchic types of kingship, or sometimes even non-royal rulership, which were responsible for shaping independent as well as fragmented political formations. This type of rulership existed 
before the Great Migrations began, ${ }^{39}$ and did not completely vanish within the Roman Empire when following Alaric I the Visigothic kingship gradually assumed monarchic power. Of necessity the socio-economic status of Gothic warriors had to be guaranteed when they settled on Roman soil. They received a certain amount of coin and money in kind to keep up what the sources call their libertas Gothorum. This freedom was modeled after the libertas Romanorum, which free Roman landowners enjoyed, and had to be granted and guaranteed by a superior power such as an emperor, king, or kingly lord, and outlived the Gothic kingdoms. ${ }^{40}$ Finally, the same held true for the lex Gothica, the Gothic law and faith, and for the Gothic language, which was related.

\section{The perseverance of the clan structure}

After the catastrophe of 711 quite a few Visigothic grandees, who had refused to join the royal army against the Arabs, were quite able and willing to put their clansmen and unfree followers in the field and offer resistance. Whether they converted to Islam or not, they were able to establish dominions of their own..$^{41}$ So it seems that the extended family, the clan, together with its head, had survived 'the day after' and remained a vital element of Gothic identity. Indeed, the Gothic Bible calls the fellow tribesman inkunja, somebody who is not a member of the Gothia or Gutthiúda, but a native of a kuni, a Gothic clan. This means that the Goth refers to a clan as the basis of his identity which proves the name long after 711 . The Goth Smaragdus, abbot of St. Mihiel, deals with the lingua theodisca and discusses the peculiarity of Gothic names at length. ${ }^{42}$ His contemporary Bishop Prudentius of Troyes was a Goth who also left Spain for Francia and made a clerical career under the Carolingians. His original name was Galindo/us, as was the name of Azenar, the father of Sunifred, a Frankish count among the first to be called Frankish margraves. The Galindi were a Baltic people with whom the Gutones were associated in the first two centuries AD. Years later on the other side of Europe the ethnonym survived as a personal name used in a certain Gothic clan. ${ }^{43}$ The onomastic evidence seems to mirror the consistency of the 
Gothic clan structure, although its elements were continuously changing and open to foreigners. The Goth Bessas, a corrupt officer in the imperial army, was named after the Bessi, a Thracian non-Germanic people. He might have had a Visigothic namesake. ${ }^{44}$ The formation of a tribal society was not a matter of blood and common descent. Furthermore ethnic identity was situational, as Patrick Geary rightly pointed out long ago. ${ }^{45}$ Depending on opportunity and circumstances, the same person could profess a Hunnic or Gepid or Gothic legal identity, ${ }^{46}$ questioning what mechanism kept such a polyethnic community together, making it a people. Apparently, after time there were only Goths in Italy, in Spain, and southern France, ${ }^{47}$ It was only a kingly figure or emperor who recognized the lex Gothica, the Arian faith as well as the Gothic law that guaranteed the legal and socio-economic status of a Gothic people, the libertas Gothorum.

\section{Libertas Gothorum}

Once the Roman Empire spread over the Old World, foreigners, peregrini of all kinds, settled on Roman soil, either voluntarily or by force. The overwhelming majority of these newcomers were integrated into the lower agrarian strata of Roman society, losing their ethnic identity and social status. This mechanism ceased to work by the eve of the battle of Adrianople in August $378,{ }^{48}$ and became entirely outdated once barbarian kingdoms were installed within Roman borders. Now the newcomers had to be integrated into the Roman landowning upper class by maintaining their ethnic identity and socio-economic status. This process - whatever the techniques of accommodation - did little harm to Roman landowners in the Gothic and Burgundian kingdoms. ${ }^{49}$ In contrast, the settlement of Vandals, Longobards, and Anglo-Saxons ${ }^{50}$ could affect the Roman upper class to the extent that they lost their property together with their ius libertatis Romanae. ${ }^{51}$ In Theodoric's Italian kingdom, people cheated their

Wolfram 1988, pp. 235 and 356.

Geary 1983 , pp. $15^{-26}$.

Pohl 2018, p. 43, and 1986, p. 446.

Wolfram 1988, pp. 231 seqq. and pp. 290 seqq.

48 Ibid., pp. 125 seq.

49 Wolfram 2005, pp. 187 seqq.

50 Ibid., pp. 184-187 and 200 seq.

$5^{1}$ Salvianus of Marseille, De gubernatione Dei, V.24; Cassiodorus, Epistulae Theodoricianae variae, X.33.3. 
fellow tribesmen out of their property, thereby exposing them to slavery. But if faced with such a threat they could prove before the king or his envoys, saiones, that 'he had marched in the Gothic army', nobody would dare deprive him of his property and his legal and socio-economic status. This meant, in Cassiodorus's words, that the warrior enjoyed the 'freedom of the Goths', and that all ethnic groups who were part of the Gothic army shared in the Gothic identity called libertas Gothorum. ${ }^{2}$ This 'freedom' was not Montesquieu's enlightened liberté, but the socio-economic independence of a landowner. It followed the ius libertatis Romanae and was guaranteed and secured by Theodoric the Great. This king could rely on a centralized administrative agency comprising a well-functioning Roman bureaucracy and a well-organized chain of military command. And yet there is the statement by Procopius that there existed a people in the Gothic army called the Rugians who did not intermarry with the Goths. ${ }^{53}$ The Rugians confessed the Gothic faith and followed Theodoric to Italy and settled in the Veneto. In the spring of 541 their chieftain even managed to become the king of the Italian Goths. But the same Rugians kept apart from the Goths and did not mingle with the name-givers of the army they served in, and of the kingdom they provided with a king, if only for five months. ${ }^{54}$ All the same, they enjoyed the libertas Gothorum, which survived the Gothic kingdoms. After the death of their king Teja in the Battle on the Milk Mountain, the Goths fought on until the imperial commander-in-chief Narses guaranteed return to their proper land if they promised to become faithful subjects of the emperor. ${ }^{55}$ Centuries later there was 'a day after' even for those Goths who did not want to become subject to the caliph. The queen of King Alfons I of Asturia (d. 757), as well as his brother and son, bore Gothic names. An Asturian king issued a law for the free Gothic land-owners in Asturia, Galicia, and Bardulia..$^{6}$ A great many fully integrated Septimanian and Spanish Goths made ecclesiastical or secular careers in the Carolingian Empire - Witiza, better known as Benedict of Aniane, Theodulf of Orléans, Agobard of Lyon, Galindus/o as Prudentius of Troyes, Helisachar, the first chancellor of Louis the Pious, and Abbot Smaragdus of St. Mihiel. ${ }^{57}$ Many Carolingian documents, charters as well as capitularies, deal with the status of Gothic refugees, mainly in southern Gaul. They were guaranteed freedom 
and property for service under a certain count in the Frankish army. Such decrees could have been issued by Cassiodorus in the name of Theodoric the Great as well..$^{8}$

\section{The Gothic faith}

There was no common pagan religion in the pre-Christian era. Beginning with Caesar and Tacitus, Germanic paganism was conceived of a diverse polytheism. ${ }^{59}$ Even within the same people, different groups and subdivisions, men and women, worshipped different gods and goddesses and performed different cults and rites. Instead, the conversion of the Gothic peoples to Christianity, or rather to its Homoean denomination, brought about an enormous change and considerably furthered tribal unity. This holds especially true for the Gothi minores, the people of Bishop Ulfilas, who were driven out of their homeland and settled in what is now northern Bulgaria around 350 . In and after 376 they refused to join the Fritigern-Goths and probably all other Goths under kings and kingly leaders who marched through their new homeland. ${ }^{60}$ In fact, they could rely on an imperial decision. In 381, the year before the first treaty between the Visigoths on Roman soil and the Emperor Theodosius was concluded, the second ecumenical Council of Constantinople solemnly condemned Arianism. But the second canon of the same council decreed that the 'churches of God among the barbarian peoples [...] are to be governed in the manner that already existed among their forefathers' - and that is where the matter stood for a while. As late as the first half of the ninth century, Walahfrid Strabo, abbot of the monastery Reichenau, knew that 'Goths among the Greeks' celebrated the divine service in Gothic, which likely meant that these Goths were still Arians. Barbarian Arianism survived for several reasons. The standardizing force of Ulfilas's translation of the Bible, the religious zeal of converts which reached what is now Austria and southern Germany, the support of the Roman crypto-Arians in settlement areas of the Goths and Vandals, all favoured the maintenance of Arianism. As the lex Gothica, the Gothic faith, it served as a means of preserving and creating ethnic identity, even though, or because, their Roman environment became more and more

58 Conversio Bagoariorum et Carantanorum, pp. 349-353.

59 Wolfram 1988, pp. 106 seqq.; 2005, pp. 98 seqq.; cf. Gaius Iulius Caesar, Bellum Gallicum, VI.21.1 seq., with Tacitus, Germania, 9 seq. and 39 seq.

6o Wolfram 1988, p. 121. 
radically Catholic. ${ }^{61}$ For the Goths in Spain, the Arian faith as a category of distinction and element of identity vanished in 589 when King Reccared I converted to Catholicism. ${ }^{62}$

After the destruction of their kingdom, Italian Goths came under Longobard domination, but could remain Arians as considerable numbers of Longobards remained Arians until the end of the seventh century - perhaps the term theodiscus was related to these Italian Goths.

\section{The Gothic law}

The Gothic law, which outlived the kingdom of Toledo for several hundred years and was only abolished by the French king Louis the Saint in the middle of the thirteenth century, ${ }^{63}$ consisted mainly of a lex scripta, the constantly updated Liber Iudiciorum, ${ }^{64}$ and customary laws such as duels on horseback. ${ }^{6}$ In $75^{2}$, the newly elected king of the Franks, Pepin I, conquered several cities of Septimania with the help of indigenous Goths. Seven years later the Gothic inhabitants of Narbonne annihilated the Arab garrison and pledged allegiance to the Frankish king, if he would recognize their law, which he did. Still in high medieval Catalonia and Septimania this law was cited not only frequently but usually with meticulous accuracy. The duel on horseback was the only case of customary Gothic law, and therefore was never codified in any lex scripta. ${ }^{66}$

\section{The Gothic language}

In theory the gentes differed from each other according to several criteria, among which lingua is listed last. ${ }^{67}$ The 'Scythians', i.e. the Huns, 'were [only] glued together' so that from the beginning they were a polyethnic medley that spoke all languages side by side. ${ }^{68}$ On the other hand, Procopius of Caesarea explained that once there had been only one people that had

\footnotetext{
61 Wolfram 1988, p. 85; 2005 , p. 262.

62 Wolfram 2018, p. 271.

63 Wolfram 2oog, pp. 232 seq.

64 José-Miguel Alonso-Núñez 2001, pp. 215 seq.

65 Wolfram 1997, p. 269.

66 Wolfram 1988, p. 194, n. 193. Zöllner, p. 128.

67 Regino of Prüm, Chronicon, p. xx.

68 Wolfram 1997, pp. 132 seq.
} 
been split into what he called the Gothic peoples, primarily Visigoths, Ostrogoths, Vandals, Gepids, and the original non-Germanic Alans. They all spoke the same Gothic language, adhered to the same Gothic laws, and to the same Gothic (Homoean) faith. ${ }^{69}$ But the Visigothic king Wamba (672-680) may not have been able to form a Gothic sentence with his name as 'womb' $7^{0}$ There had been a 'silent change of language' in most parts of Europe during the early Middle Ages, without, however, changing ethnic identity. ${ }^{71}$ Obviously, the concept of language is not a reliable category of distinction. Only Christian cult-languages such as Bible Gothic and Old Church Slavic had a meaningful effect on the making of peoples and nations.

\section{Summary}

The answer to the question 'How to stay Gothic without a Gothic king' is simply in 'looking for another one', be that emperor, a foreign king, caliph, or clan chieftain. But this change could not have functioned if not for the small- and multi-centred units of Gothic society whose needs had to be secured by a superior power. The Goths of the Crimea might have felt deeply honoured when King Theodoric the Great invited them to join the march to Italy in 488 . But they sent their regrets and stayed behind, gladly kingless under the light yoke of a distant emperor in Constantinople, confessing to some sort of Christianity. Asked by authorities of Byzantium whether they were Arians or Catholics, they did not understand the question..$^{2}$ Still in the fourteenth century, citizens of Constantinople ranked them number four among the five worst nuisances in the world. ${ }^{73}$ And whoever the Germanic-speaking people from the Crimea were, whom Ogier Ghislain de Busbecq met in Constantinople in the sixteenth century, they had no king. When the Turks conquered Byzantium, and the last emperor was killed, the Crimeans, looking for another monarchic figure, followed the khan of the Tartars, whom they supported with 800 musketeers. ${ }^{74}$ Leaving them all behind we are approaching the multilingual chorus of Gothicists. In 1843, George Perkins Marsh announced the Gothic origins of New England, the

69 Procopius, De bello Vandalico, I(III).2.2 seqq.; Wolfram 1988, pp. 19 seq.

70 Wolfram 2018, p. 42, n. 182.

71 Wolfram 2017, pp. 33 seq.; cf. 2005, pp. 245-247.

72 Wolfram 2009, pp. 87 seq. and 279.

73 Koder 2016, p. 41.

74 Scardigli 1973, pp. 246-265. 
Pilgrims, and heroes of the American revolution, all in a book with the revealing title The Goths in New England. 75

\section{Bibliography}

\section{Primary sources}

Cassiodorus, Epistulae Theodoricianae variae, in Cassiodori Senatoris variae, ed. by Theodor Mommsen (Berlin: Monumenta Germaniae Historica, Auctores Antiquissimi 12, 1961 [1894]), pp. 387-392.

—, Epistulae Theodoricianae variae, ed. by Åke J. Fridh (Turnhout: Corpus Christianorum, Series Latina 96, 1973).

Conversio Bagoariorum et Carantanorum = Das Weißbuch der Salzburger Kirche über die erfolgreiche Mission in Karantanien und Pannonien mit Zusätzen und Ergänzungen, ed., trans., and comm. by Herwig Wolfram (Ljubljana/Laibach: Hermagoras, 2013).

Cornelius Tacitus, Annalium libri III-XVI, ed. by Henry Furneaux and Horace Pitman (Oxford: Clarendon Press, 1962 [1904]).

- Germania $=$ De origine et situ Germanorum, in Cornelii Taciti opera minora, ed. by Michael Winterbottom and Robert Maxwell Ogilvie (Oxford: Oxonii, Scriptorum Classicorum Bibliotheca Oxoniensis, 1975), pp. 35-62.

Dexipp von Athen = Übersetzung und begleitende Studien, ed. by Gunther Martin (Tübingen: G. Narr, Classica Monacensia 32, 2006).

Eugippius, Vita Severini, ed. by Theodor Mommsen (Berlin: Monumenta Germaniae Historica, Scriptores Rerum Germanicarum, 1898).

Gaius Iulius Caesar, Bellum Gallicum, ed. by Otto Seel (Leipzig: Teubner, Bibliotheca Scriptorum Graecorum et Romanorum Teubneriana, 1961).

Iordanes, Getica, in Iordanis Romana et Getica, ed. by Theodor Mommsen (Berlin: Monumenta Germaniae Historica, Auctores Antiquissimi 5.1, 1882), pp. 53-200. Paulus Diaconus, Historia Langobardorum, ed. by Ludwig Bethmann and Georg Waitz in Scriptores rerum Langobardicarum et Italicarum saec. VI-IX (Hanover: Monumenta Germaniae Historica, Scriptores Rerum Lengobardicarum 1, 1878), pp. $12-187$.

75 Wolfram 1988, p. 2 seq. I wish to thank Sabine Panzram (University of Hamburg), for having offered me the opportunity for a discussion of the present article at the conference, "The Visigothic Kingdom of Toledo: Concepts and Forms of Power', which she held in Hamburg between 25 and 27 October 2018. I also wish to thank Ian Wood (Leeds), and Anton Scharer (Vienna), for considerably improving the English of this paper. 
Procopius, De bello Gothico, ed. by Otto Veh (Munich: Heimeran, Tusculum-Bücherei 1966).

, De bello Vandalico I-II (III-IV), ed. by Otto Veh (Munich: Ernst Heimeran, Tusculum-Bücherei, 1971).

Regino of Prüm, Chronicon, ed. by Friedrich Kurze (Hanover: Monumenta Germaniae Historica, Scriptores Rerum Germanicarum in Usum Scholarum 50, 1890).

Salvianus of Marseille, De gubernatione Dei, in Salviani Presbyteri Massiliensis Libri qui supersunt, ed. by Karl Felix Halm (Berlin: Monumenta Germaniae Historica, Auctores Antiquissimi 1, 1877), pp 1-108.

Walahfrid Strabo, De imagine Tetrici, in Poetae latini aevi Carolini, 4 vols., vol. 2, ed. by Ernst Dümmler (Munich: Monumenta Germaniae Historica, Antiquitates 1, 1999 [Berlin, 1884]), pp. 370-378.

Wattenbach, Wilhelm, Wilhelm Levison, and Heinz Löwe, eds., Deutschlands Geschichtsquellen im Mittelalter: Vorzeit und Karolinger, 6 vols., vol. 3: Die Karolinger vom Tode Karls des Grossen bis zum Vertrag von Verdun (Weimar: Böhlau, 1957).

\section{Secondary sources}

Alonso-Núñez, José-Miguel, s.v. 'Leges Visigothorum', in Reallexikon Germanischer Altertumskunde, 35 vols., vol. 18, 2nd ed. (Berlin: De Gruyter, 2001), pp. 215-216.

Brunner, Karl, Oppositionelle Gruppen im Karolingerreich (Vienna: Böhlau, Veröffentlichungen des Instituts für Österreichische Geschichtsforschung $25,1979)$.

Claude, Dieter, Adel, Kirche und Königtum im Westgotenreich (Sigmaringen: Thorbecke, Vorträge und Forschungen - Sonderbände, 8, 1971).

Geary, Patrick Joseph, 'Ethnic Identity as a Situational Construct in the Early Middle Ages', Mitteilungen der anthropologischen Gesellschaft in Wien 113 (1983), pp. $15^{-26 .}$

- Before France and Germany: The Creation and Transformation of the Merowingian World (New York/Oxford: Oxford University Press, 1988).

Green, Dennis Howard, Language and History in the Early Germanic World (Cambridge: Cambridge University Press, 1998).

Grusková, Jana, and Gunther Martin, 'Ein neues Textstück aus den "Scythica Vindobonensia" zu den Ereignissen nach der Eroberung von Philippopolis (Taf. 12-15)', Tyche. Beiträge zur Alten Geschichte, Papyrologie und Epigraphik 29 (2014), pp. 29-43.

-, 'Zum Angriff der Goten unter Kniva auf eine thrakische Stadt (Scythica Vindobonensia, f. $195^{\mathrm{V}}$ )', Tyche: Beiträge zur Alten Geschichte, Papyrologie und Epigraphik 30 (2015), pp. 35-56. 
Guttenstein, Bernhard F., Geschichte des spanischen Volkes in gedrängter Übersicht dargestellt, 2 vols., vol. 1 (Mannheim: Heinrich Hoff, 1836).

Haubrichs, Wolfgang, 'Ethnisch signifikante und andere sprechende Namen im wisigotischen Spanien und im gotischen Italien', in Sprache-Rhetorik-Translation: Festschrift für Alberto Gil zu seinem 6o. Geburtstag, ed. by Vahram Atayan and Ursula Wienen (Frankfurt am Main: Lang, Rhethos 3, 2012), pp. 41-54.

Köbler, Gerhard, Gotisches Wörterbuch (Leiden: Brill, 1989).

Koder, Johannes, Die Byzantiner: Kultur und Alltag im Mittelalter (Vienna: Böhlau, 2016).

Martin, Gunther, and Jana Grusková, 'Scythica Vindobonensia by Dexippus (?): New Fragments on Decius' Gothic War', Greek, Roman and Byzantine Studies 54 (2014), pp. 728-754.

Pohl, Walter, s.v. 'Edika', in Reallexikon Germanischer Altertumskunde, 35 vols., vol. 6, 2nd ed. (Berlin: De Gruyter, 1986), pp. 446-447.

- The Avars. A Steppe Empire in Central Europe. 567-822 (Ithaca/London: Cornell University Press, 2018).

Scardigli, Piergiuseppe, Die Goten: Sprache und Kultur (Munich: C.H. Beck, 1973).

Steinacher, Roland, Die Vandalen: Aufstieg und Fall eines Barbarenreichs (Stuttgart: Klett-Cota, 2016).

Wallace-Hadrill, John Michael, Review of Stammesbildung und Verfassung: das Werden der frühmittelalterlichen Gentes, by Reinhard Wenskus, English Historical Review 79.310 (1964), pp. 137-139.

Wenskus, Reinhard, Stammesbildung und Verfassung: das Werden der frühmittelalterlichen Gentes, 2nd ed. (Cologne/Graz: Böhlau, 1977 [1961]).

Wolfram, Herwig, Intitulatio, 3 vols., vol. 1: Lateinische Königs- und Fürstentitel bis zum Ende des 8. Jahrhunderts (Vienna: Böhlau, Mitteilungen des Instituts für Österreichische Geschichtsforschung, Suppl. 21, 1967).

—, 'The Shaping of the Early Medieval Kingdom', Viator 1 (1970), pp. 1-20.

—, History of the Goths (Berkeley/Los Angeles: University Press Group, 1988).

— , s.v. 'Ermanarich', in Reallexikon Germanischer Altertumskunde, 35 vols., vol. 7, 2nd ed. (Berlin: De Gruyter, 1989), pp. 510-512.

- The Roman Empire and its Germanic Peoples (Berkeley: University of California Press, 1997).

— , s.v. 'Heerkönigtum', in Reallexikon Germanischer Altertumskunde, 35 vols., vol. 14, 2nd ed. (Berlin: De Gruyter, 200o), pp. 115-118.

— Gotische Studien: Volk und Herrschaft im frühen Mittelalter (Munich: C.H. Beck, 2005).

— , s.v. 'Kniva', in Reallexikon Germanischer Altertumskunde, 35 vols., vol. 17 (Berlin: De Gruyter, 2006), pp. 34-37. 
_ Die Goten: von den Anfängen bis zur Mitte des sechsten Jahrhunderts; Entwurf einer historischen Ethnographie, 5th ed. (Munich: C.H. Beck, 2009 [1979]).

, 'Die frühmittelalterliche Romania im Donau- und Ostalpenraum', in Walchen, Romani und Latini: Variationen einer nachrömischen Gruppenbezeichnung zwischen Britannien und dem Balkan, ed. by Walter Pohl, Ingrid Hartl, and Wolfgang Haubrichs (Vienna: Denkschriften Österreichische Akademie der Wissenschaften, Philosophisch-Historische Klasse 491, Forschungen zur Geschichte des Mittelalters 21, 2017), pp. 27-57.

— Das Römerreich und seine Germanen (Cologne: Böhlau, 2018).

Zöllner, Erich, Die politische Stellung der Völker im Frankenreich (Vienna: Böhlau, Veröffentlichungen des Instituts für Österreichische Geschichtsforschung 13, 1950).

\section{About the author}

Herwig Wolfram is Professor Emeritus for Medieval History and Auxiliary Sciences at the University of Vienna (Austria). His major fields of research are late antiquity and the early Middle Ages. He has published twenty-five books and monographs in German, English, French, Italian, Spanish, Russian, Polish, Turkish and Bulgarian. 



\title{
$8 \quad$ Who are the Visigoths?
}

Concepts of Ethnicity in the Kingdom of Toledo: A Case Study of the Vitas Sanctorum Patrum Emeretensium

\section{Manuel Koch}

\begin{abstract}
Although the Visigoths were an ethnic group within the kingdom of Toledo, the traditional view on Visigothic identity in sixth-century Spain has been challenged by abundant research concerning ethnicity in the transformation of the Roman world. The use of the term Gothus in sources of the kingdom of Toledo clearly manifest the presence of Visigoths and an awareness of a Visigothic identity. Careful examination of the records, however, suggests that the ethnic label Gothus differs from its established understanding. This chapter represents a case study of a particular source offering an exceptional insight into the social and political environment of the city.
\end{abstract}

Keywords: Iberia; Visigoths; Gothus; Toledo; Mérida; ethnicity

A renowned expert on Visigothic Spain, Collins, summarized in 2004 the perspective that scholars have concerning the concept of ethnicity in the kingdom of Toledo: 'One tradition of interpretation of the internal development of the Visigothic kingdom in Spain between 589 and 711 has been concerned almost exclusively with the dichotomy between Roman and German. This approach to the period that emphasizes contrasts and conflicts between two sections of the population has been challenged, but is not entirely superseded'. ${ }^{1}$ Following this view, the population of the kingdom throughout the sixth century - and some would say still during the seventh century ${ }^{2}$ - was ethnically divided into two basic

1 Collins 2004, p. 240.

2 Besga Marroquín 200o, pp. 518-530; Martínez Pizarro 2005, pp. 10-11 and 36-37.

Panzram, S. and P. Pachá (eds.). The Visigothic Kingdom: The Negotiation of Power in Post-Roman Iberia. Amsterdam: Amsterdam University Press 2020 DOI: 10.5117/9789463720632_CHo8 
groups: a large majority of so-called Hispano-Romans on the one hand, representing the established population of the peninsula - and on the other a minority of Visigoths, generally having emigrated from Gaul after their defeat by the Franks in 507. While scholars have recently challenged this established view, ${ }^{3}$ the supposed dichotomy between Visigoths and Romans generally continues to be influential for the understanding of the Visigothic kingdom. ${ }^{4}$ This, nonetheless, considering that over the last decades there have been significant evolutions in our knowledge about the transformation of the Roman world and our understanding of ethnic identity in this process. ${ }^{5}$ Due to this evolution many certainties, which served as evidence for the dichotomy of the population, have been weakened. We now know that the archaeological evidence of names or religious affiliation are not reliable proof for an ethnical attribution. While these features can be used as signs of ethnic identity, but they are not, per se, certain markers. ${ }^{6}$

There were obviously Visigoths in the Visigothic kingdom. The term Gothus is present in almost all written sources from the kingdom of Toledo. But it is difficult to clearly identify these persons and to distinguish them from the so-called Hispano-Romans. The inability to differentiate these groups is due to the lack of exclusive signs of identity to unmistakably separate Gothic from Roman identity. ${ }^{7}$ In the light of new studies and after a careful examination of sources, the conclusion is that, with regards to the sixth century, neither archaeological evidence, nor Arianism, nor law codes, nor names can be used to clearly identify Goths from Hispano-Romans within the Visigothic kingdom. ${ }^{8}$ Goths had already been important in the transformation of the Roman world and had been for a long period assimilated into it.

3 Koch 2012; Quirós Castillo and Castellanos García 2015; Buchberger 2017. This view is shared by Wood and Martínez Jiménez 2016, p. 31: 'Recent work has underlined the way in which individuals particularly at the elite level, were able to "mix" their identities.'

4 See recently e.g. Valverde Castro 2015, pp. 78-81. For more details and bibliography see Koch 2012, pp. 24-26.

5 Among the abundant works see for example the fourteen volumes published between 1997 and 2004 of the Transformation of the Roman World series.

6 For an overview of the methodological discussions see for archaeology, Curta 2007 and Von Rummel 2010; for name studies, Goetz, Jarnut, and Pohl 2003; and for Arianism, Berndt and Steinacher 2014.

7 For the concept of 'signs of identity', see Pohl 1998.

8 See in detail Koch 2012, pp. 130-150 (archaeology), pp. 183-189 (name studies), pp. 190-216 (arianism), and pp. 375-404 (law codes). For a recent discussion of the archaeological material, see the paper of Christoph Eger in this volume. 
The texts of the sixth and seventh centuries identify Visigoths as the population of the regnum Gothorum as a whole and, in certain circumstances, stress the Gothic identity of magnates who personified the power structures of the realm. Although this might fit an established understanding of ethnic identity within the peninsula, actually the term Gothus at that time was not defined by ancestry and descent, but rather as a social-political label.

A detailed study ${ }^{9}$ analysed the narrative, as well as the documentary texts of the kingdom of Toledo, in order to locate written sources that distinguish between Hispano-Romans and Goths, and, more specifically, the contexts of ethnical classifications and the particular functions and concepts of ethnicity.

A particular example is offered by the so-called Vitas Sanctorum Patrum Emeretensium, written around $635 .{ }^{10}$ Though the author is unknown, it was likely written by a cleric familiar with the appearance of the city, who refers to topographical and edificial aspects consistent with the results of archaeological excavations. ${ }^{11}$ The text covers the second half of the sixth and the beginning of the seventh century, and emphasizes the pontificate of Bishop Masona, the protagonist of the opusculum $V$ from 573 to 605 .

It is extraordinary among the literary texts of the Visigothic kingdom. It has a particular configuration: 'It is hagiography; but not exclusively. It is also biography. Among the literary productions of Hispania in the seventh century, it is an unusual piece, because it is neither ecclesiastical history, nor is it a chronicle, nor an account of the lives of distinguished men and women. ${ }^{12}$ But importantly it delivers an exceptional insight into the social environment of a specific city, namely Emerita. The author refers to numerous groups, such as Arians and Catholics, ${ }^{13}$ nobles of the Visigothic court, ${ }^{14}$ senators from the Lusitania, ${ }^{15}$ a group of insurgents, ${ }^{16}$ the followers

9 Koch 2012.

10 There is a slightly different second version of the text made by the end of the seventh century. For general information about the source, see Maya Sánchez 1992, pp.x-liv.

11 See Mateos Cruz 2000, pp. 504-512.

12 Arce 1999, p. 5.

13 Since the struggle between these groups is the major concern of this chapter, the sources make abundant and various references to both Catholics an Arians. For an overview, see the documentation of Martínez Pastor, Aldama Roy, Castro Jímenez et al. 2001. For Catholics, see catholici/catholicus (p. 53), christianvs (p. 57), fidelis/fides (p. 152-53), orthodoxvs (p. 286); and for Arians, arriani/arrianvs (p. 35), haeresis/haereticvs (p. 170), infidelis (p. 196), and profanvs (p. 325). 14 Nobles as 'ministers' of the court, Vitas Sanctorum Patrum Emeritensium, 5.6, p. 63; 5.6, p. 69; as messengers of the king, 5.4, p. $55 ; 5.6$, p. 66 , or generally as the public of the royal court, 5.6 , p. $68 ; 5.6$, p. $70 ; 5.8$, p. 74 .

15 Ibid., 4.2, p. 26 ; 4.2, p. 3 o.

16 Ibid., 5.12, p. 92. 
of the Arian Bishop Sunna ${ }^{17}$ and those of the Catholic Bishop Nepopis,$^{18}$ free people and slaves, ${ }^{19}$ and rural and urban populations. ${ }^{20}$ Although a number of ethnical denominations can be observed, it was not the author's primary concern. The Vitas, which extends in their edited version to about a hundred pages, display a multitude of social groups but only about a dozen passages connected with 'ethnicity'.

Despite the fact that ethnic classifications are scarce, references provide interesting insights into the concept of ethnicity at the time of the kingdom of Toledo. The first criterion for an ethnic identification of persons or groups is one of external provenience, i.e. as coming from outside the kingdom. This is the case, for example, in a passage about the multitudine Francorum, which is mentioned in the context of an uprising in Narbonne. ${ }^{21}$ Twice the author refers to Greeks. First, when he mentions negotiatores Grecos ${ }^{22}$ who arrived at the city, and secondly when he introduces Paulus, who would later become bishop, as natione Grecum. ${ }^{23}$ The remote provenience of these people is underlined further by the expressions de Orientibus and de Orientis partibus.

Goths are mentioned eight times. ${ }^{24}$ Three of these consist of the set phrase rex Gothorum or rex Visegotorum. ${ }^{25}$ In the context of the conversion from Arianism to the Nicene faith, one passage focuses on the gens Wisegotorum. ${ }^{26}$ Remaining references refer to a group of Gothic noblemen and to individuals of Gothic identity, ${ }^{27}$ all of them bishops. ${ }^{28}$ Although this is scant evidence, it outweighs any Roman element, which is represented by a single person, a

17 See e.g. ibid., 5.5 , p. $61 ; 5.10$, p. 81 .

18 Ibid., 5.8 , p. 76 .

19 Ibid., $5 \cdot 3$, p. $5^{0 .}$

20 Ibid., 5.3, p. 51.

21 Ibid., 5.12, 'Nam resultantes aduersus fidem catholicam infinita multitudine Franchorum in Galliis introduxerunt, quatenus et prauitatem Arriane partis uindicarent et [...] regnum uiro catholico Reccaredo preriperent', p. 92.

22 Ibid., 4.3, 'accidit die quadam [...] negotiatores Grecos in nauibus de Orientibus aduenisse', p. 31 .

23 Ibid., 4.1, 'Referunt multi sanctum uirum nomine Paulum, natione Grecum, arte medicum, de Orientis partibus in Emeretensem urbem aduenisse', p. 25.

24 For an overview of the passages, see Martínez Pastor, Aldama Roy, Castro Jímenez et al. 20o1; p. 164, for Gothvs; and p. 446, for Visigothus.

25 Vitas Sanctorum Patrum Emeretensium, 3, 'temporibus Leuuigildi Visegotorum regis', p. 21; 5.4, 'hec opinione seuissimi atque crudelissimi Wisigotorum Leouigildi regis penetrarent auditum', p. 54; 5.10 'unus ex illis cui Wittericus nomen erat, qui etiam post rex Gotorum fuit', p. 82.

26 Ibid., 5.9, 'Recaredus [...] totumque Wisegotorum gentem [...] ad ueram fidem perduxit', p. 79 .

27 Ibid., 5.10, p. 81.

28 Ibid., 5.2 , p. $48 ; 5.10$, p. $81 ; 5.14$, p. 100. 
dux named Claudius. ${ }^{29}$ In a city such as Emerita scholars can hardly take a handful of Goths and one Roman as a reliable proof for an entire mixed society.

An explanation for this phenomenon is called the 'model of exception'. Accordingly, the potential audience of the Vitas was supposedly aware of an established social order in Visigothic society orientated along ethnic identities, i.e. people automatically associated Goths with certain social positions and Romans with others. Fitting this model, scholars can only expect explicit ethnic identification to be made in cases of exception from the norm. ${ }^{30}$ In other words: following the established explanation, some of the multiple social groups one finds in the Vitas are not ethnically identified, precisely because the recipients of the texts could align them naturally either with Goths or with Romans. This elaborate explanation, however, is a lectio difficilior of sources in order to make their analysis fit into nineteenth- and twentieth-century primordial concepts of ethnicity in order to detect something in the sources which, a priori, has to be detected.

In the Vitas, the dux Claudius seems to be a fruitful example. Scholars have often thought that social role models in the Visigothic kingdom defined Goths basically as warriors and part of the court, whereas Hispano-Roman landowners either chose an ecclesiastical career or acted as administrators. ${ }^{31}$ Evidently, the case of Claudius was different: as a $d u x$ he held a high military office and the Vitas stresses his military capability. At the same time, the text explicitly mentions that he is of Roman descent. ${ }^{32}$ Correspondingly, he is often viewed as a single verifiable example of a Hispano-Roman general in Visigothic service in the sixth-century kingdom. ${ }^{33}$ And it seems reasonable that the author mentions his Roman descent precisely because of his exceptional position.

29 Ibid., 5.10, p. 83 .

30 See e.g. most recently Buchberger 2017, concerning the presentation of Masona in the Vitas, p. 58 : 'Clearly he expected his audience in the 630 s to be surprised that a Goth in the time before Reccared's conversion could be Catholic, in opposition to the stereotypical link of Arianism with the Gothic people.'

31 See e.g. Claude 1971, p. 54; Thompson 1969, pp. 114-131; Velázquez Soriano 2003, p. 180.

32 Vitas Sanctorum Patrum Emeretensium, 5.10, p. 83: 'Idem uero Claudius nobili genere hortus Romanis fuit parentibus progenitus; existebat prossus fide catholicus et religionis uinculis fortiter adstrictus, in preliis strenuus, in timore Dei ualde promtissimus, in bellica studia eruditus, in causis bellicis nicilominus exercitatus'; trans. by Garvin, p. 235: 'Claudius was sprung of noble stock, the son of Roman parents. He was staunchly Catholic in faith and strongly bound by the bonds of religion, strenuous in war, most responsive in the fear of the Lord, trained for the pursuits of war, and also experienced in the deeds of war.'

33 See e.g. Claude 1971, p. 54; Orlandis Rovira 2003, pp. 369-370; Velázquez Soriano 2003, p. 180; Kampers 2008, p. 183. 
However, if only exceptions to a given model were considered as noteworthy, it seems inconsistent to find Arian bishops as well as Catholic ones among the three persons the author identifies as Goths..$^{34}$ An Arian bishop, bearing the Germanic name Sunna, perfectly reflects established assumptions about the social and religious environment of the kingdom and would hardly require an ethnic denomination.

This leads to an alternative and more coherent understanding of what Roman descent could mean in this context. As already seen, ethnic denomination in the Vitas generally serves to identify foreigners. This understanding does not seem to help because at first sight it seems to be evident that Romanus refers to indigenous people of Hispania. But this would be another a priori interpretation, presupposing the awareness of an ethnic group in the seventh-century Visigothic kingdom which we ethnically label as HispanoRoman. Actually, in Hispanic narrative sources of the period, Romanus in most cases - if not all - signifies Byzantine. ${ }^{35}$ Accordingly, both the current application of the term Romanus as well as the context of the source suggest that Claudius was originally a Byzantine officer. Therefore, we can conclude that there is no reason why the author of the Vitas should have stressed the Hispano-Roman background of a person as exclusive.$^{36}$ Instead, it is more plausible to assume that it was his provenience from outside the Visigothic kingdom that motivated his explicit identification. Such a career might not have been common, but there are sufficient examples of persons from outside the kingdom who reached high positions to make this explanation

34 The Arian bishop Sunna (Vitas Sanctorum Patrum Emeretensium, 5.10, p. 81) as well as the Catholic bishops Renovatus (5.2, p. 48) and Masona (5.14, p. 100) are introduced as Goths.

35 It is common sense that for example Isidore of Seville uses the term Romanus exclusively to identify Byzantines. See Diesner 1973, pp. 67-68; García Moreno 2002, pp. 258-259; Caerols 2001, p. 231. A passage of the chronicle of John of Biclar, which was written at the very end of the sixth century, is frequently taken as evidence for a differentiation between Visigoths and Hispano-Romans by the terms Gothi and Romani ('Que causa in prouinciam Ispanie tam Gothis quam Romanis maioris exitii quam aduersariorum infestatio fuit', John of Biclar, Chronicon, 54). But even in this case the Romani can be identified as Byzantines; see Koch 2012, pp. 225-235.

36 Recently Erica Buchberger 2017, p. 61, argued that the author mentions Claudius's Roman descent in order to stress the religious nature of the struggle between the Arian bishop Sunna and the Catholics: $d u x$ Claudius and Bishop Masona: 'By showing the Arian Sunna attacking both a Goth and a Roman, the author emphasized that the conflict was based not on ethnic tensions but on religious identity.' She concludes that '[i]t is precisely in this context that Roman and Gothic descent suddenly become a useful tool for painting a picture of a society newly unified behind the right and proper faith.' She correctly points to the religious function of the text. However, a single person of Roman descent is hardly a useful tool for depicting an ethnically divided society united by the Catholic faith. 
plausible. ${ }^{37}$ For instance, in Emerita two people from Greece, Paulus and Fidelis, would later become bishops in the city.

Another influential premise for the interpretation of ethnicity in early medieval Spain is that ethnic parting lines corresponded with religious ones. ${ }^{38}$ Therefore, another widespread explanation suggests that in certain contexts the terms Romanus and Gothus were used to distinguish between Gothic Arians and Nicene Romans. According to some scholars, this is the case in the Vitas. ${ }^{39}$ Because of the fact that the religious struggles between the two denominations in the city are a major concern of this hagiographical text, differentiations between religious groups frequently use a multitude of terms, such as catholicus, christianvs, fidelis, orthodoxvs, for the Nicene side and arrianvs, haereticvs, infidelis, profanvs for the Arians. ${ }^{40}$ Against this background, it seems questionable that in the case of Claudius the expression Romanis fuit parentibus progenitus was meant to underline his Nicene faith: more so since the author of the Vitas refers explicitly to his faith in the following sentence: 'He was staunchly Catholic in faith and strongly bound to the bonds of religion. ${ }^{41}$

All three individuals identified as Goths were bishops. One of them is already mentioned as Arian bishop Sunna, appointed by Liuvigild. Rather surprisingly, however, the two others are the Catholic bishops Renovatus and Masona, the latter being the hagiographical protagonist of the main chapter of the text. This is a contradiction to the conflation of ethnic and religious identity. The text introduces Masona in the following manner:

Denique sanctus Masona antestis nobilis hortus in hoc seculo origine, sed uite meritis extitit multo nobilior; genere quidem Gotus, sed mente promtissima erga Deum perquam deuotus atque uiriliter altissimi uirtute fundatus. ${ }^{42}$

37 For a further discussion of this aspect, see Koch 2012, pp. 288-292.

38 For a discussion of this, see Koch 2014, pp. 257-26o. In her recent study Buchberger 2017 acknowledges the complexity and the occasional inconsistency of religious affiliations. Nevertheless, in her view the religious difference represents a significant obstacle to a unity of Romans and Goths within the kingdom, see pp. 61-66. See also Valverde Castro 2015, pp. 71 and 79 .

39 Teillet 1984, p. 554, García Moreno 2002, p. 253.

40 See above, note 13 .

41 See above, note 32.

42 Vitas Sanctorum Patrum Emeretensium, 5.2, p. 48; trans. by Garvin, p. 235: 'The holy bishop Masona was of noble origin in this world but much more noble by the merits of his life: by birth a Goth but with ready heart entirely devoted to God and steadfastly reliant upon the power of the Most High'. 
Following the concept that Goths are to be identified as Arians, attention has been focused on the word sed in the second phrase: genere quidem Gotus, sed mente promtissima erga Deum perquam deuotus. According to some scholars, this concessive conjunction reveals that to the author's mind Gothic identity was a contradiction to true religiousness. If we pay attention to the whole passage, however, there appears to be a different reading of this phrase which focuses on the textual evidence rather than on assumptions about the author's mentality. The introduction of Masona begins with a comparison of nobilis and nobilior - a commonplace in hagiographical literature. The text underscores that Masona was of noble stock on this earth but (sed) showed himself more noble still through good deeds. This, in fact, is an exact parallel to the construction of the following sentence. But in the second phrase, the author adapts the hagiographical commonplace for the specific example of Masona. Therefore, genere Gotus has to be seen as a reference to Masona's high social standing in this world. Regardless of Masona's earthly well-being he nevertheless devoted himself entirely to the service of God. Following a hagiographical topos, this whole passage is designed to introduce the 'Holy Man', at the same time highlighting his nobility, as well as his humility and devoutness. Moreover, it should be emphasized that Gotus is accompanied by the term genus. This term, in the context of our source, is often combined with the adjective nobilis ${ }^{43}$ - or in one case we find the expression $e x$ genere senatorum. ${ }^{44}$ Since genus is used to indicate a social status this is another argument in favour of an understanding of the passage as just expounded. The introduction of Bishop Renovatus follows the pattern seen in Masona's case:

uir denique natione Gotus, generoso stigmate procreatus, familie splendore conspicuus [...] Sed quamuis extrorsus habitus sui esset gloria decoratus, introrsus pulcrior habebatur lumine sancti Spiritus inlustratus. ${ }^{45}$

Adding to his initial presentation as a Goth, the text further explicates that he 'was born of noble stock, conspicuous for the splendor of his family'. ${ }^{6}$

43 Vitas Sanctorum Patrum Emeretensium, 5.10, 'quosdam Gotorum nobiles genere opibusque perquam ditissimos', p. 81, and 'idem uero Claudius nobili genere hortus [...] progenitus', p. 83; 5.12, 'duo denique comites, incliti licet opibus et nobiles genere', p. 83 .

44 Ibid., 4.2, 'primarii ciuitatis ex genere senatorum nobilissimi uiri egrotasse matrona, que et ipsa inlustri stigmate progenita nobilem traebat prosapiem', p. 26.

45 Ibid., 5.14, p. 100.

46 Vitas Sanctorum Patrum Emeretensium, trans. by Garvin, p. 255. 
This is followed by a description of his favourable appearance, ${ }^{47}$ in which all his features pay tribute to his glory. Following the structure observed in Masona's case, all this leads to a comparison, initiated with the concessive conjunction sed, which highlights his virtues: Sed [...], introrsus pulcrior habebatur lumine sancti Spiritus inlustratus. ${ }^{48}$

Finally, we find some Gothic noblemen involved in a conspiracy against Masona, headed by Sunna. This plot is to be seen against the background of the general conversion of all Goths to the Nicene faith initiated by Liuvigild's son and successor Reccared.

Sunna namque Gotus episcopus, cuius supra memoriam fecimus, irritatus a diabolo quosdam Gotorum nobiles genere opibusque perquam ditissimos, e quibus etiam nonnulli in quibusdam ciuitatibus comites a rege fuerant constituti, consilio diabolico persuasit eosque de catholicorum hagmine ac gremio catholice eclesie cum innumerabile multitudine populi separauit et contra famulum Dei Masonam episcopum fraudulenta consilia, qualiter eum interficeret, commentabit. ${ }^{49}$

In the sentence construction, it appears that the Gothic noblemen are clearly related to the multitudo populi: groups that are two elements of a whole - both separated from the Catholic church by the Arian bishop: 'eosque [the noblemen] de catholicorum hagmine ac gremio catholice eclesie cum innumerabile multitudine populi separavit'. Once again, this challenges the established concept of ethnic role models because the Gothic nobles were presumed to be Arians. Hence, Thompson, for example, elaborated a complex explanation of this passage: 'The comites were Goths who had become Catholic but who now reverted to Arianism. ${ }^{50} \mathrm{He}$ did not

47 Vitas Sanctorum Patrum Emeretensium, 5.14: 'Erat enim procerus corpore, forma prespicuus, statura decorus, obtutu gratus, uenusto uultu, decora facie nimiumque admirabilis adspectu', p. 100; trans. by Garvin, p. 255: 'He was [...] tall of body, remarkably handsome, of graceful build, pleasing to look upon, of attractive face, comely countenance, and exceedingly admirable to behold'.

48 Vitas Sanctorum Patrum Emeretensium, trans. by Garvin, p. 257: 'he was more beautiful within, alight with the light of the Holy Spirit'.

49 Ibid., 5.10, p. 81; trans. by Garvin, p. 233: 'Sunna, the Gothic bishop whom we mentioned above, urged on by the devil, with diabolic cunning prevailed upon some Goths who were noble by birth and very wealthy, some of whom had even been made counts by the king in certain cities, and separated them from the ranks of the Catholics and the bosom of the Catholic church together with an innumerable multitude of the faithful, and devised deceitful plans against the servant of God, Masona, to kill him.'

50 Thompson 1969, p. 102. 
provide further explanation why these people had to be reconverts. In the understanding of his time this was a given fact. Furthermore, together with Garvin he translates the term populus as 'the faithful'. Following Thompson's line of interpretation this shows, that '[ $t$ ] he large number of the people who followed them, however, were Catholics throughout and had never been Arians'.

Leaving presumptions about ethnical concepts aside, a different understanding of the passage is possible. Undoubtedly, the word populus in the Vitas can refer to Catholics. But in addition to that, the term is also used without religious meaning. In combination with attributes like cunctus, universus, and totius, the word populus clearly refers to the people of the city as a whole. ${ }^{11}$ With regard to a third semantic level the expression caterva populi seems significant. It is used twice to denominate some of the Sunna's Arian followers and certainly does not refer to Catholics in this context.

The first record is set in a court of law. This was initiated by Liuvigild in order to settle the conflict between Masona and Sunna concerning the possession of the prestigious relics of St. Eulalia. This took place even before the conspiracy. After Masona had arrived at the court the author writes that '[f]inally the Arian bishop and the judges came in, accompanied by throngs of people' ('Tandem Arrianus episcopus una cum iudicibus septus cateruis populi [...] ingressus est')..$^{2}$ As the translation of Garvin appropriately indicates, the phrase caterua populi seems to indicate 'the common people'. This understanding is confirmed by the second passage:

Denique cum vir illustris Claudius atrium introisset protinus et illi qui supra memorati sunt cum ingentibus catervis populi introierunt ac deinde salutato viro sancto ex more considerunt. ${ }^{53}$

In the broader context, the author is writing again about the conspiracy of Sunna and the same people involved. That means illi qui supra memorati sunt are Sunna and the Gothic noblemen, who enter the atrium to meet the Catholic bishop Masona. They did not go there alone but cum ingentibus catervis populi, 'with huge crowds of people', as Garvin puts it. The people

$5^{1}$ Vitas Sanctorum Patrum Emeretensium, 5.2, p. 49. See also Castellanos García 2003, pp. 393-394.

52 Vitas Sanctorum Patrum Emeretensium, 5.5, p. 6o; trans.by Garvin, p. 205.

53 Vitas Sanctorum Patrum Emeretensium, 5.10, p. 83; trans. by Garvin, p. 235: 'When the noble Claudius entered the bishop's house they whom we have spoken of above at once went in also, with huge crowds of people and, saluting the holy man according to custom, sat down.' 
involved are the same as in the aforementioned passage. The ingens caterva populi is the same as the multitudo populi of the first sentence. ${ }^{54}$ Thus, the 'common people' represent the contrasting, yet complementary, element to the Goths. The latter are further characterized as of noble birth and wealth, some holding the position of comes - all typical components of a high social standing.

In both cases the term populus differentiates the followers socially into high-standing members on the one hand and common people on the other. Accordingly, Gothus has neither a religious nor ethnic significance, at least in classical terms, but a social one. This corresponds with the conclusions drawn from the author's introduction of Renovatus and Masona. Such a reading fits the topos of late-antique hagiography and one of the text's major aims. As Castellanos García has demonstrated, the Vitas paints a picture of social unanimity, showing the felicitas of all the people of Emerita directly linked to the Catholic church, personified by the bishop. ${ }^{55}$ Accordingly, the text shows the highest members of society as well as the masses unified in the community of the Catholic church. It is only Sunna - 'urged on by the devil' (5.10, irritatus a diabolo [...] consilio diabolico persuasit, p. 81) - who destroys this unanimity.

An analysis of the Vitas has shown that ethnic terms are used mostly to identify persons who come from outside the Visigothic kingdom. Within the society, the source does not provide evidence of an ethnic separation between Romans and Visigoths. In fact, the Vitas do not record an awareness of an ethnical group that we may identify as Hispano-Roman. Nevertheless, the text does document a Visigothic identity, but rather than being bound to a notion of supposed ancestry, the term Gothus has a social and political meaning. Since there was a term rex Gothorum, one level of Gothic identity was defined by allegiance to the king. In all other cases within the city society, Goths appear as members of the ruling class.

Conclusions drawn from the study of this particular text can be applied to other sources as well. Some texts, nevertheless, seem to be in contradiction. For example, some laws display a legal differentiation between Romani and Gothi. A detailed examination of those examples, however, shows, due to the specific genesis of the Liber Iudicorum, that those passages do not reflect the society of sixth-century Visigothic Spain but should be regarded 
as an anachronistic legacy from the Visigothic settlement in Gaul at the beginning of the fifth century. ${ }^{6}$

As to the question of the identity of the Visigoths, the population of the regnum Gothorum as a whole, and sometimes the exercitus in particular, are characterized as Gothic. For the social environment within the kingdom, Goths constitute a social and political elite. Opposed to a primordial concept of ethnicity, by the end of the sixth century this elite is not defined by descent and does not solely stem from an immigrated group of Goths but includes members of families that exerted local power since Roman times. One did not become elite by being Goth; one could become Goth by being part of the elite.

Of course, this conclusion has to be seen in the broader context of relations between central and regional power; during the fifth and sixth centuries these relations were dominated by the long-term transformation of Hispania from Roman to Visigoth. This began with frequent Visigothic military expeditions into the peninsula and the establishment of bases during the time of the kingdom of Toulouse. The Gothic identity of the emerging kingdom of Toledo was not the result of a long-lasting conflation of two ethnically and culturally separated groups. Instead, Gothic identity emerged from the gradual formation of a political supra-structure which was identified as Gothic. To a degree, then, Visigothic identity can be understood as replacing the former Roman identity, which by the end of the fifth and beginning of the sixth century ceased to be powerful in Hispania. Indeed, the establishment of the Visigothic kingdom was achieved by military dominance over regional resistance. More importantly, it was raised on late antique Roman structures in cooperation with established local elites. Recent studies - among them many of the chapters in this volume $^{57}$ - analyse the fluctuating and multifaceted relations between central and regional powers..$^{58}$ In that context, loyalties and affiliations were flexible and had constantly to be negotiated. Gothic identity in certain contexts could be a means of the articulation of a common identity, in order to reassert loyalty. This identity seems significant concerning central power and the kingdom itself. In this regard, Gothic identity

56 For a detailed analysis of the law codes, see Koch 2012, pp. 375-404; other categories of written sources examined are literary sources (pp. 217-328) and files of church councils (pp. 331-375). 57 E.g. the papers of Jamie Wood, Markus Mülke, Paulo Pachá, and Javier Martínez Jiménez in this volume.

$5^{8}$ See Wood and Martínez Jiménez 2016, p. 31: 'One of the key debates is that of state power, centralization, regionalization and the inter-relation between central powers (or powers to occupy a central position) and regional power blocks.' 
served as a social and political bond and as a distinction. Of course, since the written sources themselves are often an expression of central power, they are complicated evidence concerning how important Gothic identity actually was.

Due to the fragmented picture sources depict, it is difficult to tell which role Gothic identity actually assumed in local contexts. In some cases - as for example in case of the Vitas - it is used to identify a prestigious social elite within the kingdom. At the same time this is only a marginal aspect. Looking at all our evidence it appears that in local contexts Gothic identity was not a major issue for the legitimation of elites.

\section{Bibliography}

\section{Primary sources}

John of Biclar, Chronicon, ed. by Carmen Cardelle de Hartmann in Victor Tvnnvnensis Chronicon cum reliquiis ex Consularibus Caesaraugustanis et Iohannis Biclarensis Chronicon (Turnhout: Brepols, Corpus Christianorum, Series Latina 173A, 2001), pp. 59-83.

The Story of Wamba: Julian of Toledo's Historia Wambae Regis, ed. by Joaquín Martínez Pizarro (Washington, DC: Catholic University of America Press, 2005). Vitas Sanctorum Patrum Emeretensium, ed. by Antonio Maya Sánchez (Turnhout: Brepols, Corpus Christianorum, Series Latina 116, 1992).

The Vitas Sanctorum Patrum Emeretensium: Text and Translation, with an Introduction and Commentary, ed. by Joseph Garvin (Washington, DC: Catholic University of America Press, Studies in Medieval and Renaissance Latin Language and Literature 19, 1946).

\section{Secondary sources}

Arce, Javier, “The City of Mérida (Emerita) in the Vitas Patrum Emeritensium (VIth Century A.D.)', in East and West: Modes of Communication, ed. by Evangelos Chrysos and Ian Wood (Leiden: Brill, Transformation of the Roman World 5, 1999), pp. 1-14.

Berndt, Guido M., and Roland Steinacher, eds., Arianism: Roman Heresy and Barbarian Creed (Farnham: Taylor \& Francis, 2014).

Besga Marroquín, Armando, Orígenes hispanogodos del Reino de Austurias (Oviedo: Real Instituto de Estudios Asturianos, Fuentes y Estudios de Historia de Asturias 21, 2000). 
Buchberger, Erica, Shifting Ethnic Identities in Spain and Gaul, 500-70o (Amsterdam: Amsterdam University Press, 2017).

Caerols, José J., 'El encuentro entre godos e hispanorromanos; un análisis filológico', in Integrazione, mescolanza, rifiuto: incontri di popoli, lingue e culture in Europa dall'antichità all'umanesimo, ed. by Gianpaolo Urso (Rome: L'Erma di Bretschneider, 2001), pp. 199-238.

Castellanos García, Santiago, 'The Significance of Social Unanimity in a Visigothic Hagiography: Keys to an Ideological Screen', Journal of Early Christian Studies 11.3 (2003), pp. 387-419.

Claude, Dietrich, Adel, Kirche und Königtum im Westgotenreich (Sigmaringen: Jan Thorbecke, Vorträge und Forschungen, Sonderbände, 8, 1971).

Collins, Roger, Visigothic Spain (409-711) (Oxford: Blackwell, 2004).

Curta, Florin, 'Some Remarks about Ethnicity in Medieval Archaeology', Early Medieval Europe 15 (2007), pp. 159-185.

Diesner, Hans Joachim, Isidor von Sevilla und seine Zeit (Stuttgart: Calwer, Arbeiten zur Theologie 52, 1973).

García Moreno, Luis Agustín, 'Urbs cunctarum gentium victrix Gothis triumphis victa: Roma y el reino visigodo', in Roma fra oriente e occidente (Spoleto: Centro Italiano di Studi sull'Alto Medioevo, Settimane di Studio del Centro Italiano di Studi sull'Alto Medioevo 49, 2002), pp. 239-322.

Goetz, Hans-Werner, Jörg Jarnut, and Walter Pohl, eds., Regna and Gentes: The Relationship between Late Antique and Early Medieval Peoples and Kingdoms in the Transformation of the Roman World (Leiden: Brill, Transformation of the Roman World 13, 2003).

Kampers, Gerd, Geschichte der Westgoten (Paderborn: Schöningh, 2008).

Koch, Manuel, Ethnische Identität im Entstehungsprozess des spanischen Westgotenreiches (Berlin: De Gruyter, Reallexikon der Germanischen Altertumskunde, Suppl. 75, 2012).

, 'Arianism and Ethnic Identity in Sixth-Century Visigothic Spain', in Arianism: Roman Heresy and Barbarian Creed, ed. by Guido M. Berndt and Roland Steinacher (Farnham: Taylor \& Francis, 2014), pp. 257-270.

Martínez Pastor, Marcelo, Ana Maria Aldama Roy, Maria Dolores Castro Jímenez, Manuel Martínez Quintana, and Maria José Muñoz Jímenez, Vitas Sanctorum Patrum Emeretensium: Léxico latino-español (Hildesheim/Zürich/New York: Olms-Weidmann, Alpha-Omega, Reihe B, Indizes, Konkordanzen zur Lateinischen und Griechischen Philologie des Mittelalters und der Neuzeit 19, 2001).

Mateos Cruz, Pedro, 'Avgvsta Emerita, de capital de la diocesis Hispaniarum a sede temporal visigoda', in Sedes regiae (ann. 40o-8oo), ed. by Gisela Ripoll López and Josep M. Gurt-Esparraguera (Barcelona: Memorias de la Real Academia de Buenas Letras 25, 2000), pp. 491-520. 
Maya Sánchez, Antonio, 'Introducción', in Vitas Sanctorum Patrum Emeretensium, ed. by Antonio Maya Sánchez (Turnhout: Brepols, Corpus Christianorum, Series Latina 116, 1992), pp. vii-lxxiii.

Orlandis Rovira, José, Historia del reino visigodo español: los acontecimientos, las instituciones, la sociedad, los protagonistas (Madrid: Rialp, 2003).

Pohl, Walter, 'Telling the Difference: Signs of Ethnic Identity', in Strategies of Distinction: The Construction of Ethnic Communities (300-80o), ed. by Walter Pohl and Helmut Reimitz (Leiden: Brill, Transformation of the Roman World 2, 1998), pp. 17-69.

Quirós Castillo, Juan Antonio, and Santiago Castellanos García, 'Identidades y etnicidad en la Península Ibérica en los siglos V-VIII: una introducción', in Identidady etnicidad en Hispania: propuestas teóricas y cultura material en los siglos V-VIII, ed. by Juan Antonio Quirós Castillo and Santiago Castellanos García (Bilbao: Universidad del País Vasco, Documentos de Arqueología Medieval 8, 2015), pp. 67-85.

Teillet, Suzanne, Des goths à la nation gothique: les origines de l'idée de nation en occident $d u V^{e}$ au VII siècle (Paris: Les Belles Lettres, Collection d'Etudes Anciennes, 1984).

Thompson, Edward A., The Goths in Spain (Oxford: Clarendon Press, 1969).

Valverde Castro, María del Rosario, 'El reino de Toledo y su supuesta "identidad goda"', in Identidad y etnicidad en Hispania: propuestas teóricas y cultura material en los siglos V-VIII, ed. by Juan Antonio Quirós Castillo and Santiago Castellanos García (Bilbao: Universidad del País Vasco, Documentos de Arqueología Medieval 8, 2015), pp. $67-85$.

Velázquez Soriano, Isabel, 'Pro patriae gentisquae Gothorum statu', in Regna and Gentes: The Relationship between Late Antique and Early Medieval Peoples and Kingdoms in the Transformation of the Roman World, ed. by Hans-Werner Goetz, Jörg Jarnut, and Walter Pohl (Leiden: Brill, Transformation of the Roman World 13, 2003), pp. 161-217.

Von Rummel, Philipp, 'Gotisch, barbarisch oder römisch? Methodologische Überlegungen zur ethnischen Interpretation von Kleidung', in Archaeology of Identity/Archäologie der Identität, ed. by Walter Pohl and Mathias Mehofer (Wien: VÖAW, Forschungen zur Geschichte des Mittelalters 17, 2010), pp. 51-77. Wood, Jamie, and Javier Martínez Jiménez, 'New Directions in the Study of Visigothic Spain', History Compass 14.1 (2016), pp. 29-38.

\section{About the author}

Manuel Koch is a teacher at the Westfalen-Kolleg Paderborn (Germany) and has published his $\mathrm{PhD}$ thesis on ethnic identity in the process of the formation of the Visigothic kingdom (Ethnische Identität im Entstehungsprozess des spanischen Westgotenreiches, Berlin: De Gruyter, 2012). 



\title{
9 The Visigothic Kingdom - A Kingdom without Visigoths?
}

\author{
The Debate on the Ethnic Interpretation of the Early \\ Medieval Cemeteries on the Iberian Peninsula
}

\section{Christoph Eger}

\begin{abstract}
The years 507 and 711 frame the period of the Spanish Visigothic kingdom, although the history of the Visigoths in Spain dates back to the fifth century. The political history of the Visigoths in Spain is well known from the fifth century onwards, but we know much less from written sources about the history of the population and the settlement process. By the 1920 s and 3os, researchers had already interpreted several late antique necropolises as Visigothic because they contained grave goods deposited in a specific form that distinguished them from native tombs. However, in the last twenty years, critics have taken aim at the interpretive model used.
\end{abstract}

Keywords: ethnicity; identity; archaeology; tombs; necropolis

The assignment of groups of pre- and protohistoric finds to certain peoples and tribes has played a major role in research for a long time. It is referred to as an 'ethnographic method', an unfortunate expression, since in fact a recognized method of an ethnic interpretation of finds has not yet been worked out.

Hans Zeiss, 'Zur ethnischen Deutung frühmittelalterlicher Funde'

(Zeiss 1930, p. 11)

If the present state of research is summarized below, it must again be remembered that our knowledge of the archaeological record is very fragmentary, and that therefore future careful observation may lead to substantially different results. Hans Zeiss, Die Grabfunde aus dem spanischen Westgotenreich (Zeiss 1934, p. 93)

Panzram, S. and P. Pachá (eds.). The Visigothic Kingdom: The Negotiation of Power in Post-Roman Iberia. Amsterdam: Amsterdam University Press 2020 DOI: $10.5117 / 9789463720632 \_$CHo9 
For a long time, a group of necropolises have played a prominent role in the archaeology of the Visigoth period in the Iberian Peninsula, which - although their interpretation is controversial - are referred to as Visigothic cemeteries. Alternative names, such as Duratón-Madrona type, Castilian cemeteries or necropolis comunitarios have found no consensus. Visigothic cemeteries are large, densely populated burial grounds with a high percentage of furnished tombs (inhumations habillées), created in the central Meseta in the last quarter of the fifth century AD, their grave goods mainly consisting of personal adornment, including artefacts that derive from the Danube and Black Sea region as well as from Ostrogothic Italy and Merovingian Europe (Fig. 9.1).

Fifteen years ago, I presented an overview of the problems of the ethnic interpretation of Visigothic cemeteries. ${ }^{1}$ At that time, the main topic of debate was whether those buried were truly Visigoths or could be associated with other immigrant groups. Various Gothic or other barbarian groups, whose culture bore eastern Germanic or Danubian features, were considered. ${ }^{2}$ A sepulchral community of native Hispano-Roman population was also suggested, as each of the Visigothic cemeteries had a significant percentage of burials without grave goods or burials with a more or less Roman-style inventory. ${ }^{3}$ Individual points of view differed in the assessment of ethnicity: Sasse, among others, argued against the classical, Visigoths theory propounded by Zeiss and Martínez Santa-Olalla, later maintained with modification by Werner, Bierbrauer, Ripoll López, and Ebel-Zepezauer, ${ }^{4}$ that there were no unambiguous archaeological criteria to prove a (Visi-) Gothic identity. Nevertheless, funeral practices, clothing, and various types of material culture pointed to a foreign origin of the buried. Only a few authors, such as Hübener, Olmo Enciso, and Fuentes Domínguez, have questioned an ethnic ascription of a migration of foreign groups as an explanation for the Visigothic necropolises, or have rejected this idea explicitly without detailing their objections or providing alternatives. ${ }^{5}$

After the publication of my contribution in 2005, a controversy concerning the interpretation of Visigothic burial grounds on the Iberian Peninsula occurred, continuing today with polemical arguments, such as

$1 \quad$ Eger 2005.

2 Périn 1993; Kazanski and Périn 1997; Sasse 1997, 2000.

3 König 1985, pp. 287-289; Sasse 2000, pp. 163-165.

4 Zeiss 1934; Martínez Santa-Olalla 1934; Werner 1956; Bierbrauer 1980, 1994; Ripoll López 1991, 2001; Ebel-Zepezauer 2000.

5 Hübener 1970; Fuentes Domínguez 1989. Cf. Eger 2005, pp. 169 seq. 

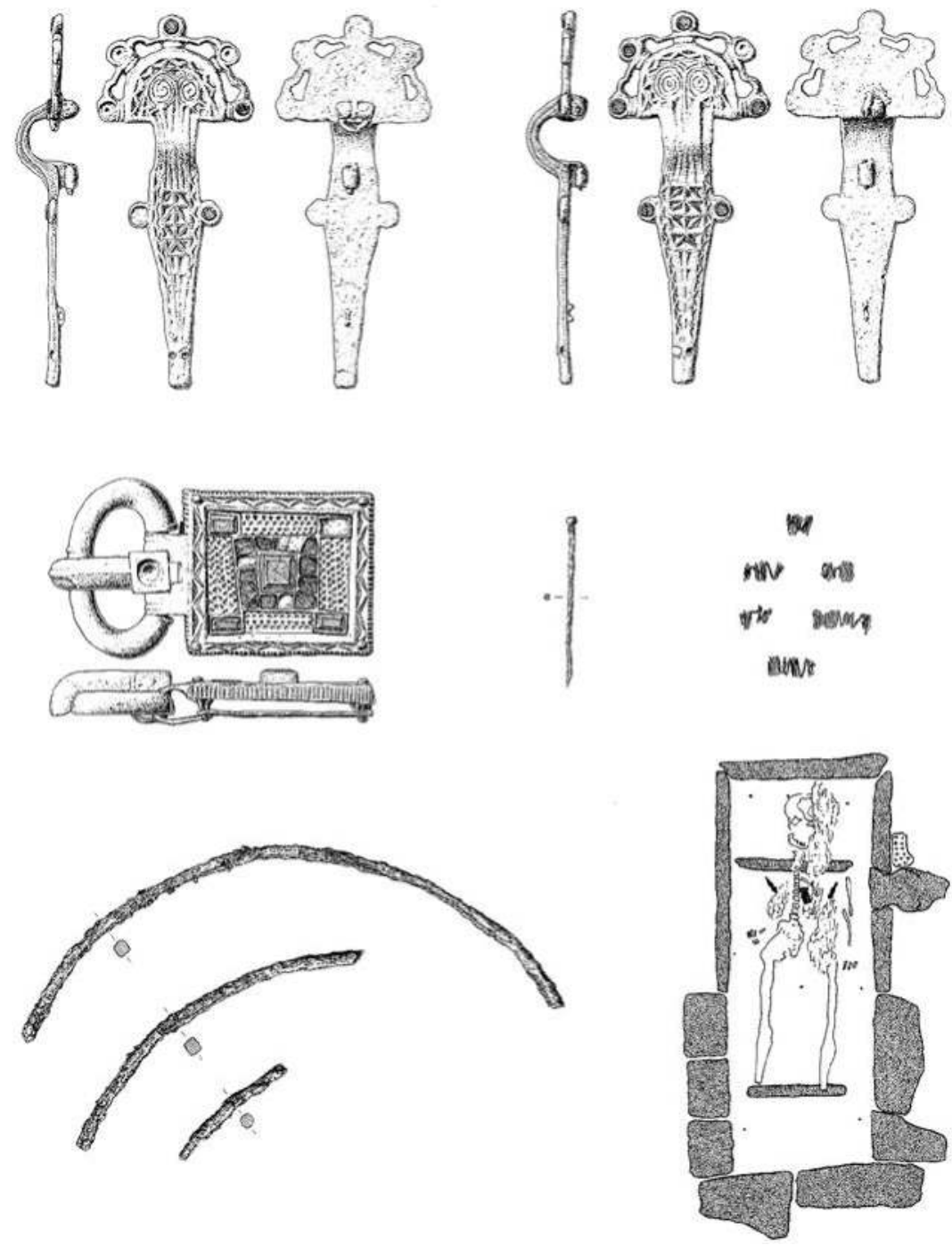

Fig. 9.1 Cacera de las Ranas, Prov. Toledo, burial 7. @ After Ardanaz Arranz 2000, pp. 25-32.

accusations of auto-referential research. ${ }^{6}$ Historians entered the debate. ${ }^{7}$ Unfortunately, calls for moderation and a reminder that adversaries have

6 Cf. Jepure 2015, p. 240; Barroso Cabrera 2018, p. 31.

7 Koch 2006; García Moreno 2009; Arce 2011, pp. 23-44; Koch 2012. - Concerning Arce's overall gloomy and leaden picture of the Visigoth period, which is also reflected in the title of the book, cf. the review of Martin 2012. Cf. also the discussion of Spanish historians on the terms ethnos, ethnicity and gens: Marcela Mantel 2017. 
more in common than differences have had no lasting effect, ${ }^{8}$ although parties assert that the focus is on archaeological facts and scientific, methodical work: 'el análisis riguroso y objetivo del mundo funerario sin apriorismos ni condicionantes ideológicos'. ${ }^{9}$ The reason this has proved so difficult is closely linked to the historiography of ethnic interpretation and the resulting ideological and politicization of the discussion..$^{10}$ The ethnic interpretation as an archaeological 'method' was first formulated by Gustaf Kossinna (1868-1931) and was misused by him and his students for a Germanocentric, nationalistic archaeology that reached its low point in the Third Reich.

Fundamental studies of the Visigothic necropolises, which continue to have effect, were written by two scholars, Hans Zeiss (1895-1944) and Julio Martínez Santa-Olalla (1905-1972), whose careers are closely linked to the rise of fascist dictatorship in Germany and Spain. ${ }^{11}$ More than two decades after the end of the Franco era, from a new generation of Spanish scholars, the ethnic interpretation was too closely linked with the taint of the past and regarded as a relic of a nationalist history that had long since become obsolete. ${ }^{12}$ For too long, archaeology has been concerned with locating, delimiting, and characterizing ethnic groups. ${ }^{13}$ They not only missed important international developments, but also neglected to develop further questions - 'The point for us is not to analyze who were the specific people buried, but what their societies were like. In other words, the main point is not whether they were or were not Visigoths, but if they were Visigoths, so what?'14 In contrast, Fernández-Götz and García Fernández have argued for the need for an 'archaeology of ethnicity', which should not be removed from the agenda. ${ }^{15}$

8 Vigil-Escalera 2011, p. 45: 'The increasing verbal aggressiveness shown by the participants of the ongoing debate on the presence of ethnic features in the archaeological record may have gone too far, in my opinion. [...] there are more things that link us than things that keep us separated. Therefore, we believe it is necessary to intervene, to ask for a pause to think and tackle the topic with calm[...]'.

9 López Quiroga 2008, p. 8 o.

10 On the ideological and political backgrounds, cf. Barroso Cabrera 2018, pp. 1-14, 29-33.

11 In both the German and the Spanish research, opinions differ in the evaluation of these two personalities. Regarding Zeiss, cf. the critical study by Fehr 2001, pp. 316-330, 370-380 (some corrective remarks in Eger 2012, pp. 274 seq.); and regarding J. Martínez Santa-Olalla: Dohijo 2017, pp. 215-222; very apologetic: Barroso Cabrera 2018, pp. 14-25.

12 Cf. Tejerizo García 2011, p. 39.

13 Jepure 2006, p. 174; Tejerizo García 2011, p. 33.

14 Tejerizo García 2011, p. 35.

15 Fernández-Götz and García Fernández 2011, p. 114. 
The following is a brief overview of the research on the archaeology of the Visigothic necropolises since 2005, which attempts to systematize diverse criticism of the ethnic interpretation, but also presents individual interpretative models in as unbiased a way as possible, although with a few critical remarks that draw attention to certain shortcomings in existing approaches that may serve as a stimulus for further exploration. ${ }^{16}$

\section{Criticism of the ethnic interpretation of the Visigothic necropolises}

The reorientation of aspects of Spanish archaeology is based on concepts of ethnicity, developed since the late 196os, predominantly by anthropologists and sociologists in Anglo-American and French-speaking countries, as well as a changed historical understanding of the barbarian gentes and their role in the late antique world to which American and British historians, but also those of the Vienna school contributed. With the exception of R. Barroso Cabrera, the authors cited below have opposed a traditional ethnic interpretation, ${ }^{17}$ pointing to flaws in both the method of ethnic interpretation and in the customary interpretation of Visigothic burial grounds. However, in addition to legitimate objections, polemical positions based on misunderstandings or even factual errors need to be borne in mind..$^{18}$

Methodological weaknesses of the ethnic interpretation are based on the dogmatic view of an unchangeable ethnicity, based on assumptions, ${ }^{19}$ including the assumption that ethnicity played such a prominent role in the everyday life of late antiquity and the early medieval populace that they wanted to be recognized as members of an ethnic group. ${ }^{20}$ This exclusiveness of ethnic identity was seemingly fundamental to the constitution of early medieval societies. ${ }^{21}$ This interpretation proves dependent on an outdated historical framework. ${ }^{22}$ If one rids a stale reception of written sources,

16 An urgently needed, comprehensive study of the individual theses is unfortunately not possible at this point.

17 In the following, I limit myself to a large extent to contributions that have been published on the problem of ethnic interpretation and ethnicity of the Visigoth period since 2005 .

18 See below.

19 Härke 2007, p. 14; López Quiroga 2008, p. 57; 2010, pp. 99 seq.; Tejerizo García 2011, p. 39;

2015, p. 221.

20 Cf. López Quiroga 2008, p. 49; Tejerizo García 2011, p. 31.

21 Tejerizo García 2015, p. 233.

22 Jepure 2015, p. 239. 
according to Halsall, it becomes clear that there was no dichotomous selfperception as either Goth or Roman, but that several identities were possible, depending on context. ${ }^{23}$ In his study of ethnic identity in the Visigothic kingdom, Koch concluded that ethnic distinction, as described by Gothi and Romani in sixth- and seventh-century sources, no longer played a role, that the citizens of the kingdom were identified respectively identified themselves as 'Goths'. ${ }^{24}$

We cannot simply equate archaeological culture and ethnicity, as was commonplace in Kossinnas's days and has seemingly remained unchanged. ${ }^{25}$ That ethnicity is reflected in the archaeological findings can be disabused using archaeological means. ${ }^{26}$ Ethnic identities arise as a result of certain socio-political processes and are not an immutable trait of population groups. Modern concepts emphasize a complexity of social identities from a variety of expressions ${ }^{27}$ For Tejerizo García, alleged ethnic markers, especially jewellery in cemeteries, actually demonstrate identity within a social field.$^{28}$ Closely dependent on Brather, López Quiroga concluded that while archaeology can answer social, economic, and cultural questions, it does not answer questions of ethnic identity. ${ }^{29}$ This, however, has recently been contradicted by Dohijo and Barroso Cabrera from differing perspectives..$^{30}$

In the case of Visigothic burial grounds, an ethnic interpretation breaks down, according to some writers, due to inadequate information from historical sources. The written sources do not support any mass immigration of Visigoths to the Iberian Peninsula, nor their settlement in central Castile. ${ }^{31}$ It seems that Visigoths settled mainly in cities and not in the countryside, which contradicts Visigothic cemeteries in rural areas. ${ }^{32}$ Moreover, the ethnically homogeneous structure of Visigoths cannot be seen as an indispensable prerequisite for an ethnic interpretation.

23 Halsall 2011, pp. 15, 25. - A concise overview of the post-war concepts of ethnicity by historians is presented in Koch 2006, pp. 9-24; see also Marcela Mantel 2017.

24 Summarizing Koch 2006, pp. 405-412.

25 Cf. Quirós Castillo and Castellanos García 2015, p. 25: 'hoy se acepta que el estudio arqueológico de la etnicidad y la identidad es una temática compleja y díficil puesto, que no se puede establecer una equivalencia simple entre cultura material e identidad étnica'.

26 Jepure 2015 , p. 247.

27 Tejerizo García 2015, p. 231. Cf. Brather 2004, pp. 97-103.

28 Tejerizo García 2015, pp. 233 seq.

29 López Quiroga 2008, p. 6o; cf. Brather 2000, p. 176; 2004, p. 627.

30 Dohijo 2017, pp. 200 seq.; Barroso Cabrera 2018, pp. 28-58. See below.

31 Koch 2006; Jepure 2006, p. 174; Arce 2011, pp. 23-44 (immigration essentially after AD 507); Jepure 2015, p. 240. For this problem, see also Eger 2005, p. 172; Barroso Cabrera 2018, pp. 61, 177. 32 Martínez Jiménez, Sastre de Diego, and Tejerizo García 2018, p. 144. 
Rather, in the late fourth and fifth centuries we see the formation of a heterogeneous, multi-ethnic society, and a homogeneous material culture could not be expected. ${ }^{33}$ Indeed, as Pinar Gil pointed out in his detailed typo-chronological analysis, it is possible to show different cultural strands in Visigothic burials, which opposes an ethnic interpretation. ${ }^{34}$ In addition, Visigothic cemeteries as communitarian cemeteries (cementerios comunitarios) represent only one of several burial types of the fifth to seventh centuries in central Castile, but previous analyses disregard the diversity of death rituals of this time. ${ }^{35}$

An interpretation of furnishing the dead and special clothing as typically Visigothic is also questionable. A 'classic' reference, brought up in the 199os, to the absence of Visigothic burial grounds or burials with 'Visigothic' dress accessories is ascribed in the core area of the Tolosan Empire. ${ }^{36}$ The fact that structurally and economically similar settlements in Castile, such as Gozquez and El Pelícano (both in the Province of Madrid), have cemeteries that considerably differ in funeral practices, is for Vigil-Escalera not only reason to doubt ethnic evidence of funeral practices, as the settlement structure seems to indicate the same population in both settlements (Gozquez and El Pelícano), but to doubt the relevance of the ethnic paradigm. ${ }^{37}$ Furthermore, typical Visigothic finds occur only in few graves of a burial ground and therefore could not express ethnicity. ${ }^{38}$ The analysis of dress accessories, particularly important in this discussion, also creates difficulties. Apart from the fact that until recently finds from well-documented burials and those less well documented were mixed, fibulae and buckles being treated as non-contextualized objects in the typo-chronological analyses. In view of the lack of grave goods in late antique burials, as in many burials of Visigothic cemeteries, the accidental presence or absence of 'Visigothic' finds could not be a decisive factor for an ethnic description of a cemetery. 39

33 Koch 2006, p. 86; López Quiroga 2008, pp. 57, 168; 2010, pp. 105-108, 265; Dohijo 2017, p. 235; Martínez Jiménez, Sastre de Diego, and Tejerizo García 2018, p. 144.

34 Pinar Gil 2012a, pp. 726 seq., 736; 2012b, p. 109.

35 Tejerizo García 2015, pp. 225-227; cf. Jepure 2015, p. 247.

36 Koch 20o6, p. 86; Martínez Jiménez, Sastre de Diego, and Tejerizo García 2018, p. 145; Barroso Cabrera 2018, pp. 28, 71. Cf. Eger 2005, p. 166.

37 Vigil-Escalera 2011, p. 5 o.

38 Tejerizo García 2015, pp. 229 seq.; Martínez Jiménez, Sastre de Diego, and Tejerizo García 2018 , p. 141.

39 Jepure 2006, p. 178; 2015, p. 242. In extremo this argument was also made by Tejerizo García in 2011, p. 34: Thus it could not be that the ethnic interpretation of a whole graveyard could be based on a single fibula. But this is polemic. Even a 'die-hard advocate of Kossinna' (Florin Curta) like Bierbrauer would not rest an ethnic ascription on a single brooch as demonstrated above. 
Incidentally, the stylistic characteristics of assigning finds, especially fibulae, to the Visigoths is highly questionable; because fibulae have no ethnicity it can only be given to them by their wearer..$^{40}$ In fact, there is nothing to suggest that the dress accessories in question were worn only by barbarian immigrants. They were adopted as well by locals as markers of rank and social status. ${ }^{41}$ Recently it has been claimed that clothing accessories were not worn in life, but were made specifically for representation in the tomb and therefore did not express an ethnic identity during life. ${ }^{42}$

\section{Patterns of interpretation}

Interpretations of Visigothic cemeteries published since 2005 can be divided into three categories: 1) ethnic interpretation in the narrow sense (traditional by Barroso Cabrera and contextual by Dohijo); 2) ethnic interpretation in the broad sense, based on the recognizability of migrants through cultural indicators in the archaeological record, and perhaps better designated as a migration-based interpretation (López Quiroga and Pinar Gil); and 3) rejection of the ethnic or migration-based interpretation in favour of a socio-political construct (Jepure, Halsall, Vigil-Escalera, Tejerizo García, and lastly Martínez Jiménez, Sastre de Diego and Tejerizo García).

\section{Ethnic interpretation}

In the most extensive and detailed study to date on the ethnic issue of Visigothic cemeteries, Barroso Cabrera has taken a stand in favour of a classical interpretation, introducing recent ideas of the Viennese school on the nature of gentes and integrating dynamic concepts of ethnicity into conventional ideas. In his view, the Visigoths were a population with their own ethnic identity distinct from the Hispanic people, whose successive immigration into the Iberian Peninsula was well documented by both written and archaeological evidence. ${ }^{43} \mathrm{An}$ important feature of this

40 Tejerizo García 2011, p. 32; Martínez Jiménez, Sastre de Diego, and Tejerizo García 2018, p. 139.

41 Quirós Castillo and Castellanos García 2015, p. 27 referring to Arce 2011, pp. 41 seq.

42 Tejerizo García 2015, pp. 227 seq.

43 On the dichotomous concept of Germanic people and Romans: Barroso Cabrera 2018, pp. 45-49: 'el final del Imperio romano no puede entenderse sin el enfrentamiento dialéctico 
identification are grave inventories of female burials with 'Pontic-Danubian type' clothing accessories, which were used in the Iberian Peninsula in the late fifth century. That such graves were previously unknown, i.e. lacking in old southern French settlements, may be a problem of the state of research in southern France, as the investigations of Pinar Gil suggest. However, this could also be explained by the arrival of other Gothic groups and/or special political circumstances that provided external visible marking of ethnicity in certain strata of the Visigothic population ('goticismo'). ${ }^{44}$ For Barroso Cabrera, the 'duality' in the archaeological findings (regions with and without Pontic-Danubian finds) is a clear indication that a separate settlement of Hispanics and Visigoths ('duality of colonization') lasted until the first third of the seventh century and was consistent with historical evidence. ${ }^{45}$

In principle, Dohijo is in favour of an ethnic interpretation using archaeological means, because written sources speak of Visigothic migrations and archaeology is able to sift out foreign material in the Hispanic-Roman milieu connected with the Visigoths. However, unlike Barroso Cabrera, Dohijo rejects the notion of a persisting ethnic identity of the Visigoths, reflected in material culture. This idea is incompatible with the multiethnic composition of the Visigoth gens and the gradual character of their ethnogenesis. ${ }^{46}$ Following the methodological reflections on the ethnic interpretation of Fernández-Götz and Ruiz Zapatero developed for protohistoric Spain, Dohijo assumes that under certain circumstances aspects of a culture can turn into identity-forming symbols ('cultural markers'). ${ }^{47}$ The task of archaeology is to analyse the existence of such temporally differentiated markers (ideally in a sequence of generations) in order to show dynamic development. Furthermore, the continuity of the ethnic markers and their interaction or integration with other social markers needs to be examined. ${ }^{8}$ However, Dohijo's gives no indication as to how he intends to achieve this.

entre bárbaros y romanos'. On the immigration of the Visigoths to the Iberian Peninsula, cf. Barroso Cabrera 2018, pp. 65-67.

44 Barroso Cabrera 2018, pp. 62-64 (arrival of the Vidimir Goths); pp. 74-76 (evidence for Visigothic tomb inventories of the fifth century in southern Gaul); pp. 77-80 (new burgeoning 'goticismo' among the Visigoths).

45 Barroso Cabrera 2018, p. 175.

46 Dohijo 2017, p. 200.

47 Ibid., pp. 202 seq. - See also Fernández-Götz and Ruiz Zapatero 2011, p. 231; Fernández-Götz and García Fernández 2011, p. 114.

48 Dohijo 2017, p. 236. 


\section{Ethnic interpretation in the broader sense: the migration-based interpretation}

López Quiroga and Pinar Gil have clearly distanced themselves from the ethnic interpretation in its traditional sense. In a widely extended study, López Quiroga explains that an ethnic interpretation of the Castilian burial grounds as burial places of the Visigoths fails not only because of new concepts of ethnicity and ethnogenesis, but also because of the lack of archaeological parameters for this purpose ${ }^{49}$ Different customs regarding tombs, grave goods, and clothing, which can be observed in the Castilian necropolises and by which they can be distinguished from the indigenous, Hispanic-Roman population, cannot serve to prove the ethnic identity of the buried as Visigoths. However, they are suitable proof of the mobility and heterogeneity of the migrants subsumed under the term 'Visigoths'. Due to acculturation and adaptation processes it is no longer possible to distinguish in individual cases who was Goth and who was Roman by origin..$^{\circ}$ To an extent López Quiroga synthesized different considerations, ranging from Kazanski's 'Mode danubienne' to Quast's concept of foreigners. ${ }^{5^{1}}$

In his fundamental typo-chronological study of early Visigothic dress accessories, Pinar Gil was only marginally addressing ethnic issues. An important result was the precise disclosure of cultural strands that manifest themselves in aspects of the funeral practices, especially in dress accessories and their arrangement (Fig. 9.2). In his opinion, the detailed analysis of the material goes against an ethnic interpretation..$^{2}$ Rather, the cultural diversity and certain regional peculiarities of burial grounds reflect a complexity to which a simple dichotomy between Visigoths and Hispano-Romans

49 López Quiroga 2008. However, his ambitious attempt to trace the problem of gothic identity back to the Eastern Germanic groups of the Roman Iron Age is not completely convincing because of some inaccurately recorded facts. Sometimes a contradictory attitude is noticeable. He e.g. repeatedly refers to Sebastian Brather, who unmistakably rejected not only the ethnic interpretation in the narrower sense, but also the migration-based interpretations advocated by López Quiroga. 50 López Quiroga 2008, pp. 58, 82, 169 seq. But the following statement is confusing: 'Las costumbres de carácter etnográfico podrían igualmente constituir un indicador de "identidad" y/o criterio de diferenciación, aunque no de "etnicidad" strictu sensu en ningún caso' (ibid., p. 86). One would almost like to assume that this assertion of the author is due to the opinion and attitude requirements of an almost inquisitorial environment. Cf. also Barroso Cabrera 2018, pp. 25 seq. 51 Kazanski 1989; Quast 2009. Cf. also Härke 2007, p. 15: 'it is clear that in some cases, burial rites and grave-goods can be used convincingly to identify early medieval migrations but factors such as acculturation and environmental adaptation must constantly be borne in mind'.

52 Pinar Gil 2012a, p. 736: 'La valoracion estrictamente arqueologica de los materiales y combinaciones indumentarias documentados proporciona argumentos mayormente contrarios a una interpretacion en clave de signos de identidad etnica.' See Pinar Gil 2012b, p. 109. 


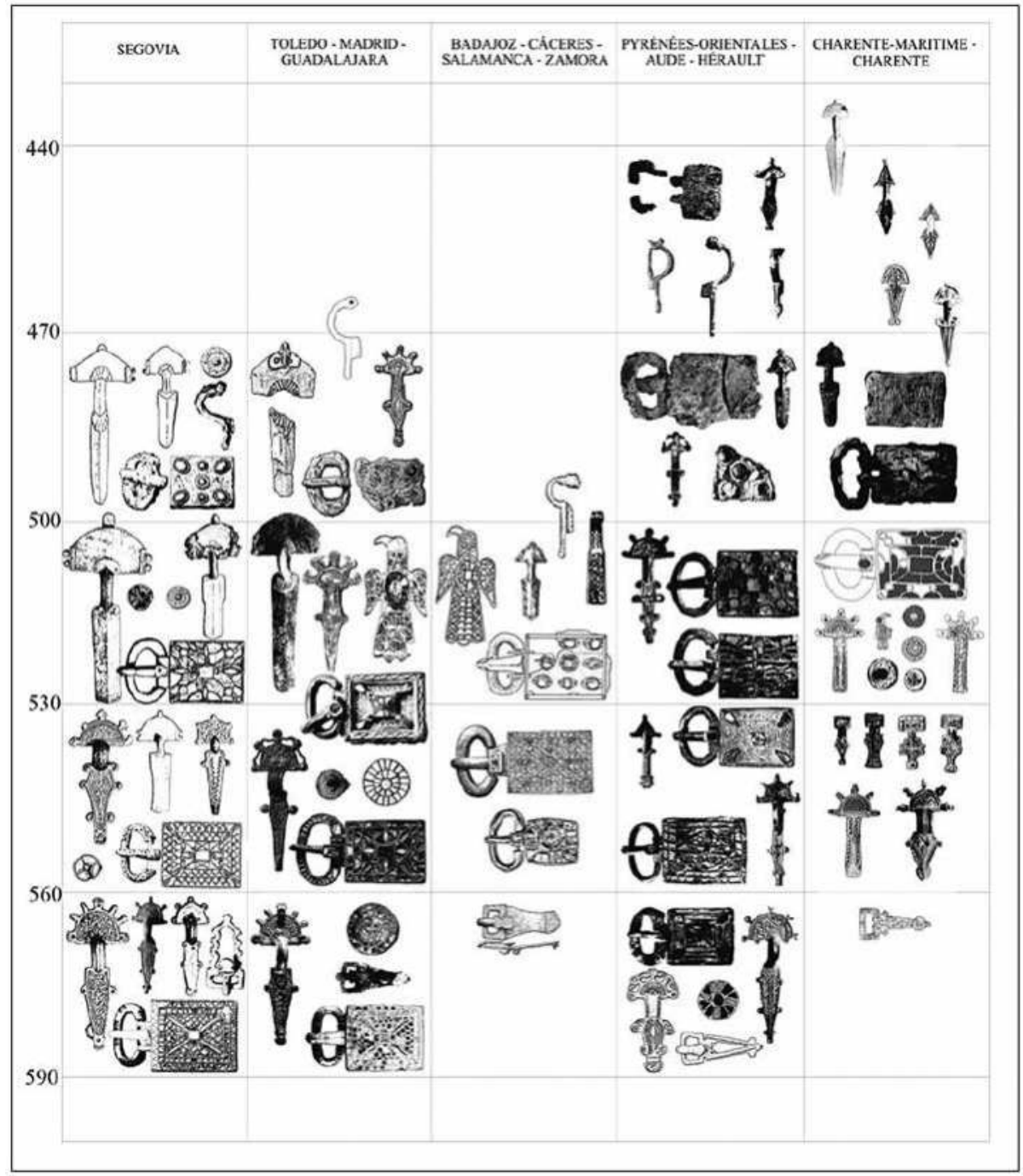

Fig. 9.2 The evolution of 'Visigothic' dress accessories in southern France and Spain: diachronic regional sequences. (๑) After Pinar Gil 2012b, p. 118, fig. 9.

does not do justice. Nonetheless, an important phenomenon, namely the emergence of 'Danubian fashion' and its associated barbarian objects, may well be explained by the migration of population groups from the Danube region to the Iberian Peninsula. ${ }^{53}$ Of course, this applies mainly to the

53 Pinar Gil 2012a, pp. 396, 727 seq., 738; 2012b, p. 115: 'There is little doubt that the funerary practice of burying the dead with everyday life's adornments and accessories shows a close 
initial phase, because in following years clothing accessories and their use in the funerary rituals changed, as well as did the identities of the burial population. ${ }^{54}$

\section{Socio-political interpretations}

In his dissertation dedicated to the reworking of the Madrona cemetery, including the excavation log and numerous unpublished photographs of the excavator, Jepure proclaimed a 'radical paradigm shift', which primarily deconstructed ethnic assignment. ${ }^{55}$ Without an alternative interpretative proposal he suggested that the phenomenon of the cemetery type DuratónMadrona could, inter alia, be associated with a distinction between rural and urban burial grounds, considering the Duratón, Madrona, and Espirdo burial grounds as either urban or suburban necropolises..$^{6}$

The seemingly 'foreign' finds in these necropolises should, however, be excluded from consideration because the special funeral practices cause a 'falsification of the actual spread of the finds' and possibly a much stronger reception of the 'Visigothic' clothing accessories in the Iberian Peninsula assumed by native populations. ${ }^{57}$ This presupposes an ethnically indistinguishable use of 'Visigothic' clothing accessories. On this point, the ideas of Jepure agree with those of subsequent authors. However, later authors attributed a greater significance to the foreign character of the finds and regionally limited occurrences. So Halsall considered whether the finds in the Meseta could be worn by Goths as well as non-Goths. The latter, who would have dressed in the Gothic style, specifically claimed power and status under changed political conditions. ${ }^{8}$ In a similar vein, Vigil-Escalera, comparing the different grave-good inventories of the older cemeteries of the Duero type with later Visigothic burial grounds, wrote: 'The substitution of a broad range of provincial, late Roman material indicators in the [Duero]

relationship between barbarian objects and clothing traditions during the second half of the fifth century. Thus, the general picture points to a link between such innovations and the presence of barbarian populations in southern Gaul and Hispania.'

54 Pinar Gil 2012a, p. 739 .

55 Jepure 2006, p. 174 .

$5^{6}$ Rejecting this idea: Tejerizo García 2015, p. 229; Barroso Cabrera 2018, pp. 85, 133 .

57 Jepure 2006, p. 178.

$5^{8}$ Halsall 2011, p. 25: 'In Gothic Italy or on the margins of the Gothic kingdom of Spain, individuals might very well have styled themselves Gothi without being descended from people who had crossed the Danube in the 370 or or 380 s. It was a claim to power and status.' 
necropoleis by a new one in which the indicators point toward the exotic fashion [i.e. in the "Visigothic" cemeteries] should be understood as a change of the cultural and political reference of the local elites. We believe that the public expression of this link to the new ruling power by a part of the members of some communities can also be linked to the preservation of social order within these populations. ${ }^{59}$ Tejerizo García further elaborated on this. In the Duero and Visigothic cemeteries, he saw successive types of burial places of local Meseta communities, with the Visigothic burial grounds having expanded with the emergence of those communities that in the fourth/fifth centuries had been buried on post-imperial (= Duero) necropolises. The radical change of funerary practices - grave inventories of Roman tradition (Fig. 9.3) and personal accessories of 'Germanic' character (Fig. 9.1) - can be explained by the economic and political developments that began around the middle of the fifth century.$^{60}$ The arrival of the Visigoths and their assumption of power changed the systems of the representation of power ${ }^{61}$ The elites of the communities buried in the Castilian burial grounds took 'Gothic' elements as symbols of power. It served them to internalize and solidify their social position in a public ceremony such as a funeral, and build the outward appearance of leadership with the help of the new symbols. The luxurious forms of dress accessory that adopted this symbolic function were probably the products of urban workshops that were made specifically for funerary use and were conveyed through exchange relations between the urban aristocracy and the rural elite. ${ }^{62}$ The new 'Visigothic' finds thus reflect a form of ethnicity, which, however, differs from the conventional concept in that foreign symbols are adapted in a specific geographical and social context in order to redefine social relationship frameworks and shape power relations, not to perpetuate ethnic ancestral traditions. ${ }^{63}$

In a recent view of late antiquity in the Iberian Peninsula, the authors generally followed the ideas of Tejerizo García. Moreover, they attempted to explain the phenomenon of Castilian burial grounds by the regionalization of social processes in post-Roman Hispania, which led to different forms of resilience among local communities. This is visible, among other things, in the variety of funeral practices. ${ }^{64}$

61 Ibid., p. 37 .

62 Ibid., p. 39; Tejerizo García 2015, pp. 228-232.

63 Tejerizo García 2011, p. 38: 'We can therefore interpret ethnicity as an element of "Gothic" simbology inside a wide hegemonic system.' See also Tejerizo García 2015, p. 232.

64 Martínez Jiménez, Sastre de Diego, and Tejerizo García 2018, p. 218. 

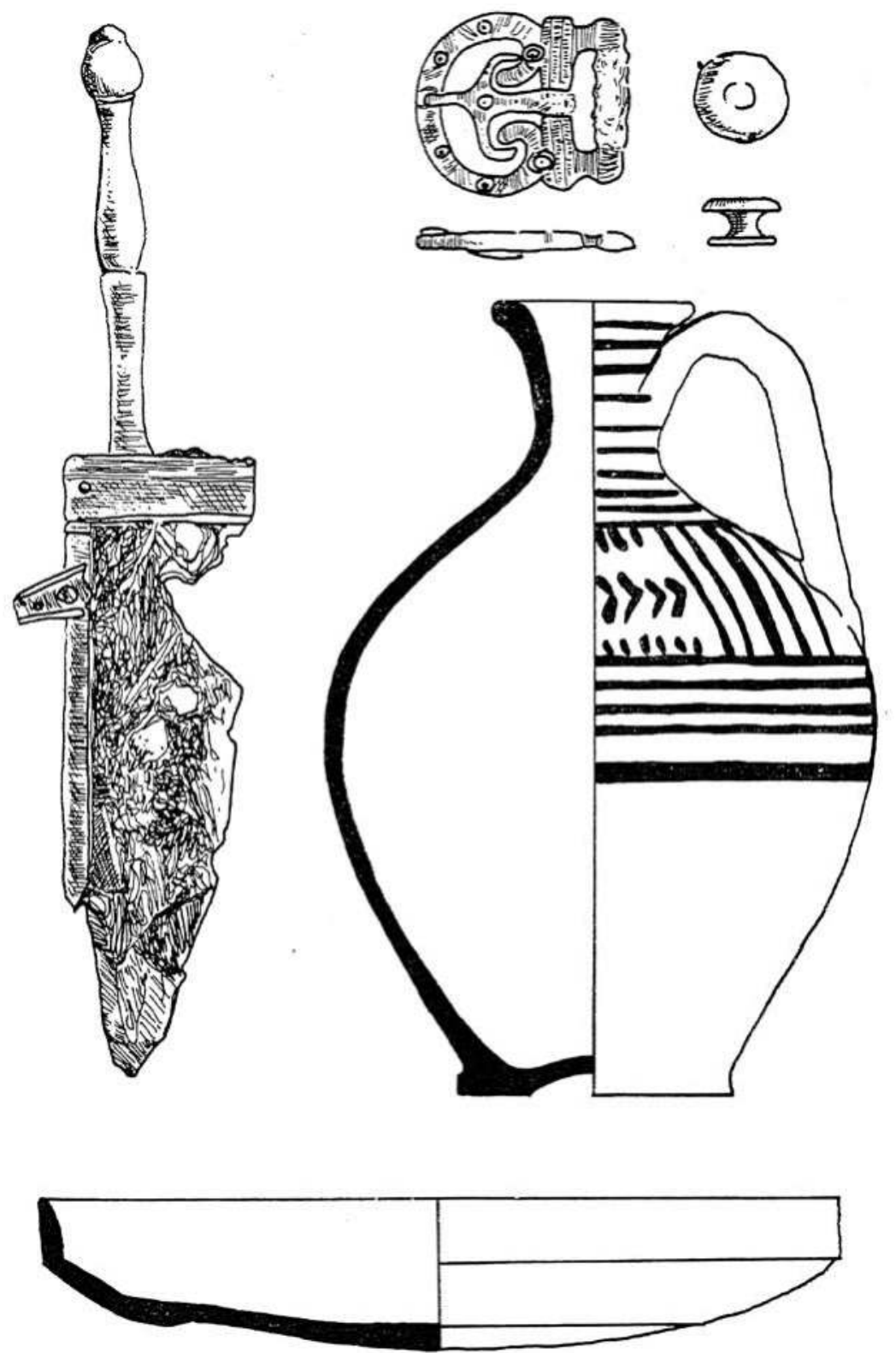

Fig. 9.3 San Miguel de Arroyo, Province of Valladolid, burial 10. ๑ After Palol y Salellas 1969, p. 108 , fig. 9. 


\section{Some misunderstandings, errors, and facts}

I would like to focus attention on a few points. The majority opinion of the scholars cited is that German (and Spanish) archaeology of the early Middle Ages before 1945, and to a large extent even after 1945, remained completely in the spirit of Kossinna. However, already in 1930 Zeiss was well aware of the inadequacy of the Kossinna method, without questioning the ethnic interpretation itself. In a much-acclaimed article, Zeiss sharply criticized Kossinna and called for caution in dealing with ethnic interpretation. ${ }^{65} \mathrm{Bi}-$ erbrauer has been working since the 1970s on the definition of 'high-ranking' indicators for an ethnic interpretation which is largely based on ethnic markers avant la lettre. With his theses on acculturation processes, which he developed using the example of the Duratón cemetery, he pointed to the dynamic process of visible signs of ethnic identity in the sixth century. ${ }^{66}$ But, in general - here a critique of an outdated picture of history and a simplified concept of ethnicity applies - his as well as Zeiss's and Werner's vision of the Goths and their identity relied on an immovable, static concept.

Modern historical research points out the importance of primordial occurrences that permanently changed the essence and identity of the Visigoths in the fourth and fifth centuries, as much as did the separation of Gothic groups and the influx of groups of diverse origins. Referring to the 'multi-ethnicity' of the Visigoths, the majority of authors cited spoke against the possibility of an ethnic interpretation. In fact, Pinar Gil has been able to prove different regions of origin or cultural traditions of those buried in the Castilian necropolises. However, the question arises whether the result is evidence of multi-ethnicity or proof of multiculturalism, possibly with sub-identities within the broader term 'Visigoth'. Despite this unanswered question, Pinar Gil's analysis strongly supports the assumption that those buried there are members of groups who migrated to the Iberian Peninsula over a long period, probably in several waves, including those whose cultural habitus is linked to the Danube region. By contrast, the assumption of a largely indigenous emergence in the Castilian cemeteries of particular funerary practices, underlying the socio-political model of interpretation, presents several problems that are difficult to reconcile with the archaeological record. The 'Visigoth' burial grounds were created ex novo in the course of the second half of the fifth century. From the beginning, the cemeteries feature characteristics such as furnishing the dead with personal adornments, female clothing, and some types of artefacts (mainly

65 Zeiss 1930; see his quotations at the beginning of my contribution.

66 Bierbrauer 1980, pp. 91-96. 
dress accessories) which were unknown in the previous Duero necropolises. Such a radical change in the behaviour of an indigenous population without any transitional forms seems highly unlikely. All the more so, as individual Duero burial grounds continued to be occupied until the early sixth century, without taking on elements of the 'Visigoth' necropolises, while conversely the 'Visigoth' burial grounds had no grave inventories similar to those of the Duero, even in their early stages. Also, the fact that the rapid adoption of the foreign way of clothing whose clothing accessories initially consisted almost exclusively of non-Mediterranean brooches and buckles ${ }^{67}$ (and whose foreign, 'Germanic' character is not denied by Halsall, Tejerizo and Martínez Jiménez, et al.) cannot be explained solely by changing socio-economic and socio-political framework conditions. A diffusion of foreign objects into the Iberian Peninsula, which were sooner or later used by certain (elite) groups of the indigenous population, would have left other traces in the archaeological record. The assumption that these clothing accessories were made only for use in funerary practices is simply wrong. Traces of use and repairs to some of the pieces speak to clothing accessories that were worn during their owner's lifetime.

\section{Conclusion}

The ethnic question has not been brought from outside the archaeological material or imposed 'by force'. It results from the material-culture aspect of the archaeological record and from written sources, therefore remaining a legitimate question.

An ethnic interpretation stricto sensu of the Meseta cemeteries - i.e. attributing the ethnic identity 'Visigoth' - as a whole or just of the inhumations habillées does not seem possible for reasons of the cultural diversity of dress accessories and the regional diversity of the Meseta cemeteries themselves. However, the Barbarian-influenced dress and dress accessories, as well as particular funeral practices (e.g. inhumation habillées), must be accepted as indices of the visible presence of migrated barbarians, at least in the early phases of the Meseta cemeteries.The archaeological record hardly supports concepts that neglect a (visible) presence of migrated people, but rather favours a (predominantly) native development of the Meseta cemeteries.

From my point of view there are three fundamental questions: If we accept the idea of immigrated barbarians visible in the archaeological record, then the relationship between these barbarian groups and the Visigoths are in 
question. With respect to the inhumations habillées, we need to know about the way of dressing and the meaning of dress in Visigothic Spain - such as who could wear special sets of dress accessories of foreign provenance or tradition. This makes the future study of the so-called Visigothic cemeteries a veritable task. To conclude with the statement of Quirós Castillo and Castellanos García in their introduction to the 2015 volume on ethnicity in early medieval Spain: 'Es decir, si bien el paradigma visigotista ha dejado de ser convincente, a fecha de hoy no hay una forma adecuada de explicar el significado histórico de las necropolis visigodas. ${ }^{68}$

\section{Bibliography}

\section{Secondary sources}

Arce, Javier, Esperando a los Árabes: los visigodos en Hispania (507-711) (Madrid: Marcial Pons, 2011).

Ardanaz Arranz, Francisco, La necrópolis visigoda de Cacera de las Ranas (Aranjuez, Madrid) (Madrid: Comunidad de Madrid, Arqueología, Paleontología y Etnografía 7, 2000).

Barroso Cabrera, Rafael, Etnicidad vs. Aculturación. Las necrópolis castellanas de los siglos V-VI d.C. y el asentamiento visigodo en la Península Ibérica: una mirada desde la Meseta sur (Oxford: Archaeopress, 2018).

Bierbrauer, Volker, 'Frühgeschichtliche Akkulturationsprozesse in den germanischen Staaten am Mittelmeer (Westgoten, Ostgoten, Langobarden) aus der Sicht des Archäologen', in Atti del 6 congresso internazionale di studi sull'alto medioevo, Milano 21-25 ottobre 1978 (Spoleto: Centro Italiano di Studi sull'Alto Medioevo, Settimane di Studio del Centro Italiano di Studi sull'Alto Medioevo 27, 1980), pp. 89-105.

—, 'Archäologie und Geschichte der Goten vom 1.-7. Jahrhundert', Frühmittelalterliche Studien 28 (1994), pp. 51-171.

Brather, Sebastian, 'Ethnische Identitäten als Konstrukte der frühgeschichtlichen Archäologie', Germania 78 (200o), pp. 139-177.

—_Ethnische Interpretationen in der frühgeschichtlichen Archäologie: Geschichte, Grundlagen und Alternativen (Berlin: Ergänzungsbände zum Reallexikon der Germanischen Altertumskunde 42, 2004). 
Dohijo, Eusebio, 'La etnicidad de la gens Gothorum Spaniae y su asociada "cultura material”, un posicionamiento y una propuesta como línea de investigación', Oppidum 13 (2017), pp. 199-248.

Ebel-Zepezauer, Wolfgang, Studien zur Archäologie der Westgoten vom 5.-7.Jh. n. Chr. (Mainz: Philipp von Zabern, Iberia Archaeologica 2, 200o).

Eger, Christoph, 'Westgotische Gräberfelder auf der Iberischen Halbinsel als historische Quelle: Probleme der ethnischen Deutung', in Cum grano salis: Festschrift für Volker Bierbrauer, ed. by Bernd Päffgen, Ernst Pohl, and Michael Schmauder (Friedberg: Likas, 2005), pp. 165-181.

-, Spätantikes Kleidungszubehör aus Nordafrika, vol. 1: Trägerkreis, Mobilität und Ethnos im Spiegel der Funde der spätesten römischen Kaiserzeit und der vandalischen Zeit (Wiesbaden: Reichert, Münchener Beiträge zur Provinzialrömischen Archäologie 5, 2012).

Fehr, Hubert, 'Hans Zeiss, Joachim Werner und die archäologischen Forschungen zur Merowingerzeit', in Eine hervorragend nationale Wissenschaft: deutsche Prähistoriker zwischen 1900 und 1995, ed. by Heiko Steuer (Berlin: Ergänzungsbände zum Reallexikon der germanischen Altertumskunde 29, 2001), pp. 311-415.

Fernández-Götz, Manuel A., and Francisco José García Fernández, 'Die ethnische Fragestellung in der spanischen Archäologie: eine wissenschaftsgeschichtliche Perspektive', Ethnographisch-Archäologische Zeitschrift 52.1 (2011), pp. 104-118.

Fernández-Götz, Manuel A., and Gonzalo Ruiz Zapatero, 'Hacia una arqueología de la etnicidad', Trabajos de Prehistoria 68.2 (2011), pp. 219-236.

Fuentes Domínguez, Ángel, La necrópolis tardorromana de Albalate de las Nogueras (Cuenca) y el problema de las denominadas 'Necrópolis del Duero'(Cuenca: Excma, Diputación Provincial, 1989).

García Moreno, Luis Agustín, 'Gothic Immigrants in Spain', in Foreigners in Early Medieval Europe: Thirteen International Studies on Early Medieval Mobility, ed. by Dieter Quast (Mainz: Römisch-Germanisches Zentralmuseum, Monographien des Römisch-Germanischen Zentralmuseums Mainz 78, 2009), pp. 169-180.

Halsall, Guy, 'Ethnicity and Early Medieval Cemeteries/Etnicidad y cementerios altomedievales', Arqueología y Territorio Medieval 18 (2011), pp. 15-27.

Härke, Heinrich, 'Ethnicity, "Race" and Migration in Mortuary Archaeology: An Attempt at a Short Answer', Anglo-Saxon Studies in Archaeology and History 14 (2007), pp. 12-18.

Hübener, Wolfgang, 'Zur Chronologie der westgotenzeitlichen Grabfunde in Spanien', Madrider Mitteilungen 11 (1970), pp. 187-211.

Jepure, Antonel, Das westgotenzeitliche Gräberfeld von Madrona (Segovia, Spanien) (Würzburg, 2006), https://opus.bibliothek.uni-wuerzburg.de/frontdoor/index/ index/docId/5935 (accessed 4 July 2020). 
, 'El ocaso del paradigma visigodo', in Identidad y etnicidad en Hispania: propuestas teóricas y cultura material en los siglos V-VIII, ed. by Juan Antonio Quirós Castillo and Santiago Castellanos García (Bilbao: Universidad del País Vasco, Documentos de Arqueología Medieval 8, 2015), pp. 239-248.

Kazanski, Michel, 'La diffusion de la mode danubienne en Gaule (fin du IV siècledébut du VI ${ }^{\mathrm{e}}$ siècle): essai d'interprétation historique', Antiquités Nationales 21 (1989), pp. 59-73.

Kazanski, Michel, and Patrick Périn, 'Les Barbares "orientaux" dans l'armée romaine en Gaule', Antiquités Nationales 29 (1997), pp. 201-217.

Koch, Manuel, 'Gotthi intra hispanias sedes acceperunt: consideraciones sobre la supuesta inmigración visigoda en la Península Ibérica', Pyrenae 37.2 (2006), pp. 83-104.

— Ethnische Identität im Entstehungsprozess des spanischen Westgotenreiches (Berlin: Ergänzungsbände zum Reallexikon der Germanischen Altertumskunde $75,2012)$.

König, Gerd G., s.v. 'Duratón', in Reallexikon der Germanischen Altertumskunde, vol. 6, 2nd ed. (Berlin: De Gruyter, 1985), pp. 284-294.

López Quiroga, Jorge, 'Gentes barbarae: los bárbaros y roma; mito-motor explicativo o paradigma necesario?', Antigüedad y Cristianismo 25 (2008), pp. 1-170.

—, Arqueología del mundo funerario en la Península Ibérica (siglos $V-X$ ) (Madrid: La Ergástula, 2010).

Marcela Mantel, María, 'Etnogénesis, relatos de origen, etnicidad e identidad étnica: en torno a los conceptos y sus definiciones', Anales de Historia Antigua, Medievaly Moderna 51 (2017), pp. 71-86.

Martin, Céline, 'La notion des gens dans la péninsule Ibérique des $\mathrm{VI}^{\mathrm{e}}-\mathrm{VII}^{\mathrm{e}}$ siècles: quelques interprétations', in Identité et ethnicité: concepts, débats historiographiques, exemples (III $-X I I^{e}$ siècle), ed. by Véronique Gazeau, Pierre Baudun, and Yves Modéran (Caen: Brepols, 2008), pp. 75-89.

- Review of Esperando a los árabes: los visigodos en Hispania (507-711), by Javier Arce, Hispania 72 (2012), pp. 241-244.

Martínez Jiménez, Javier, Isaac Sastre de Diego, and Carlos Tejerizo García, The Iberian Peninsula between 300 and 850: An Archaeological Perspective (Amsterdam: Amsterdam University Press, 2018).

Martínez Santa-Olalla, Julio, 'Notas para un ensayo de sistematización de la arqueología visigoda en España', Archivo Español de Arqueología 29 (1934), pp. 139-176.

Palol y Salellas, Pedro de, 'La necropolis de San Miguel del Arroyo y los broches hispanorromanos del siglo IV', Boletín del Seminario de Estudios de Arte y Arqueología 34-35 (1969), pp. 93-16o.

Périn, Patrick, 'L'Armée de Vidimir et la question des dépôts funéraires chez les wisigoths en Gaule et en Espagne ( $\mathrm{V}-\mathrm{VI}^{\mathrm{e}}$ siècles)', in L'Armée romaine et les 
barbares du III ${ }^{e}$ au VII ${ }^{e}$ siècle, ed. by Françoise Vallet and Michel Kazanski (Saint-Germain-en-Laye: Association Française d'Archéologie Mérovingienne et du Musée des Antiquités Nationales, 1993), pp. 411-423.

Pinar Gil, Joan, Accesorios de indumentaria del regnum visigodo temprano (siglos $V-V I)$ (Bologna, 2012a), http://amsdottorato.unibo.it/5068/1/TESI.f.pdf (accessed 4 July 2020).

— , 'A Crossroads of Cultures in a Mosaic of Regions? The Early Visigothic Regnum from the Perspective of Small Finds', Archaeologia Baltica 18 (2012b), pp. 109-123.

Quast, Dieter, 'Communication, Migration, Mobility and Trade', in Foreigners in Early Medieval Europe: Thirteen International Studies on Early Medieval Mobility, ed. by Dieter Quast (Mainz: Römisch-Germanisches Zentralmuseum, Monographien des Römisch-Germanischen Zentralmuseums Mainz 78, 20o9), pp. 1-26.

Quirós Castillo, Juan Antonio, and Santiago Castellanos García, 'Identitdad y etnicidad en la Península Ibérica en los siglos V-VIII: una introducción', in Identidady etnicidad en Hispania: propuestas teóricas y cultura material en los siglos V-VIII, ed. by Juan Antonio Quirós Castillo and Santiago Castellanos García (Bilbao: Universidad del País Vasco, Documentos de Arqueología Medieval 8, 2015), pp. 21-40. Ripoll López, Gisela, 'Materiales funerarios de la Hispania visigoda: problemas de cronología y tipología', in Gallo-romains, wisigoths et francs en aquitanie, septimanie et Espagne, Kongress Toulouse 1985, ed. by Patrick Périn (Rouen: Musée des Antiquités de la Seine-Maritime Association française d'Archéologie mérovingienne, 1991), pp. 111-132.

— archeologico', in Le invasione barbariche nel meriodione dell'impero: visigoti, vandali, ostrogoti, Kongress Cosenza 1998, ed. by Paolo Delogu (Catanzaro: Soveria Mannelli, 2001), pp. 99-117.

Sasse, Barbara, 'Die Westgoten in Südfrankreich und Spanien: zum Problem der archäologischen Identifikation einer wandernden "gens"', Archäologische Informationen 20 (1997), pp. 29-48.

—_, 'Westgotische' Gräberfelder aufder Ibersichen Halbinsel am Beispiel der Funde aus El Carpio de Tajo (Torrijos, Toledo) (Mainz: Philipp von Zabern, Madrider Beiträge 26, 2000).

Tejerizo García, Carlos, 'Ethnicity in Early Middle Age Cemeteries: The Case of the "Visigothic" Burials', Arqueología y Territorio Medieval 18 (2011), pp. 29-43. _ media: reflexiones desde la arqueología', in Identidad y etnicidad en Hispania: propuestas teóricas y cultura material en los siglos V-VIII, ed. by Juan Antonio Quirós Castillo and Santiago Castellanos García (Bilbao: Universidad del País Vasco, Documentos de Arqueología Medieval 8, 2015), pp. 221-238. 
Vigil-Escalera, Alfonso, 'Is It Really Relevant the Ethnicity of Our Historical Subjects?', Arqueología y Territorio Medieval 18 (2011), pp. 45-53.

Werner, Joachim, 'Die archäologischen Zeugnisse der Goten in Südrußland, Italien und Spanien', in I goti in occidente (Spoleto: Centro Italiano di Studi sull'Alto Medioevo, Settimane di Studi del Centro Italiano sull'Alto Medioevo 3, 1956), pp. 127-130.

Zeiss, Hans, 'Zur ethnischen Deutung frühmittelalterlicher Funde', Germania 14 (1930), pp. 11-23.

— Die Grabfunde aus dem spanischen Westgotenreich (Berlin: De Gruyter, 1934).

\section{About the author}

Christoph Eger studied prehistoric and early medieval archaeology, classical archaeology, and ancient history at the universities of Bonn and Munich (Germany): MA in 1993, doctorate in 1997, habilitation (the second thesis required to teach at university in Germany) in 2009. His research interests include late antique North Africa and Spain, focusing on funeral practices. He has been serving as chief curator of the Roman Museum of Xanten since 2015 . 



\title{
10 Local Citizenships and the Visigothic Kingdom
}

\author{
Javier Martínez Jiménez
}

\begin{abstract}
In recent decades, ethnicity and ethnic identity have been one of the main issues of academic discussions of late antique and early medieval studies - including in Visigothic Iberia. Even if the tendency to correlate race and ethnicity has largely ended, the debate on the role of Goths and Romans in the Visigothic kingdom is still ongoing. Most of these discussions are based on funerary remains and how they can be interpreted, and in these contexts we find an application for comparative anthropology. However, in urban contexts there is a tendency to obviate this theoretical perspective. In this chapter I want to go beyond this duality to further develop the validity of urban identity and citizenship as a form of self-presentation outside of ethnic duality.
\end{abstract}

Keywords: Visigothic Iberia; cemetery; city; citizenship; identity; ethnicity

In the last forty years, the study of the Visigothic centuries has reached a new level of scientific maturity as a result of increased contacts between Iberian and foreign researchers, and the successful exchange of methodological approaches. The Visigoths are no longer a dull list of kings to be memorized by schoolchildren, but rather agents who helped to determine the evolution of Roman society after the fall of the West in the Iberian Peninsula. Within this state of affairs, the Visigothic monarchy, its process of state formation, and the functioning of its administration have been the focus of many studies, both from archaeological and historical perspectives. ${ }^{1}$ The role of

$1 \quad$ Wood and Martínez Jiménez 2016.

Panzram, S. and P. Pachá (eds.). The Visigothic Kingdom: The Negotiation of Power in Post-Roman Iberia. Amsterdam: Amsterdam University Press 2020 DOI: 10.5117/9789463720632_CH1O 
cities is usually highlighted as performative spaces for the monarchy to exercise its power.

Similarly, cities tend to be linked to bishops, who are presented as dialectically essential in the formation of the Visigothic state. In parallel, these bishops are seen as representatives of the traditional Hispano-Roman elite, which together with the landed nobility and the Gothic military leadership formed the aristocracy with which the monarchy had to define its own power. This perception introduces another key area in Visigothic studies, which is that of identities. This buzzword in early medieval studies normally presents a Visigothic society divided into Goths and Romans: a set of opposed alterities ethnically defined against each other.

As part of the necessary scientific revision of current positions, it is crucial to re-assess various points, in particular regarding the validity of this ethnic dual model and the role of cities and city dwellers in the Visigothic kingdom. A way of approaching both issues could be to address urban communities as active social agents within the state, who expressed their sense of belonging by means of local citizenships (rather than solely to ethnic categories). From this perspective, the Goth-Roman identity duality is undermined and locality (urbanity) appears as a new salient way of expressing alterity and community. Furthermore, by thinking of cities as active groups of inhabitants rather than as an anonymous, passive mass led by a bishop, we may be able to re-think the way we understand the dynamics of power in the Visigothic kingdom.

In this chapter, therefore, I propose to explore further the nature of local citizenship in the Visigothic period and the way citizens interacted with the state and the monarchy. In order to do this, I will introduce the anthropological concept of urban identities, and how this form of place-based identity appears to correlate with late antique notions of citizenship. An explanation of how post-Roman citizenships can be used to understand the social and political dynamics of cities addresses the relationship between the citizen bodies and the Visigothic monarchy, helping to achieve a better understanding of the nature of the state in this period.

\section{Continuity of civic life}

It is clear that, in the early imperial period, cities and towns were the basic unit of territorial control in Roman Hispania. As opposed to the forms of urbanism that characterized Gaul (with the tribal civitates), Hispania was a patchwork of large cities, towns, and even de-centralized smaller 
settlements that had evolved from Roman foundations and from assimilated pre-Roman clustered settlements. ${ }^{2}$ Traditionally, it had been proposed that the third-century crisis had caused the abandonment of many small settlements and the decline of larger cities. Thankfully, an increasing interest in late antique archaeology has cast new light on the evolution of cities beyond their classical phases. As a result, there is enough available data to discuss the archaeological evolution of cities in the Iberian Peninsula into the Islamic period and beyond.

It is true that some smaller settlements and secondary towns (paradigmatically exemplified by Los Bañales) entered - already in the second century - a phase of stagnation, where no new developments were visible, but still showed signs of habitation. ${ }^{3}$ However, from the fourth century onwards, administrative reforms introduced by Diocletian (and further developed by Constantine) deeply affected the network of cities. A considerable number of towns were relegated to secondary positions and were placed outside the main networks of imperial patronage. This, in combination with a new tax system (which collected taxes directly for the central administration), led many of these secondary nuclei to a state of civic decay (where no traces of municipal administration were visible any longer, such as minting coins, honorific inscriptions, maintenance of buildings) and even to abandonment. On top of this, during the fifth century, the barbarian invasions and the subsequent dismantling of the Roman imperial economic-administrative system left some areas of the peninsula cut off from main trading networks. This appears to have prompted various local responses and, in those regions where cities were not the most advantageous form of central place, it appears that hill forts and other fortified settlements became more prominent. As a result, cities which had thrived in earlier periods such as Ampurias, Baelo Claudia, Munigua, Numantia, Italica, Calagurris, or Bilbilis (and even conventual capitals like Clunia and Cádiz) ceased to show any traces of civic activity by the fifth century. ${ }^{4}$

Despite this, the late Roman administrative reorganization benefitted other cities, especially those that became administrative centres (like Mérida, Córdoba, Tarragona, Cartagena, Braga), or those well-connected to the Mediterranean trading networks (e.g. Valencia, Barcelona, Seville, Lisbon). Most of these became the locations of active Christian communities,

2 For a general and recent overview, see Houten 2018.

3 Andreu Pintado 2017.

4 Cepas Palanca 1997; Kulikowski 2004; Martínez Jiménez, Sastre de Diego, and Tejerizo García 2018, pp. 52-53. 
becoming episcopal sees, where each bishopric was equated with a civitas. By the Visigothic period, there were 71 bishoprics (which includes new Visigothic establishments), a number which can hardly compare to the near 400 towns and cities known for the Roman period. Even if these sees were evenly spread across the peninsula, some of these would have been civitates sine urbe, bishoprics which did not have a defined urban centre (like Egara, Orense, or Aquae Flaviae). ${ }^{5}$ Some others would have been established on old Roman cities without known urban life in these centuries (like Ercavica, Segovia, or Salamanca). Urban life and civic communities appear to have continued along the Mediterranean coast, the Ebro and Guadalquivir valleys, and the Lusitanian lowlands. In the mountainous areas north and west, and in the two Mesetas, cities did not survive well. Along the north and Atlantic coasts, smaller trading hubs appear more common - although these areas had never been as heavily urbanized as the Mediterranean side. ${ }^{6}$

This complex landscape of administrative units theoretically based on towns, but not always correlating to an urban nucleus with an active civic community, makes the current study difficult. However, a theoretical model can still be proposed; one supported by examples from those major cities which continued to be complex and densely occupied urban settlements, with a known administrative role and from which we can infer an active local administration.

\section{Urban communities and citizenship}

Inasmuch as cities continued to be active as settlements and central places during the Visigothic period in large areas of the peninsula, urban communities existed. These communities were the direct descendants of the first settlers, usually colonists from Italy (as in main Roman cities such as Mérida, Córdoba, Tarragona, Zaragoza), but sometimes of local communities that nucleated into a settlement and developed Roman-style civic institutions (like Conimbriga or Lisbon). It is true that some secondary settlements declined and lost civic status, but the urban network at large was resilient. The long history of these urban populations gave them a sense of individuality and local particularity (together with local traditions, calendars, laws and statutes, and a unique monumental townscapes) which characterized them as self-defined and identifiable communities.

6 Martínez Jiménez and Tejerizo García 2015. 
From an anthropological point of view, these communities shared a placebased, urban identity. ${ }^{7}$ Place-based identities are a form of group definition, based on the emotional and social bonds developed by an individual who lives in a shared space (and by the local community itself) with their physical surroundings. The connection between the environment, the individual, and the surrounding community (and the emotional memories that are fixed to certain surroundings) prompt the development of a sense of belonging. These places, memories, reflections, and constructed spaces form, together, a 'cognitive map' (an imagined geography defined by visual landmarks and their associated emotions and memories), which differs for each individual. However, communities sharing a space and in constant interaction also develop communal, shared cognitive maps. The shared space, communal rites, and collective memories that define this perception give the group a sense of cohesive belonging, as well as links to past generations that inhabited the same space. This link to the past provides a shared constructed ancestry, independent of kinship, that further gives the community a cohesive sense of acting as a group with common mindsets and objectives.

The written and material records available for cities in this period make it possible to identify various elements that can further explain the existence of self-defined and cohesive post-Roman urban communities. Perhaps the most important element in the building of an urban community was the cult of martyrs, which substituted pagan civic cults as the main form of public communal piety. The cult celebrated a member of the local community who was usually one of the first Christians of the city. This meant that a martyr was, in Augustinian terms, a citizen of the earthly city (and thus a fellow) but also of the heavenly one, and as the person who began the new Christian community in the city, a second founder - a figure around whom the local Christians could rally. Of course, this links back to practices of hero/ancestor cults. These martyrs, as concives, represented the citizen body in Heaven, and protected them on Earth. The alleged inscription of Wamba over the gates of Toledo places local martyrs (sancti domini) as guardians of the city. ${ }^{8}$ Already in the fifth century, St. Eulalia protected Mérida from the Goths, ${ }^{9}$ and in the sixth, St. Acisclus smote Agila in Córdoba ${ }^{10}$ while St. Vincent drove the Franks away from Zaragoza. ${ }^{11}$ In fact, martyrs were not only a symbol of the city's

8 Continuatio Isidoriana Hispana a. DCCLIV, 46.

9 Hydatius, Chronica subdita, 8o[90].175[182].

10 Isidore of Seville, Historia de Regibus Gothorum, Wandalorum et Sueborum, 45. 
Christian community, they altered the shared, imagined perception of the city by modifying the townscapes. The focal points of martyr cults became hotspots', usually commemorated with churches and basilicas which were, in turn, interconnected by processional routes. These processions further reinforced the Christian geography of cities and established new nodes and paths to the map. The most famous procession we know of is that of St. Eulalia in Mérida, which appears to have been an annual event, led by the bishop and followed by the city's clergy. ${ }^{12}$ Popular feasts took place on martyr days, with large crowds, market stalls, dances, and drunkenness, further providing a sense of cohesion within the community (by a common association with their martyr). ${ }^{13}$

The construction of new churches and shrines was a response to the Christian demands of the community, but were also a way for local elites to show munificence, and a competition with other cities (what in the classical period is labelled peer polity interaction). ${ }^{14}$ These competitions spread to the acquisition of relics, seeking to collect the largest amount in order to increase the standing of a church (and, by extension, of its community). An inscription in Mérida mentions that the cathedral had the relics of no fewer than ten saints, but bishop Pimenus of Medina Sidonia collected twenty-five relics of nineteen different saints through his episcopate. ${ }^{15}$ Even King Liuvigild supported Toledo's claims over Mérida's tunic of St. Eulalia. ${ }^{16}$ Even among holy men there was competition, or at least a wish to dominate. This might be a literary topoi that would demonstrate these communities' desire to out-do their neighbours on holy matters. When St. Fructuosus was in Baetica, the citizens (cives) of Seville attempted to convince him to stay in their city, rather than going on to build a monastery near Cádiz. ${ }^{17}$ Similarly, the bishop of Tarazona ordered St. Aemilian to remain in the church he had been given - firmly under the bishop's control and for the benefit of the city's congregation..$^{18}$ And when holy men or relics could not be secured, mythical bishops could conveniently be created. ${ }^{19}$

\footnotetext{
12 Vitas Sanctorum Patrum Emeritensium, V.3.12; Fuentes Hinojo 2008. Civil processions, linked to triumphs, royal parades, and other forms of late antique adventus ceremonies also existed (John of Biclar, Chronica a. DLXVII-DXC, 590.3; Julian of Toledo, Historia Wambae regis, 21), and defined the axial views of the city - cf. Dey 2014.

13 Cf. III Toledo 23.

14 Ma 2003.

15 Inscripciones cristianas de la España romana y visigoda, 548 (Mérida), 303-305 and 209

(Medina Sidonia).

16 Vitas Sanctorum Patrum Emeritensium, V.6.9-26.

17 Valerius of El Bierzo, Vita Fructuosi Bracarensis, 14.

18 Braulio of Zaragoza, Vita Sancti Aemiliani, V.12.

19 Panzram 2010.
} 
This re-definition of the urban community in Christian terms (and its rallying around local martyrs) explains the prominence of bishops - but a lay municipal administration also existed. ${ }^{20}$ Counts and dukes might have been the king's representatives in the city but, despite the lack of traditional curial magistracies, there were local administrative auxiliary positions (such as judges and, above all, the defensor civitatis), ${ }^{21}$ and one should not rule out the continuity of councils either, perhaps led by a primarius civitatis as we know for Mérida. ${ }^{22}$ We even know of a (municipal?) mid-sixth-century lictor from Mértola called Tyberius. ${ }^{23}$ From what can be inferred from the sources, the citizen body appears to have had a say in the appointment of both lay and ecclesiastic nominations. ${ }^{24}$ The obscure but ancient institution of the conventus publicus vicinorum (first mentioned in the codes of Alaric and Liuvigild) has traditionally been linked with rural assemblies, ${ }^{25}$ but a mention in the acts of the XVI Council of Toledo possibly places a conventus civitatis in an urban context, ${ }^{26}$ and may relate to a form of citizen gathering or assembly. The state operated through municipal administration when administering local justice, ${ }^{27}$ and minting coins ${ }^{28}$ - both of which would have visually highlighted the individuality of the city in terms of prestige. Similarly, while the construction of new administrative buildings (palaces) might be related to the strengthening of the centralized administration, ${ }^{29}$ the deliberate management of pre-existing public monuments and infrastructure was the result of local policies. The continuity of some Roman aqueducts into the fifth and sixth centuries, for example, seems to be the result of ongoing maintenance and management, which reflects an active municipal administration rather than a central interest in urban issues. ${ }^{30}$ The dismantling of public buildings for reuse might also have taken place under the supervision of municipal administration. The defense of the city would certainly have been up to local initiative, and in the case of Córdoba,

20 Curchin 2014.

21 Frakes 1994; cf. Codex Iustinianus, I.55.8 and Lex Visigothorum, XII.1.2.

22 Vitas Sanctorum Patrum Emeritensium, IV.2.1; cf. Fuentes Hinojo 2008.

23 Inscripciones cristianas de la España romana y visigoda, 97 - this is most probably a lector, an ecclesiastical position.

24 IV Toledo 19; Julian of Toledo, Historia Wambae regis, 6; cf. Gregory of Tours, Decem Libri Historiarum, V.47.

25 Daflon 2015.

26 XVI Toledo 7.

27 Koon and Wood 2009.

28 Pliego and Ibrahim 2018.

29 Martínez Jiménez, Sastre de Diego, and Tejerizo García 2018, pp. 170-173.

30 Martínez Jiménez 2019. 
its 'rebel' status against Agila (and during most of the sixth century) is the best example of a city surviving without 'state' troops - comparable to those we see in the rebellion of Paulus in Septimania. ${ }^{31}$

These urban communities reflect a sense of individuality and competition against peers, but also a large degree of self-management and concern for their members and infrastructure. Considering this form of group agency and legal precedents from the Roman period, it is possible to claim that these urban communities were using citizenship as a legally sanctioned form of identity, of separating 'us' from 'them'. ${ }^{2}$ In these late antique/early medieval contexts, we should understand citizenship as signifying local citizenship, and not Roman citizenship. Up to the fifth century, Roman citizenship had still been a valid form of political identity common to all provincials (as a result of the extension of citizenship in $212 \mathrm{AD}$ with the constitutio Antoniniana), as there was still a Roman state to validate it. At that moment, however, civis was increasingly used as a marker of local citizenship because Roman citizenship was so diluted as to be superfluous, something only reflected in the literary usage of the term. Sources from the fifth to the eighth century (from Hydatius to the Continuatio Isidoriana Hispana, including Isidore and the church councils) use civis in this context. ${ }^{33}$ The usage is, furthermore, inclusive in this aspect, highlighting residence and membership in the local community: in the Lives of the Fathers of Mérida, the citizen body is described as including the urban population as a whole (including Arians and Catholics), while the rustici are left aside. ${ }^{34}$ In no case is it possible to read these uses of civis as an exclusive indicator of the urban elites, the curiales. ${ }^{35}$ Belonging to the elites was signified in other ways, like with epithets such as honesti, clarissimi, or inlustris,,$^{36}$ or other indications, such as patricius, genus senatorum, or nobilissimi. ${ }^{37}$ It is only in the law that cives appear as generic inhabitants of the kingdom (although sometimes distinguishing citizens from the remainder of the people: civibus populisque). This is to be expected, as

31 Córdoba: Isidore of Seville, Historia de Regibus Gothorum, Wandalorum et Sueborum, 45; Septimania: Julian of Toledo, Historia Wambae regis, 7 .

32 Martínez Jiménez 2020.

33 Ibid.

34 Vitas Sanctorum Patrum Emeritensium, IV.2.1, V.3.7, V.5.2.

35 As it has been proposed (wrongly as well, in my opinion) for Merovingian Gaul and Gregory of Tours: Durliat 1997.

36 Álvarez Melero 2017.

37 Cf. Vitas Sanctorum Patrum Emeritensium, IV.2.1; Braulio of Zaragoza, Vita Sancti Aemiliani, XI.18, XV.22; Julian of Toledo, Historia Wambae regis, 6; or Epistulae Wisigothicae, 3. 
Visigothic law comes from Roman provincial tradition, where the language implies that the fiction of Roman citizenship still applies (for instance, when freeing slaves ad dignitatem civium Romanorum ${ }^{38}$ ), and where local citizenships are not reflected.

Overall, it is clear that we can understand urban dwellers in the Visigothic period as cohesive and self-defined communities. Local citizenship might have been the way in which this belonging was voiced. After all, for Isidore a city was a gathering of citizens (cives vocati, quod in unum coeuntes vivant, ut vita communis et ornatior fiat [...] sicut urbs unius populi [they are called citizens because they live together, so that they may live more honourably and safer [...] as the city of a single people] ${ }^{39}$ ). It may be that, despite the blurred view given by the sources, townsfolk as self-defined urban communities might have been more involved in the Visigothic state than previously thought.

\section{Citizens and the crown}

The legal definition of citizenship in the Visigothic codes might indicate that the monarchy perceived all its subjects to be the same, but it is clear that each city saw itself as different from the others. And yet, interaction between the crown and city communities was essential to the validation of urban identities and to the justification of local citizenships, the so-called institutionalization of identities. ${ }^{40}$

For Gaul and Italy we have letters and narratives, such as those of Gregory of Tours and Cassiodorus, which give a clearer view (and several examples) of the direct relationship between urban communities and the crown by means of embassies and addresses. Only the royal replies survive (usually granting tax or military exemptions), but they must have resulted from requests by city councils. ${ }^{41}$ Two possible Visigothic examples would be the remission of taxes after a series of droughts and famines in the late seventh century, ${ }^{42}$ and tax exemptions to the church in Arles in the fifth century. ${ }^{43}$ Other acts of royal munificence towards cities

38 Lex Visigothorum, XII.2.14

39 Isidore of Seville, Etymologiae, IX.4.2-3 (author's translation).

40 Bourdieu 2000; Jenkins 2008, ch. 13.

41 For Gaul: Cassiodorus, Epistulae Theodoricianae variae, III.40, 42, IV.19; cf. Gregory of Tours, Decem Libri Historiarum, V.28.

42 XIII Toledo 3.

43 Vita Caesarii Arelatensis, I.20. 
appear to have been the construction of city walls (which, together with churches, appear to have been the extent of royal urban patronage). After the sixth century, such fortification efforts were paid for by the central administration due to their cost, as in Arles or Cartagena. ${ }^{44}$ In the late fifth century, similar efforts might have been carried out by the municipality and the episcopate in Mérida, ${ }^{45}$ but elsewhere it was probably by royal input. Italica, Valencia, Córdoba, and Toledo (and maybe Pamplona) are the main examples. ${ }^{46}$ It was to the benefit of both the monarchy and of local communities to have walls reinforced and repaired - although it is not possible to identify whether these were the result of local requests or royal initiative. Perhaps, the reference to 'latrant fora' in Sisebut's poem to Isidore may reflect this direct interaction between the demands of citizens and the crown. ${ }^{47}$

The monarchy also recognized communities and promoted them to urban status. The promotion of certain towns to civitas status certainly benefitted the king, as it extended the administrative system to previous 'grey areas' of royal control. The promotion of Italica to an independent civitas in the $5^{80}$ is the best example. ${ }^{48}$ Italica had been the first Roman colony outside Italy, and had become a secondary town under the influence of Seville as a better connection by river to Mediterranean trading networks. When Seville became a stronghold of Hermenegild during his rebellion in the 580 s, Liuvigild made Italica a bishopric, and built a new set of walls. ${ }^{49}$ This was a way to outdo the city's rivals, and certainly to the benefit of the local community, which from the fourth century had been relegated to a minor role (and practically an archaeological invisibility). There were other settlements that were promoted to civic status by means of bishoprics in Baetica and the Duero valley,,$^{\circ}$ and while, again, there is little information on the actual urban environment, a civic local community would have been promoted by mere royal fiat.

44 Cassiodorus, Epistulae Theodoricianae variae, III.44 (Arles) and CIL II 3420 (Cartagena); cf. Heijmans 2004, pp. 84-106; Vizcaíno Sánchez 2009, pp. 417-420.

45 Inscripciones cristianas de la España romana y visigoda, 363; cf. Arce 2008; Alba Calzado 2018; Osland 2019.

46 Italica: Ruiz Prieto 2013; Sánchez Ramos 2010, p. 252; Toledo: Continuatio Isidoriana Hispana a. DCCLIV, 46; Valencia: Ribera i Lacomba and Rosselló Mesquida 2013; Conimbriga: De Man 2011; Córdoba: León Muñoz and Murillo Redondo 2009; Pamplona: Mezquíriz de Irujo 2004.

47 Astronomicon, 6.

48 Sánchez Velasco 2018, p. 8 o.

49 John of Biclar, Chronica a. DLXVII-DXC, s.a. 584.1: maximum impedimentum Hispalensi populo exhibuit.

50 Sánchez Velasco 2018; Castellanos García and Martín Viso 2005. 
This can be better explored in the new urban foundations that characterized the Visigothic period, especially during its period of state formation..$^{1}$ Recopolis is the best-known example, but there were others: Eio, Victoriacum, Amaya, and Ologicus. Recopolis and Eio were certainly monumentally urban; with walls, houses, a basilica, and a palace. Eio was built on top of Roman oppidum abandoned in the late second century AD, but Recopolis was built entirely ex novo, and was more monumental (including a large open square and an aqueduct). The inhabitants of Recopolis were granted privileges, as mentioned by John of Biclar, together with their newly built homes and amenities (privilegia populo novae Urbis instituit),$^{52}$ which might have included tax exemptions and market rights. This would have set the new inhabitants in a privileged position when compared to the surrounding rural inhabitants and would compete directly with whatever urban form neighbouring Arcavica might have preserved. ${ }^{53}$ In these new foundations, even without a historical continuity, the actual experience of settling a new city and being part of the 'founding fathers' must have been a strong cohesive element for the community. When Swinthila founded Ologicus, ${ }^{54}$ he had the defeated Basques build it using their own resources (stipendiis suis et laboribus conderent), even if itself a 'city of the Goths' (civitatem Gothorum). By the reign of Swinthila (621-631) this probably meant Goths as citizens of the kingdom as a whole, especially within Isidore's narrative. Ologicus was a city built to control a frontier territory and was was hardly urbanized: Goths lived in the city, Basques lived outside in the countryside and mountains, beyond the pale of Visigothic law. In the same way, Recopolis had been built in honour of Liuvigild's son, Reccared, and was a key administrative centre from the beginning.

These new foundations with their inhabitants (and we know that these sites continued to be inhabited for generations) must have developed some form of local community. It may be daring to assume that there was some concept of civis Reccopolitanus, but a local sense of belonging certainly emerged. Furthermore, an internal social differentiation, municipal administration, local traditions (perhaps based on the recent foundation), which mirrored those existing in coeval cities, would have emerged organically, if not from the beginning.

$5^{1}$ Martínez Jiménez, Sastre de Diego, and Tejerizo García 2018, pp. 173-180; Olmo Enciso 2007; cf. Rizos 2017 .

$5^{2}$ John of Biclar, Chronica a. DLXVII-DXC, s.a. 578.4 .

53 If at all; Martínez Jiménez, 2020.

54 Isidore of Seville, Historia de Regibus Gothorum, Wandalorum et Sueborum, 63. 
Lastly, in exchange for royal protection and honours, cities had to contribute to the kingdom with taxes and soldiers. Cities were not always keen to pay taxes and often tried to obtain exemptions. This may partly explain the inefficiency of the Visigothic taxation system..$^{55}$ Regarding troops, kings are known to have taken oaths from citizens in Gaul,,$^{6}$ but it is more obscure for Visigothic examples. It is possible to read fidem populorum in the History of King Wamba as the oaths of the people given to the king (which were being undermined by Paulus), but not explicitly mentioned as such. ${ }^{57}$ Hermenegild's rebellion specifically mentions him making cities join with him (alias civitates atque castella secum contra patrem rebellare facit), $5^{8}$ which could also be interpreted as civic oaths of allegiance. Oaths can also be inferred from the accounts of Vouillé, ${ }^{59}$ and from Wamba's military law, ${ }^{60}$ in which it is clear that the king expected all inhabitants to rally to the call of arms (and that those who did not answer the call lost certain citizenship rights similar to those of Roman infamia).

While it is true that the interaction between the monarchy and its subjects was mostly done through the intermediation of elites, some represented the interest of their local communities. It would be too cynical to see bishops and other local aristocrats completely disregarding their own role within their communities (their source of power and legitimization). If we acknowledge that urban communities existed and defined themselves in terms similar to citizenship, we may begin to reassess the dialectical relationship between the crown and the civitates - understanding the term as a community of city dwellers and not just as a territorial administrative unit.

\section{Re-thinking citizenships}

The existence of civic communities with a strong sense of urban self-identity continued after the edict of Caracalla, and throughout late antiquity locality was an essential part of communal definition. The usage of civic language into the Visigothic period confirms this, affirmed by new readings of the archaeology from socio-anthropological principles of (urban) place-based identity. 2005, pp. 100-101.

$5^{8}$ John of Biclar, Chronica a. DLXVII-DXC, s.a. 579.3.

59 Gregory of Tours, Decem Libri Historiarum, II.37.

6o Lex Visigothorum, IX.2.8. 
This should be enough to re-consider the generally assumed dichotomy of a society divided into Goths and Romans, as both could be citizens of a given city and share emotional bonds more so than with a peer from a different community. It is perhaps, however, more interesting to see citizen bodies not just as self-defined groupings, but as agents within society and not just passive observers of royal and episcopal elite politics.

The relationship between the civitates and the crown, overall, was established through local elites, but a city was the sum of its inhabitants and local elites (to an extent) had to act on behalf of their power base. As a first step, this approach may serve as food for thought for future work on the nature of the Visigothic monarchy and on our understanding of the post-Roman state. ${ }^{61}$

\section{Bibliography}

\section{Primary sources}

Astronomicon $=$ Sisebut, Epistula missa ad Isidorum de libro rotarum $=$ Anthologia Latina 483 (Leipzig: Teubner, 1906).

Braulio of Zaragoza, Vita Sancti Aemiliani, trans. by Andrew Fear (Liverpool: University of Liverpool Press, Translated Texts for Historians 26, 1997).

Cassiodorus, Epistulae Theodoricianae variae, in Cassiodori Senatoris variae, ed. by Theodor Mommsen (Berlin: Monumenta Germaniae Historica, Auctores Antiquissimi 12, 1961 [1894]), pp. 387-392.

CIL II = Corpus Inscriptionum Latinarum: Inscriptiones Hispaniae Latinae, ed. by Emil Hübner (Berlin: De Gruyter, 1956 [1869]).

Codex Iustinianus = Corpus Iuris Civilis, 3 vols., vol. 2: Codex Iustinianus, ed. by Theodor Mommsen and Paul Krueger (Berlin: Weidmann, 1915).

Continuatio Isidoriana Hispana a. DCCLIV, in Chronica minora, 3 vols., vol. 2, ed. by Theodor Mommsen (Berlin: Monumenta Germaniae Historica, Auctores Antiquissimi 11, 1894), pp. 323-369.

61 This paper has been written within the 'Impact of the Ancient City Project' led by Andrew Wallace-Hadrill (Faculty of Classics, University of Cambridge). This project has received funding from the European Research Council (ERC) under the European Union's Horizon 2020 research and innovation programme (grant agreement no. 693418). This paper is indebted to the Toletum 2018 workshop held in Hamburg as much as it is to the 'Cities and Citizenship' workshop I partly organized in Cambridge. I need to thank the organizers of both events Sam Ottewill-Soulsby and Tom Langley, Sabine Panzram and Paulo Pachá, for all their help and useful suggestions. 
Epistulae Wisigothicae, ed. by Theodor Mommsen in Epistolae Merowingici et Karolini aevi, 6 vols., vol. 1 (Berlin: Monumenta Germaniae Historica, Epistolae 3, 1892), pp. 658-69o.

Gregory of Tours, Decem Libri Historiarum, trans. by Lewis Thorpe (London: Penguin, Penguin Classics, 1974).

Hydatius, Chronica subdita, in The Chronicle of Hydatius and the Consularia Constantinopolitana: Two Contemporary Accounts of the Final Years of the Roman Empire, ed. and trans. by Richard Burgess (Oxford: Oxford University Press, 1993), pp. 69-124.

Inscripciones cristianas de la España romana y visigoda, ed. by José Vives (Barcelona: Instituto Jerónimo Zurita, Consejo Superior de Investigaciones Científicas, 1942).

Isidore of Seville, Etymologiae = Isidori Hispalensis episcopi etymologiarum sive originum, libri $X X$, ed. by Wallace Lindsay (Oxford: Clarendon, Scriptorum Classicorum Bibliotheca Oxoniensis, 1911).

—, Historia de Regibus Gothorum, Wandalorum et Sueborum, in Chronica minora, 3 vols., vol. 2, ed. by Theodor Mommsen (Berlin: Monumenta Germaniae Historica, Auctores Antiquissimi 11, 1894), pp. 241-303.

John of Biclar, Chronica a. DLXVII-DXC, in Chronica minora, 3 vols., vol. 2, ed. by Theodor Mommsen (Berlin: Monumenta Germaniae Historica, Auctores Antiquissimi 11, 1894), pp. 163-207.

Julian of Toledo, Historia Wambae regis, ed. by Jocelyn N. Hillgarth in Iulianus Toletanus Opera, vol. 1 (Turnhout: Brepols, Corpus Christianorum, Series Latina 115, 1976), pp. 218-244.

La Colección Canónica Hispana, 6 vols., ed. by Gonzalo Martínez Díez and Félix Rodríguez (Madrid: Consejo Superior de Investigaciones Científicas, 1966-2002).

Lex Visigothorum, ed. by Karl Zeumer in Leges Visigothorum (Berlin: Monumenta Germaniae Historica, Leges nationum Germanicarum 1, 1902), pp. 33-456.

Sidonius Apollinaris, Epistulae, ed. and trans. by William Anderson (Cambridge, MA: Harvard University Press, Loeb Classical Library, 1936).

Valerius of El Bierzo, Vita Fructuosi Bracarensis, ed. and trans. by Andrew Fear (Liverpool: University of Liverpool Press, Translated Texts for Historians 26, 1997).

Vita Caesarii Arelatensis, ed. and trans. by William Klingshirn (Liverpool: University of Liverpool Press, 1994).

Vitas Sanctorum Patrum Emeritensium, ed. and trans. by Andrew Fear (Liverpool: University of Liverpool Press, Translated Texts for Historians 26, 1997). 


\section{Secondary sources}

Alba Calzado, Miguel, 'Secuencias en la transformación de Augusta Emerita (siglos I-IX): tres concepciones distintas de ser ciudad', in Entre civitas y madina: el mundo de las ciudades en la Península Ibérica y en el norte de África (siglos IV-IX), ed. by Sabine Panzram and Laurent Callegarin (Madrid: Collection de la Casa de Velázquez 167, 2018), pp. 51-74.

Álvarez Melero, Anthony, 'Honesti, clarissimi e inlustres en la Hispania tardoantigua (siglos IV-VIII)', in OPPIDUM-CIVITAS-URBS. Städteforschung auf der Iberischen Halbinsel zwischen Rom und al-Andalus, ed. by Sabine Panzram (Münster: Lit, Geschichte und Kultur der Iberischen Welt 13, 2017), pp. 107-130.

Andreu Pintado, Javier, ed., Oppida Labentia: transformaciones, cambio y alteración en las ciudades hispanas entre el siglo IIy la tardoantigüedad (Pamplona: UNED, 2017).

Arce, Javier, 'La inscripción del puente de Mérida de época del rey Eurico (483 d.C.)', Pyrenae 39.2 (2008), pp. 121-126.

Bourdieu, Pierre, Esquisse d'une théorie de la pratique (Paris: Seuil, 200o).

Castellanos García, Santiago, 'The Political Nature of Taxation in Visigothic Spain', Early Medieval Europe 12.3 (2003), pp. 201-228.

Castellanos García, Santiago, and Iñaki Martín Viso, 'The Local Articulation of Central Power in the North of the Iberian Peninsula (500-1000)', Early Medieval Europe 13.1 (2005), pp. 1-42.

Cepas Palanca, Adela, Crisis y continuidad en la Hispania del siglo III (Madrid: Consejo Superior de Investigaciones Científicas, Anejos de Archivo Español de Arqueología 17, 1997).

Curchin, Leonard, 'The Role of Civic Leaders in Late Antique Hispania', Studia Historica: Historia Antigua 32 (2014), pp. 281-304.

Daflon, Eduardo, 'Tumultos e clamores: assembleias rurais e resistência camponesa na Hispânia visigoda (séculos VI-VIII)', Brathair 15.2 (2015), pp. 132-167.

De Man, Adriaan, Defesas urbanas tardias da Lusitânia (Mérida: MNAR, Stvdia Lusitania 6, 2011).

Dey, Hendrik, The Afterlife of the Roman City: Architecture and Ceremony in Late Antiquity and the Early Middle Ages (Cambridge: Cambridge University Press, 2014).

Durliat, Jean, 'Episcopus, civis et populus dans les Historiarum Libri de Grégoire', Supplément à la Revue Archéologique du Centre de la France 13 (1997), pp. 185-193. Faro Carballa, José Antonio, María García-Barberena Unzu, and Mercedes Unzu Urmeneta, 'Pamplona y el Islam: nuevos testimonios arqueológicos', Trabajos de Arqueología de Navarra 20 (2008), pp. 229-284. 
Frakes, Richard, 'Late Roman Social Justice and the Origin of the Defensor Civitatis', Classical Journal 89.4 (1994), pp. 337-348.

Fuentes Hinojo, Pablo, 'Patrocinio eclesiástico, rituales de poder e historia urbana en la Hispania tardoantigua (siglos IV-VI)', Studia Historica: Historia Antigua 26 (2008), pp. 315-344.

Halsall, Guy, Barbarian Migrations and the Roman West (Cambridge: Cambridge University Press, 2007).

Harris, Marvin, Antropología cultural [Cultural Anthropology], trans. by Vicente Bordoy and Francisco Revuelta, 2nd ed. (Madrid: Alianza, 2011 [1983]).

Heather, Peter, 'Goths and Huns', in Cambridge Ancient History, vol. 13: The Late Empire, $A D$ 337-425, ed. by Averil Cameron and Peter Garnsey (Cambridge: Cambridge University Press, 1998), pp. 487-515.

Heijmans, Marc, Arles durant l'antiquité tardive: de la duplex Arelas à l'urbs Genesii (Rome: École Française de Rome, Collection de la École Française de Rome $324,2004)$.

Houten, Pieter, 'Civitates Hispaniae: Urbanisation on the Iberian Peninsula during the High Empire', unpublished PhD thesis, Department of Ancient History, University of Leiden, 2018.

Ingold, Tim, 'The temporality of the landscape', World Archaeology 25.2 (1993), pp. $15^{2-174}$.

Jenkins, Richard, Social Identity, 3rd ed. (Abingdon: Routledge, 2008 [1996]).

Koon, Sam, and Jamie Wood, 'Unity from Disunity: Law, Rhetoric and Power in the Visigothic Kingdom', European Review of History/Revue Europeenne d'Histoire 166 (2009), pp. 793-808.

Kulikowski, Michael, Late Roman Spain and its Cities (Baltimore, MD:Johns Hopkins University Press, 2004).

Lalli, Marco, 'Urban-Related Identity: Theory, Measurement, and Empirical Findings', Journal of Environmental Psychology 12 (1992), pp. 285-303.

León Muñoz, Alberto, and Juan Francisco Murillo Redondo, 'El complejo civil tardoantiguo de Córdoba y su continuidad en el alcázar omeya', Madrider Mitteilungen 50 (2009), pp. 399-432.

Ma, John, 'Peer Polity Interaction in the Hellenistic Age', Past \& Present 180 (2003), pp. 9-39.

Martínez Jiménez, Javier, Aqueducts and Urbanism in Post-Roman Spain (Piskataway, NJ: Gorgias Press, Gorgias Studies in Classical and Late Antiquity 26, 2019).

—, 'Urban identity and citizenship in post-Roman Gaul and Spain', al-Masaq 32.1 (2020), pp. 87-108.

, 'Reccopolitani and Other Town Dwellers in the Southern Meseta during the Visigothic Period of State Formation', in Urban Interactions: Communication 
and Competition in Late Antiquity and the Early Middle Ages, ed. by Michael Burrows and Michael J. Kelly (New York: Gracchi Books, 2020), 181-222.

Martínez Jiménez, Javier, and Carlos Tejerizo García, 'Central Places in the PostRoman Mediterranean: Regional Models for the Iberian Peninsula', Journal of Mediterranean Archaeology 28.1 (2015), pp. 81-104.

Martínez Jiménez, Javier, Isaac Sastre de Diego, and Carlos Tejerizo García, The Iberian Peninsula 30o-850: An Archaeological Perspective (Amsterdam: Amsterdam University Press, Late Antique and Early Medieval Iberia 6, 2018).

Martínez Pizarro, Joaquín, The Story of Wamba:Julian of Toledo's Historia Wambae Regis (Washington: Catholic University of America Press, 2005).

Mezquíriz de Irujo, María Ángeles, 'Necrópolis visigoda de Pamplona', Trabajos de Arqueología de Navarra 17 (2004), pp. 43-90.

Oller Guzmán, Joan, 'La civitas sine urbe y su funciónalidad de vertebración en el territorio provincial hispano: los casos de Egara y de Caldes de Montbui', Pyrenae 45.1 (2014), pp. 89-110.

Olmo Enciso, Lauro, 'The Royal Foundation of Recópolis and the Urban Renewal in Iberia during the Second Half of the Sixth Century', in Post-Roman Towns and Trade in Europe and Byzantium, ed. by Joachim Henning (Berlin: De Gruyter, 2007), pp. 181-199.

Osland, Daniel, 'Text and Context: Patronage in Late Antique Mérida', Studies in Late Antiquity 3.4 (2019), pp. 581-625.

Panzram, Sabine, 'Mérida contra Toledo, Eulalia contra Leocadia: listados "falsificados" de obispos como medio de autorepresentación municipal', in Espacios urbanos en el occidente mediterráneo (siglos VI-VIII), ed. by Alfonso García (Toledo: Toletum Visigodo, 2010), pp. 123-130.

Pliego, Ruth, and Tawfiq Ibrahim, 'La ciudad a través de las emisiones monetarias y sigilográficas de la Península Ibérica de la antigüedad tardía a la conquista omeya', in Entre civitas y madina: el mundo de las ciudades en la Península Ibérica y el norte de África (siglos IV-IX), ed. by Sabine Panzram and Laurent Callegarin (Madrid: Collection de la Casa de Velázquez 167, 2018), pp. 135-152.

Ribera i Lacomba, Albert, and Miquel Rosselló Mesquida, 'La ocupación tardoantigua del circo romano de Valentia', in Acta XV congressus internationalis archaeologiae christianae Toleti, 8-12.9.2008: episcopus, civitas, territorium, ed. by Olof Brandt (Vatican City: Pontificio Istituto di Archeologia Christiana, 2013), pp. 47-62.

Richard, Michel, Los dominios de la psicología [La psychologie et ses domains: de Freud a Lacan] (Madrid: Istmo, 1974).

Rizos, Efthymios, ed., New Cities in Late Antiquity: Documents and Archaeology (Turnhout: Brepols, Bibliothèque de l'Antiquité Tardive 35, 2017). 
Ruiz Prieto, Enrique, 'Itálica tardoantigua: reflexiones y asignaturas pendientes', Ligustinus 1 (2013), pp. 81-117.

Sánchez Ramos, Isabel, 'Las ciudades de la Bética en la antigüedad tardía', Antiquité Tardive 18 (2010), pp. 243-273.

Sánchez Velasco, Jerónimo, The Christianization of Western Baetica: Architecture, Power and Religion in a Late Antique Landscape (Amsterdam: Amsterdam University Press, Late Antique and Early Medieval Iberia 5, 2018).

Tejerizo García, Carlos, and Javier Martínez Jiménez, 'De colonizados a colonizadores: apuntes para una lectura poscolonial de los "tiempos oscuros"', in Repensar el colonialismo: Iberia, de colonia a potencia colonial, ed. by Beatriz Marín Aguilera (Madrid: JAS, 2018), pp. 163-197.

Vizcaíno Sánchez, Jaime, La presencia bizantina en Hispania (siglos VII-VIII). La documentación arqueológica, 2nd ed. (Murcia: University of Murcia, Antigüedad y Cristianismo 24, 2009).

Wood, Jamie, and Javier Martínez Jiménez, 'New Directions in the Study of Visigothic Spain', History Compass 14.1 (2016), pp. 29-38.

\section{About the author}

Javier Martínez Jiménez, DPhil Oxon - PDRA for the Western Mediterranean, Impact of the Ancient City ERC Project (Cambridge, UK) - co-author of The Iberian Peninsula between 300 and 850:An Archaeological Perspective (Amsterdam: Amsterdam University Press, 2018). 


\section{Representations of Power}





\title{
11 Recopolis
}

\author{
The Representation of Power in a Complex Landscape
}

\author{
Lauro Olmo Enciso
}

\begin{abstract}
The foundation of the city of Recopolis on the initiative of King Liuvigild in $\mathrm{AD} 578$ is the clearest material expression of the participation of the Visigothic state in urban development and in the creation of power landscapes. The ex novo construction of the city - city walls, palatial complex, elite houses, commercial and industrial buildings, hierarchical organization of space - and its impact on the wider territory, with the reorganization and renovation of the road network and creation of new rural settlements, was a clear demonstration of political prowess and an expression of the tax-collecting power of the state. Contextualizing these features within the broader landscape helps in understanding the spatial and social inequality that characterized the beginning of the early medieval period.
\end{abstract}

Keywords: archaeology; landscapes of power; Visigothic state; early medieval urbanism; spatial inequality

The consolidation of the Visigothic state in the second half of the sixth century allowed for the development of a major city-building programme, the projection of a well-defined urban model. This programme was carried out by the state and the church during the second half of the sixth and the first half of the seventh century, and is a reflection of the success of the new state created by King Liuvigild. This urban revival affected a limited number of cities, which included several episcopal centres, and the significant development of a new state foundation, directly related to the state's fiscal capacity, which also benefited the church, as reflected by the

Panzram, S. and P. Pachá (eds.). The Visigothic Kingdom: The Negotiation of Power in Post-Roman Iberia. Amsterdam: Amsterdam University Press 2020 DOI: 10.5117/9789463720632_CH11 


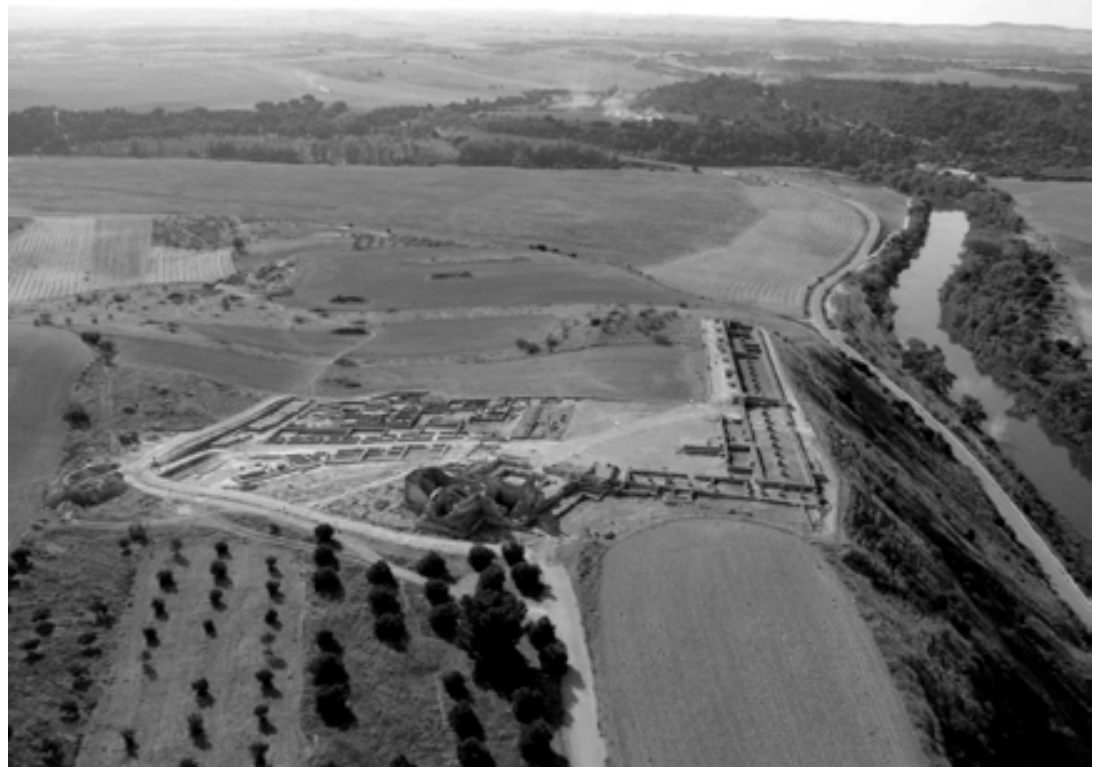

Fig. 11.1 Recopolis. @ Department of Archaeology, University of Alcalá.

written record. ${ }^{1}$ All these cities were economic and administrative centres, and from the reign of Liuvigild were endowed with a mint, becoming bases for the redistribution of agricultural surplus. However, this urban dynamism must be framed within a wider social context; this period witnessed the consolidation of a new urban and rural landscape characterized by multiple layers of inequality. ${ }^{2}$

The success of the new state created by Liuvigild and his active role in the urban sphere are clearly expressed by the records of the foundation of Recopolis (Fig. 11.1). These written references convey the exceptional importance of the city in the state-building discourse and in ideological project that aimed to construct a new political identity while establishing a renovated fiscal structure. ${ }^{3}$ John of Biclar's Chronicle for the year 578 clarifies:

ANNO II TIBERII IMPERATORIS QUI EST LIVVIGILDI IX REGIS AN. $\mathrm{X}$ Liuigildus rex extinctis undique tyrannis, et pervasoribus Hispaniae

1 Isidore of Seville, Historia Gothorum, 51, 5; Epistola de Fisco Barcinonensi.

2 Olmo Enciso 1998, pp. 109-118; 2008, pp. 42-43 and 58-6o; 2015, pp. 15-29; 2018, pp. $199-200$ and 203.

3 Olmo Enciso 2008, pp. 43-45; 2015, pp. 31-35; 2018, p. 194. 
superatis sortitus requiem propiam cum plebe resedit civitatem in Celtiberia ex nomine filii condidit, quae Recopolis nuncupatur: quam miro opere et in moenibus et suburbanis adornans privilegia populo novae Urbis instituit. ${ }^{4}$

Isidore of Seville also links the foundation of the city with Liuvigild's consolidation of a central Visigothic state supported by a solid fiscal structure:

Aerarium quoque ac fiscum primus iste auxit, primusque inter suos regali ueste opertus solio resedit, nam ante eum et habitus et consessus communis ut genti, ita et regibus erat. Condidit autem ciuitatem in Celtiberia, quam ex nomine filii Recopolim nominauit. 5

Similarly, the existence of coins struck during Liuvigild's and Reccared's reigns, with the legend RECCOPOLI FECIT, a unique type during the Visigothic period, constitutes exceptional evidence of the ideological and political trends that converged in the foundation of the city. ${ }^{6}$ These two references convey the importance of this urban foundation, which is considered key factor in the consolidation of the kingdom of Toledo, and help to frame the significance of the state's city-building programme.

Ideologically, the foundation of Recopolis was part of the programme of aemulatio imperii launched by Liuvigild - throne, ceremonial accoutrements, coins, urban foundations, and adoption in Recopolis of a Byzantium-inspired topography - demonstrating the importance of Byzantine influences. With the foundation of Recopolis, named after Reccared, one of the king's sons, Liuvigild placed himself at a level with Byzantine emperors, specifically Justinian, within a dynasty-reinforcing policy aimed to complement his state model. ${ }^{7}$

4 Campos 196o, p. 88; John of Biclaro, Chronicle, ed. by Baxter Wolf, p. 67: 'In the second year of the emperor Tiberius, which was the tenth year of King Liuvigild (578). With tyrants destroyed on all sides and invaders of Spain overcome, King Liuvigild had peace to reside with his own people. He founded a city in Celtiberia, which he named Recopolis after his son. He endowed it with splendid buildings, both within the walls and in the suburbs, and he established privileges for the people of the new city.'

5 Isidore of Seville, Historia Gothorum, 51,5, pp. 258-259; trans. by Baxter Wolf, p. 102: 'He was the first to enrich the fisc and the first to enlarge the treasury, robbing the citizens and despoiling the enemy. He also founded a city in Celtiberia which he named Recopolis after his son.'

6 McCormick 1990, pp. 317-318.

7 Olmo Enciso 2008, pp. 43-46; 2010, pp. 104-105; 2018, p. 194. 


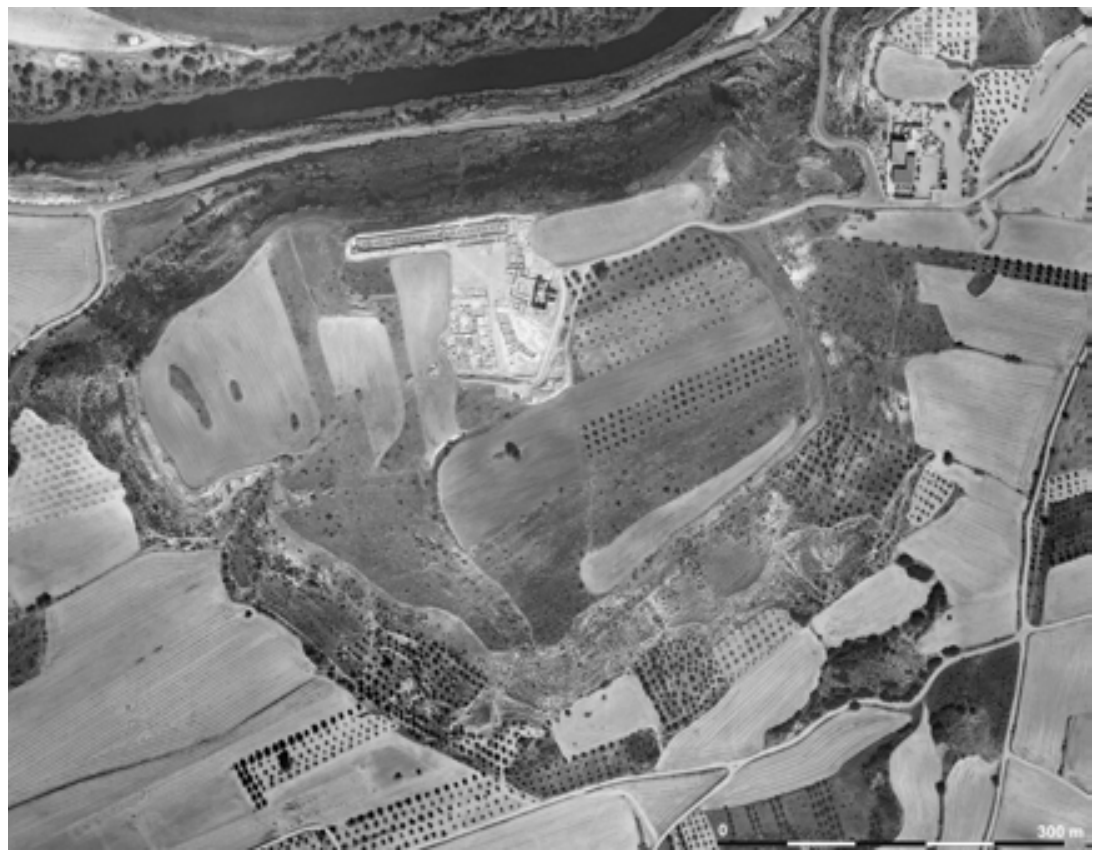

Fig. 11.2 Aerial view of Recopolis. @ cnig.es - Centro Nacional de Información Geográfica, PNOA, 2010, Spain.

\section{The archaeological evidence}

As an urban centre, Recopolis had an active trajectory spanning two and an half centuries, including two phases during the Visigothic period (late sixth-early eighth century) and the early Islamic period (early eighth-first half of the ninth century). ${ }^{8}$ The record clearly reflects the fact that the city was not a static entity, but rather a dynamic and shifting reality that related to changes transforming the social fabric around it. ${ }^{9}$ Archaeological research has demonstrated that the city was created after a large scale terracing operation that divided the city into several hierarchically arranged areas. The wider territory bears traces of the construction of Recopolis, for instance the opening of quarries in a $2 \mathrm{~km}$ radius from the city and the intense deforestation fuelled by the builders' demand for timber, as confirmed by statigraphically contextualized palaeo-environmental indicators. ${ }^{10}$

10 Ruiz-Zapata, Gil-García, and Olmo Enciso 2018, pp. 101-110. 


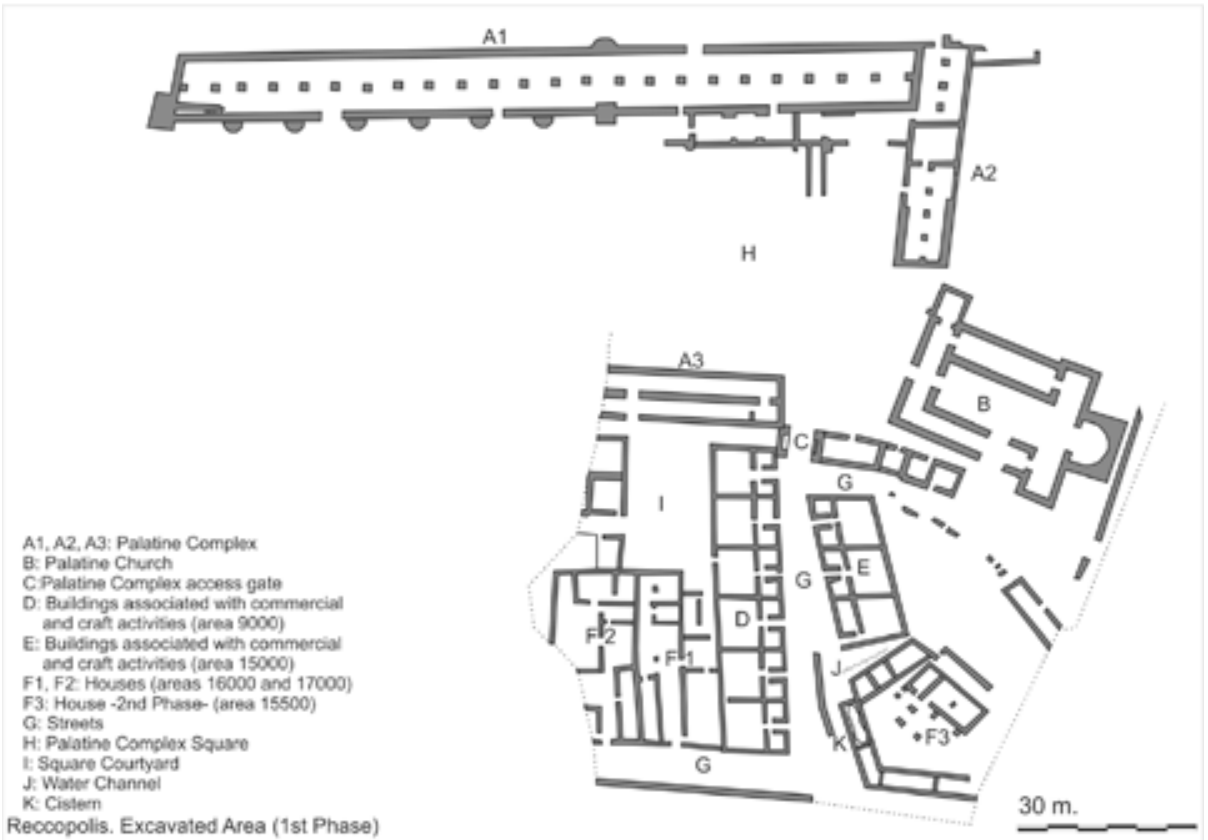

Fig. 11.3 Recopolis: excavated area. ๑ Olmo Enciso 2018.

Recopolis is located on a hilltop 33 ha in size, partially embraced by the Tagus river (Fig. 11.2).

The city was surrounded by a wall $1.9 \mathrm{~km}$ long, which encircles an urban area 21.5 ha in size. The wall, one of the city's most significant features, was $2 \mathrm{~m}$ thick, and was endowed with several rectangular towers $(5.50 \mathrm{~m} \times 5 \mathrm{~m})$, the maximum documented height of which is $5.8 \mathrm{~m}$. The wall consisted of two external faces of masonry and an internal fill of rubble, all of which was bound by lime mortar. The only gate excavated to date opens straight into the city and was flanked by two carefully built masonry towers. The whole wall was lined by a layer of lime mortar. ${ }^{11}$

The topography of the site allowed the planners to divide the city into hierarchically arranged areas, with buildings that represented the city's landscape of power at the apex (Fig. 11.3). The palatial complex, 1.4 ha of which have been excavated, was visible from the entire city and most of the surrounding countryside. It constituted three civic buildings and a church, arranged around a large courtyard (Fig. 11.3, A1, A2, A3). In addition to its position within the city and the wider archaeological context, the dimensions of this complex eloquently express the ideological expression of power. The 
North Building (A1) is rectangular in plan, and has two wings attached to the eastern side; it is $137 \mathrm{~m}$ long and between 12 and $18 \mathrm{~m}$ wide and was traversed by a longitudinal row of 24 square pillars (1.10 $\mathrm{m}$ side) that supported the second floor. Building A2, which, alongside the palatine church, formed the courtyard's eastern side, was $40 \mathrm{~m}$ long and $10 \mathrm{~m}$ wide, and presented an identical row of pillars. Building $A_{3}$, which is currently being excavated, closed the courtyard to the south. It was a large construction, about $111 \mathrm{~m}$ long and $9.15 \mathrm{~m}$ wide. ${ }^{12}$ In contrast to the two other buildings, the spine of the building was not constituted by a row of pillars, but by a central wall, which divides the building into two $3 \mathrm{~m}$-wide naves. The palatine church was located at the eastern end of the complex (Fig. 11.3, B). It was $41 \mathrm{~m}$ long by between 21 and $25 \mathrm{~m}$ wide and was built of masonry and paved by a layer of opus signinum. The plan of the church was cruciform, with a longitudinal central nave, flanked by two lateral naves, a perpendicular nave that operated as a transept, and an apse that formed a half-circle inside the church and projected as a rectangle on the outside. Access to this palatine area was achieved through a monumental gate made of tuff and limestone blocks (Fig. 11.3, C). The square around which all these buildings were situated was approximately $5,600 \mathrm{~m}^{2}$ in size $(140 \mathrm{~m}$ long $\times 40 \mathrm{~m}$ wide; Fig. 11.3, H) and was paved by a layer of lime mortar laid over a terrace of river pebbles; the roads surrounding the palatial complex were levelled by similar terraces. All the civil buildings had two stories, the upper one being more carefully built, with opus signinum pavements and architectural decoration, while the lower one, paved with a layer of lime mortar, must have had various uses. ${ }^{13}$ They were built in masonry and lined by lime mortar, some remains of which were found in the facades and the interior walls. Numerous remains of timber were found inside $\mathrm{A}_{3}$, including oak, Pinus sylvestris, and Pinus nigra, used both as beams for the ceiling and to support the opus signinum pavement. These remains yielded radiocarbon dates contemporary to the construction of the building (Beta 480494 and Beta 480495 /AD 582-66o) as well as slightly (Beta 394657 and Beta 394659/AD 405-550) and significantly earlier (Beta 394658/AD 240-395/Beta 480495/AD 137-334), which suggests that older material was reused in the construction of the building. This is also indicated by the discovery of reused sculpted stones dated to the Roman

12 To date, approximately 27 per cent of the building has been excavated, as the remaining 73 per cent lies on privately owned land. The interpretation of this building, therefore, is largely based on data provided by walking surveys, LiDAR (Light Detection and Ranging), infrared and thermal imaging, and geomagnetic survey. The available data clearly suggests that the building continues to the west of the current excavation limits.

13 Olmo Enciso 2008, pp. 47-52. 
period, the reuse of earlier construction and decorative material being a common feature in Visigothic sites. ${ }^{14}$ Similarly, the stratigraphy of the site reveals several construction phases, the levelling out of some buildings and the construction of new structures, suggesting a dynamic urban life during the years that followed the foundation of the city, a period of frantic activity that has also been attested in coeval contexts in the Visigothic kingdom.

Archaeological finds reveal the representative, administrative, economic, storage, and fiscal uses of the palatial buildings. ${ }^{15}$ Following the excavations carried out in the early 1990s, some of the architectural features attested in Recopolis ${ }^{16}$ - two-story buildings, opus signinum pavements and decorations in the second floor, and lime mortar pavements in the multifunctional ground floor - and their functional inferences began to be recognized in contemporary buildings in the Iberian Peninsula. Jointly, they constitute evidence of a well-defined, sui generis architecture of power defined by the ideology of hegemonic power exercised by the aristocracy and the Visigothic state.

To the east of the palatial complex, and clearly related to it, recent research has identified the remains of an interesting architectural complex. Geomagnetic surveys carried out in 2015 (Fig. 11.4) ${ }^{17}$ have identified the remains of four buildings (the largest ones are up to $20 \mathrm{~m}$ wide) the size and plan of which are reminiscent of the episcopal palace in Barcelona, the elite residence of Sant Julia de Ramis, and the early-Islamic residences found in Mérida, which followed Visigothic palatial traditions. ${ }^{18}$ These features were also detected during a GPR (Ground Penetrating Radar) survey undertaken in 2017 (Fig. 11.5); this survey also suggested different phases in this complex, the oldest constructions corresponding to the features detected by the geomagnetic survey ${ }^{19}$ The likely dimensions of this potential expansion of the palatial area must be around 6,00o $\mathrm{m}^{2}$ (o.6 ha). Archaeologically, these buildings are to be considered part of the palatial complex, as the remains of a building predating $\mathrm{A} 2$, found on its eastern side, are projected in the direction of the newly identified constructions. In addition to their proximity, these features are similar in plan to the palatial buildings, and

Balmaseda Muncharaz 2008, pp. 151 and 156.

Olmo Enciso 1987, pp. 346-352; 2015, p. 31; 2018, p. 195.

Olmo Enciso 1998.

Henning, McCormick, Olmo Enciso et al. 2019, pp. 742-743, figs. 4, nos. 8, 6, and 7.

8 Beltrán de Heredia Bercero 2014, pp. 469-471; Burch, Garcia, Nolla et al. 2006; Alba Calzado 2009, pp. 398-402, figs. 5 and 14; Henning, McCormick, Olmo Enciso et al. 2019, pp. 742-743, fig. 6 .

19 Olmo Enciso, Castro-Priego, and Diarte-Blasco, in press. 


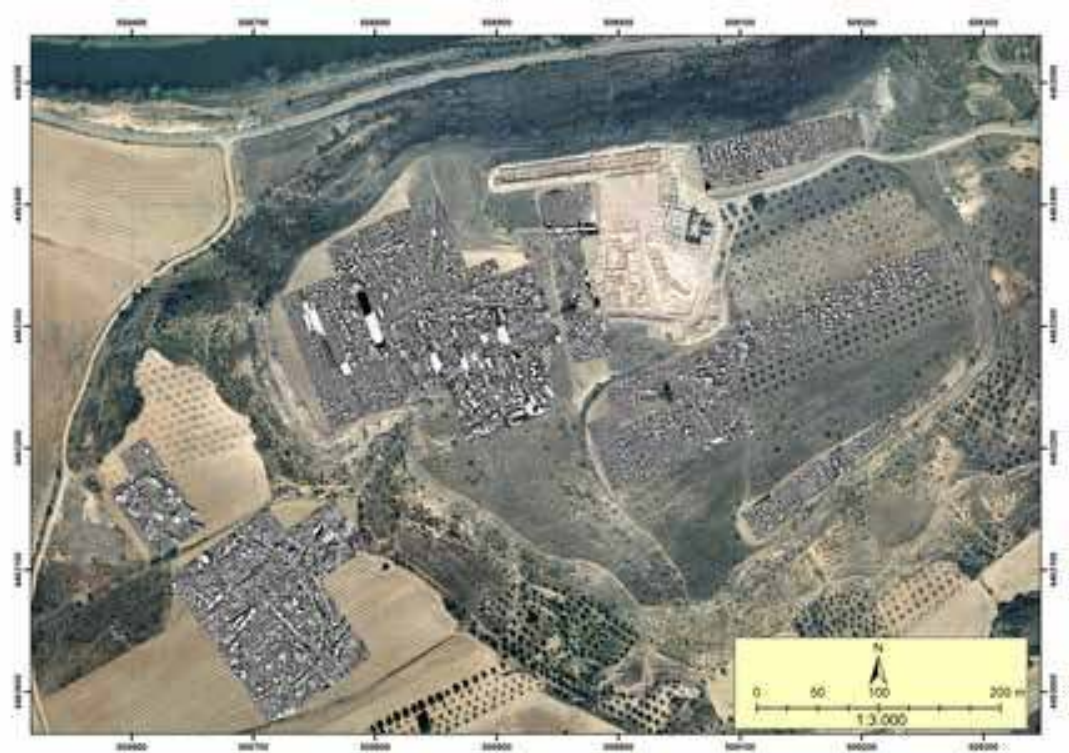

Fig. 11.4 Recopolis: geomagnetic survey in 2015. ๑ Henning, McCormick, Olmo Enciso et al. 2019.
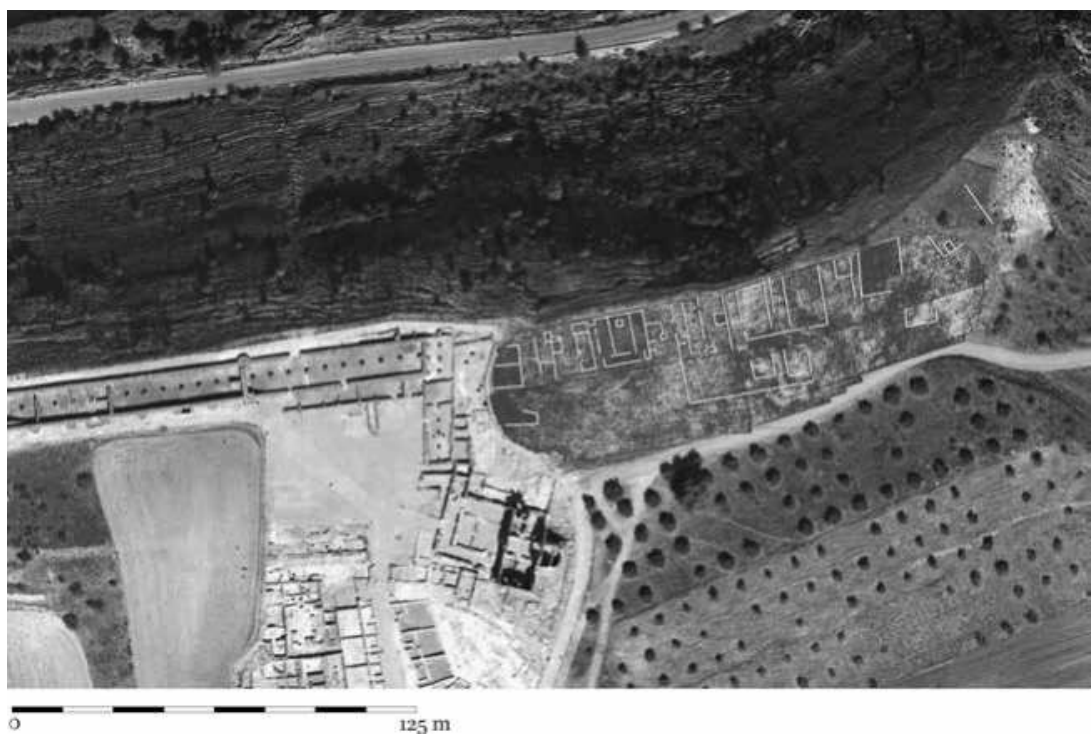

Fig. 11.5 Archaeological interpretation of GPR (Ground Penetrating Radar) data from the eastern part of the palatial complex. $\odot$ Olmo Enciso, Castro-Priego, and Diarte-Blasco, in press. 
therefore have been tentatively interpreted as a residential zone for the aristocracy that inhabited and ran the complex. This also increases the size of the palatial area to about $20,000 \mathrm{~m}^{2}$ (2 ha), that is, 9.3 per cent of the space of the city.

The main thoroughfare, immediately outside the palatial complex, was flanked by two large buildings $(54 \times 12 \mathrm{~m}$ the one to the west - Fig. 11.3 $\mathrm{D}$ - and $27 \times 12 \mathrm{~m}$ the one to the east - Fig. $11.3 \mathrm{E}$ ), which housed workshops and commercial spaces. These establishments included glass and jewellery workshops ${ }^{20}$ and shops selling Mediterranean imports. ${ }^{21}$ Two houses (446 and $459 \mathrm{~m}^{2}$ in size) were identified near the palace, to the south of $\mathrm{A}_{3}$ and the west of commercial Building D (Fig. 11.3, F1 and F2), opening to the street that traversed the city from east to west. These houses were divided into different functional areas - rooms, kitchens, etc. - around open courtyards. The houses were built upon stone foundations, the walls being built with rammed earth and lined with lime mortar; the pavements were of lime mortar, as was the ground floor of the palace. The presence in these buildings of North African amphorae and spatheia, thrown kitchen and table wares, glass tablewares, late Roman bronze coins and a tremis coined by Liuvigild in the Élvora mint, ${ }^{22}$ identifies the inhabitants of this building as members of the urban elite (Fig. 11.3, F1 and F2). Geomagnetic survey data show that these buildings were part of a large rectangular city block situated to the south of the palatial complex. ${ }^{23}$ Concerning water supply, Recopolis had two separate systems: while the palatial area was supplied by an aqueduct, the rest of the city was equipped with cisterns, a mixed system already attested in other cities during this period, for instance Tarraco and Mérida. ${ }^{24}$ The aqueduct, which probably supplied the palatial complex, was also built ex novo.

Geomagnetic survey, which covered 19 ha, both inside and outside the city, revealed the density of the urban landscape and, more recently, the presence, outside the city, of disperse constructions to the west of the only city gate yet to have been excavated (Fig. 11.4). ${ }^{25}$ Inside the city, the evidence points to houses of different sizes and levels of complexity being generally built around courtyards; the evidence from Recopolis seems to tally with

Gómez de la Torre Verdejo 2011.

21 Bonifay and Bernal Casasola 2008.

22 Olmo Enciso and Castro-Priego 2018, p. 560.

23 Henning, McCormick, Olmo Enciso et al. 2019, pp. 740-742, figs. 3 and 4.

24 Olmo Enciso 2008, pp. 54-55.

25 Henning, McCormick, Olmo Enciso et al. 2019, pp. 744-749, figs. 2, 3.3, 3.5, 3.8, 3.9, 3.10, 3.11, 3.12, 3.13. 
what little we know about the typology of domestic structures in Iberian cities in the sixth-eighth centuries. ${ }^{26}$ The presence of large buildings in different areas of the site, and an understanding of their functional role within the urban structure of Recopolis, is a future research challenge, along with an improved understanding of the organization of urban areas and the road network. ${ }^{27}$

The excavation has yielded clear evidence for the transformation of the city in the second half of the seventh century, during the second Visigothic phase of Recopolis. These transformations imply changes in the urban fabric, including the disruption of the street that ran around the palatial area to the south by a series of domestic buildings; the end of most craft and commercial activity in the vicinity of the palace, and the transformation of those commercial buildings into houses; the general decline in construction techniques; the occupation of public spaces by technically inferior housing; and the substitution of mortar pavements for clay floors in the larger houses and the ground floor of the southern palatial building. In addition, a decline in the operation of the Recopolis mint ${ }^{28}$ and, more broadly, in commercial activity have been attested. Commercial contraction seems to have been a widespread phenomenon, and construction, be it state- or church-sponsored, seemed to stagnate during this period, even in those cities that had flourished during the previous period of urban growth. ${ }^{29}$ This decline was caused by the crisis undergone by the Visigothic state, which affected its fiscal capacity undermined by the monetary crisis ${ }^{30}$ when the weak fiscal structure of the state found itself unequal to the challenge posed by the accelerating feudalization of the kingdom from the second half of the seventh century onwards. Regardless, most of these urban centres continued playing a central territorial role until the early ninth century, already under Islamic rule. Recopolis stands as a clear example of this process; the city has yielded the greatest number of 'Abd al Rahman I dirhems (dated to AD $773-785 \mathrm{AD} / \mathrm{H} 156-169$ ) found in the interior of the Iberian Peninsula, along with one struck by al-Hakam I in AD 812/H 197, which confirms that the city continued playing a central role in the organization of the territory for over a century after the Islamic conquest, until its abandonment around AD $8500^{31}$

26 Ibid., pp. 746, figs. 3.3, 3.10, 3.11, 8 .

27 Ibid., pp. 742, 746, figs. 3.5, 3.9.

28 Castro-Priego 2010, pp. 288-289.

29 Olmo Enciso 1998, p. 115; 2008, pp. 58-60; 2010, pp. 106-107; 2015, pp. 35-37; 2018, p. 198.

30 Castro-Priego 2008, pp. 139-140; 2016, pp. 27 and 50-51; Olmo Enciso and Castro-Priego 2018, p. 558 .

31 Olmo Enciso, Castro-Priego, Checa-Herráiz et al. 2017, pp. 89-91 and 95-96. 
Recopolis was a production and consumption centre throughout, although its most active phase in this regard corresponds to the late sixth and the first half of the seventh centuries, as shown by the commercial and industrial buildings found in the city. Two glass workshops were active simultaneously until the mid-seventh century, when one of them closed down; the other one remained in operation throughout the eighth century and into the Islamic period..$^{2}$ The presence of a jeweller's workshop with all its equipment - bivalve moulds, scale dishes, metal scoria - emphasizes the city's intense productive activity. ${ }^{33}$ The arrival of international imports is confirmed by the presence of ARSW D, North African amphorae and spathia, and wares manufactured in the region around Constantinople, ${ }^{34}$ suggesting that the city's elites had access to Mediterranean consumer goods; this is the most representative assemblage to have been found in the centre of the Iberian Peninsula. ${ }^{35}$ Pottery production in Recopolis (fast wheel) presents the greatest formal and functional diversification, cooking and table wares, in the central regions of the Iberian Peninsula. Most of these productions were locally sourced, as indicated by the petrology of the fabrics, characteristic of the region's geology. Contextualized coins, including gold tremisses, but especially bronze late Roman coins, found in the elite houses are indicative of monetary circulation, ${ }^{36}$ which were not particularly intensive but still important for the operation of elite trade circuits. ${ }^{37}$ The city's role as a fiscal centre and collector of surpluses is related to the construction of the mint, where several Visigothic kings are known to have struck coins, including Liuvigild (568-586), Reccared (586-6o1), Sisebut (612-621), Swinthila (621-631), and Wittiza (698-710).

In addition to the construction of the city, the foundation of Recopolis involved the restructuration of the surrounding territory. Space was organized around a new road network, which facilitated the foundation of rural settlements, hamlets, and farmsteads mostly located within a $4 \mathrm{~km}$ radius of the city (Fig. 11.6). This territory was traversed by a newly built aqueduct - a $1.89 \mathrm{~km}$-long section is preserved, and is currently under study. Different analyses carried out in Recopolis and nearby rural settlements suggest a mixed economic regime: stock-breeding seems to have been the predominant activity, but cereal agriculture - wheat, barley, and rye - vines, 


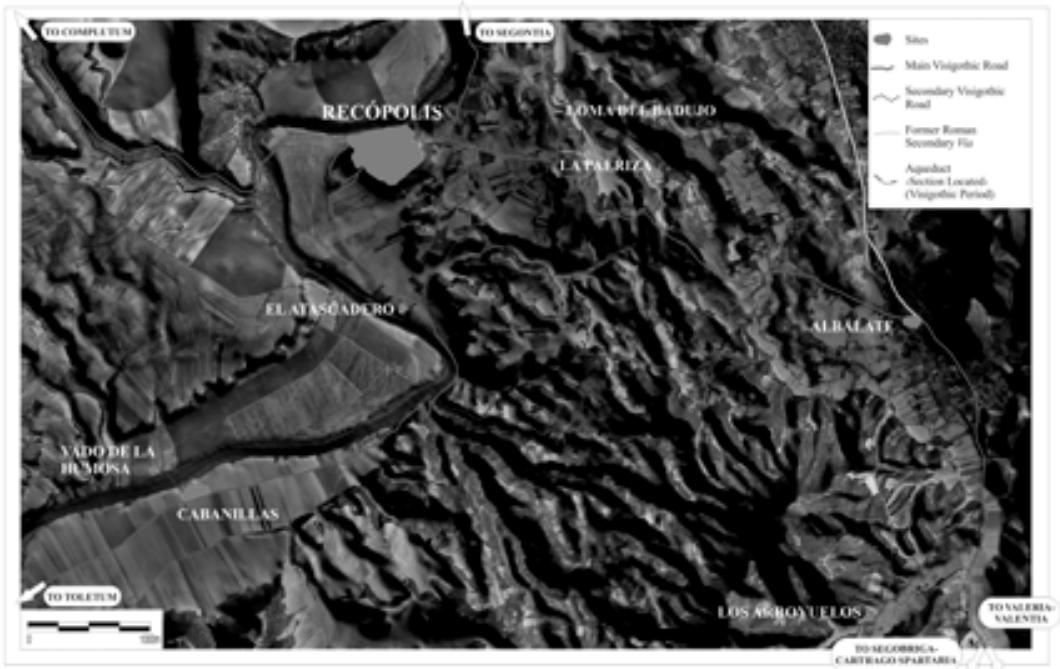

Fig. 11.6 Recopolis: reorganization of the territory, new settlement, and road network. ๑ Lauro Olmo Enciso.

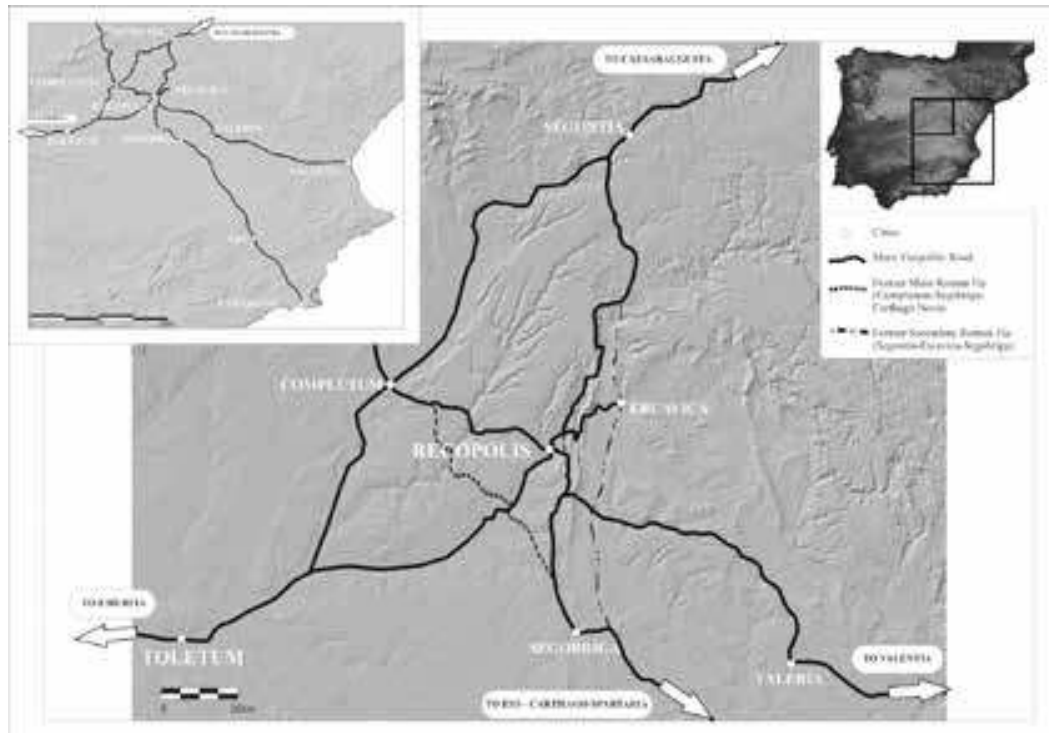

Fig. 11.7 The reorganized road system around Recopolis. ๑ Olmo Enciso 2018. 
and such tree species as the olive, hazelnut, and walnut, were also important. Intense deforestation, within generally dry climatic conditions, resulted in largely open landscapes. This has been put in relation to the effects of the hemispheric-wide climatic phenomenon known as the Early Medieval Cold Episode, followed by a progressive increase in temperatures from the late sixth century onwards. In this region, this climatic cycle was also characterized by drought, bad harvests, famine, plagues of Yersinia pestis, and swarms of locusts. $3^{8}$ Of special interest is the fact that the foundation of the city in the last third of the sixth century was accompanied by changes in the road network that turned Recopolis into a central node for communications between the central plateau and the Spanish Levante (Fig. 11.7).

\section{A new landscape of power}

The foundation of a city ex novo - including city walls, palace, public buildings, a hierarchical urban planning, etc. - the reorganization of the road network, the foundation of rural settlements and the construction of an aqueduct, and the development of a new agricultural system were all ways to discipline the landscape as social space, and a clear demonstration of the ability to control resources. Urban planning implies the disciplining not only of the urban landscape, but also of the surrounding territory and its population, which were thus introduced to the influence of the elite. The materialization of the landscape, therefore, is tantamount to an ideological display through the constructed environment. It is a clear example of the construction of space as a medium for the cohesion of the ruling elite..$^{39}$ This is most effectively conveyed by Recopolis, the ex novo city, free from previous urban shackles, as a full expression of the ideology of Liuvigild's new state. The city is, for the moment, the clearest materialization of the political identity of the regnum Gothorum. From the start, this new state pursued his own hegemony both over the aristocracy and the church. This is clearly expressed in Recopolis, where the palatine church - even if it was one of the largest in Hispania - occupied a secondary position vis-à-vis civic buildings. Therefore, the city clearly expressed the ideological project of Liuvigild, who did not grant the city a bishopric, not even an Arian one, but

38 Büntgen, Tegel, Nicolussi et al. 2011, pp. 578-582; McCormick, Büntgen, Cane et al. 2012, pp. 169-220; Olmo Enciso 2018, pp. 198-199 and 202-203; Olmo Enciso, Castro-Priego, Ruiz Zapata et al. 2019, pp. 106, 107-108, 109-110, 111-112, 117-123.

39 Paynter and McGuire 1991, p. 10. 
endowed it with a mint, and miro opere et in moenibus [...] adornans as a way to emphasize the sole domain of the state. Significantly, Isidore of Seville reflects Liuvigild's ideological position by defining him as inreligiosus. ${ }^{40}$ As such, the city of Recopolis, and especially the palatial complex, became the expression of the urban and political identity of the state. The wall was another essential element for the city's urban identity. Furthermore, the dimensions of the palatial complex and the walls of Recopolis also recall symbolically the coercive power of the state. In this regard, it must be kept in mind that these landscapes of power - the organization of the whole territory - cannot be divorced from the city's role as a collector of surplus. ${ }^{41}$ The fact that coinage was a state monopoly is a reflection of the early success of this strategy, ${ }^{42}$ and the state's capacity to collect tax. As such, urban planning in both Recopolis and Toledo were an expression of the initial success of Liuvigild's project - the city as showcase of the material expression of the state and its ability to collect revenue. ${ }^{43}$ Essential in this regard is the fact that, in addition to other archaeological markers, Toledo's and Recopolis's mints were the most active in the central Iberian Peninsula between the late sixth and the first half of the seventh century. ${ }^{44}$ It is not a coincidence that the city combined political, administrative, and fiscal functions, the latter embodied in the mint and its associated storage areas, which were related to the administration of productive surpluses. The city was to retain these functions, more or less actively, throughout the Visigothic period and during the early years of Islamic rule.

Other examples mirror the finds in Recopolis, and progressively outline the characteristics of an increasingly well-defined architecture of power in early medieval Iberia. The excavation of the hill of Falperra, which presides over Braga, capital of the Suebi kingdom, resulted in the identification of a complex of buildings within a walled precinct. Based on functional and topographic similarities with Recopolis, the complex has been identified as a palatial acropolis. ${ }^{45} \mathrm{On}$ a different scale, but also representative of state architecture, are the two palaces interpreted as the seat of the comes civitatis in Girona and Barcelona. ${ }^{46}$ Concerning aristocratic architecture,

Isidore of Seville, Historia Gothorum, $5^{2}$.

Olmo Enciso 2015, pp. 39-41.

2 Castro-Priego 2010.

43 Olmo Enciso 2010.

44 Castro-Priego 2016, p. 46.

45 Real 200o, pp. 26-27.

46 Nolla, Palahí Grimal, Sagrera et al. 2008, pp. 28, 180, and 189; Beltrán de Heredia Bercero 2014, pp. 471-472, fig. 1, n. 6. 
the second half of the sixth century witnessed the emergence of a model of residence with parallels in the episcopal palace in Barcelona, in Sant Julià de Ramis (Girona), and Els Casal de Morella (Castelló); this phenomenon stretched to the early Islamic period, with palaces B and D of Morería, in Mérida. ${ }^{47}$ A significant late, and sui generis, example is the Pla de Nadal palace, built in the late seventh century.

These examples combined reveal that, from the second half of the sixth century onwards, the state adopted its own multi-scale architectural language. A similar phenomenon crystallized around the church. The elites, however, also adopted this language, so we need to understand regional differences and the different levels of coercion imposed by the state, the church, and the aristocracies over the rest of the population. The archaeological record reveals a complex, stratified society. The largest social group, in demographic and productive terms, was formed by the peasants, who exploited the agro-ecosystem and were required to hand over part of their produce as tribute. This control over resources was an expression of the dominant position of the elites and the state. Even if we accept that during this period their economic capacity was more restricted and, therefore, their demand less ${ }^{48}$ they nevertheless behaved as elites ${ }^{49}$ and created their own space of political identity. This obviously means that surplus existed, and that it was collected by the elites and the state, but at different levels, as reflected in the archaeological record. The accumulation of surplus, in this case by the state, made possible an urban operation such as the construction and development of Recopolis. Unless we accept this explanation, we would be hard put to answer questions such as where did the surplus necessary to build such a major work as Recopolis come from, and how are these palatial complexes ( $2 \mathrm{ha})$, major buildings, mints, walls, churches, stone architecture, aqueducts, cisterns, new road networks, and rural settlements to be explained otherwise..$^{0}$ The answer, however, is obvious: this urban operation was possible owing to the accumulation of surplus, and the archaeological and written record are clear in this regard. This points to a social reality defined by patterns of spatial inequality, a social model in which elites and non-elites lived separate but interdependent lives. ${ }^{1}$ This factor is key to any broad understanding of the analysis of

47 Antonio-Otal and Perez-Milián 2017, p. 1; Beltrán de Heredia Bercero 2014, pp. 469-473; Alba Calzado 2009, pp. 398-402, figs. 5 and 14.

48 Wickham 2008, p. 20.

49 Olmo Enciso 2015, p. 39.

50 Ibid., p. 40.

$51 \quad$ Ibid., pp. 41-42. 
Visigothic society; answers will only be possible through the full integration of the archaeological record in its territorial framework..$^{2}$

\section{Bibliography}

\section{Primary sources}

Epistola de Fisco Barcinonensi, in Concilios visigóticos e hispano-romanos, ed. by José Vives (Barcelona: Instituto Enrique Flórez, Consejo Superior de Investigaciones Científicas, España Cristiana, Textos 1, 1963), p. 54.

Isidore of Seville, Historia Gothorum = Las historias de los godos, vándalos y suevos de Isidoro de Sevilla, ed. by Cristóbal Rodríguez Alonso (León: Centro de Estudios e Investigación 'San Isidoro', 1975).

- History of the Kings of the Goths, in Conquerors and Chroniclers of Early Mediaval Spain, trans. by Kenneth Baxter Wolf, nnd ed. (Liverpool: University of Liverpool Press, Translated Texts for Historians 9, 1999), pp. 79-109.

John of Biclaro, Chronicle, in Conquerors and Chroniclers of Early Mediaval Spain, trans. by Kenneth Baxter Wolf, 2nd ed. (Liverpool: University of Liverpool Press, Translated Texts for Historians 9, 1999), pp. 57-77.

\section{Secondary sources}

Alba Calzado, Miguel, 'Los edificios emirales de Morería (Mérida), una muestra de arquitectura del poder', Anales de Arqueología Cordobesa 20 (2009), pp. 379-419. Antonio-Otal, José Manuel de, and Ramiro Perez-Milián, El edificio visigodo de els casals del Mas de Sabater (Morella, Castelló) (Morella, 2017).

Balmaseda Muncharaz, Luis Javier, 'La escultura de Recópolis', in Recópolis y la ciudad en la época visigoda, ed. by Lauro Olmo Enciso (Madrid: Museo Arqueológico Regional Comunidad de Madrid, Zona Arqueológica 9, 2008), pp. 143-157.

Beltrán de Heredia Bercero, Julia, 'Edilizia residenziale tardoantica a Barcellona: i palatia di Barcino', in La villa restaurata e inuovi studi sull'edilizia residenziale tardoantica, ed. by Patrizio Pensabene and Carla Sfameni (Bari: Edipuglia, 2014), pp. 467-476.

52 This work was carried out within the framework of the project, 'Cambio climático y construcción del paisaje Medieval: dinámicas de variabilidad en un periodo de transformaciones: HAR2017-84144-P', Plan Nacional de I+D+I, Ministerio de Economía y Competitividad, Proyectos de Excelencia 2017-2020. The archaeological excavations in Recópolis are funded by the Consejería de Educación, Cultura y Deportes, Gobierno Regional de la Comunidad Autónoma de Castilla-La Mancha. 
Bonifay, Michel, and Dario Bernal Casasola, 'Recópolis: paradigma de las importaciones africanas en el Visigothorum regnum; un primer balance', in Recópolis y la ciudad en la época visigoda, ed. by Lauro Olmo Enciso (Madrid: Museo Arqueológico Regional Comunidad de Madrid, Zona Arqueológica 9, 2008), pp. 99-115.

Büntgen, Ulf, Willy Tegel, Kurt Nicolussi, Michael McCormick, David Frank, Valerie Trouet, Jed O. Kaplan, Franz Herzig, Karl-Uwe Heussner, Heinz Wanner, Jürg Luterbacher, and Jan Esper, '250o Years of European Climate Variability and Human Susceptibility', Science 331 (2011), pp. 578-582.

Burch, Josep, G. Garcia, Josep Maria Nolla, Lluís Palahí Grimal, Jordi Sagrera, Marc Sureda, David Vivó, and I. Miquel, Excavacions arqueològiques a la muntanya de Sant Julià de Ramis, 4 vols., vol. 2: El castellum (Girona: Universitat de Girona, 2006).

Castro-Priego, Manuel, 'Los hallazgos numismáticos de Recópolis: aspectos singulares de su integración en la secuencia histórica del yacimiento', in Recópolis y la ciudad en la época visigoda, ed. by Lauro Olmo Enciso (Madrid: Museo Arqueológico Regional Comunidad de Madrid, Zona Arqueológica 9, 2008), pp. 131-141.

-, 'El sistema monetario visigodo y su alcance regional: el ejemplo de la provincia Carthaginensis y la ceca de Toledo', in Espacios urbanos en el Occidente Mediterráneo (siglos VI-VIII), ed. by Alfonso García, Lauro Olmo Enciso, Ricardo Izquierdo Benito, and Diego Peris Sánchez (Ciudad Real: Toletum Visigodo, 2010), pp. $285^{-294}$.

, 'Absent Coinage: Archaeological Contexts and Tremisses on the Central Iberian Peninsula in the 7 th and 8th Centuries AD', Medieval Archaeology 60.1 (2016), pp. 27-56.

Diarte-Blasco, Pilar, Late Antique and Early Medieval Hispania: Landscapes without Strategy? (Oxford: Oxbow Books, 2018).

Gelichi, Sauro, and Lauro Olmo Enciso, Mediterranean Landscapes in Post Antiquity: New Frontiers and New Perspectives (Oxford: Archaeopress, 2019).

Gómez de la Torre Verdejo, Amaya, 'La muralla de Recópolis', in Recópolis y la ciudad en la época visigoda, ed. by Lauro Olmo Enciso (Madrid: Museo Arqueológico Regional Comunidad de Madrid, Zona Arqueológica 9, 2008), pp. $77-86$.

— - 'La producción de viodrio en época visigoda: el taller de Recópolis', Zona Arqueológica 15.2 (2011), pp. 255-279.

-, 'La producción y uso del vidrio visigodo en Recópolis. Siglos VI y VII', in Arqueología Medieval en Guadalajara: agua, paisaje y cultura material, ed. by Guillermo García-Contreras Ruiz and Lauro Olmo Enciso (Granada: Ed. Alhulia, 2018), pp. 67-98. 
Henning, Joachim, Michael McCormick, Lauro Olmo Enciso, Knut Rassman, and Eyub Fikrit Eyub, 'Recopolis Revealed: The Frst Geomagnetic Mapping of the Early Medieval Visigothic Royal Town', Antiquity 93 (2019), pp. 735-751.

McCormick, Michael, Eternal Victory: Triumphal Rulership in Late Antiquity, Byzantium, and the Early Medieval West (Cambridge: Cambridge University Press, 1990).

— and after the Roman Empire: Reconstructing the Past from Scientific and Historical Evidence',Journal of Interdisciplinary History 43.2 (2012), pp. 169-220.

Nolla, Josep Maria, Lluís Palahí Grimal, Jordi Sagrera, Mark Sureda, et al., Del fòrum a la plaça de la catedral: histórico urbanística del sector septentrional de la ciutat de Girona (Girona: Ajuntament de Girona, 2008).

Olmo Enciso, Lauro, 'Los conjuntos palatinos en el contexto de la topografíe urbana altomedieval de la Península Ibérica', in Arqueología Medieval Española, II Congreso, 3 vols., vol. 2 (Madrid: Comunidad de Madrid, Consejería de Cultura y Deportes, Dirección General de Patrimonio Histórico, 1987), pp. $345^{-35^{2} \text {. }}$

— , 'Consideraciones sobre la ciudad en época visigoda', Arqueología y Territorio Medieval 5 (1998), pp. 109-118.

— , 'Recópolis: una ciudad en una época de transformaciones', in Recópolis y la ciudad en la época visigoda, ed. by Lauro Olmo Enciso (Madrid: Museo Arqueológico Regional Comunidad de Madrid, Zona Arqueológica 9, 2008), pp. 40-62.

— - 'Ciudad y estado en época visigoda: Toledo, la construcción de un nuevo paisaje urbano', in Espacios urbanos en el occidente mediterráneo (siglos VI-VIII), ed. by Alfonso García, Ricardo Izquierdo Benito, Lauro Olmo Enciso, and Diego Peris Sánchez (Ciudad Real: Toletum Visigodo, 2010), pp. 87-112.

-, 'The Materiality of Complex Landscapes: Central Iberia during 6th-8th Centuries A.D.', in New Directions in Early Medieval European Archaeology: Spain and Italy Compared; Essays for Riccardo Francovich, ed. by Sauro Gelichi and Richard Hodges (Turnhout: Brepols, 2015), pp. 15-42.

— , 'Spatial Inequality and the Formation of an Early Medieval Landscape in the Centre of the Iberian Peninsula', in Interpreting Transformations of People and Landscapes in Late Antiquity and the Early Middle Ages, ed. by Pilar Diarte-Blasco and Neil Christie (Oxford: Oxbow Books, 2018), pp. 193-206.

Olmo Enciso, Lauro, and Manuel Castro-Priego, 'Coins, Cities and Archaeological Contexts in the Centre of the Iberian Peninsula between the 6th and 8th Centuries AD: Recopolis and Toledo', in Numismatica e Archeologia: monete, stratigrafie e contesti; dati a confronto, ed. by Giacomo Pardini, Nicola Parise, and Flavia Marani (Rome: Quasar, 2018), pp. 557-571. 
Olmo Enciso, Lauro, Manuel Castro-Priego, and Pilar Diarte-Blasco, 'Visigothic Palatial Complexes: The cases of Recopolis and Toledo', in Late Antique Archaeology: Imperial Archaeologies, ed. by Luke Lavan (Leiden: Brill, in press).

Olmo Enciso, Lauro, Manuel Castro-Priego, Joaquín Checa-Herráiz, and Amaya Gómez de la Torre-Verdejo, 'Espacios de Poder en Recópolis en las épocas visigoda y primitiva andalusí', in La Meseta sur entre la tardía antigüedad y la alta edad media, ed. by Maria Remedios Perlines-Benito and Patricia Hevia-Gómez (Toledo: Junta de Comunidades de Castilla La Mancha, 2017), pp. 75-106.

Olmo Enciso, Lauro, Manuel Castro-Priego, Blanca Ruiz Zapata, Maria José Gil García, Marian Galindo Pellicena, Joaquín Checa-Herráiz, and Amaya de la Torre-Verdejo, 'The Construction and Dynamics of Early Medieval Landscapes in Central Iberia', in Mediterranean Landscapes in Post Antiquity: New Frontiers and New Perspectives, ed. by Sauro Gelichi and Lauro Olmo Enciso (Oxford: Archaeopress, 2019), pp. 104-128.

Paynter, Robert, and Randall H. McGuire, 'The Archaeology of Inequality: Material Culture, Domination and Resistance', in The Archaeology of Inequality, ed. by Robert Paynter and Randall H. McGuire (Oxford: Blackwell, 1991), pp. 1-27.

Real, Manuel Luís, 'Portugal: cultura visigoda e cultura moçárabe', in Visigodos y omeyas: un debate entre la antigüedad tardía y la alta edad media; I Simposio internacional de Mérida, 1999, ed. by Luis Caballero-Zoreda and Pedro Mateos Cruz (Madrid: CSIC, 200o), pp. 21-75.

Ruiz-Zapata, Blanca, Maria José Gil García, and Lauro Olmo Enciso, 'Paisaje y reconstrucción paleoambiental de la época medieval en la provincia de Guadalajara', in Arqueología medieval en Guadalajara: agua, paisaje y cultura material, ed. by Guillermo García-Contreras Ruiz and Lauro Olmo Enciso (Granada: Alhulia, 2018), pp. 101-112.

Wickham, Chris, 'Rethinking the Structure of the Early Medieval Economy', in The Long Morning of Medieval Europe: New Directions in Early Medieval Studies, ed. by Jennifer R. Davis and Michael McCormick (Padstow: Ashgate, 2008), pp. 19-31.

\section{About the author}

Lauro Olmo Enciso is Full Professor in Archaeology at the Department of History, University of Alcalá de Henares (Spain), and chair of Archaeology of this university. His research focuses on medieval, and historical archaeology, and landscape archaeology and heritage. 



\title{
12 Figura et potentia
}

\author{
Coin and Power in the Visigothic Kingdom
}

Ruth Pliego

\begin{abstract}
The coins issued by the Germanic peoples during late antiquity and the early Middle Ages initially shared an iconographic repertoire, borrowed from imperial Rome. The evolution these coins underwent, however, reveals characteristic features that served as the basis of the coinage of the later Germanic kingdoms, and then of the medieval states that followed. This work analyses their prominent aspects as symbols of authority and power, such as typology - including references to historical events - the degree of romanitas claimed by each of these peoples, and religious distinctions, as well as the extent to which these features responded to matters of political expediency.
\end{abstract}

Keywords: Visigothic kingdom; Liuvigild; Agila II; coinage; romanitas; power

Power is a difficult concept in the social and human sciences, which has led to the concept being interpreted from multiple analytical perspectives. The range of theories, from Weber's theory of social power to Bordieu's notion of symbolic power or Foucault's multiple-power model, ${ }^{1}$ lies outside the scope of numismatics as a discipline. According to the Oxford dictionary, power is 'authority that is given or delegated to a person or body'. The concept of power, as a web of asymmetric relationships, is thus related to that of authority, of which the use of force is -implicit or not - an inescapable feature. Power needs to be legitimized before the ruled and, historically, religion has played a key role. During the early Middle Ages,

1 See e.g. Gerth and Wright Mills 2014; Hall 2001; Navarro 2006.

Panzram, S. and P. Pachá (eds.). The Visigothic Kingdom: The Negotiation of Power in Post-Roman Iberia. Amsterdam: Amsterdam University Press 2020 DOI: 10.5117/9789463720632_CH12 
Christianity played a variable role in the emergence and development of post-Roman monarchies in the west. The sociologist Bendix, in his work Kings or People: Power and the Mandate to Rule, argued that 'the ideas and actions of those in positions of power or authority are the best documented part of the human record,', and there is little doubt that this applies to their cultural expressions as well. Power, authority, legitimacy, and holiness are ubiquitously represented in early medieval works of art as propaganda for the power that sponsored them. Coinage, by itself, is a manifestation of power. ${ }^{3}$

This paper examines the exercise of power in the Visigothic kingdom through its coinage, a concise symbolic manifestation of the Visigothic monarchy. Although it can be examined stylistically, as can other forms of cultural production, coinage is an official document issued by authorities. In contrast with other documents, however, coinage cannot be manipulated or reinterpreted ex post facto. A coin's small size imposes the need for a precise message and thus becomes an essential document for the analysis of the exercise of power in the Visigothic kingdom.

Visigothic coinage is full of symbols which allude to the issuing authority. In their attempts to impose their power over a unified kingdom, the Visigothic monarchs imitated imperial policies and ideas. ${ }^{4}$ Coins were also imitated; firstly, those issued by the last Western emperors and, finally, by those issued by emperors of the East. Despite their apparent homogeneity, which, simplistically, can be interpreted as a lack of ability to go beyond imitation, the balance between imitation and transformation, even innovation, became a permanent feature of Visigothic coinage. The development of Visigothic coin types allows us to trace the ideological evolution of the regnum. Several period may be distinguished. The first period goes approximately from the settlement of the Visigothic people (c.418) to the beginning of Liuvigild's reign as sole ruler (c.572), and is characterized by coin types that chiefly imitate Roman models; the second period goes from the beginning of Liuvigild's reign to the end of the civil war against Hermenegild (c.572-c.584); the third period ended with that of Chindaswinth's reign (c.584-649); and the fourth and final period ranges from the mid-seventh century to the end of the Visigothic kingdom, a few years after the Umayyad conquest (711-c.714).

2 Bendix 1980, p. 14.

3 See e.g. Valverde Castro 2000, p. 97. In this essential work for the study of the symbology of Visigoth power, there is, however, no approach to monetary symbology.

4 Phillips 2013, cit. Drews 2006, p. 13. 


\section{Romanitas as a sign of power in the earliest Visigothic emissions}

The Visigoths were the earliest Germanic people to strike their own coinage, c.420, soon after settling within the imperial frontiers. Although in general these coins were essentially imitations, this calls for qualification. Solidi and tremissis continued being issued with the emperor's name until the last third of the sixth century, ${ }^{5}$ the solidi reproduced official types until that date, but tremissis soon deviated. The main novelty was not so much with the creation of new types, but with the selection of these types to be struck among the Roman monetary iconography. The types stressed the legitimacy of the Visigothic kingdom in its relationship with the empire. As such, in this first period (c.420-c.572), the most significant feature of Visigothic coinage was romanitas.

The earliest type was a tremissis with a Victory supporting a long cross, which did not correspond to the contemporary iconography for this denomination (Fig. 12.1). ${ }^{6}$ This type, during the reign of Theodosius II, was symbolically connected with the cross on the Calvary, and thus emphasized the sacred nature of Roman power. In the West, however, the type was used by Galla Placidia's solidi, struck in Rome in $425^{-426}$, in the context of her court of Ravenna's power struggles during the reign of her brother Honorius. Galla Placidia maintained a close entanglement with the Visigothic kingdom, from being a hostage of Alaric (410) to becoming the wife of Athaulf (414) and mother to his ill-fated heir. This seems to explain the relevance of this typology, not only in Visigothic tremissis but also in the solidi, which, on the reverse, persisted until the denomination was finally abandoned, immediately before the beginning of Liuvigild's reign. The selection of this, rather than the official type, had to do with the emphasis of the romanitas of the Visigoths: so the type could commemorate the links of Visigoths with the Romans by Galla Placidia's marriage, justifying and confirming the Visigoth's pre-eminent place among the barbarian peoples.

This typological novelty has been largely ignored by numismatic research, obscured as it is by another, more relevant, novelty, with the issue of tremissis carrying a Victory holding wreath and palm-branch ${ }^{7}$

5 Solidi are known by the name and the image of the different Western emperors from Honorius to Libius Severus, and of the Eastern emperors from Leo I to Justinian I.

6 We know Visigoth tremisses with this typology in the name of Valentinian III, Libius Severus, Zeno, and Basiliscus, none of whose emperors coined tremissis with this typology.

$7 \quad$ Named 'pseudo-imperial' series by Grierson and Blackburn 1986, p. 39. Cf. Steinbach 2017, p. 38 . 


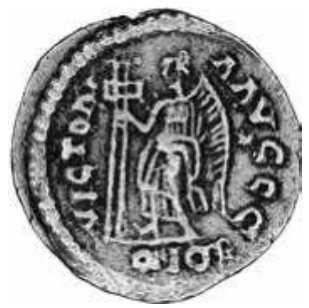

Fig. 12.1 Reverse of a Visigothic tremissis of Theodoric II or Euric in the name of Libius Severus (461-465). @ Bibliothèque Nationale de France Paris.

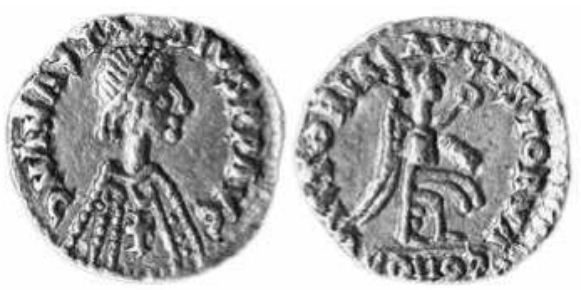

Fig. 12.2 Visigothic tremissis in the name of Anastasius, with pectoral cross. ๑ British Museum, inv. no. $1860,0330.1034$.

during the reign of Alaric II (Fig. 12.2). ${ }^{8}$ The earliest Visigothic tremissis bearing this type carry the name of Emperor Anastasius (491-518), whose rule encompassed the reigns of Alaric II (484-507), Gesaleic (507-510), and Amalaric $(510-526)$, the latter under the regency of Theodoric 'the Ostrogoth' (489/93-526). The new typology appeared only on Visigothic tremissis and lasted approximately a century. However, during this period the type was to evolve substantially, and ended looking like a sort of cicada, including antlers, wings, and six legs. It has been argued recently that this may be intentional, the cicada being traditional in barbarian iconography. ${ }^{9}$ My opinion is that the Visigoths chose this iconography due to its links with Valens, the emperor who opened the frontiers of the empire to them in 376 , allowing them to settle in the abandoned province of Thrace. ${ }^{10}$ In this regard, the type was yet another allusion to the Visigoths' legitimacy as heirs of the empire.

In contrast with the previous series, the Victory and wreath type was successful among other peoples, especially Burgundians and Franks. Perhaps

8 Some authors do not agree with this attribution; see the discussion in Pliego, in press.

9 Pliego, in press.

10 Pliego 2009, vol. 1, p. 78. This idea, although contemplated by Tomasini 1964, p. 64, was not assumed by him. 
for this reason, the Visigothic series showed another change, this time on the obverse: the introduction of the pectoral cross (observe of Fig. 12.2). ${ }^{11}$ It is likely that this was added later, in order to distinguish the type from those issued elsewhere. Within the framework of a Roman type with possible implications, the addition of the sign of the cross was a decisive step towards the adoption of a Christian symbolism, which was to become dominant in the following century.

\section{The reign of Liuvigild and monarchy as symbol of Visigothic power}

The most significant feature of Visigothic gold coinage is its close links with the monarchy. ${ }^{12}$ Visigothic coinage was always issued by the crown; this already appears to have been the case during the 'imitative' period but becomes clear from the beginning of Liuvigild's role as sole ruler (c.572-586). In contrast with other states, in the Visigothic kingdom no gold coinage was issued by anyone other than the king, and all the series invariably carried the name of the king and the title Rex. This innovation was for the most part simultaneous with the beginning of the practice of including the name of the mint in the legend. Together, they represent the foundations of the Visigothic monarchical power: the king and the territory, the rex and the patria. ${ }^{13}$ The new numismatic formula alludes to an institution, the monarchy, with the king at its head, now an autonomous ruler independent from the empire. But this royal authority, at its centre, needed the local powers to exercise their authority as delegates of the king. ${ }^{14}$ The, sometimes precarious, equilibrium between powers was to mark the evolution of the Visigothic state. ${ }^{15}$

Concerning coin types, romanitas, the primary symbol of the association of the Visigoths and the empire, was not abandoned, but evolved over time. Nearly a century after the collapse of Roman authority in the west,

On the institution of the monarchy, see Díaz Martínez 1998.

13 Gens, patria et Rex, as the three pillars on which Visigoth power rests, is evident in the IV Council of Toledo (633). See Velázquez Soriano 2003, p. 196; Wood 2012, p. 6. However, the allusion to the gens, unlike the coinage of other kingdoms, not only does not occur in the Visigoth coin, but is rare in its official documentation (about this, see Pliego, in press).

14 For the negotiated relationship between central and local power see Castellanos García and Viso 2005. See also Koon and Wood 2009; Wood 2015.

15 See Koon and Wood 2009. 
the image of the empire changed substantially. Despite his open conflict with the emperor, after the Byzantine occupation of Visigothic territories in the Iberian Peninsula, Liuvigild's earliest series followed the previous monetary policies, issuing coins in the name of the reigning emperor, Justin II, sometimes, illegible. ${ }^{16}$ The first sign of change was the inclusion of the king's name on the coins. However, this innovation was followed by the substitution the Victory-cicada by a type introduced by Tiberius II ( $578-580)$, the new Byzantine emperor, the cross on steps (Fig. 12.3). ${ }^{17}$ This typology (on the reverse), lasted no more than five years, being replaced by the traditional bust with diadem on both reverse and obverse around 584 . Therefore, the final years of Liuvigild's reign witnessed the systematization of Visigothic coinage at all levels: metrological, with the weight of the Visigothic tremissis adapted to the official Roman-Byzantine standard of $1.516 \mathrm{~g},{ }^{18}$ epigraphic, with the clear message conveyed by the name of the monarch along with the title Rex on the obverse, and the name of the mint on the reverse; and typological, with the representation of the frontal bust of the monarch on both obverse and reverse.

With this new type, the Visigothic king was represented on coins as splendidly as he was described in the writings of Isidore of Seville ${ }^{19}$ and, later, Julian of Toledo. ${ }^{20}$ Isidore wrote that Liuvigild was the first king to adopt the Roman-Byzantine ceremonial and garments. ${ }^{21}$ Both literary and numismatic sources have been interpreted merely as the expression of typological imitation, without further implications. ${ }^{22}$ While the texts have been analysed intensely, although unevenly, the numismatic approach to this phenomenon has been superficial. In this regard, the most significant feature of this new type with the royal bust on both

16 There is a series with an illegible legend ('Curru series'), which seems to be intentional trying to avoid the name of the rival emperor, Justin II. (see Tomasini 1964, p. 126).

17 Tomasini 1964 , p. 63 , states that when the 'Victory and wreath' type 'is retired from the currency of Liuvigild, it is because it is no longer a symbol of the power of Rome. The only power in Rome is the pope, and his symbol is the cross'.

18 See Grierson 1953, p. 81.

19 Isidor of Seville, Sententiae, 3.48.6: 'But those who exercise badly their royalty behind sumptuous garments [...]'; see Valverde Castro 2015, p. 73 .

20 Julian of Toledo, Historia Wambae regis, 4: 'When he (King Wamba) had arrived there [...] he stood resplendent in his regalia'.

21 'Primus que etiam inter suos regali veste opertus in solio resedit' (Isidore of Seville, Etymologiae, 18.2-5, and 19.24.2.9, and 30.1; Isidore of Seville, Historia de Regibus Gothorum, Wandalorum et Sueborum, 51.258). However, Sidonius Apollinaris (Epistolae, I.2.4) already described the adoption of imperial pomp in recounting the way of life of Theodoric II (453-466).

22 Bloch 1924, pp. 461 seqq.; MacCormack 1981, p. 48; Arce 2011, p. 72. Cf. Reydellet 1981, pp. 532-534; McCormick 1990, pp. 298-299. See discussion in Arce 2011, pp. 59 seqq. 


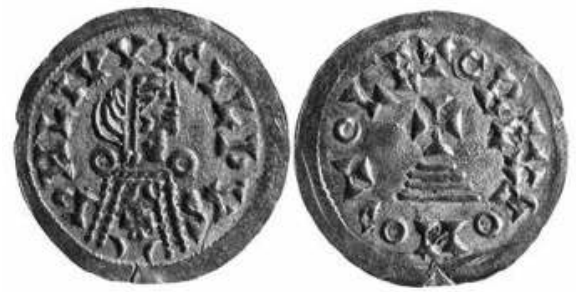

Fig. 12.3 Liuvigild of Toledo, c.580-582. @ Mérida Hoard, Consejo Superior de Investigaciones Científicas Mérida.

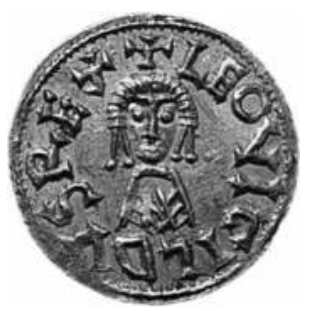

Fig. 12.4 Obverse of a tremissis of Liuvigild (Tarracona), post-584. @ American Numismatic Society, New York.

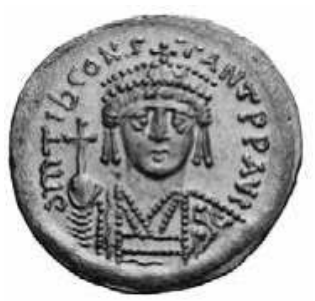

Fig. 12.5 Obverse of a solidus of Tiberius II Constantine (578-582). ๑ private collection.

obverse and reverse was the open representation of the monarch with a closed crown (Fig. 12.4), a stemma introduced by Tiberius II in his coins (Fig. 12.5). This type was to remain unchanged until the end of the reign of Chindaswinth (649).

\section{Regnum et ecclesia: The sacred nature of the Visigothic monarchy}

As previously noted, Christianity played a central role in the origin and development of early rent medieval monarchies. The earliest apparent identification between regnum et ecclesia is to be found in the works of Isidore of Seville (d. 636), who placed the monarchy in the centre of the religious and political integration of the Visigothic reign. ${ }^{23}$ Luivigild had already invested great efforts to unify the kingdom politically. ${ }^{24}$ Although an Arian, Liuvigild was convinced of his own orthodoxy and Iohannis

23 Wood 2012, p. 5; 2013, p. 148.

24 However, the relationship between king and church can be traced back to the Toulousian period of the Visigothic kingdom (see Koon and Wood 2009, p. 794). 
Biclarensis declared that 'Liuvigild held that his was the Catholic Faith'25. Liuvigild had no problem in adopting the 'cross on steps' iconography on the reverse of one of his series of tremissis, ${ }^{26}$ a symbol that was to become the most commonly used throughout the whole Visigothic period, placing the legend along the central vertical axis. From a numismatic perspective, the period that followed the conversion of Reccared I (589) to the Nicene orthodoxy, until the end of the reign of Chindaswinth (649), was marked by the relatively homogenous typology of the bust introduced byLiuvigild $c .584$.

In comparison, the period that began with the joint reign of Chindaswinth and Recceswinth (649-653) was marked by numerous numismatic innovations, which reflect political changes. On the one hand, policies attempted to strengthen the monarchy by stressing its Catholicism, signalled by anti-Semitic measures instituted by Recceswinth and Erwig. ${ }^{27}$ On the other hand, the rebellion of Paulus against Wamba, and the convulsive final years of the Visigothic kingdom, during which up to three different sides could disputed the throne, likely had a reflection on numismatic typologies.

\section{The numismatic symbols of sacred power}

During the reign of Recceswinth, it became obvious that conversion to the Nicene orthodoxy, from 589 onwards, had not brought about the desired unification of elites under Catholicism. This realization was followed by the enactment of a series of laws intended to regulate the role of Jews in this Catholic kingdom. ${ }^{28}$ Symbolically, the new period inaugurated by Recceswinth was marked by the recovery of the 'cross on steps', which was to remain the main type on the reverse of the coins until the end of the Visigothic period. Other significant changes were to take place from the reign of Wamba (672-680) onwards. After the period of relative homogeneity that followed Liuvigild's last monetary reform, with the representation of the bust on both obverse and reverse (584-649), during Wamba's time, the empire, and official Byzantine models, again became a primary reference. Probably, by this time, explicitly stressing the relationship between Visigoths and the Roman Empire was no longer considered necessary, even if the Byzantine

25 See Hillgarth 1966, p. 489, n. 121. John of Biclar, Chronica a. DLXVII-DXC, 580.2: De Romana religione ad nostram catholicam fidem [...].

26 Abandoned c.584, it was recovered in times of the reign of Recceswinth $\left(653^{-672}\right)$ until the end of the period.

27 Koon and Wood 2009.

28 Phillips 2013, p. 85 . 


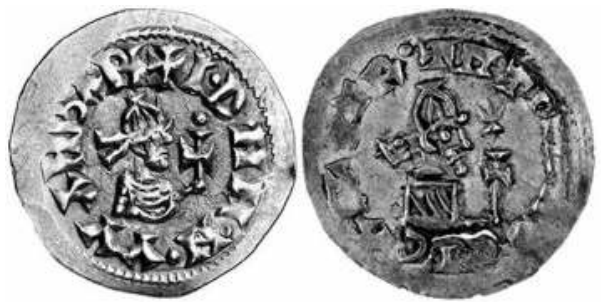

Fig. 12.6 Visigothic crowns: obverse of a tremissis of Wamba of Toledo and obverse of a tremissis of Egica of Toledo. @ Private collection and Numismatic Society of America, New York.

Empire was the subject of animosity, according to Isidore's testimony. ${ }^{29}$ Imperial symbols were adopted openly, which were regarded as a common Roman heritage which the Byzantines had no exclusive claim.

If the cross was the main Christian symbol, the crown was the main emblem of sovereign power. Although the crown had already been adopted by Liuvigild, its symbolism in coinage became especially significant around the mid-seventh century. Some authors are reluctant to accept that the Visigothic kings adopted the imperial insignia, especially the use of crowns, due to the close link of these with the coronation ceremonies..$^{30}$ However, even a cursory glance at the Visigothic monetary corpus suffices to confirm that Visigothic kings were represented with crowns on coins from a very early date..$^{31}$ The symbolism of the crown gained its full meaning in the context of the event of the royal anointment of Wamba in Toledo in 672 or $673,{ }^{32}$ after his military victory over Paulus (Fig 12.6).33

Stylistically, crowns evolved over time; 34 the symbolism of the crown and its relationship with religious power can be appreciated in a rare series from Mentesa, dated to Egica's reign, in which the obverse carries a stemma, topped by a cross but without the bust (Fig. 12.7). ${ }^{35}$ On the other hand, despite the obvious Byzantine association, Visigothic coinage also developed an original type of crown, present in the few coins known to have been issued during the reign of Roderic (711; Fig. 12.8). ${ }^{36}$ In this type, the bearded

\footnotetext{
29 Wood 2013.

30 Principally King 2006, p. 48, and Arce 2011, p. 68.

31 Facing this position, Elze 1976, pp. 570-576.

32 See Martin 2008, p. 294.

33 López Sánchez 2009, pp. 176-177. This author identifies Wamba's headdress with a helmet type spangenhelm.

34 See Pliego, in press.

35 Pliego 2009, vol. 2, no. 676d; Pliego 2011, p. 330, fig. 15.

36 On this typology and its relation to the representation of Roderic in the frescoes of the Umayyad baths of Qusayr 'Amra, see Pliego, in press.
} 


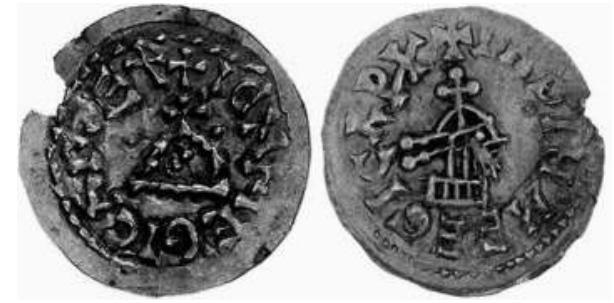

Fig. 12.7 Visigothic crowns: obverse of a tremissis of Egica (Mentesa) and obverse of a tremissis of Egica (Córdoba) with crown topped by cross. ( ) Royal Coin Cabinet Stockholm and American Numismatic Society, New York.

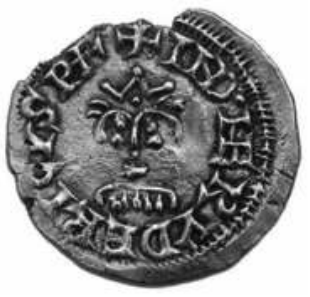

Fig. 12.8 Visigothic crowns: obverse of a tremissis of Roderic (Egitania). @ Museo de Conimbriga.

monarch is depicted frontally, covered by what looks like a bicorne and pointed crown. We have a nearly contemporary representation in which that kind of bicorny crown is associated with power. In a fresco painting in the Umayyad baths of Qusayr 'Amra, in the Jordan desert, dated to between 720 and 724 , the reign of Yazid ibn Al-Malik, the six kings defeated by the Umayyad Empire are represented. In this fresco, Roderic is represented alongside other important characters, such as the Byzantine emperor, the Abyssinian Negus, and Cosroes, king of the Sasanians. Although the character represented below the name 'Roderikos' is badly preserved, a closed crown can be discerned. But the character portrayed under the name 'Cosroes' seems to be wearing a horned crown. ${ }^{37}$ Also in the Codex Vigilanus or Albeldense, currently in the library of El Escorial and dated to the tenth century, several Visigothic kings are represented wearing a similar piece of headwear. ${ }^{3}$

There are no numismatic parallels from the same period, although the relationship between horns and potentia goes back to antiquity. ${ }^{39}$ Images in which Alexander was represented with horns must have been known in the early Middle Ages. Although, in general, these attributes represent the wearer as a warrior, we must also remember the medieval iconographic representations of 'horned' Moses, recalling the description of the prophet in the Old Testament, ${ }^{40}$ including some from the Iberian Peninsula. ${ }^{41}$ The convulsive ending of the Visigothic kingdom has been presented as a conflict

On this subject, see Pliego, in press.

38 Considered the oldest representation of Visigothic kings, see Silva Verástegui 1986.

39 Also in the Iberian Peninsula, as shown by the decorated stelae of the Final Bronze Age (see Torres Ortiz 1999, pp. 29 seqq.).

40 Exodus 34:30.

41 Mellinkoff 1970, p. 70. 
between three factions. ${ }^{42}$ This probably contributed to stressing the military nature of Roderic's rule and its iconographic representations on its coins can be understood in a contemporary stylistic trend, as shown by a fresco located in the heart of the Umayyad Empire whether it belongs to Roderic or not. This iconography may have been adopted later by the Christian kings that launched against al-Andalus.

The sceptre is another controversial symbol. Like crowns and other royal paraphernalia, some authors have rejected its iconographic use during this period. ${ }^{43}$ This element has its origins in the Roman consular sceptre, which eventually became the symbol of the emperor's faith in Christ. ${ }^{44}$ The cruciform sceptre - held in the king's right hand - appears in Visigothic coins during the reign of Wamba, and has been interpreted by some authors as a processional Victory cross, ${ }^{45}$ considered different from the sceptre. ${ }^{46}$ Hendy argued that the term sceptrum/skeptron must have embraced a whole range of 'items of insignia and so on', the common denominator of which was a long handle, and that looking for exact correspondence in ancient terminology was futile. Hendy emphasizes two possible identifications; 'the labarum, and what might best be termed the processional cross'. ${ }^{47}$ In the same sense, Grierson pointed out that, until the eleventh century, sceptres seem to have played a minor role in Byzantine ritual, although both the model topped by a cross and that decorated with an eagle, which is also represented in Byzantine coins, remained in use throughout the seventh century. ${ }^{48}$

The Visigothic processional cross must also have been used as army standard, as in the Byzantine Empire. It is likely that the processional cross represented this role for the first time in Wamba's ${ }^{49}$ series; according to the Liber Ordinum, the cross was used in the ceremonies celebrated in the basilica Praetoriensis in Toledo, dedicated to the apostles Peter and Paul,,$^{50}$ which probably explains the link between the type and the mint of Toleto. The typology is symbolic since this basilica witnessed not only Wamba's unction, but was also the place where the standard with the cross was presented before

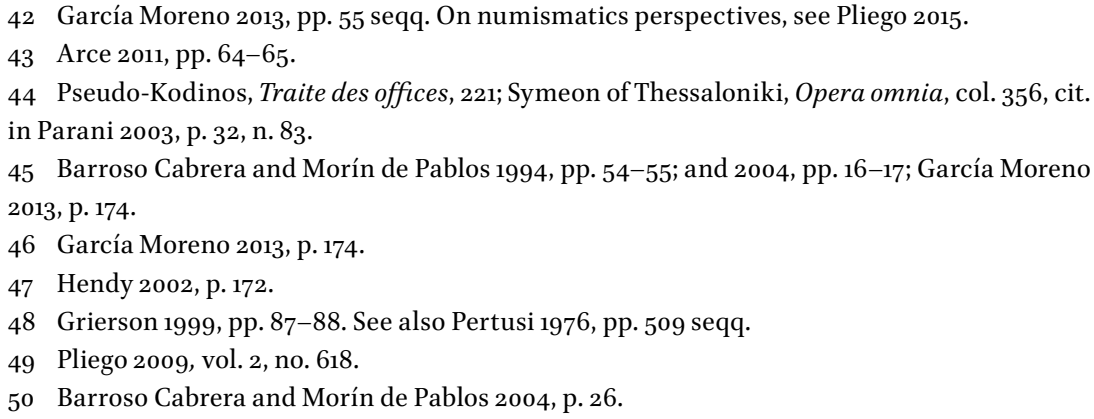


military campaigns..$^{51}$ This typology of Wamba would celebrate the victory over Paulus' attempted usurpation and secession. Later monarchs also used the sceptre in monetary series, especially during the reign of Egica (see Fig. 12.6) and the joint reign of this king with his son, Witiza $\left(695^{-702}\right)$, in which both monarchs are presented holding the item..$^{2}$ The rare examples issued by the almost unknown Suniefred in Toleto, probably after Wittiza's death, ${ }^{53}$ stand as a suggestive, although ineffective, symbol of legitimacy, before Roderic's attempts on the one hand to grasp the Visigothic throne and Agila II's secessionist policies in the northeast, on the other. ${ }^{54}$ In my opinion, the sceptre is another symbol of monarchical and religious power, which reached its zenith during this period. Given how important symbols were during Wamba's reign, I find no reason to believe that the sceptre was represented but also used.

In addition to these, other symbols became common during Wamba's reign, some of which had been used previously, generally in legends as space fillers. This includes vegetal symbols such as trees - or branches - and especially the fleur-de-lis, depicted on the coin's field on the obverse next to the bust or crowning the sceptre (see Fig. 12.6), and in the reverse flanking the cross on steps. ${ }^{55}$

Although the use of the fleur-de-lis became common in the Iberian Peninsula in later medieval coinage, ${ }^{6}$ its origins can be traced back to the Visigothic period. ${ }^{57}$ This symbol is related to the Tree of Jesse - father of David - described in Isaiah 11. If the Visigothic royalty considered themselves heirs of the Old Testament's kings, it seems logical that they would have borrowed symbols like the fleur-de-lis, which represents Christ as the perfect king. This is the first image in which a king is represented in association with the fleur-de-lis, symbol of divine royalty. ${ }^{8}$

51 García Moreno 2013, p. 174.

$5^{2}$ In the Chronicle of 754 (e.g. p. 16), the formula susceptit sceptra is common in describing the ascent to the throne. We have a representation of this type of cross in the reliefs of Quintanilla de las Viñas, as well as in the representation of the monarchs in the Codex Albeldense (see Silva Verástegui 1986).

53 Pliego 2009, vol. 2, no. 712a-b.

54 See García Moreno 2013, pp. 135-175.

55 But there are some exceptions: in Ispali under Chintila ruler the fleur-de-lis appears flanking the reverse type and also with Tulga in Egitania.

56 Mateu y Llopis 1969.

57 The fleur-de-lis appears in other architectural elements such as in the Visigoth church of Santa María de Melque (Toledo), where remains of stucco decoration with this motif are conserved.

$5^{8}$ The adoption of the fleur-de-lis by the French monarchy apparently occurred in the Carolingian period when Charles 'the Bald' placed this symbol on his scepter (Van Malderghem 1894, p. 205), although it did not appear on the coin until the thirteenth century. The enormous 


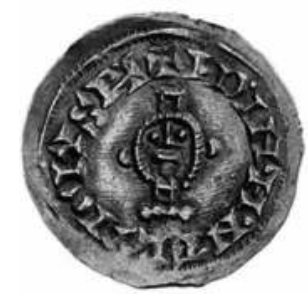

Fig. 12.9 Visigothic crowns: obverse of a tremissis of Erwig (Emerita). @ Royal Coin Cabinet Stockholm.

\section{Christ's power in the coins of the final decades of the regnum}

Erwig's reign (680-687), like Wamba's, was characterized by significant changes in the symbolism conveyed by its coinage. Among a varied typology of busts, bearded and beardless, frontal and profile, with and without sceptre, with open or closed crown, Erwig introduced a novel typology: the 'majestic Christ' bust, with a cruciform halo around his head. The fact that this type was introduced by the mint of Emerita, one of the regnum's most important cities, must mean that it had been inaugurated in that city at the beginning of Erwig's reign (680). This new type coincided with the enactment of anti-Semitic laws, which suggests that the monarchy was emphasizing its religious role. The type had little impact in other mints during Erwig's reign (Fig. 12.9),59 but became much more common during Egica's subsequent rule (687-702).

The same type was introduced to Byzantine coinage by Justinian II, who

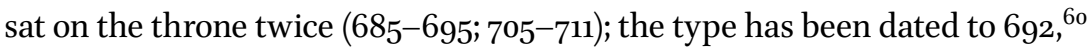
in relation to canon 83 of the Council of Trullo. ${ }^{61}$ Therefore, Erwig was the first Christian monarch to use the image of Christ Pantocrator on his coinage. ${ }^{62}$ Some authors have seen Christ's face in series issued in other kingdoms, for instance a Merovingian tremissis from Aventicum (Avenches, Switzerland), dated $c .625,{ }^{63}$ and by others in reference to a rare Anglo-Saxon coin dated to the first half of

influence exerted on the Frankish court by Visigoth intellectuals exiled after the Arab conquest of the peninsula must have played an important role in this adoption (see García Moreno 1992; Riché 1992).

59 Only in the mints of Elvora and Córdoba but not as an exclusively type. It is not possible to confirm whether the typology showing the rare Valentia specimen is intended to represent Christ (Pliego 2009, vol. 2, no. 639).

6 o Breckenridge 1959, pp. 86-87; cit. Grierson 1999, p. 570. Recently, Travaini 2015, pp. 68-69.

61 See discussion in Pliego, in press.

62 Grierson 1976, pp. 626-627, has already noticed this Visigothic rarity. See Pliego 2013; see also 2019 .

63 Travaini 2003. 


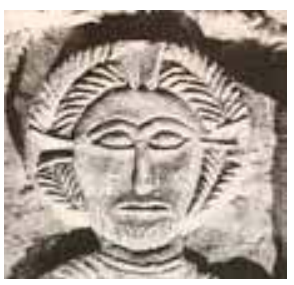

Fig. 12.10 The image of Christ: relief of Christ with a nimb, church of Quintanilla de las Viñas (Burgos). @ Jorge Morín de Pablos.

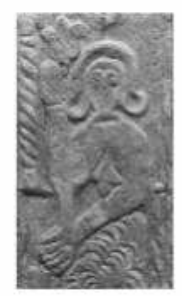

Fig. 12.11 The image of Christ: Placa de las Tamujas (Malpica, Toledo). ๑ Jorge Morín de Pablos.

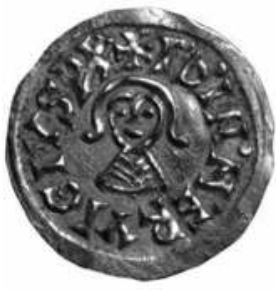

Fig. 12.12 Obverse of a tremissis of Erwig (Córdoba). ( Museo Prasa.

the eighth century ${ }^{64}$ However, both of these coins, whose typologies are not so obviously allusive to Christ, would represent, according to their authors, the image of the Edessa shroud or mandelion not that of the Pantocrator.

Coeval representations of Christ Pantocrator include one in the church of San Pedro de la Nave (Campillos, Zamora), and another in Santa María, in Quintanilla de las Viñas (Burgos). For several authors the figure depicted in the relief of Tamujas (Malpica, Toledo) is without doubt that of Christ. ${ }^{65}$ The image, however, differs from previous models - it has long hair, curled towards the ends - and appears in the company of several elements that could be interpreted as fleurs-de-lis. In Ispali, Erwig used a type that resembles the relief from Tamujas, ${ }^{66}$ which was likely emulated in the mint of Córdoba (Figs. 12.10, 12.11, and 12.12). The rarity of the type and its similarity to the relief leads us to consider that this could be another monetary representation of Christ in the Visigothic coinage.

\section{The eagle: symbol of power during the reign of Agila II}

The traditional lineal account of the end of the Visigothic kingdom, with Roderic and his successor Pelagio as main protagonists, is interrupted by that of Suniefred and Agila II. The role of Suniefred in the final moments of the Visigothic kingdom ${ }^{67}$ is suggested solely by numismatic evidence, ${ }^{68}$ while

64 Stewartby and Metcalf 2007; see also Gannon 2011.

65 Barroso Cabrera and Morín de Pablos 1994, p. 45, passim; 2004.

66 Pliego 2009, vol. 2, no. 642.

67 Yet it is defended by García Moreno 2013, pp. 157 seqq.

68 García Moreno 2013, pp. 155 seqq.; Pliego 2015. 


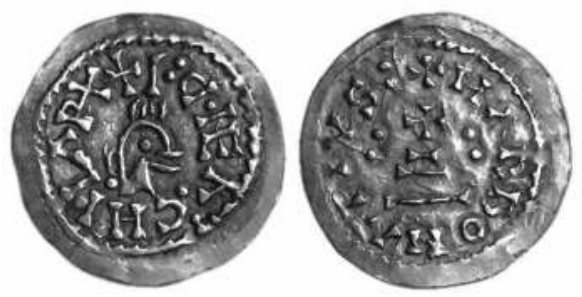

Fig. 12.13 Tremissis of Agila Il of Narbona. @ Museo Arqueológico Nacional Madrid.

the documentation for Agila II is more solid. Agila's name is mentioned in the Codex Parisinus 4667 of the Laterculus Regum Visigothorum, ${ }^{69}$ not only in a small but nevertheless highly descriptive group of coins. Several series by this monarch are known from mints in Tarraconensis - Cesaragusta, Gerunda, and Tarracona - in addition to Narbonne. ${ }^{70}$ This seems to confirm Ahmad al-Razi's late report ${ }^{71}$ that this king ruled over the northeast of the Iberian Peninsula. ${ }^{72}$

Most of the types used by Agila II reproduce former models. One series from Narbonne, however, which represents what looks like a bird, has been interpreted as alluding to the king's name (Fig. 12.13). ${ }^{73}$ The use of the eagle as a symbol of political power must have been familiar to the issuer, as well as the users of these coins. Although eagles had enormous political and military implications for the Roman state, the symbolism is much older and could have reached the Visigoths through a multitude of channels. ${ }^{74}$ Eagles are frequently represented in Visigothic art, especially in the form of eagle-shaped fibulae. ${ }^{75}$ The type has no precedent as far as coins are concerned, and suggests, as with Roderic's coin series, that Visigothic coinage was beginning to follow its own path, apart from imperial models.

\section{Conclusion}

The expression of power in coinage changed at the same pace as the regnum itself. Beginning with attempts to legitimize the monarchy by emphasizing

69 Conserved in the Bibliothèque Nationale de France.

70 See Pliego 2009, vol. 2, nos. 795-799; on these issues, see Pliego 2015.

71 Also recorded by Saavedra 1892, pp. 27-28.

72 Although both in this late source and in others, mention is made of the sons of Wittiza, García Moreno 2013, pp. 136, 138, and 161-162, denies this filiation.

73 Pliego, in press.

74 See Wittkower 1939.

75 See Santa-Olalla 1940. 
links with the Roman Empire, the Visigoths used all of the symbols imperial power afforded. From the early adoption of the cross, both in the legends and in main types - first the pectoral cross in pseudo-imperial series, followed by the 'cross on steps' type - to the crown and the sceptre, these attributes symbolize the sacred dimension of royal power. Some of these elements become especially prominent during the reign of Recceswinth, due to the greater emphasis on the Catholic nature of his rule. The political context of Wamba's reign, with Paulus's revolt and the symbolic projection of royal coronation and unction, is also reflected on coinage, with the profusion of closed crowns, sceptres, and fleurs-de-lis. When Erwig adopted the Christ Pantocrator type in the city of Mérida, he may have been anxious to express, like Recceswinth, the sacred nature of his rule and its legitimacy - given the dubious means used to expel Wamba from the throne. This was an important innovation in the wider framework of post-Roman monarchies. The most important changes, however, took place in the last years of the regnum, when Roderic appears represented with the bicorne crown, and when Agila II used the typology of the eagle with an enormous symbolism that also could allude to his own name as a punning type.

\section{Bibliography}

\section{Primary sources}

Chronicle of 754 = Crónica mozárabe de 754: continuatio Isidoriana Hispana, ed. by José Eduardo López Pereira (León: Centro de Estudios e Investigación 'San Isidoro', 2009).

Isidore of Seville, Etymologiae = Etimologías, ed. by José Oroz-Reta and Manuel Antonio Marcos Casquero (Madrid: Biblioteca de Autores Cristianos, 2004).

- Historia de Regibus Gothorum, Wandalorum et Sueborum = Las historias de los godos, vándalos y suevos de Isidoro de Sevilla, ed. by Cristóbal Rodríguez Alonso (León: Centro de Estudios e Investigación 'San Isidoro', 1975).

- Sententia = Isidorus hispalensis sententiae, ed. by Pierre Cazier (Turnhout: Brepols, Corpus Christianorum, Series Latina 111, 1998).

John of Biclar, Chronica a. DLXVII-DXC, in Chronica minora, 3 vols., vol. 2, ed.

by Theodor Mommsen (Berlin: Monumenta Germaniae Historica, Auctores Antiquissimi 11), pp. 163-207.

Julian of Toledo, Historia Wambae regis = The Story of Wamba: Julian of Toledo's Historia Wambae Regis, ed. by Joaquín Martínez Pizarro (Washington: Catholic University of America Press, 2005). 
Pseudo-Kodinos, Traite des offices = Pseudo-Kodinos: introduction, texte et traduction, ed. by Jean Verpeaux (Paris: Éditions du Centre National de la Recherche Scientifique, 1966).

Sidonius Apollinaris, Epistolae = Epistolae et carminae, ed. by Christian Lütjohann (Berlin: Monumenta Germaniae Historica, Auctores Antiquissimi 8, 1961 [1887]). Symeon of Thessaloniki, Opera omnia, ed. by Jaques-Paul Migne (Paris: Brepols, Patrologia Graeca 155, 1866).

\section{Secondary sources}

Arce, Javier, Esperando a los árabes: los visigodos en Hispania (507-711 A.D.) (Madrid: Marcial Pons, 2011).

Barroso Cabrera, Rafael, and Jorge Morín de Pablos, 'Dos relieves de época visigoda como representación figurada: la placa de Las Tamujas y la de Narbona', Anales Toledanos 31 (1994), pp. 41-64.

-, 'Imagen soberana y unción regia en el reino visigodo de Toledo', Codex aquilarensis: cuadernos de investigación del Monasterio de Santa María la Real 20 (2004), pp. 6-65.

Bendix, Reinhard, Kings or People: Power and the Mandate to Rule (California: University of California Press, 1980).

Bloch, Marc, Les rois thaumaturges: étude sur le caractère surnatural attribué à la puissance royale particulierement en France et en Angleterre (Strasbourg: Istra, 1924).

Breckenridge, James Douglas, The Numismatic Iconography ofJustinian II (685-695, 705-711 AD) (New York: American Numismatic Society, 1959).

Castellanos García, Santiago, and Iñaki Martín Viso, 'The Local Articulation of Central Power in the North of the Iberian Peninsula (500-1000)', Early Medieval Europe 13.1 (2005), pp. 1-42.

Díaz Martínez, Pablo de la Cruz, 'Rey y poder en la monarquía visigoda', Iberia: Revista de la Antigüedad 1 (1998), pp. 175-196.

Drews, Wolfram, The Unknown Neighbour: The Jew in the Thought of Isidore of Seville (Leiden: Brill, 2006).

Elze, Reinhard, 'Insigne del potere sovrano e delegato in Occidente', in Simboli e simbologie nell'alto medioevo (Spoleto: Centro Italiano di Studi sull'Alto Medioevo, Settimana di Studio del Centro Italiano di Studi sull'Alto Medioevo 23, 1976), pp. 569-593.

Gannon, Anna, 'Coins, Images and Tales from the Holy Land: Questions of Theology and Orthodoxy: New Perspectives', Studies in Early Medieval Coinage 2 (2011), pp. 88-103. García Moreno, Luís Agustín, 'El estado protofeudal visigodo: precedente y modelo para la Europa carolingia', in L'Europe héritière de l'Espagne wisigothique, ed. 
by Jacques Fontaine and Christine Pellistrandi (Madrid: Collection de la Casa de Velázquez 35, 1992), pp. 17-43.

, España 702-719: la conquista musulmana (Seville: Editorial Universidad de Sevilla, Historia y Geografía 244, 2013).

Gerth, Hans Heinrich, and Charles Wright Mills, From Max Weber: Essays in Sociology (London: Routledge, 2014).

Grierson, Philip, 'Visigothic Metrology', Numismatic Chronicle, ser. 6, 13 (1953), pp. $74-87$.

— , 'Symbolism in Early Medieval Charters and Coins', in Simboli e simbologia nell'alto medioevo (Spoleto: Centro Italiano di Studi sull'Alto Medioevo, Settimane di Studio del Centro Italiano di Studi sull'Alto Medioevo 23, 1976), pp. 601-640.

- Catalogue of the Byzantine Coins in the Dumbarton Oaks Collection and in the Whittemore Collection: 1258-1453, 5 vols., vol. 5: Michael VIII to Constantine XI (Harvard: Dumbarton Oaks, 1999).

Grierson, Philip, and Mark Blackburn, Medieval European Coinage, vol. 1: The Early Middle Ages (Fifth to Tenth Centuries) (Cambridge: Cambridge University Press, 1986).

Hall, Stuart, 'Foucault: Power, Knowledge and Discourse', in Discourse Theory and Practice: a Reader, ed. by Margaret Wetherell, Stephen Taylor, and Simeon J. Yates (London: Sage, 2001), pp. 73-81.

Hendy, Michael F., Catalogue of the Byzantine Coins in the Dumbarton Oaks Collection and in the Whittemore Collection, 5 vols., vol. 4: Alexius I to Michael VIII, 1081-1261, pt. 2: The Emperors of Nicaea and their Contemporaries (Harvard: Dumbarton Oaks, 2002).

Hillgarth, Jocelyn N., 'Coins and Chronicles: Propaganda in Sixth-Century Spain and the Byzantine Background', Historia 15 (1966), pp. 483-508.

King, Paul David, Law and Society in the Visigothic Kingdom (Cambridge: Cambridge University Press, 2006).

Koon, Sam, and Jamie Wood, 'Unity from Disunity: Law, Rhetoric and Power in the Visigothic Kingdom', European Review of History/Revue Européenne d'Histoire 16.6 (2009), pp. 793-808.

López Sánchez, Fernando, 'La moneda del reino visigodo de Toledo: ¿por qué? ¿para quién?', Mainake 31 (2009), pp. 175-186.

McCormick, Michael, Eternal Victory: Triumphal Rulership in Late Antiquity, Byzantium and the Early Medieval West, 2nd ed. (Cambridge: Cambridge University Press, 1990).

MacCormack, Sabine, Art and Ceremony in Late Antiquity (Berkeley/Los Angeles/ London: University of California Press, 1981).

Martin, Céline, 'L'Innovation politique dans le royaume de Tolède: le sacre du souverain', in Élections et pouvoirs politiques du VII ${ }^{e}$ au XVII e siècle, ed. by Corinne Péneau (Bordeaux: Éditions Bière, 2008), pp. 281-300. 
Martínez de Santa-Olalla, Julio, 'Nuevas fíbulas aquiliformes hispanovisigodas', Archivo Español de Arqueología 14.40 (1940), pp. 33-54.

Mateu y Llopis, Felipe, 'El "arbor ad modum floris" en dineros de Cataluña, Navarra, Aragón y Valencia, siglos X a XIII', Príncipe de Viana 30.116 (1969), pp. $245^{-254}$.

Mellinkoff, Ruth, The Horned Moses in Medieval Art and Thought (Berkley/Los Angeles/London: University of California Press, 1970).

Navarro, Zander, 'In Search of a Cultural Interpretation of Power: the Contribution of Pierre Bourdieu', IDS Bulletin 37.6 (2006), pp. 11-22.

Parani, Maria G., Reconstructing the Reality of Images: Byzantine Material Culture and Religious Iconography 11th-15th Centuries (Leiden: Brill, 2003).

Pertusi, Agostino, 'Insegne del potere sovrano e delegato a Bisanzio e nei paesi di influenza bizantina', in Simboli e simbologie nell'alto medioevo (Spoleto: Centro Italiano di Studi sull'Alto Medioevo, Settimana di Studio del Centro Italiano di Studi sull'Alto Medioevo 23, 1976), pp. 481-563.

Phillips, Jonathan, “The Perfidy of the Jews": Visigothic Law and the Catholic Public Sphere', Anthós 5.1 (2013), pp. 81-96.

Pliego, Ruth, La moneda visigoda, 2 vols. (Seville: Editorial Universidad de Sevilla, Historia y Geografía 159, 2009).

—_ 'La moneda en el ocaso del reino godo de Hispania', in 711: Arqueología e historia entre dos mundos, ed. by Luís Agustín García Moreno and Alfonso VigilEscalera (Alcalá de Henares: Museo Arqueológico Regional, Zona Arqueológica 15.2, 2011), pp. 321-337.

— , 'El origen de la representación de Cristo en la moneda del rey visigodo Ervigio (68o-687)', Numismatica e Antichità Classiche: Quaderni Ticinesi 42 (2013), pp. 251-264.

—_, 'El tremis de los últimos años del reino visigodo (702-714)', in Monnaies du haut Moyen Âge: histoire et archéologie (péninsule Ibérique, Maghreb - VII $-X I^{e}$ siècle), ed. by Phillippe Sénac and Sébastian Gasc (Toulouse: Presses Universitaires du Midi, 2015), pp. 17-58.

_ their coinage', in Coinage and Economy of the Early Medieval Mediterranean, ed. by Michael Kelly and Andrew Kurt (New York: Punctum Books), in press.

Reydellet, Marc, La royauté dans la littérature latine de Sidoine Apollinaire à Isidore de Séville (Rome: Écoles Françaises d'Athènes et de Rome, 1981).

Riché, Pierre, 'Les réfugiés wisigoths dans le monde carolingien', in L'Europe héritière de l'Espagne wisigothique, ed. by Jacques Fontaine and Christine Pellistrandi (Madrid: Collection de la Casa de Velázquez 35, 1992), pp. 177-183.

Saavedra, Eduardo, Estudio sobre la invasión de los árabes en España (Madrid: El Progreso Editorial, 1892). 
Silva Verástegui, Soledad, 'La más antigua iconografía medieval de los reyes visigodos', in Los visigodos: historia y civilización, antigüedad y cristianismo 3 (1986), pp. 537-558.

Steinbach, Sebastian, Imitation, Innovation und Imperialisierung - Geldwesen und Münzprägung als wirtschaftshistorische Quellen zur ethnischen Identität und Herrschaftsorganisation des spanischen Westgotenreiches (Münster: LIT, 2017).

Stewartby, Lord, and David Michael Metcalf, 'The Bust of Christ on an Early AngloSaxon Coin', Numismatic Chronicle 167 (2007), pp. 179-182.

Tomasini, Wallace J., The Barbaric Tremissis in Spain and Southern France: Anastasius to Leovigild (New York: American Numismatic Society, 1964).

Torres Ortiz, Mariano, Sociedad y mundo funerario en Tartessos (Madrid: Real Academia de la Historia, 1999).

Travaini, Lucia, 'La zecca merovingia di Avenches e le prime monete con il volto di Cristo', Numismatica e Antichità Classiche: Quaderni Ticinesi 32 (2003), pp. 291-301.

— , 'Coins, Images, Identity, and Interpretations: Two Research Cases - A Seventh-Century Merovingian Tremissis and a Fifteenth-Century Ducat of Milan', in Medieval Coins and Seals: Constructing Identity, Signifying Power, ed. by Susan Solway (Turnhout: Brepols, 2015), pp. 65-80.

Valverde Castro, María del Rosario, Ideología, simbolismo y ejercicio del poder real en la monarquía visigoda: un proceso de cambio (Salamanca: Ediciones de la Universidad de Salamanca, 2000).

__, 'El reino de Toledo y su supuesta “identidad goda”, in Identidad y etnicidad en Hispania: propuestas teóricas y cultura material en los siglos V-VIII, ed. by J. Antonio Quirós and Sebastián Castellano (Bilbao: Universidad del País Vasco, Documentos de Arqueología Medieval 8, 2015), pp. 67-86.

Van Malderghem, Jean, 'Les fleurs de lis de l'ancienne monarchie française: leur origine, leur nature, leur symbolisme', Annales de la Société d 'Archéologie de Bruxelles 8 (1894), pp. 180-212.

Velázquez Soriano, Isabel, 'Pro patriae gentisque Gothorum statu (4th Council of Toledo, Canon 75, A. 633)', in Regna and Gentes: The Relationship between Late Antique and Early Medieval Peoples and Kingdoms in the Transformation of the Roman World (Leiden: Brill, Transformation of the Roman World 13, 2003), pp. 161-217.

Wittkower, Rudolf, 'Eagle and Serpent: A Study in the Migration of Symbols', Journal of the Warburg Institute 2.4 (1939), pp. 293-325.

Wood, Jamie, The Politics of Identity in Visigothic Spain: Religion and Power in the Histories of Isidore of Seville (Leiden: Brill, 2012). 
—_, 'Religiones and gentes in Isidore of Seville's Chronica maiora', in Post-Roman Transitions: Christian and Barbarian Identities in the Early Medieval West, ed. by Walter Pohl and Gerda Heydemann (Turnhout: Brepols, 2013), pp. 125-168.

— - 'Borders, Centres and Peripheries in late Roman and Visigothic Iberia', International Journal of Regional and Local History 10.1 (2015), pp. 1-17.

\section{About the author}

Ruth Pliego is a Principal Researcher at the Center of Archaeology (Uniarq), University of Lisbon (Portugal). She works on numismatics of the period between late antiquity and the early Middle Ages in the West, focusing especially on the coinage of the Visigoths, and has published widely on this subject. 



\title{
13 The Liber Iudiciorum
}

\author{
A Visigothic Literary Guide to Institutional Authority and \\ Self-Interest
}

Michael J. Kelly

\begin{abstract}
A comparative commentary on how the Liber Iudiciorum (or, Lex Visigothorum), promulgated in AD 653 by the Visigothic King Recceswinth (AD 649/653-672), and the version of the Liber Iudiciorum produced by the Visigothic King Erwig (AD 680-687) functioned in their respective contexts and in relation to one another.
\end{abstract}

Keywords: Visigothic kingdom; Liber Iudiciorum; Lex Visigothorum; Recceswinth; Erwig; legal history; narrative

The ninth annual workshop of the Toletum Network, in Hamburg in October 2018, interrogated the issue of 'power' within the Visigothic kingdom, specifically in reference to Toledo, the Visigothic capital. The aim was, in part, for scholars to grasp Visigothic normativity in its constituent parts, to uncover the concurrent (Foucauldian) épistémè of Visigothic, early medieval Iberian society. As was demonstrated, this 'power' was created, displayed, expressed, and challenged via a multitude of media (e.g. writing, construction, minting, and materiality), illustrating a decentralized and Eastern-focused social landscape.

The normative rhetorics of authority emanating from the capital were exemplified by one of its most emblematic objects of power, the Liber Iudiciorum ('Book of Laws'). The Liber Iudiciorum is a legal code and artefact of Visigothic literature constructed by the Visigothic king Recceswinth (AD 649/653-672) and promulgated at the VIII Council of Toledo in 653 in

Panzram, S. and P. Pachá (eds.). The Visigothic Kingdom: The Negotiation of Power in Post-Roman Iberia. Amsterdam: Amsterdam University Press 2020 DOI: $10.5117 / 9789463720632 \_C H 13$ 
the praetorian church of Sts. Peter and Paul. ${ }^{1}$ After Recceswinth, the Liber Iudiciorum was edited or added to in various ways by subsequent kings. Traditional historiography has grouped these as three distinct versions of the code: respectively, of Recceswinth, Erwig, and Egica, the latter of which is known as the vulgata, after the 1902 Monumenta Germaniae Historica edition of Zeumer. Recceswinth's Liber Iudiciorum had supplanted all existing Visigothic legal codification. ${ }^{2}$ Power was represented through the codification of law, through a narration by literary means of law's history and thus the creation of a normative discourse. This legal-literary text represents power on the surface level of force, with its prescriptions and commands, but is especially authoritative in its categorization of human activities and literal creation of the 'un-lawful person', the outcast. By the law (and history), individuals become subject to the manipulations of the definers of traditions (i.e. subjects). To prescribe discipline and punishment (to include and exclude) are the conjunctive act in the creation of an economy of power. ${ }^{3}$

The use of the word 'inhuman' (inhumanum or immanum, depending on the manuscript tradition) was unusual in Visigothic texts. In one of its rare uses, found in the records of the VI Council of Toledo (638), what

1 See Chronicle of 754,35 , XII Toledo 4, and the opening of VIII Toledo: 'Anno quinto orthodoxi atque gloriosi et vera clementiae dignitate praespicui Recesuinthi regis, cum nos omnes divinae ordinatio voluntatis euisdem principis serenissimo iussu in basilicam sanctorum apostolorum ad sacrum synodi coegisset aggregari conventum' (La Colección Canónica Hispana, V.366). This church would become the site where kings were anointed and blessed before going off to war and was raised by Wamba to the status of being its own see. Thus, just outside the walls of Toledo there was a competing bishop and site of royal, ecclesiastical authority. The progress towards total royal authority in the king seems to have reached new heights, to the extent that the king created a parallel church authority. This may have been the reason for Julian of Toledo apparently leading a coup to overthrow Wamba, and then in XII Toledo 4 abolishing the praetorian church and Wamba's new diocese at Aquis (Chaves), Lusitiania. For the primary evidence of this see XII Toledo 9, and for discussion see Collins 2004, p. 100. XII Toledo is also the council in which Gundemar's actions over the church were reintroduced into the record. For the Chronicle of 754 see the López Pereira edition (Crónica mozárabe de 754: edición crítica y traducción), II.334-360, and Christys 2010, pp. 28-51 (esp. pp. 33-35).

2 That is, the Codex Euricianus, the Breviarium of Alaric II, and the hypothesized Codex Revisus of father-son kings Liuvigild and Reccared. In favor of the new, the old were literally discarded, as our only remaining manuscript of the Codex Euricianus - an eleven-folio, sixth-century palimpsest containing only the laws numbered 276-336- seems to indicate (Manuscript Paris BN Lat. 12161). The text survives under a copy of the Jerome-Gennadius's De Viris Illustribus that was written over Euric's Code in the seventh or eighth century at a scriptorium in the north of France in which, as Lowe notes, 'many discarded old manuscripts were available' (Codices Latini

Antiquiores 5, ed. by Elias Avery Lowe, p. 31).

3 For the theoretical explanation see Foucault 1975. 
is considered 'inhuman' is not to reward the faithful. That is, fidelity to a truth, or blind faith, is the ultimate expression of humanity, in contrast to the inhuman denial of the faithful. ${ }^{4}$ In The Inhuman: Reflections on Time, Lyotard explores the replacement of the human as such, as subject, with the technical, and demonstrates from that how it is the purpose of literature to present this dialectical struggle. This competition between truth and immanence - notable in transitive moments like those discussed below - is that same one found in Visigothic literature and evident in the legal-literary text, the Liber Iudiciorum. ${ }^{5}$ In this brilliant code, the nondialectical conjunction of legality operates in dialogue with the existential dialectic to create multiple, dynamic performances of (political, normative) power.

In bringing the original form of the code (Recceswinth's) into conversation with the version produced by the Visigothic king Erwig (AD 680-687), I expose the shifting political unconscious, and power, of the Liber Iudiciorum. ${ }^{6}$ This critical examination elicits also the ways in which subsequent changes to the code by Erwig undermined its Recceswinthine political unconscious and altered the code's socially symbolic core. A primary result of this Erwigian activity was the construction of another distinct piece of Visigothic literature, unique from the first Liber Iudiciorum and a testament to a different political struggle. To reach this, methodologically, I explain the (form) narrativity of Recceswinth's Liber Iudiciorum as (mode) literature, in the literary frameworks from which it emerged and into which it subsequently entered. From that, I illustrate the contexts of the substantive emendations and additions of Erwig and illustrate how they affected the meaning of the code.

\section{A Visigothic literature}

Each year at Binghamton, I teach an annual survey called 'World Literature'. In that course, we primarily read contemporary literature. The first issue we need to deal with, even before the methodological question of what is 'World Literature', is the basic one of what literature is. For readers of this chapter,

4 The use of the word is in the fourteenth canon (VI Toledo 14). For the critical edition of the council and explanation of the manuscripts, see La Colección Canónica Hispana, V. For more on the implication of the 'inhuman' in Visigothic thinking, see Kelly, 2021.

5 On Lyotard's theory of the dialectics between human and inhuman, modern and postmodern, see Lyotard 1992.

$6 \quad$ Kelly 2017. 
what does it mean to say Visigothic literature? For the students, I like to assign Eagleton's How to Read Literature, a basic introduction to the subject that is fairly straightforward, comically cynical, and embedded with Marxist critique. ${ }^{7}$ If the readers of this article were my class, I would assign Vessey's 'Writing before Literature: Derrida's Confessions and the Latin Christian World'. In that, Vessey explains the idea of literature as a product of late antiquity. ${ }^{8}$ From Derrida-Vessey, one can say that literature is a network of letters inseparable from the 'as if', from fiction. Expanding on that, one can say that literature is a translating of figures into other figures - i.e. the performance of figuration. Literature, as mode, provides the factuality of truth - whether historical or metaphysical - that is, literature - with its form, narrative - provides the conditions by which any thing becomes a truth. It is a network which performs literarily, converting letters (litterae) into literature.

The erosion of absolute truths and metanarratives by postmodernism subverts the modern idea of the duality of narrative: on the one hand, a fictive narrative that invents everything and, on the other hand, a nonfictive narrative, history, that describes real things but adds literary and poetic effect to engage the reader. Such a supposed distinction between real and imaginary discourses, which demands an ontological difference between types of narrative, should be replaced, in the words of White, 'in favor of stressing their common aspect as semiological apparatuses that produce meanings by the systematic substitution of signifieds (conceptual contents) for the extra-discursive entities that serve as their referants'. ${ }^{9}$ In other words, narrative - literature's form - should be seen as an undivided form that provides the foundational conditioning for the possibility of any truth, including historical truth. ${ }^{10}$ Historical 'facts' exist only as positional, in position to a conditioning device. As a necessary conditioning device, narrative as literary form factualizes the past. When the authors of the Liber Iudiciorum narrated the history of the legal past of the Visigoths,

$7 \quad$ Eagleton 2013.

8 Particularly of the Latin 'fathers' and the performance of confession in writing. See Vessey 2010.

$9 \quad$ White 1987, p. $x$.

10 The main argument of the opponents of historical narrativity, the so-called post-narrativists, is effectively to defend this kernel of believability, while also returning, without acknowledged irony, to the modernist conception of unconditioned absolute truths. As such, they wittingly or not re-announce the duality of narrative, with history using narrative to provide literary flourish to facts; it is only through this re-opened caesura - a necessary break with postmodernism - that they can proclaim a space for narrativity which is post. For an example and some discussion see Kuukkanen 2015. 
they - before even the specific poetic choices made - added a conditioning network of meaning to the 'real' past.

When Isidore of Seville was declared a Doctor of the church in December 653, in the second canon of Recceswinth's VIII Council of Toledo, this was a literary move, a performative (fictive) 'as if', as if Isidore approved of the canons and of the lex in confirmatione and the subsequent Liber Iudiciorum. ${ }^{11}$ Isidore, including his Sententiae and Synonyma, are re-figured, translated into objects, things, figures, which represent the relationship with the canons, authority, and the laws of Recceswinth. They are brought into - if I may elasticize Goethe's meaning of the term - a sort of Weltliteratur, of a Visigothic brand of literature, endowed with meaning around the kingdom, and exportable beyond. ${ }^{12}$

This performance of figuration reflects the language and competitive dialectics of seventh-century Iberian writers, for whom this literature, as mode, was equated with the form 'history-writing'. The idea that 'history' equates to narrative was consistent with literary and popular culture in the peninsula. ${ }^{13}$ For Isidore, history is narration and as such is a believable story. ${ }^{14}$ In a letter between a monk Mauricius and the metropolitan Bishop of Narbonne in the early 61os, 'history' is likewise equated with narration. ${ }^{15}$ In 615, King Sisebut and Caesarius, a patrician in Byzantine

11 VIII Toledo 2: 'Nostri quoque saeculi doctor egregius, ecclesiae catholicae novissimum decus, praecedentibus aetate postremus, doctrinae comparatione non infimus, et, quod maius est, in saeculorum fine doctissimus atque cum reverentia nominandus, Isidorus, in libro Sententiarum secondo' (La Colección Canónica Hispana, V.411).

12 This may not have been the first attempt at incorporating the dynasty of Chindaswinth into the Isidorian historiography of the Goths in Iberia. The Ortographia Isidori Iunioris is an extension of Isidore's De Origine Gothorum that extends the text from Swinthila to Chindaswinth. Roger Collins argues that it is 'feasible' that this 'hybrid Historia Gothorum' was constructed during the reign of Chindaswinth, although such a conclusion is, as he notes, not one that can be proved with any degree of certainty. The full continuation found in Manuscript Madrid Biblioteca Nacional de España 1346, fols. $18^{\mathrm{r}}-18^{\mathrm{v}}$ goes until the unction of Wittiza. For discussion see Collins 2014, p. 496, and 2018, p. 29.

13 On the nature and existence of the border between the Byzantine province of Spania and the Visigothic kingdom see Ripoll López 2000 and Wood 2010.

14 Isidore of Seville, Origines, or Etymologies, 1.41.1 and 1.44.5. On the meaning of argumentum, see Curtius 1953, pp. 452-455, and Isidore of Seville, Origines, 1.44.5. In Roman law, argumentum is a general term for evidence (for reference see Berger 1953, and on the relevant procedure: Borkowski and Plessis 2005, pp. 79-82).

15 Epistolae Wisigothicae, 18: 'Hos namque et alios quam plurimos Dei notatos electione multum sacra narrat historia, quos nec tempori nec loci coarctat necessitas per ordinem replicare.' The see of the bishop referred to, Agapius, is uncertain, but it is most likely that he was the bishop of Narbonne. For a brief discussion see García Moreno 1974, n. 223. For the Epistolae Wisigothicae, see the Gundlach edition, pp. 658-69o, and Gundlach 1891, pp. 45-46. 
Spania, exchanged letters in which they discussed the uses of history and the tripartite structure of classical narrativity - figuration, history, and trope. ${ }^{16}$ In his Sententiae, Isidore imbues this figuration with a mystice intellegatur, with a spiritual salvation. Thus, when Isidore proclaims that history is narration he means that history - including legal history - is the form by which truths - profane and metaphysical - through the mode literature, are constructed. This would have been the view held by the bishops Braulio of Zaragoza and Eugenius II of Toledo, both involved in the Liber Iudiciorum and canons of VIII Toledo.

Iberian writers and audiences knew the function of narrative, of its ability to condition truths and thus to direct myths and ideologies, and so practical actions on the ground, such as support for one institution, or one aristocratic network over another - hence literature as network. So, even if the narrative conditioning found in the canons and laws of VIII Toledo and the Liber Iudiciorum were somehow unconscious choices, that would not change the latter's narrativity and its symbolic core for Recceswinth: promoting Toledo's drive to become the centre of all authority in the kingdom, a new Jerusalem, in the tradition of kings, 2 Chronicles, Ezra, Nehemiah, 2 Maccabees, and other scripture whose original aim had been the consolidation of religious-political power in one priestly-kingly city.

\section{Recceswinth's Liber Iudiciorum}

The VI Council of Toledo in 638, led by King Chintila, spoke of rewarding fidelity to the king, to protect and promote the universal virtue of faithfulness, and to protect religious piety by 'the people'. ${ }^{17}$ In an unapologetic move, Recceswinth's father and predecessor Chindaswinth in his VII Council of Toledo in October of 646, several years after his infamous slaughter of nobles and mediocres, inaugurated the event by attacking traitors and

16 Epistolae Wisigothicae, 5: 'Aliquae sane vestris tenentur affatibus, ubi pars figuraliter, pars historialiter intimatur, nonnulla tropicae narrationis obtinet locum.' This refers to the uses of history in the shared 'spiritual warfare' (spiritale bellum) going on in Byzantine Spania and Visigothic Hispania. Isidore would maintain this structure of narrativity with its history and tropic narration but while replacing the Roman 'figuration', figurative or allegorical interpretation, with an explicitly spiritual (mystical) one, a mystice intellegatur that imbues allegory with spirituality. In Sententiae, 1.18.12 Isidore claims that, 'Lex divina triplici sentienda est modo: primo ut historice, secundo ut tropologice, tertio ut mystice intellegatur. Historice namque iuxta litteram, tropologice iuxta moralem scientiam, mystice iuxta spiritalem intellegentiam'. Isidore of Seville, Sententiae, ed. by Cazier, 1.18.12, see p. 64 .

17 VI Toledo 13 and 16. 
deserters. Chindaswinth went straight to the matter in the very first canon. ${ }^{18}$ Recceswinth would also deal with the matter early in his opening council, VIII Toledo, but not until after a lengthy proclamation of faith. ${ }^{19}$ At VII Toledo, in contrast to VI, fidelity was established for the sake of the king's benefit, and not for the benefit of salvation. An explicit purpose of the Liber Iudiciorum was to return to the salvific path, following the terrorizing reign of Chindaswinth, which established a fatal pattern of noble emigration. To entice the emigrés, Recceswinth set out to limit the king's powers, ensure justice, protect property and return to this holy path. ${ }^{20} \mathrm{He}$ did so, in part, with the Liber Iudiciorum.

The Liber Iudiciorum contains over 500 laws. The majority of them have had the names of their promulgators erased from the record and are instead attributed to having been ancient laws. The attribution antiqua was supposed to indicate that a law was derived from 'Arian' kings, from the kings up to and including Liuvigild, a collective, un-nominated mass, unworthy of naming. That this antiqua occasionally include canons and laws from the Catholic kingdom demonstrates their tropical function. ${ }^{21}$ Except for a handful of laws in the final book, which at times travelled separately, the only names of legislators mentioned in this Liber Iudiciorum are Chindaswinth and Recceswinth. This was done not because kings in between them and Liuvigild did not legislate; it was a rhetorical device serving to collectivize the unnamed as a past outside of the significance of the present. ${ }^{22}$

The entire first book of the Liber Iudiciorum is anonymous: none of the laws are attributed, neither to Chindaswinth nor Recceswinth, and none are even described as antiqua. This was a different type of universalization and removal from time than that of the antiqua, which were anonymous parts of totalized time, but not of the nominated and imagined present. The universal laws of the so-called Visigothic constitution, the first book of the Liber Iudiciorum, were meant to be self-evident. Recceswinth brilliantly removed them from the underlying historical narrative of the text and, in so

18 De refugis atque perfidis clericis sive laicis (VII Toledo 1 ).

19 Recceswinth included a law in the Liber Iudiciorum based on VII Toledo 1 (Liber Iudiciorum, 2.1.6).

20 On the education of Recceswinth, see Riché 1972, esp. p. 238.

21 For example, Liber Iudiciorum, 5.7.1, 5.7.9, and 10.3.5.

22 The two laws by Sisebut are Liber Iudiciorum, 12.2.13 and 14, and the three of Reccared are Liber Iudiciorum, 3.5.2, 12.1.2, and 12.2.12. Three of these five are listed together (Liber Iudiciorum, 12.2.12-14), with another nearby. Outside of the twelfth book, the only law attributed to a king other than Chindaswinth and Recceswinth is Liber Iudiciorum, 3.5.2, which was re-attributed to Recceswinth in later manuscripts and so not firmly associated with Reccared. 
doing, did not tie his historically and spiritually constructed legitimacy to the prescriptions of this constitution. Any violation of the laws would not be an affront either to his legitimacy or to his dynasty, or to any contradiction of his word according to the law. The second book of the Liber Iudiciorum, which specifically lays out the rights and duties of kings and judges, is almost completely constituted by laws of Chindaswinth and Recceswinth, in higher proportion than laws of the other books, a point worth remembering when discussing Erwig's edition.

What this structure did was direct the memory of the laws, and thus the present opinion about them, in such a way that Chindaswinth and Recceswinth were the Catholic legislators, the bringers of Catholicapproved law to the kingdom. This model of tying Catholic justice to the history and present of Visigothic law, embodied in Recceswinth's family, promoted Recceswinth's legitimacy in the eyes of religious leaders and their local populaces. ${ }^{23}$ It also served to restore the image of Chindaswinth, who had lived the last years of his life in penitence, presenting both Chindaswinth and Recceswinth as the kings who brought Christian-inspired justice to the kingdom. This helped create a positive image of Chindaswinth, whose legacy desperately needed a re-imagination to repair it. The Liber Iudiciorum crafted the history of the law to elevate the memory of Chindaswinth and the legitimacy of Recceswinth, suggesting them as the unique defenders of justice and piety in the history of the Catholic kingdom. In creating a sort of mass damnationes memoriae of previous kings, the Liber Iudiciorum provided a historical lineage that favoured Recceswinth's dynasty and removed others from the historical record. ${ }^{24}$

The internal structure of Recceswinth's Liber Iudiciorum - complemented by the canons of VIII Toledo - was a strategy for the king to support reconciliatory acts, while maintaining his ultimate authority over ecclesiastical affairs. By creating a narrative of historical legitimacy of the Catholic kings, of which Recceswinth was the ultimate embodiment, the Liber Iudiciorum gave legitimacy to laws of his dynasty and to his legal position, which, since Gundemar, was also de facto head of the Spanish church.

The use of the number twelve for the number of books and religious laws further imbued the Liber Iudiciorum with a sense of spirituality. Twelve also connected Recceswinth and Visigothic law with the Roman Empire, 
since, as Isidore relates, Roman law began with the Twelve Tables. ${ }^{25}$ The fact that the eleventh book of the Liber Iudiciorum is a relatively hapless collection of constitutions, all of which could have been placed elsewhere, enhances the view that the authors of the Liber Iudiciorum ensured that it had exactly twelve books. The conscious application of the number twelve to the structure of the code is confirmed further by the fact that the council at which it was promulgated, VIII Toledo, had exactly twelve canons, which was almost unique in Visigothic conciliar history.

Recceswinth's Liber Iudiciorum wove together the past and present into a legal-literary narrative that endowed the laws with their own origins-story, one that both suppressed ideological opposition and promoted Recceswinth's dynasty as the true converters of the kingdom, the fathers of justice, the only rightful princes, and the direct line of authority from the conversion: it was they who represented the conversion of the kingdom from the antiquae. ${ }^{26}$

\section{Erwig's Liber Iudiciorum}

King from 680 to 687 , Erwig, a blood relative of Recceswinth, ${ }^{27}$ produced the first revision of Recceswinth's Liber Iudiciorum. ${ }^{28}$ Erwig began his new code shortly into his reign in October $680,{ }^{29}$ and requested approval of his laws at XII Toledo. The fourth canon of that council abolished the praetorian church, the very site at which Recceswinth's Liber Iudiciorum had been promulgated. Erwig's new version was promulgated on 21 October 681 ( $L I$ 2.1.1)..$^{30}$ Erwig dramatically reshaped the narrative of the code. He reframed it with an alternative introduction and conclusion, inserted thirty-four new laws - twenty-eight (82 per cent) of which referred to Jews - removed eight laws of Recceswinth, and applied his editorial fingerprint across eighty laws..$^{11}$

25 Isidore of Seville, Origines, 5.1.3.

26 See Reydellet 1981, pp. 526-527. Recceswinth never added his later laws to the Liber Iudiciorum. See also Collins 2004, p. 235, and Diplomática Hispano-Visigoda.

27 He was the son of one of Chindaswinth's nieces. See García Moreno 2008.

28 The laws of Erwig, in the Liber Iudiciorum and the councils, represent the main body of evidence for his reign.

29 This is evident by the request in XII Toledo in January 681 to the bishops at the council to approve his laws.

30 The new code was promulgated with anti-Jewish laws from XII Toledo.

31 Erwig included only eighty of Recceswinth's laws, in revised form, plus Wamba's three laws. Recceswinth promulgated the Liber Iudiciorum with eighty-eight of his own laws and ninety-nine of his father. 
The second book of Erwig's Liber Iudiciorum opens with a new law by him, which literally and metaphorically proclaims the authority of his new code. This new $L I$ 2.1.1 replaces Recceswinth's commanding voice with Erwig's in what is the longest and arguably the most significant book in the code, the first book of statutory laws and the one that begins the narration of nominated royal authority. The new introduction also subtly, or perhaps not so subtly, criticizes the existing Recceswinthine book, by saying that the code contains edicts that have 'obscure and contradictory language' (obscuritas, nebuloso) which give rise to 'sophisms' and controversies, new legal cases, and confusion on the part of judges (litigantium controversias). As such, Erwig's court, the only one that can maintain peace in the kingdom, has decided that the laws need amending.

This not only sublimates the previous authority of Recceswinth as narrator of the text, but also distorts the opening of the book, purposely disconnecting it from Book 1. In Recceswinth's version, the opening of Book 2 flowed naturally from Book 1. His own LI 2.1.1, on royal power, bridges the promises of equality in the law, the duties of the lawgiver, and his respect of sacred precepts, with the constitutions on judicial duty and restraint. Mirroring the criticisms of judges by Taio in his Toledo-requested revision of Isidore's Sententiae, Erwig's law limits the authority of judicial precedent in the face of constitutional intent. This was a significant move to undermine the functioning of the law outside the purview of Erwig and his associates (e.g. Julian of Toledo), who were the later beneficiaries of nice tax breaks from Erwig. ${ }^{2}$ Alterations such as these re-narrated the history of the law and the facticity of its truths, and effaced the code's political unconscious.

Following the suppression of the revolt of $d u x$ Paulus, Wamba, in October 673 - in the second year of his reign - reorganized the army in a decree that is now $L I$ 9.2.8. ${ }^{33}$ In that, Wamba demands first that certain groups (clergy, bishops, dux, comes, vicarious, gardingus, thiufadus) had to take up arms to defend the kingdom's territory once the dux, comes, thiufadus, or vicarious announced a call to arms; secondly, it promises that internal rebels would now automatically face confiscation of property and exile. ${ }^{34}$ This law also introduced into the Liber Iudiciorum a clear territoriality, with a direct reference to Spain, that is, to the territorial jurisdiction of the code.

$3^{2}$ In the fourth year of his reign, Erwig issued an edict relaxing the tax situation for certain people. See the Edictum Ervigii Regis de Tributis Relaxatis.

33 Issued on the Kalends of November, second year of the reign.

34 For discussions see Barbero de Aguilera and Vigil 1978, pp. 155-174. 
Erwig, Wamba's successor and potential usurper, also dealt with the perfidy of Paulus, in the first canon of XIII Toledo in $683,{ }^{35}$ and in the lex in confirmatione, or $L I$ 12.1.3. Furthermore, in response to Wamba's decree ( $L I$ 9.2.8) on the military - also discussed in canon 7 of XII Toledo ${ }^{36}$ - Erwig's law ( $L I$ 9.2.9) complained that those who were required by law to go to war with their full complement of serfs to defend the kingdom after the call to arms had been made by the duces or comites were only bringing tiny portions of their serfs. The new legislation demanded that at least 10 per cent of a landowner's serfs were to come and that the servifiscales, the free and freed, Goths and Romans, were all obliged to serve in the army. A dux, comes, or gardingus who did not follow the rule was to be exiled, after property confiscated; lower officials were to be physically punished and pay fines or be enslaved. Clergy were no longer required to fight. The law effectively extended the announcement of territorial jurisdiction in declaring its validity for everyone, whether Goth or Roman (seu sit Gotus sive Romanus). It was a considerable innovation as part of an overhaul of the way the military was manned and functioned. ${ }^{37}$ It also supported the broader aims of Erwig's revision, expanding his power under a veneer of enhancing clerical rights.

Erwig's twelfth book of the Liber Iudiciorum has forty-five laws, 6o per cent of which are his..$^{8}$ So, even by sheer numbers, Erwig turned the closing book into his own..$^{39}$ It is, however, the third chapter of Book 12 that is his major intervention; it is an exclusively Erwigian chapter in Visigothic law. The twenty-eight laws that constitute the chapter all take aim at Jews and the Jewish community and, as the code's new closing chapter, reconstructs the code's narrative, reframing its laws around anti-Jewish legislation, which

35 XIII Toledo 1: 'De reddito testimonio dignitatis eorum quos profanatio infidelitas cum Paulo traxit in societatem tyrannidas' (La Colección Canónica Hispana, VI.228).

36 XII Toledo 7: 'De recepto testimonio personarum qui per legem quae de promotione exercitus facta est testificandi licentiam perdiderunt' (La Colección Canónica Hispana, VI.171).

37 See Isla Frez 2010.

38 This is excluding Liber Iudiciorum, 12.1.3, which is the lex in confirmatione of XIII Toledo added later, a summation of the canons of XIII Toledo. For some reason, the canons of XII Toledo as well as its lex in confirmatione were not retroactively added to the revised Liber Iudiciorum, but were appended in 683 .

39 The twelfth book of the Liber Iudiciorum as Recceswinth constructed it is titled De temperando iudicio et removenda pressura and is meant to prevent oppression by state judicial figures. Its opening constitutions, by Chindaswinth and Reccared, respectively, emphasize this purpose: Liber Iudiciorum, 12.1.1: 'De commonitione principis, qua iubetur, ut iudicium temperent iudices'; and Liber Iudiciorum, 12.1.2: 'Ut nullus ex his, qui populorum accipiunt potestatem et curam, quoscumque de populis aut in sumtibus aut indictionibus inquietare pertemtet.' 
serves as the theological and teleological confirmation of the inevitable will of God through the law and through Erwig.

Erwig turned the Liber Iudiciorum into an anti-Jewish tractate. Passover was banned, Jews were commanded to eat pork, previous laws against circumcision were reiterated, and Jews were supposed to convert immediately. This was the harshest anti-Jewish legislation yet passed, and no Visigothic legislation ever again referred to Jews as Jews, only to Christians who had been Jews. In the new narrative, Jews, thanks to Erwig, were entirely unwelcome, were outside others, criminals; and the clergy were a special class of persons not liable to physically defending the kingdom.

It would seem that Erwig meant to highlight his reign as providential, or at least the culmination of the monarchy's collaboration with the church, with Julian. This tying of the history of the monarchy into the law, entangling history and law, helps explain the revival of Gundemar's decretal as well as the innovation of the Chronica Regum Visigothorum (or, $C R V$ ). The $C R V$ is a basic, non-descriptive list (laterculum) of the Visigothic kings from Athanaric in 362 to Erwig in 680. The oldest extant manuscript of the $C R V$ is the eighth-century manuscript Vaticanus Reginae Lat. 1024, which also contains the most ancient copy of the Liber Iudiciorum. This connection to the $C R V$ reinforces the particular historicity of the code, and the history of its revision.

Thus, from the opening of $L I$ 2.1.1 to the close of Book 12 with 12.3, and potentially the $C R V$ in parallel, Erwig reframed the Liber Iudiciorum. The alternative structure frames the law as authoritatively Erwigian, and with Erwig as the embodiment of the righteous ruler. Erwig is fully in control of the church while serving as its just leader and granting it responsibility over a politically non-threatening minority community.

\section{Conclusion}

In closing, Collins has argued that the purpose of the code is 'symbolic and political'. I agree. Moreover, when looking at the total production of the laws and versions of the Liber Iudiciorum, Collins has called it an 'ill-assorted mixture' which 'taken as a whole or in parts represented by three versions [...] hardly looks like a coherent program of the codification of existing royal law'. I agree, it was not. Collins, moreover, wonders why Recceswinth's team of legal codifiers were seemingly more interested in the antiqua than in the legislation of recent kings, and says that this is 
an issue that 'has never been adequately addressed'. ${ }^{40} \mathrm{I}$ believe that this reading of the Liber Iudiciorum as literature, with narrative, begins to properly address this issue.

While not an exhaustive study of the historical narrative of Recceswinth's or Erwig's Liber Iudiciorum or of the input of other kings, what can be concluded is that the Liber Iudiciorum of Recceswinth and that of Erwig present two separate examples of Visigothic literature, each endowed with its own narrative. When we refer to the Liber Iudiciorum we must speak of unique literary events, at least two different examples of the narration of the law for the purposes of creating institutional authority and promoting self-interest.

These considerations are vital for us, more broadly, as historians of Visigothic Spain and its literature and of the subsequent history of the Liber Iudiciorum, as they help us to better understand, in historicizing, the performative possibilities of the code. Such an analysis is crucial also to the work of myself and my co-editors as we prepare a new critical edition of the Liber Iudiciorum,,$^{41}$ an edition that contains an extended historical apparatus and critical historiography which must begin with a firm grasp of the code's political unconscious over time and place. ${ }^{42}$

\section{Bibliography}

\section{Primary sources}

Chronicle of 754 = Crónica mozárabe de 754: edición crítica y traducción, ed. by José Eduardo López Pereira (Zaragoza: Anúbar, 1991).

Chronica Regum Visigothorum = Laterculus regum Visigothorum, in Chronica minora, 3 vols., vol. 3, ed. by Theodor Mommsen (Berlin: Monumenta Germaniae Historica, Auctores Antiquissimi 13, 1898), pp. 461-468.

Codex Euricianus, in Leges Visigothorum Antiquiores, ed. by Karl Zeumer (Hanover:

Fontes Iuris Germanici Antiqui in Usum Scholarum 5, 1894), pp. 1-20.

40 Collins 2004, p. 235.

41 I am co-directing with Isabel Velázquez the new, Open-Access critical edition of the Liber Iudiciorum as a long-term project of Networks and Neighbours (networksandneighbours.org). 42 I would like to thank Sabine Panzram and Paulo Pachá for inviting me to have been part of this important conference, which contemporized the Visigoths by gazing at them from future and past perspectives. This subjective positioning elicited their role within Iberian cultural memory and historiography as both aberrational Others and as the 'middle age' of Iberian history. I would also like to congratulate Sabine and Paulo for keeping the event fees-free, as all humanities conferences should be. 
Codices Latini Antiquiores, 12 vols., vol. 5, ed. by Elias Avery Lowe (Paris/Oxford: 1950).

Diplomática Hispano-Visigoda, ed. by Ángel Canellas López (Zaragoza: Institución Fernando el Catolico, 1979).

Edictum Ervigii Regis de Tributis Relaxatis, in Leges Visigothorum, ed. by Karl Zeumer (Hanover: Monumenta Germaniae Historica, Legum Nationum Germanicarum 1, 1902), pp. 479-480.

Epistolae Wisigothicae, ed. by Wilhem Gundlach, in Epistolae Merovingici et Karolini aevi, 6 vols., vol. 1 (Berlin: Monumenta Germaniae Historica, Epistolarum 3, 1892), pp. 658-69o.

Isidore of Seville, The Etymologies of Isidore of Seville, trans. by Stephen A. Barney, W.J. Lewish, J.A. Beach, and Oliver Berghof (Cambridge: Cambridge University Press, 2006).

—, Origines, or Etymologies = Isidori Hispalensis Episcopi etymologiarum sive Originum libri $X X$, ed. by W.M. Lindsay (Oxford: Scriptorum Classicorum, Bibliotheca Oxoniensis, 1911).

- Sententiae: Isidorus Hispalensis Sententiae, ed. by Pierre Cazier (Turnhout: Brepols, Corpus Christianorum, Series Latina 111, 1998).

La Colección Canónica Hispana, 6 vols., ed. by Gonzalo Martínez Díez and Félix Rodríguez (Madrid: Consejo Superior de Investigaciones Científicas, 1966-2002). Leges Visigothorum, ed. by Karl Zeumer (Hanover: Weidmann, Monumenta Germaniae Historica, Legum Nationum Germanicarum 1, 1902).

Liber Iudiciorum, in Leges Visigothorum, ed. by Karl Zeumer (Hanover: Monumenta Germaniae Historica, Legum Nationum Germanicarum 1, 1902), pp. 33-456.

\section{Secondary sources}

Barbero de Aguilera, Abilio, and Marcelo Vigil, La formación del feudalismo en la Península Ibérica (Barcelona: Editorial Crítica, 1978).

Berger, Alfred, 'Dictionary of Roman Law', Transactions of the American Philosophical Society, n.s., 43 (1953), pp. 333-809.

Borkowski, Andrew, and Paul du Plessis, Roman Law, 3rd ed. (Oxford: Oxford University Press, 2005).

Christys, Ann, Christians in al-Andalus, 711-1000, 2nd ed. (New York: Routledge, 2010). Collins, Roger, Visigothic Spain: 409-711 (Malden, MA: Blackwell, 2004).

—, 'Ambrosio de Morales, Bishop Pelayo of Oviedo and the Lost Manuscripts of Visigothic Spain', in Wisigothica after Manuel C. Díaz y Díaz, ed. by Carmen Codoñer Merino and Paulo Farmhouse Alberto (Florence: MediEVI, series of the Società Internazionale per lo Studio del Medioevo Latino 3, 2014), pp. 485-503. 
, 'Ambrosio de Morales and the Codex Vetustissimus Ovetensis' (2018), www. academia.edu/36632333/Ambrosio_de_Morales_and_the_Codex_Vetustissimus (accessed 4 July 2020).

Curtius, Ernst R., European Literature and the Latin Middle Ages, trans. by Willard R. Trask (Princeton: Princeton University Press, 1953).

Eagleton, Terry, How to Read Literature (New Haven: Yale University Press, 2013). Foucault, Michel, Discipline and Punish: the Birth of the Prison (New York: Vintage Books, 1975).

García Moreno, Luis Agustín, Prosopografia del Reino Visigoda de Toledo (Salamanca: Ediciones de la Universidad de Salamanca, 1974).

— , 'Prosopography, Nomenclature, and Royal Succession in the Visigothic Kingdom of Toledo', Journal of Late Antiquity 1.1 (2008), pp. 142-157.

Gundlach, Wilhelm, 'Der Anhang des III. Epistolae-Bandes der Monumenta Germaniae Historica: Epistolae ad res Wisigothorum pertinentes', Neues Archiv der Gesellschaft für ältere deutsche Geschichtskunde 16 (1891), pp. 9-48.

Isla Frez, Amancio, Ejército, sociedad y política en la Península Ibérica entre los siglos VII y XI (Madrid: Consejo Superior de Investigaciones Científicas, 2010).

Kelly, Michael J., 'Recceswinth's Liber Iudiciorum: History, Narrative and Meaning', Visigothic Symposia 1 (2017), pp. 110-130.

—, Isidore of Seville and the "Liber Iudiciorum": The Struggle for the Past in the Visigothic Kingdom (Boston/Leiden: Brill, The Medieval and Early Modern Iberian World 80, 2021).

Kuukkanen, Jouni-Matti, Postnarrativist Philosophy of Historiography (London: Palgrave MacMillan, 2015).

Lyotard, Jean-François, The Inhuman: Reflections on Time, trans. by Geoffrey Bennington and Rachel Bowlby (Palo Alto: Stanford University Press, 1992).

Martin, Céline, 'Le Liber Iudiciorum et ses differentes versions', Mélanges de la Casa de Velázquez, n.s., 41 (2011), pp. 17-34.

Pérez Sánchez, Dionisio, El ejército en la sociedad visigodo (Salamanca: Ediciones de la Universidad de Salamanca, 1989).

Reydellet, Marc, La royauté dans la littérature latine de Sidoine Apollinaire à Isidore de Séville (Rome: École Française de Rome, Bibliothèque des Écoles Françaises d'Athènes et de Rome 243, 1981).

Riché, Pierre, 'L'Enseignement et la culture des laïcs dans l'occident pré-carolingien', in La scuola nell'occidente latino dell'alto medioevo (Spoleto: Centro Italiano di Studi sull'Alto Medioevo, Settimane di Studio del Centro Italiano di Studi sull'Alto Medioevo 19, 1972), pp. 231-253.

Ripoll López, Gisela, 'On the Supposed Frontier between the Regnum Visigothorum and Byzantine Hispania', in The Transformation of Frontiers from Late Antiquity 
to the Carolingians, ed. by Walter Pohl, Ian Wood, and Helmut Reimitz (Leiden: Brill, 200o), pp. 95-115.

Vessey, Mark, 'Writing before Literature: Derrida's Confessions and the Latin

Christian World', in Derrida and Antiquity, ed. by Miriam Leonard (Oxford: Oxford University Press, 2010), pp. 290-318.

White, Hayden, The Content of Form (Baltimore, MD: Johns Hopkins University Press, 1987).

Wood, Jamie, 'Defending Byzantine Spain: Frontiers and Diplomacy', Early Medieval Europe 18 (2010), pp. 292-319.

\section{About the author}

Michael J. Kelly is Visiting Assistant Professor in Comparative Literature and Judaic Studies at Binghamton University (New York), co-editor of Gracchi Books, and the director of Networks and Neighbours. His research connects the history of the early medieval Mediterranean with historical and critical theory. 


\title{
14 Epigraphic Habit and Power in Visigothic Hispania
}

\author{
Javier de Santiago Fernández
}

\begin{abstract}
Epigraphic production is a means of representing power. The most powerful classes of Visigothic society used epigraphs as a tool to disseminate their ideas. The church used epigraphs as a means to make known its liturgy, doctrine, buildings, and hierarchies. In addition, the civil hierarchy (monarchy and nobility) used them to demonstrate their privileged social position. Epigraphs employed technical communicative strategies to transform them into an effective means to disseminate ideas.
\end{abstract}

Keywords: Visigoths; epigraphs; Christianization; church; elite; representation

Epigraphic production, the so-called epigraphic habit, was a means to represent power. This became especially evident in the case of Emperor Augustus, who employed epigraphic messages, among other means, for the purposes of propaganda, as a vehicle for self-representation and glorification. The practice was quickly imitated by Roman elites (but also by other social groups that imitated the practices of the elites) as a means of self-promotion. Thus, the epigraphic message assumed importance in public life as a tool for affirming power and for political persuasion. The Visigothic kingdom inherited the usage, adapting it to new historical and social circumstances, especially following conversion to Christianity.

Panzram, S. and P. Pachá (eds.). The Visigothic Kingdom: The Negotiation of Power in Post-Roman Iberia. Amsterdam: Amsterdam University Press 2020 DOI: $10.5117 / 9789463720632$ CH14 


\section{Who commissioned the epigraphs?}

Answers as to who utilized inscriptions can be found in the dedicants' names recorded in the epigraphs themselves. In general, the main institution to commission inscriptions was the church, as a means to disseminate its liturgy, doctrine, buildings, and hierarchies. The practice was followed by the monarchy and by social elites.

Funerary inscriptions were the most abundant type of epigraph. Although not explicit about the social status of the deceased, they usually give the person's name together with an epithet in the form of an elogium. The most common of these - especially in Lusitania, Baetica, and Gallaecia - is famulus/a Dei/Christi, which stresses servitude to God, Christian society's highest value and a principal virtue shown by the deceased in life. The term was not applied exclusively to people in religious orders, as Handley has claimed. ${ }^{1}$

When explicit references to an individual's social status occur, however, they usually concern members of the ecclesiastical hierarchy, and are generally associated with the formula famulus/a Dei. We find general mention of bishops, presbyters, deacons, archdeacons, readers, ostiaries, abbots, monks, and members of the clergy. To a lesser extent, mention is made of members of the civil hierarchy, such as vir honestus or honesta femina, titles indicating membership of the honestiores, people of high social class. Other names appear associated with the terms clarissimus vir, clarissima femina, vir inlustris, or inlustris femina, which allude to Roman nobility. References to monarchs appear, for example to Chindaswinth and his wife Riciberga in inscriptions recorded by Eugenius of Toledo, although there is some doubt as to whether these epitaphs were ever actually incised. Mention is never made of humble origins as was the case in Roman epigraphy.

Despite these examples, references to social status are most often absent in funerary inscriptions. However, there is little doubt that the majority of the commissioners belonged to the upper strata of Visigothic society. The number of inscriptions preserved suggests that the epigraphic habit was not nearly as widespread as it had been in the Roman world, where the entire range of social classes produced inscriptions, which was not likely in Visigothic Hispania. Perhaps the need to make explicit mention of social status was unnecessary. The mere presence of an inscription on an expensive support such as stone, using the specialized form of writing of classical Roman capitals, would be sufficient indication of the privileged status of the deceased and their

1 Handley 2003, pp. 43-44. My opinion on this subject can be seen in Santiago Fernández 2011, pp. 378-379. 
families, and itself a manifestation of power. The production of an epitaph was a social act, a means of highlighting the status of the deceased and his or her family. The erection of a tomb endowed with an inscription entailed considerable expense. For example, the epitaph of Immafrita, from Toledo, indicates datum est pro locello ipso in auro solidos III ('the price of this epitaph was 3 solidi'), a considerable cost, even considering that this was a relatively modest epitaph with careless writing and a simple support. Handley provides evidence of the cost of epitaphs from different areas that ranged from 1.5 up to 18 solidi. ${ }^{2}$ The conclusion is that epigraphs, at least the ones on stone that have survived, would have been beyond the reach of most people.

Consecration inscriptions are epigraphs with a liturgical content. Thus, members of the ecclesiastical hierarchy obviously predominated among the people recorded on such epigraphs, more specifically bishops who were responsible for conducting these ceremonies. These inscriptions present a repetitive structure with the text usually mentioning the name of the bishop who consecrated the church. Such an example is the case of the consecration inscription at the church of Santa María de Mijangos in the province of Burgos, which was consecrated by the bishop Asterio:

[In n(omin)e D(omi)n]i consacratus est/ [hec lo]cus S(an)c(t)e Marie/ [ab p]ontifice Asterio/ sub d(ie) pr(idie) non(a)s m(a)ias/ [anno] XVI gl(oriosissimi) dom(ini) n(o)s(tr)i Recca/ [redi r]eg[is Era DCXXXVIIII]. ${ }^{3}$

Even when the officiating bishop's name does not appear, there is no doubt that these inscriptions were commissioned by the ecclesiastical hierarchy and disseminated an official message.

Construction inscriptions often featured members of civil society associated with the erection of buildings, predominantly religious ones. In this type of inscription, members of the civilian elite, monarchs, and the nobility predominate among the dedicants. The inscription concerning construction of the church of San Juan de Baños, sponsored by King Recceswinth, is a well-known example:

(crux) Precursor D(omi)ni, martir Babtista Iohannes,/ posside constructam in eterno munere sede,/ quam devotus ego rex Reccesvinthus, amator/

2 Handley 2003, pp. 38-39.

3 Fernández Flórez 2002, p. 22. It could be translated: 'This Church of Saint Mary was consecrated In the Name of our Lord by bishop Asterio on 6th May of $601 \mathrm{AD}$, the 16th year of the reign of the most glorious king our lord Reccared.' 
nominis ipse tui, proprio de iure dicavi/ tertii post dec(e)m regni comes inclitus anno/ sexcentum decies era nonagesima nobem. ${ }^{4}$

Members of the social hierarchy also appear in inscriptions related to donations of votive objects to churches. For example, magnificent crowns from the Treasure of Guarrazar record the name of a king, such as those of Swinthila and Recceswinth. These bear a simple text with the king's name and the verb offert, as can be seen on Recceswinth's crown: (crux) Recceswinthus Rex offeret. ${ }^{5}$ In addition, crosses also bear names, although they lack any allusion as to social status; however, given the value of these objects there is little doubt of the elevated status of the donor. A good example of this is a cross from the treasure of Torredonjimeno, which records the name Iabasta: (crux) Offe/ret Iaba/sta s(a)nc(t)e Iuste/ et/ Rofi/ne. ${ }^{6}$

In conclusion, most epigraphs in Visigothic Hispania were commissioned by the social elite: kings, the nobility, and the ecclesiastical hierarchy.

\section{Why were the epigraphs written?}

The essential goal of the epigraph was to publicize a message and ensure that it was disseminated as widely as possible. Considering this motive, more specific intentions for each type of inscription and author are required.

Funerary inscriptions are the most abundant type. The basic purpose of these inscriptions was to immortalize the memory of the deceased, but they served other functions as well, such as to promote the Christian faith and the church. Thus, the texts express Christian beliefs about death, especially the idea that the path of Christianity led to eternal life after death, stressing that the deceased had led a Christian life and therefore had attained salvation. Hence, the deceased became an example to follow, one which was used to affirm and propagate the Christian creed. Epitaphs played a proselytizing role, announcing the resurrection of all who adopted the Christian faith. This can be seen in the formulae used in the inscriptions,

4 Inscripciones cristianas de la España romana y visigoda, pp. 106-107, n. 314. It could be translated as follows: 'Precursor of our Lord, martyr John the Baptist, possesses this Basilica like an eternal gift. It was dedicated by me, the king Recceswinth, loving your name, by my own right in the third year of my reign and the tenth year as illustrious partner of the kingdom.'

5 Velázquez Soriano 2001, p. 327, n. 2.

6 Inscripciones cristianas de la España romana y visigoda, p. 134, no. 384 . 
in which verbs such as requiescit or recessit were used to refer to eternal rest and the doctrine of a belief in the hereafter. The same concepts appear in authors such as St. Isidore and in liturgical texts; the Visigothic liturgy, in fact, envisages the body resting in a tomb as an interval between death and resurrection. ${ }^{7}$ Such verbs were often accompanied by the formula in pace, intended to reinforce the promise of the deceased's peaceful rest ${ }^{8}-$ the deceased's peace after death, peace with God and with the church, and the peace of the tomb. ${ }^{9}$ The aim was to express the ultimate destiny of Christians: a peaceful resurrection. ${ }^{10}$

These concepts were not limited to the text, but could be reinforced by iconographic elements produced in some workshops. The use of such motifs to accompany texts was relatively common in Christian epigraphy, a symbolic meaning that complemented the textual message, rendering its meaning more accessible, especially to the numerous members of society in this period who were illiterate. The combination of text and figurative elements helped also to draw attention to the monument. ${ }^{11}$ Some of the most common elements in epitaphs were the chrismon, the monogrammatic cross, and the cross. These represented the figure of Christ. Both the chrismon and the monogrammatic cross appear frequently in Hispanic inscriptions, often accompanied by the alpha and omega, which identify Christ as the beginning and end of all things, reaffirming his divinity (see Fig. 14.1). These symbols may have served to indicate that the tomb was under the protection of Christ. ${ }^{12}$ Sometimes, they appear flanked by doves, the symbol of peace, simplicity, innocence, purification, reward, and happiness. They are also used to represent souls released from bodily bondage. Lastly, the dove is the messenger that proclaimed salvation to Noah after the Flood, as related in Genesis (8:10-11), and is therefore a herald of salvation. All of these motifs fit perfectly with a funerary context. Quite often, these Christian symbols appear on the interior of a laurel wreath, combining the representation of Christ with the pagan symbol of victory, thus depicting his triumph.

Some workshops developed their own symbolic images. The Mérida workshop was a particularly significant example. One of its iconographic practices was to incise the text of the epitaph on the inside of a laurel wreath.

7 Sanders 1984.

8 Carletti 1997, p. $15^{2}$.

9 Iscrizioni cristiana di Roma: testimonianze di vita cristiana, p. 72.

10 Sartori 1988, p. 167.

11 Santiago Fernández 2009, p. 309.

Carletti 1997, p. 154. 


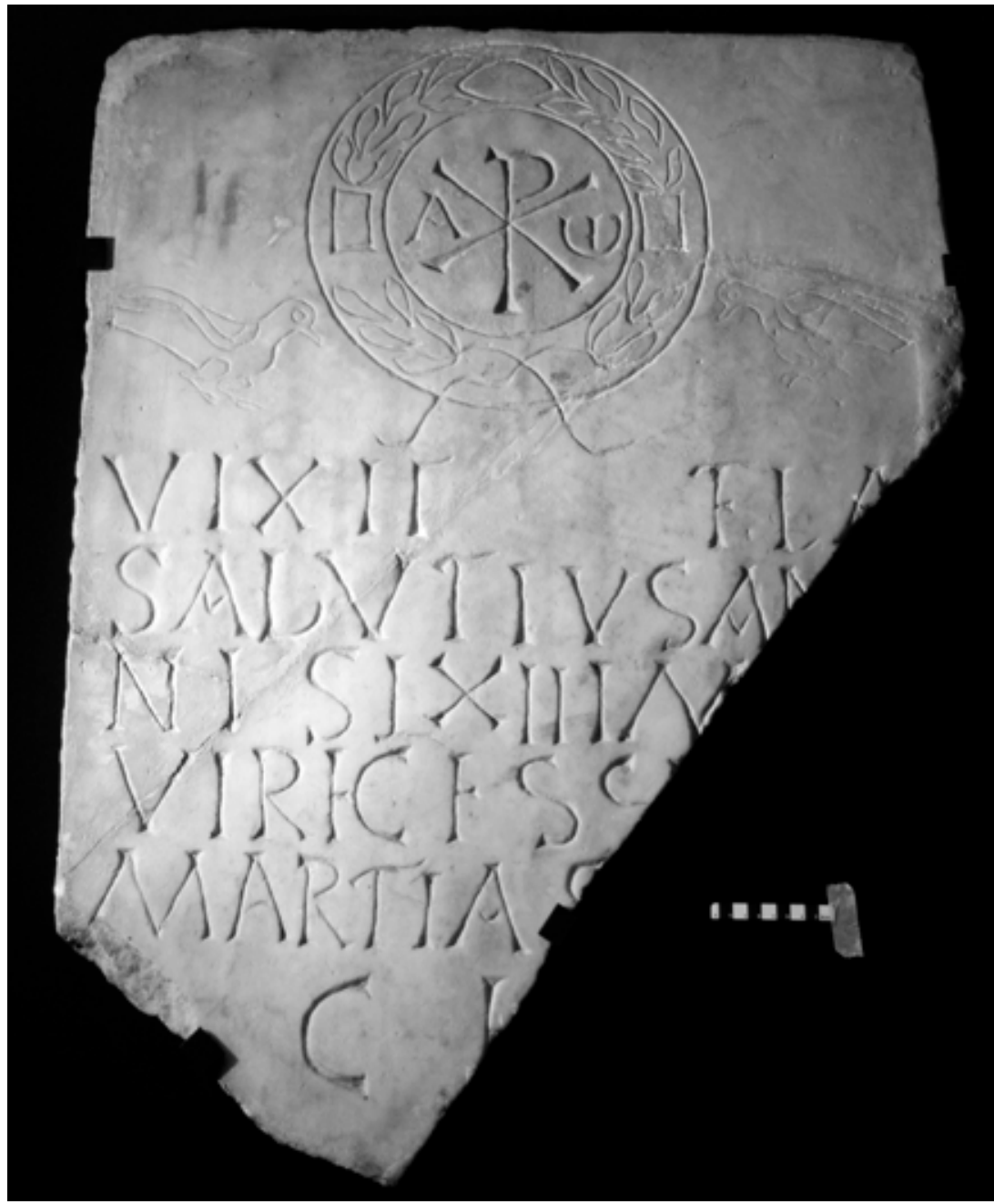

Fig. 14.1 Epitaph of Fl. Salutius. @ Museo Arqueológico Nacional Madrid, inv. no. 50083.

This decorative element is probably related to the chrismon/cross on the inside of the wreath. But it is now the text, together with the name of the deceased, which is located on the inside of the wreath (Fig. 14.2), which can easily be interpreted as the deceased's triumph over death and union with Christ, whose symbol the epitaph has replaced in the iconographic composition. ${ }^{13}$ According to Christian doctrine, baptism unites man with Christ in life as well as in death, so that he is assimilated with Christ and will share in the resurrection (Romans 6:3). 


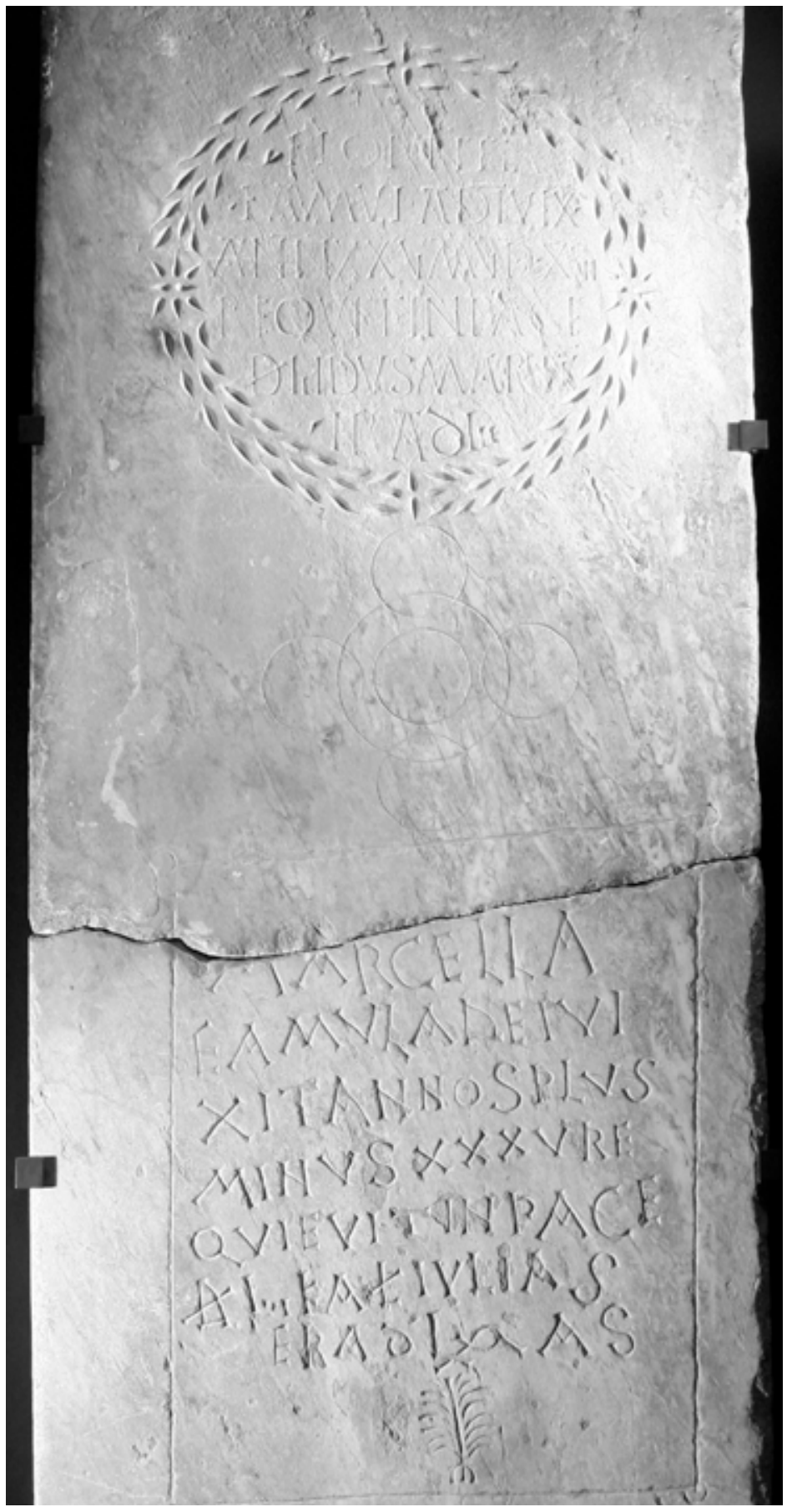

Fig. 14.2 Epitaph of Florentia and Marcella. @ Museo Arqueológico Nacional Madrid, inv. no. 57769. 
When the dedicant's office was mentioned more often it was religious in nature. This served to promote the ministerial functions of the church among the faithful in the Christian community. Some lengthy and elaborate epitaphs praised the deceased's significant merits, especially those related to Christian virtues, along with his ecclesiastical curriculum. Whether commemorating a bishop or simply a priest, many indicated the number of years he had exercised his ministry rather than the normal practice of providing his age. This had a clear exemplary intention. A lost epitaph of Justinian, bishop of Valencia, described him as pious, distinguished, jovial, and eloquent, credited him with founding and building churches and convents, praised his writings and indicated their continued value, reported that he had died devoutly, and recorded that he had been bishop for twenty years and eight months, for all of which time he formed part of the company of the saints:

Pius preclarus doctor alacer facundus,/ Iustinianus caelebs pontifex sacer[dos?]/ noba te(m)pla co(n)struens vetustaq(ue) rest[aurans],/ ornabit festa dictis predicans in populis./ Virgines instituens monacosque guvernans,/ scripsit plura posteris profutura [seclis]. Hic miro maris insola[m] munimine sepsi[t], in qua maris circumfluentibus undis/ silice disrupto predulcem repperit limfam./ Hic Vincentium gloriosum martirem Chr(ist) $\mathrm{i}$,/ sat pio quem coluit moderamine vivens, / hunc devotus moriens reliquid eredem./ Undecim presentis quinquennia vite, / quattuor lustris visq(ue) quaternis mensib(us)/ connumerandus $\mathrm{s}(\mathrm{an}) \mathrm{c}(\mathrm{t})$ is ministrab(it) antestis. ${ }^{14}$

Together with functions clearly linked to prevailing Christianity in Visigothic society and therefore to the power of the church and its doctrine, epitaphs played a role in demonstrating the wealth of the deceased and his family, who could afford such an erection. Epigraphs became an external means employed to proclaim a social standing, as were burial rites, ${ }^{15}$ which

14 Inscripciones cristianas de la España romana y visigoda, p. 85, no. 279; Carande Herrero, Escolà Tuset, Fernández Martínez, Gómez Pallarès et al. 20o6, pp. 11-13. A possible translation is: 'The pious, distinguished, wise, jovial, eloquent Iustinianus, who was celibate, bishop and priest, embellished the holy days by preaching his word, built new temples and restored others. He founded and led convents of monks and nuns. He wrote many things that would be fruitful for the future. He surrounded the peninsula with a magnificent wall, where he found freshwater flowing from a rock, although it was surrounded by the sea. When he devoutly died, his successor was Saint Vicent, glorious martyr of Christ, whom he had protected with his pious guide. He lived for 55 years and was bishop for 20 years and 8 months. Now he forms part to the company of the saints.'

15 Handley 2003, p. 14. 
transferred the expression of power to the individual sphere, even if this social standing was not recorded in the inscriptions.

Related was the function of identifying and proclaiming ownership of the tomb, thus playing a legal role; epigraphs served as notarial deeds, as a public announcement of a transaction that had been carried out and registered in accordance with the provisions of the law. This included in some epitaphs of a formula intended to prevent violation of the tomb, threatening potential violators with spiritual punishment. The most widespread formula threatens any violator, like Judas, to be banished to hell. An illustration of this is Teudesinda's epitaph, which bears the explicit formula, cum Iudam traditorem anathema ad ignum:

[Hi]c est sepulcr(u)s Teu/desinde $\mathrm{u}[\mathrm{t}]$ si quis se/pulcrum inquie/taverit istum/ cum Iudam tradit/orem anat(hema) at ignum. ${ }^{16}$

Such inscriptions appear to be in the nature of a property deed.

Inscriptions of consecration and construction clearly demonstrate the power of the church. Consecration inscriptions displayed an important liturgy in Christian life, the consecration of a church and its transformation into the house of God. Most known inscriptions are from the seventh century, especially its first half, although some are from the second half of the sixth century. This may relate to the official policy of religious unity initiated by Liuvigild and continued by Reccared, a policy that culminated in the III Council of Toledo at which Reccared officially converted to Catholicism. This was a time of union between church and state, marked by involvement of religious hierarchies in the governance of the kingdom and in a renewed policy of building and urban expansion. In that sense, 589 , the year of the III Council of Toledo, is significant to the chronology of consecration inscriptions. After the council, these inscriptions by the official church can be connected with the abundance of churches dedicated to the Virgin Mary. This perhaps reflects a Catholic attempt to promote Marian devotion and piety centred around virginal motherhood in order to counter Arianism, which denied the divinity of Christ. There is an interesting consecration inscription at the church of Santa María de Toledo, which was consecrated two years before the official conversion. The chronology might explain why the expression 'in catolico' is explicitly used:

16 Corpus de inscripciones romanas de Andalucía:Jaén, II.587. A possible translation is: 'This is the tomb of Teudesinde. If someone desecrates this tombe he will be thrown into the fire with the traitor Judas.' 
(crux) In nomine $\mathrm{D}$ (omi)ni consecra/ta eclesia S(an)c(t)e Marie/ in catolico die prim[o]/ idus a[p]rilis anno fe[li]/citer primo regni $\mathrm{d}($ omi)ni/ nostri gloriosissimi Fl(lavii)/ Reccared[i r]egis, era/ DCXXV. ${ }^{17}$

Consecration as a liturgical ceremony also had institutional significance, as it was the means by which the church sanctioned worship in the building. In addition, the dowry and properties of the church become the property of the diocese and were subject to ecclesiastical law. Thus, consecration epigraphs were a symbol of the power of the bishop over the churches; many churches were founded by private individuals who might expect to have certain rights over them, while a consecration inscription countered this with an expression of episcopal power.

The inscriptions not only disseminated a meaningful liturgical act, but also publicized bishops who officiated at consecration services and whose names appear in most inscriptions. The bishop sanctified the building; it was only the diocesan bishop who could consecrate a church within its territory. Hence, such inscriptions became an instrument of the stabilization and consolidation of episcopal power in the diocesan territory, and the inclusion of the bishop's name a demonstration of his eminence

An aspect of these inscriptions is the inclusion of a list of relics, especially evident from the first third of the seventh century. The inscription records the culmination of the consecration service, in which the celebrant deposited remains of one or more saints inside the altar. This was likely aimed at stimulating popular fervour for martyrdom, and channelling it for Eucharistic worship ${ }^{18}$. Thus, these inscriptions simultaneously empowered the consecration service and the worship of relics, which was recommended by the older Hispanic liturgy. Additionally, the bishop's name was associated in these inscriptions with those of the holy martyrs, serving as propaganda in favour of ecclesiastical power and the religious hierarchy.

While consecration inscriptions proclaimed ecclesiastical power, many construction or reconstruction inscriptions communicated the exemplary nature of the monarchy or high nobility by chronicling the foundation or construction of churches and monasteries sponsored by these elite classes, at the same time that the church was promoting the construction of new churches. They served as a means to publicize the service rendered to the

17 Velázquez Soriano 2011, p. 272. It could be translated as follows: 'In the name of our Lord this church of Saint Mary was consecrated into the catholic faith on the first day of Idus of April of the first year of the reign of our lord the most glorious Flavian king Reccared.'

18 Godoy Fernández 1995, pp. 53 and 80. 
church by members of the civil hierarchy and to demonstrate the churchstate union characteristic of the Visigothic kingdom. Together, they testify to the dynamism of urban construction at the service of the church (as does archaeological research). Building activity transmitted the ideological message of the Christian city; churches were not only meeting places for Christian worship, but were also an allegory of the Heavenly City and the Kingdom of God on earth. ${ }^{19}$ The inscriptions eloquently and effectively demonstrated the role that members of the civilian elite played in this endeavour, revealing the integration and collaboration that both social groups had attained in governance of the kingdom, arguments that may explain the paucity of inscriptions referring to civilian buildings.

Visigothic Hispania has left other inscriptions that, as with others, contributed to consolidating the power of the church by disseminating its doctrine. Some epigraphs are exhortations to observe precepts, to pray and worship in church, thus playing a doctrinal and evangelizing role, and often reflect biblical exhortation. A magnificent example is the inscription from Toledo that contains some fragments of the Creed:

\begin{abstract}
[Credo in Deum Patrem omnipotentem/ et in Ihesum Christum,/ filium eius, unicum/ Deum et Dominum nostrum/ qui natus est de Spiritu Sancto et Maria Virgine./ Passus sub Pontio] Pilato, cru[cifixus et sepultus./ Descendit] ad inferna,/ [tertia die res] urrexit v[ivus a mortuis,/ ascendit in ce]los, sedet ad [dexteram Dei, Patris omnipotentis,/inde venturus] iudicare [vivos et mortuos./ Credo in San]ctum [Spiritum,/ sanctam eclesiam catho]li[cam,/ remissionem omni]u[m peccatorum,/ carn]is resurre[ctionem et vitam eternam. Amen]. ${ }^{20}$
\end{abstract}

This was of unquestionable liturgical value, as the faithful could observe it on the walls of the baptistery next to the basilica of St. Leocadia, ${ }^{21}$ the meeting place of various councils. The text provided a kind of catechetical summary of how to achieve salvation, while serving as a fundamental tool

19 González Salinero 2009, p. 17.

20 Revuelta Tubino 1979, p. 51. It could be translated this way: 'I believe in God, the Father Almighty and in Jesus Christ, his only son, our Lord, who was conceived of the Holy Spirit, born of the Virgin Mary, suffered under Pontius Pilate, was crucified, died, and was buried. He descended to hell, on the third day, he arose again from the dead. He ascended into heaven and is seated at the right hand of God the Father Almighty. From there he will come to judge the living and the dead. I believe in the Holy Spirit, the holy Christian church, the communion of saints, the forgiveness of sins, the resurrection of the body, and life everlasting. Amen.'

21 Velázquez Soriano and Ripoll López 2000, p. 546. 
for teaching the church's faith and preparing adult candidates to receive baptism. Its role in doctrinal teaching is evident. Jorge Aragoneses has called it 'a permanent affirmation of orthodoxy repudiating the heretical beliefs of the Arians, Nestorians, Monophysites, Macedonians, Bonosians Monothelites and Jews'. ${ }^{22}$ It served an evident proselytizing function in favour of official Catholicism, and thus benefitted the structure of the kingdom, firmly based on the union between civilian power and the Catholic church.

Other inscriptions, commonly termed hortatory, which besides fulfilling the same function of encouraging the faithful to observe certain precepts of Christian doctrine, may have performed functions related to consecration of the church in emphasizing the church as the sacred house of God.

A well-known example from the archaeological site of Los Hitos (Arisgotas, Orgaz, Toledo) clearly exalts the importance of the church for the faithful. Due to its concluding notificatory formula, this epigraph could be considered a construction inscription, but most of the text is devoted to an exhortation to pray in the church:

[-c.4-]++ [h?]unc aditu[m] b[-c.7/8 t]empli/ [i]ntrantis Xp(ist)o carme(n) re[citate?] melodum/lumina cum [m]anib(us) et corda s[usto]llite fle(n) tes/diluat ut [cul]pas Xp(istu)s et debita laxet/ corpora emacula[t] a servet et penetralia me(n)tis/ effuget ac tetrum c[o]lubrum r[ur]su(m)q(ue) retrudat/ quo $\mathrm{u}(\mathrm{e}) \mathrm{s}(\mathrm{tr})$ is absit animis inlectio eius/ luxur[ia]e leporisq(ue) $\{u\}$ uile oblectatio turpis/ garru[lit]as uana fastus rerumq(ue) cupido./ Glorific[ate] po(r?)tas uos imnis is po(n)e pare(n)tes./ (crux) in D(e)i n(o) $\mathrm{m}$ (in)e anc ecl[es]ia(m) +un+[-c.3-]do fecit. ${ }^{23}$

The content of this epigraph may bear a relation to some antiphons of the consecration service, especially to those for vespers, the office of which begins 'In templo Domini omnes dicent gloriam, et sedebit Dominus rex in eo. Afferte Domino gloriam et honorem, adferte Domino gloriam nomini eius, adorate Dominum in aula sancta eius' ('In his temple does everyone speak of his glory and God King will remain in it. Give unto the Lord glory

\footnotetext{
22 Aragoneses 1957.

23 Velázquez Soriano 2008, pp. 27-29. A possible translation might be: 'You who go into this church, recite a melodious poem to Christ, lift up your crying eyes with your hands and hearts in order for Christ to wash away your blames and forgive your sins, preserve the bodies immaculately and the inwardness of the mind, and drive away the abominable snake and again cast it away to remove from your spirits its seduction, the embarrassing delight of the lust, its negligible charm, the banal chatter and the ambition for riches. You who obey voluntarily, glorify these doors with hymns. In the name of Christ [...] you who did build this church.'
} 
and honour, give unto the Lord the glory due to his name. Adore the Lord in his Holy Church'), and subsequently indicates 'Altaria tua, Domine virtutum, rex meus et Deus meus. Beati qui habitant in domo tua, in secula seculorum laudabunt te in atria tua, Christe, alle' ('Your altars, oh God of hosts, my King and my God. Blessed are those who dwell in your house, they will be singing your praises all the day long in your churches, oh Christ'). One could speculate on such an allusion to the antiphons given the exhortation to recite a melodious poem and to glorify God with hymns. The solemn inscription, written in verse and carefully incised, would have played an important role in informing the faithful that they were in a sacred building, thus constituting a sign of sanctity.

Other similar inscriptions from the Visigothic period must have been related to the consecration liturgy and therefore to the antiphons sung during the service. These texts refer to the church as the house of God, a concept contained in sacred scripture and in the consecration liturgy, an exhortation to the faithful to pray in the church as a means to obtain divine grace. They provide the congregation with a permanent reminder of these precepts. As inscribed on church walls, they form part of the building and reaffirm its sacredness in eternum, in contrast to the transience of the consecration service. These inscriptions support the notion that they contributed to sanctifying the building and therefore to asserting the power of the church. ${ }^{24}$

Inscriptions accompanying iconographic representations played an explanatory role, being intended to clarify and define iconographic programmes. An example is provided by those from the church of San Pedro de la Nave, in which the first words indicate the names of the saints portrayed and others describe the scene in writing. The capital depicting the prophet Daniel bears the inscription: (crux) Ubi Daniel missus est in laqum leonum ('When Abraham offered his son Isaac as a sacrifice to the Lord'), ${ }^{25}$ while the scene of Abraham's sacrifice is accompanied by: (crux) Ubi Habraam obtulit Isac (crux) filium suum olocaustum D(omi)no ('When Abraham offered his son Isaac as a sacrifice to the Lord') ${ }^{26}$ In both cases, the scene and its inscription reproduce two biblical passages from the Old Testament. The Bible circulated at the time in some areas, and even the laity had knowledge,

24 I explored these questions in greater depth in my paper 'Celebración litúrgica, rito y doctrina en la Epigrafía Medieval hispania' (Liturgy, rites and doctrine in medieval Hispanic epigraphy), presented at the international conference entitled Social Communication in Medieval Europe, Lisbon, Universidade Nova de Lisboa, 3-5 December 2018.

25 Inscripciones cristianas de la España romana y visigoda, p. 119, no. 347A.

26 Ibid., p. 119, no. 347 B. 
however cursory, of its content. ${ }^{27}$ Obviously, inscriptions such as these helped disseminate this knowledge, serving the functions of instruction, moral indoctrination, and a catechetical instrument. Naturally, this was true only for those who were literate, but the inscriptions helped spread the meaning of the image and the text to other segments of the population; they also may have served to support the clergies' sermons.

Inscriptions that frequently appear on votive offerings made of precious metals were usually associated with the monarchy, the nobility, and the church hierarchy. They reflected a widespread tradition of donations to the churches. Their function was to record donors' names, the donations made in gratitude or supplication to God or the saints, while also exalting their magnificence and, in the case of monarchs such as Swinthila or Recceswinth who offered lavish crowns, highlighting their right to rule, according to the ideology of the time derived from the will of God and supported by the ecclesiastical hierarchy, once again illustrating the union between church and state in the representation of the power.

\section{How were the epigraphs made?}

The bulk of epigraphic production in the Visigothic period was carried out in workshops devoted to this activity, although some inscriptions were probably made by people knowledgeable about scripture but not professionals; this would be a consideration in economic or geographical factors such as distance from large centres of epigraphic production. These workshops created their individual monumental language, to use Susini's terminology, ${ }^{28}$ to deal with repetitive production, enabling workshops to be identified. Mérida and Mértola workshops, for example, are characterized by the presence of epitaphs inside laurel wreaths (Mérida; see Fig. 14.2), ${ }^{29}$ or by the presence of an arch over a chrismon or a cross with the text below (Mértola). $3^{0}$

These workshops developed techniques to render their products more attractive and effectively to draw the attention of potential viewers. Decorative and symbolic elements often accompanied the text. The writing itself was designed to catch the eye, explaining the persistence of the Roman classical 


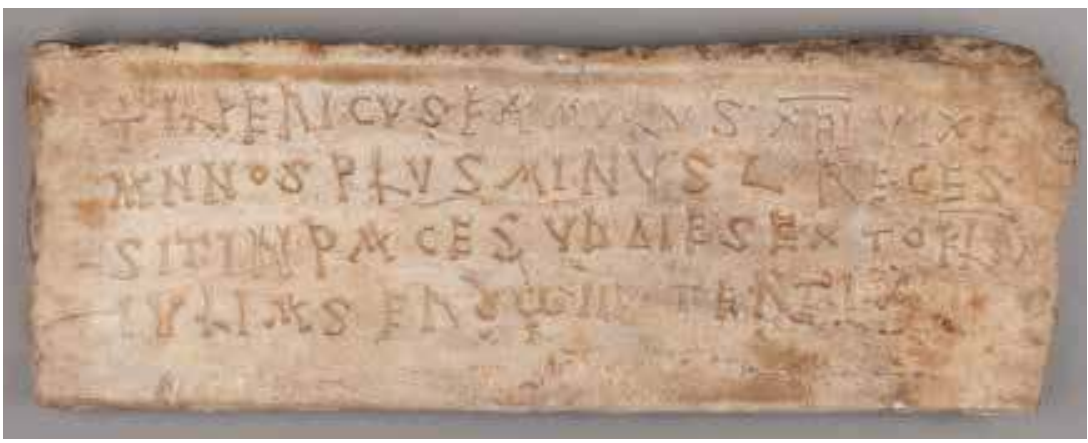

Fig. 14.3 Epitaph of Ilpericus. @ Museo Arqueológico Nacional Madrid, inv. no. 62292.

capital in Visigothic inscriptions. However, production led both to a loss of compositional organization, proportion, geometry, and regularity that had characterized Roman epigraphic production, and shifted to other forms of writing. In the post-imperial world, the classical capital constituted an old-fashioned form of writing that survived almost solely in inscriptions, some luxury books, and the incipits of books and book chapters. In order to attract, epigraphs needed to be incised in a style that permitted immediate and perfect legibility. The monumental Roman form offered an advantage over other writing forms because the population was accustomed to seeing it in streets, squares, monuments, and, above all, in cemeteries, as opposed to models of writing that arose in the late Roman period. Rome was an epigraphic culture par excellence that had employed writing techniques specific to and eventually intimately associated with inscriptions, a custom that was maintained by Christian elites. Thus, stone-cutting workshops continued to use a form of writing with a tested capacity for attracting attention and to which the population had become accustomed.$^{31}$

Obviously, the appearance of the classical capitals was not always identical; variants were dependent on the care taken in their execution. This not only denoted the greater or lesser skill of the cutter, but also the cost of the inscription itself and the design of the text, an indication of the economic capacity of the person who commissioned it. This can be seen in the strong contrast between epitaphs. Some magnificent tomb covers measured $2 \mathrm{~m}$ long, about $60 \mathrm{~cm}$ wide, and approximately $5 \mathrm{~cm}$ thick, with a text incised in the upper part; these inscriptions tend to be carefully incised and decorated, as for instance in the double epitaph of Florentia and Marcella (letters between 5 and $3 \mathrm{~cm}$; see Fig. 14.2). On the other hand, smaller, thinner inscriptions have a horizontal layout, such 
as the one of Ilpericus, with smaller writing (in this case between 3.5 and $1.3 \mathrm{~cm}$ ) and poorer quality, besides being undecorated (Fig. 14.3). The first support was destined for better quality tombs while the second for more modest burials, with less expensive inscriptions due to the simplicity of the writing and the lack of decoration, thus saving in labour and the amount of stone required..$^{2}$

Besides the material, writing, and decoration, another element that enhanced an inscription was a text in verse. These were used in epitaphs for people such as bishops, or in solemn inscriptions such as those at San Juan de Baños concerning the king, and even for less illustrious people such as the one for the priest Crispin, with verses after the epitaph of Riciberga, wife of Recceswinth, composed by Eugenius of Toledo:

(crux) Quisquis hunc tabule/ 1[ustra]ris titulum huius/ [cern]e locum respice situm [p(er)spice vic]inum malui abere/ [locum sa]c[r] um/ [sac(er?) ipse $\mathrm{m}(\mathrm{i}) \mathrm{n}(\mathrm{is})]$ ter annis sexsa/[ginta p]eregi tempora/ [vite] (vacat)/ [...? fun]ere perfunctum $\mathrm{s}(\mathrm{an}) \mathrm{c}(\mathrm{t}) \mathrm{is} /[\mathrm{co}] \mathrm{mmendo}$ tuendum/ [ut cum] flamma vorax ve/[n]iet conburere terras/ cet[i]bus s(an)c(t)orum merito/ sociatus resurgam/ hic vite curso anno finito Crispinus $\operatorname{pr}(\mathrm{e}) \mathrm{sb}(\mathrm{i}) \mathrm{t}(\mathrm{er})$ peccator/ in Xp(ist)i pace quiesco era DCC/ XXXI. ${ }^{33}$

The goal was to achieve maximum solemnity to exalt the inscription and, therefore, its protagonists. Poetry came to play an aulic role to serve ideological propaganda. ${ }^{34}$ Its use evidenced social superiority and became an explicit sign of privileged social status. Thus, the material, decoration, writing, and form of wording were used to exalt the importance and power of the inscription's intellectual author. ${ }^{35}$

32 Navascués 2019, pp. 904-905.

33 Velázquez Soriano 2001, pp. 340-346. The text could be translated as follows: 'Who ever reads this inscription, take note of the place and observe its surroundings. As a sacred minister I have preferred to possess a holy place. I lived for 60 years. Dying I entrust myself to the protection of the saints to resurrect in their company properly when the ravenous flames come to light the Earth. When his lifetime ended, Crispin, sinner presbyter, rested here in the peace of Christ in 693 AD.'

34 Velázquez Soriano 2007, p. 102.

35 This paper has been published with financial support from the Spanish Ministry of Economy and Competitiveness via a grant for the project, 'Corpus Inscriptionum Hispaniae Mediaevalium II' (PID2019-104395RB-100), and the Community of Madrid (Spain) via a grant for the project, 'Archivo Virtual para las Investigaciones sobre Patrimonios Epigráficos Medievales de la Comunidad de Madrid' (AVIPES -CM)(H2019/HUM-5742). 


\section{Bibliography}

\section{Primary sources}

Corpus de inscripciones romanas de Andalucía:Jaén, 3 vols., vol. 3, ed. by Cristobal González Román and Julio Mangas Majarrés (Seville: Junta de Andalucía, 1991). Inscripciones cristianas de la España romana y visigoda, ed. by José Vives (Barcelona: Consejo Superior de Investigaciones Científicas, 1969).

Iscrizioni cristiana di Roma: testimonianze di vita cristiana (sec. III-VII), ed. by Carlo Carletti (Florence: Nardini, 1986).

\section{Secondary sources}

Aragoneses, Manuel Jorge, 'El primer credo epigráfico visigodo y otros restos coetáneos, descubiertos en Toledo', Archivo Español de Arte 30 (1957), pp. 295-323.

Carande Herrero, Rocío, Josep M. Escolà Tuset, Concepción Fernández Martínez, Joan Gómez Pallarès, and José C. Martín Camacho, 'Poesía epigráfica latina de transmisión manuscrita: ¿ficción o realidad?', in Temptanda viast: nuevos estudios sobre la poesía epigráfica latina, ed. by Concepción Fernández Martínez and Joan Gómez Pallarès (Cerdanyola del Vallès: SPUAB, 2006), pp. 1-39.

Carletti, Carlo, 'Nascita e sviluppo del formulario epigrafico cristiano', in Le iscrizioni dei cristiani in Vaticano: materiali e contributi scientifici per una mostra epigrafica, ed. by Ivan Di Stefano Manzella (Vatican City: Musei e Gallerie Pontificie, Inscriptiones Sanctae Sedis 2, 1997), pp. 143-164.

Fernández Flórez, José Antonio, La elaboración de los documentos en los reinos hispánicos occidentales (siglos VI-XIII) (Burgos: Institución Fernán González, Academia Burgense de Historia y Bellas Artes, 2002).

Godoy Fernández, Cristina, Arqueología y liturgia: iglesias hispánicas (siglos IVal VIII) (Barcelona: Universitat de Barcelona, 1995).

González Salinero, Raúl, 'La dimensión edificante del espacio sagrado: la arquitectura de culto cristiano en las fuentes escritas hispano-visigodas del siglo VII', in El siglo VII frente al siglo VII: arquitectura, ed. by Luis Caballero Zoreda, Pedro Mateos Cruz, and María de los Angeles Utrero Agudo (Madrid: Consejo Superior de Investigaciones Científicas, 2009), pp. 11-24.

Handley, Mark, Death, Society and Culture: Inscriptions and Epitaphs in Gaul and Spain, AD 300-75o (Oxford: Archaeopress, British Archaeological Reports 1135, 2003).

Muñoz García de Iturrospe, Maria Teresa, Tradición formular y literaria en los epitafios latinos de la Hispania cristiana (Bilbao: Universidad del País Vasco, 1995).

Navascués, Joaquin Maria de, Obra epigráfica, 2 vols. (Madrid: Numisdoc, 2019). 
Petit, Carlos, 'Derecho visigodo del siglo VII: un ensayo de síntesis e interpretación', in Hispania Gothorum: San Ildefonso y el reino visigodo de Toledo, ed. by Rafael García Serrano (Toledo: Museo de Santa Cruz, 2007).

Pietri, Luce, 'Pagina in pariete raserata: épigraphie et architecture religieuse', in La terza età dell'epigrafia: colloquio AIEGL-Borghesi 1986, ed. by Angela Donati (Faenza: Fratelli Lega Editori, Epigrafia \& Antichità 9, 1988), pp. 137-158.

Revuelta Tubino, Matilde, Museo de los Concilios de Toledo y la cultura visigoda, and ed. (Madrid: Ministerio de Cultura, Dirección General del Patrimonio Artístico, Archivos y Museos, 1979).

Sanders, Gabriel, 'Le tombe et l'eternité: categories distinctes ou domaines contigus? Le dossier épigraphique latin de la Rome chrétienne', in Le temps chrétien de la fin de l'antiquite au Moyen Âge, III ${ }^{e}-X I I I^{e}$ siecles, ed. by Jean Marie Leroux (Paris: Centre National de la Recherche Scientifique, 1984), pp. $185^{-218}$.

Santiago Fernández, Javier de, 'Materia y elementos iconográficos en las inscripciones cristianas de Mértola', Documenta \& Instrumenta 2 (2004), pp. 193-226. _ , 'El hábito epigráfico en la Hispania visigoda', in VIIIJornadas Científicas sobre Documentación de la Hispania Altomedieval (siglos VI-X), ed. by Juan Carlos Galende Díaz, Javier Santiago Fernández, Nicolás Ávila Seoane, Manuel Joaquín Salamanca López, and Leonor Zozaya Montes (Madrid: Universidad Complutense de Madrid, 2009), pp. 291-344.

__ 'Memoria de la vida y publicidad de la muerte en la Hispania tardorromana y visigoda: las inscripciones funerarias', in IXJornadas científicas sobre documentación: la muertey sus testimonios escritos, ed. by Juan Carlos Galende Díaz, Javier Santiago Fernández, Nicolás Ávila Seoane, Manuel Joaquín Salamanca López, and Leonor Zozaya Montes (Madrid: Universidad Complutense de Madrid, 2011), pp. 365-403.

Sartori, Antonio, 'Formularii funerari cristiani: la tradizione innovata', in La terza età dell'epigrafia: colloquio AIEGL-Borghesi 1986, ed. by Angela Donati (Faenza: Fratelli Lega Editori, Epigrafia \& Antichità 9, 1988), pp. 159-168.

Susini, Giancarlo, Il lapicida romano: introduzione all'epigrafia latina (Rome: L'Erma di Bretschneider, 1966).

Velázquez Soriano, Isabel, 'Las inscripciones del tesoro de Guarrazar', in El tesoro visigodo de Guarrazar, ed. by Alicia Perea (Toledo: Consejo Superior de Investigaciones Científicas, 2001), pp. 319-346.

— , 'El acto epigráfico en la Hispania visigoda (del rey abajo, todos)', in Hispania Gothorum: San Ildefonso y el reino visigodo de Toledo, ed. by Rafael García Serrano (Toledo: Museo de Santa Cruz, 2007), pp. 87-106.

— , 'Los estudios epigráficos: cuestión de métodos interdisciplinares', Pyrenae 39.1 (2008), pp. 7-40. 
—_ 'La inscripción de consagración de la Catedral de Toledo', in Excavaciones en el claustro de la Catedral de Toledo, ed. by Martin Almagro-Gorbea, José María Barranco Ribot, and Markel Gorbea Pérez (Madrid: Real Academia de la Historia, Bibliotheca Archaeologica Hispana 33, 2011), pp. 261-280.

Velázquez Soriano, Isabel, and Gisela Ripoll López, 'Toletum, la construcción de una Urbs Regia', in Sedes Regiae (ann. 40o-8oo), ed. by Gisela Ripoll López and José María Gurt Esparraguera (Barcelona, Memorias de la Real Academia de Buenas Letras 25, 2000), pp. 521-578.

\section{About the author}

Javier de Santiago Fernández is Full Professor at Complutense University of Madrid (Spain). His area of expertise is epigraphy and numismatics. He has published widely in Spanish medieval epigraphy and he is working on the Corpus Inscriptionum Hispaniae Mediaevalium. 



\section{Power and Church}





\title{
15 Between Throne and Altar
}

Political Power and Episcopal Authority in the Beginning of the Visigothic Kingdom of Toledo

\section{Rafael Barroso Cabrera}

\begin{abstract}
This chapter analyses the alliance between political power and the ecclesiastical hierarchy of Toledo during the reign of Theudis (531-548), within the general context of the settlement of the Visigoths in the Meseta ('Plateau') of the Iberian Peninsula. The consequences that this collaboration had on the promotion of Toledo from a simple diocese to the metropolitan see of the Carthaginiensis province, and subsequently primacy of Spain, are seen through the specific case of the creation of the diocese of Segovia.
\end{abstract}

Keywords: Montanus of Toledo; council; Visigoths; barbarians, Theudis; Priscillianism

\section{Theudis and Toledo: A Bond Stronger than Death}

The creation of the Visigothic kingdom of Toledo is frequently presented as the fortunate sum of Liuvigild's military effort and Reccared's political talent. Without denying this, a period of crucial importance in the history of the Iberian Peninsula and, especially, in that of the city of Toledo, one that does not usually attract much interest, requires attention. The end of the Balti dynasty and Theudis's murder is a period that could be termed the first Visigothic kingdom of Toledo. ${ }^{1}$

On 24 November 546, Theudis sanctioned a decree concerning procedural costs in Toledo and ordered its inclusion in the Codex Theodosianus. The initiation of this law has been considered the initial moment in a process

$1 \quad$ See Fuentes Hinojo 1996; Koch 2008.

Panzram, S. and P. Pachá (eds.). The Visigothic Kingdom: The Negotiation of Power in Post-Roman Iberia. Amsterdam: Amsterdam University Press 2020 DOI: 10.5117/9789463720632_CH15 
that turned Toledo into the capital of the Visigothic kingdom. ${ }^{2}$ There are indications, however, that the city had been acting as such for some years before. Although no document or chronicle of the time informs us of the reasons that led the king to choose Toledo as his court, it is possible to discern factors that could have affected his decision. Undoubtedly, the selection was influenced by Toledo's privileged geographical location as the centre of communications between two plateaus and the Tagus corridor. Its central location in the Iberian Peninsula and on the ford of the Tagus, as well as its defensive position and the fertility of its plains, turned the city into a highly privileged urban centre. Besides, Toledo had in its favour the fact that it was barely affected by the insecure atmosphere of the fifth century AD. This enabled it to preserve intact important urban infrastructures that would be useful in establishing the Visigothic court in the future. In fact, decades before Theudis decided to set his court in Toledo, the city had already hosted an important national council. ${ }^{3}$

A council held in 531 was a major turning point in raising the importance of Toledo in the Iberian Peninsula. This synod marks the de facto independence of the inner Carthaginiensis with respect to Cartagena and the recognition of the metropolitan character of the bishop of Toledo. ${ }^{4}$ It took place two decades before the imperial landing in Hispania, as well as at a point where the implicit complicity can be seen between two strong men of the moment: Theudis and Montanus, the bishop of Toledo. Theudis had always kept an excellent relationship with Hispanic-Roman Catholic circles, even when in theory he was subject to Amalaric, proven by the fact that several councils were held under his protection (Council of Toledo in 531, Barcelona in 540, Lerida and Valencia in 546).

Obviously, another important factor was Toledo's location far from Emerita Augusta, the former capital of the diocesis Hispaniarum and the Toulouse administration, and, therefore, from Franks and Ostrogoths. It must have given Theudis a freedom of movement that enabled him to develop his own political framework independent of the dictates of the courts of Amalaric and Theodoric. ${ }^{5}$

2 'Dat. sub die VIII. kalendas Decembrias anno XV. regni domni nostri gloriosisimi Theudi regis Toleto' (Supplementa ex lege Romana excepta, 8o, p. 469).

3 Fita 1889.

4 'ut frater et coepiscopus noster Montanus, qui in metropoli est, ad coprovinciales nostros Domini sacerdotes litteras de congreganda sinodo adveniente tempore debeat destinare'. Concilios visigóticos e hispano-romanos, 45 .

5 Velázquez Soriano and Ripoll López 200o; Barroso Cabrera, Carrobles Santos, Morín de Pablos et al. 2015. 
A further element has to do with the impact that the Visigothic settlement and the arrival of new contingents of Ostrogoths had on the central area of the Meseta. Amid the latter, there were important noble families that would reaffirm Gothic identity among the barbarians. This arrival must have supposed a reinforcement of the Gothicist party contrary to the Roman-style policy of the Balti dynasty and, consequently, a fundamental support for Theudis and his political ambitions. ${ }^{6}$

Moreover, as the archaeological record has shown, the territory of Toledo abounded in large latifundia. This implies the existence of a prominent provincial oligarchy increasingly unconcerned by affairs of the empire. An important point must have had a decisive impact on the choice of Toledo as sedes regia, which is usually overlooked. The political factor, and, more specifically, the notion of historical and symbolic continuity of the Valley of the Tagus in relation to the Roman imperial past, represents an aspect brilliantly pointed out by Canto. ${ }^{7}$

Continuity with the Roman past is well illustrated by the episode of the nuptials of Theudis with an important Hispano-Roman matron. ${ }^{8}$ The story narrated by Procopius of Caesarea has been analysed especially in relation to the formation of private armies in ancient times. ${ }^{9}$ However, this marriage transcended mere military intent as a long-term political agreement. Indeed, Procopius affirms that the lady belonged to one of the most distinguished lineages in Hispania and that she possessed great wealth, as well as enormous prestige and power. The Greek historian states that her private army of 2,000 warriors allowed Theudis to enjoy a de facto independence over Theodoric authority and that way usurp ( $\tau$ úpavvos, 'tyrant' is the term used by Procopius) the throne of Amalaric in 531. The term used by Procopius to refer to the armed retinue of this lady is striking.

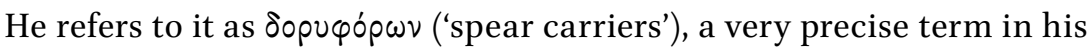
time from both a military and institutional point of view. It was not, then, simple soldiers or armed clients, but elite warriors linked to their lord by oath of fidelity. ${ }^{10}$ The importance and quality of this troop can be seen by

6 Iordanes, Getica, 283, 297, and 302; Procopius, Gothic War, V.12.45-49 and 13.12 seq. König 1980, pp. 246 seq.; Périn 1993; Schwarcz 2001; Wolfram 1990, p. 146; Pérez Rodríguez-Aragón 2002; Kazanski and Périn 2011, pp. 306-308; Koch 2006, pp. 86 seq.; Pinar Gil 2014. Cf. Eger 2005. García Moreno 2008a, p. 152. Cf. Halsall 2011, pp. 16 and 19. Settlement post 531: Arce 2011, pp. 38 seq. See Barroso Cabrera 2018, pp. 62-67.

7 Canto 2006.

8 Procopius, Gothic War, V.12.50 seq.

9 Sanz Serrano 1986, p. 261.

10 Bruhn Hoffmeyer 1996, p. 119; Amory 1997, p. 177. 
the fact that Belisarius brought a force of 10,000 against the Vandals, 5,000 of these knights. ${ }^{11}$

It is more difficult to prove the Toledan origo of Theudis's wife, since Procopius simply points out that she was of Hispanic origin and not of the Gothic race. Nevertheless, there are other reasons that lead us to consider her, more than possible, imperial lineage and her relationship with Theodosius's family. ${ }^{12}$ The archaeological record supports the existence of a powerful aristocratic provincial class around the city of Toledo and the fertile valleys of the Tagus. ${ }^{13}$

The fact that Theudis, following the example of other Gothic kings and nobles attracted to the idea of Roman heritage, was the first monarch among the Visigoths to adopt the title of Flauius, significant because the Visigothic king, unlike Fravitta or Theodoric the Great, did not receive the title from the hands of an emperor. Instead, he assumed it himself. ${ }^{14}$ Considering that Theudis belonged to an outstanding Ostrogothic lineage, perhaps related to the royal and semi-divine lineage of the Amali, ${ }^{15}$ it would be more than reasonable to admit that the idea of marrying a distinguished Hispanic matron who likely belonged to the lineage of Theodosius would have had an obvious political objective. In this respect, he would have been following the ill-fated example of the princely nuptials of Athaulf and Galla Placidia, and that king's desire to revive the glory of Rome, as well as the policy adopted by Theodoric in Ravenna aimed at attracting the Roman population. ${ }^{16}$ From that point of view, the appellation Flauius was the privative title of the Visigothic royalty, to the degree that in 974 Ramiro III, in an attempt to emphasize the continuity between the kingdom of León and the ancient Visigothic kingdom, had himself crowned as Flauius princeps magnus basileus unctus. ${ }^{17}$

Onomastic is another element to be added to this evidence. Although most chroniclers - and particularly Isidore of Seville - used the name Theudis, the name with which he has gone down in history, it is almost certain that his real name was Theodoric. At least, this is how he is registered in the

15 Amory 1997, pp. 451 and 457-459; Heather 1996, p. 242; García Moreno 2008a, pp. 149 seq.

Procopius, Vandalic War, III.11.

Barroso Cabrera, Carrobles Santos, Morín de Pablos et al. 2015.

Carrobles Santos 2007.

Pérez Sánchez 1984-1985, pp. 259 seq.; Cameron, Long, and Sherry 1993, pp. 236-252; Arnold Amory 1997, pp. $45_{1}$ and 457-459; Heather 1996, p. $242 ;$
Paulus Orosius, Historiae adversus Paganos, VII.43.6.

Wolfram 1997, pp. 109, 273, and 277 
proceedings of the councils of Lerida and Valencia of the year $546 .^{18}$ The new name may be seen as an attempt to link himself to Emperor Theodosius as the result of his nuptial bond with an aristocrat belonging to the imperial lineage. In that case, the decision would be due to Theudis's desire to legitimize his power over Hispania. In that context, Procopius's allusion to the Visigothic king as tyrannus ('usurper') would be better understood as a means to provide propagandistic ammunition for a future Byzantine intervention on the Iberian Peninsula. ${ }^{19}$ The truth is that, increasingly occupied by southern affairs and with an eye on the growing imperial threat on the Strait of Gibraltar, Theudis had to leave Toledo to settle in Hispalis (Seville), where he was murdered for reasons beyond politics, surely fulfilling a blood revenge. ${ }^{20}$

It can truly be said that the political project designed by Theudis was aimed at fulfilling the old dream of Athaulf, that is, the creation of a Visigothic kingdom whose borders coincided with those of the ancient diocesis Hispaniarum. In that sense, the policy developed by Theudis can be considered as a failed precedent of what Liuvigild would successfully carry out half a century later, with surprising parallels (or not so much, taking into account the threat of the Franks) such as the Amalaric-Theudis and LiuvaLiuvigild dualities. But, as Koch has pointed out, " $[\mathrm{u}]$ nlike Liuvigild, Theudis had the bad luck of losing, at least once, a battle and, shortly thereafter, his own life.'. ${ }^{21}$ Despite this failure, the link between the Visigothic political power and the ecclesiastical authority of Toledo was revealed as stronger than that death. The metropolitan rank of the royal seat reached with the help of the monarch was hardly disputed, at least until the situation became evident with the conquest of Cartagena. This pre-eminence was an important issue in which the Gothic contingents settled on the Meseta were involved: the creation of the diocese of Segovia.

\section{Toledo, Segovia, and the conversion of the Goths}

Except for certain exceptional cases, the distribution map of the PonticDanube-type findings on the Iberian Peninsula establishes two axes that

\footnotetext{
18 Concilios visigóticos e hispano-romanos, 55 and 61. Such fact was already noted by other authors: Collins 2005, p. 38.

19 The classical term ('tyrant') does not have the present pejorative connotation in relation to a bad exercise of power. It simply implies his illegitimate character: Orlandis Rovira 1959 .

20 Isidore of Seville, Historia Gothorum, 43.

21 Koch 2008, p. 110.
} 
run almost parallel to the Sistema Central. In this distribution there exists an interest in controlling roads that converge in Toledo and communications among the cities of Astorga, Mérida, and Zaragoza: the route from Emerita to Caesaraugusta and the one that leads from Complutum to Palentia through Segovia and Cauca. ${ }^{22}$

The first of these axes is located to south of the Sistema Central and seems to continue the road that leads from Gaul to Emerita. The second is located north of the Sistema Central, and would have the current province of Segovia as its alfoz (district), although Palencia would be related to it as well.

In relation to the latter axis, correspondence carried out by Bishop Montanus with the Palencia church is interesting because it reveals the power that Toledo was acquiring within the political structures of the Visigothic kingdom. These are two epistles added to the proceedings of the II Council of Toledo held in the last year of the reign of Amalaric (526-531), most probably with the acquiescence of Theudis. The chronology of both epistles is before 17 May 531, the date the synod gathered. ${ }^{23}$

The first letter is a public admonition of the clergy and people of the Palencia diocese on the occasion of certain disciplinary abuses in relation to the blessing of the chrism by presbyters, who had usurped a privilege reserved exclusively for the episcopal order. In this epistle, Bishop Montanus also denounces the invitation made to foreign prelates, as well as certain Priscillianist inclinations observed among the local clergy. ${ }^{24}$ As is known, Gallaecia had been one of the provinces where the Priscillian heresy had been firmly established and that Palencia was located precisely on the border with the Suevic kingdom.

The second epistle is a private letter addressed to a person from the diocese of Palencia named Turibius, whom many authors identify with the head of the see. ${ }^{25}$ However, there are disagreements. Flórez held a contrary position. Other authors, such as Vilella Masana or Martin, for different reasons, assume that the Palencia see was vacant, while Isla Frez places Turibius as bishop of Astorga. In addition, both Isla Frez and Martin suggest a kinship relationship between this Turibius and the homonymous bishop of Astorga, one of Priscillianism's adversaries, considering the proximity of both sees and the evolution of the late Roman onomastic. What is

\footnotetext{
22 Domínguez Monedero 1986, p. 64; García Moreno 1987; Sastre de Diego 2001, p. 284.

23 Vilella Masana 2003, p. 107, n. 75. For this section we refer to our paper, Barroso Cabrera 2018.

24 Concilios visigóticos e hispano-romanos, 46-5o. Ildefonsus of Toledo, De Viris Illustribus, ed. by Codoñer Merino, pp. 119-121.

25 Concilios visigóticos e hispano-romanos, 50-52.
} 
unquestionable is that Turibius belonged to the clerical state because, according to Montanus, even when he still flourished (cum enim adhuc floreres in saeculo), he distinguished what belonged to Caesar and what belonged to God. Similarly, almost a century later, Ildefonsus of Toledo mentions that Montanus wrote another epistle - ad Turibium religiosum. ${ }^{26}$

As is evident from this second epistle, a certain bishop (coepiscopus uester) had managed to obtain the municipalities of Brittablum (Vertavillo), Segobia (Segovia) and Cauca (Coca), all located in the territory of the diocese of Palencia, from Celsus, predecessor of Montanus. ${ }^{27}$ Years later Montanus considered that this decision had damaged the supervisory prerogative that the bishops of Toledo had assigned themselves to act as metropolitans of the inner Carthaginiensis. ${ }^{28}$

The context of this letter is uncertain and has given rise to controversy. Father Flórez assumed that the Palencia see was vacant because the bishop had been irregularly ordered, which would have motivated Montanus's intervention. ${ }^{29}$ Vilella Masana argued that the vacancy of the Palencia see was due to confrontation with the Suevi, or tensions between Toledo's political power and the local aristocrats, suggesting that the fugitive bishop was actually its holder. $3^{30}$ Martin, meanwhile, assumes that the bishop would have been deposed by conciliar decision. ${ }^{31}$

That the see was vacant for a period of time is difficult to determine, but the custom of consecrating the chrism among presbyters was quite extensive. It is difficult to assume that the bishop referred to by Montanus was the holder of the Palencia see, since, granting him new municipia once deposed makes little sense: if his ordination had been irregular, he would not have been assigned any territories, since his dignity would not have been recognized. Montanus's sentence, therefore, includes an explicit recognition

26 Ildefonsus of Toledo, De Viris Illustribus, 2; Flórez, España sagrada, V.25-27; Martin 1998a; Vilella Masana 2003; Martin 1998b and 2006; Isla Frez 2000-2001, pp. 43-45.

27 Ildefonsus of Toledo, De Viris Illustribus, ed. by Codoñer Merino, pp. 58-64; Orlandis Rovira 1984, pp. 144-146; Thompson 1985, pp. 47 seq.; Barbero de Aguilera 1989; Isla Frez 200o-2001, pp. 41-52; Vilella Masana 2003; Martin 1998b and 2006. For the location of Brittablum, see Sánchez Doncel 1950, pp. 117-120.

28 The term coepiscopus should not be interpreted as having two Catholic bishops in the same see (something prohibited in ecclesiastical legislation), but that it was the dignity of Turibius's colleague.

29 Flórez, España sagrada, V.25 seq.

30 Vilella Masana 2003, p. 108, n. 88 and p. 111, n. 110.

31 That is what the sentence 'quod tamen priuilegium decessori nostro, necnon dominis et fratribus nostris Carpetaniae et Celtiberiae episcopis uester coepiscopus fecit' refers to. See Vilella Masana 2003, p. 106, n. 57 and p. 111, n. 110; Martin 2006, p. 4. 
of a valid episcopal condition. Most likely, then, this vagabond bishop was an exiled prelate who would have found asylum in Palencia and was granted such villages according to his rank.

This issue is inserted in a confusing passage that seems to mix two different topics: the one referred to and the complaint that had reached the ears of the bishop of Toledo that some presbyters of the diocese of Palencia invited 'foreign bishops' (alienae sortis episcopi) to consecrate basilicas outside the metropolitan authority. Although this is an obscure episode, it seems that Montanus was going to suggest the nomination of Turibius as bishop of Palencia (iure etenim auctorem te diuini cultus in hac praesertim prouincia nominabo), and at the same time was informing him about some irregularities that were occurring in the diocese because of the absence of a prelate, a situation to which Turibius's appointment would put an end. This is even clearer when Montanus urges Turibius to halt the abuses in relation to the consecration of the chrism..$^{2}$ The fact that the bishop of Toledo was going to propose his correspondent as a new prelate is also the interpretation given by Ildefonsus of Toledo (committit ei sacerdotalis auctoritatem uigoris). ${ }^{33}$

In this context, Montanus's second letter must be understood as evidence of Turibius's appointment in pectore and, despite its tone, should not be interpreted as a harsh threat to Turibius. Instead, it could be seen as a series of guidelines the metropolitan suggested to his pupil to be put into practice at the see of Palencia, in order to end irregularities that had been taking place. By following them, Turibius would avoid abuses in ecclesiastical discipline (consecration of the chrism), combat idolatry (paganism) and Priscillianist practices, and also prevent the interference of foreign bishops in relation to the consecration of basilicas. ${ }^{34}$

In any case, it is curious that, despite this attention of the Toledan bishop, carried out in terms that today may seem harsh - since the letter includes recourse to the authority of iudex $\operatorname{Ergan}^{35}$ - Montanus's predecessor decided to keep the errant bishop at the forefront of a territory in the southeastern

32 Ep. 2: 'et ideo spero ut pro enervanda hac ipsa superfluitate severissimi sacerdotis auctoritate utaris, et tanta rei temeratores districtiori increpatione coerceas'. This sentence reflects the exclusive privilege of the bishops to consecrate the chrism mentioned by Montanus. Cf. Vilella Masana 2003, p. 110, n. 103 .

33 Ildefonsus of Toledo, De Viris Illustribus, 2.15, ed. by Codoñer Merino, pp. 120 seq.

34 Vilella Masana 2003 offers the best analysis, even though we do not agree with some details. In his Ep. 1 Montanus had already asked the Palencia's priests whether they wanted him to treat them 'with a stick, or with charity and a meek spirit' (Vilella Masana 2003, p. 107).

35 It is debated whether Ergan was count of Palencia (García Moreno 1974 and 1987, pp. 325-337; Vilella Masana 2003, p. 118) or Toledo (Barroso Cabrera 2018). 
area of the Palencia diocese, and to also give him the municipia mentioned above, by reason of 'not seeing his episcopal dignity defiled by his wandering around', not because he was assisted by any right. This anomalous situation was still in force at the time of Montanus, hence the protest that he raises to Turibius, which in fact should be understood as a reminder that the situation was tolerated by virtue of a privilege granted by the Toledo see. As Barbero de Aguilera stated, this is inferred by the fact that, contrary to what would be logical, the district of the Palencia conuentus granted to this prelate was not removed from the ecclesiastical map, but was in time consolidated as a new episcopal see: the diocese of Segobia. The new episcopal see is documented for the first time with certainty in the year 589 when its holder, Bishop Petrus, appears among those attending the III Council of Toledo. ${ }^{6}$

Leaving aside possible ecclesiastical implications, what is of interest is what territory was assigned to the new Segovia see. Its limits can be inferred with some confidence: since the land detached from the Palencia conuentus corresponds to the municipalities Brittablum, Cauca, and Segobia, the area of the new see must have coincided with the region of Tierra de Pinares, south of the line formed by the rivers Douro and Esgueva. This land occupies precisely the distribution map of the necropoleis with Pontic-Danubian-type goods located north of the Sistema Central: Castiltierra, Duratón, Aguilafuente, Espirdo-Veladiez, Sacramenia, etc. All this suggests that the ratification of this district as a diocese based in Segovia, outside the tradition, was a process encouraged by the prelates of Toledo themselves with the endorsement of Theudis. It would otherwise be difficult to understand that, half a century before the III Council of Toledo, Montanus would have allowed a situation he considered anomalous, although it is true that Montanus's predecessor had protected the dignity of the new bishop to maintain that irregular situation. There were two good reasons, however, to explain this decision: one in terms of political-ecclesiastical interests and the other in purely pastoral terms.

The first reason is that with this measure the power of a possible competitor of the regia sedes in the framework of the Carthaginiensis province diminished, whereas the power and dignity of the Toledo see were enhanced over the Palencia see. ${ }^{37}$

The second reason is interesting because it can shed light on the significance of the archaeological finds in the central area of the Iberian Peninsula.

36 Barbero de Aguilera 1989, pp. 173-175. The diocese is attested from that date until the year 693. Flórez, España sagrada, VIII.73-81; García Moreno 1974, pp. 142 seq.

37 Barbero de Aguilera 1989. 


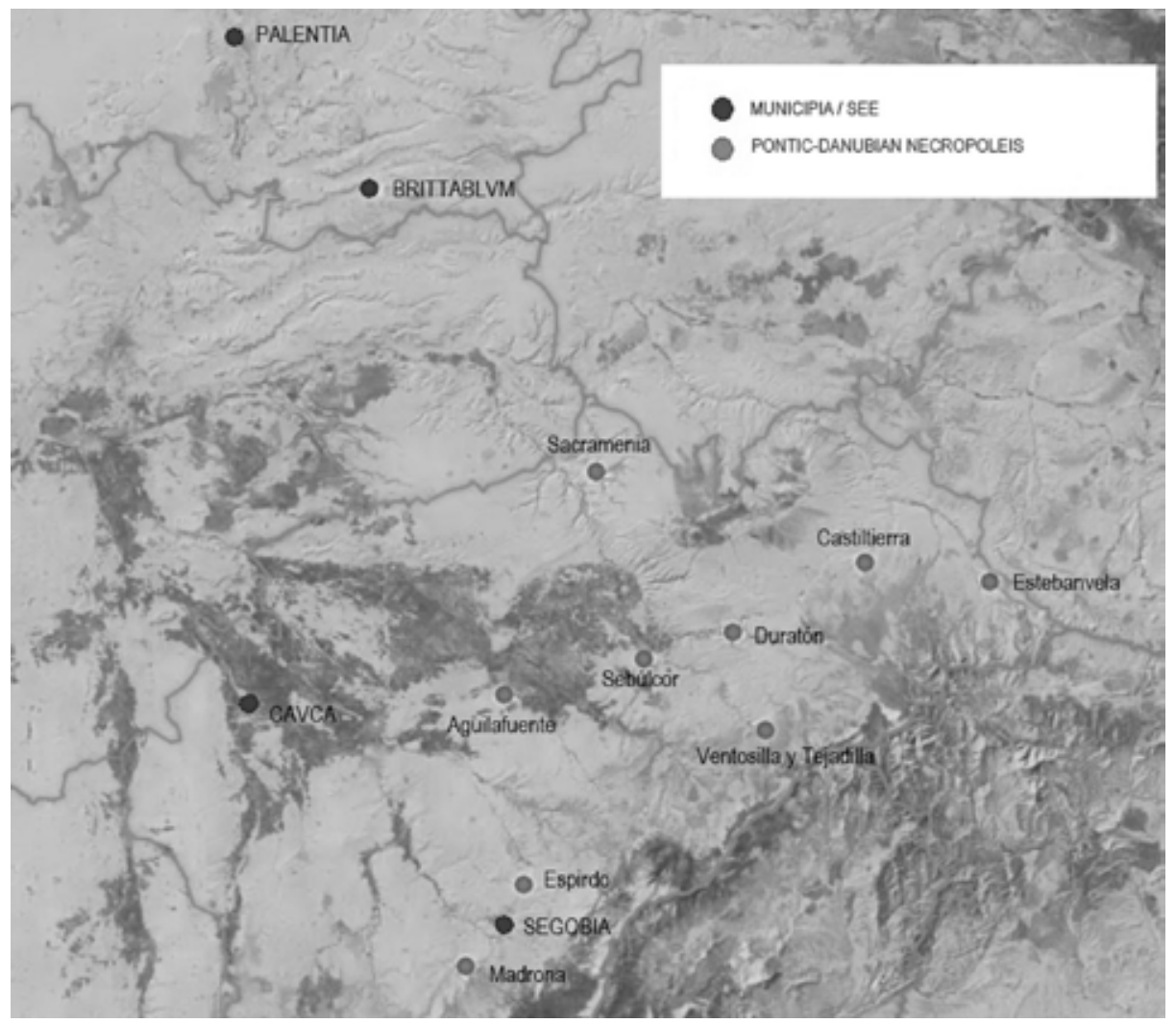

Fig. 15.1 Map of the municipalities and necropoleis with Pontic-Danubian materials north of the Sistema Central. @ Rafael Barroso Cabrera.

One of the reasons that would have led the Toledo see to allow this anomalous situation can be deduced from the comparison between the centres delivered to the new bishop and the dispersion map of the Visigothic necropoleis north of the Sistema Central (Fig. 15.1). The appointment of the new bishop resulted from the desire on the part of the Catholic hierarchy to evangelize Arian Visigoths established in Segovia's lands, by taking advantage of the favourable inclination to Catholics shown by Theudis. $3^{8}$ Undoubtedly, the scarce hierarchy and poor organization of the Arian church would facilitate this pastoral work. And since the diocese of Palencia was vacant at that time, it is quite logical to consider this as an initiative of the bishop of Toledo, who acted de facto as a metropolitan of the Carthaginiensis and also had the support of the strongman of the regime. 
In fact, the conversion of the Visigoths must have occurred at two levels: in the case of the nobility settled in cities, it must have been carried out through the episcopal and monastic circles that comprised the highest culture of the time. But in the rural environment, especially in those areas where there was no strong monastic implantation, perhaps due to the Barbarian settlement, this work must have remained in the hands of the parish clergy under the direct supervision of the current bishop. This, without a doubt, must have been the case of Segovia and its territorium.

Some indications suggest that the evangelization of the Goths might have had a remarkable success towards the middle of the sixth century. We know, for example, that at the moment when the religious crisis caused by Hermenegild's rebellion broke out, many Goths had abandoned the faith of their elders. ${ }^{39}$ Rightly, Thompson assumed that these conversions would ultimately result in the loss of Gothic identity. ${ }^{40}$ Liuvigild was well aware of this and hence the desperate irenical measures emanating from the Arian synod of 580 .

It is interesting in Montanus's letters to note how the bishop of Toledo praises Turibius for his fight against idolatrous and heretical practices (referring both to Priscilianism and Arianism) as a sign of pastoral interest in the conversion of the Goths, considering the support provided by Theudis (a Goth) to Montanus and the confluence of interests that seems to have existed between the actions of the prelate and the future monarch. Isla Frez believed that the allusion to paganism should be interpreted in relation to the Suevi, assuming that Turibius was bishop of Asturica and not of Palentia. ${ }^{41}$ Although difficult to accept, there is no doubt that a bishop who knew how to combat heresy and pagan practices would undoubtedly be the ideal candidate for the work that Montanus wished to entrust to someone who should act as pastor of the Goths settled north of the Sistema Central.

As for the allusion to idolatrous worship, it is obvious that the situation among the Visigoths settled on the Plateau cannot have differed too much from that of the Suevi, at least as regards the popular estate, where the mix of pagan practices and a nominal Arianism would be commonplace. There were in fact abundant allusions to idolatrous practices and paganism in the ecclesiastical documentation of the time. ${ }^{42}$ Some veiled references

39 Thompson 1985, pp. 50-52. Cf. Vázquez de Parga 1973, pp. 25 seq., and García Moreno 20o8b, p. 134 .

40 John of Biclar, Chronicon, 57. Thompson 1985, pp. 50-52.

41 Isla Frez 2000-2001, p. 43.

42 McKenna 1938; King 1981, p. 169; Thompson 1985, pp. 70 seq. Archaeological findings prove the survival of some of these rites: Lantier 1943, pp. 173 and 183 . 
to pastoral concern in relation to the Visigoths, graphically described as 'fierce', can even be seen in Montanus's correspondence with Turibius. ${ }^{43}$ From this, it follows that what was in the mind of the Toledan see when it tolerated the creation of a new diocese was the evangelization of the Goths settled there. And, for that purpose, Arianism paradoxically revealed itself as a favourable element for unification. The maintenance of the Arian faith had been a powerful ideological element of identity cohesion for the Visigoths, useful to the extent that it served to differentiate them from the Hispanic-Roman population, but it is unlikely that it was a creed rooted in dogmas and ceremonies among the rural population. It is not that the Goths were Arians, it was that they were Arians because they were Goths.

Indeed, from the doctrinal point of view, and leaving aside exceptional cases such as that of the noble Agila narrated by Gregory of Tours ${ }^{44}$ or Sunna of Mérida, 45 the Visigoths, especially those of humble extraction, must have had a poor religious formation. Therefore, the conversion to Catholicism caused little opposition, except for some individuals belonging to the highest circles of power. Such notorious deficiency in spiritual formation was due to the fact that the Arian bishops did not have the pastoral sense of Catholic prelates. Instead, their ordination was rather due to political or military issues. In fact, the Arian bishops acted as a kind of priestly body at the service of the kings, serving as advisors to those who were entrusted with a special mission, usually alongside the campaigning army. In this sense, and unlike what happened in the Catholic church, the Arian bishops were not attached to any see, but rather acted as a kind of 'bishop without portfolio' always subject to the will of the king. ${ }^{4}$

The link between bishops and militia helps to explain Spain's situation and how easy it was for the Goths to convert to Catholicism. Beltrán Torreira has brilliantly analysed this issue in relation to the Gallaecia case during the Visigothic conquest. ${ }^{47}$ The same reflection can be extended to other areas in the kingdom where the presence of Arian bishops (Palentia,

43 Ep. 2: 'Nam de terrenorum dominorum fide quid loquar? Cui ita tuum impendisti laborem, ut feroces cohabitantium tibi animos ad salubrem regulam et normam regularis disciplinae perduceres.' See Vilella Masana 2003, p. 110; Isla Frez 2000-2001, p. 43. Cf. Martin 2006, p. 3.

44 Gregory of Tours, Libri historiarum X, 5.43 .

45 Vitas Sanctorum Patrum Emeretensium, 5.11.14-15.

46 Jones 1953; Mathisen 1997.

47 Beltrán Torreira 1989. 
Valentia, Barcino or Dertosa) is mentioned. ${ }^{4}$ However, all these episcopal sees seem to have been established late and, in fact, are directly related to the reform carried out by Liuvigild around 580 . Prior to that date, there is no Arian episcopal structure, either in documentary sources or in the legislation. ${ }^{49}$

In short, all the data reviewed support the idea advanced by Mathisen that until Liuvigild's reign there would have been no real hierarchical structure in Spain's Arian church, and that, when it was established, it was done imperfectly, at a late time, and under the exceptional circumstances from the uprising of Prince Hermenegild.$^{50}$ This absence of ecclesiastical structure would also have been reflected on a material plane, especially with regard to churches and monasteries of Arian ascription, which explains the lack of objects of worship related to this belief at archaeological and documentary levels. Similarly, when arriving in Mérida, the Arian bishop Sunna had to requisition some Catholic basilicas and all their goods, with Liuvigild's acquiescence..$^{11}$ The re-consecration of the church of St. Mary (Santa María) and the famous episode of the dispute over the tunic of St. Eulalia seem to confirm similar actions in relation to the regia sedes. Actually, except for the so-called basilica of Recopolis, and unlike what we know for Ostrogothic Ravenna, no Arian temple is known in Spain with certainty. ${ }^{52}$ In some cases (Egitania, Barcino, or Toledo itself) there are well-founded suspicions that some Catholic basilicas could have been used for the Arian cult. But even there, it is intuited that this occupation must have occurred in the context of the confiscations after 580 and the usurpation of the 'Catholic' name by Liuvigild. ${ }^{3}$

Taking into account the absence of hierarchical organization, lack of a coherent doctrinal corpus, and material structures to develop the cult, the Visigoths settled on the Plateau were easy prey for Catholic evangelizing work once Segovia's episcopal structure was established. In this sense, Arianism acted as a unifying factor between the two ethnic

48 The list of Arian dioceses is provided by the prelates who renounced Arianism in the III Council of Toledo and those three registered in literary sources: Sunna of Mérida, Uldila (of Toledo?), and Athalocus of Narbona.

49 Mathisen 1997, pp. 683 seq.

50 Ibid., pp. 681-686.

51 Vitas Sanctorum Patrum Emeretensium, 5.5.2-4 and 5.11.16; García Moreno 1974, p. 224, n. 2; Mathisen 1997, p. 684. Cf. Rico Camps 2009, p. 11.

$5^{2}$ About this basilica we have raised serious doubts that it really had an Arian phase: Barroso Cabrera 2019, pp. 122-130.

53 Gurt i Esparraguera and Sánchez Ramos 2011, p. 288; Beltrán Heredia de Bercero 2013, p. 26; Barroso Cabrera, Carrobles Santos, Morín de Pablos et al. 2015, pp. 29 seq.; Chavarría Arnau 2017. 
groups as, to a certain extent, it was to prepare the pastoral work of Catholic priests.

Although the identity of the anonymous bishop refuged in the Gothic kingdom and mentioned in Montanus's correspondence is not revealed in the letters, we favour the hypothesis that this prelate $a$ termino was a certain Bishop Marrucinus, who subscribed the minutes of the II Council of Toledo. ${ }^{4}$ Thompson already pointed out that only those bishops who came from a province other than the Carthaginiensis were recorded in the proceedings of the council..$^{55}$ Marrucinus, however, instead of mentioning his see, claims to be 'exiled in the city of Toledo because of his Catholic faith' (ob causam fidei catholicae in Toletana urbe exilio deputatus). This confirms the idea that such a see did not belong to the Visigothic kingdom, but to a kingdom that was hostile to Catholicism. In principle, it could be assumed that the exiled bishop was originally from the Vandal kingdom in North Africa. Nonetheless, Hilderic's reign (520-530) was characterized by his tolerance for the Catholic church. ${ }^{6}$ In turn, his successor Gelimer was busy enough facing Belisarius. ${ }^{57}$

If the African option is disgarded, only a see in the Suevic territory as the origin of Marrucinus can be considered, and explain his presence in the Toledan council of 531 in the context of the hostility between Suevi and Visigoths of the time. Between 465 (arrival of Ajax) and 561 (Council of Bracara) the Suevi underwent a period of intense Arianism. These reasons identify the see from which Marrucinus had been expelled as Asturica, a city in which there was a vacuum in its episcopal fast $i$ at that time, and which was on the border with the Visigothic kingdom, well connected with Palencia. ${ }^{8}$ The case of Marrucinus would reproduce a situation analogous to that experienced by Ortygius at the dawn of the fifth century AD. ${ }^{59}$ The difference is that at the time of Ortygius, Hispania was still a province of the empire and the prelate could be restored to his see. ${ }^{60}$

54 Concilios visigóticos e hispano-romanos, 46.

55 Thompson 1985, pp. 47 seq.; Barbero de Aguilera 1989, p. 173.

56 Procopius, Gothic War, 3.9.1 and 3.9.5; Vallejo Girvés 2012, pp. 63 seq. and 87 seq.

57 Bury 1923, vol. 1, pp. 124-139.

58 Flórez, España sagrada, XVI.89-108.

59 Hydatius, Chronica subdita, 31; Concilios visigóticos e hispano-romanos, 19-33.

6o I would like to thank Guadalupe Barroso Cabrera for the translation of this paper into English. 


\section{Bibliography}

\section{Primary sources}

Concilios visigóticos e hispano-romanos, ed. by José Vives (Barcelona: Instituto Enrique Flórez, Consejo Superior de Investigaciones Científicas, España Cristiana, Textos 1, 1963).

Flórez, Enrique, España sagrada, vol. 5: De la provincia Carthaginense (Madrid: 1859).

— España sagrada, vol. 8: De las iglesias sufragáneas antiguas de Toledo (Madrid: 1752).

— España sagrada, vol. 16: De la Santa Iglesia de Astorga (Madrid: 1762).

Gregory of Tours, Libri historiarum X, ed. by Bruno Krusch and Wilhelm Levinson

(Hanover: Monumenta Germaniae Historica, Series Rerum Merovingicarum 1.1, 1951).

Hydatius, Chronica subdita, in The Chronicle of Hydatius and the Consularia Constantinopolitana: Two Contemporary Accounts of the Final Years of the Roman Empire, ed. and trans. by Richard Burgess (Oxford: Oxford University Press, 1993), pp. 69-124.

Ildefonsus of Toledo, De Viris Illustribus, ed. by Carmen Codoñer Merino (Salamanca: Ediciones de la Universidad de Salamanca, Acta Salmanticensia, Estudios Filológicos 65, 1972).

Iordanes, Getica, in Iordanis Romana et Getica, ed. by Theodor Mommsen (Berlin: Monumenta Germaniae Historica, Auctores Antiquissimi 5.1, 1882), pp. 53-200. Isidore of Seville, Historia Gothorum = Las historias de los godos, vándalos y suevos de Isidoro de Sevilla, ed. by Cristóbal Rodríguez Alonso (León: Centro de Estudios e Investigación 'San Isidoro', 1975).

John of Biclar, Chronicon, ed. by Carmen Cardelle de Hartmann in Victor Tvnnvnensis Chronicon cum reliquiis ex Consularibus Caesaraugustanis et Iohannis Biclarensis Chronicon (Turnhout: Brepols, Corpus Christianorum, Series Latina 173A, 2001), pp. 59-83.

Paulus Orosius, Historiae adversus paganos = Seven Books of History against the Pagans, trans. by A.T. Fear (Liverpool: Liverpool University Press, 2010).

Procopius, The Gothic War, trans. by H.B. Dewing (Cambridge, MA: Harvard University Press, Loeb Classical Library, Procopius: Buildings, History of the Wars, and Secret History 3-5, 1919-1928).

- The Vandalic War, trans. by H.B. Dewing (Cambridge, MA: Harvard University Press, Loeb Classical Library, Procopius: Buildings, History of the Wars, and Secret History 2, 1916).

Supplementa ex lege Romana excepta, in Leges Visigothorum (Hanover: Monumenta Germaniae Historica, Leges Nationum Germanicarum 1, 1902), pp. 465-469.

Vitas Sanctorum Patrum Emeretensium, ed. by Antonio Maya Sánchez (Turnhout: Brepols, Corpus Christianorum, Series Latina 116, 1992). 


\section{Secondary sources}

Amory, Patrick, People and Identity in Ostrogothic Italy, 489-554 (Cambridge: Cambridge University Press, 1997).

Arce, Javier, Esperando a los árabes: los visigodos en Hispania (507-711) (Madrid: Marcial Pons, 2011).

Arnold, Jonathan J., Theodoric, the Goths and the Restoration of the Roman Empire (Ann Arbor, MI: University of Michigan, 2008).

Barbero de Aguilera, Abilio, 'Las divisiones eclesiásticas y las relaciones entre la iglesia y el estado en la España de los siglos VI y VII', in La Historia en el contexto de las ciencias humanas y sociales: homenaje a Marcelo Vigil Pascual, ed. by Maria J. Hidalgo de la Vega (Salamanca: Ediciones de la Universidad de Salamanca, Acta Salmanticensia, Estudios Históricos y Geográficos 61, 1989), pp. 169-189.

Barroso Cabrera, Rafael, Etnicidad vs. aculturación: las necrópolis castellanas de los siglos V-VIy el asentamiento visigodo en la Península Ibérica; una mirada desde la Meseta sur (Oxford: Archaeopress, 2018).

— De la provincia Celtiberia a la Qura de Santabaryya: arqueología de la antigüedad tardía en la provincia de Cuenca (siglos V-VIII d.C.) (Oxford: Archaeopress, 2019).

Barroso Cabrera, Rafael, Jesús Carrobles Santos, Jorge Morín de Pablos, and Isabel Sánchez Ramos, 'Ciudad y territorio toledano entre la Antigüedad tardía y el reino visigodo: la construcción de una ciuitas regia (siglos IV-VIII d.C.)', Erytheia 36 (2015), pp. 9-61.

Beltrán Heredia de Bercero, Julia, 'Barcino, de colònia romana a sede regia visigoda, medina islàmica i ciutat comtal: una urbs en transformació', Quaderns d'Arqueologia i Història de la Ciutat de Barcelona 9 (2013), pp. 16-118.

Beltrán Torreira, Federico-Mario, 'La conversión de los suevos y el III Concilio de Toledo', Mayurqa 22.1 (1989), pp. 69-84.

Bruhn Hoffmeyer, Ada, 'Military Equipment in the Byzantine Manuscript of Scylitzes in Biblioteca Nacional in Madrid', Gladius 5 (1996), pp. 1-194.

Bury, John Bagnell, History of the Later Roman Empire, 2 vols. (London, 1923).

Cameron, Alan, Jacqueline Long, and Lee Sherry, Barbarians and Politics at the Court of Arcadius (Berkeley: University of California Press, Transformation of the Classical Heritage 19, 1993).

Canto, Alicia M., 'Sobre el origen bético de Teodosio I el Grande y su improbable nacimiento en Cauca de Gallaecia', Latomus 65.2 (2006), pp. 388-421.

Carrobles Santos, Jorge, 'Toledo 284-546: los orígenes de la capitalidad visigoda', in Regia sedes Toletana, 2 vols., vol. 1: La topografía de la ciudad de Toledo en la antigüedad tardía y alta edad media, ed. by Rafael Barroso Cabrera, Jesús 
Carrobles Santos, Jorge Morín de Pablos, and Fernando Valdés Fernández (Toledo: Diputación de Toledo, 2007), pp. 43-92.

Chavarría Arnau, Alexandra, 'Finding Invisible Arians: An Archaeological Perspective on Churches, Baptism and Religious Competition in 6th Century Spain', Hortus Artium Medievalium 23.2 (2017), pp. 674-685.

Collins, Roger, La España visigoda 409-711 (Barcelona: Critica, Serie Mayor, 2005). Domínguez Monedero, Adolfo, 'La "Chronica Caesaraugustana” y la presunta penetración popular visigoda en Hispania', Los visigodos: historia y civilización, = Antigüedad y Christianismo 3 (1986), pp. 61-68.

Eger, Christoph, 'Westgotische Gräberfelder auf der Iberischen Halbinsel als historische Quelle: Probleme der ethnischen Deutung', in Cum grano salis: Beiträge zur europäischen Vor- und Frühgeschichte; Festschrift für Volker Bierbrauer zum 65. Geburststag, ed. by Bernd Päffgen, Ernst Pohl, and Michael Schmauder (Friedberg: LIKIAS, 2005), pp. 165-181.

Fita, Fidel, 'Noticia de una ley de Teudis desconocida, recientemente descubierta en un palimpsesto de la Catedral de León', BolRAH 14.6 (1889), pp. 473-495.

Fuentes Hinojo, Pablo, 'La obra política de Teudis y sus aportaciones a la construcción del reino visigodo de Toledo', En la España Medieval 19 (1996), pp. 9-36.

García Moreno, Luis Agustín, Prosopografía del reino visigodo de Toledo (Salamanca: Ediciones de la Universidad de Salamanca, Acta Salmanticensia, Estudios Históricos y Geográficos 77, 1974).

—_ 'La arqueología y la historia militar visigoda en la Península Ibérica', in Arqueología medieval Española, Madrid, 19-24 enero 1987, 3 vols., vol. 2 (Madrid: Comunidad, Consejería de Cultura y Deportes, 1987), pp. 331-336.

— , 'Prosopography, Nomenclature, and Royal Succession in the Visigothic Kingdom of Toledo', Journal of Late Antiquity 1.1 (2008a), pp. 142-156.

- Leovigildo: unidad y diversidad de un reinado (Madrid: Real Academia de la Historia, Discurso Recepción en la Real Academia de la Historia, 2008b). Gurt i Esparraguera, Josep M., and Isabel Sánchez Ramos, 'Episcopal Groups in Hispania', Oxford Journal of Archaeology 30.3 (2011), pp. 273-298.

Halsall, Guy, 'Ethnicity and Early Medieval Cemeteries', Arqueología y Territorio Medieval 18 (2011), pp. 15-27.

Heather, Peter, The Goths (Oxford: Blackwell, 1996).

Isla Frez, Amancio, 'Desde el reino visigodo y la ortodoxia toledana: la correspondencia de Montano', Studia Historica: Historia Medieval 18-19 (2000-2001), pp. 41-52. Jones, Arnold Hugh Martin 'Military Chaplains in the Roman Army', Harvard Theological Review 46.4 (1953), pp. 239-240.

Kazanski, Michel, and Patrick Périn, 'Identity and Ethnicity during the Era of Migrations and Barbarian Kingdoms in the Light of Archaeology in Gaul', in Romans, Barbarians, and the Transformation of the Roman World: Cultural 
Interaction and the Creation of Identity in Late Antiquity, ed. by Danuta Shanzer and Ralph W. Mathisen (Farnham: Routledge 2011), pp. 299-329.

King, P.D., Derecho y sociedad en el reino visigodo (Madrid: Alianza Editorial, Alianza Universidad Textos, 1981).

Koch, Manuel, 'Gotthi intra Hispanias sedes acceperunt: consideraciones sobre la supuesta inmigración visigoda en la Península Ibérica', Pyrenae 37.2 (2006), pp. 83-104.

—_ 'La imperialización del reino visigodo bajo Leovigildo: ¿Es la imitatio imperii de Leovigildo la manifestación de un momento de cambio en la pretensión de poder y la ideología visigodas?', Pyrenae 39.2 (2008), pp. 101-117.

König, Gerd G., 'Archäologische Zeugnisse westgotischer Präsenz im 5. Jahrhundert', Madrider Mitteilungen 21 (1980), pp. 220-247.

Lantier, Raymond, 'Le cimetière wisigothique d'Estagel (Fouilles de 1935 et 1936)', Gallia 1.1 (1943), pp. 153-188.

McKenna, Stephen, Paganism and Pagan Survivals in Spain up to the Fall of the Visigothic Kingdom (Washington, DC: Theophania, 1938).

Martin, Céline, 'In confinio externis gentibus: la percepción de la frontera en el reino visigodo', Studia Historica: Historía Antigua 16 (1998a), pp. 267-28o.

— , 'Las cartas de Montano y la autonomía episcopal de la Hispania septentrional en el siglo VI', Hispania Antiqua 22 (1998b), pp. 403-426.

— - 'Montanus et les schismatiques: la reprise en main d'une périphérie hispanique au début du VIe siècle', Mediévales 51 (2006), pp. 1-10.

Mathisen, Ralph W., 'Barbarian Bishops and the Churches “in Barbaricis Gentibus” during Late Antiquity', Speculum 72.3 (1997), pp. 664-697.

Orlandis Rovira, José, 'En torno a la noción visigoda de tiranía', AHDE 29 (1959), pp. $5^{-46 .}$

—, Hispania y Zaragoza en la antigüedad tardía (Zaragoza: IBERCAJA, 1984).

Pérez Rodríguez-Aragón, Fernando, 'Las “necrópolis visigodas” y el asentamiento militar de los ostrogodos de Vidimiro', in Arqueología militar romana en Hispania, ed. by Ángel Morillo Cerdán (Madrid: Consejo Superior de Investigaciones Científicas, Instituto Histórico Hoffmeyer, Polifemo, 2002), pp. 637-650.

Pérez Sánchez, Dionisio, 'El ejército y el pueblo visigodo desde su instalación en el Imperio hasta el reino visigodo de Tolosa', Studia Historica: Historia Antigua 2-3 (1984-1985), pp. 249-269.

Périn, Patrick, 'L'Armée de Vidimer et la question des dépôts funéraires chez les wisigoths en Gaule et en Espagne ( $\mathrm{V}^{\mathrm{e}}-\mathrm{VI}^{\mathrm{e}}$ siécles)', in L'Armée romaine et les barbares du III ${ }^{e}$ au VII siècle, ed. by Françoise Vallet and Michel Kazanski (Saint-Germain-en-Laye: Association Française d'Archéologie Mérovingienne, 1993), pp. 411-423. 
Pinar Gil, Joan, 'Coming Back Home? Rare Evidence for Contacts between the Iberian Peninsula and the Carpathian Basin in the Late 5th-Early 6th Century', Ephemeris Napocensis 24 (2014), pp. 117-129.

Rico Camps, Daniel, 'Arquitectura y epigrafía en la antigüedad tardía: testimonios hispanos', Pyrenae 40.1 (2009), pp. 7-53.

Sánchez Doncel, Gregorio, Estudio documentado de la villa de Vertavillo (Palencia: Institución Tello Téllez de Meneses 4, 1950), pp. 63-134.

Sanz Serrano, Rosa, 'Aproximación al estudio de los ejércitos privados en Hispania durante la antigüedad tardía', Gerión 4 (1986), pp. 225-264.

Sastre de Diego, Isaac, 'La villa romana de Santa Lucía (Aguilafuente, Segovia): aproximación a su estudio treinta años después de su excavación', Espacio, Tiempo y Forma, ser. 1: Prehistoria y Arqueología 14 (2001), pp. 277-304.

Schwarcz, Andreas, 'The Visigothic Settlement in Aquitania: Chronology and Archaeology', in Society and Culture in Late Antique Gaul, ed. by Danuta Shanzer and Ralph W. Mathisen (Aldershot: Routledge, 2001), pp. 11-24.

Thompson, Edward A., Los Godos en España (1969; repr., Madrid: Alianza, 1985).

Vallejo Girvés, Margarita, Hispania y bizancio: una relación desconocida (Madrid: Akal, 2012).

Vázquez de Parga, Luis, San Hermenegildo ante las fuentes históricas: discurso leído el día 18 de noviembre de 1973 en el acto de su recepción pública por el Excmo. Sr. D. Luis Vázquez de Parga Iglesias, y contestación por Excmo. Sr. D. José María Lacarra y de Miguel (Madrid: Real Academia de la Historia, 1973).

Velázquez Soriano, Isabel, and Gisela Ripoll López, 'Toletum, la construcción de una urbs regia', in Sedes Regiae (40o-80o), ed. by Gisela Ripoll López and José María Gurt Esparraguera (Barcelona: Real Acadèmia de Bones Lletras, Series Maior 6, Memorias de la Real Academia de Buenas Letras de Barcelona 25, 2000), pp. $5^{21-578 . ~}$

Vilella Masana, Josep, 'Los obispos toledanos anteriores al reino visigodo-católico', in Actas del III Encuentro Hispania en la antigüedad tardía (Madrid: Universidad de Alcalá, 2003), pp. 101-119.

Wolfram, Herwig, History of the Goths (Berkeley: University of California Press, 1990). - The Roman Empire and its Germanic Peoples (Berkeley: University of California Press, 1997). 
About the author

Rafael Barroso Cabrera is an independent researcher in prehistory and archaeology. He focuses in particular on the analysis of the barbarian settlement on the Iberian Peninsula, as well as the study of power architecture from the sixth to eighth century. Currently he is preparing a book on Landscapes and the Architecture of Power in the Territory of the Regia Sedes Toletana. 


\title{
16 Ecclesiastical Landscapes in the Visigothic Capital and Countryside of Toledo (Spain)
}

\author{
Isabel Sánchez Ramos and Jorge Morín de Pablos
}

\begin{abstract}
With its strategic geographic location near the major Roman roads in the middle of the Iberian Peninsula, Toledo was the Visigoth capital under Theudis in the year AD 546 until the collapse of the kingdom in the early eighth century. Most of the evidence of its architectural power linked to new local elites is located in the countryside rather than in the city of Toledo. Archaeology has attested the collapse of the Roman territorial model and its substitution by a medieval one. This model is characterized by the appearance of monumental complexes, in which monastic and sacred complexes linked to the aristocracies of Toledo acquired preference, key for understanding the social, cultural, and economic dynamics of the fifth and the eighth centuries.
\end{abstract}

Keywords: Visigoths; Toledo; landscape; Christianization; architecture; elites

The regnum Gothorum in the Iberian Peninsula began its process of political and territorial consolidation in the second half of the sixth century, when an ambitious cultural and legislative program was set into action in order to achieve the unification of ancient Roman Hispania. ${ }^{1}$ Archaeological and documental records demonstrate a continued monumentalization process

1 The definitive establishment of the Visigothic court in Toletum happened during the reign of Theudis (531-548), specifically following the promulgation of his procedural-costs law, dated to 24 November 546 (Fita 1889).

Panzram, S. and P. Pachá (eds.). The Visigothic Kingdom: The Negotiation of Power in Post-Roman Iberia. Amsterdam: Amsterdam University Press 2020 DOI: $10.5117 / 9789463720632 \_$CH16 
of the kingdom's capital, and its territory, throughout the seventh century. Toletum (Toledo) was an economic centre of power inside a system in which bishops had extensive fiscal responsibilities and exercised increasingly significant political authority, which resulted in an increase in long-distance communication among church elites from different geographical areas. ${ }^{2}$

Toledo was not burdened by an historical weight, by well-established elites and networks that could rival royal authority. It was a relatively new city, atop a defensible site in a central location in the middle of the Iberian Peninsula. The definitions of local, regional, and central boundaries of authority in Visigothic Spain stem from long-standing historiographical controversies and remain under debate within Visigothic studies today. ${ }^{3}$ The prevailing argument is that the kingdom, from its Toledo location, sought to - and to a considerable measure did - create political and even religious unity within a diverse society with its relatively independent local elites and cultural traditions. ${ }^{4}$ This diversity has been read in contrast to the argument of a unified kingdom. However, extensive urban interactions resulting from the diversity of local and regional institutions, practices, and social organizations, such as competing episcopal administrations, may have been, in fact, powerful instruments for building central power, rather than undermining it.

Archaeology has documented the collapse of the ancient territorial model of the Roman Empire and its substitution by a genuine Visigothic one. This model is characterized by the appearance of new monumental complexes after large Roman villae were abandoned, 5 in which monastic and sacred complexes, e.g. Los Hitos, Melque, and Guarrazar, linked to elites of Toledo, acquired a presence. ${ }^{6}$ The city's architecture was especially influenced by this change and was transformed into an image of the court and of religious elites. Archaeologists are nonetheless faced with buildings that present problems of visibility, 7 and relatively few case studies in Toledo ${ }^{8}$ in order to analyse the impact of transformations in the urban landscapes,

2 The imports of North African ceramics found in cities as Toletum and Recopolis, and rural settlements in inland Spain such as Los Hitos and Gózquez de Arriba, also show both the continuity of a long-distance overseas trade and operation of land routes in the seventh century, as well as the capacity of the local elites and the monarchy to acquire these products.

3 Díaz Martínez 2006, p. 213; Castellanos García 2008, p. $15^{2}$.

4 Díaz Martínez 2000, p. 33.

5 Arce 2012.

6 Barroso Cabrera, Carrobles Santos, and Morín de Pablos 2012.

7 Recently, ed. by Sánchez Ramos and Mateos Cruz.

8 Barroso Cabrera, Carrobles Santos, Morín de Pablos et al. 2018, p. 206. 
and to understand the evolution of the territory through late antique elite landmarks in terms of ideological, economical, and political issues.

\section{The making of a new Visigothic capital in a Roman city}

Historical circumstances, and above all the desire to extend Visigothic rule over the wealthy province of Baetica, encouraged the Visigothic monarchs to leave Toledo for Seville (Hispalis) until, with the accession to Athanagild, ${ }^{9}$ the court settled in the city of Toledo along the Tagus, ${ }^{10}$ which marked a new topographical developement of the capital from this period (Fig. 16.1). The urbs toletana formed a specific form of aulic complex that met the requirements of an imperial court: royal palace, chancellery, treasure chamber, and palatine church. All formed the components of an administrative kingdom that, in the seventh century, would crystallize into a political unit, the officium palatinum, in charge of the government of the kingdom and constituted by viri inlustres. ${ }^{11}$ From the conciliar documentation of the seventh century, Toledo had three churches that served as settings for the celebration of councils and marked milestones of Visigothic urban topography: the episcopal see of St. Mary, the ecclesia praetorensis of the Holy Apostles (Peter and Paul), and the martyrial basilica of St. Leocadia in the suburbium, of which, unfortunately, we have no archaeological knowledge. ${ }^{12}$ The limitation of excavated buildings and the context of hundreds of sculptures recovered from the city are issues for archaeological research. However, the Visigoth capital can be rebuilt from evidence available from three ecclesiastical structures.

Toledo had been a bishopric from the beginning of the fourth century, when a certain Melancio subscribed to the minutes of the Council of Eliberri, while the first references seem to allude to the episcopal space as the Council of Toledo held in the year 400 and assembled in the ecclesia Toleto. ${ }^{13}$ This apparently neutral denomination refers to the ecclesia principalis, opposed to two other conciliar basilicas: the Praetorian in the palatine neighborhood and that of St. Leocadia located in the Roman suburb of the area called the Vega Baja.

Carrobles Santos 2007.

o Martin 2003.

11 Sánchez-Albornoz 1946.

12 Palol i Salellas 1991; Velázquez Soriano and Ripoll López 2000, p. 550; Balmaseda Muncharaz $2007 \mathrm{~b}$.

13 Concilios visigóticos e hispano-romanos, p. 19. 


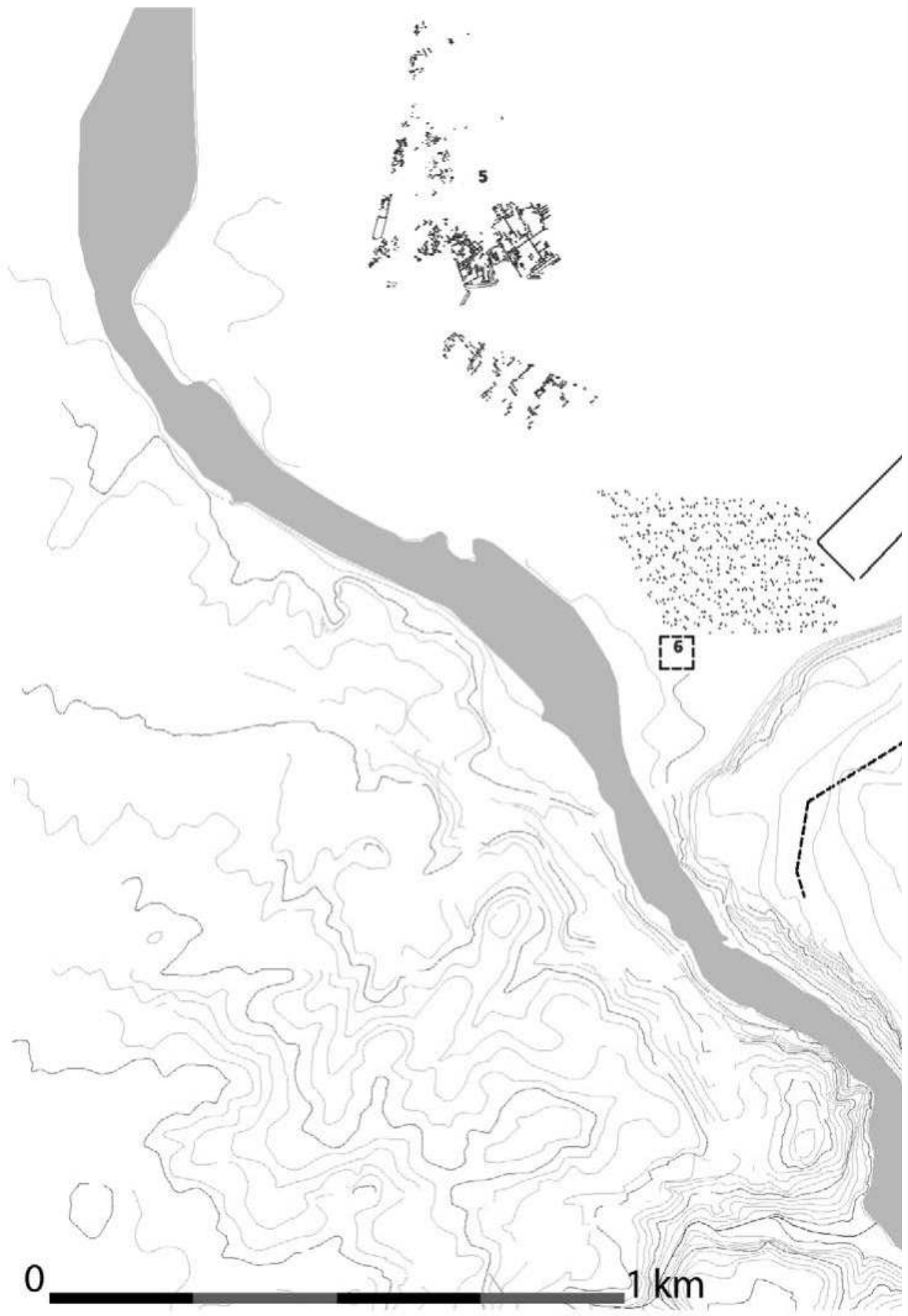

Fig. 16.1 Plan of Toledo in the seventh century. 1) Location proposed for the episcopal see; 2) fragment of sacred stones related to the Visigothic cathedral (St. Ginés street and St. Pedro Martir convent); 3) location proposed for the Holy Apostles church (St. Mary of Alficén church); 4) Visigothic palace (Alcázar, St. Cruz, and St. Fe convent hospital); 5) residential buildings in the Vega Baja; 6) St. Leocadia and late antique necropolis (hermitage of Cristo de la Vega). () Isabel Sánchez Ramos and Jorge Morín de Pablos. 


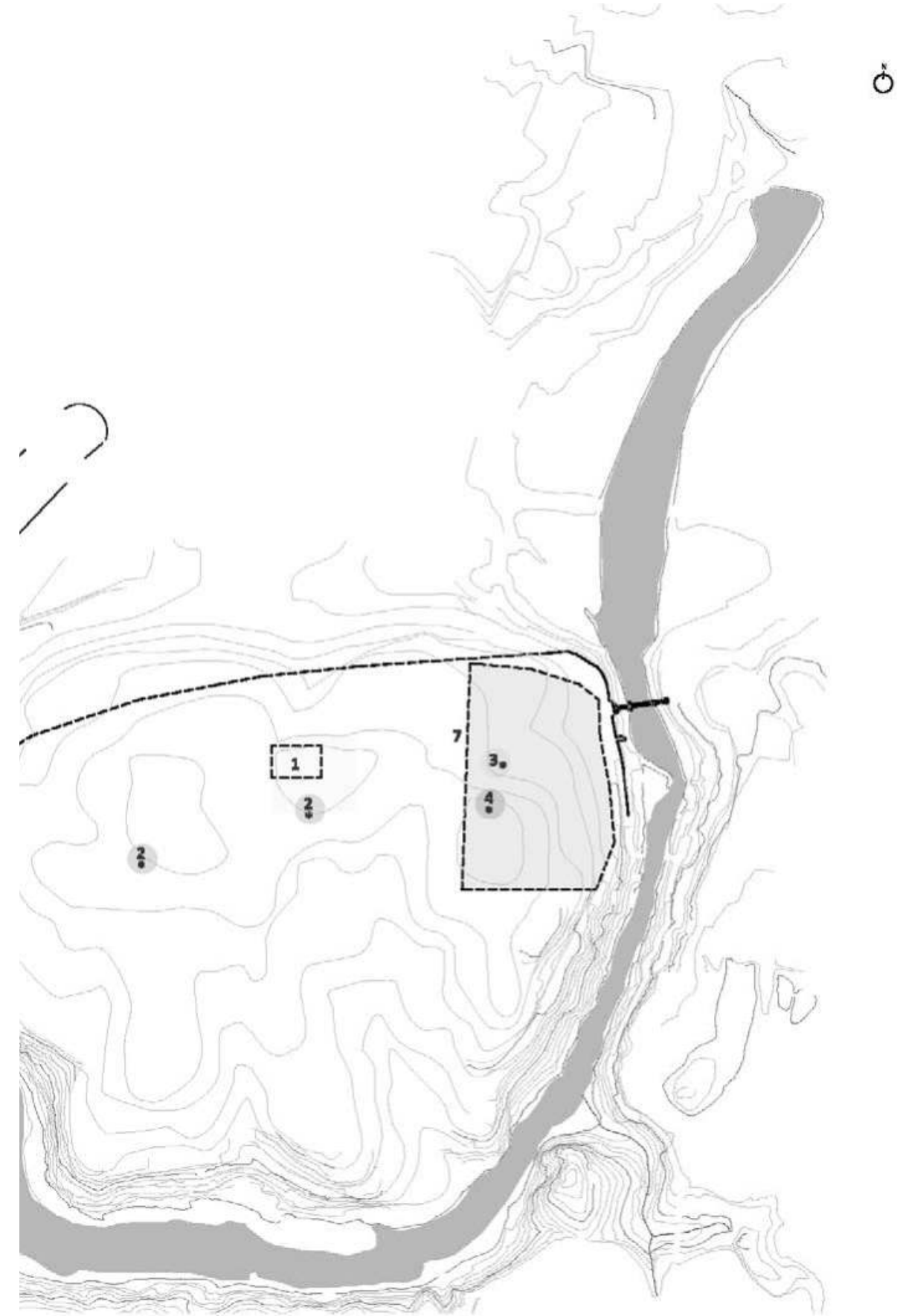



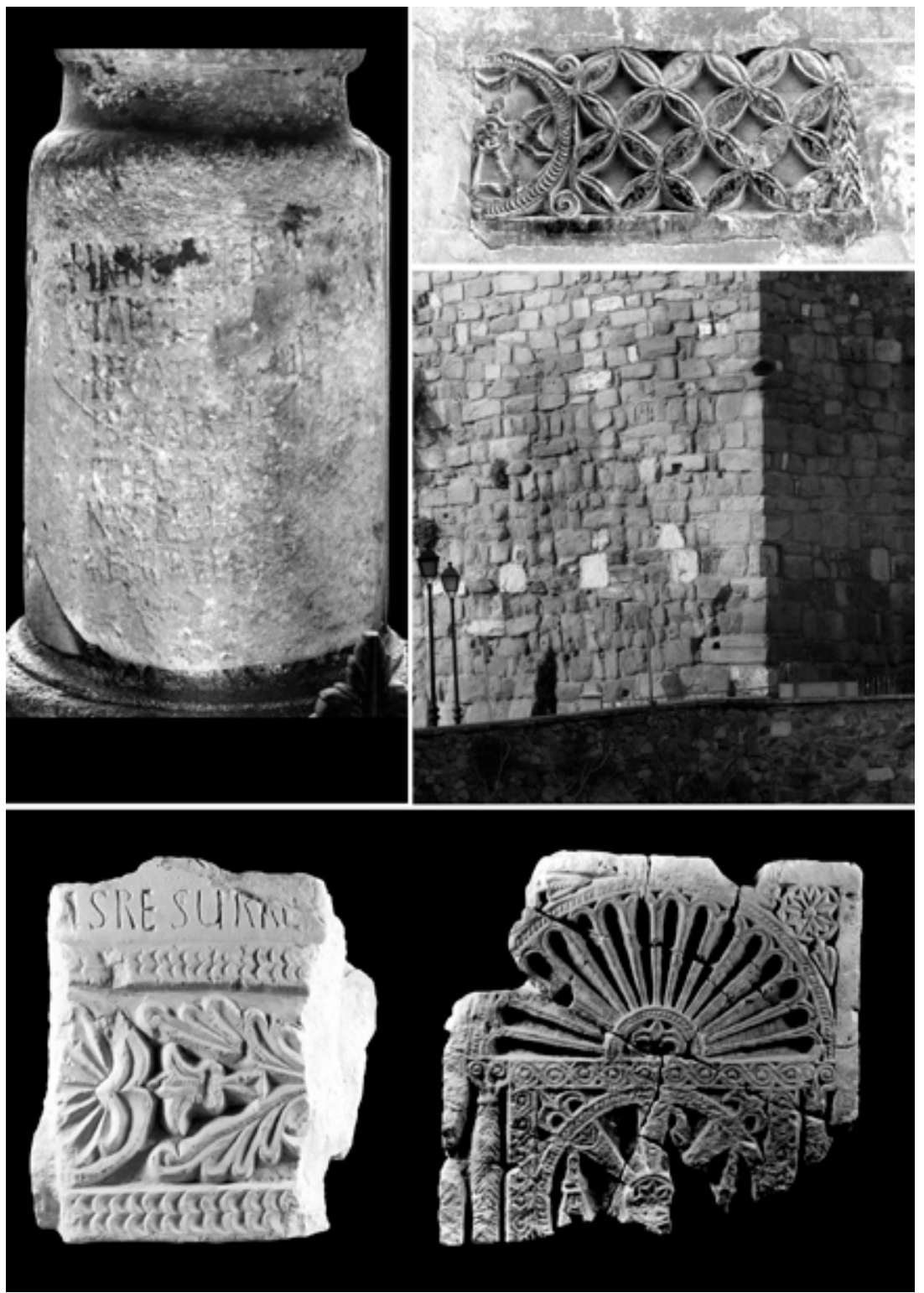

Fig. 16.2 Sculptural decoration in marble found in Toledo. a) An epigraph that commemorates the Catholic reconsecration of the basilica of St. Mary (ecclesia sanctae Mariae virginis); b) a cancel of the liturgical sculptural group reused in the walls of St. Gines street; c) elements of decorative sculpture used as spolia at the Alcantara's bridge and gate; d) the marble epigraphic Creed found near the hermitage of Cristo de la Vega; e) a marble niche-plaque from the hermitage of Cristo de la Vega. @ Isabel Sánchez Ramos and Jorge Morín de Pablos. 
The conciliar records reveal the dedication of the cathedral church to the Virgin Mary, a frequent title for episcopal sees. An epigraph dated to the year 587 commemorates the Catholic reconsecration of the basilica of St. Mary (ecclesia sanctae Mariae virginis). The inscription is considered as further testimony to Reccared's policy of returning assets seized by Liuvigild to Catholics during the civil war with Hermenegild (Fig. 16.2a). ${ }^{14}$ The epigraph further suggests that Reccared was commemorating the reconsecration of a church near the ancient Roman forum that until then would have been Arian. Theudis, it seems, used the ecclesia intramuros for the celebration of Arianism. This meant that, at least temporarily, the congregation of the faithful and the development of the Catholic episcopal liturgy would have taken place in a different urban space, as has been shown to be the case in Barcelona when the city served as the royal see..$^{15}$ As for its location, it has been assumed that the episcopal complex of Toledo is located under the foundations of the current Gothic cathedral, where a former mosque was built. ${ }^{16}$ This seems to be inferred from the traditional overlapping of sacred spaces, but also from a Muqtabis of Ibn Hayyan, which states that in 871 there was a church attached to the mosque. ${ }^{17}$ Recent excavations carried out in the cloister of the cathedral, however, have not provided new archaeological data on this controversial issue. The only element that could support this hypothesis is the sculptural group reused in the walls of the nearby alley of St. Gines (Fig. 16.2b). ${ }^{18}$

Although some studies insist on placing the Visigoth palace outside the walls in the current Vega Baja next to the late antique St. Leocadia church, ${ }^{19}$ the church of the Holy Apostles, which was related to the Visigoth Palace, was likely located in the upper area of the city, near the later alcázar (Islamic citadel), and in conjunction with control of the Roman bridge over the Tagus river. ${ }^{20}$ This Visigoth praetorium would probably correspond to the previous Roman castellum and its medieval evolution as the alficén or alcazaba. The discovery of important elements of decorative sculpture used as spolia at the Alcantara's gate, renovated by Abd al-Rahman III in the tenth century, seems to confirm this identification (Fig. 16.2c). ${ }^{21}$

\footnotetext{
14 Inscripciones cristianas de la España romana y visigoda, 302; Santiago Fernández 2009, p. 318; Barroso Cabrera and Morín de Pablos 2007a, p. 99; Velázquez Soriano 2011.

15 Beltrán de Heredia Bercero 2018, p. 90.

16 Carrero Santamaría 2009, p. 325.

17 Barroso Cabrera and Morín de Pablos 2007a, p. 104.

18 Barroso Cabrera and Morín de Pablos $2007 \mathrm{~b}$.

19 Ewig 1963; Velázquez Soriano and Ripoll López 2000; Teja and Acerbi 2010.

20 Barroso Cabrera, Carrobles Santos, Morín de Pablos et al. 2015a, p. 345 .

Barroso Cabrera, Carrobles Santos, and Morín de Pablos 2009.
} 
Outside the Roman walls, the martyrdom of St. Leocadia has been situated but has not been confirmed archaeologically. Written sources allude to episcopal burials in the martyrial basilica of St. Leocadia, which was consecrated by King Sisebut in $618 .^{22}$ Yet, it is difficult to imagine that there had not already been a monument dedicated to St. Leocadia before 618 , given the funerary nature of this space and the fame of the saint (Figs. 16.2d and 16.2e). It is probable that Sisebut undertook the monumentalization of an old cella memoriae or martyrium to elevate the importance of Leocadia's cult as patron of Toledo. In the hermitage of Cristo de la Vega, there once stood a sturdy construction perhaps belonging to a building similar to a classroom. ${ }^{23}$ The building reused Roman stonework in its construction, but stands out for its significant use of buttresses that suggest a rectangular floor plan for a central nave with flying buttresses, possibly to anchor a vaulted ceiling or the presence of a crypt, much like those documented at St. Antolín (Palencia) and La Alberca (Murcia), and which appear in St. Leocadia's crypt in Oviedo. Thus, it should be identified as a pantheon that shares the same dynamic space with other Iberian sacred structures. ${ }^{24}$

\section{Reshaping the rural landscape around the capital}

Corresponding to conciliar records, there were several monasteries under the patronage of St. Cosmas and Damian close to Toledo - otherwise known as Agali or Agaliense from the situation ad Galiense iter or on the way to Gallia - St. Michael, Holy Cross, St. Vincent, and St. Eulalia of Mérida. Written sources provide information about religious complexes in the countryside of Toledo. The monastery Deibiensis, founded by St. Ildefonsus for virgins, in a family-owned property, probably located in Los Yébenes, ${ }^{25}$ and the coenobium Cabensis with an unknown location, had been noted monasteries found in this territory. St. Felix quae est in Tatanesio is known only by a few verses composed by Eugenius, and could be located near Toledo in the village of Totanés, somewhere between Melque and Los Yébenes. From Eugenius's poem, it appears that it was a foundation linked to important figures of the Visigoth court. ${ }^{26}$

Crónicas Asturianas, pp. 475-493.

Palol i Salellas 1991, p. 790.

Barroso Cabrera, Carrobles Santos, Morín de Pablos et al. 2015b, p. 6 o.

Balmaseda Muncharaz 2007b, p. 208.

Eugenii Toletani episcopi carmina. 


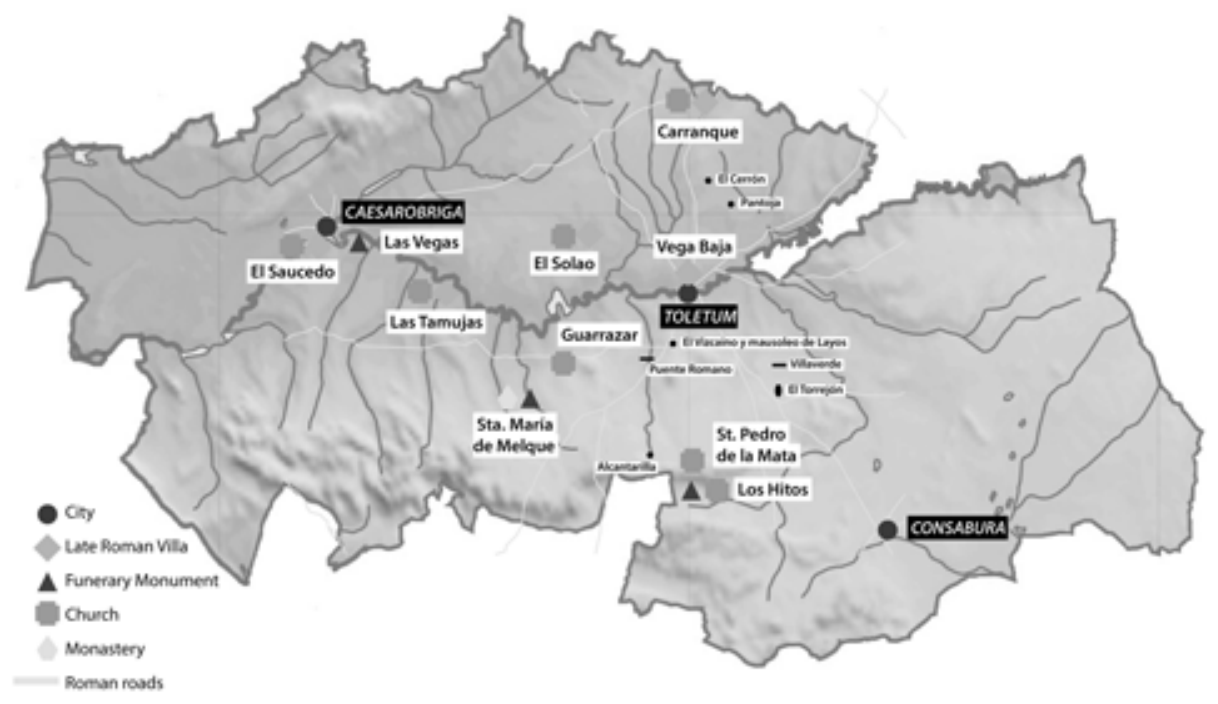

Fig. 16.3 Location of the main Visigothic archaeological sites in the region of Toledo. 1) Las Vegas (La Pueblanueva); 2) El Saucedo (Talavera de la Reina); 3) Las Tamujas (Malpica de Tajo); 4) St. Maria de Abajo (Carranque); 5) El Rincón (Alcolea de Tajo); 6) Cuatro Fanegas (Alcabón); 7) El Guerrero (Escalonilla); 8) Los Hitos (Arisgotas); 9) St. Maria of Melque (San Martín de Montalbán); 10) St. Pedro de La Mata (Casalgordo); 11) Guarrazar (Guadamur). @ Isabel Sánchez Ramos and Jorge Morín de Pablos.

Thanks to recent archaeological research our knowledge of architectural complexes in the Toledan countryside during the Visigoth period is more accurate (Fig. 16.3). Of particular interest are private churches of modest size that were built by rural owners, ones with restricted burial uses, paradigmatic of funerary and monastic monuments located in the central plateau of the Iberian Peninsula.

The first temples, built in the end of the fifth century, took advantage of Roman villae, which for more than a century had been abandoned. Known examples documented around Toledo are Las Vegas (La Pueblanueva), El Saucedo (Talavera de la Reina), Las Tamujas (Malpica de Tajo), and St. Maria de Abajo (Carranque). In these cases, the construction for Christian worship had corresponding liturgical furniture. Their chronology is precise and places them in the last moments of the sixth century by the dates of personal adornments located in the tombs. Similar evidence in other places close to Toledo such as El Rincón (Alcolea de Tajo), Cuatro Fanegas (Alcabón), or even El Guerrero (Escalonilla), provide associations between the remains of ornamental sculpture and burials with objects of personal adornment dated in the seventh century. 
Other relevant rural sacred complexes have been excavated in the last four years. Cases that have provided new data are those at La Mata, Los Hitos, Guarrazar, and Melque. The first of them is the church of St. Pedro de la Mata, with an original cross-shaped plan, where neither baptistery nor burials have been found. This church was built with granite ashlars that came from quarries nearby, although any recycled materials have not been identified. Stonework masonry indicating the technical skills needed to build such a prestigious architecture should be linked to the economic capacity of the benefactors. In 2018, we obtained an orthophotograph of this building in order to study its construction techniques and phases, and to create a three-dimensional architectonical model (see Fig. 16.5a). The church was located near an ancient Roman road that ran from Toledo to Córdoba, and close to the archaeological complex of Los Hitos.

Los Hitos (Arisgotas, Orgaz) is a large pantheon with spaces surrounding it - including a church - which could also have been an aristocratic residence. It is possible that it was the burial place for a figure and family from the high nobility in Toledo on a latifundium that likewise could have maintained an important religious centre. This would explain the lengthy inscription, the burials, and the pagan altar retained in the current parish church with a loculus to store relics. The excavation in 2016 discovered forty burials facing east inside the building and arranged into two rows around an alabaster sarcophagus in the middle of the central room (Fig. 16.4). All burials were in stone containers covered by slabs of slate, sealed with an opus signinum floor. This funerary occupation can be dated to the seventh century given fragments of pottery, and the elements of personal adornment recovered from the tombs, pendants, a belt buckle, and four-petal cloisonné rivets. Fragments of spatheia (small ceramic amphorae) that are documented as having been imported from North Africa confirm the chronology of this building in the the pre-Umayyad period, as well as demonstrating the commercial exchanges between Byzantine Africa and the Visigothic cities of the central Iberian Peninsula. The main rectangular floor plan maintained technical features similar to other constructions documented in the Iberian Peninsula, characterized by a tripartite plan and the appearance of buttresses. ${ }^{27}$ The importance of Los Hitos is to offer new types of buildings dated to the seventh century, which became a reference for

27 The scale, the preference of central floor plans, and a robust construction supported by buttresses, the presence of stucco, sculpted decoration, and epigraphy are some of these features that characterized the late antique buildings. 


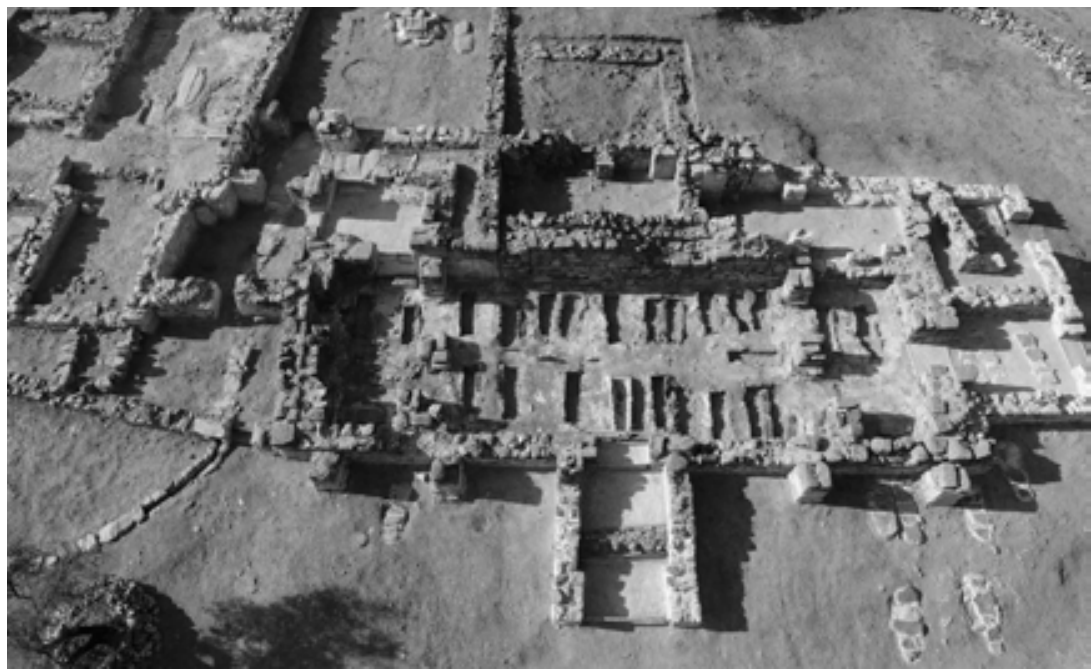

Fig. 16.4 Areal view of the pantheon and all the burials documented in the archaeological site of Los Hitos. @ Isabel Sánchez Ramos and Jorge Morín de Pablos.

the Visigoth kingdom. ${ }^{28}$ The use of annexing supports for outside walls to raise the height of the building - with a vaulted ceiling or construction of a higher floor - are characteristics that link this building to other examples in the Iberian Peninsula, including buildings of residential architecture, ${ }^{29}$ with others of funerary or sacred functions. ${ }^{30}$ The type was used for palace architecture in the Asturian kingdom from the eighth to ninth centuries. In the palatium of St. Maria del Naranco, we can appreciate the continuity of the kingdom of Toledo, and the legitimization of the power based on the Visigoth past, as regards the Chronicle of Albelda that in the city of Oviedo, as Gothorum ordinem, sicuti Toleto fuerat, tam in ecclesia quam palatio ('he established the order of the Goths as it had been at Toledo, in both church and palace'). $\cdot^{31}$

The site of the settlement of Guarrazar is $12 \mathrm{~km}$ from the Visigoth capital. The first excavations carried out in the second half of the twentieth century documented the famous treasure of crowns dated to the seventh century, a burial space, and the remains of a large building. A privileged grave there corresponds to the presbyter Crispin who was buried in the year $6933^{32}$ 

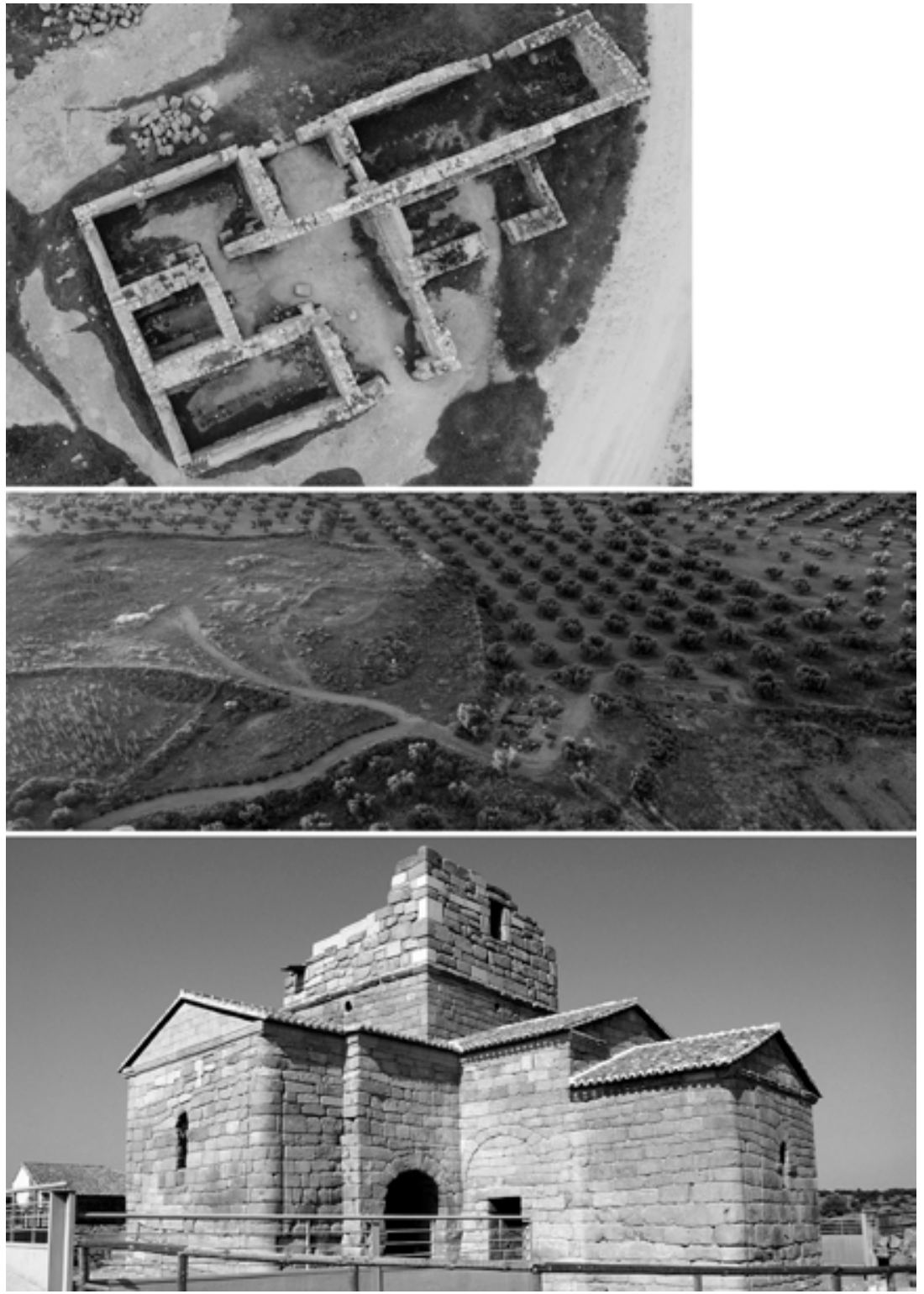

Fig. 16.5 Sacred architecture in the territory of Toledo: a) St. Pedro de la Mata church; b) Guarrazar; c) St. Maria de Melque church. () Isabel Sánchez Ramos and Jorge Morín de Pablos.

according to an inscription. Excavations carried out between 2013 and 2017 have revealed the existence of buildings - a potential church among them - that were raised with large blocks of ashlars and reused Roman materials (Fig. 16.5b). 
St. Maria of Melque (San Martín de Montalbán) represents an early medieval ecclesiastic complex in Spain with a history of excavations and studies since the 1980 os. $^{33}$ The site has been the recent focus of new studies ${ }^{34}$ that propose that the monumental complex had been transformed into a monastery from its origins as a funerary building for elite tombs. ${ }^{35}$ The building was erected in the centre of an enclosure that allowed a visual surveillance of the area. It bears a cross-shaped plan with a straight headwall outside, the shape of a horseshoe arch inside, and a portico at the bottom (Fig. 16.5c). An arcosolium, which was used for a privileged burial, is located precisely at the southern arm of the cross. This is a clear indicator that the church was raised to serve as a monumental pantheon. Although doubts expressed about its chronology by Caballero Zoreda, the decorative elements and archaeological findings point to a chronology between the mid-seventh and the beginning of the eighth century. ${ }^{36}$ Its promoter could have been from the royal family or at least one of the primates or fideles regis frequently alluded to in the literature. The identity of this person lacks any explicit textual or epigraphic evidence, but sources must exist for an endeavour of this magnitude and unique characteristics, especially considering its proximity to the Visigoth capital. ${ }^{37}$ The space founded for a private burial was replaced with a monastery dedicated to working the land for economic gain. Its location was strategic in order to control the passage of livestock through the transhumant networks - the glens - traveling from the north of the Sistema Central toward the valleys of the former Roman province of Baetica. The geographic placement of the monastic complex at Melque is not simply a funerary monument erected to commemorate the memory of nobles in the kingdom, but also stands as a magnificent example of the enormous social and economic power of Visigoth elites in the territory of Toledo.

\section{Conclusion}

Archaeology attempts to unravel the social history of the Visigothic sedes regiae, but it is difficult to build arguments based on material evidence to

Balmaseda Muncharaz 2007a, p. 290.

Barroso Cabrera, Carrobles Santos, and Morín de Pablos 2011, pp. 57-63.

Arbeiter 200o, p. 255.

Barroso Cabrera, Carrobles Santos, and Morín de Pablos 2011, pp. 61-62. 
reveal symptoms of power and social identity. It is possible, nevertheless, to approach the discussion through other factors, for example, the study of landscape management (i.e. communication channels) and the role of the episcopal elites and their use of ecclesiastical assemblies.

Priorities for archaeological research in Toledo and its territory should be pointed to crucial questions related to urbanism, topographies, and constructions, such as to identify possible Roman precedents in the late antique settlements; investigate the Visigoth capital and the rural landscape by studying communication networks, natural resources, etc.; understand late antique architecture as a key economic exponent; make a deep study of building techniques and materials; explain the architectonical transformations and spatial occupations; and confront material evidence both urban and rural with other western Mediterranean cases.

Archaeological records and documentary sources presented in this paper highlight the existence of a building program developed in Toledo and its territory in the second half of the seventh century. These programs were the result of an earlier reorganization of the Visigothic kingdom after the celebration of the III Council (589) and the IV Council (633) of Toledo. The consolidation of the regnum visigothorum was the result of the action of monarchs as prominent as Athanagild or Liuvigild. Toledo as regia urbs was a continuous process thanks to the increasing evolution of the aula regia and the Toledan episcopate: for instance, with the metropolitan range of Carthaginiensis provincia awarded to Toledo in 610 by Gundemar, and the Iberian ecclesiastical primacy in 681 on occasion of the provisions adopted by the bishops of the XII Council of Toledo. The Christianization of the territory was a phenomenon not simply understood as an alteration of beliefs, but as the articulation of productive spaces within a network of civil and ecclesiastical power drawn from the royal city that connected elites with developed rural settlements.

Therefore, late antique architecture as sacred or funerary should be considered as another economic exponent in the administration of the territory. These constructions-turned-churches, or perhaps privileged churches used as burial spaces, are an argument in favour of the transformation of former estates of secular aristocracy into the foundations for monasteries during the seventh century. This was a common practice in written sources, confirmed by archaeological evidence at Melque, Carranque, and El Saucedo. All can be interpreted as a sign of the ability of the ruling classes of the Visigoth kingdom to search for and consolidate new sources of wealth, through the creation of ecclesiastical and civil complexes that would acquire a strong role in the landscape. 
The archaeological record shows that, apart from small rural churches that provide decorative elements and reused structures, we also find buildings built completely ex novo. Large properties traditionally identified as monasteries have focused on the study of Visigothic art and architecture. Visigothic art of the seventh century, however, takes on its greatest importance in the city of Toledo, and should be seen as a local reflection of a broader Mediterranean reality dependent on the ancient Byzantine models. The classical inheritance that has been attributed mainly to local tradition needs to be explained through them. Its codification in the sixth century was developed in most of the Iberian cities, not only in Mérida, Córdoba, or Seville, but those that remained active, such as as Barcelona, Zaragoza, or Toledo. Linkage allows us to recognize an obvious resemblance in practically all sixth- through seventh-century sculptural productions on the shores of the Mediterranean area. ${ }^{8}$

\section{Bibliography}

\section{Primary sources}

Chronica Albeldensis, in Crónicas Asturianas, ed. by Juan Gil Fernández, José L.

Moralejo, and Juan Ignacio Ruiz de la Peña (Oviedo: Universidad de Oviedo, 1985), pp. 151-193.

Concilios visigóticos e hispano-romanos, ed. by José Vives (Barcelona: Instituto Enrique Flórez, Consejo Superior de Investigaciones Científicas, España Cristiana, Textos 1, 1963).

Crónicas Asturianas, ed. by Juan Gil Fernández, José L. Moralejo, and Juan Ignacio Ruiz de la Peña (Oviedo: Universidad de Oviedo, 1985).

Eugenii Toletani episcopi carmina, in Fl. Merobaudis reliquiae, Blossii Aemilii Dracontii carmina, Eugenii Tolitani episcopi carmina et epistolae, ed. by Friedrich Vollmer (Berlin: Monumenta Germaniae Historica, Auctores Antiquissimi 14, 1905). Inscripciones cristianas de la España romana y visigoda, ed. by José Vives (Barcelona: Instituto Jerónimo Zurita, Consejo Superior de Investigaciones Científicas, 1942).

38 This work was produced as part of the research project 'Urban landscape of power in the Iberian Peninsula from Late Antiquity to the Early Middle Ages (ULP.PILAEMA)', supported by funding from the Marie Skłodowska-Curie Actions Horizon 2020-MSCA-IF-EF-ST-2016, under the grant agreement no. 740123. Fieldworks conducted by Jorge Morín de Pablos and Isabel Sánchez Ramos in Los Hitos and Melque are also part of the research project 'Landscape and Architecture of Power' funded by Castilla-La Mancha Region and the City Hall of Orgaz from 2014 up to now. 


\section{Secondary sources}

Alba Calzado, Miguel, 'Diacronía de la vivienda señorial de Emerita (Lusitania, Hispania): Desde las domus altoimperiales y tardoantiguas a las residencias palaciales omeyas (siglos I-IX)', in Archeologia e società tra tardoantico e alto medioevo: $12^{\circ}$ Seminario sul tardo antico e l'alto medioevo, Padova, 29 settembre-ottobre 2005, ed. by Gian Pietro Brogiolo and Alexandra Chavarría Arnau (Mantua: SAP Società Archeologica s.r.l., 2007), pp. 163-192.

Arbeiter, Achim, 'Alegato por la riqueza del inventario monumental hispanovisigodo', in Visigodos y omeyas: un debate entre la antigüedad tardía y la alta edad media, ed. by Luis Caballero Zoreda and Pedro Mateos Cruz (Madrid: Consejo Superior de Investigaciones Científicas, Anejos de Archivo Español de Arqueología 23, 2000), pp. 251-253.

Arce, Javier, 'Campos, tierras y villae en Hispania (siglos IV-VI)', in Visigodos y omeyas: el territorio, ed. by Luis Caballero Zoreda, Pedro Mateos Cruz, and Tomás Cordero Ruiz (Madrid: Consejo Superior de Investigaciones Científicas, Anejos de Archivo Español de Arqueología 61, 2012), pp. 21-30.

Balmaseda Muncharaz, Luis Javier, 'Algunos problemas de la escultura visigoda toledana', in Escultura decorativa tardorromana y altomedieval en la Península Ibérica, ed. by Luis Caballero Zoreda and Pedro Mateos Cruz (Mérida: Consejo Superior de Investigaciones Científicas, Anejos de Archivo Español de Arqueología 41, 2007a), pp. 275-300.

-, 'En busca de las iglesias toledanas de época visigoda', in Hispania Gothorum: San Ildefonso y el reino visigodo de Toledo, ed. by Rafael García Serrano (Toledo: Museo de Santa Cruz, 2007b), pp. 197-214.

Barbero de Aguilera, Abilio, 'Las divisiones eclesiásticas y las relaciones entre la iglesia y el estado en la España de los siglos VI y VII', in La Historia en el contexto de las ciencias humanasy sociales: homenaje a Marcelo Vigil Pascual, ed. by María José Hidalgo de la Vega (Salamanca: Ediciones de la Universidad de Salamanca, Estudios Históricos y Geográficos 61, 1989), pp. 169-19o.

Barroso Cabrera, Rafael, and Jorge Morín de Pablos, 'La ciuitas regia Toletana en el contexto de la Hispania de la séptima centuria', in Regia sedes Toletana, 2 vols., vol. 1: La topografía de la ciudad de Toledo en la antigüedad tardía y alta edad media, ed. by Jesús Carrobles Santos, Rafael Barroso Cabrera, Jorge Morín de Pablos, and Fernando Valdés Fernández (Toledo: Diputación de Toledo, 2007a), pp. 97-161.

_ 'Toledo en el contexto de la escultura hispanovisigoda peninsular', in Regia sedes Toletana, 2 vols., vol. 2: El Toledo visigodo a través de su escultura monumental, ed. by Rafael Barroso Cabrera and Jorge Morín de Pablos (Toledo: Diputación de Toledo, 2007b), pp. 21-64. 
Barroso Cabrera, Rafael, Jesús Carrobles Santos, and Jorge Morín de Pablos, 'Toledo visigodo y su memoria a través de los restos escultóricos', in Spolien im Umkreis der Macht: Akten der Tagung in Toledo vom 21. bis 22. September 20o6/Spolia en el entorno del poder: Actas del coloquio en Toledo del 21 al 22 de septiembre 2006, ed. by Thomas G. Schattner and Fernando Valdés Fernández (Mainz: Philipp von Zabern, Iberia Archaeologica 12, 2009), pp. 171-197.

, 'Arquitectura de poder en el territorio toledano en la antigüedad tardía y época visigoda: los palacios de Toledo como referente en la edilicia medieval', in La ciudad medieval: de la casa principal al palacio urbano; Actas del III Curso de historia y urbanismo medieval organizado por la Universidad de Castilla-La Mancha, ed. by Jean Passini and Ricardo Izquierdo Benito (Toledo: Consejería de Educación, Ciencia y Cultura, 2011), pp. 1-69.

-, 'La articulación del territorio toledano entre la antigüedad tardía y la alta edad media (siglos IV al VIII d.C.)', in Visigodos y omeyas: el territorio, ed. by Luis Caballero Zoreda, Pedro Mateos Cruz, and Tomás Cordero Ruiz (Madrid: Consejo Superior de Investigaciones Científicas, Anejos de Archivo Español de Arqueología 61, 2012), pp. 263-304.

Barroso Cabrera, Rafael, Jesús Carrobles Santos, Jorge Morín de Pablos, and Isabel Sánchez Ramos, 'El paisaje urbano de Toledo en la antiguedad tardia', Antiquité Tardive 23 (2015a), pp. 329-352.

— Los Hitos: Arisgotas-Orgaz, Toledo; de palacio a panteón visigodo (Madrid: 2015b).

- 'Toletum: configuración y evolución urbana de la capital visigoda y su territorio', in Territorio, topografía y arquitectura de poder durante la antigüedad tardía, ed. by Isabel Sánchez Ramos and Pedro Mateos Cruz (Mérida: Instituto Arqueología Mérida, Serie Mytra 1, 2018), pp. 195-236.

Beltrán de Heredia Bercero, Julia, 'Barcelona, la topografía de un centro de poder visigodo: católicos y arrianos a través de la arqueología', in Territorio, topografía y arquitectura de poder durante la antigüedad tardía, ed. by Isabel Sánchez Ramos and Pedro Mateos Cruz (Mérida: Instituto Arqueología Mérida, Serie Mytra 1, 2018), pp. 79-125.

Bonifay, Michel, and Dario Bernal Casasola, 'Recópolis: paradigma de las importaciones africanas en el Visigothorum regnum; un primer balance', in Recópolis y la ciudad en la época visigoda, ed. by Lauro Olmo Enciso (Madrid: Museo Arqueológico Regional, Zona Arqueologica 9, 2008), pp. 98-115.

Bonnery, André, 'La cathédrale des ariens et la fin de l'arianaisme a Narbonne', in Gallo-romaines, wisigoths et francs en Aquitaine, Septimanie et Espagne: Actes des VII Journées internationales d'archéologie merovingienne, Toulouse 1985, ed. by Patrick Périn (Rouen: Musée des Antiquités de la Seine-Maritime, Association Française d'Archéologie Mérovingienne, 1991), pp. 155-160. 
Caballero Zoreda, Luis, 'El Monasterio de Balatalmelc, Melque (San Martín de Montalbán, Toledo); en el centenario de su descubrimiento', in Monasteria et territoria: elites, edilicia y territorio en el Mediterráneo medieval (siglos V-XI): Actas del III Encuentro internacional e interdisciplinary sobre la alta edad media en la Península Ibérica, ed. by Jorge López Quiroga, Artemio Manuel Martínez Tejera, and Jorge Morín de Pablos (Oxford: British Archaeological Reports International Series S1720, 2007), pp. 91-120.

Caballero Zoreda, Luis, and Margarita Fernández, 'Notas sobre el complejo productivo de Melque (Toledo)', Archivo Español de Arqueología 72 (1999), pp. 199-239.

Carrero Santamaría, Eduardo, 'Presbiterio y coro en la Catedral de Toledo: en busca de unas circunstancias', Hortus Artium Medievalium 15.2 (2009), pp. 315-328.

Carrobles Santos, Jesús, 'Toledo 284-546: los orígenes de la capitalidad visigoda', in Regia sedes Toletana, 2 vols., vol. 1: La topografía de la ciudad de Toledo en la antigüedad tardía y alta edad media, ed. by Jesús Carrobles Santos, Rafael Barroso Cabrera, Jorge Morín de Pablos, and Fernando Valdés Fernández (Toledo: Diputación de Toledo, 2007), pp. 45-92.

Carrobles Santos, Jesús, and Santiago Palomero Plaza, 'Toledo: un vado y una ciudad estratégica', Revista del Instituto Egipcio de Estudios Islámicos en Madrid 30 (1998), pp. 245-261.

Castellanos García, Santiago, 'La construcción del poder político visigodo y los horizontes locales: canales de participación y de hostilidad', in De Roma a los bárbaros: poder central y horizontes locales en la cuenca del Duero, ed. by Santiago Castellanos García and Iñaki Martín Viso (León: Universidad de León, 2008), pp. 145-170.

Castellanos García, Santiago, and Iñaki Martín Viso, 'The Local Articulation of Central Power in the North of the Iberian Peninsula (500-1000)', Early Medieval Europe 13.1 (2005), pp. 1-42.

Christie, Neil, 'Landscapes of Change in Late Antiquity and the Early Middle Ages: Themes, Directions and Problems', in Landscapes of Change: Rural Evolutions in Late Antiquity and the Early Middle Ages; Late Antiquity and Early Medieval Studies, ed. by Neil Christie (Aldershot: Routledge, Late Antique \& Early Medieval Studies, 2004), pp. 1-37.

Collins, Roger, 'Julian of Toledo and the Royal Succession in Late Seventh-Century Spain', in Early Medieval Kingship, ed. by Peter H. Sawyer and Ian N. Wood (Leeds: University of Leeds, 1977), pp. 30-49.

Díaz Martínez, Pablo C., 'City and Territory in Hispania in Late Antiquity', in Towns and their Territories between Late Antiquity and the Early Middles Ages, ed. by Gian Pietro Brogiolo, Nancy Gauthier, and Neil Christie (Leiden: Brill, Transformation of the Roman World 9, 2000), pp. 3-35. 
, 'Extremis mundi partibus; Gallaecia tardoantigua; periferia geográfica e integración política', in Comunidades locales y dinámicas de poder en el norte de la Península Ibérica durante la antigüedad tardía, ed. by Urbano Espinosa Ruiz and Santiago Castellanos García (Logroño: Universidad de La Rioja, 2006), pp. 201-215.

Eger, Christoph, 'Guarrazar', in El tiempo de los bárbaros: pervivencia y transformación en Galia e Hispania (siglos V-VI d.C.), ed. by Jorge Morín de Pablos, Jorge López Quiroga, and Artemio Manuel Martínez Tejera (Alcalá de Henares: Museo Arqueológico Regional, Zona Arqueológica 11, 2010), pp. 563-565.

Escrivà Chover, Isabel, Jorge Morín de Pablos, Albert Ribera i Lacomba, Miquel Rosselló Mesquida, and Isabel Sánchez Ramos, 'Estudio y propuesta de reconstrucción', in Pla de Nadal (Riba-roja del Túria): el Palacio de Tevdinir, ed. by Albert Ribera i Lacomba (Valencia: Ajuntament de Riba-roja del Túria, 2015), pp. 36-41.

Ewig, Eugen, 'Résidence et capitale pendant le haut Moyen Âge', Revue Historique 230 (1963), pp. $25^{-72}$.

Fernández-Ochoa, Carmen, Manuel Bendala Galán, and Virginia García Entero, 'Últimos trabajos arqueológicos en el yacimiento de Carranque (Toledo): 2004-2005', in Actas de las IJornadas de Arqueología de Castilla-La Mancha, ed. by Juan Manuel Millán Martínez and Concepción Rodríguez Ruza (Cuenca: Universidad de Castilla-La Mancha, Coediciones 6o, 2007), pp. 743-753.

Fita, Fidel, 'Noticia de una ley de Teudis desconocida, recientemente descubierta en un palimpsesto de la Catedral de León', Boletín de la Real Academía de la Historia 14.6 (1889), pp. 473-495.

García Moreno, Luis Agustín, 'El hábitat rural disperso en la Península Ibérica durante la antigüedad tardía', Antigüedady Cristianismo 8 (1991), pp. 265-273.

—_ 'Guarrazar y la conquista islámica', in Actas de las VIIJornadas visigodas tesoro de Guarrazar, 16, 17 y 18 de mayo de 2014 (Toledo: Ayuntamento de Guadamur, 2014), pp. 6-9.

González Ollé, Fernándo, 'Consolatio (Concilio Toledano VII)', Voces 5 (1994), pp. 61-64.

Le Jan, Regin, 'Convents, Violence and Competition for Power in Seventh-Century Francia', in Topographies of Power in the Early Middle Ages, ed. by Mayke De Jong, Carine Van Rhijn, and Frans Theuws (Leiden: Brill, 2001), pp. 243-269.

Martin, Céline, La géographie du pouvoir dans l'Espagne visigothique (Lille: Presses Universitaires du Septentrion, 2003).

Martín Viso, Iñaki, 'Colapso político y sociedades locales: el noroeste de la Península Ibérica (siglos VIII-IX)', Reti Medievali Rivista 17.2 (2016), pp. 335-369, http:// www.rmojs.unina.it/index.php/rm/issue/view/389 (accessed 7 October 2020). Morín de Pablos, Jorge, s.v. 'Guarrazar (trèsor de)', in Les barbares, ed. by Bruno Dumézil (Paris: Puf, 2016), pp. 676-679. 
Nolla Brufau, Josep María, 'Ciudades, torres y castella: la defensa de la Vía Augusta', in Las fortificaciones en la tardoantigüedad: élites y articulación del territorio (siglos V-VIII d.C.), ed. by Raúl Catalán Ramos, Patricia Fuentes Melgar, and José Carlos Sastre Blanco (Madrid: Ediciones La Ergástula, 2014), pp. 43-56.

Olmo Enciso, Lauro, 'Nuevos paisajes urbanos y consolidación del estado en época visigoda', in Hispania Gothorum: San Ildefonso y el reino visigodo de Toledo, ed. by Rafael García Serrano (Toledo: Museo de Santa Cruz, 2007), pp. 161-180.

— - 'Ciudad y estado en época visigoda: Toledo, la construcción de un nuevo paisaje urbano', in Espacios urbanos en el Occidente mediterráneo (siglos VI-VIII), ed. by Alfonso García (Madrid: 2010), pp. 87-111.

Palol i Salellas, Pere de, 'Resultados de las excavaciones junto al Cristo de la Vega, supuesta basílica conciliar de Sta. Leocadia, de Toledo: algunas notas de topografía religiosa de la ciudad', in Concilio III de Toledo: XIV Centenario; 589-1989 (Toledo: Arzobispado de Toledo, 1991), pp. 787-832.

Peidro Blanes, Jesús, 'La región de la Oróspeda tras Leovigildo: organización y administración del territorio', Verdolay-MAM 11 (2008), pp. 263-276.

Pliego, Ruth, La moneda visigoda, 2 vols. (Seville: Editorial Universidad de Sevilla, Historia y Geografía 159, 2009).

Real, Manuel Luis, 'Portugal: cultura visigoda e cultura moçarabe', in Visigodos y omeyas: un debate entre la antigüedad tardía y la alta edad media, ed. by Luis Caballero Zoreda and Pedro Mateos Cruz (Mérida: Consejo Superior de Investigaciones Científicas, Anejos de Archivo Español de Arqueología 23, 2000), pp. 21-75.

Rivera, Juan Francisco, 'La Catedral de Toledo: museo de historia, 2: Época visigoda', Boletín de la Real Academía de Toledo 64-65 (1950-1951), pp. 24-75.

Rizos, Efthymios, 'Centres of the Late Roman Military Supply Network in the Balkans: A Survey of horrea',Jahrbuch des Römisch-Germanischen Zentralmuseums 6 o (2013), pp. 659-696.

Rojas Rodríguez-Malo, Juan Manuel, 'El primer año de trabajos en Guarrazar. La confirmación de un yacimiento arqueológico', in Actas de las VIIJornadas visigodas tesoro de Guarrazar, 16, 17 y 18 de mayo de 2014 (Toledo: Ayuntamento de Guadamur, 2014), pp. 37-66.

Rojas Rodríguez-Malo, Juan Manuel, and Antonio José Gómez Laguna, 'Intervención arqueológica en la Vega Baja de Toledo: características del centro político y religioso del reino visigodo', in El siglo VII frente al siglo VII: arquitectura, ed. by Luis Caballero Zoreda, Pedro Mateos Cruz, and María de los Angeles Utrero Agudo (Madrid: Consejo Superior de Investigaciones Científicas, Anejos de Archivo Español de Arqueología 51, 2009), pp. 45-89. 
Sánchez Pardo, José Carlos, 'Power and Rural Landscapes in Early Medieval Galicia (400-900 AD): Towards a Re-incorporation of the Archaeology into the Historical Narrative', Early Medieval Europe 21.2 (2013), pp. 140-168.

Sánchez-Albornoz, Claudio, 'El Aula Regia y las asambleas políticas de los godos', Cuadernos de Historia de España 5 (1946), pp. 5-110.

Sánchez Ramos, Isabel, 'Looking through Landscapes: Ideology and Power in the Visigothic Kingdom of Toledo', in Urban Interactions: Communication and Competition in Late Antiquity and the Early Middle Ages, ed. by Michael J. Kelly and Michael Burrows (New York: Gracchi Books, in press), pp. 248-281.

Sánchez Ramos, Isabel, and Pedro Mateos Cruz, eds., Territorio, topografía y arquitectura de poder durante la antigüedad tardía (Mérida: Instituto Arqueología Mérida, Serie Mytra 1, 2018).

Sánchez Ramos, Isabel, Jorge Morín de Pablos, and José Ramón González de la Cal, 'El edificio funerario tardoantiguo de Los Hitos en Arisgotas (Toledo, España): un panteón de época visigoda', in Loci Sepulcrales: Pantheons and Other Places of Memory and Burial in the Middle Ages (Lisbon, in press).

Santiago Fernández, Javier de, 'El hábito epigráfico en la Hispania visigoda', in VIII Jornadas científicas sobre documentación de la Hispania altomedieval (siglos $V I-X)$, ed. by Juan Carlos Galende and Javier de Santiago Fernández (Madrid: Universidad Complutense de Madrid, 2009), pp. 291-344.

Teja, Ramón, and Silvia Acerbi, 'El palacio visigodo y el circo de Toledo: hipótesis de localización', Reti Medievali Rivista 11.2 (2010), pp. 81-86.

Valdés Fernández, Fernando, 'Un puente sobre el Tajo: el proceso de islamización de la ciudad de Toledo', in Regia sedes Toletana, 2 vols., vol. 1: La topografía de la ciudad de Toledo en la antigüedad tardía y alta edad media, ed. by Jesús Carrobles Santos, Rafael Barroso Cabrera, Jorge Morín de Pablos, and Fernando Valdés Fernández (Toledo: Diputación de Toledo, 2007), pp. 165-206.

Velázquez Soriano, Isabel, 'Las inscripciones del tesoro de Guarrazar', in El tesoro visigodo de Guarrazar, bk. 5: De las coronas y las cruces, ed. by Alicia Perea (Madrid: Consejo Superior de Investigaciones Científicas, 2001), pp. 319-346.

—_ 'La inscripción de consagración de la Catedral de Toledo', in Excavaciones en el claustro de la Catedral de Toledo, ed. by Martín Almagro-Gorbea, José María Barranco Ribot, and Markel Gorbea Pérez (Madrid: Real Academia de la Historia, Bibliotheca Archaeologica Hispana 33, 2011), pp. 261-280.

Velázquez Soriano, Isabel, and Gisela Ripoll López, 'Toletum, la construcción de una urbs regia', in Sedes Regiae (ann. 40o-8oo), ed. by Gisela Ripoll López and José María Gurt Esparraguera (Barcelona: Memorias de la Real Academia de Buenas Letras 25, 2000), pp. 521-578. 
About the author

Isabel Sánchez Ramos is a Marie Curie Research Fellow at the UCL Institute of Archaeology (UK). Her research has focused strongly on urban development, power centres, and especially the Christianization of cities. Her current research interest lies in settlements and the public architecture that corresponds to religious and civil buildings.

Jorge Morín de Pablos is a postdoctoral researcher who focuses on archaeology from the late Roman to medieval times, and serves as director-manager of the Department of Cultural Heritage Resources at AUDEMA Madrid (Spain). He has conducted more than a hundred excavations from the Palaeolithic period to today in Spain and abroad. 


\title{
17 Ancient Classics and Catholic Tradition through Time and Space
}

\author{
Martin of Braga and his Cultural Claims
}

Markus Mülke

\begin{abstract}
Martin, Bishop of Braga, is of importance not only in the reign of the Suebi. He also influenced the Visigothic reign years before its Arian King Liuvigild completed his military submission of Galicia. Martin's activities beginning from the middle of the sixth century, during the conflict between Arians and the Catholic Hispano-Roman church on the Iberian Peninsula, promoted once again the classical tradition, as well as the theological traditions of Christian doctrines from late antiquity. He supported his initiatives through a wide-ranging, 'international' network with Gallia, Italy/Rome, and the Greek East/Constantinople.
\end{abstract}

Keywords: Galicia; Martin of Braga; Suebi; church councils; Arian confession; education

In $580 \mathrm{AD}$, the Visigothic King Liuvigild gathered a church council of Arian bishops in the city of Toledo, at a time when he had to resist the 'Catholic' rebellion of his son Hermenegild. Our main source for this historical period, Iohannis Biclarensis, informs us concerning the event. ${ }^{1}$ The king had renewed Arian heresies 'dicens de Romana religione ad nostram catholicam fidem venientes non debere baptizari, sed tantummodo per manus impositionem et communionis preceptione ablui, et gloriam Patri per Filium in Spiritu Sancto dare'. Liuvigild insisted on the confessional opposition between his own Arian fides and the mere religio of others, i.e. the Hispano-Roman

1 John of Biclar, Chronicon, 57 ad annum 579.

Panzram, S. and P. Pachá (eds.). The Visigothic Kingdom: The Negotiation of Power in Post-Roman Iberia. Amsterdam: Amsterdam University Press 2020 DOI: 10.5117/9789463720632_CH17 
church. Using the rhetorical strategy of exclusion, on the one hand, through the application of the possessive pronoun (nostra [...] fides), and, on the other, stressing the spatial dimension of the issue. ${ }^{2}$ While Liuvigild - when through regions of the former Imperium Romanum the Arian confession had lost most of its territories - explicitly designates his own fides as catholica, i.e. as universal, he defines the opponent religio as Romana, as simply Roman, spatially limited and not universal. Modern research has stressed that, by the decision of the Arian Council, Liuvigild identified the HispanoRoman church as bound to the Roman see, i.e. to the pope but also to the Roman emperor, as a Byzantine opposition. As to the relationship between universality and particularity, Martin of Braga effected influence not only in the Suebic area, but also on developments within the Visigothic reign

\section{Martin of Braga}

The consequences that the conversion of the Suebi from Arian to Catholic faith (by tradition dated to the middle of the sixth century ${ }^{3}$ ) and that Martin's mission as bishop of Dumio, then bishop of Bracara (and Dumio), brought about had an effect on the entire Visigothic area in various ways. Decades after Martin's death, Isidore of Seville in his authoritative work $D e$ Viris Illustribus testifies to the high reputation the bishop of Braga enjoyed among the Visigoths:

Martinus Dumiensis monasterii sanctissimus pontifex, ex Orientis partibus navigans, in Gallaeciam venit, ibique conversis ab Ariana impietate ad fidem catholicam Suevorum populis, regulam fidei et sanctae religionis constituit, ecclesias confirmavit, monasteria condidit copiosaque praecepta piae institutionis composuit. Cuius quidem ego ipse legi librum de differentiis quattuor virtutum et aliud volumen epistolarum, in quibus hortatur vitae emendationem et conversationem fidei, orationis instantiam et elemosynarum distributionem et super omnia cultum virtutum omnium et pietatem. floruit regnante Theodemiro rege Suevorum temporibus illis, quibus Iustinianus in re publica et Athanagildus in Hispaniis imperium tenuerunt. ${ }^{4}$ 
This influence can be identified more directly, however, through Martin's letters, which survive in a small number, ${ }^{5}$ particularly the dedication letters to some of his literary works that addressed not only within the Suebic reign viri ecclesiastici (for example the dedication letter of De ira directed to Victimer, bishop of Auria/Orense, the dedication letter of De correctione rusticorum directed to Polemius, bishop of Astorga, ${ }^{6}$ the inscriptio of the so-called Capitula Martini to Nitigisius, bishop of Lugo, and the dedication letter Formula honestae vitae to King Miro), ${ }^{7}$ but also in the Visigothic reign. ${ }^{8}$ Martin wrote, in epistolary form, his small treatise De trina mersione to a Bonifatius, whose identification with a bishop in the Visigothic area is today communis opinio. ${ }^{9}$

A thorough analysis of the complex literary work that Martin published over the years of his service in Dumio/Braga distinguishes it as extensively international. In this regard, his two works Sententiae Patrum Aegyptiorum quas de Graeco in Latinum transtulit Martinus Dumiensis episcopus and Capitula ex Orientalium Patrum Synodis (shortly: Capitula Martini) are extremely important. The titles themselves indicate that the author is going to import distant wisdom, whether in a spatial dimension - of the Egyptian desert fathers ${ }^{10}$ and dogmatic decrees of synods in the Greek East - or in a temporal dimension as the Sententiae went back, according to early Christian tradition, at least to fathers in the third-fourth century (collected probably during the second half of the fourth ${ }^{11}$ ) and the Capitula to councils of the fourth and fifth centuries (e.g. Nicaea, Ankyra, Laodicea, and Antiochia). ${ }^{12}$

5 Isidore obviously knew a whole corpus of Martin's letters (cf. above: volumen epistolarum; cf. Fontaine 1983, pp. 693-694; 704 seq. about his intimate knowledge of Martin's oeuvre). The dedication letter to De trina mersione presupposes a letter exchange with Bishop Bonifatius, and that one to Formula honestae vitae several letters written by King Miro to Martin himself (cf. the first sentence of the work: 'non ignoro [...] humilitatem meam tuis saepius litteris admoneri, ut dignationi tuae crebro aliquid per epistolam scribens aut consultationis aut exhortationis alicuius etsi qualiacumque sint offeram dicta'). About epistolography in the sixth century cf. Velázquez Soriano 1994, pp. 348-349 and below p. 346.

6 Cf. Martin of Braga, Contro le superstizioni: catechesi al popolo, p. 26.

7 About the relationship between Martin and Miro, cf. Ferreiro 1988, pp. 229-23o; Díaz Martínez 2000, pp. 412-413 and 418-419.

8 Cf. Martin of Braga, De ira, pp. 12-13.

9 Cf. Martin of Braga, Obras completas, p. 31; Ferreiro 2007, pp. 194-197; Martin of Braga, De ira, p. $13^{13}$, and below note 36 .

10 Cf. Ferreiro 1988, p. 227; Díaz Martínez 200o, p. 418, and 2011, p. 234.

11 Cf. Martin of Braga, Opera omnia, p. 11; Ferreiro 1998, p. 55.

12 Cf. Branco 1990, p. 89; Díaz Martínez 2000, p. 418; Andrés Sanz 2010, p. 74; Díaz Martínez 2011, pp. 235-236. The canon De salutatione of the First Council of Braga (561 CE) explicitly stresses the unanimity with Eastern christianity, as opposed to Priscillianism: 'sicut et ab ipsis 
Furthermore, both works had been translated from Greek originals. ${ }^{13}$ If it is true that the Sententiae had been the first work Martin published as bishop of Dumio among the Suebi, ${ }^{14}$ beginning his literary activity and introducing himself to new readers, then his claim of connecting his teaching to earlier normative traditions of the Christian East becomes evident. ${ }^{15}$ Similarly, the Capitula, probably assembled in the years immediately before the Second Council of Braga (572 AD), ${ }^{16}$ had been addressed to Nitigisius, bishop of Lugo, but later were sent to the council and were incorporated into the collections of Visigothic council acts. That Martin kept in mind the whole Iberian Peninsula and that the border to the Visigothic reign did not represent for him an obstacle to theological unity is clear also from the fact that he further added to the capitula of former Greek synods more recent canones of the I Council of Toledo (400 AD). ${ }^{17}$

The testimonies of Venantius Fortunatus and Gregorius of Tours have been studied intensively by modern research and prove the reputation Martin of Braga had gained during his lifetime. Both authors came from the south of Gallia and indicate the close relationship Martin kept with this region. Both comment not only on the Orthodox mission Martin completed among the Suebi, but also on his impressive cultural influence. ${ }^{18}$ While Venantius's Letter 5.1 suggests that Martin was able to exchange ideas about ancient philosophy (not only Plato and Aristotle, but also the Stoic and Peripatetic schools), ${ }^{19}$ Gregory explicitly writes about Martin's journeys to the Greek East: ${ }^{20}$ 'Pannoniae ortus fuit, et

apostolis traditum omnis retinet Oriens et non sicut Priscilliana pravitas permutavit' (Concilios visigóticos e hispano-romanos, p. 72).

13 Cf. Riché 1962, p. 349; Orselli 1999, p. 92; Fontaine 2002, p. 55; Martin of Braga, De ira, p. 13; more sceptical against Martin's knowledge of Greek language, Do Espírito Santo 1993, pp. 49-176, and 2007, passim; Branco 1990, p. 82.

14 Cf. Martin of Braga, Opera omnia, p. 12; Andrés Sanz 2010, p. 72.

15 Cf. Fontaine 1983, p. 847; Díaz Martínez 2011, p. 234: 'La condición de Dumio como foco cultural es evidente; desde aquí el modelo de monacato egipcio se defundió por toda Gallaecia, en lo que, a la postre, sería una de las experiencias monásticas más ricas y originales de la Antigüedad tardía.'

16 Cf. Martin of Braga, Opera omnia, pp. 86-87.

17 About the Sententiae and the Capitula as testimonies of cultural renovatio, cf. Mülke, in press-b, passim.

18 Cf. Ferreiro 1980, p. 244, and 1981, p. 17; Alberto 1991, pp. 182-183; Velázquez Soriano 1994, pp. 339-340; Díaz Martínez 2007, p. 372; Martin of Braga, De ira, p. 12.

19 Cf. Ferreiro 1988, p. 237; Díaz Martínez 2011, p. 223; more sceptical Do Espírito Santo 2007, p. 269 .

20 The question whether Martin ever had gone to the Greek speaking East and studied there, or whether he exclusively completed his paideia in the Latin speaking West, i.e. in Rome and in 
exinde ad visitanda loca sancta in oriente properans, in tantum se litteris imbuit, ut nulli secundus suis temporibus haberetur.' Isidore later echoes this reputation in his Historia Gothorum (624, longer version) when he describes Martin as 'episcopus fide et scientia clarus, cuius studio et pax ecclesiae ampliata est et multa in ecclesiasticis disciplinis Galliciae regionibus instituta'. ${ }^{21}$

In a short work, De trina mersione, written between $55^{6}$ and $561 \mathrm{CE},{ }^{22}$ Martin answers a letter of Bonifatius explaining proper baptismal rites that were practiced in the reign of the Suevi and, according to Martin, that correspond to the Orthodox praxis (against a suspicion that they could be understood as an expression of Arian liturgy). ${ }^{23}$ It is interesting that Martin legitimates his position, first with instructions Pope Vigilius wrote in a letter from Rome to Bishop Profuturus of Braga in $538 \mathrm{CE}$ on the same issue, ${ }^{24}$ then with rules of oriental church councils of the past and explanations given by former church fathers, and finally by the fact that the same practices were observed in Constantinople, a notice brought back by legates of Braga who went there. $^{25}$ The only biblical reference in the treatise (Paul. Eph. 4:5), by which Martin supports his argumentation, appears in chapter 3 and follows

Gallia, remains open; cf. e.g. Schäferdiek 1967, pp. 120-121; Šašel 1978, pp. 249 and 253; Ferreiro 1981, pp. 11-13; Martin of Braga, Obras completas, pp. 11-18; Banniard 1991, p. 663; Martin of Braga, Contro le superstizioni: catechesi al popolo, pp. 7-8; Díaz Martínez 1994, p. 380-381, and 2011, pp. 220-221; Martin of Braga, Instrução pastoral sobre superstições populares, pp. 28-31; Martin of Braga, Pro castigatione rusticorum, pp. 6-7; Do Espírito Santo 2007, pp. 265-267 (sceptical and even denying that Martin was born in Pannonia); Martin of Braga, De ira, pp. 9-10 and 14; Andrés Sanz 2010, p. 71 .

21 Gregory of Tours, Libri historiarum X, 5.37. Therefore, Martinus Bracarensis is to consider - within the Suebic reign! - an important predecessor of the socalled 'Isidorian Renaissance' (cf. Riché 1962, p. 169; Fontaine 1983, p. 9; 1986, pp. 154, 170, 201-202, and 2002, p. 57; Valverde Castro 2000, pp. 179-181; Mülke 2009, passim, and 2015, passim - instead, relying on the communis opinio, e.g. Rodríguez de la Peña 2008, pp. 246-247: 'lo cierto es que el panorama cultural en la Hispania goda resultaba bastante pobre [sc. before the III Council of Toledo 589 $\left.\mathrm{CE}]^{\prime}\right)$.

22 Cf. Ferreiro 1981, p. 20, and 2007, pp. 195-196.

23 Cf. Andrés Sanz 2010, p. 74.

24 Cf. Ferreiro 2007, pp. 198-199 and 205.

25 See chapter 3: 'antiqua et apostolica est traditio [...] et a Constantinopolitanae urbis praesule, praesentibus huius regni legatis, qui ad imperium fuerant destinati, in ipsa Paschali festivitate pervisa est'; cf. Martin of Braga, Instrução pastoral sobre superstições populares, pp. 28-29; Branco 1990, p. 84; Orselli 1999, p. 91; Ferreiro 1988, p. 226, and 2007, pp. 199 and 205-207; Vallejo Girvés 2012, pp. 228-229: 'los suevos eran un reino que, lejos de estar aislado y de tener tan sólo relaciones con los merovingios, desarollaban una política exterior importante'. The fact that Martin knew of the delegation demonstrates his close relationship with the court, already in those early years. 
references to the Roman auctoritas and the Constantinopolitana urbs, before being discussed in same chapter. ${ }^{26}$

These facts have an importance for the study not only of the contemporary Suebic, but also of the Visigothic reign. They prove the wide-ranging diplomatic relationships the Suebi, situated on the extreme western shore, kept up with political powers that concerned the Visigoths in the East, with Gallia ${ }^{27}$ and with the pope in Rome who showed a vivid interest in the ecclesiastical and theological issues on the Iberian Peninsula, ${ }^{28}$ and, finally, with the Byzantine emperor. ${ }^{29}$

Furthermore, Martin, by addressing his work to a bishop within the Visigothic reign, touched not only on Suebic, but also Visigothic issues. In the final chapter of De trina mersione, Martin once again legitimates the Suebic baptismal practice against suspicions of Arianism, listing decisions of the Eastern synods, which prove concordance with Catholicism and arguments of the church fathers..$^{30}$ That he qualifies the see of the Roman pope - mentioned first place on the list - by the term auctoritas should not be overlooked, ${ }^{31}$ especially with regard to the Visigothic reign which some years later would be governed by Liuvigild. ${ }^{2}$ Yet, Martin's De trina mersione testifies to the fact that, about twenty years before the so-called conversion of the Suebi to Catholicism, there had been a lively Orthodox opposition within the Suebic clerisy that had maintained

26 Cf. Ferreiro 2007, p. 205: 'Martin did not identify specifically the authority of St. Paul (Scripture) even though he quoted the apostle directly in the letter.'

27 Cf. Ferreiro 1988, pp. 226-227; Díaz Martínez 2011, pp. 224-225.

28 Cf. Ferreiro 1988, pp. 226-227; Díaz Martínez 2011, pp. 224-225.

29 Byzantium, just during the fifties of the sixth century, came into action on the Iberian Peninsula, during the conflict between the Visigothic king Agila and his opponent Athanagild, and put under its own (military) control the southern coastal areas (cf. Šašel 1978, p. 250; Vallejo Girvés 1993, pp. 79-130, and 2012, pp. 228-229 and 256-257; Kampers 2008, pp. 165-166; Díaz Martínez 2011, pp. 221-222). About Justinian's renovatio imperii, cf. Vallejo Girvés 1993, pp. 19-22, 36-39, and 41-47; Maas 2015, pp. 173-175.

30 Cf. Mülke, in press-b, passim, about the importance of those written documents.

31 Cf. chapter 5 : 'teneant a nobis fiducialiter quod et per auctoritatem Romanae sedis est traditum, et Orientalium provinciarum institutio prisca demonstrat, et antiquorum patrum expositionibus, quin etiam officialium sacramentorum documentis scribitur' (notice the intentional 'Ringkomposition' to the certissima auctoritas of the beatissimi Petri cathedra in chapter 2). Cf. also chapter 3 about the old, apostolic tradition of Orthodox baptismal rite: 'traditio, quam ex Romani antistitis auctoritate sacerdotes huius provinciae retinent scriptam'. About the 'hohe Achtung' which enjoyed the 'Autorität [...] des Römischen Stuhls [...] im Suebenreich'; cf. Orlandis Rovira and Ramon-Lissón 1981, pp. 77 and 79; Ferreiro 2007, pp. 204-205.

32 Pope Vigilius himself, in his letter to Profuturus of Braga, had stressed the apostolicae sedis auctoritas (cf. Ramon-Lissón 1994, p. 449). 
close contacts with the pope in Rome. In this context, a further detail is striking. In chapter 3 , Martin notices 'similiter et apud Acta S. Silvestri Constantinus admonitus in visione ter mergi iubetur' - the Acta S. Silvestri (an important documentary source for ecclesiastical history) hints to Byzantium as the capital and see of the emperor, i.e. of the first Christian emperor Constantine the Great whose imitatio would be a major goal of the coming Visigothic kings, both of the Arian Liuvigild and, then, of his son, the Catholic-converted Reccared. ${ }^{33}$

Why Martin mentions that the reproach of Arianism could have its reasons in the suspicion that in former times the Suebic baptismal rite corresponded with Arian practice is significant. ${ }^{34}$ As bishop, having begun an intensive study through the archives and having read Pope Vigilius's letter from $538 \mathrm{CE}$, he recognized the dogmatical legitimacy of current baptismal practice. ${ }^{35}$ Once again, the tension between space and time, which is so characteristic of Martin's efforts, becomes evident. On the one hand, he approves the Suebic baptismal practice as legitimate, in concordance with the traditional Orthodoxy based on Roman authority. On the other hand, he represents himself as a determined, resolute, and independently acting church leader: The uncertainty about the dogmatical issue that existed among the Suebi and their neighbours - which Martin does not deny - has been overcome by his own researches and by his detection of an historical background ${ }^{36}$ i.e. by measures that presuppose historical understanding,

33 Cf. Mülke 2015, passim, and 2016, passim (with bibliography). Anyway, one encounters similar acts of Constantinian self-representation also within the Suebic reign, already before Liuvigild and during Martin's lifetime, e.g. at the First Council of Braga, which had been summoned by the Catholic king Ariamir (cf. Orlandis Rovira and Ramon-Lissón 1981, p. 79; Ferreiro 1988, p. 229). 34 Cf. chapter 2: 'nam, ut ego arbitror, qui hoc [sc. that baptism is not practiced uno trinitatis nomine, but in nominibus] vobis voluit intimare, aut numquam vidisse baptizantes episcopos aut certe voluisse aliquid referre, quod hic antea gestum fuerat'.

35 Cf. chapter 2: 'sed nam et ego manifestius hic cognovi, quod de institutione baptismatis metropolitanus huius provinciae ante hos aliquos annos ab ipsa beatissimi Petri cathedra certissimae auctoritatis formulam postulavit. cuius etiam exemplar curiosius legens ita reperii scriptum, ut in uno trinitatis nomine is, qui baptizandus est, aut tertio perfundatur aut mergatur' (cf. about chapter 3 above note 31 ).

$3^{6}$ At the First Council of Braga, Pope Vigilius's letter came to be read once again, explicitly acknowledged as papal instructio: 'Omnes episcopi dixerunt: [...] cum et de certis quibusdam causis instructionem apud nos sedis apostolicae habeamus, quae ad interrogationem quondam venerandae memoriae praecessoris tui Profuturi ab ipsa beatissimi Petri cathedra directa est. Lucretius episcopus dixit: recte vestra fraternitas pro auctoritate sedis apostolicae reminiscita est, quae licet eodem tempore innotuerit, quo directa est, tamen pro firmitate testimonii et instructione multorum, si vestrae unanimitati conplacet, quia prae manibus est, coram his omnibus legatur' (Concilios visigóticos e hispano-romanos, pp. 70-71, with double repetition 
theological reason, administrative competence, precise knowledge of literary and documentary sources - in sum, a certain wide-ranging level of education and culture. ${ }^{37}$

In this context, the short work De ira deserves special consideration. Recent research has brought to light the intense reception of Johannes Cassianus with regard to this treatise,$^{38}$ i.e. the close connection to the theological influence of southern Gallia and to an impressive teacher who himself had formerly come to Gallia from the far east (Scythia?). But De ira indicates a further dimension of Martin's literary activities: the ongoing chresis of Seneca's book of the same title. Martin's De ira has been identified as an 'epitome of Seneca's De ira', ${ }^{39}$ and in fact, some of Martin's sentences directly copy the wording of the ancient author ${ }^{40}$ - similar to his work Formula vitae honestae which makes use of Senecan material so extensively that

of auctoritas/doctrina apostolica/sedis apostolicae in what follows, then in canon 4: ab ipsa apostolicae sedis auctoritate and canon 5 : a sede beatissimi apostoli Petri; cf. Orlandis Rovira and Ramon-Lissón 1981, pp. 81-82; Ramon-Lissón 1994, pp. 453-454). The direct citation of the words ab ipsa beatissimi Petri cathedra from Martin's De trina mersione (cf. above note ooo), proves the early date of this work (pace Vallejo Girvés 2012, pp. 225-229, with bibliography). The council refers to another letter from the Roman see (written by Pope Leo I in the fifth century) with a different expression: a sede beatissimi Petri apostoli (Concilios visigóticos e hispano-romanos, p. 66). The fact that neither the participants on the council nor Martin himself in De trina mersione introduced Pope Vigilius by his name does not indicate that they considered him, within the context of the three-chapters-controversy, as 'poco leal a Calcedonia' (Vallejo Girvés 2012, p. 186; cf. Martin of Braga, Opera omnia, p. 82).

37 Cf. chapter 3 about the testimony from Jerome (cf. Contra Luciferianos, 12), which confirms the Suebic baptismal practice: 'nos [...] legimus et expositionem beati Hieronymi, in qua sub unius nominis invocatione tertio tingendos esse confirmat. et ipsum librum iam vetustissimum chartaceum apud virum venerabilem sanctumque fratrem nostrum Ausentium presbyterum, si requiras, invenies'. Notice Martin's intentional pointe that he had the opportunity of reading Jerome's old book Contra Luciferianos at his own episcopal see in Braga, but did not expect the same for Bonifatius within the Visigothic reign (did he know his library that precisely?) and refered him to the 'common brother' Ausentius (cf. Ferreiro 2007, pp. 195-196 and 205)! Concerning the relationship between the Visigothic and the Suebic clerics, cf. again the First Council of Braga: the presiding Bishop Lucretius, right in the beginning of the synod, refers to the close cooperation of former times among the Roman pope, the church of Galicia and the Tarraconensis et Carthaginensis episcopi, Lusitani quoque et Baetici, against Priscillianism (cf. Concilios visigóticos e hispano-romanos, p. 66).

38 Cf. Martin of Braga, Instrução pastoral sobre superstições populares, pp. 30-31; Orselli 1999, pp. 104-105; Martin of Braga, De ira, pp. 28-33; Andrés Sanz 2010, p. 73.

39 Martin of Braga, Opera omnia, p. 145; cf. Fontaine 1983, p. 693; Fontan 1986-1987, pp. 189 and 195; Alberto 1991, pp. 183-184 and 195-196; Banniard 1991, pp. 665 and 667-668; Martin of Braga, Contro le superstizioni: catechesi al popolo, pp. 9-11; Orselli 1999, pp. 92-93; Fontaine 2002, p. 55. 40 Cf. Ferreiro 1980, p. 249; Branco 1990, pp. 84-85 and 92-93; Rodríguez de la Peña 2008, p. 252; Martin of Braga, De ira, pp. 22-28; Andrés Sanz 2010, p. 73. 
over the centuries it had been considered as originally Senecan. ${ }^{41}$ Perhaps it is not coincidence that Seneca had been Spanish (born in Córdoba), an author of Iberian literary history. Particularly interesting is the reason that Martin, chronologically, goes back to an author of the first century AD who continued, in late antiquity, as a representative of the Stoic philosophy to be considered by the Christian tradition as an author with a certain intimate connection to early Christian faith, not the least because of the apocryphal but widely read letter exchange with the apostle Paul. ${ }^{42}$

\section{Conclusion}

What does it mean: fides catholica? One could consider Martinus Bracarensis as a model, as an expression of the fact that, beginning from the fifties of the sixth century, the conflict between the Arians and the Catholic Hispano-Roman church on the Iberian Peninsula assumed new dimensions in space and time, ${ }^{43}$ whether in the reign of the Suevi or in that of the Visigoths: in time, because he promoted the classical tradition (in education, literature, philosophy, rhetorics, poetry), as well as theological traditions of - Western and Eastern - Christian doctrines from the third, fourth, and fifth centuries; ${ }^{44}$ in space, because he supported his initiatives through a wide-ranging, 'international' network with Gallia, ${ }^{45}$ Italy/Rome, ${ }^{46}$ and the Greek East/Constantinople. ${ }^{47}$ If Martin's activities went back to some

41 Cf. Martin of Braga, Opera omnia, p. 204; Ferreiro 1981, p. 17, and 1988, p. 236; Fontaine 1983, pp. 693-694; Orselli 1999, passim; Andrés Sanz 2010, pp. 74-75.

42 Cf. above p. ooo (about Martin and ancient philosophy); Fontan 1986-1987, p. 198; Alberto 1993, p. 138. In this context, Martin's three poetical compositions deserve a more thorough study (cf. Mülke, in press-a, passim).

43 Cf. the introduction to the acts of the First Braga Council (Concilios visigóticos e hispanoromanos, pp. 65-66): Lucretius links spatial Catholicity ('decreta catholicae et apostolicae disciplinae [...] doctrinam apostolicam [...] instituta fidei catholicae') and tradition in time which was preserved in the canones of former Orthodox councils and in the church fathers' writings ('instituta venerabilium canonum [...] sanctorum patrum instituta').

44 Cf. Ferreiro 1980, p. 250; Fontaine 2002, p. 56; Maas 2015, p. 175 (more generally about Justinian's epoch). Therefore, Martin - born in Pannonia, i.e. a mainly Greek-speaking border region between East and West (cf. Šašel 1978, pp. 252-253) - bears important witness to the continuous cultural exchange and religious-theological ties between Oriens and Occidens in the fifties/ sixties of the sixth century.

45 Cf. Branco 1990, pp. 83-84; Díaz Martínez 2011, pp. 223-225.

46 Cf. Branco 1990, pp. 84-85.

47 Cf. Riché 1962, pp. 321-322; Herbers 20o6, pp. 46-47. 
mandate of the Roman emperor, ${ }^{48}$ or, perhaps, of the Roman pope, ${ }^{49}$ must remain open to debate.

A few years before the military expansion of the Visigothic reign (against Byzantine areas on Iberian ground, as well as against the Suebi themselves) and before the culmination of the conflict between the Hispano-Roman church and Arians under the Visigothic King Liuvigild, Bishop Martin of Braga (re)established, by his theological, pastoral, and administrative mission in the extreme northwest of the peninsula, a cultural, religious, dogmatical, and ecclesiastical bridge with Gallia, Rome, and Byzantium, which resulted in eminent political consequences..$^{0}$ Both his personal relationships and his instruments, especially the use of written communication (in literary works of various forms/genres and letter exchanges ${ }^{51}$ ), operated in modern terms, but, in fact, effectively continued late antique strategies of international networking.

As an eminent figure, with an influence on the whole Iberian area, Martin expressed early a cultural phenomenon that soon should become more evident in the Visigothic reign, in protagonists such as Leander of Seville or Iohannis Biclarensis..$^{2}$ In which way could one explain the relationship between Martin in the reign of the Suebi and these Visigothic figures within the Hispano-Roman church/culture? And, regarding the Hispano-Roman church/culture: How could one define the relationship between 'tradition' (communis opinio) and some sort of 'actualization' in a contemporary, international-universal network's contest? Liuvigild, however, seems to

48 Cf. (with bibliography) Šašel 1978, p. 251; Fontan 1986-1987, p. 194; Martin of Braga, Contro le superstizioni: catechesi al popolo, p. 7 ; Ferreiro 1980, pp. 249-250; 1988, p. 228, and 1998, pp. 52-53; Martin of Braga, Pro castigatione rusticorum, p. 7; Orselli 1999, p. 9o; Díaz Martínez 20oo, p. 412 ('enviado de Constantinopla'), and 2011, pp. 221-222; Martin of Braga, De ira, p. 11; Andrés Sanz 2010, p. 71; Vallejo Girvés 2012, pp. 137 and 186; Mülke, in press-a, passim.

49 Cf. Ribeiro Soares 1986, p. 64; Branco 1990, p. 83.

$5^{0}$ Cf. Šašel 1978, p. 250; Thompson 1980, p. 85; Ferreiro 1981, p. 16; Kampers 2008, p. 181; Díaz Martínez 2011, p. 221; Vallejo Girvés 2012, pp. 225-229. Not only the Byzantines, but also the Suebi supported Hermenegild during the conflict against his father Liuvigild (cf. Kampers 2008, p. 179, and Vallejo Girvés 2012, pp. 242-243). Regarding the contacts between the Suebic king Miro and King Gunthram of Burgundy, cf. Díaz Martínez 2007, p. 372; Vallejo Girvés 2012, p. 226 .

51 Cf. Mülke, in press-b, passim.

$5^{2}$ Cf. Hillgarth 1961, pp. 444-445; Fontaine 1986, p. 158, and 2002, p. 56: 'el metropolitano de Galicia anuncia el ideal episcopal de Leandro y de Isidoro, a los que precede, en poco más o menos, de una generación'; Hillgarth 2009, pp. 12-13; Díaz Martínez 2011, p. 232 (with the observation that Martin's role as abbot-bishop is unusual within the Hispanic environment and rather indicates Eastern models); Koch, p. 29o. See also Fontaine 1983, p. $85^{0^{2}}$, about Braga and the Orient. 
have understood the cultural advantage of the church quite well and to react to it with his own expansive 'religious-cultural-politics' during the second half of the sixth century. But, one could ask, does this really mean that his own faith became catholica?

Soon after his succession to Justinian, Emperor Justin II (565-587 AD) abandoned the three-chapters controversy, returned to Chalcedon faith and, in the eyes of the Western church, brought the Eastern world back to Orthodoxy. In the light of this decision, the wife of the Frankish king Clothar I, Radegundis, who had founded the monastery of Sainte-Croix in Poitiers (c.56o AD) and held intimate contacts with Martin of Braga, sent in a letter a poem (written by Venantius Fortunatus) to the emperor and his wife Sophia, praising his decision in encomiastic terms:

reddite vota deo, quoniam nova purpura, quidquid [25]

concilium statuit Calchedonense, tenet.

hoc meritis, Auguste, tuis et Gallia cantat,

hoc Rhodanus, Rhenus, Hister et Albis agit.

axe sub occiduo audivit Gallicia factum,

Vascone vicino Cantaber ista refert. [30]

currit ad extremas fidei pia fabula gentes

et trans Oceanum terra Britanna favet. ${ }^{53}$

In these verses, the praise of the emperor's return to Chalcedonian faith is extolled by those Western regions that were not subject to his imperium in the East, and saw themselves again and again in sharp contrast to it. ${ }^{54}$ The Catholic Gallicia of the Suebi is located so far in the West ${ }^{55}$ that from there no voice is perceived; nevertheless, it has 'heard' (audivit) of the fact. But what about the Visigothic reign under Liuvigild?

53 Venantius Fortunatus, Ad Iustinum et Sophiam Augustos, 25-32.

54 About Byzantium and the Franks under Justin II, cf. Vallejo Girvés 2012, pp. 228-229.

55 The Suebi themselves were aware of their marginal location in the extreme West. Cf. the acts of the First Braga Council: Orthodox teaching 'manifestius ignaris hominibus declaretur, quia in ipsa extremitate mundi et in ultimis huius provinciae regionibus constituti aut exiguam aut pene nullam rectae eruditionis notitiam contingerunt' (Concilios visigóticos e hispano-romanos, p. 66) and: 'sunt aliqua ecclesiasticae institutionis obsequia, quae in huius praesertim extremitate provinciae non per contentionem [...], sed magis [...] per incuriam aut per ignorantiam variantur'. 


\section{Bibliography}

\section{Primary sources}

Concilios visigóticos e hispano-romanos, ed. by José Vives (Barcelona: Instituto Enrique Flórez, Consejo Superior de Investigaciones Científicas, España Cristiana, Textos 1, 1963).

Gregory of Tours, Libri historiarum X, ed. by Bruno Krusch and Wilhelm Levinson (Hanover: Monumenta Germaniae Historica, Series Rerum Merovingicarum 1.1, 1951).

Isidore of Seville, De Viris Illustribus = El De viris illustribus de Isidoro de Sevilla: estudio y edición crítica, ed. by Carmen Codoñer Merino (Salamanca: Ediciones de la Universidad de Salamanca, 1964).

John of Biclar, Chronicon, ed. by Carmen Cardelle de Hartmann in Victor Tvnnvnensis Chronicon cum reliquiis ex Consularibus Caesaraugustanis et Iohannis Biclarensis Chronicon (Turnhout: Brepols, Corpus Chrsitianorum, Series Latina 173A, 2001), pp. 59-83.

Martin of Braga, Contro le superstizioni; Catechesi al popolo; De correctione rusticorum, ed. by Mario Naldini (Florence: Nardini, Biblioteca Patristica 19, 1991).

—, De ira = Martini Bracarensis De ira: introduzione, testo, traduzione e comment, ed. by Chiara Torre (Rome: Herder, Studi e Testi Tardoantichi 7, 2008).

- Instrução pastoral sobre superstições populares: De correctione rusticorum, ed., trans., introd., and comm. by Aires A. Nascimento (Lisbon: Cosmos, Medievalia 11, 1997).

— , Martini Episcopi Bracarensis Opera omnia, ed. by Claude W. Barlow (New Haven: Yale University Press, 1950).

— Obras completas, ed. by Ursicino Dominguez del Val (Madrid: Fundación Universitaria Española, Corpus Patristicum Hispanum 4, 1990).

- Pro castigatione rusticorum = Martini Bracarensis Pro castigatione rusticorum: introduzione, testo critico, traduzione, ed. by Gennaro Lopez (Rome: Herder, Biblioteca di Cultura Romanobarbarica 3, 1998).

Venantius Fortunatus, Ad Iustinum et Sophiam Augustos, in Venanti Honori Clementiani Fortunati presbyteri Italici Opera poetica, ed. by Friedrich Leo (Berlin: Monumenta Germaniae Historia, Auctores Antiquissimi 4.1, 1881), pp. 275-278.

\section{Secondary sources}

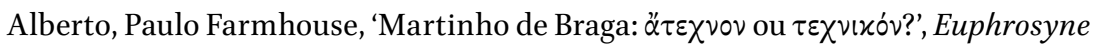
19 (1991), pp. 175-200.

— , 'Seneca e Martinho de Braga: Alguns fantasmas de una recepção', $E u$ phrosyne 21 (1993), pp. 105-139. 
, 'Para uma revalorização dos poemas de Martinho de Braga', Euphrosyne 22 (1994), pp. 215-223.

Andrés Sanz, María Adelaida, 'Martín de Braga', in La Hispania visigótica y mozárabe: dos épocas en su literatura, ed. by Carmen Codoñer Merino (Salamanca: Ediciones de la Universidad de Salamanca, Obras de Referencia 28, 2010), pp. 71-81.

Arce, Javier, Esperando a los árabes: los visigodos en Hispania (507-711) (Madrid: Marcial Pons, 2011).

Banniard, Michel, 'Normes culturelles et realisme langagier en Galice au VI' siècle: les choix de Martin de Braga', in Concilio III de Toledo: XIV centenario 589-1989 (Toledo: Arzobispado de Toledo/Caja Toledo, 1991), pp. 661-676.

Branco, Maria João Violante, 'St. Martin of Braga, the Sueves and Gallaecia', in The Visigoths: Studies in Culture and Society, ed. by Alberto Ferreiro (Leiden: Brill, Medieval Mediterranean 20, 1990), pp. 63-97.

Díaz Martínez, Pablo C., 'Monacato y ascesis en Hispania en los siglos V-VI', in Cristianesimo e specificità regionali nel Mediterraneo latino (sec. IV-VI), XXII Incontro di studiosi dell'antichità cristiana, Roma, 6-8 maggio 1993 (Rome: Institutum Patristicum Augustinianum, Studia Ephemeridis Augustinianum 46, 1994), pp. 377-384.

, 'El reino suevo de Hispania y su sede en Bracara', Memorias de la Real Academia de Buenas Letras de Barcelona 25 (2000), pp. 403-424.

—_, 'La Hispania Visigoda', in Hispania tardoantigua y visigoda, ed. by Pablo C. Díaz Martínez, Clelia Martínez Maza, and Francisco Javier Sanz Huesma (Madrid: Ediciones Istmo, Historia de España 5, 2007), pp. 259-611.

—, El reino suevo (411-585) (Madrid: Akal, 2011).

Do Espírito Santo, Arnaldo, 'A Recepção de Cassiano e das Vitae Patrum: um estudo literário de Braga no século VI', unpublished PhD thesis, University of Lisbon, 1993 .

— - 'Origem e formação de Martinho de Braga', in Munus quaesitum meritis: homenaje a Carmen Codoñer, ed. by Gregorio Hinojo Andrés and José Carlos Fernández Corte (Salamanca: Ediciones de la Universidad de Salamanca, Acta Salmanticensia, Estudios Filológicos 316, 2007), pp. 263-271.

Ferreiro, Alberto, 'The Westward Journey of St. Martin of Braga', Studia Monastica 22 (1980), pp. 243-251.

, 'The Missionary Labors of St. Martin of Braga in 6th Century Galicia', Studia Monastica 23 (1981), pp. 11-26.

— , 'Early Medieval Missionary Tactics: The Example of Martin and Caesarius', Studia Historica: Historia Antigua 6 (1988), pp. 225-238.

— , 'Braga and Tours: Some Observations on Gregory's De virtutibus sancti Martini (1.11)', Journal of Early Christian Studies 3 (1995), pp. 195-210.

—. 'Sueves and Martin of Braga: Historiography and Future Research Projects', in Suevos = Schwaben: das Königreich der Sueben aufder Iberischen Halbinsel 
(411-585); interdisziplinäres Kolloquium, Braga 1996, ed. by Erwin Koller and Hugo Laitenberger (Tübingen: Narr, Tübinger Beiträge zur Linguistik 426, 1998), pp. 37-62.

— - 'Martin of Braga, De trina mersione and the See of Rome', Augustinianum 47 (2007), pp. 193-207.

Fontaine, Jacques, Isidore de Seville et la culture classique dans l'Espagne wisigothique, 2nd ed. (Paris: Brepols, 1983).

_ othique', in La scuola nell'occidente latino dell'alto medioevo (Spoleto: Centro Italiano di Studi sull'Alto Medioevo, Settimane di Studio della Fondazione Centro Italiano di Studi sull'Alto Medioevo 19, 1972; repr. London: Culture et Spiritualité en Espagne de IV ${ }^{\mathrm{e}}$ au VII ${ }^{\mathrm{e}}$ siècle, 1986), pp. 145-202.

— Isidoro de Sevilla: génesis y originalidad de la cultura hispánica en tiempos de los visigodos (Madrid: Ediciones Encuentro, Ensayos 197, 2002).

Fontan, Antonio, 'San Martín de Braga una luz en la penumbra', Cuadernos de Filologia Clásica 20 (1986-1987), pp. 185-199.

Herbers, Klaus, Geschichte Spaniens im Mittelalter: vom Westgotenreich bis zum Ende des 15. Jahrhunderts (Stuttgart: Kohlhammer, 2006).

Hillgarth, Jocelyn N., 'The East, Visigothic Spain and the Irish', Studia Patristica 4 (1961), pp. 442-456.

- The Visigoths in History and Legend (Toronto: Pontifical Institute of Mediaeval Studies, Studies and Texts 166, 2009).

Kampers, Gerd, Geschichte der Westgoten (Paderborn: Schöningh, 2008).

Koch, Manuel, Ethnische Identität im Entstehungsprozess des spanischen Westgotenreichs (Berlin: Ergänzungsbände zum Reallexikon der Germanischen Altertumskunde 75, 2012).

Maas, Michael R., John Lydus and the Roman Past: Antiquarianism and Politics in the Age ofJustinian (London/New York: Routledge, 1992).

— , 'Backdrop to Exile: Imperial Perspectives on the World's Communities in the Age of Justinian', in Movilidad forzada entre antigüedad clásica y tardía, ed. by Margarita Vallejo Girvés, Juan Antonio Bueno Delgado, and Carlos SánchezMoreno Ellart (Alcalá de Henares: Ediciones de la Universidad de Alcalà de Henares, Obras Colectivas, Humanidades 44, 2015), pp. 171-176.

Mülke, Markus, 'Romana religio oder catholica fides? Der Westgotenkönig Leovigild und das arianische Reichskonzil von $5^{80}$ n.Chr. in Toledo', Frühmittelalterliche Studien 43 (2009), pp. 53-69.

, '“Isidorische Renaissance" - oder: Über die Anbahnung einer Wiedergeburt', Antiquité Tardive 23 (2015), pp. 95-107. 
, 'Guter König und doch Verfolger? Die Religionspolitik des Westgotenkönigs Leovigild im Urteil der zeitgenössischen Historiker (Johannes Biclarensis und Isidor von Sevilla)', Frühmittelalterliche Studien 50 (2016), pp. 99-128.

— , 'Zu den Gedichten Martins von Braga', Bollettino della Badia Greca di Grottaferrata 16 (in press-a).

— , 'Übersetzung und Schriftlichkeit. Martin von Braga als Wegbereiter der sogenannten “Isidorischen Renaissance”', Cristianesimo nella storia (in press-b).

Orlandis Rovira, José, and Domingo Ramon-Lissón, Die Synoden aufder Iberischen Halbinsel bis zum Einbruch des Islam (Paderborn: Schöningh, Konziliengeschichte, Reihe A, Darstellungen, 1981).

Orselli, Alba Maria, 'Eredità senecane nel tardo antico: l'esempio di Martino de Braga', in Seneca nella coscienza dell'Europa, ed. by Ivano Dionigi (Milan: Mondadori, Centro studi 'La Permanenza del Classico', Testi e Pretesti, 1999), pp. 81-107.

Ramon-Lissón, Domingo, 'Rapports entre le siège romain et l'Église du royaume Suève pendant le VI ${ }^{\mathrm{ème}}$ siècle', in Cristianesimo e specificità regionali nel Mediterraneo latino (sec. IV-VI), XXII Incontro di studiosi dell'antichità cristiana, Roma, 6-8 maggio 1993 (Rome: Institutum Patristicum Augustinianum, Studia Ephemeridis Augustinianum 46, 1994), pp. 447-456.

Ribeiro Soares, Luís, 'São Bento visto de Dume', in Monacato Galego: sexquimilenario de San Bieito, Actas do primeiro coloquio, Ourense 1981 (Ourense: Museo Arqueolóxico Provincial, Boletin Avriense 6, 1986), pp. 55-65.

Riché, Pierre, Éducation et culture dans l'occident barbare $6^{e}-8^{e}$ siècle (Paris: Seuil, Patristica Sorbonensia 4, 1962).

Rodríguez de la Peña, Manuel Alejandro, Los reyes sabios: cultura y poder en la antigüedad tardía y la alta edad media (Madrid: Actas, 2008).

Šašel, Jaroslav, 'Divinis nutibus actus: due postille per San Martino di Bracara', Historia 27 (1978), pp. 249-254.

Schäferdiek, Knut, Die Kirche in den Reichen der Westgoten und Suewen bis zur Errichtung der westgotischen katholischen Staatskirche (Berlin: De Gruyter, Arbeiten zur Kirchengeschichte 39, 1967).

Thompson, Edward Arthur, 'The Conversion of the Spanish Suevi to Catholicism', in Visigothic Spain: New Approaches, ed. by Edward James (Oxford: Oxford Clarendon Press, 1980), pp. 77-92.

Vallejo Girvés, Margarita, Bizancio y la España tardoantigua (siglos V-VIII): un capítulo de historia mediterránea (Alcalá de Henares: Ediciones de la Universidad de Alcalá de Henares, Memorias del Seminario de Historia Antigua 4, 1993). 
—, Hispania y bizancio: una relación desconocida (Madrid: Akal, 2012).

Valverde Castro, María del Rosario, Ideología, simbolismo y ejercicio del poder real en la monarquía visigoda: un proceso de cambio (Salamanca: Ediciones de la Universidad de Salamanca, Acta Salmanticensia, Estudios Históricos y Geográficos 110, 2000).

Velázquez Soriano, Isabel, 'Ambitos y ambientes de la cultura escrita en Hispania (siglo VI) de Martín de Braga a Leandro de Sevilla', in Cristianesimo e specificità regionali nel Mediterraneo latino (sec. IV-VI), XXII Incontro di studiosi dell'antichità cristiana, Roma, 6-8 maggio 1993 (Rome: Institutum Patristicum Augustinianum, Studia Ephemeridis Augustinianum 46, 1994), pp. 329-351.

\section{About the author}

Markus Mülke is Lecturer in Classics at the Augustana-Hochschule (Neuendettelsau, Germany), the theological college of the Evangelical-Lutheran Church of Bavaria. He has published widely on Arianism in the Iberian Peninsula. 


\title{
18 Conflicts over Episcopal Office in Southern Hispania
}

\author{
Comparative Perspectives from Visigothic and Byzantine \\ Territories
}

Jamie Wood

\begin{abstract}
As key figures within their cities and members of regional aristocracies, bishops have often been seen as playing a pivotal role in the transition from Roman to post-Roman Hispania. There was a steady growth of episcopal power in Hispania and the office of bishop frequently became a source of conflict within Christian communities, as well as between those communities and neighbours seeking to assert authority from further afield. The nature of relations between the 'church' and the 'state' has long been a staple historiographical debate, while in recent decades 'centre' and 'periphery' has become one of the more popular heuristic dichotomies. This chapter takes a bottom-up approach to thinking about how local conflicts within cities related to those between bishops and 'central' powers - the imperial government in the case of Spania and the Visigothic monarchy in the case of Hispania.
\end{abstract}

Keywords: Hispania; church; state; bishops; centre; periphery

The nature of the relationship between the 'church' and the 'state' has long been a staple historiographical debate in studies of Visigothic Hispania, while in recent decades 'centre'-'periphery' interactions have taken centre stage in discussions about how individuals and groups negotiated their positions at local, regional, and 'national' levels in the post-Roman period. ${ }^{1}$ Evidence from

1 For summary and bibliography, see Wood and Martínez Jiménez 2016; Wood 2015.

Panzram, S. and P. Pachá (eds.). The Visigothic Kingdom: The Negotiation of Power in Post-Roman Iberia. Amsterdam: Amsterdam University Press 2020 DOI: $10.5117 / 9789463720632 \_C H 18$ 
disputes over episcopal office in sixth- and early seventh-century Hispania can be used to analyse how bishops operated within their cities, to consider their interactions with other bishops, and to understand their evolving relations to different kinds of 'central' powers (the Byzantine imperial government, the Visigothic monarchy, and the broader church of Hispania). Drawing on recent work that has demonstrated significant continuities in social and political organization at local and regional levels in the south of Hispania in the post-Roman period, I argue that conflicts over a bishop's position should be understood as evidence of competition both within and between elites. Such competition was activated by intervention by aspiring central powers and operated at local (in cities) and regional levels, where elites ('ecclesiastical', 'aristocratic') sought to establish their right to exert authority over peers and neighbours. These efforts often involved support from outsiders, a process that contributed to the piecemeal establishment of a range of competing central powers. ${ }^{2}$ Interference from outsiders ('royal', 'imperial', 'ecclesiastical') who sought to establish their authority in the south acted as a catalyst for conflict and inscribed records of conflict. Authority in the cities of the south was established neither from the top-down nor from the bottom-up, but rather as a result of the continuing interplay of a range of actors across the social scale. Disputes over episcopal office served to challenge the bishop's authority within the city, while successful resolutions had a potential multiplier effect on the prestige of the office and of episcopal power, both in the locality and in relation to outsiders.

Establishing political authority over cities of the south of the Iberian Peninsula was no easy matter for aspiring political authorities in the sixth century. As Collins noted in 1980, southern cities such as Mérida were able to exist largely independent of royal authority well into the sixth century. ${ }^{3}$ A good example of the independence of such cities and the urban elites that controlled them is Córdoba, which was able to inflict a significant defeat on King Agila in 549. ${ }^{4}$ Building on the insights of Collins, Kulikowski and Fernández have demonstrated extensive continuity in terms of civic and state institutions, and aristocratic patterns of socio-economic organization in fifth- and sixth-century Hispania. ${ }^{5}$ Other scholars have examined the increasingly important role played by bishops in post-Roman Spain, although

2 On 'central power', see Castellanos García and Martín Viso 2005. For an archaeological perspective, see Martínez Jiménez and Tejerizo García 2015.

3 Collins 1980, pp. 198-199.

4 Isidore of Seville, Historia Gothorum, 45.

5 Kulikowski 2004; Fernández 2017. 
interrelations with the civic and aristocratic elites from which they were elected has not received the attention that it deserves.

While there is no doubt that bishops played key religious, social, and political roles in post-Roman Hispania and loom large in our sources as both authors and historical actors, like other elites (aristocratic, civic, royal) their power did not go unchallenged, either within their cities or more broadly. ${ }^{6}$ Panzram has recently argued that letters between churchmen in Hispania and the papacy in late antiquity demonstrate that local quarrels and the power of cities contributed to the delayed establishment of a metropolitan ecclesiastical system in the Iberian Peninsula. ${ }^{7}$ Bishops were just one (albeit important) element within the elites that governed late antique Hispania, and cases of dispute over episcopal office are relatively well represented in the evidentiary record. Episcopal disputes were moments at which the practical fragility of episcopal power is evident. As a result - as in cases of dispute over the bishop's office elsewhere in late antiquity - social dynamics at such times come to the fore.

Recent studies of episcopal elections in late antiquity and the Middle Ages have shown that, during transitional periods, bishops' consensus could break down, while subsequent resolutions of dispute represented an opportunity to reassert communal solidarity. Non-Iberian studies have revealed a great deal about the functioning of religious authority, demonstrating that rules about election were not followed mechanistically, but were often moulded in response to shifting social and political contexts on a local level. ${ }^{8}$ The situation in the Iberian Peninsula has, however, received minimal attention despite the fact that there is considerable evidence for disputes about bishops. ${ }^{9}$

This chapter analyses two episodes of disputed episcopal office. First, the evidence of the Vitas Sanctorum Patrum Emeretensium, a seventhcentury hagiographical compilation, is used to explore the situation in late sixth-century Mérida, the civil and ecclesiastical head of the former Roman province of Lusitania and capital of Hispania in the late Roman period. Second, a small dossier of letters sent by Pope Gregory I (d. 604) in 603 to the defensor John, a papal representative who had been sent to the Byzantine province of Spania in the southern part of the Iberian Peninsula to investigate alleged misdeeds by the imperial governor against bishops.

? 
These case studies demonstrate that a similar situation pertained in both Byzantine and Visigothic territory as royal and imperial agents struggled to assert their authority over bishops, who were equally able to seek assistance from outsiders as well as from their local power bases. In Mérida, support came from the city's spiritual patron, the martyr saint Eulalia, while in Byzantine territory appeal was made to the pope in Rome. Local support was mobilized as well. However, while these bishops were powerful and able to resist interference from 'centralizing' outsiders, they had constantly to negotiate their positions locally. Our surviving (and one-sided) sources depict bishops heroically defending the local community against oppression from without. However, when read 'against the grain' they reveal that the bishops who led such communities were often subject to pressure from factions within their cities and from neighbours. Power relations had constantly to be negotiated and the fragmentary potential of local and regional communities opened opportunities for interference from and integration with 'central' authorities that could either validate existing power relations in the locality or open up access to new sources of authority, such as the royal government. ${ }^{10}$

\section{Royal and episcopal rivalry in sixth-century Mérida}

The Vitas Sanctorum Patrum Emeretensium focuses most of its narrative on the development of the bishopric of Mérida, often considered the most powerful bishopric of the post-Roman period in the Iberian Peninsula, in the sixth century. It offers detailed information about conflicts over the episcopate and indicates what a seventh-century author thought were plausible parameters for disputes in the sixth century. ${ }^{11}$ While the account may not reflect the exact configuration of the conflicts, the author would have been constrained by the expectations of his audience ${ }^{12}$ and there is also strong evidence that hagiographer was not impartial, representing the interests of the descendants of one of the parties to the earlier dispute. The Vitas thus provide us with valuable evidence for how memories of conflict over episcopal office were cultivated in the decades after their seeming resolution.

10 As analysed by Castellanos García and Martín Viso 2005.

11 For an introduction to the text, see Velázquez Soriano 2008. For an analysis of the social dynamics in Mérida, see I. Wood 2003.

12 On this issue, see Fouracre 1990. 
Perhaps the key underlying cause of conflict in Mérida in the early $580 \mathrm{~s}$ was the attempt of King Liuvigild (r. 568-586) to establish his authority over the city. ${ }^{13}$ Throughout the 570 s and first part of the 580 , Liuvigild had conducted a number of military campaigns across Hispania and had gone some way towards unifying the peninsula under the power of the Visigothic monarchy, centred on Toledo. ${ }^{14}$ Although Liuvigild had military control of Mérida he used a range of tactics to assert his authority over the bishop, the leading figure in the city. Presented as an act of persecution on a local level by the hagiographer, intervention in Mérida seems to have been part of a broader attempt by Liuvigild to bring together the Homoian and Nicene populations of Hispania, for example by calling a Council of Homoian bishops in Toledo in 580 and removing the requirement for the rebaptism of Nicene converts. ${ }^{15}$ Koch has recently argued that the borders

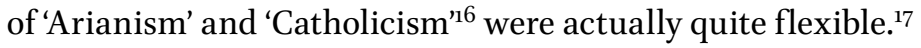

One means by which Liuvigild sought to assert his authority in Mérida was to persuade the incumbent Nicene bishop Masona to convert to Arianism. According to the Vitas, the king repeatedly sent messengers to Mérida to urge conversion upon the bishop. ${ }^{18}$ Later in the dispute, he 'removed the holy man from his see' and had Masona brought to court in Toledo. ${ }^{19}$ The Toledo-strategy failed when Masona proved unwilling to compromise and, as a result, was sent by the king into exile for three years, ${ }^{20}$ an approach Liuvigild adopted in the case of other recalcitrant Nicene bishops in this period. ${ }^{21}$ While the Visigothic king was able to remove the bishop from the city, the hagiographer emphasizes that the strategy was not successful due to Masona's steadfast faith.

Liuvigild's ability to intervene directly in Mérida is underlined by the fact that earlier in the dispute he had appointed an Arian bishop, Sunna,

13 Collins 1980.

14 On the reign of Liuvigild, see García Moreno 2008.

15 J. Wood 2006.

16 In the current chapter I use the terms 'Homoian' and 'Nicene', except when describing the episode at Mérida, when I use the terms 'Arian' and 'Catholic' to reflect the polemical usage of the hagiographer.

17 Koch 2014, which includes an important discussion of the organization of the 'Arian' church of the Visigoths.

18 Vitas Sanctorum Patrum Emeretensium, 5.4.3-4.

19 Ibid., 6.6.

20 Ibid., 6.6.28 and 6.7.

21 For example, the bishops Leander of Seville and John of Biclar both spent time in exile during Liuvigild's reign. See Handley 2003, p. 62, for further evidence of exiled clerics during the reign of Liuvigild. 
to rival Masona ${ }^{22}$ and dispossessed the incumbent of churches within the city, handing them over to his rival: 'he took for himself on the order of the king certain basilicas with all their privileges, rashly snatching them from their rightful bishop,.$^{23}$ Control of ecclesiastical real estate had, according to the hagiographer, already been a contentious issue in Mérida in the decades before Liuvigild's intervention in the bishopric as clergy jockeyed for control of the patrimony of Paul, an earlier bishop, and his nephew and successor, Fidelis. ${ }^{24} \mathrm{~A}$ particularly contentious point was possession of the basilica - and relics - of Mérida's patron saint, Eulalia, which Sunna attempted to control: he continually tried to seize the basilica of the most holy Eulalia, so that having snatched it from its rightful bishop he might dedicate it to the Arian heresy'. ${ }^{25}$

Masona resisted the efforts of incoming bishops and the king to intervene via a number of means, including mobilizing the local population in displays of support, for example in processing through the streets and calling forth divine support from Santa Eulalia. Masona apparently outmaneuvered Liuvigild when the king tried to secure Eulalia's tunic by concealing it under his own clothes. ${ }^{26}$ Masona's rivals in the city responded, seeking control of the basilica of Eulalia, the saint's relics, and the wealth of the church of Mérida. After this failure to displace Masona, Sunna remained in the city and participated in a conspiracy against Reccared, Liuvigild's son and successor, at the time of the conversion of the Visigoths to Catholicism in $587-589 .{ }^{27}$ This episode is an indication of disunity within the elite of Mérida and the methods used by monarchs to deal with troublesome bishops. The conspiracy failed and Sunna was banished to Mauretania, ${ }^{28}$ as Liuvigild had earlier sought to displace Masona from his power base.

When Liuvigild recognized that his attempt to pressure the bishop into compromising by inserting Sunna had failed, he transferred in a rival Catholic bishop, Nepopis, who the hagiographer says came from a neighbouring city. ${ }^{29}$ Moveable wealth was also an issue at this stage of the dispute.

Vitas Sanctorum Patrum Emeretensium, 6.5.2-3.

23

24 This was a particular point of contention during the transition from Paul Fidelis, narrated at ibid., $1.5 \cdot 1-2$.

25 Ibid, 6.5.7.

26 Ibid., 5.6.12-21.

27 Ibid., 6.10-11.

28 Ibid., 6.11.14-15.

29 Ibid., 6.6.29. 
Masona's triumphant return led to Nepopis's return to his home city, but not before he attempted to divest Mérida's churches of 'a great amount of silver, ornaments, and anything else he saw of beauty'. ${ }^{\circ}$ Masona apprehended some of those taking the goods and forced their return. ${ }^{31}$

The terminology the hagiographer used to describe the parties of Masona and Nepopis during the former's return to Mérida is particularly interesting. Despite the emphasis on consensus behind Masona, there are hints that Nepopis had managed to gain support within the city, and was not solely reliant upon those who had come with him from his home city. The hagiographer begins by stating that Masona had an 'enormous retinue' on returning to Mérida..$^{22}$ Nepopis had used men of the church of Mérida to transport property to his 'home' bishopric, ${ }^{33}$ having been driven from the city by 'all its clergy and people', ${ }^{34}$ fleeing in disgrace 'with a few helpers who all belonged to his household' ${ }^{35}$ Returning to Mérida on the same road with a 'great host', ${ }^{6}$ Masona confronted those taking the wealth, at which point they replied, filled with great joy, 'We are your servants, Lord', 37 adding that they are wretches and 'going into captivity separated from our goods, our sons, and our wives' $3^{8}$ Masona asserts his authority and orders 'that they all be taken back to their own city' (6.8.16), and then enters Mérida 'with all his people rejoicing'. ${ }^{39}$ These assertions of Masona's popularity in Mérida no doubt reflect the hagiographer's desire to emphasize consensus within the city in the aftermath of conflict. ${ }^{40}$ Although the author of the Vitas is keen to obscure episodes of disunity, the account does suggest that Nepopis was able to persuade some within the Nicene population of Mérida to support him, even when his position had become untenable. Other episodes of disputes over episcopal office support the proposition that elites within cities were often not particularly united behind their bishop. For example, records of the deposition of Martianus of Écija in the 62os stress that Aventius, who

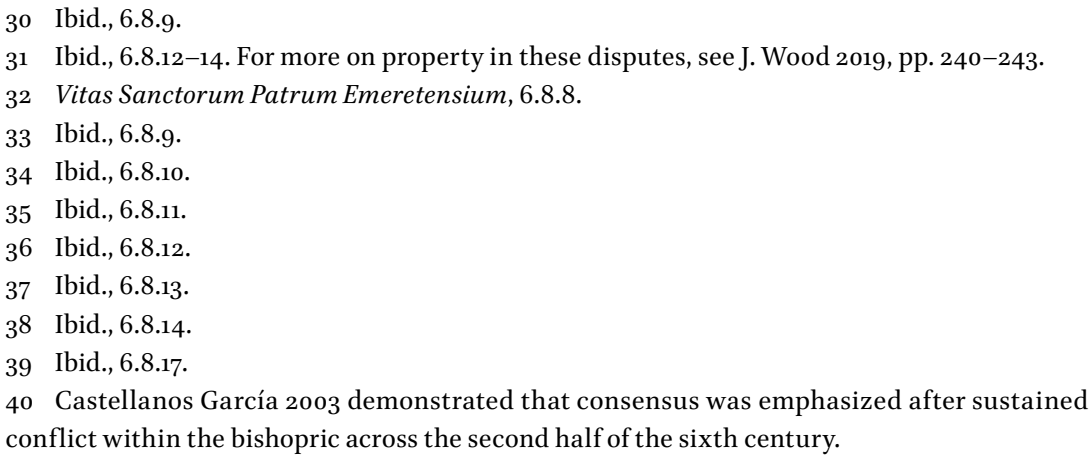

40 Castellanos García 2003 demonstrated that consensus was emphasized after sustained conflict within the bishopric across the second half of the sixth century. 
had subsequently taken over as bishop, had mobilized his clients against Martianus - including among the local clergy. ${ }^{41}$

On one level, the intervention of Liuvigild disrupted the bishop's position in Mérida, enabling challenges to emerge, as for example from Sunna and his supporters. The text has often been read as reflecting a power struggle between Mérida, the former capital of Roman Hispania, and Toledo, the new Visigothic capital city. Liuvigild thus intervened in Mérida to disrupt the power base of the main figure within the city, the bishop..$^{42}$ Despite the author's concern to stress that there had always been consensus in the city, he suggests that royal actions activated latent opposition to Masona in Mérida, including the Arian supporters of Sunna and those Catholics who rallied behind Nepopis. At the same time, elements of the Catholic population united behind Masona and celebrated his return to the city. Indeed, the fact that Liuvigild had been able to insert Nepopis into the bishopric from elsewhere suggests a breakdown in Meridan authority across the ecclesiastical province of Lusitania of which it was nominally the head. In contemporary disputes over episcopal office elsewhere in Visigothic Hispania, jurisdictional conflicts within and between provinces played a more explicit role.

\section{Imperial-episcopal conflict in Byzantine Spania at the end of the sixth century}

In the aftermath of King Agila's defeat at Córdoba in 549, a civil war began among the Visigothic ruling elite out of which Athanagild (r. 554-567) emerged victorious. During this conflict, Emperor Justinian (r. 527-565) sent an expeditionary force to Hispania, resulting in the establishment of the province of Spania that lasted until the 620 s when it was taken by the Visigothic king Swinthila (r. 621-631).43 Powerful cities of the south, including Córdoba, Seville, and Mérida found themselves only loosely under Visigothic influence well into the second half of the sixth century. Córdoba's victory over Agila was a clear demonstration of its independence from Visigothic royal authority. Although later chroniclers attempted to present this episode as an act of rebellion, Visigothic political and military power cannot have extended far into 
the south this early. ${ }^{44}$ As in the case of Mérida, it was only in the reign of Liuvigild that the king began the struggle to assert his authority in the south.

Spania was centred on the important port cities of Cartagena (the capital) and Málaga and stretched across the coastal fringe of two provinces: Baetica and Carthaginiensis. This had important implications since it meant that bishops in Byzantine territory could not participate in ecclesiastical and provincial governance. For instance, bishops from Spania are not recorded as having taken part in provincial (for Baetica or Carthaginiensis) or 'national' (for Hispania as a whole) councils during the period of Byzantine rule. There was also controversy over the issue of metropolitan status, especially within Carthaginiensis. ${ }^{45}$ The severing of bishoprics within Byzantine territory from their comprovincials in Visigothic territory was not a problem for the imperial authorities as long as the Visigoths remained Homoian because the majority of the population of Hispania was, like the Byzantines, Nicene. There are several instances of contact across the border, including a polemical tract that was written by Severus of Málaga against the only bishop known to have given in to Liuvigild's conversion efforts, Vincentius of Zaragoza. ${ }^{46}$

The situation changed, however, with the conversion of the Visigoths to Nicene orthodoxy in 589 . The resultant lowering of the confessional barrier between the Visigothic elite and Nicene bishops - and their congregations across Hispania increased the anxiety of the imperial administration about the loyalty of the bishops of Spania. ${ }^{47}$ Vallejo Girvés has suggested that the Visigoths made military advances against the Byzantines in the 59os, perhaps depriving some bishoprics of property. This may have motivated the bishops to negotiate with authorities in Visigothic-controlled areas in an attempt either to reunify their sees or to maintain some sort of interest in the lost territories. ${ }^{48}$

In addition to the changing situation within Hispania, during the reign of Emperor Maurice (582-602), the military and civil functions of the imperial administration were merged. ${ }^{49}$ Scholars have tended to see Comitiolus, a

44 J. Wood 2010, pp. 308-309.

45 On Comitiolus, see Vallejo Girvés 1996-1997.

46 Thompson 1969, pp. 83-87.

47 Vallejo Girvés 1993, pp. 424-425; Salvador Ventura 2013, p. 255. J. Wood 2010, pp. 311-315: the attitude of the imperial government towards the Visigoths became increasingly militant after the conversion.

48 Vallejo Girvés 1993, p. 425.

49 For a detailed study of Maurice's reign, see Whitby 1988. 
governor who was active in Spania in the 59os, as pursuing a particularly active policy of subordinating ecclesiastical authorities to the imperial administration..$^{0}$ This was part of a wider effort to assert imperial power in opposition to the Visigoths, famously articulated in an inscription raised by Comitiolus at Cartagena to commemorate the renovation of part of the city's defences 'contra hostes barbaros' (i.e. against the Visigoths). ${ }^{51}$

At some point in the mid-59os, Comitiolus deposed two of the bishops in Spania, Januarius of Málaga and Stephanus, whose see is not stated in the sources, although it has been suggested that it was Medina Sidonia. ${ }^{2}$ The only evidence for this episcopal dispute is a series of four letters exchanged between Pope Gregory I (d. 604) and John, a defensor (legal representative $)^{53}$ he had sent to Hispania. ${ }^{54}$ Although the exact nature of the charges against Januarius and Stephanus is unknown, they were probably accused of treason because in Letter 13.49 Gregory cites a number of treason laws in order to demonstrate their innocence. ${ }^{55}$ Gregory's intervention was highly contingent because, although he clearly received notice of the events in Spania in the mid-59os, he waited until 6o3, after the fall of the government of Emperor Maurice (d. 602), before launching an inquiry and sending John. ${ }^{6}$ It is probable that this was precipitated by a second appeal from the deposed bishops. The sources do not reveal how this dispute was resolved but they do demonstrate the porous nature of the boundary between imperial and church power in Spania, and the international connections

$5^{0}$ J. Wood 2010, pp. 313-314. Bishop Licinianus of Cartagena was also dealt with harshly, Vallejo Girvés 1993, p. 425.

$51 \quad$ Prego de Lis 2000.

$5^{2}$ This would mean that both bishoprics were situated in the ecclesiastical province of Baetica. Vallejo Girvés 1993, pp. 424-425, hypothesises that Stephanus was bishop of Assido (Medina Sidonia), which she argues had recently fallen to the Visigoths. She suggests that all of the Baetican bishoprics were now Nicene and under Visigothic control - except Assido and Malaca - so there would have been pressure for them to join their Baetican fellows, although I would argue that this somewhat overestimates the pull of provincial interests/identity. See also Vallejo Girvés 2012, p. 299.

53 Sessa 2012, pp. 119-120: the defensor ecclesiae was one of the key officials deployed by the papacy since the fourth century, and before 500 the defensores had acted predominantly as legal officials, although their roles expanded during the sixth century.

54 For earlier studies of this dispute, see González Fernández 1997; Vallejo Girvés 1991. For Gregory the Great and the Iberian Peninsula, see Díaz Martínez 2008; Richards 1980, pp. 209-212; Markus 1997, pp. 164-168; Orlandis Rovira 1984, pp. 88-89.

55 Vallejo Girvés 2012, pp. 297-298.

56 Orlandis Rovira 1984, p. 101 suggested that Gregory had already formed his opinion and decided on a course of action that was favourable to the bishops. This is not surprising if Probinus had carried out a preliminary investigation earlier. 
of some episcopal disputants (who were able to appeal to Gregory, perhaps on multiple occasions), and, as at Mérida, the role of local (dis)unity in establishing and/or challenging episcopal authority.

Gregory's interest in Spania tells us something about the extension of papal power in the western Mediterranean. As in Mérida, established and aspiring bishops in the Byzantine territory had to contend not only with a range of local elites, but also with potential intervention from further afield. Scholars such as Thompson and Orlandis Rovira argue that Gregory was able to exert tighter control over the church in Byzantine territory than in the Visigothic kingdom because Rome was within the empire. ${ }^{57}$ Gregory's ability to intervene in Spania (or at least his attempt to do so) suggests that the province was integrated into the empire and thus that communication with Italy was relatively easy. $5^{8}$ Gregory made extensive use of agents when investigating potential abuses and representing the Roman see's interests throughout the Mediterranean, so his intervention in Spania was not unusual. ${ }^{59}$ For example, the presbyter Probinus may have been sent to Málaga in the mid-59os to conduct a preliminary investigation into the cases of Januarius and Stephanus. ${ }^{60}$ In 603 , in addition to investigating these cases, the defensor John was instructed to re-establish discipline among the monks at a monastery in the Balearics. ${ }^{61}$ The concern to maintain ecclesiastical discipline is also present in some of Gregory's other letters to the Visigothic kingdom. ${ }^{62}$ The disputing bishops of Spania were not alone in their calls for papal oversight.

In Letter 13.46, the first in the sequence concerning Spania, and probably the first chronologically although all four are dated to August 603, Gregory instructed the defensor John to inquire into the cases of Januarius and Stephanus. Gregory had been informed about the case of Januarius through a petition that the bishop had sent him. Januarius had apparently been

57 Orlandis Rovira 1988, p. 292, suggests that the papacy exercised direct jurisdiction over the church in the Byzantine territories in Hispania and contrasts this integration with the friendly but distant relations that existed with the newly converted Visigothic kingdom. Cf. Thompson 1969, p. 330: 'It is hard to believe that he would have dealt so overbearingly with a governor of the contemporary King Witteric.' Salvador Ventura 2013, p. 257, suggests that Phocas, the new emperor, adopted a more conciliatory attitude towards Rome, giving Gregory a better chance of success than he would have had under Maurice.

58 Vallejo Girvés 1993, p. 420.

59 Conant 2012, pp. 324-330, for Gregory's interventions in Byzantine Africa.

60 Vallejo Girvés 1993, p. 395.

61 Gregory the Great, Epistolae, 13.47. The Balearics were probably tied to Spania for administrative purposes, Orlandis Rovira 1988, p. 296. The monastery was located on the island of Cabrera. 62 Thompson 1969, pp. 41 and 109. 
deposed by his fellow bishops, forcibly removed from his church, and sent into exile, rather like Masona at the hands of Liuvigild. ${ }^{63}$

Further similarities with the situation in Mérida include the intervention of other bishops and their clergy. In a reply, Letter 13.48, John reports accusations from Januarius that the clergy of opposing bishops and servants of Comitiolus had violently removed him from his church, allegations found proven by John. The bishops concerned were condemned to confinement in a monastery and to penance, while the bishop who invaded Januarius's office was to be removed from every church office and to never take up such a position again. ${ }^{64}$ As with Nepopis at Mérida, despite the opprobrium heaped on the new bishop by the sources, it does not seem to have been difficult to find replacements for deposed or exiled bishops.

Gregory also ruled on the compensation due to the deposed bishops for losses and any damage done to their bishoprics. Comitiolus (or his heir, in the case of Stephanus) should repay Januarius and Stephanus for whatever they had lost, should charges be proven. ${ }^{6}$ In the case of Stephanus, the church should not suffer from any loss of property, and any goods taken away from his church must be restored ${ }^{66}$ Another connections may be made with the situation at Mérida, where control of church property was a concern to all parties in disputes, while the hagiographer obscured any hint of uncanonical activities in relation to the property interests of favoured bishops.

In Letter 13.49, Gregory listed the punishments that were due to replacement bishops, as well as those who had elected them. If the criminal case against Januarius had not been made or proven, the replacement should be deprived of the priesthood, banned from church ministry, and either handed over to Januarius to be held in custody or sent to Rome. The bishops who consecrated the replacement bishop should be deprived of communion and made to do penance in a monastery for six months. The time and scale of punishment could be reduced if the bishops were near to death or if they consecrated the replacement out of fear of condemnation or removal from office. ${ }^{67}$ Gregory thus suggests that some pressure was brought to bear presumably by Comitiolus - on the bishops who acted against Januarius, just as Liuvigild had used Sunna and Nepopis against Masona. The hagiographer

63 Ibid., p. 330. For a study of exile in this period, see Vallejo Girvés 2004.

64 Gregory the Great, Epistolae, 13.48.

65 Thompson 1969, p. 330. Throughout his initial discussion of the Januarius case, Gregory states that the accusations must be investigated carefully before any judgement is made.

66 Gregory the Great, Epistolae, 13.46.

67 Ibid. If the replacement bishop has died and been replaced, then the second replacement bishop should be removed from the bishopric of Málaga, but could become a bishop elsewhere. 
also states that Masona was sent to a monastery by Liuvigild during his exile ${ }^{68}$ while candidates who were unable to garner the necessary support (as were Sunna and Nepopis) were expelled from the city and/or deposed. Episcopal power was not secure once a bishop had been elected to office or removed from it; it had continually to be reasserted in the face of competition within and outside the bishopric.

\section{Gregory's legal dossier about the deposed bishops of Spania}

Although the exact order of composition of the letters is unclear as they are all dated to August 603, it is likely that after John's initial investigation Gregory sent Letter 13.49 with further instructions and what is best described as a dossier of imperial laws to back up the rulings he had made. ${ }^{69}$ Again, we do not have specific details; John states that he held an 'internal inquiry' into Januarius's petition to judge the dispute and make an initial ruling. Gregory then provided imperial laws to persuade the imperial administration of the position that his agent had advocated. In citing these laws, Gregory aimed to demonstrate that Comitiolus and the bishops and clergy who had sided with him had acted illegally. ${ }^{70}$

The two main strands to Gregory's argument were as follows, first, he sought to establish that correct procedure had not been followed and therefore that the punishments were illegal; and, second, he attempted to show that there had been an infringement of the legal rights of the bishops. For Januarius, Gregory adopted the straightforward argument that the invasion of his church and the physical violation of his person as a bishop were illegal under imperial law. For Stephanus, Gregory argued that he had not been tried before the correct judge (Gregory as pope). Three elements of the dossier illuminate Gregory's overall argument. First, Gregory stresses the inviolability of the episcopal office, suggesting that it had, in fact, been violated. Second, he points out procedural irregularities, suggesting interference by the imperial administration and lack of unity within the bishoprics concerned. Finally, he emphasizes jurisdictional boundaries, suggesting interference by other bishops. All three of these elements were also features of the dispute at Mérida, only in Gregory's letters they are refracted through a legalistic rather than a hagiographical lens.

69 For detailed analysis of Gregory's use of these laws, see González Fernández 1997, pp. 292-297.

Orlandis Rovira 1984, p. 101; Vallejo Girvés 1993, p. 419. 
- The inviolability of the office of bishop - In the case of Januarius, Gregory cites Codex Iustinianus 1.3.10 to make the point that any person who has injured a bishop in his church should receive capital punishment from the governor of the province because such an action constitutes a public crime. Similarly, violating the right of asylum by removing a fugitive from a church is tantamount to treason and should lead to capital punishment. ${ }^{1}$ Individuals of any rank seeking refuge cannot be expelled from a church. Gregory's legal argument in relation to Januarius, then, was concerned above all with boundaries. First, the boundaries ( fines) of the church were supposed to remain inviolable. Second, the integrity of the bishop's person should be respected. Breaking these boundaries was punishable by death and Gregory was in little doubt that there had been infringement in the case of Januarius. If our sources are to be believed, Liuvigild's threats to the person of Masona and his forcible removal from the bishopric was virtually identical to the actions of Comitiolus against Januarius and Stephanus.

- Procedural irregularities and local disunity - In the second half of the letter, Gregory identifies procedural irregularities in the treatment of Stephanus. He focused on the witnesses that had been called. Codex Iustinianus 9.1.20 is cited to establish that accusations from servants or slaves should not have been taken account of. Gregory states that a 'great many laws' make clear what sort of witnesses, and of what sort of reputation, should be admitted to give evidence. 'Worthless witnesses' should not be trusted without having undergone bodily examination (i.e. torture). The focus of this legal dossier on due process is clarified later, where Codex Iustinianus 7.44.3 is used to stress two essential points: that a judgment should be made from written evidence and must be recorded.${ }^{2}$ Coupled with evidence for the involvement of Comitiolus's retainers and the concern for church property examined earlier, this suggests some degree of turbulence at a local level, perhaps precipitated by the intervention of Comitiolus, who (according to Gregory) did not follow due process. As in Mérida, it is clear that our one-sided sources obscure the extent of disunity within the bishoprics as groups competed for position, sometimes taking advantage when outside powers destabilized the position of incumbent bishops.

71 Codex Iustinianus, 1.12.2 and 1.12.6; Vallejo Girvés 1993, p. 420.

72 Here it is interesting to compare with the accusations that Sunna levelled against Masona in Mérida, including writing an indictment against Masona, which led to the public disputation discussed above (Vitas Sanctorum Patrum Emeretensium, 5.5.8); he also accused Masona of various crimes before Liuvigild (Vitas Sanctorum Patrum Emeretensium, 5.6.2). 
- Interference from other bishops - Connected to the issue of local disunity, Gregory references the misbehavior of other - presumably neighbouring - bishops. He cites several laws to underscore the point that Stephanus should not have been tried unwillingly or before bishops of a 'non-local council' (alienum concilium) ${ }^{73}$ This probably means that Stephanus, whose see was in Baetica, had been tried by a council including bishops from Carthaginiensis, or by a combined council made of bishops from parts of both provinces that were partially under Byzantine control. ${ }^{74}$ Gregory again emphasizes procedure and jurisdiction, using Novellae 123.8 to show how civil or military judges have no legitimate jurisdiction, without an imperial order, to judge a bishop for financial or criminal offences. Rather, accusations against bishops should be judged by metropolitans 'following the sacred rules and laws' and if the judgement proves unsatisfactory then the archbishop and patriarch of the diocese should judge the outcome according to the 'canons and the laws' (canones et leges). ${ }^{75}$ In the following section, Gregory states that if Stephanus had no metropolitan or patriarch, then the case should have been heard by the papacy, 'the chief of all churches' (omnium ecclesiarum caput est $) \cdot{ }^{7}$ Gregory's procedural argument was thus related to the contravention of jurisdictional boundaries. He develops this argument by outlining what should happen to those who have transgressed such boundaries. To base a case on written or verbal complaint receives a severe punishment, comprising payment of twenty pounds of gold to the bishop's church, ending his career, a beating, and exile overseas. The accusations Sunna leveled against Masona when communicating with Liuvigild were of exactly this sort (written and perhaps verbal), suggesting that this was a fairly common element of episcopal dispute and one that Gregory was keen to eliminate. Gregory next notes: 'in private cases, a form of this sort should be preserved, so that a sentence not pronounced by his own judge should not be binding for any of the litigants'. Gregory closes this section of the letter by citing Codex Iustinianus 7.48.4 to underline his position as the only legitimate judge.

As with Masona in Mérida, Januarius and Stephanus were clearly in a difficult position, squeezed on all sides by imperial governors, their fellow bishops 
and elements within the clergy, and by a part of their cities' populations. Their appeal to Gregory was an attempt to draw an outside patron onto their side in a dispute with the imperial governor and his entourage. We do not know whether Gregory's intervention was sufficient to settle the matter in the bishops' favour and secure their reinstatement. It is clear, however, that, despite the different nature of the evidence, strong similarities with the situation in Mérida a generation earlier exist: pressure from external powers and fellow bishops ruptured local consensus about a bishop's position, opening up opportunities for interference from other bishops.

\section{Conclusion}

Despite the stress that many normative sources place on the growing dominance of bishops in late antique Iberia, bishops had constantly to negotiate and renegotiate their positions within their cities in relation to outsiders. Imperial and royal governments were increasingly pivotal in facilitating or challenging a bishop's authority. Indeed, by the seventh century Visigothic monarchs played the decisive role in episcopal appointments. ${ }^{77}$ But a unified episcopacy should not be assumed. There was potential for considerable infighting and such dispute was not simply the result of confessional divisions. Indeed, the rules that were laid down for episcopal elections, which mandated that neighbouring bishops participate in the process, functioned almost as a template for such interference..$^{7}$ Episcopal authority within cities did not go unchallenged as factions jostled for position whenever an incumbent looked weak, often, it seems, drawing support from neighbouring bishops, aristocratic factions, and/or royal/imperial agents, and their clients.

From the perspectives of the bishops who had displaced Masona, Stephanus, and Januarius, the same situation pertains: they were backed by elements within the local population, including clergy, and royal or imperial authorities. Former bishops who did not accept their deposition (the legality of which was presumably not questioned) were able to seek outside help. Whether from the papacy, from Santa Eulalia, or, in the case of Masona after the Visigothic conversion, from the king, such interference destabilized the position of Nepopis, Sunna, and the replacement bishops of Spania. Their ultimate fate is, however, lost due to the control that their opponents were eventually able to exercise over the records of the disputes. 
The cases at Mérida and Spania in the second half of the sixth century illustrate the contingent nature of episcopal power. However, some bishops - and their apologists - were able to turn potential vulnerability to their advantage, enabling them to depict themselves as protectors of the city in the face of oppression and as recipients of patronage from saints or popes. A bishop who could successfully broker a position that was respected by agents of both 'church' and 'state', and could chart a course between 'central' and 'local' powers, was in a position to retain his power base, to survive and, perhaps, to prosper.

\section{Bibliography}

\section{Primary sources}

Codex Iustinianus = Corpus iuris civilis, 3 vols., vol. 2: Codex Iustinianus, ed. by Theodor Mommsen, Paul Krüger, Wilhelm Kroll, and Rudolf Scholl (Berlin: Weidmann, 1877).

Gregory the Great, Epistolae = Sancti Gregorii Magni: Registrum epistolarum, 2 vols., ed. by Dag Norberg (Turnhout: Brepols, Corpus Christianorum, Series Latina 140-140A, 1982).

Isidore of Seville, De ecclesiasticis officiis = Sancti Isidori Episcopi Hispalensis: De ecclesiasticis officiis, ed. by Christopher M. Lawson (Turnhout: Brepols, Corpus Christianorum, Series Latina 113, 1989).

— Historia Gothorum = Las historias de los godos, vándalos y suevos de Isidoro de Sevilla, ed. by Cristóbal Rodríguez Alonso (León: Centro de Estudio e Investigacion 'San Isidoro', 1975).

Novellae $=$ Corpus iuris civilis, 3 vols., vol. 3: Novellae, ed. by Theodor Mommsen, Paul Krüger, Wilhelm Kroll, and Rudolf Scholl (Berlin: Weidmann, 1895).

Vitas Sanctorum Patrum Emeretensium, ed. by Antonio Maya Sánchez (Turnhout: Brepols, Corpus Christianorum, Series Latina 116, 1992).

\section{Secondary sources}

Castellanos García, Santiago, 'The Significance of Social Unanimity in a Visigothic Hagiography: Keys to an Ideological Screen', Journal of Early Christian Studies 11 (2003), pp. 387-419.

Castellanos García, Santiago, and Iñaki Martín Viso, "The Local Articulation of Central Power in the North of the Iberian Peninsula (500-1000)', Early Medieval Europe 13 (2005), pp. 1-42. 
Collins, Roger, 'Mérida and Toledo: 550-585', in Visigothic Spain: New Approaches, ed. by Edward James (Oxford: Clarendon Press, 1980), pp. 189-219.

Conant, Jonathan, Staying Roman: Conquest and Identity in Africa and the Mediterranean, 439-70o (Cambridge: Cambridge University Press, 2012).

Díaz Martínez, Pablo C., 'Gregorio Magno y el reino visigodo: un conflicto de poderes', in Gregorio Magno, l'impero e i 'regna', ed. by Claudio Azzara (Florence: Sismel, 2008), pp. 59-8o.

Fernández, Damián, Aristocrats and Statehood in Western Iberia, 300-6oo c.E. (Philadelphia, PA: University of Pennsylvania Press, 2017).

Fouracre, Paul, 'Merovingian History and Merovingian Hagiography', Past \& Present 127 (1990), pp. 3-38.

García Moreno, Luís Agustín, Leovigildo: unidady diversidad de un reinado (Madrid: Real Academia de Historia, Discurso Recepción en la Real Academia de la Historia, 2008).

González Fernández, Rafael, 'Las cartas de Gregorio Magno al defensor Juan: la aplicación del derecho de Justiniano en la Hispania bizantina en el siglo VII', Antiguedady Cristianismo 14 (1997), pp. 287-298.

Handley, Mark A., Death, Society and Culture: Inscriptions and Epitaphs in Gaul and Spain, AD 350-70o (Oxford: Archaeopress, 2003).

Koch, Manuel, 'Arianism and Ethnic Identity in Sixth-Century Visigothic Spain', in Arianism: Roman Heresy and Barbarian Creed, ed. by Guido M. Berndt and Roland Steinacher (Farnham: Ashgate, 2014), pp. 257-270.

Kulikowski, Michael, Late Roman Spain and Its Cities (Baltimore, MD: Johns Hopkins University Press, 2004).

Leemans, Johan, Peter Van Nuffelen, Shawn W.J. Keough, and Carla Nicolaye, eds., Episcopal Elections in Late Antiquity (Berlin: De Gruyter, 2011).

Markus, Robert, Gregory the Great and his world (Cambridge: Cambridge University Press, 1997).

Martínez Jiménez, Javier, and Carlos Tejerizo García, 'Central Places in the PostRoman Mediterranean: Regional Models for the Iberian Peninsula', Journal of Mediterranean Archaeology 28 (2015), pp. 81-103.

Martyn, John R.C., The Letters of Gregory the Great, 3 vols. (Toronto: Pontifical Institute of Mediaeval Studies, 2004).

Norton, Peter, Episcopal Elections 250-6oo: Hierarchy and Popular Will in Late Antiquity (Oxford: Oxford University Press, 2007).

Orlandis Rovira, José, Hispania y Zaragoza en la antigüedad tardia: estudios varios (Zaragoza: Caja de Ahorros y Monte de Piedad de Zaragoza, Aragón y Rioja, 1984).

- Historia del reino visigodo español (Madrid: Rialp, 1988).

Panzram, Sabine, 'La formación del orden metropolitano en la Península Ibérica (siglos IV a VI)', Pyrenae 49 (2018), pp. 125-154. 
Prego de Lis, Augusto, 'La inscripción de Comitiolus del Museo Municipal de Arqueología de Cartagena', in V Reunión de Arqueología Cristiana Hispánica, Cartagena, 16-19 de abril 1998 (Barcelona: Institut d'Estudis Catalans, 2000), pp. 383-392.

Rapp, Claudia, Holy Bishops in Late Antiquity: The Nature of Christian Leadership in an Age of Transition (Berkeley: University of California Press, 2005).

Richards, Jeffrey, Consul of God: The life and Times of Gregory the Great (London: Routledge \& Kegan Paul, 1980).

Salvador Ventura, Francisco, 'The Bishops and the Byzantine Intervention in Hispania', in The Role of the Bishop in Late Antiquity, ed. by Andrew Fear, José Fernández Ubiña, and Mar Marcos (London: Bloomsbury, 2013), pp. 245-261.

Sessa, Kristina, The Formation of Papal Authority in Late Antique Italy (Cambridge: Cambridge University Press, 2012).

Stocking, Rachel L., 'Martianus, Aventius, and Isidore: Provincial Councils in Seventh-Century Spain', Early Medieval Europe 6 (1997), pp. 169-188.

— Bishops, Councils and Consensus in the Visigothic Kingdom, 589-633 (Ann Arbor, MI: University of Michigan Press, 2000).

Thompson, Edward A., The Goths in Spain (Oxford: Clarendon Press, 1969).

Vallejo Girvés, Margarita, 'Bizancio ante la conversión de los visigodos: los obispos Jenaro y Esteban', in XIV Centenario Concilio III de Toledo (589-1989) (Toledo: Arzobispado de Toledo, 1991), pp. 477-483.

—_ Bizancio y la España tardoantigua (siglos V-VIII): un capítulo de historia mediterránea (Alcalá de Henares: Ediciones de la Universidad de Alcalá de Henares, 1993).

, 'Commentiolus, Magister militum Spaniae missus a Mauricio Augusto contra hostes barbaros: The Byzantine Perspective on the Visigothic Conversion to Catholicism', Romano-Barbarica 14 (1996-1997), pp. 289-306.

- 'El exilio bizantino: Hispania y el Mediterráneo occidental (siglos V-VII)', in Bizancio y la Península Ibérica: de la antigüedad tardía a la edad moderna, ed. by Inmaculada Pérez Martín and Pedro Bádenas de la Peña (Madrid: Consejo Superior de Investigaciones Científicas, 2004), pp. 117-154.

—, Hispania y bizancio: una relación desconocida (Madrid: Akal, 2012).

Velázquez Soriano, Isabel, Vidas de los santos padres de Mérida (Madrid: Editorial Trotta, 2008).

Whitby, Michael, The Emperor Maurice and his Historian: Theophylact Simocatta on Persian and Balkan Warfare (Oxford: Clarendon, 1988).

Wood, Ian, 'Social Relations in the Visigothic Kingdom from the Fifth to the Seventh Century: The Example of Mérida', in The Visigoths from the Migration Period to the Seventh Century: An Ethnographic Perspective, ed. by Peter Heather (Woodbridge: Boydell, 2003), pp. 191-208. 
Wood, Jamie, 'Religious Strategies of Distinction: Baptism in Visigothic Spain', in Elite and Popular Religion, ed. by Kate Cooper and Jeremy Gregory (Woodbridge: Boydell, 2006), pp. 3-17.

— , 'Defending Byzantine Spain: Frontiers and Diplomacy', Early Medieval Europe 18 (2010), pp. 292-319.

— , 'Borders, Centres and Peripheries in late Roman and Visigothic Iberia', International Journal of Regional and Local History 10 (2015), pp. 1-17.

—_, 'Building and Breaking Episcopal Networks in Late Antique Hispania', in Episcopal Networks in Late Antiquity, ed. by Peter Gemeinhardt and Carmen Cvetkovic (Berlin: De Gruyter, 2019), pp. 227-247.

Wood, Jamie, and Javier Martínez Jiménez, 'New Directions in the Study of Visigothic Spain', History Compass 14 (2016), pp. 29-38.

\section{About the author}

Jamie Wood is Associate Professor in History at the University of Lincoln (UK). He works on the social and religious history of the late antique West, especially in the Iberian Peninsula and has published widely on the works of Isidore of Seville. 


\section{The Day After - Epilogue}





\title{
19 In a Savage Kingdom (regnum efferum)?
}

\author{
Evaluating the Islamic Conquest of Spania from the \\ Archaeological Record
}

Julián M. Ortega Ortega

\begin{abstract}
The Umayyad conquest of the Iberian Peninsula is an event fundamental to understanding the history of Islam and southern Europe. Despite its historical significance and the controversies that its interpretation has generated, archaeology has contributed little to its elucidation. A review of the material testimony associated with this event from a critical perspective attentive to the novelties that have occurred in the field of archaeology addresses issues left by military operations, the implementation of the new administrative apparatus, the migration process of Arab and Berber contingents, and, especially, the technological, social, and cultural transformations that triggered these events in successive decades.
\end{abstract}

Keywords: Iberia; Umayyad conquest; al-Andalus; coins; territory; taxation

A 'savage kingdom' (regnum efferum) is the expression used by the anonymous author of the Chronicle of 754 to define the political regime organized by the Muslim conquerors who defeated the Goth army after landing in the bay of Algeciras in 92/711. ${ }^{1}$ According to this chronicle, probably written by a cleric connected with the Visigothic administration, that was the first of a series of rapid victories that forced the submission of all Hispanic cities. With it came the complete replacement of the previous network of political

$1 \quad$ Chronicle of 754, pp. 70 and 72 : 'Ciuitates decoras igne concremando precipitat, seniores et potentes seculi adiudicat, iubenes atque lactantes pugionibus trucidat. Sicque du tali terrore cunctos, stimulat, pacem nonnulle ciuitates que residue erant iam coacte proclamitant adque suadendo et inridendo astu quoddam nec mora petita condonant.' Also, Chronicle of 754, p. 30 : '[Damasco] splendidissimam Sirie urbem'; p. 82: 'ex Arabum gente'; and p. 86: 'rex Sarracenoruum'.

Panzram, S. and P. Pachá (eds.). The Visigothic Kingdom: The Negotiation of Power in Post-Roman Iberia. Amsterdam: Amsterdam University Press 2020 DOI: 10.5117/9789463720632_CH19 
power. The rex Gothorum was ousted by the rex Sarracenorum; the gens Gothorum was displaced by the Arabum gente; the royal seat passed from Toledo to Damascus; and the country was changed by a regime dedicated to burning cities, depopulating territories, assassinating aristocrats, enslaving the people, and capturing booty.

The catastrophic images transmitted by the Chronicle of 754 are not arbitrary; they respond to an ideological construction aimed at delegitimizing a state structure designed to sustain the Islamic occupation of Spania. ${ }^{2}$ Beyond the rhetoric of these narratives, the material trace left by the institutional structure implanted by the vanquishers can focus on the establishment of the conquerors in rural areas and on the organization of an administrative apparatus, in particular through coinage, an important set of newly published lead seals, and by some revealing sites. ${ }^{3}$

\section{The conquest}

\section{Putting in order the spoils}

Arabic texts that narrate the Muslim conquest of the Iberian Peninsula are not decisive in clarifying whether the distribution of booty taken during the conquests of the Maghreb and al-Andalus took place in accordance with legal regulations. The debate already existed in the Middle Ages. Some authors, such as Ibn Ḥazm and al-Dāwūdī, argued that the appropriation of lands was carried out without legal stipulation. ${ }^{4}$ Others were of the opinion that everything conquered - slaves, lands, and goods - were appropriately subject to distribution by competent authorities, with a few exceptions. ${ }^{5}$ By the mid-third/ninth century, Sahnūn recognized that the issue, at least for North Africa, was difficult to resolve. The reason given lay in the growing rationale by the caliphs and later by the emirs that, during the Islamic expansion, most territories were conquered by force, which implied their transfer to the entire Muslim community, and therefore for the regime to increase taxation. In al-Andalus, sages in the service of the Umayyad cause defended such ideas. An example is that of

2 Ṭāha 1989; Chalmeta Gendron 2003; Manzano Moreno 20o6; Clarke 2011; García Sanjuán 2013 .

3 Jonson 2014; Sénac and Ibrahim 2017; Ortega Ortega 2018.

4 Asín Palacios 1934, p. 41.

5 For this information, see al-Maqqarī in Chalmeta Gendron 2015, pp. 55-56. 


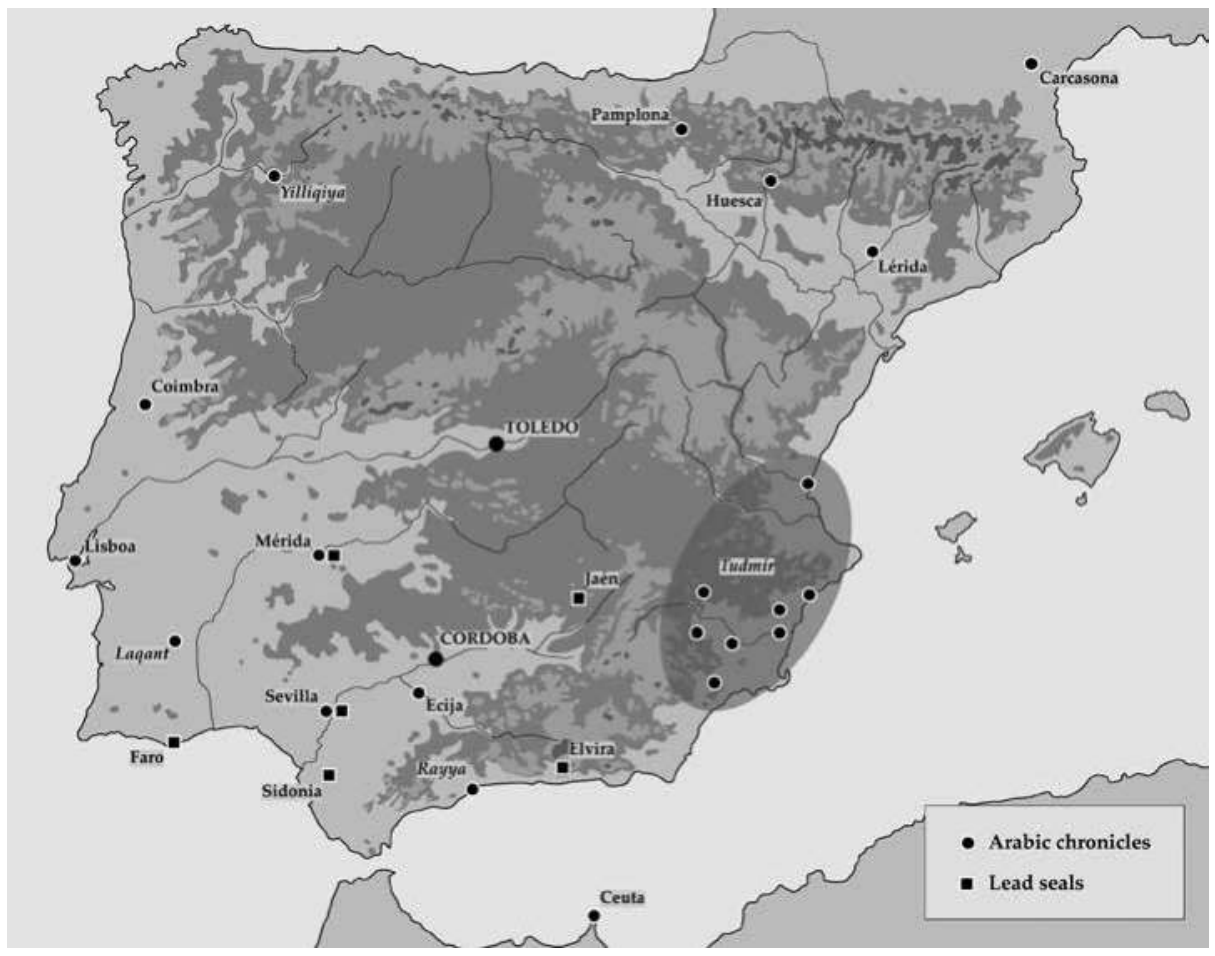

Fig. 19.1 Cities that signed peace treaties, according the Arabic chronicles and the lead seals. ๑) Julián M. Ortega Ortega.

Aḥmad al-Rāzī, who used the work of ${ }^{\varsigma} \mathrm{Abd}$ al-Malik b. Habīb to affirm that, under the government of al-Samh (100/718-112/721), the southern lands of al-Andalus were taken by force (ard ' 'anwatan), to be differentiated from the northern lands, which were incorporated into the Muslim domain by capitulation (ard al-shammāl), leaving its inhabitants obliged to pay a jizya equivalent to a third or a quarter of the harvest, depending on the land quality. ${ }^{6}$

Direct material evidence of these distributions constitutes a series of lead seals or bulla used to stamp real estate titles and loot distributed among Muslim combatants (Fig. 19.1). Most of the texts are too brief to draw conclusions. They only mention distribution operations, adding, in some cases, that these were carried out under the supervision of competent authorities. ${ }^{7}$ Other seals contain geographical references, usually only

6 Manzano Moreno 2006, pp. 34-42.

7 Sénac and Ibrahim 2017, nos. 54-55: qad / qusim; and nos. 52-53: bismi / Allāh // maqsūm / tayyib. 
al-Andalus, although exceptions may name a city. ${ }^{8}$ When the objects of distribution are goods and chattels, the texts use the word ghanima. ${ }^{9}$ Only a single precinct has documented that this, with some doubts, could refer to young girls $(j a r \bar{a} i d) .{ }^{10}$ The rest refer to real estate $\left(f a y^{2}\right)$, which in a specific case refers to those located in Rayyo, i.e. in the lands of Málaga. ${ }^{11}$

\section{The instruments of surrender}

The attempts by those in the service of the Umayyad cause to propagate that most of Spania was taken by force argue an incomplete assumption. ${ }^{12}$ This is indicated by bullae that indicate the cessation of hostilities conducted against several cities in the south of the Iberian Peninsula. A single case, the proposed reading of which is in the name of God/ covenant of peace/ [of] 'Abd Allāh Ibn Mālik' ('bismi Allah/ sulḥ/ Abd Allāh/ ibn Mālik'), only mentions the authority that granted and guaranteed the pact, the emir 'Abd Allāh al-Ṣamh Ibn Mālik, without referring to the population that signed it. ${ }^{13}$ In a second type of bullae, inscriptions exactly exemplify the population. On one of these faces the expression 'peace pact' (mușālaha) was printed, while another bears the name of the community that received it. Two without any doubt refer to Seville (Ishbiliya) and Medina Sidonia (Shadhüna), while a third could refer to Ossonoba (Ashknūniya), now Faro, on the southern-most coast of Portugal. Another text refers in all probability to Jaén (Jayyān), although this place at the beginnings of the second/eighth century could hardly be characterized as a city, preceded by a difficultto-read 'land' (ard).${ }^{14}$ A recently published bulla, also difficult to read, bears the inscription mușālaḥa / [-]r.dā, perhaps in reference to Mérida. ${ }^{15}$

8 Ibid., nos. 1-6: amara al-Hurr/qism//al-Andalus; nos. 42-50: bismi Allāh/qismal/Andalus // [-//-]; no. 5o:bismi / Allāh // qism/al-Anda / lus; no. 56: bismi /Alläh //mim qism / al-Anda / lus; nos. 77-79: bismi Allāh /al-Andalus; nos. 87-90: [bismi] /Allāh//jāwaz/al/Andalus; nos. 91-92: bismi Allāh / had̄ājāwaz // min al-A / ndalus; no. 93: bismi / Allāh a /jaza // [qism?] al-Anda / lus; no. 94: bismi Allāh / [mim?] mājaw [-] // [-] al-Anda / lus; and no. 51: bismi / Allāh // qism / Qurțuba.

9 Ibid., nos. 58-73: magnūm/țayyib/bi-Arbüna.

10 Ibid., no. 57: bismi/Allāh/qism/jarā'id?

11 Ibid., nos. 74-76: bismi / Allāh // fay / Allāh; Gaspariño and Ibrahim 2015, p. 7: [-] / fay ? Allāh / Rayyo.

12 Manzano Moreno 2006, pp. 34-42.

13 Sénac and Ibrahim 2017, nos. 7-11.

14 Ibid., nos. 16-18: muṣālaḥat//Shidūūna; nos. 19-27: muṣālaḥat//Ishbüliya; no. 28: mușālahat // Ukshuniba; no. 29: mușālaḥat //Libīra; nos. 30-32: muṣālaḥat // al-arḍJayyān; no. 33: mușālaḥat // $[-(?)]$.

15 Gaspariño and Ibrahim 2019. 
Another seal of this series refers to a place to which the only thing that can be deciphered from the inscription is '[-] r.z.m.. ${ }^{16}$ It is certain that a significant number of Hispanic cities, including important ones, agreed to surrender to the Muslim army.

\section{The occupation}

\section{Troops and settlers}

Unlike other regions of the Umayyad Empire, in the Iberian Peninsula Muslim conquerors never created militarized cities (amșār, sg. mișr), settling and maintaining armed units segregated from the native populations. It was more normal to install troops in cities that were maintained with a certain vitality. ${ }^{17}$ Unfortunately, available evidence concerning the establishment of these settlements is minimal. It is difficult to know whether the houses and properties of the dead or escaping inhabitants were distributed to members of the Islamic army (khițat, sg. khitttat). ${ }^{18}$

The main evidence for the settlement of Muslim troops corresponds to a series of burials documented in ancient civitates, which the Arab chronicles identify as 'frontier forts' (ribāțāt, sg. ribātt). ${ }^{19}$ One of these is Nîmes, where three tombs of Islamic rite were recently discovered. Their dating supports Muslim troops stationed in the city before $75^{\circ}$. The DNA (deoxyribonucleic acid) analysed from these tombs, however, could suggest a North African origin. ${ }^{20}$ The same possible geographic origin has been indicated for three individuals of the almost 200 Islamic inhumations excavated in the Plaza del Castillo of Pamplona. ${ }^{21}$ Several of the skeletons documented, always male, present features of personal confrontations, which in some cases were fatal. ${ }^{22}$ Barcelona has also contributed data on the early Muslim occupation. Archaeological excavation carried out in the Plaza Comercial, facing the

16 Sénac and Ibrahim 2017, no. 33.

17 Al-Rāzī, Ajbār mulūk, p. 365: 'E [Abrahen, fijo Amelic] fizopoblar muchas villas que auian quedado yermas.' Al-Rāzī, Ajbār mulūk, p. 370: 'E [Cobet, fijo de Talame] dejaba en todas [las villas] e en sus fortalezas buena pieza de caballeros, e a todos dejaba por señores de aquellas villas donde quedaban. E de esta guissa andubo hinchendo de su gente todas las villas e logares que tomaba.'

18 Donner 1981, pp. 245-247; Sijpesteijn 2009, p. 123.

19 Chalmeta Gendron 2003, pp. 294-295.

20 Gleize, Mendisco, Pemonge et al. 2016.

21 Prevedorou, Diaz Zorita, Romero et al. 2010.

Faro Carballa and García-Barberana 2011; De Miguel 2012, pp. 357-361. 
Mercado del Born, has documented two dozen Islamic burials. Although $\mathrm{C}^{14}$ (carbon-14) dates have not been published, evidence points to a dating before the Carolingian conquest of the city in $185 / 801 .^{23}$

\section{Landowners and estates}

The settlement of Muslims in the Egyptian countryside was a slow process. Soldiers established in Fustāt were expressly forbidden from engaging in agriculture, unless permission was clearly stated. During the first half of the second/eighth century, the only information that papyri provide about Muslims in rural locations corresponds to tax collectors, military personnel linked to the postal service, and to a lesser extent soldiers who moved their flocks to pastures before the summer months when military campaigns were carried out. Since the middle of the second/eighth century, the first mention of Muslim traders involved in agriculture and landlords of Muslim name are difficult to determine whether Arab or converts. ${ }^{24}$

The situation in al-Andalus seems to have been completely different. The establishment of the conquerors in the urban environment, not in amșār, allowed easier access to rural properties, in which the Muslims soon settled. Veterans of the Muslim army were thus transformed into something more than conquerors: they were settlers. Lead seal number 84 contains the phrase 'villages of Seville' (day ${ }^{\varsigma}$ at / Hums), which clearly refers to estates located in the environs of this city. ${ }^{25}$ The use of the place name Hums to refer to Seville dates the bulla after the fiscal and territorial reorganization that occurred in 123/741 as a consequence of the Arab army's arrival from Syria. Unfortunately, the brief nature of the text makes it impossible to determine whether the content is about taxation or estate distribution.

In Arabic written sources it is possible to find references with some frequency to the region surrounding Granada. The village of Cájar, known in medieval times as Yajar al-Baladiyyìn, was a place name referring to the first wave of Muslims who arrived in the Iberian Peninsula and which they used to differentiate themselves from people of a neighbouring village, Yäjar al-Shämiyyīn, which was settled by a group of Syrians as part of the second wave. ${ }^{26}$ The Cájar lands are currently irrigated by the Acequia Gorda, one of five channels that constitute the irrigation system of the 
Monachil river. This could have equally been the case in the second/ eighth century. Close to Cájar is Armilla, probably the same place as the Armillat mentioned by the Akhbār Majmū $\bar{c}^{\mathrm{s}} a$ when describing the path followed by ${ }^{\varsigma} \mathrm{Abd}$ al-Rahmmān I after his arrival at the beach of Salobreña. The place is linked to the upper orchards of the Genil river, which follow earlier orchards that take water from the Monachil river, implying the likely existence of orchards since the second quarter of the second/eighth century. ${ }^{27}$

The rural environment in this zone was determined by a dense mesh of small farms and villages clearly associated with valley bottoms and sometimes with natural springs, whose waters now irrigate areas of orchard. A well-known report by Ibn al-Qūtiyya testifies to this when he narrates the delivery of rural and agricultural holdings (diya $a^{\varsigma}$, sg. day $a$ ) to the Syrians settled in the Ilbira region: ${ }^{28}$

[Arțubāsh] drafted the notarial deed of donation and ordered its administrators to deliver them [villages]. People say that they were her best properties. He donated a hundred villages, ten to each of them. Of these, Turrush corresponded to Abū ' Utmān, al-Funtayn [al-Funtīn] to b. Khālid, and ${ }^{\varsigma}$ Uqdat al-Zaytūn in al-Mudawwar al-Ṣumayl.

The locations of these two hamlets have been identified with some precision in the surroundings of Loja, in the western-most sector of the plain of Granada (Fig. 19.2). The first of these, Turrush, in the vicinity of the Cortijo del Aire, is where the remains of a Nasrid tower are conserved. In the Repartimiento of Loja this fortification is called the 'watchtower of Torrox'. In its vicinity an irrigation system, the so-called Plines and Genazar orchards, covered about 114 ha at the end of the fifteenth century. ${ }^{29}$ The identification of al-Funtin within the La Esperanza area, between the municipalities of Loja and Huétor-Tájar, has been documented by a late Roman necropolis composed by several rock-cut tombs - presumably Christian - and by medieval pottery. The place has a topographical relationship with the spring of El Frontil, where an extensive irrigation system begins..$^{30}$ Finally, near Turrush and al-Funtin is the qarya of Shikanb/Agicampe, where according to Ibn al-Khațîb, ' ${ }^{\varsigma}$ qba b. Nu'aym al-Ma'āfirì, a member of the jund of 


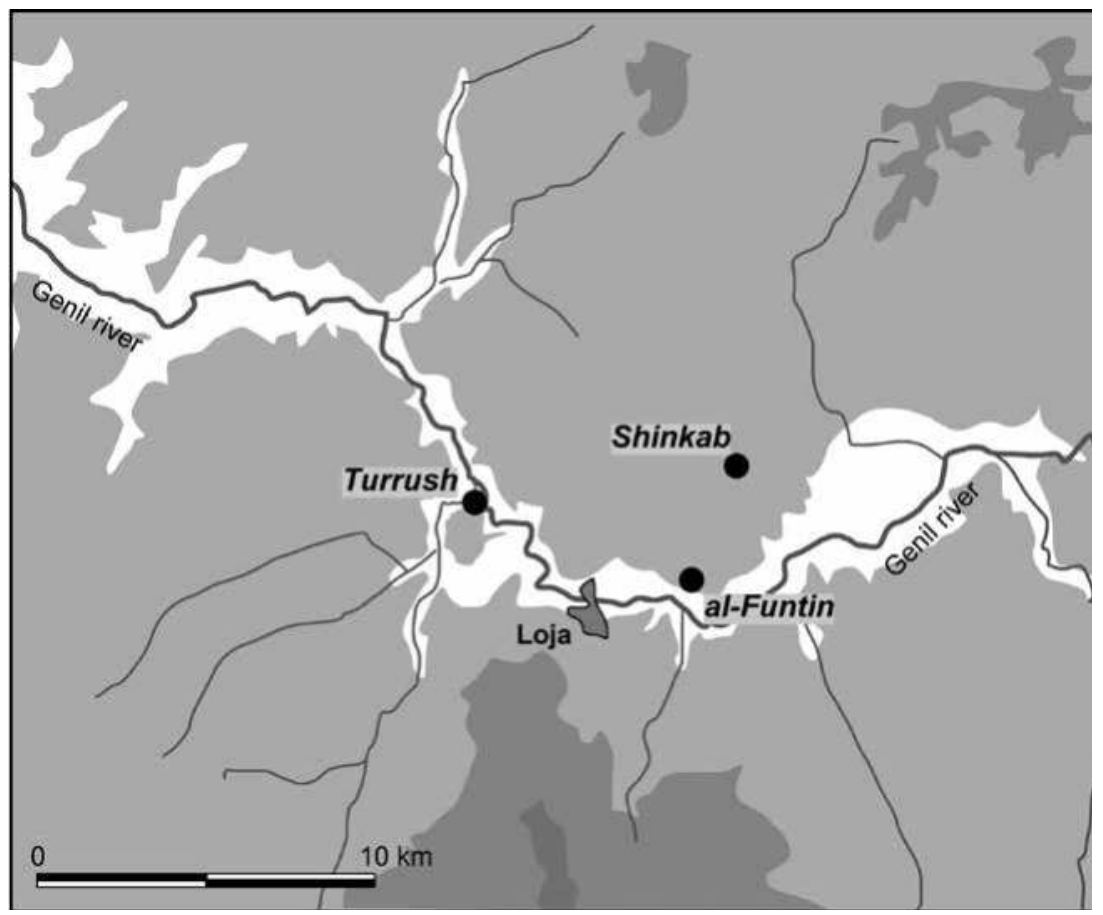

Fig. 19.2 Location of the archaeological sites of the municipality of Loja (Granada) cited in the text. @ Julián M. Ortega Ortega.

Damascus resided.$^{31}$ A recent project led by García Porras has located this settlement linked to a spring, which at the end of the fifteenth century irrigated a significant area. ${ }^{32}$

\section{Taxation}

\section{The territorial organization}

Medieval Arabic chronicles cite the population of the ancient cities of Spania as the main object of Muslim domination in the decades following 92/711. The inhabitants of these cities capitulated and accepted the imposed taxation, which is expressed in a number of inscribed lead seals with texts that specifically mention urban communities (Seville, Beja, Elvira, etc.) whose 
fiscal contribution seems probable. ${ }^{33}$ The collection of taxes indicated in these documents is concentrated in cities. There are, however, two other lead bullae that suggest a more complex tax organization, which include territorial units. In one seal is with the text 'Sidueña district' (kürat Shadhüna) without any other detail. Although initially it was dated in the Caliphate period, it is possible to date this bulla in the second/eighth century. ${ }^{34}$ The words 'land of Jaén' (ard Jayyān) in another of these seals also seems to mention a territorial unit. 35

The use of such administrative vocabulary has clear parallels at the other end of the Mediterranean. The circumscription (iqlim)-district (küra)-province (ard ) sequence is attested in Nessana papyri in southern Palestine, where the iqlim was identified with a territorial division of the küra, which was part of $a r d$, each of five military territories in which Great Syria was divided: Palestine, Jordan, Damascus, Homs, and Qinnasrīn. ${ }^{6}$ This is reflected in other documents, such as the inscription written in ink on a marble tablet found in Andarin, in northern Syria, where the district of Ra'bān al-Awwal is integrated into the Cyrrus district belonging to the province (ard) of Qinnasrīn. ${ }^{37}$ The same sequence iqlïm-kūra-ard is evident in several seals of Syrian and Palestinian origin, as one kept in the British Museum. ${ }^{3}$

\section{The coinage}

A study by Jonson has shown that coins minted in al-Andalus during the early stages of the Islamic conquest were only gold, possibly recycled from the seized treasures (Jonson's IP 2 series), clearly linking this coinage with the military campaigns of the Islamic army. ${ }^{39}$ The relative decentralization in the production of these first dinars in the Iberian Peninsula soon disappeared and thenceforth the mint was placed under the exclusive control of the governor of al-Andalus, unlike some eastern provinces where coins

33 Sénac and Ibrahim 2017, nos. 34-39: bismi / Allāh // ahl / Ishbüliya; no. 40: bismi / Allāh // Khatim / ahl Bāja; nos. 80-81: Khatim //Libīratu; nos. 82-83: bismi / Allāh // Khutima / [-?]. For the text min ahl Mișr in a lead seal from Egypt, see Mikhail 2008.

34 Martínez Enamorado 2003.

35 Sénac and Ibrahim 2017, nos. 30-32: muṣālaḥat // al-arḍ Jayyān.

36 For example, circumscription (iqlìm) of Sycomazon in the district (kūrat) of Gaza (papyrus 61) and la circumscription (iqlìm) of Elusa in the district (kürat) of Gaza (papyrus 64) in Kraemer $195^{8 .}$

37 Sénac and Ibrahim 2017, nos. 30-32: muṣālaḥat // al-arḍ Jayyān.

38 Porter 2011, p. 29: iqlìm al-S. / d.y.r. (?) kūra / Bulunyās / Himṣ.

39 Jonson 2014; Chalmeta Gendron 2015, pp. 50-51 and 70-71. 
were minted by lower-ranking officials. ${ }^{40}$ When the $\bar{a} m i r$ ('governor') Mūsā b. Nușayr moved to Ifrīqiya in $95 / 713-96 / 715$, he accompanied the sole mint active in the region, which adopted a format of better quality (NA series 2-phase 3), while gold taken from the Visigoths was still used in his production. The trend to improve the quality of coins made from recycled gold of Hispanic origin was continued, both in North Africa (series NA 3) and in the Iberian Peninsula, where a new mint coined the dinars of the IP 3 series, with an average purity exceeding 80 per cent. This increase in the amount of gold was noted by Roux, who connected the improvement to the growing administrative stability in two regions during the mandate of the new governor of Ifrīqiya, Muhammad b. Yazīd al-Qurayshī, who appointed al-Ḥurr b. 'Abd al-Raḥmān al-Teaqafī (97/714-10o/718) as emir of al-Andalus in $98 / 716$, coinciding with the first coins of the IP 3 series. ${ }^{41}$

The monetary reform initiated by the Umayyad caliph ${ }^{\varsigma} A b d$ al-Mālik in the North African and al-Andalus mints (series NA 4 and IP 4, respectively) introduces a different problem. The change was not limited to copying the appearance of the reformed coins, but assumed the standard of oriental dinars. This explains the quality that characterizes dinars of the series NA 4 and IP 4 , with a gold content ( 98 per cent) similar to the dinars coined in the rest of the Umayyad Empire. The same can be said about dirhams of the same series, whose weight and proportion of silver is found in dirhams struck in other mints of the Caliphate.

Despite these similarities, the legends of the dinars continued to vary up to at least 110/728, following the guidelines of the NM 4 nisf series, which underlines the regional character of the currency of North Africa and al-Andalus. ${ }^{42}$ In general, the monetary policy of the governors in these regions shows a wide margin of autonomy with respect to the government of Damascus. Indeed, although the mints of Great Syria always served as a model for the western provinces, their governors were never eager to incorporate novelties that would have correlated the currencies of the Iberian Peninsula and North Africa with those of the rest of the Umayyad Empire. On the contrary, in North Africa the earliest coinage was mainly designed for local and regional markets and subsequent modifications, especially the incorporation of Islamic legends, were delayed for decades, while Byzantine currency was kept as a reference. In al-Andalus, the case was different because the Muslim conquerors never used the Visigothic 


\begin{tabular}{llcccc}
\hline Country & \multicolumn{1}{c}{ Place } & Name & Coins & Andalusian Coins & Date \\
\hline Jazìra & & & 2820 & $1(0.03 \%)$ & $116 / 734$ \\
Iraq & Kufa & & 178 & $1(5.5 \%)$ & $118 / 736$ \\
Syria & Damascus & Sāthat al-Tahrīr & 2377 & $28(1.59 \%)$ & $104 / 722-122 / 739$ \\
Syria & Ma'arra & & 151 & $1(0.66 \%)$ & $121 / 738$ \\
Syria & Qamishliyya & & 238 & $1(0.42 \%)$ & $131 / 748$ \\
Israel/Palestine & Beth Sean & treasure E & 36 & $1(2.77 \%)$ & $120 / 737$ \\
Israel/Palestine & Beth Sean & treasure H & 105 & $1(0.95 \%)$ & $111 / 729$ \\
Turkey & Dennizbakhi & & 139 & $2(1.43 \%)$ & $114 / 731-120 / 737$ \\
\hline
\end{tabular}

Fig. 19.3 Dirhems minted in al-Andalus before year 756 in hoards documented in the central regions of the Umayyad Empire. @ Julián M. Ortega Ortega.

tremisses as a model. Instead, it followed a similar pattern to the North African coinage of Byzantine inspiration. Thus, the periods of production (with peaks of minting linked to the military campaigns), the contents of gold and silver, and the absence of findings outside the two regions indicate that the earliest dinars were coined both in al-Andalus and North Africa according to regional interests, mainly the distribution of booty, payment of soldiers, and the establishment of a tax administration at the service of provincial governors.

\section{Colonial payments?}

The minting of the IP 4 and NA 4 series was a deliberate attempt to align the economies of the western provinces with those of the rest of the Caliphate. Despite this, however, a connection never was implemented and the monetary circuits of Ifrīqiya and al-Andalus maintained a regional character. This suggests a scarcity of western currency in the oriental provinces of caliphate and the small circulation of Iberian and North African coinage indicated by the coin findings (Fig. 19.3). ${ }^{43}$ In fact, the presence of early Andalusian silver coins in the main hoards known in in the central areas of the Umayyad Empire is sporadic and that of dinars is non-existent. In the example of the city of Beth Shean, in the Northern District of Israel, almost totally destroyed by the earthquake at the beginning of 131/749, of the seven hoards detected among its ruins, only two contained coins minted in al-Andalus. The first is a dirham of 120/737 found in treasure E, consisting of 36 dirhams, the last dated in $29 / 746$. The second dirham, 
coined in al-Andalus in the year 111/729, was part of treasure $\mathrm{H}$, consisting of 105 dirhams hidden in $130 / 747 .^{44}$

Even assuming that a part of the silver coin that came from al-Andalus was recycled into new issues, the weakness of monetary flows from the periphery to central regions of the empire is notable. This is hardly surprising. Some time ago, Dennet showed that only 5 per cent of the total tax revenue collected in Egypt came to Damascus. ${ }^{45}$ For reasons of logistics, it is reasonable to assume that it was even lower in a distant lands such as al-Andalus.

\section{Conclusion}

Different aspects of the Islamic conquest of Spania, the distribution of the booty, the signing of agreements to pacify the country, the settlement of veterans in lands obtained as a reward for their participation in the military campaigns, the implementation of a tax organization that quickly replaced the Visigothic taxation system, all form an essential part of the material infrastructure that supported the complex institutional framework of command in the name of the Umayyad caliphate. The organization of this institutional complex was not automatic but was the result of an elaborated process of negotiations within a structure of competing interests that does not fit with any simplistic view of a metropolis-colony binomial. The difficult management of the Muslim occupation of Spania was carried out through the arduous work of articulating an institutional arrangement between conquerors and natives, but among the conquerors themselves (Arabs vs. Berbers, Baladiyyin vs. Syrians; Arabs vs. Arabs) and with their command structures (army vs. emirs, emirs vs. caliphs). This explains difficulties encountered by the Umayyad caliphs in implementing control forms in the Iberian Peninsula similar to those implanted in the Levant. In Great Syria, Egypt, and North Africa, the caliphal control of the conquering troops was carried out through settlement in large urban garrisons, where they became a salaried army weakly connected to the rural population. The land was left in the hands of the native aristocracy who maintained only occasional relationships with the Muslim military garrisons. According to Ibn 'Abd al-Hakam, in Egypt the members of the jund were forbidden to settle in rural areas and live off agriculture. ${ }^{46}$ Thus 
the armies tended to exhaust the tax revenues that were collected, so that the Umayyad caliphs were compelled to compete with the governors and their armies for a sizeable portion of the taxes collected. ${ }^{47}$ Kennedy has drawn attention to the huge amounts of metal, presumably gold, that the state required to pay military salaries and pensions in Syria and Egypt. ${ }^{48}$ Unlike what happened in other provinces of the Umayyad Empire, the troops that arrived in al-Andalus during the first wave of conquest - the - and the second wave - the Shamiyyin - settled in farms and villages that they had obtained during the distributions of booty.

Archaeological research on power structures organized by the Muslim conquerors in Spania does not correspond with the idea of a savage kingdom dedicated to sowing panic among the native population and destabilizing the country, nor does it fit with the image of an efficient imperial machinery. The institutional framework organized by the provincial governors who established the Umayyad rule in Spania followed precise administrative procedures, norms, and regulations. However, the main beneficiaries from this rule were not the caliphs but troops and their commanders. Those who lost the most were those who openly confronted the new regime. Others became resigned and adopted more literary forms of protest, such as the anonymous author of the Chronicle of 754 .

\section{Bibliography}

\section{Primary sources}

Chronicle of 754 = Crónica mozárabe de 754: edición crítica y traducción, ed. and trans. by José E. López Pereira (Zaragoza: Anubar, 1980).

Ibn al-Khațīb, Al-Ihạța = Ibn al-Khațīb, Al-Ihāṭafı́ ta'rījGarnāṭa, ed. by Muhammad `Abd Allāh 'Inān, 4 vols. (Cairo, 1973-1978); partially trans. into French by Reinhart P.A. Dozy in Recherches sur l'histoire politique et littéraire de l'Espagne pendant le Moyen Âge, 2 vols., vol. 2, 2nd ed. (Leiden: Brill, 186o).

Ibn al-Qūṭiyya, Ta'rīkh = Ibn al-Qūṭiyya, Ta'rīj iftitāh al-Andalus, trans. by Julián Ribera in Historia de la conquista de España de Abenalcotía el Cordobés (Madrid: Real Academia de la Historia, 1926).

al-Rāzì, Akhbār mulūk = al-Rāzī, Ajbār mulūk al-Andalus, in Crónica del Moro Rasis, ed. by Diego Catalán and María Soledad Andrés (Madrid: Gredos, 1975). 


\section{Secondary sources}

Amara, Allaoua, 'L'Organisation foncière du Maghreb central (VII $-\mathrm{XIV}^{\mathrm{e}}$ siècle)', Al-Mawaqif 5 (2010), pp. 53-65.

Amitai-Preiss, Nitzan, 'Umayyad Coin Hoard from the Beth Sean Excavations of the Hebrew University', Israel Numismatic Journal 14 (2002), pp. 224-238.

Asín Palacios, Miguel, 'Un códice inexplorado del cordobés Ibn Ḥazm', Al-Andalus 2 (1934), pp. 1-56.

'Athamina, Khalil, 'Some Administrative, Military and Socio-political Aspects of Early Muslim Egypt', in War and Society in the Eastern Mediterranean, 7 th-15th $^{\text {th }}$ Centuries, ed. by Ya'acob Lev (Leiden: Brill, 1997), pp. 101-113

Beltrán de Heredia Bercero, Julia, 'Santa María del Mar: un enclave cultual de la antigüedad tardía en el suburbium de Barcino', QuarHis: Quaderns d'Arqueologia i Historia de la Ciutat de Barcelona 7 (2011), pp. 102-143.

Carvajal López, José C., 'El poblamiento altomedieval en la vega de Granada a través de su cerámica', unpublished PhD thesis, Department of Medieval History, University of Granada, 2007, http://digibug.ugr.es/handle/10481/1428 (accessed 4 July 2020).

Chalmeta Gendron, Pedro, Invasión e islamización: la sumisión de Hispania y la formación de al-Andalus, 2nd ed. (Jaén: Universidad de Jaén, 2003 [Madrid: 1994]).

—_ 'Los primeros 46 años de economía andalusí', Alhadra 1 (2015), pp. 41-88.

Clarke, Nicola, The Muslim Conquest of Iberia: Medieval Arabic Narratives (London/ New York: Routledge, 2011).

Dennett, Daniel C., Conversion and the Poll-tax in Early Islam (Delhi: Idarah-i Adabyat-i Delli, 1950).

Donner, Fred M., The Early Islamic Conquests (Princeton: Princeton University Press, 1981).

Faro Carballa, Jose A., and María García-Barberana Unzu, 'Las necrópolis pamplonesas del 70o', in 711 Arqueología e historia entre dos mundos, 3 vols., vol. 1 (Alcalá de Henares: Museo Arqueológico Nacional, Zona Arqueológica 15, 2011), pp. 295-312.

García Sanjuán, Alejandro, La conquista islámica de la Península Ibérica y la tergiversación del pasado (Madrid: Marcial Pons, 2013).

Gaspariño, Sebastián, and Tawfiq Ibrahim, 'Adiciones a los precintos de la conquista: ¿Rayyo?', Manquso 1 (2015), pp. 7-10.

— , 'Nuevo precinto de "pacto de paz", mușalaha, de lugar desconocido', Manquso 10 (2019), pp. 5-6.

Gleize, Yves, Fanny Mendisco, Marie-Hélène Pemonge, Christophe Hubert, Alexis Groppi, Bertrand Houix, Marie France Deguilloux, and Jean-Yves Breuil, 'Early Medieval Muslim Graves in France: First Archaeological, Anthropological and 
Palaeogenomic Evidence', PLoS ONE 11.2 (2016), https://journals.plos.org/plosone/ article?id=10.1371/journal.pone.0148583 (accessed 4 July 2020).

Gondonneau, Alexandra, and Maria Filomena Guerra, 'The Circulation of Precious Metals in the Arab Empire: The Case of the Near and the Middle East', Archaeometry 44.4 (2002), pp. 573-599.

González García, Alberto, and David Martínez Chico, 'Cuatro hallazgos aislados de dinares epigráficos latinos hispano-musulmanes en Jaén', Documenta \& Instrumenta 15 (2017), pp. 45-56.

Guerra, Maria Filomena, Thomas Calligaro, and Alicia Perea, 'The Treasure of Guarrazar: Tracing the Gold Supplies in the Visigothic Iberian Peninsula', Archaeometry 49.1 (2007), pp. 53-74.

Guerra, Maria Filomena, and Corinne Roux, 'L'Or de la Peninsula Ibérique des invasions a la reconquista: circulation monétaire des wisigoths aux rois chrétiens', Revue d'Archéométrie 26 (2002), pp. 219-232.

Gutiérrez Lloret, Sonia, 'La materialidad del Pacto de Teodomiro a la luz de la arqueología', eHumanista/IVITRA 5 (2014), pp. 262-288.

Hoyland, Robert G., 'Khanāșira and Andarīn (Northern Syria) in the Umayyad Period and a New Arabic Tax Document', in Power, Patronage and Memory in Early Islam: Perspectives on Umayyad Elites, ed. by Alain George and Andrew Marshaw (Oxford: University Press, 2017), pp. 134-146.

Jiménez Puertas, Miguel, El poblamiento del territorio de Loja en la edad media (Granada: Universidad de Granada, 2002).

— Los regadíos tradicionales del territorio de Loja: historia de unos paisajes agrarios de origen medieval (Granada: Universidad de Granada, 2007).

— El caso de la Vega de Granada', in Arqueologia medieval. Els espais de secá, ed. by Flocel Sabaté (Lleida: Universitat de Lleida, 2011), pp. 51-85.

Jonson, Trent, 'A Numismatic History of the Early Islamic Precious Metal Coinage of North Africa and the Iberian Peninsula', unpublished PhD thesis, Faculty of Oriental Studies, University of Oxford, 2014, www.academia.edu/30630922/A_Numismatic_History_of_the_Early_Islamic_Precious_Metal_Coinage_of_North_Africa_and_the_Iberian_Peninsula_VOL._2_] (accessed 4 July 2020).

Kennedy, Hugh, 'Military Pay and the Economy of the Islamic State', Historical Research 188 (2002), pp. 155-169.

Kraemer, Casper J., Excavations at Nessana, 3 vols., vol. 3: Non-literary Papyri (Princeton: Princeton University Press, 1958).

Manzano Moreno, Eduardo, Conquistadores, emires y califas: los omeyas y la formación de al-Andalus (Barcelona: Crítica, 2006).

Martínez Enamorado, Virgilio, 'Un plomo con la leyenda en árabe kūrat Shadūuna', Almajar 1 (2003), pp. 111-113. 
Miguel Ibáñez, María Paz de, 'Mortui viventes docent: la maqbara de Pamplona', in De Mahoma a Carlomagno: XXXIX Semana de Estudios Medievales, ed. by Philippe Sénac (Pamplona: Gobierno de Navarra, 2012), pp. 351-375.

Mikhail, Maged S.A., 'Notes on the Ahl al-Dīwān: The Arab-Egyptian Army of the Seventh through the Ninth Centuries C.E.', Journal of the American Oriental Society 12 (2008), pp. 273-284.

Noonan, Thomas S., 'Andalusian Umayyad Dirhams from Eastern Europe', Acta Numismatica 10 (1980), pp. 81-92.

Ortega Ortega, Julián M., La conquista islámica de la Península Ibérica, una perspectiva arqueológica (Madrid: La Ergástula, 2018).

Porter, Venetia, Arabian and Persian Seals and Amulets in the British Museum (London: British Museum Press, 2011).

Prevedorou, Eleanna, Marta Diaz Zorita, Alejandro Romero, Jane Buikstra, María Pilar de Miguel Ibáñez, and Kelly J. Knudson, 'Residential Mobility and Dental Decoration in Early Medieval Spain: Results from Eighth Century Site of Plaza del Castillo, Pamplona', Dental Anthropology 23 (2010), pp. 42-52.

Roux, Corinne, 'Le premier monnayage musulman d'occident: dinars et dirhams africains et andalous du VIII ${ }^{\mathrm{e}}$ siècle', in Actos do V Congresso nacional de numismatica/I Congresso Luso-Brasileiro, ed. by Francisco A. Costa Magro (Lisbon: Associação Numismática de Portugal, 2000), pp. 35-53.

Sénac, Philippe, and Tawfiq Ibrahim, Los precintos de la conquista omeya y la formación de al-Andalus (711-756) (Granada: Universidad de Granada, 2017).

Sijpesteijn, Petra M., 'The Arab Conquest of Egypt and the Beginning of Muslim Rule', in Egypt in the Byzantine World, 300-70o, ed. by Roger S. Nagnall (Cambridge: Cambridge University Press, 2007), pp. 437-459.

— , 'Landholding Patterns in Early Islamic Egypt', Journal of Agrarian Change 9.1 (2009), pp. 120-133.

Ṭāha, 'Abdulwāḥd Dhanūn, The Muslim Conquest and Settlement of North Africa and Spain (London/New York: Routledge, 1989).

Voguet, Elise, 'Le statut foncier et fiscal des terres de l'Ifrīqiya et du Maghreb: l'apport des sources juridiques', in Islamisation et arabisation de l'occident musulman médiéval $\left(V^{e}{ }^{e}-X I I^{e}\right.$ siècle), ed. by Dominique Valérian (Paris: Publications de la Sorbonne, 2011), www.academia.edu/2196032/Le_statut_foncier_et_fiscal_des_terres_de_lIfriqiya_et_du_Maghreb_lapport_des_sources_juridiques (accessed 4 July 2020).

Wickham, Chris, 'Tributary Empires: Late Rome and the Arab Caliphate', in Tributary Empires in Global History, ed. by Peter F. Bang and Christopher A. Bayly (Houndmills: Palgrave Macmillan, 2011), pp. 205-213. 


\section{About the author}

Julián M. Ortega Ortega is an independent researcher linked to the Teruel Museum and the University of Zaragoza (Spain). He has published widely on the medieval history and archaeology of al-Andalus. His most recent book is La conquista islámica de la Península Ibérica: una perspectiva arqueológica (Madrid: La Ergástula, 2018). 



\title{
20 Conclusions and Future Perspectives
}

\author{
Paulo Pachá
}

Since the beginning of the twentieth century, power has been the main category used by historians to explain both the structure and dynamics of the Visigothic kingdom of Toledo. Thus, most analyses focused on political aspects of Visigothic society rather than on economic or cultural ones. Given the general position among historians that most written sources had a normative character, this focus on political aspects is understandable. ${ }^{1}$ The main consequence was the development of a historical narrative about the Visigothic kingdom of Toledo structured by its political history and focused on the monarchy's development. ${ }^{2}$

The 1970s were an important introduction of change, especially for Spanish historiography. During those years, historians developed new models in order to interpret the Visigothic kingdom of Toledo's historical development - once again, however, looking mainly to its political structure and dynamics of power. ${ }^{3}$ The result of their combined work (not always congruent and sometimes at odds) in the following two decades has become a hegemonic model for how power and power relationships operated and were transformed in the Visigothic kingdom of Toledo. ${ }^{4}$ At the centre of this model (with or without the inclusion of the church as a third power) is the conflict between the monarchy and the aristocracy as the primary defining power relationship - a conflict between aristocratic factions for authority and power over the others. This new model was thereby able to explicate the classical narrative without any challenge or critique, and by doing so strengthened the old narrative by updating it to a new historiographical context.

Despite a general agreement about this model, research over the past three decades has contributed in crucial ways to enriching - and challenging - our

\footnotetext{
$1 \quad$ Stocking 2007, p 347; Wickham 2005, p. 219.

2 Barbero de Aguilera and Vigil 1978; García Moreno 1989; Collins 2004.

3 García Moreno 1974, pp. 5-156; 1975; Barbero de Aguilera and Vigil 1970, pp. 71-91.

4 Díaz Martínez 1999, pp. 321-372; Valverde Castro 2000.
}

Panzram, S. and P. Pachá (eds.). The Visigothic Kingdom: The Negotiation of Power in Post-Roman Iberia. Amsterdam: Amsterdam University Press 2020 DOI: 10.5117/9789463720632_CH2O 
understanding of power in the Visigothic kingdom of Toledo. Among other developments, the progress of Iberian archaeology, the contextualization of peninsular realities within wider Mediterranean contexts, and innovative analyses of the relationships between central and local powers have transformed our understanding of power structures and dynamics within the Visigothic kingdom. ${ }^{5}$

It has become clear that these new historiographical developments are in flagrant contradiction to the traditional model and classical narrative. Nevertheless, historians have yet to produce a major revision of the traditional model - it still represents a key influence (even if presupposed) and serves as an impediment to further comprehending Visigothic society. Without specialists subscribing to the current model in its entirety, it still remains the default, consensual explanation for the historical development of the Visigothic kingdom of Toledo. The main objective of this volume has been to present important critiques to the existing model and to contribute to the development of a new narrative for the Visigothic kingdom of Toledo.

A key to understanding contradictions in Visigothic studies lies in the crucial distinction between model and narrative. The narrative is one of a historical presentation of emergence, development, and crisis/transformation, while the model is a structural explanation of underlining forces that move the narrative. Thus, it is clear that every narrative needs some kind of model attached to it. Models, nevertheless, can change - and have changed profoundly in the last centuries due to developments in historical studies. Narratives also can change, but only insofar as new ones replace them. While a narrative can be explained in several ways - i.e. have competing explanatory models - only another narrative can substitute it. ${ }^{6}$

The simple Visigothic kingdom's narrative is that the kingdom was built during Liuvigild's and Reccared's reigns, developed in the course of the seventh century, and entered into a period of decadence in the last decades of that century, its lowest point happening in parallel with the Umayyad conquest of Iberia. This narrative is, of course, much older that of the 1970 . It was traditional and stable. The novelty that Spanish historians developed in the 1970 s was a model that explained in new terms an already established narrative. Informed by European historiography, this model utilized the idea of feudalism (or protofeudalism) as its centrepiece. In that, the new model explained the old narrative of monarchical centralization, its crisis and subsequent conquest, in structural terms as an opposition between 
monarchy and nobility. Therefore, a balance of this opposition explained every phase of Visigothic history: whether monarchical prominence and centralization or aristocratic prominence and fragmentation. ${ }^{7}$ This model grounded both the formation and development of the Visigothic kingdom of Toledo as a process where two elements were central: unity and centralization. ${ }^{8}$ Centralization and unity appear as the monarchy's exclusive attributes (as the only institution able to direct this process), in opposition to the aristocracy's interests of independence and fragmentation. This opposition developed into open conflict during the seventh century characterized by historiography as the 'origin of the central power structural fragility' - and became the recurrent political dynamic of the Visigothic kingdom of Toledo until its end in $711 .^{9}$

Profound developments in Visigothic studies in the last thirty years have produced a growing contradiction with the traditional narrative. On the one hand, the multiplication of specific researches that have new starting points and arrived at new conclusions and, on the other hand, the reproduction of a fossilized narrative that is not explicitly subscribed by almost no specialist. ${ }^{10}$ In a recent analysis of the field (between 1995 and 2015), Wood and Martínez Jiménez highlighted the 'burgeoning interest in the study of late antique and early medieval Spanish history'." According to the authors, three specific factors contributed to this development: the end of Franco's dictatorship and the historical narrative associated with it, an intense process of internationalization and contact with other historical traditions, an immense increase in commercial archaeology, and the growing amount of available material. ${ }^{12}$

Important critiques of traditional historiography are directly related to these three factors: the limits of conceptual binaries in the analysis of power relationships, the centralizing biases of both written sources and historical narrative developed from this standpoint, and the (self)imposed limits of archaeological studies..$^{13}$ These critiques, in turn, gave rise to new

7 The two paradigmatic works are Barbero de Aguilera and Vigil 1978 and García Moreno 1975 .

8 García Moreno 1989.

9 Velázquez Soriano 1989, pp. 213-222; Díaz Martínez 2013, pp. 167-206; García Moreno 1975; García Sanjuán 2013.

10 Some examples of those new approaches: Castellanos García and Martín Viso 2005, pp. 1-42; Koon and Wood 2009, pp. 793-808; Martín Fernández 2016.

11 Wood and Martínez Jiménez 2016, p. 29.

12 Ibid.

13 Ibid., pp. 29-30. 
approaches, to a greater focus on regionalism, the diversity of power and its negotiated character - beyond conceptual binaries with the development of new archaeological approaches. ${ }^{14}$ In Wood and Martínez Jiménez's diagnostics, two aspects appear as central to these new approaches: they are increasingly international and interdisciplinary. ${ }^{15}$

Interdisciplinarity is a core characteristic of this volume. Diverse disciplines have contributed to an insightful dialogue. Visigothic studies since its beginnings was built upon diverse disciplines, but only in the last decades has this diversity been transformed into an interdisciplinary endeavor. Given the pace of specialization, interdisciplinarity depends upon the collaboration of diverse specialists. One of this volume's objectives has been to bring together specialists from diverse disciplines and diverse perspectives to analyse a certain set of issues: power and its forms in the Visigothic kingdom of Toledo. The volume gathered contributions from disciplines such as history, archaeology, numismatics, literature, philology, and epigraphy. The list is not exclusive of the many disciplines in Visigothic studies, but is a diverse panorama of core disciplines in the field.

This volume is also an evidence of Visigothic studies' increasing internationalization, evident in the varied national origins of our contributors - from seven different countries around the world: Spain, Germany, France, Austria, the UK, the USA, and Brazil. The variety of national origins is crucial as it brings together different historiographical traditions, presenting a break from a national (Spanish) framing of Visigothic history. These diverse ways to frame Visigothic society and its relation with power dynamics offers a wider context (mainly Mediterranean) and establishes a critique of traditional (Spanish) historiography.

In a previous article, Dell'Elicine developed another (and wider) diagnostic about the past and current development of Visigothic studies. Dell'Elicine attempted to establish two objectives: 'to outline the development of a historiography with a long tradition' and 'to present the rich variety of derived themes that have been recorded throughout this development'. ${ }^{16}$ According to the author, since the mid-nineteenth century Visigothic studies developed from two specific approaches: one juridical and another philological. The juridical approach gave rise to two lines of inquiry: one about the 'nature, constitution and evolution of the Visigothic state' and the other on the 'material organization of the social relations' (with special 
emphasis on the question of Iberian feudalism). ${ }^{17}$ Dell'Elicine locates the last of this evolution during the decade of 1980 with the emergence of research framed by a question of regionalism, the urban space and identity, and determined by developments in Iberian archaeology. As do Wood and Martínez Jiménez, Dell'Elicine presents Visigothic studies as a field determined by interdisciplinarity - not only in its present state, but since its emergence. While Dell'Elicine recognizes the profound development of Iberian archaeology during the last forty years, she acknowledges how law and philology established a basis for Visigothic studies.

Both analyses agree and make clear that power (in all of its dimensions) was and still is a main theme of Visigothic studies. This is a direct consequence of the centrality of political history in traditional historiography, but also of the fact that new and alternative approaches have developed critique of the same power relations. Traditional historiography operates as a general frame of reference that new approaches necessarily have to deal with in their critiques: new historiographical developments are always set in relation to traditional historiography ${ }^{18}$ and to continue, Visigothic studies needs a new narrative with which to break free from the constraints imposed by the traditional one.

In the 1970s, Visigothic studies developed a new explanatory model for Visigothic history, but those pioneers still preserved the established historical narrative. In the last thirty years, new developments have questioned the traditional narrative itself. The field as a whole, however, keeps reproducing the traditional narrative as an inadequate framework against which specific analyses are developed. The main reason for this is the absence of a new general narrative. If historiographical knowledge proceeds by a progressive accumulation of partial results, the current accumulation dwarfs the traditional narrative without actually overthrowing it.

Power is undeniable a traditional theme and continues as one of the most important in Visigothic studies. Our understanding of power structures and dynamics, however, is changing rapidly and makes necessary new and more adequate concepts. The perspectives outlined in this volume point to the widening of our understanding of power as both a concept and its dynamics in Visigothic society. Visigothic studies continues to enrich its long history with conceptual and methodological innovations. As this volume indicates, we are witnessing a period when the very way of framing Visigothic society

18 This is an aspect that Stocking recognized, but was not able to explain: Stocking 2007, pp. 347-348. 
is changing. With a break from national perspectives, there is a vigorous development of more varied ones, contextualizing Visigothic society in wider and more complex frames.

This volume focuses on the central element of the traditional narrative - a given idea of power - and has two main objectives: first, to contribute to a major revision of the traditional model; second, to contribute to the development of new approaches to the analysis of power in the Visigothic kingdom of Toledo. One key step to achieve these objectives was to reframe the concept of power as way to analyse its many forms and types of representation. This new framing, grounded in the historical processes of formation and integration of the kingdom, is thus able to account for both conflict and cooperation through an analysis of power relationships that are simultaneously central and local, material and symbolic, political, cultural, and economic. By reframing and widening the concepts of power, this volume gathers new understandings of power in the Visigothic kingdom and deepens the contradiction in relation to the traditional narrative. The volume's contributors have developed approaches through which they have analysed power in a more integrated and relational way, contributing to the establishment of a new historical narrative of its emergence and development.

\section{Bibliography}

\section{Secondary sources}

Barbero de Aguilera, Abilio, and Marcelo Vigil, 'Algunos aspectos de la feudalización del reino visigodo en relación a su organización financiera y militar', Moneda y Crédito 112 (1970), pp. 71-91.

—_ La formación del feudalismo en la Península Ibérica (Barcelona: Editorial Crítica, 1978).

Castellanos García, Santiago, and Iñaki Martín Viso, 'The Local Articulation of Central Power in the North of the Iberian Peninsula (500-1000)', Early Medieval Europe 13.1 (2005), pp. 1-42, doi:10.1111/j.1468-0254.2005.00147.x (accessed 23 March 2020).

Collins, Roger, 'Merida and Toledo: 550-585', in Visigothic Spain: New Approaches, ed. by Edward James (Oxford: Clarendon Press, 1980), pp. 189-219.

Collins, Roger, Visigothic Spain 409-7n (Oxford: Blackwell, 2004).

Dell'Elicine, Eleonora, 'La ley, el rey, la iglesia: un recorrido sobre las temáticas y debates en el campo de los estudios visigodos', Temas Medievales 17 (2009), pp. $7-35$. 
Díaz Martínez, Pablo C., 'Visigothic Political Institutions', in The Visigoths: From the Migration Period to the Seventh Century. an Ethnographic Perspective, ed. by Peter Heather (San Marino: Boydell Press, Studies in Historical Archaeoethnology 4, 1999), pp. 321-372.

-, 'La dinámica del poder y la defensa del territorio: para una comprensión del fin del reino visigodo de Toledo', in De Mahoma a Carlomagno: los Primeros Tiempos, siglos VII-IX (2013), pp. 167-206.

García Moreno, Luís Agustín, 'Estudios sobre la organización administrativa del reino visigodo de Toledo', Anuario de Historia del Derecho Español 44 (1974), pp. $5^{-156 .}$

— El fin del reino visigodo de Toledo: decadencia y catástrofe; una contribución a su crítica (Madrid: Universidad Autónoma, 1975).

—, Historia de España visigoda (Madrid: Cátedra, 1989).

García Sanjuán, Alejandro, La conquista islámica de la Península Ibérica y la tergiversación del pasado: del catastrofismo al negacionismo (Madrid: Marcial Pons, 2013).

Koon, Sam, and Jamie Wood, 'Unity from Disunity: Law, Rhetoric and Power in the Visigothic Kingdom', European Review of History/Revue Europeenne d'Histoire 16.6 (2009), pp. 793-808, doi:10.1080/13507480903368061 (accessed 23 March 2020).

Kuhn, Thomas S., The Structure of Scientific Revolutions (Chicago: University of Chicago Press, 1996).

Martín Fernández, Damian, 'Persuading the Powerful', in Motions of Late Antiquity: Essays on Religion, Politics, and Society in Honour of Peter Brown, ed. by Jamie Kreiner and Helmut Reimitz (Turnhout: Brepols, 2016), doi:10.1484/M.CELAMAEB.5.108046 (accessed 23 March 2020).

Stocking, Rachel L., 'Continuity, Culture and the State in Late Antique and Early Medieval Iberia', Early Medieval Europe 15.3 (2007), pp. 335-348, doi:10.1111/j.14680254.2007.00209.x (accessed 23 March 2020).

Valverde Castro, Maria del Rosario, Ideología, simbolismo y ejercicio del poder real en la monarquía visigoda: un proceso de cambio (Salamanca: Ediciones de la Universidad de Salamanca, Acta Salmanticensia, Estudios Históricos y Geográficos 110, 2000).

Velázquez Soriano, Isabel, 'Wamba y Paulo: dos personalidades enfrentadas y una rebelión', Espacio, Tiempo y Forma, ser. 2, Historia Antigua 2 (1989), pp. 213-222.

Wood, Jamie, and Javier Martínez Jiménez, 'New Directions in the Study of Visigothic Spain', History Compass 14.1 (2016), pp. 29-38, doi:10.1111/hic3.12294 (accessed 23 March 2020). 
About the author

Paulo Pachá is Assistant Professor of Medieval History at the Universidade Federal do Rio de Janeiro (Brazil). He works on the history of the Visigothic kingdom and the development of its political structure and power relationships. 


\section{Index of Places, Names and Subjects}

Rulers (emperors, kings; caliphs, emirs) and their relatives have been formatted in small caps; both they and the antique authors appear under the names with which they are commonly referred to in Anglo-American bibliography. Other Roman personal names are sorted by gentilicia.

`ÁAD AllāH AL-ȘAMḤ IBN MĀLIK (emir) 378

'ABD AL-MALIK B. ḦABĪB $377 ; 384$

'ABD AL-RAب̣MĀN I 224; 381

'ABD AL-RAḦMĀN III 321

Abrittus/Hisarlâk, battle of 141

Acisclus (martyr) 199

Adrianople, battle of 147

Africa see North Africa

Agde $122 ; 127$

agentes in rebus 44

Agicampe/Shikanb 381

AgILA I 199; 202; 342,29;354;360

AgILA II 246; 248-250

Agobard of Lyon 148

agriculture $\quad 41 ; 81 ; 225 ; 257 ; 380 ; 386$

Aguilafuente $82 ; 303$

Aḥmad al-Rāzī $\quad 377 ; 249$

Akhbār Majmū $\bar{u}^{\varsigma} a \quad 381$

al-Andalus 245;375, passim

Alans/alani $\quad 24 ; 40 ; 68 ; 131 ; 151$

AlARIC I 17;64-65; 131; 143-144;146; 237

Alaric II $\quad 63 ; 68-69 ; 144 ; 201 ; 238$

Alaviv 143

Alcalá de Henares/Complutum $\quad$ 47;79; 300

alcázar 17;318;321

al-Dāwūdī 376

alficén 321

Alfons I OF Asturia 148

al-Funtin/al-Funtayn see El Frontil

Algeciras, bay of 375

AL-НАКАМ I 224

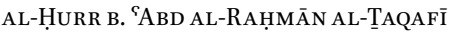
(emir) $\quad 384$

AMALARIC $\quad 62-63 ; 238 ; 296-297 ; 299-300$

AMALASUINTHA 140

Amals 140

Ampelius 71

amphorae $\quad 87 ; 223 ; 225 ; 324$

Ampurias/Emporiae $\quad 46 ; 197$

AnAstasius 238

Andarìn 383

Anglo-Saxons 147;247

Ankyra 339

ANTHEMIUS 68-69

Antiochia 339

antiphon $\quad 284-285$

aquaeduct 201;229

Aquitania 26;59, passim

Arabs $81 ; 107 ; 146 ; 375$ passsim

Aregio (bishop) 121

Arianism 144;147;149-151;158-166 aristocracy/aristocrats $\quad 19 ; 25 ; 61 ; 69 ; 72$; 103-113; 122, 28; 124; 131; 143-144; 185; 196; 206; 221; 223; 227-229; 262; 298; 301; 315; 328; $353-355 ; 368 ; 376 ; 386 ; 393 ; 395$

Armilla 381

Asido see Medina Sidonia

Asterio (bishop) 275

Astigi see Écija

Astorga/Asturica Augusta $\quad 47 ; 72 ; 300 ; 305$; 308; 339

Asturias, kingdom of $\quad 23 ; 148 ; 325$

ATHALARIC 140

AthaNAGILD $\quad 317 ; 328 ; 342,29 ; 360$

ATHANARIC 268

AthaUlF $17 ; 39 ; 64 ; 65 ; 237 ; 298 ; 299$

auctoritas 342

Augusta Emerita see Mérida

Augustus (Octavian) 19; 273

aula regia 328

Aurelian 141

Austrigusa (princess) 142

auxilia palatina 44

Avenches/Aventicum 247

Aventius (bishop) 359

Avitus 68

BADDA 21

Baelo Claudia $\quad 46,197$

Baetica $42-43 ; 64 ; 71 ; 73 ; 79 ; 95 ; 204 ; 274 ; 317$; $327 ; 361-362$

Baladiyyin 386

Balearic Islands/Insulae Baleares $\quad 43 ; 363$

Balti dynasty $140 ; 146 ; 295 ; 297$

Barcelona/Barcino $\quad 13 ; 125 ; 126 ; 197 ; 221 ; 228$; 229; 296; 321; 329; 379

Bardulia 148

Basques 120-122;124;126;128; 205

Beja 382

Belisarius (general) 298; 308

belt buckle $84-85 ; 87 ; 89-90 ; 92 ; 324$

Benedict of Aniane 148

Berbers $\quad 30 ; 375 ; 386$

Beth Shean $\quad 385$

Béziers 127;129

Bilbilis 197

Bonifatius (bishop) $339 ; 341 ; 344,37$

border $29 ; 45 ; 147 ; 261,13 ; 299 ; 300 ; 308 ; 340$; $345 ; 361$

Bourbon dynasty 17

Braga/Bracara Augusta $\quad 72 ; 197 ; 228 ; 339 ; 341$; $346,5^{2}$ 
Braulio of Zaragoza $\quad 262$

Breviarium 258,2

Brittablum see Vertavillo

bulla $\quad 377-383$

Burdunelus (usurper) 6o;69-70;

Burgos (province) 275

Burgundians $147 ; 238 ; 346,50$

burials (Islamic) $\quad 379-380$

Byzantine Empire $\quad 69 ; 83 ; 95 ; 126 ; 162 ; 217 ; 240$; 242; 245; 299; 324; 342; 346; 353, passim

Byzantium see Constantinople

Cádiz/Gadir/Gades 197; 200

Caesaraugusta see Zaragoza

Caesarius (patrician) $\quad 261$

Cájar/Yājar al-Baladiyyīn 380

Calahorra/Calagurris $\quad 124 ; 197$

caliphate $383-386$

Capitula Martini (Capitula ex Orientalium

Patrum Synodis) 339-340

Carolingians $146 ; 148 ; 380$

Carpio 62; 90

Carranque/Santa Maria de Abajo (villa romana) $323 ; 328$

Cartagena/Carthago Nova/Carthago Spartaria $\quad 46 ; 79 ; 82 ; 90 ; 197 ; 204 ; 296 ; 299$; $361 ; 362$

Carthaginiensis $\quad 42 ; 79$, passim; $111 ; 295 ; 296$; 301; 303-304; $328 ; 361 ; 367$

Cassiodor $63 ; 71 ; 140 ; 148-149 ; 203$

Castile $\quad 22-23 ; 178-179 ; 182 ; 185 ; 187$

Castilian Meseta/plateau $62 ; 82 ; 84 ; 174$; 184-185; 188; 198; 295, passim

Castiltierra 62;303

Catalonia $67 ; 150$

Catholicism $\quad 20 ; 23 ; 144 ; 150 ; 242 ; 281 ; 284$; $306-308 ; 338 ; 342 ; 357 ; 35^{8}$

Cauca see Coca

cemetery/necropolis $\quad 62 ; 79$, passim;132; 173, passim; 287;303-304; 318; 381

central power $102-109 ; 113 ; 168-169 ; 316$

Chalcedonian faith 347

Charlemagne 145

Charles III OF SPAIN $\quad 18-19$

Childebert 63

Chindaswinth 119,$10 ; 120 ; 236$; 241-242; 261,$12 ; 262-264 ; 274$

Chintilla $17 ; 111 ; 262$

Christ Pantocrator $247-248 ; 25^{\circ}$

Christianization 273, passim; 315, passim

Chronica Regum Visigothorum 268

Chronicle of $754 \quad 258,1 ; 375-376 ; 387$

Chronicle of Albelda see Codex Albeldensel Codex Vigilanus

citizenship 195, passim

city walls $47 ; 61 ; 126-127 ; 204 ; 205 ; 215 ; 219-220$; $223 ; 227-228$

civitates $\quad 45-49 ; 126 ; 196 ; 206-207 ; 379$

clarissimi 202
Claudius (dux) 161-164

clergy, clerics $\quad 122 ; 130-131 ; 200 ; 266-267 ; 268$; 274; 286 ; 300; 305; 342; 344,37; 357-360; 364-369

cloisonné $\quad 79 ; 83-84 ; 87 ; 88-89 ; 90-96$ 'clasped cloisonné' 88

'jointed cloisonné' 88 ; 91; 93

Clothar I 347

Clovis I $126 ; 143$

Clunia 197

CNIVA 141-142

Coca/Cauca 301

Codex Albeldense/Codex Vigilanus 244

Codex Iustinianus $\quad 366-367$

Codex Theodosianus 42;46;63;295

Codex Toletanus 61

coinminting/coinage 228;235,

passim; $376 ; 383-386$

coloni 42

colonia $46 ; 70$

comes $121 ; 167 ; 266 ; 267$

comes civitatis 228

comes notarii 122

comes rerum privatarum 44

comes sacrarum largitionum 44

comitatenses $\quad 44-45$

Comitiolus 361-362; 364-366

Complutum see Alcalá de Henares

concives 199

conductores 41

Conimbriga 47,$46 ; 198 ; 204,46$

consecration $124 ; 275 ; 281-282 ; 284-285$; 301-302; 320-322; 364

Constantine the Great $\quad 43-44 ; 46 ; 50 ; 197$; 343

Constantinople/Byzantium $\quad 21 ; 29 ; 65 ; 69 ; 151$; $217 ; 225 ; 337 ; 341 ; 343 ; 345-346$

Constitutio Antoniniana 202

consulares 43

Consularia Caesaraugustana $\quad 60 ; 69$

conventus civitatis 201

conventus publicus vicinorum 201

conversion $\quad 20-23 ; 50 ; 108 ; 144 ; 146 ; 149-150$; 160; 165-166; 242; 268; 273; 281; 299; 305-306; $338 ; 342-343 ; 357-358 ; 361 ; 368 ; 380$

Córdoba/Corduba/Qurțuba $\quad 23 ; 47 ; 72 ; 107 ; 109$; 110-112; 197; 198; 199; 201; 204; 248; 324; 345; $354 ; 360$

corruption 42

Cortijo del Aire (Loja, Granada) 381

Council of Elvira/Iliberris $\quad 46 ; 49 ; 50$

Council of Nicaea $\quad 48 ; 339$

Council of Trullo 247

Councils of Toledo/Concilia

Toletana $\quad 20 ; 21 ; 24 ; 66 ; 101$, passim; 118-119; 122-123; 128-129; 144; 201; 257-258; 261-265; 267; 281; 296; 300; 303; 308; 317; $328 ; 340$

Covadonga, battle of 21 
Cuatro Fanegas (Alcabón) 323

curator reipublicae $\quad 46$

curia 46

curiales $41 ; 46 ; 47,45 ; 202$

cursus publicus $\quad 44 ; 71$

Cyrrus (Syrian district) $\quad 383$

Damascus $376 ; 381 ; 383-386$

damnatio memoriae $\quad 264$

Daniel (prophet) $\quad 285$

Danube $132 ; 140 ; 141 ; 174 ; 183 ; 184,58 ; 187 ; 299$

De Bello Gothico 62

Decius 141

De correctione rusticorum 339

Deibiensis (monastery) 322

De ira 339; 344

defensor $355 ; 362-363$

defensor civitatis $\quad 46 ; 49 ; 201$

Dertosa see Tortosa

De trina mersione $\quad 339 ; 341-344$

De viris illustribus 338

Dexippos 139;141-142;143

dirham, dirhem 224;384-386

Didimus 45

Diocletian $44 ; 197$

doctrine $\quad 66 ; 273 ; 274 ; 277-278 ; 280 ; 283-284$; $337 ; 345$

Douro/Duero $\quad 72 ; 84 ; 184-185 ; 188 ; 204 ; 303$

Dumio 338-340

duoviri 46

Duratón $62 ; 174 ; 184 ; 187 ; 303$

dux $23 ; 61 ; 117$, passim; $161 ; 266-267$

dux exercitus 122

dux provinciae 122

Early Medieval Cold Episode $\quad 227$

ecclesia intramuros 321

ecclesia principalis 317

Écija/Astigi $\quad 49 ; 359$

economy 39 , passim; $5^{0} ; 103 ; 125 ; 132 ; 147-148$; 185; 197; 216; 225; 229; 315; 316; 327-328; 354; $385 ; 393 ; 398$

Egara 198

EgICA $243-244 ; 246-247 ; 258$

Egypt $73 ; 339 ; 380 ; 386-387$

El Frontil/al-Funtīn/al-Funtayn 381

El Guerrero (Escalonilla) 323

elites $42 ; 72-73 ; 94-95 ; 103 ; 122 ; 168-169 ; 185$; 200; 202; 206-207; 225; 229; 273-274; 287; 315, passim; 354-355; 358-359;360-361; 363

elogium 274

El Rincón (Alcolea de Tajo) 323

El Saucedo (Talavera de la Reina) 323; 328

Els Casal de Morella (Castelló) 229

Elvira/Iliberris/Ilbīra 382

Élvoramint 223

Emerita (diocese) 44

emigration $60 ; 63 ; 263$

Emporiae see Ampurias epigraphic habit $\quad 45 ; 273$, passim;

episcopal see $\quad 48 ; 198 ; 303 ; 307 ; 317-318 ; 321$

epithet 202; 274

ERWIG $17 ; 128 ; 242 ; 247-248 ; 250 ; 257-259 ; 264$; 265-269

Esgueva 303

Espirdo 184

Espirdo-Veladiez 303

ethnicity $\quad 59 ; 62 ; 65 ; 95-96 ; 131-132 ; 147-149$; 150-151; 157, passim; 173, passim; 195-196

Eugenius I of Toledo (bishop) 274, 288, 322

Eugenius II of Toledo (bishop) $\quad 262$

Eulalia of Mérida $\quad 166 ; 199-200 ; 307 ; 356 ; 358 ; 368$

EURIC $17 ; 60-61 ; 67-69 ; 238 ; 25^{8,2}$

exactores 46

Falperra, hill of $\quad 228$

famulus/a Dei/Christi 274

Faro/Ossonoba/Ashknūniya 378

feasts 200

feudalization/feudalism $\quad 132 ; 224 ; 394 ; 397$

fibulae $84 ; 87-89 ; 91-92 ; 179-180 ; 249$

Fidelis (bishop) $163 ; 35^{8}$

fleur-de-lis $246 ; 248 ; 250$

foedus, foederati $63 ; 65 ; 68 ; 130$

Formula vitae honestae 344

Fosforus (bishop) 111-112

France/Francia $146-147 ; 181 ; 183$

Franks $63 ; 93 ; 127 ; 129 ; 132$

Fravitta, Flavius (magister militum) $\quad 298$

Fredegar 119

Fretum Gaditanum see Gibraltar, Strait of

FrITIGERN 143; 149

Froia (usurper) 121

frontier $45 ; 205 ; 237 ; 238 ; 379$

Fuero Juzgo 20

Fugitivus (bishop) 111

Gadir/Gades see Cádiz

GAISERIC 143-144

Galicia/Gallicia/Gallaecia $148 ; 337$, passim

Galla Placidia $64 ; 237 ; 298$

gardingio 125

Gaul/Gallia $43-44 ; 48 ; 61-62 ; 67-68 ; 73 ; 95 ; 143$; $148 ; 158 ; 168 ; 183-184,53 ; 196 ; 203 ; 206 ; 300$

GELIMER 308

Genil (river) 381

gens/gentes $125-126,49 ; 150 ; 160 ; 177 ; 180-181$; 239,13; 376

genus senatorum 202

Gepids 141-142;147;151

Gérticos 118;119,12; 123

GESALEIC 238

Getica 140-142

Gibraltar, Strait of see Fretum Gaditanum $\quad 83$; 299

Gijón 47

Girona/Gerunda 124-126; 228-229; 249

Goths 59, passim; 130-131; 139, 
passim; 157 passim; 173 , passim; 195-197; 199; 205; 207; 267; 299-307

gothus 157-159;163;167

Granada 20-21; $380-382$

Granada, plain of 381

Gregory I (pope) $\quad 355 ; 362-368$

Gregory of Tours $133 ; 203 ; 306 ; 340$;

Guadalete, battle of $118 ; 131,85$

Guarrazar, treasure of $22 ; 118 ; 276$

Gultricianus 122

Gumild of Maguelonne (bishop) 121-122; 127

GUNDEMAR $17 ; 258,1 ; 264 ; 268 ; 328$

Habsburg 17;140

Helisachar 148

heresy $145 ; 284 ; 300 ; 305 ; 35^{8}$

HeRMENEGILD $108 ; 128 ; 204 ; 206 ; 236 ; 305$; $307 ; 321 ; 337 ; 346,5^{\circ}$

Herrera del Pisuerga 62

Herulians 141-142

Hildigisus 125

Hispalis see Seville

Hispano-Romans $\quad 66-67 ; 71-73 ; 158-162 ; 167$; $174 ; 182 ; 196 ; 297 ; 337-338 ; 345-347$

Historia Wambae regis 117 , passim

Holy Cross (monastery) $\quad 322$

Homoians $357 ; 361$

honesti, honestiores $\quad 42 ; 202 ; 274$

HONORIUS $45 ; 64 ; 237$

Huétor-Tájar 381

humiliores 42

Huns $131 ; 142 ; 150$

Hydatius $\quad 61 ; 72 ; 202$

Iberian church $\quad 23 ; 48 ; 66 ; 104 ; 109-110 ; 215 ; 227$; 229; 264; 268; 273, passim; 295, passim; 315, passim; 337, passim; 353, passim; 393

Ibn 'Abd al-Hakam 386

Ibn al-Khați b 381

Ibn al-Qūṭiyya $\quad 381$

Ibn Hayyan 321

Ibn Hazm 376

identity $19 ; 22-23 ; 59$, passim; 83-84; 93; 139, passim; 157, passim; 173, passim; 195, passim; 216; 227-229; 297; 305-306; 328; 397

Ifrīqua $\quad 384-385$

Ildefonsus of Toledo $\quad 301-302 ; 322$

Ilderich of Nîmes 121

Iliberris/Ilbīra see Elvira

Ilipa 49

Imperium Romanum $\quad 39$, passim; 338

infrastructure 201-202;215,

passim; 386

inlustris 202; 274

integration $45 ; 5^{0} ; 101$, passim; $122 ; 147-148$; $181 ; 241 ; 283 ; 356 ; 363 ; 383 ; 398$

Iordanes $60-62 ; 140-142$
Isidore of Seville $\quad 63 ; 69 ; 73 ; 117-118 ; 202-204$; 217; 228; 240-241; 261-262; 265; 277; 298; $338 ; 341$

Islam $146 ; 221 ;$

224; 228

Islamic period $\quad 80 ; 197 ; 218 ; 225$;

229; 375, passim

Ispali/Ishbïliya see Seville

Israel 385

Italica $197 ; 204$

Italy $\quad 63-65 ; 71 ; 143 ; 147-148 ; 151 ; 174 ; 198$; $203-204 ; 337 ; 345 ; 363$

iudex $44 ; 302$

Iudicium in Tyrannorum Perfidia

Promulgatum 128

Ius libertatis Romanae $\quad 147-148$

Jacintus (bishop) 122

Jaén/Jayyān $\quad 378 ; 383$

Januarius of Málaga (bishop) 362-368

Jesus Christus $\quad 245-248 ; 250 ; 277-285$

Jews $20 ; 124 ; 242 ; 265 ; 267-268 ; 284$

jizya 377

Johannes Cassianus 344

John of Biclar/Iohannis Biclarensis $\quad 162,35$; 205; 216; 241-242; 337; 346

John (defensor) 355;362-365

Julian of Toledo 117 , passim; 240; 258,1; 266; 268

jund $381 ; 386$

Justin II $\quad 240,16 ; 347$

JUSTINIAN I $\quad 22 ; 217 ; 237,5 ; 342,29 ; 347 ; 360$

JUSTINIAN II 247

Justinian (bishop of Valencia) 280

kingship 139, passim

La Alberca (Algezares, Murcia) $80 ; 322$

landowners $\quad 42 ; 44 ; 130-131 ; 146 ; 147-148 ; 161$; $267 ; 380-382$

Laodicea 339

Las Navas de Tolosa, battle of 22

Las Tamujas (Malpica de Tajo) 248; 323

Las Vegas (La Pueblanueva) 323

Laterculus (by Polemius Silvius) 43

Laterculus Regum Visigothorum 249

Laterculus Veronensis 43

latifundium 297;324

law $19 ; 40 ; 42 ; 63-64 ; 105 ; 130 ; 146-148 ; 15^{0-151 ;}$ $158 ; 167 ; 198 ; 202-203 ; 205-206 ; 242 ; 247 ; 257$, passim; 281; 282; 295; 315,1;362;365-367; 397

Leander of Seville $\quad 21 ; 111 ; 346 ; 357,21$

LEO I (emperor) $\quad 69 ; 237,5$

León, kingdom of $145 ; 298$

Lepanto, battle of 21

Lerida/Ilerda 296; 299

Lex Gothica 146-147;149

lex scripta 150

Lex Visigothorum 67;203; 206; 257, passim 
Liber Iudiciorum $\quad$ 128; 150; 257, passim

Liber Ordinum 245

Libertas Gothorum 146-148

Libertas Romanorum 146

Lietus 71

limitanei $44-45$

lingua theodisca 146

Lisbon/Olisipo 197-198

LIUVA I $123 ; 299$

LIUVIGILD $17 ; 39 ; 64 ; 67 ; 71 ; 83 ; 95 ; 101-102 ; 108$; 119,10; 120 ; 123; 125; 128; 144; 163; 165-166; 200; 204; 205; 215-217; 223; 225; 227-228; 235, passim; 295; 299; 305; 307; 321; 328; 337-338; 342-343; 346-347; 357-358; 359; 361; 364-367; 394

Liuvirit $\quad 71$

liturgy $121 ; 141 ; 273$, passim; $321 ; 341$

local power 101, passim; 168; 239; 356;369; 394

loculus 324

Loja $\quad 381-382$

Longobards $145 ; 147 ; 150$

Los Hitos (Toledo) 2 284; 316; 323-325; 329,38

Los Villares (Murcia) $\quad 82-83$

Los Yébenes 322

LOUIS THE PIOUS $\quad 145 ; 148$

Lugo/Lucus Augusti $\quad$ 47; 72;339-340

Lupus $(d u x) \quad 129$

Lusitania $\quad 42-43 ; 73 ; 111,30 ; 159 ; 198 ; 274 ; 355 ; 360$

Madrid $\quad$ 17-18; 21; 22; 83

Madrid (province) 179

Madrona $\quad$ 22; $174 ; 184$

Maghreb 376

magisterium militum 143

magistri equitum 44

magistrimilitum 44

Magnentius (usurper) 45

maiores palatii 123

Málaga/Malaca $73 ; 361-364 ; 378$

Malpica de Tajo see Las Tamujas

Martianus of Écija $\quad 359-360$

Martin of Braga 337, passim

martyr $18 ; 49 ; 199-201 ; 282 ; 322 ; 356$

Masona (bishop) 111; 159; 161-167; 357-36o; 364-368

Mauretania $35^{8}$

mausoleum 86

MAURICE (emperor) 361-362; 363,57

Mauricius (monk) 261

Maximus (usurper) 45

Medina Sidonia/Assido/Shadhūna 49; 200; 362; 378

mediocres 262

Melque see Santa María de Melque

cella memoriae 322

Mérida/Augusta Emerita $\quad 23 ; 47 ; 60-61 ; 72$; 73 ; 103; 107-112; 159; 161; 163; 167; 197; 198; 199-202; 204; 221; 223; 229; 247; 250; 277; 286; 296; 300; 307; 329; 354; 355-361; 363-364; 365; $366 ; 367-369 ; 378$ basilica of Santa Eulalia $\quad 358$

Merovingians $\quad 93 ; 95 ; 174 ; 202,35 ; 247$

Mértola/Myrtillis 201; 286;

migration $22 ; 59$, passim; 92; 131; 140; 146; $158 ; 168 ; 174 ; 178 ; 180-183 ; 187-189 ; 263 ; 375$; 379-382

Milk Mountain, battle of 148

millenarius 130

Miro $339 ; 346,50$

Monachil (river) $\quad 381$

monarchy $17 ; 25 ; 101$, passim; 119; 139, passim; 195-196; 203-204; 206-207; 236; 239-242; 246-250; 268; 273-275; 282; 286; 316,2; 353-354; 357; 393-395

monastery $149 ; 200 ; 282 ; 307 ; 315-316 ; 322-323$; $327-329 ; 347 ; 363-365$

monetary crisis 224

MoNo model 102;104;106

Montalbán 323;327

Montanus of Toledo (bishop) 295-296; 300-303; 305-306; 308

morbus Gothicus/morbus Gothorum 119; 144

mosque 321

MUHAMMAD B. YAZĪD AL-QURAYSHĪ (governor of Ifriqiya) $\quad 384$

municipium 46;301;303

Munigua 197

Muqtabis 321

Murcia/Mursiya 79, passim; 322

MūsĀ B. NușAYR (emir) 384

muslims 375 , passim

Narbonensis $\quad 63 ; 65^{-67} ; 111,30 ; 117$, passim

Narbonne/Narbo/Narbona 62-63; 122; $126-128 ; 150 ; 160 ; 249 ; 261$

Narses (commander) 148

necropolis see cemetery

negotiatores Grecos $\quad 160$

Nepopis (bishop) 16o;358-36o; $364-365 ; 368$

Nicaea $48 ; 339$

Nicene faith $160 ; 163 ; 165 ; 242 ; 357 ; 361$

Nîmes $121 ; 127 ; 129 ; 379$

Nitigisus (bishop) $\quad 339-340$

nobilissimi 202

nobility $\quad 69 ; 101$, passim; 124,$37 ; 140 ; 144 ; 145$; 196; 273-276; 282; 286; 305; 324; 395

Nomina hispanarum sedium $\quad 48-49$

North Africa $\quad 71 ; 143-144 ; 223 ; 225 ; 308 ; 316,2$; $324 ; 376 ; 379 ; 384-386$

Notitia dignitatum $\quad 43-44 ; 126$

Novellae 367

Numantia 21; 197

numismatics 235, passim

officium palatinum 317

Old Testament $\quad 119,7 ; 120 ; 125 ; 128 ; 145 ; 244$; $246 ; 285$

Olisipo see Lisbon

Ologicus 205 
Olympiodorus of Thebes 64

opus signinum 220-221;324

Oretum 46

Orthodoxy $\quad 242 ; 284 ; 340-343 ; 347 ; 361$

Ossonoba see Faro

Ostrogotha 140-142

Ostrogoths $63 ; 71-72 ; 140-142 ; 151 ; 174 ; 296-298$; 307

Oviedo $\quad 322 ; 325$

Pacatus (rhetorician) $\quad 41$

palace, palatium $\quad$ 17-19; 121; 145; 201; 205; 221; 223-224; 228-229; 317-318; 321; 325

Palencia $\quad 62 ; 300-304 ; 308 ; 322$

Palestine $383 ; 385$

Pamplona 18;68; 204

Plaza del Castillo 379

parsfructuaria $\quad 80 ; 82$

pars rustica 42

patricius 202

patron, patronage $18 ; 197 ; 204 ; 322 ; 356 ; 358$; 368-369

Paul (apostle) 245; 258; 317; 345

$\begin{array}{ll}\text { Paulus (bishop of Emerita) } & 160 ; 163 ; 358\end{array}$

Paulus $(d u x) \quad$ 117, passim; 202; 206; 242-243; $246 ; 250 ; 266-267$

Pelagio 248

Peter (apostle) 245; 258; 317

Petrus (bishop) 303

Petrus (usurper) 69-70

Philip V OF Spain $17 ; 19$

Pimenus of Medina Sidonia (bishop) 200

Pla de Nadal palace $\quad 229$

Pliny the Elder 48

Plovdiv/Philippopolis 141

Polemius (bishop) 339

Polemius Silvius 43

Ponte puñide 46

Pontic-Danubian (type/finds) 181; 299; 303-304

pope $338 ; 341-344 ; 346 ; 355-35^{6} ; 362 ; 365 ; 369$

Portugal 378

praesidiales 43

primarius civitatis 201

primicerius 122

Priscilianism 50;300;302

Probinus 362,$56 ; 363$

proceres 140

procession 128-128; 200; 245

Procopius of Caesarea $\quad 62-63 ; 148 ; 150 ; 297-299$

Profuturus (bishop) 341-342

protostasia 44

Prudentius of Troyes (bishop) 146;148

purse mount 83; 90-95

Pyrenees $122 ; 125^{-126}$

Qusayr 'Amra, baths of 244

Qinnasrin (province) 383

Qurțuba see Córdoba
Rå bān al-Awwal (Syrian district) 383

RADEGUNDIS 347

RAMIROS III 145

Ranimir (abbot) 121-122

Ranosind $(d u x) \quad 123 ; 125$

Ravenna 22;65;140;145; 237; 298;307

Rayyo 378

RECCARED I $\quad 21 ; 23 ; 66 ; 102 ; 108 ; 119,10 ; 124 ; 144$; 150; 165; 205; 217; 225; 242; 263,22; 281; 295; $321 ; 343 ; 358 ; 394$

RECCARED II $17 ; 124$

RECCESWINTH $111 ; 118 ; 119,10 ; 120 ; 124 ; 242$; $250 ; 257$, passim; 275-276; 286

RECCIBERGA (wife of Recceswinth) 118

reconquista (reconquest) 21; 23; 145

Recopolis/Recópolis/Reccopolis 205; 215, passim; 316,2

regnum Gothorum $\quad 66 ; 159 ; 168 ; 227 ; 315$

regnum Tolosanum 122;144; 179

relics $166 ; 200 ; 282 ; 324 ; 35^{8}$

Renovatus (bishop) 162,34; 163-164; 167

rex Gothorum 160;167;376

rexSarracenorum 376

rex Visegotorum 160

RICIBERGA (wife of Chindaswinth) 274; 288

ripenses 44

RODERIC 131,$85 ; 143 ; 243-246 ; 248-25^{0}$

romanitas 235 , passim

Romans $20 ; 63 ; 65-66 ; 73 ; 141 ; 144 ; 158 ; 161 ; 163$; $167 ; 180,43 ; 195-196 ; 207 ; 237 ; 267$

Rome $\quad 23-24 ; 41 ; 64 ; 65 ; 68-70 ; 235 ; 237 ; 287$; $298 ; 337 ; 340,20 ; 341-343 ; 345-346 ; 363-364$

Rufus Festus 43

Rugians 148

rustici 202

Sacramenia 303

Sagunt 21

Saḥnūn $\quad 376$

Saint Acisclus see Acisclus

Sainte-Crox, monastery of (Poitiers) 347

Saint Eulalia see Eulalia of Mérida

Saint Ildefonsus see Ildefonsus of Toledo

Saint Isidore see Isidore of Seville

Saint Leander see Leander of Seville

Saint Vincent of Zaragoza see Vincent of Zaragoza

Salamanca 198

Salla $(d u x) \quad 61$

Salobreña, beach of 381

San Juan de Baños (Palencia) 275; 288

San Pedro de la Nave (Zamora) 248; 285

Sant Julia de Ramis (Girona) 221; 229

Santa María de Melque (San Martín de Montalbán) 246,57;323; 326-328

Santa María de Mijangos (Burgos) 275

Santa María de Quintanilla de las Viñas

(Burgos) 246,52; 248

Sarmatians 131

sarcophagus $73 ; 87 ; 324$ 


\author{
Saxons $124 ; 129 ; 132$ \\ scepter $245^{-247} ; 25^{\circ}$ \\ Scythia 344 \\ sedes regia 297 \\ Segovia/Segobia $\quad 62 ; 92 ; 198 ; 295 ; 299-301 ;$ \\ 303-305; 307 \\ Senate $21 ; 140$ \\ Senda de Granada (Murcia) 79, \\ passim
}

Seneca, Lucius Annaeus $\quad 344-345$

Sententiae 261-262; 266;339-340

Septimania $122 ; 127,58 ; 148 ; 150 ; 202$

Serdica 64

settlement, rural $\quad 59$, passim; 79,

passim; 178-179; 181; 215; 225-227; 229; 295; 297; $305 ; 316,2 ; 328$

Seville/Hispalis/Ispali/Ishbïliya 107-112; 128; 197; 200; 204; 299; 317; 329; 360; 378; 380; 382

Shämiyyīn $\quad 387$

SIGIBERT I 133

Sirmium 64

SISEBUT $\quad 126 ; 204 ; 225 ; 261 ; 263,22 ; 322$

Skythika 141

slaves/slavery $\quad 41 ; 65 ; 126 ; 130-131 ; 148 ; 160 ; 203$; $267 ; 366 ; 376$

Smaragdus of Saint Mihiel $\quad 146 ; 148$

society $\quad 39$, passim; 69; 70; 105; 113; 122; 139 passim; $161-162 ; 167 ; 196 ; 207 ; 229-230 ; 257$; 273-275; 277; 280; 316; 393-394; 396-398

solidus, solidi $\quad 237 ; 241 ; 275$

Spania $353 ; 355 ; 360-363 ; 365 ; 368-369 ; 375$, passim

spatheia $223 ; 324$

spolia $86 ; 320-321$

state $19-21 ; 23 ; 39-49 ; 102 ; 107 ; 109 ; 117 ; 195-197$; 201-203; 205; 207; 215, passim; 235; 239; 249; $281 ; 283 ; 286 ; 353$, passim; 376; 387; 396

Stephanus (bishop) 362-368

suburb, suburbium $\quad 73 ; 184 ; 217,4 ; 317$

Suebi/suevi $\quad 24 ; 39-40 ; 61 ; 67-68 ; 70 ; 72 ; 128$; 228; 300-301; 305; 308; 337, passim

Suniefred (usurper) $\quad 246 ; 248$

Sunna (bishop) 160; 162-163; 165-167; 306-307; $357-358 ; 360 ; 364-365 ; 366,72 ; 367-368$

susceptores 46

SWINTHILA $17 ; 123,33 ; 124 ; 205 ; 225 ; 261,12$; $276 ; 286 ; 360$

synod $296 ; 300 ; 305 ; 339-340 ; 342 ; 344,37$

Syria/Great Syria $73 ; 380 ; 383-387$

Syrians $\quad 380-381 ; 386$

Tagus/Tajo/Tejo $\quad 84 ; 117 ; 219 ; 296-298 ; 317 ; 321$ Tarraconensis $\quad 42-43 ; 67-70 ; 72 ; 123 ; 125 ; 249$

Tarragona/Tarraco $\quad 23 ; 47 ; 68-70 ; 72-73$; 197-198; 223

tax/tax collection/taxation $\quad 41 ; 44 ; 46 ; 71 ; 197$; 203; 205-206; 215; 228; 266; 375; 376; 380 ; $382-383 ; 385-387$

TEJA 148
Teudesinda $\quad 281$

THEODORIC I $17 ; 68 ; 131,85$

THEODORIC II $39 ; 238 ; \mathbf{2 4 0}, 21$

THEODORIC THE GREAT $\quad 61 ; 63 ; 71 ; 143-144$; 148-149; 151; 238; 296-298

TheOdosius THE GREAT $\quad 41 ; 50 ; 149 ; 298-299$

Theodosius II 237

Theodulf of Orléans 148

THEUDIS $62-64 ; 72 ; 145 ; 295$,

passim; $315 ; 321$

TIBERIUS II 240-241

Tierra de Pinares 303

Toledo/Toletum 17, passim; 63-64; 72; 101, passim; 117; 119-122; 129; 199-200; 204; 228; 243; 245; 257; 262; 283; 295, passim; 315, passim; $357 ; 360 ; 376$

Alcantara's Gate $\quad 320-321$

alcázar 17;318;321

castellum 321

ecclesia Praetorensis of the Holy Apostles 245

Museo de los Concilios y la Cultura

Visigoda 118

praetorium 29;321

St. Gines, alley of $\quad 318 ; 320-321$

St. Leocadia, basilica of (Cristo de la Vega) 21$22 ; 283 ; 317-318 ; 321-322$

St. Mary, basilica of $281 ; 307 ; 317-318 ; 320-321$

St. Michael (monastery) 322

St. Vincent (monastery) 322

Vega Baja 317-318; 321

Toledo, kingdom of 17 , passim; 101, passim; 150; 157, passim; 295, passim; 325; 393, passim

tombs $82 ; 85-87 ; 88-94 ; 96 ; 173$, passim; 275 ; $277 ; 281 ; 287-288 ; 323-324 ; 327 ; 379 ; 381$

Torrox/Turrush 381

Tortosa/Dertosa $70 ; 73 ; 307$

Totanés 322

Toulouse/Tolosa $\quad 69 ; 140 ; 168 ; 296$

trading networks $197-198 ; 204$

Trastámara dynasty 17

tremís, tremissis $\quad 223 ; 225 ; 237-238 ; 240-244$; 247-249; 385

Turibius of Astorga $\quad 300-303 ; 305-306$

Tyberius (lictor) 201

týche 139;143

tyrannus $\quad 70 ; 299$

'Uqba b. Nu'aym al-Ma'āfirī (member of the jund of Damascus) $\quad 381$

Ulfilas 149

Umayyads/Umayyad empire $\quad 22 ; 25 ; 236$; 244-245; 375, passim

urbanism 26; 196; 215, passim; 328

urbs regia $117 ; 119 ; 129$

Valencia/Valentia $\quad 47 ; 197 ; 204 ; 247,59 ; 280$; 296; 299; 307

VALENS 238 
VALIA 144

Vandals $24 ; 26 ; 40 ; 64-65 ; 66 ; 68 ; 142 ; 144 ; 147$; $149 ; 151 ; 298 ; 308$

Venantius Fortunatus $\quad 340 ; 347$

Veneto 148

Vertavillo/Brittablum 301;303

vicar, vicarious $\quad 44-45 ; 266$

vicus 62

Vigilius (pope) $\quad 341-344$

villa, villae $\quad 41-42 ; 62 ; 67 ; 72-73 ; 80 ; 82 ; 85 ; 87$; $316 ; 323$

Vincent of Zaragoza 199

Vitas Sanctorum Patrum Emeretensium $\quad 73$; 157, passim; $355-356$

Vouillé, battle of $\quad 63 ; 95 ; 122 ; 144206$
Walahfrid Strabo 149

WАмвА $17 ; 48 ; 117$, passim; $151 ; 199 ; 206$; 242-243; 245-247; 250; 266-267

Wilesindus of Agde (bishop) 122-123

Witimirus (rebel) 126-127

WitTIZA $148 ; 246$

Yājaral-Shāmiyyīn 380

YAZID IBN ABD AL-MALIK 244

Zaragoza/Caesaraugusta $\quad 21 ; 60,60 ; 68 ; 70$; 123,33; 198-199; 300; 329

Zeno (bishop) 61 
How did the breakdown of Roman rule in the Iberian Peninsula eventually result in the formation of a Visigothic kingdom with authority centralised in Toledo? This collection of essays challenges the view that local powers were straightforwardly subjugated to the expanding central power of the monarchy. Rather than interpret countervailing events as mere 'delays' in this inevitable process, the contributors to this book interrogate where these events came from, which causes can be uncovered and how much influence individual actors had in this process. What emerges is a story of contested interests seeking cooperation through institutions and social practices that were flexible enough to stabilise a system that was hierarchical yet mutually beneficial for multiple social groups. By examining the Visigothic settlement, the interplay between central and local power, the use of ethnic identity, projections of authority, and the role of the Church, this book articulates a model for understanding the formation of a large and important early medieval kingdom.

Sabine Panzram is Professor of Ancient History at Hamburg University (Germany). She focuses on social history of power in the Western Mediterranean, and in particular on urban history in the Iberian Peninsula. Currently she is preparing a study on Christendom without the Church: The Genesis of an Institution in the Dioecesis Hispaniarum (4th to 7 th centuries).

Paulo Pachá is Assistant Professor of Medieval History at the Universidade Federal do Rio de Janeiro (Brazil). He works on the history of the Visigothic kingdom and the development of its political structure and power relationships. 